UNIVERSIDADE DE SÃO PAULO

INSTITUTO DE GEOCIÊNCIAS

\title{
MEMORIAL DESCRITIVO DAS COLEÇÕES MINERALÓGICAS DE MUSEUS DE CIÊNCIAS DA TERRA E MUSEUS DE CIÊNCIAS NATURAIS DO SUDESTE BRASILEIRO.
}

Paulo Anselmo Matioli

Orientador: Prof. Dr. Daniel Atencio

DISSERTAÇÃO DE MESTRADO

Programa de Pós-Graduação em Mineralogia e Petrologia

São Paulo 


\section{UNIVERSIDADE DE SÃO PAULO \\ INSTITUTO DE GEOCIÊNCIAS}

"MEMORIAL DESCRITIVO DAS COLEÇÕES MINERALÓGICAS DE MUSEUS DE CIÊNCIAS DA TERRA E MUSEUS DE CIÊNCIAS NATURAIS DO SUDESTE BRASILEIRO"

\section{PAULO ANSELMO MATIOLI}

Orientador: Prof. Dr. Daniel Atencio

DISSERTAÇÃO DE MESTRADO

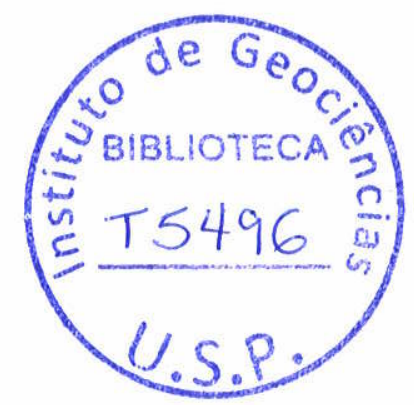

COMISSÃO JULGADORA

Nome

Presidente: Dr. Daniel Atencio

Titulares: Dr. Antenor Zanardo

Dra. Eliane Aparecida Del Lama

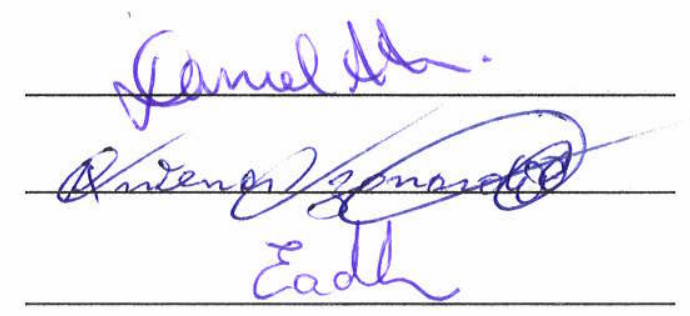




\section{MEMORIAL DESCRITIVO DAS COLEÇÕES MINERALÓGICAS DE MUSEUS DE CIÊNCIAS DA TERRA E MUSEUS DE CIÊNCIAS NATURAIS DO SUDESTE BRASILEIRO.}

Paulo Anselmo Matioli

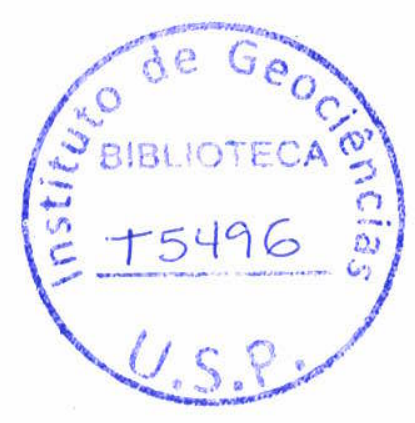

Orientador: Prof. Dr. Daniel Atencio

$$
\text { DISSERTAÇÃO DE MESTRADO }
$$

Programa de Pós-Graduação em Mineralogia e Petrologia

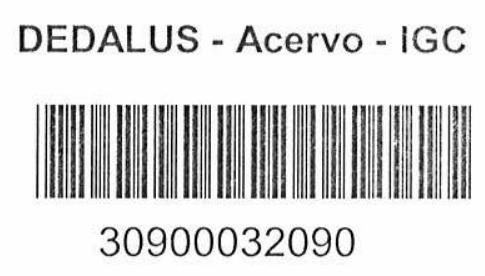

São Paulo 
Paulo Anselmo Matioli

Memorial descritivo das coleções mineralógicas de museus de ciências da terra e museus de ciências naturais do sudeste brasileiro.

São Paulo

Fevereiro 2014 


\section{GEOCIÊNCIAS}

Paulo Anselmo Matioli

Memorial descritivo das coleções mineralógicas de museus de ciências da terra e museus de ciências naturais do sudeste brasileiro.

Dissertação apresentada ao Instituto de Geociências da Universidade de São Paulo, para obtenção do título de Mestre em Mineralogia.

Área de concentração: Mineralogia e Petrologia.

Orientador: Prof. Dr. Daniel Atencio 
Ficha catalográfica preparada pelo Serviço de Biblioteca e Documentação do Instituto de Geociências da Universidade de São Paulo

Matioli, Paulo Anselmo

Memorial descritivo das coleções mineralógicas dos museus de ciências da terra e museus de ciências naturais do Sudeste brasileiro / Paulo Anselmo Matioli. - São Paulo, 2014

269 p.: il

Dissertação (Mestrado) : IGc/USP

Orient.: Atencio, Daniel

1. Coleção 2. Minerais 3. Mineralogia 4. Museu

5. Sudeste brasileiro I. Título 
Nome: MATIOLI, Paulo Anselmo.

Título: "Memorial descritivo das coleções mineralógicas dos museus de ciências da terra e museus de ciências naturais do sudeste brasileiro"

Dissertação apresentada ao Instituto de Geociências da Universidade de São Paulo USP, para obtenção do título de Mestre em Mineralogia.

Aprovada em:

Banca Examinadora:

Prof. Dr. Instituição:

Julgamento: Assinatura:

Prof. Dr. Instituição:

Julgamento: Assinatura:

Prof. Dr. Instituição:

Julgamento: Assinatura: 


\section{DEDICATÓRIA}

Dedico este trabalho aos meus filhos, Pedro e Petrus, meus minerais mais raros. 


\section{AGRADECIMENTOS}

Em primeiro lugar agradeço ao meu pai celestial, meu Deus, que sempre ilumina os meus passos e me da força nos momentos mais difíceis da minha vida.

Agradeço a minha família, em especial a minha amada esposa Milena Gomes Prol Otero Matioli, por ser a minha maior incentivadora e parceira de todas as horas e de todos os momentos. Minhas "pedras preciosas", Pedro Paulo e Petrus Enrico, sou eternamente feliz e grato aos meus filhos, por todo carinho e compreensão em todos os momentos de minha vida.

Meus agradecimentos para a minha mãe, Jane, que sempre acreditou em mim, minha tia Rô e minhas duas irmãs, Denise e Nairzinha, por me incentivarem exaustivamente.

Agradeço muito ao meu orientador de pesquisa mineralógica e de mestrado, meu amigo há mais de 30 anos, o professor livre-docente Dr. Daniel Atencio, por todo o seu apoio e colaboração nas revisões e projetos da minha pesquisa e por sempre ter me incentivado.

Agradeço a todas as pessoas das instituições museais que foram pesquisadas, por seu tempo, ajuda e colaboração.

Também agradeço aos vários amigos importantes nessa trajetória, por seu apoio incondicional e sua importante colaboração, como Sidney Francisco de Paula, Ana Hachich, Amanda Gerotto, Olívia Perez e Gabriela Gomes Prol Otero.

Agradeço aos estagiários e ex-estagiários do Museu Joias da Natureza, e toda equipe da ADESAF pela força e apoio. 
O saber não está na ciência alheia, que se absorve, mas principalmente, nas ideias próprias, que se regeneram dos conhecimentos absorvidos, mediante a transmutação por que passam, no espírito que os assimila. Um sabedor não é armário de sabedoria armazenada, mas transformador reflexivo de aquisições digeridas.

(Rui Barbosa) 


\section{Resumo}

MATIOLI, Paulo Anselmo. Memorial descritivo das coleções mineralógicas dos museus de ciências da terra e museus de ciências naturais do sudeste brasileiro. Dissertação (Mestrado) - Programa de Pós Graduação do Instituto de Geociências, Departamento de Mineralogia e Geotectônica, USP, São Paulo, 2014. Orientador: Prof. Daniel Atencio. USP. Dissertação.

O presente estudo teve como foco pesquisar as realidades das coleções geológicas, com ênfase nos acervos mineralógicos de museus de ciências da terra e ciências naturais da região sudeste brasileira. A escolha de alguns eixos teóricos e a leitura de algumas obras proporcionaram a base que fundamentou a construção deste trabalho. Foram elencados três eixos principais, que reforçaram a argumentação das pesquisas desenvolvidas nestas instituições: (1) a história das coleções e seus colecionadores, que contribuíram para a formação dos museus brasileiros, valorizando e enriquecendo a história da mineralogia no Brasil; (2) a descrição dos minerais tipo brasileiros que são 63 atualmente; (3) os principais mineralogistas, pesquisadores brasileiros e estrangeiros, que atuaram no país e colaboraram com a difusão da geologia, bem como a história dos museus no mundo e no Brasil, que iniciou com as maravilhas naturais dos gabinetes de curiosidade dos séculos XVI e XVII. Nas pesquisas desenvolvidas com 15 museus do sudeste brasileiro, foi constatado nas conversas e entrevistas com os responsáveis pelos museus, uma carência muito grande de mineralogistas e profissionais capacitados, para a curadoria e o gerenciamento de seus acervos, no que tange os setores de mineralogia. Pretende-se que este trabalho proporcione reflexões e diretrizes aos profissionais que atuam nestes museus, para que com pequenas condutas, e algumas reformulações, possam valorizar as riquezas que se encontram depositadas em suas instituições.

Palavras-chave: Coleção. Minerais. Mineralogia. Museu. Sudeste Brasileiro. 


\begin{abstract}
Matioli Paulo Anselmo,. Descriptive history of mineralogical collections of earth sciences museums and natural sciences museums in Southeastern Brazil. Thesis (Master ) - Graduate Program at the Institute of Geosciences, Department of Mineralogy and Geotectonics, USP , São Paulo , $2014 \mathrm{f}$. Advisor: Prof. Daniel Atencio. USP. Dissertation.

This study focused on researching the realities of geological collections, with emphasis on mineralogical collections of earth sciences and natural sciences museum in Southeastern Brazil. The choice of some theoretical axis, and the reading of some publications provided the basis that justified the construction of this work. Three main axis, which have strengthened the arguments of the research undertaken in these institutions were listed: (1) the history of collections and their collectors who contributed to the training of Brazilian museums, enhancing and enriching the history of mineralogy in Brazil; (2) the description of Brazilian type minerals that are currently 63; and (3) the main mineralogists, Brazilian and foreign researchers, who worked in the country and contributed to the spread of the geology and the history of museums in the world and in Brazil, which started with the natural wonders of the curiosity cabinets of the sixteenth and seventeenth centuries. Based on conversations and interviews with responsible for 15 museums in southeastern Brazil, it was found a major lack of mineralogists and skilled professionals to curate and manage their collections, regarding the sectors of mineralogy. It is intended that this work provides reflections and guidelines for professionals who work in these museums, so that with small ducts, and some adjustments, the riches deposited at their institution could be appreciated.
\end{abstract}

Keywords: collection, mineral, mineralogy, museum, Southeastern Brazil. 


\section{LISTA DE FIGURAS}

Figura 1. Ilustrando Coleções de Numismática e Filatelia......................................40

Figura 2. Coleção de Areias do Mundo (Arenofilia)............................................42

Figura 3. Minerais formados em cavidades de rochas vulcânicas........................43

Figura 4. Ortoclásio com muscovita, albita e quartzo........................................44

Figura 5. Minerais formados em cavernas (espeleotemas) ..............................45

Figura 6. Minerais estéticos - azurita (esquerda) e rodocrosita (direita).............45

Figura 7. Minerais raros matiolíta (esquerda) e coutinhoíta (direita)..................46

Figura 8. Elementos Nativos (pepitas de ouro) ............................................48

Figura 9. Mineral raríssimo, única amostra na matriz existente no mundo,

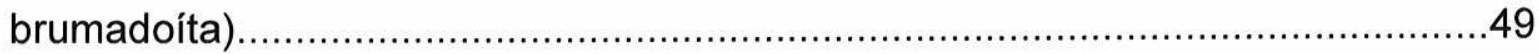

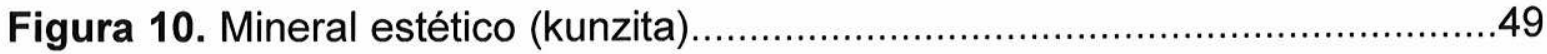

Figura 11. Minerais de urânio (marthozita e curita) da Mina Shinkolobwe,

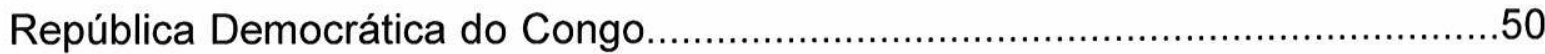

Figura 12. Museu da Empresa GEOSOL - Belo Horizonte - MG.......................51

Figura 13. As nove musas da mitologia grega - filhas de Zeus e Mnemósine....87

Figura 14. Esta é uma das mais antigas representações do gabinete de curiosidades do Boticário Ferrante Imperato, 1599..........................................8

Figura 15. Ilustração retirada da publicação Museu Cospiano - o gabinete de curiosidades do príncipe Ferdinando Cospi de Toscana anexado ao de Ulisse

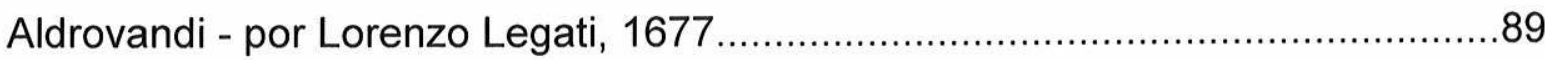

Figura 16. Frente do Ashmolean Museum em seu edifício original em Broad Street (gravura feita por Michael Burgueses 1685)............................................91

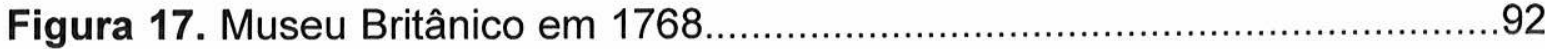

Figura 18. Museu de Mineralogia de Paris (construção original) .........................93

Figura 19. American Museum of Natural History (AMNH) - Museu de História

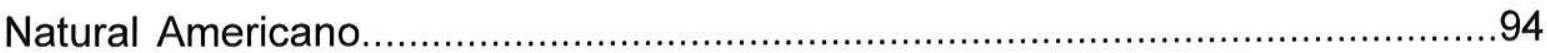

Figura 20. Museu de Ciências Naturais da Argentina........................................94

Figura 21. Museu Nacional do Rio de Janeiro..............................................96

Figura 22. Museu Paraense Emílio Goeldi. Ao centro, vista panorâmica e à direita retrato de Emílio Goeldi, fundador do museu...................................................97

Figura 23. Museu do Ipiranga, 1902, atual Museu Paulista.................................97 
Figura 24. Museu de Mineralogia da Escola de Minas de Ouro Preto

Figura 25. Museu de Minerais e Rochas Heinz Albert. Entrada do Campus de Geologia da Unesp em Rio Claro.

Figura 26. Museu de Minerais e Rochas Heinz Albert. Amostras geológicas didáticas na entrada do campus de geologia da Unesp em Rio Claro 111

Figura 27. Museu de Minerais e Rochas Heinz Albert. Vitrine clássica de madeira com vidro contendo amostras didáticas, localizados no saguão de entrada do museu

Figura 28. Museu de Minerais e Rochas Heinz Albert. Vista da entrada do Museu Heinz Ebert.

Figura 29. Museu de Minerais e Rochas Heinz Albert. Vista geral do salão expositivo com as vitrines contendo os minerais

Figura 30. Museu de Minerais e Rochas Heinz Albert. Vitrines com amostras didáticas em exposição 112

Figura 31. Museu de Minerais e Rochas Heinz Albert. Vista das vitrines com detalhes da iluminação central no teto do salão expositivo.

Figura 32. Museu de Minerais e Rochas Heinz Albert. Vitrine expositiva na parte superior e reserva técnica na parte inferior. 113

Figura 33. Museu de Minerais e Rochas Heinz Albert. Detalhe das amostras da reserva técnica.

Figura 34. Museu de Minerais e Rochas Heinz Albert. Amostras da reserva técnica sem organização.

Figura 35. Museu de Minerais e Rochas Heinz Albert. Amostras da reserva técnica com uma numeração desproporcional e que danifica os exemplares...114 Figura 36. Museu de Minerais e Rochas Heinz Albert. Amostras de minerais estéticos comuns e detalhe da etiqueta em acrílico contendo informações simples e pouco informativas 114

Figura 37. Museu de Minerais e Rochas Heinz Albert. Catalogo antigo de minerais da reserva técnica. 115

Figura 38. Museu de Minerais e Rochas Heinz Albert. Catalogo antigo de minerais da reserva técnica. 115

Figura 39. Museu de Minerais e Rochas Heinz Albert. Espaço dedicado ao patrono do museu o professor Heinz Ebert. 
Figura 40. Museu de Minerais e Rochas Heinz Albert. Espaço dedicado ao patrono do museu o professor Heinz Ebert. 116

Figura 41. Museu de Minerais e Rochas Heinz Albert. Reserva técnica mostrando as diversas gavetas com as amostras 116

Figura 42. Museu de Minerais e Rochas Heinz Albert. Detalhe da gaveta com as amostras minerais da reserva técnica. Nota-se a falta de cuidado com os exemplares 117

Figura 43. Museu de Minerais e Rochas Heinz Albert. Detalhe da gaveta com as amostras minerais da reserva técnica. Nota-se a falta de cuidado com os exemplares e a desorganização das amostras.

Figura 44. Museu da Geodiversidade. Vitrine com amostras de minerais comuns

Figura 45. Museu da Geodiversidade. Vitrine com amostras de minerais comuns. Detalhe da iluminação direcionada aos minerais. 123

Figura 46. Museu da Geodiversidade. Vitrine com as amostras separadas em grupos, no caso o grupo das Micas

Figura 47. Museu da Geodiversidade. Vitrine de minerais colocados aleatoriamente, sem nenhuma classificação preferencial. 123

Figura 48. Museu da Geodiversidade. Detalhe da etiqueta do mineral contendo informações simples equivocadas enquanto a sua classificação mineralógica. No caso a malaquita é na verdade um mineral do grupo das Cloritas.

Figura 49. Museu da Geodiversidade. Amostras estéticas em exposição na vitrine. Detalhe da etiqueta que possui informações equivocadas em relação a sua classificação

Figura 50. Museu da Geodiversidade. Vitrine com minerais diversos, sem classificação e organização.

Figura 51. Museu da Geodiversidade. Vitrine com minerais estéticos 125

Figura 52. Museu Amsterdam Sauer. Vista da entrada do museu. 128

Figura 53. Museu Amsterdam Sauer. Vista geral do salão expositivo. 128

Figura 54. Museu Amsterdam Sauer. Vista geral do salão expositivo com as vitrines modulares e iluminação reduzida. 129

Figura 55. Museu Amsterdam Sauer. Réplica de um garimpo realizado em 
pegmatitos brasileiros.

Figura 56. Museu Amsterdam Sauer. Réplica de um garimpo realizado em pegmatitos brasileiros.

Figura 57. Museu Amsterdam Sauer. Amostra grande estética de Turmalina bicolor colocada em pedestais com iluminação pontual, para valorizar a amostra. 130

Figura 58. Museu Amsterdam Sauer. Amostra grande estética de Topázio incolor. 130

Figura 59. Museu Amsterdam Sauer. Detalhe da vitrine dos diamantes, contendo uma das melhores coleções do país

Figura 60. Museu Amsterdam Sauer. Detalhe da maior água marinha do país.131 Figura 61. Museu Amsterdam Sauer. Amostra de Turmalina rosa proveniente da famosa lavra do Jonas, em Conselheiro Pena, Minas Gerais 131

Figura 62. Museu Amsterdam Sauer. Vitrine com minerais brutos e lapidados.131 Figura 63. Museu de Ciências da Terra do DNPM-RJ. Vista geral do salão expositivo com as vitrines clássicas de madeira e vidro. Iluminação geral do ambiente 139

Figura 64. Museu de Ciências da Terra do DNPM-RJ. Vista geral do salão expositivo com as vitrines clássicas de madeira e vidro. lluminação geral do ambiente 139

Figura 65. Museu de Ciências da Terra do DNPM-RJ. Vista geral das vitrines clássicas de madeira e vidro nas laterais do salão expositivo. Observam-se as gavetas na parte inferior do mobiliário da reserva técnica.

Figura 66. Museu de Ciências da Terra do DNPM-RJ. Amostras maiores colocadas em bases de madeira 140

Figura 67. Museu de Ciências da Terra do DNPM-RJ. Detalhe da vitrine - parte superior: exposição / parte inferior (gavetas): reserva técnica 140 Figura 68. Museu de Ciências da Terra do DNPM-RJ. Detalhe das gavetas da reserva técnica, contendo amostras raras 141

Figura 69. Museu de Ciências da Terra do DNPM-RJ. Vitrine com minerais expostos segundo ao sistema cristalino 141

Figura 70. Museu de Ciências da Terra do DNPM-RJ. Vitrine com minerais comuns formadores das rochas. 
Figura 71. Museu de Ciências da Terra do DNPM-RJ. Vitrine com minerais expostos segundo a classificação química.

Figura 72. Museu de Ciências da Terra do DNPM-RJ. Detalhe de três amostras raras de platina nativa de algumas ocorrências brasileiras.

Figura 73. Museu de Ciências da Terra do DNPM-RJ. Amostras de elementos nativos.

Figura 74. Museu de Ciências da Terra do DNPM-RJ. Detalhe da amostra de chumbo nativo com stistaita proveniente do estado de Rondônia. 143

Figura 75. Museu de Ciências da Terra do DNPM-RJ. Amostras de bismutita com rara associação de pucherita de uma ocorrência famosa e atualmente exaurida. Percebe-se a falta de uma maior sinalização na etiqueta apontando quais são os minerais

Figura 76. Museu de Ciências da Terra do DNPM-RJ. Amostra de brazilianita, um cristal fantástico da localidade tipo do estado de Minas Gerais 143 Figura 77. Museu de Ciências da Terra do DNPM-RJ. Amostra de topázio proveniente da Lavra do Funil, em Santa Maria de Itabira, Minas Gerais. 144

Figura 78. Museu de Ciências da Terra do DNPM-RJ. Vitrine com minerais de ferro e manganês. Vitrine lateral do salão expositivo. 144

Figura 79. Museu de Ciências da Terra do DNPM-RJ. Etiqueta em estado ruim de conservação. Amostra proveniente da uma famosa coleção Hussak. 145 Figura 80. Museu de Ciências da Terra do DNPM-RJ. Etiqueta com informações simples. Nomenclatura em desuso, por se tratar de uma variedade. Detalhe da doação do famoso mineralogista Luciano Jacques de Moraes. 145

Figura 81. Museu de Ciências da Terra do DNPM-RJ Detalhe de dois minerais tipo brasileiros, a scorzalita e a souzalita. Nota-se o famoso doador desses exemplares, o mineralogista William Pecora.... 145 Figura 82. Museu de Ciências da Terra do DNPM-RJ. Acervo exposto em caixas de plástico, dificultando um pouco a visualização das espécies. Nota-se o famoso doador desses exemplares, o mineralogista Djalma Guimarães. 146

Figura 83. Museu de Ciências da Terra do DNPM-RJ Detalhe de uma espécie tipo brasileira, a senaíta. Nota-se o famoso doador desse exemplar, o geólogo Orville Derby. 146

Figura 84. Museu de Ciências da Terra do DNPM-RJ. Cristal biterminado de 
tantalita- $(\mathrm{Fe})$ proveniente do estado de Minas Gerais.

Figura 85. Museu de Mineralogia Aitiara. Vista geral das vitrines do museu. Notase ao centro uma exposição temática de variedades de quartzo (ametista)......154 Figura 86. Museu de Mineralogia Aitiara. Detalhe da vitrine na parte superior de fosfatos, incluindo algumas espécies tipo brasileiro.

Figura 87. Museu de Mineralogia Aitiara. Vitrine com os minerais sistematizados por classes químicas segundo Strunz. Iluminação interna, valorizando a visualização dosexemplares.

Figura 88. Museu de Mineralogia Aitiara. Vitrine com os minerais sistematizados por classes químicas segundo Strunz. Nota-se na parte de baixo das vitrines, amostras de tamanhos maiores com temas diferenciados 155 Figura 89. Museu de Ciência e Técnica da Escola de Minas. Entrada do setor de mineralogia I 165

Figura 90. Museu de Ciência e Técnica da Escola de Minas. Detalhe da amostra de raiz de planta envolvendo cristais de hematita (itabirito) 165

Figura 91. Museu de Ciência e Técnica da Escola de Minas. Vista geral das vitrines modulares e da iluminação pontual nas vitrines. 166

Figura 92. Museu de Ciência e Técnica da Escola de Minas. Vista geral das vitrines modulares e do piso de mármore 166

Figura 93. Museu de Ciência e Técnica da Escola de Minas. Foto de uma variedade de clinocloro, porém sem a devida explicação de qual espécie pertence. Detalhe da etiqueta sem as informações necessárias 166

Figura 94. Museu de Ciência e Técnica da Escola de Minas. Detalhe das etiquetas sem padronização das informações sobre a variedade kunzita. 167

Figura 95. Museu de Ciência e Técnica da Escola de Minas. Vista da vitrine com amostras de elementos nativos: ouro.

Figura 96. Museu de Ciência e Técnica da Escola de Minas. Detalhe das amostras raras de ouro preto (ouro paladiado) 167

Figura 97. Museu de Ciência e Técnica da Escola de Minas. Amostras raras e estéticas de euclásio de Ouro Preto. 168

Figura 98. Museu de Ciência e Técnica da Escola de Minas. Amostras raras e estéticas de topázio Imperial de Ouro Preto. 168

Figura 99. Museu de Ciência e Técnica da Escola de Minas. Setor educativo: 
Ciclos das Minerações do Brasil

Figura 100. Museu de Ciência e Técnica da Escola de Minas. Setor educativo: Ciclo das Rochas. 169

Figura 101. Museu de Ciência e Técnica da Escola de Minas. Vista geral das vitrines clássicas. Falta iluminação...... 169

Figura 102. Museu de Ciência e Técnica da Escola de Minas. Vista geral das vitrines clássicas e dos corredores estreitos, dificultando o acesso aos deficientes físicos com baixa mobilidade ou cadeirantes. 169 Figura 103. Museu de Ciência e Técnica da Escola de Minas. Detalhe de espécie rara descoberta em Minas Gerais em homenagem ao patrono do Museu de Mineralogia da UFOP, a gorceixita

Figura 104. Museu de Ciência e Técnica da Escola de Minas. Vitrine com muitas amostras minerais classificados segundo Dana. 170

Figura 105. Museu de Ciência e Técnica da Escola de Minas. Reserva Técnica com várias vitrines de minerais. 170

Figura 106. Museu de Ciência e Técnica da Escola de Minas. Vitrines de minerais e detalhe nas gavetas completamente lotadas de amostras minerais. Em muitas ocasiões foi constato melhores amostras na reserva técnica. 171

Figura 107. Museu de Ciência e Técnica da Escola de Minas. Amostras raras e interessantes sem cuidados de manutenção ou conservação 171 Figura 108. Museu de Ciência e Técnica da Escola de Minas. Amostras raras e interessantes sem cuidados de especiais 171

Figura 109. Museu da GEOSOL. Foto da entrada da Empresa Geosol, em detalhe uma amostra muito grande de jaspilito. Não existe referência de que existe um museu dentro da instituição.

Figura 110. Museu da GEOSOL. Vitrine com diversas amostras de minerais brasileiros. Observa-se a falta de iluminação dentro das vitrines 178

Figura 111. Museu da GEOSOL. Amostra rara e estética de scheelita proveniente da Mina Velha, Morro Velho, Nova Lima - MG. Detalhe da base de madeira e da etiqueta 179

Figura 112. Museu da GEOSOL. Amostras fantásticas e estéticas de topázio imperial proveniente do Garimpo de Antônio Pereira, Ouro Preto, MG 179

Figura 113. Museu da GEOSOL. Amostra de raro euclásio da localidade tipo 
provenientes de Dom Bosco, Ouro Preto, MG.

Figura 114. Museu da GEOSOL. Amostra estética de hematita de Rodrigo Silva, Ouro Preto, MG.

Figura 115. Museu da GEOSOL. Amostra de rara e estética de montebrasita associada com kosnarita na albita do Pegmatito de Jenipapo, Itinga, MG........180 Figura 116. Museu da GEOSOL. Vista geral da entrada da empresa com as vitrines de minerais em exposição. 180

Figura 117. Museu da GEOSOL. Vitrine com dedicação especial aos minerais tipo do Brasil, expondo algumas raridades como matiolíta, atencioíta, coutinhoíta, yanomamita, entre outras.

Figura 118. Museu da GEOSOL. Amostra de raríssima de coutinhoita proveniente da localidade tipo o Pegmatito de Urucum, Galiléia, MG. Porém, notase a falta de informação na etiqueta sobre onde se observar a espécie descrita e a sua associação mineralógica. 181

Figura 119. Museu da GEOSOL. Amostra rara de yanomamita de sua ocorrência tipo no país que é o Depósito Estanífero de Mangabeira, Monte Alegre, GO. Neste exemplar, nota-se uma seta apontando para onde o observador deve olhar, facilitando a visualização do mineral 181

Figura 120. Museu da GEOSOL.Vitrine dedicada a diversos tipos de minérios 182 Figura 121. Museu da GEOSOL. Vitrine com vários minerais e, em detalhe, caixas hermeticamente fechadas contendo minerais higroscópicos e deliquescentes. A iluminação neste caso é pontual dentro das vitrines, melhorando a visualização das amostras. 182

Figura 122. Museu da GEOSOL. Vista geral das vitrines com amostras minerais dentro da biblioteca

Figura 123. Museu da GEOSOL. Amostras de minerais raros brasileiros como bismutotantalita e bismutomicrolita (desacreditada). 183

Figura 124. Museu da GEOSOL. Amostra rara de humboldtina proveniente de MG. 183

Figura 125. Museu da GEOSOL. Vitrine contendo amostras de minérios de ferro. 183

Figura 126. Museu da GEOSOL. Amostras minerais em vitrines no chão da biblioteca 184 
Figura 127. Museu da GEOSOL. Vista geral da biblioteca com as vitrines dos minerais. Detalhes da iluminação central do teto e da iluminação dentro de cada vitrine 184

Figura 128. Museu da GEOSOL. Amostra de ouro nativo da Mina Bela Fama, Nova Lima, MG. 185

Figura 129. Museu da GEOSOL. Amostras de minerais mais comuns, de tamanhos grandes, expostas em bancadas de madeira com feltro vermelho....185 Figura 130. Museu da GEOSOL. Amostra estética de ametista (variedade do quartzo) doada pelo fundador da Geosol, Vitor Dequech. Detalhe da base com

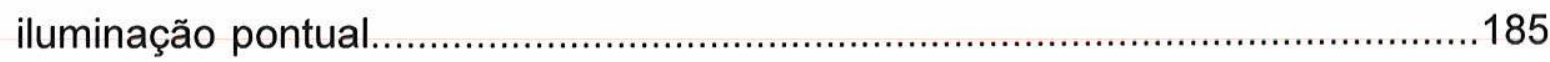

Figura 131. Museu das Minas e do Metal. Detalhes de duas amostras de diamantes com etiquetas contendo informações simples. Destaque para o belo octaedro de Diamante Negro 193

Figura 132. Museu das Minas e do Metal. Vitrine em homenagem ao geólogo e mineralogista Djalma Guimarães. 193

Figura 133. Museu das Minas e do Metal. Detalhes do mobiliário da reserva técnica. 194

Figura 134. Museu das Minas e do Metal. Mobiliário com vitrines na parte inferior com amostras minerais da reserva técnica 194

Figura 135. Museu das Minas e do Metal. Caixas de plásticos contendo amostras minerais da reserva técnica. 195

Figura 136. Museu das Minas e do Metal. Estantes de ferro contendo diversas amostras da reserva técnica sem classificação. 195

Figura 137. Museu das Minas e do Metal. Detalhes da numeração nas amostras da reserva técnica; observa-se a desproporcionalidade nas marcações. 195

Figura 138. Museu das Minas e do Metal. Vista geral do setor expositivo dos minerais. 196

Figura 139. Museu das Minas e do Metal. Amostra rara de cinábrio de Dom Bosco, Ouro Preto, MG. 196

Figura 140. Museu das Minas e do Metal. Amostra estética de hematita com rutilo proveniente de Novo Horizonte, BA 196

Figura 141. Museu das Minas e do Metal. Amostra estética de pirolusita proveniente da Mina Morro da Mina, Conselheiro Lafaiete, MG. 
Figura 142. Museu das Minas e do Metal. Vitrine com belas amostras de minerais da classe dos sulfatos; em detalhe as tecnologias interativas como tela ao fundo ilustrando os cristais gigantes do México. 197

Figura 143. Museu das Minas e do Metal. Vitrine com bons exemplares de topázio, detalhe na grande e rara amostra ao fundo de topázio incolor. Notam-se as bases que seguram as amostras.

Figura 144. Museu das Minas e do Metal. Amostras fantásticas e raras de fenacita provenientes do Rio Piracicaba, São Miguel de Piracicaba, MG..........198 Figura 145. Museu das Minas e do Metal. Vitrine dedicada especialmente aos minerais tipo do Brasil com raridades em exposição.........................................198 Figura 146. Museu das Minas e do Metal. Amostra de guimarãesita proveniente de Itinga, MG .................................................................................. 198

Figura 147. Museu das Minas e do Metal. Detalhe da placa com as nomenclaturas referentes aos minerais tipo brasileiros...................................199 Figura 148. Museu das Minas e do Metal. Exemplares de octaedros de "djalmaita", (desacreditado), provenientes do Pegmatito de Volta Grande,

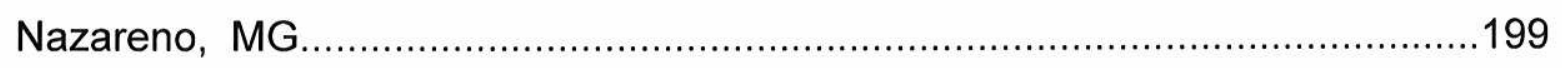

Figura 149. Museu das Minas e do Metal. Setor interativo e lúdico que mostra hologramas de minerais, chamado de Chão de Estrelas.................................200 Figura 150. Museu das Minas e do Metal. Detalhe dos salões do antigo prédio histórico, onde ficam as salas expositivas...............................................200 Figura 151. Museu das Minas e do Metal. Detalhes da interatividade da vitrine. 200

Figura 152. Museu de Mineralogia e Arte Sacra. Vista da entrada do museu...206 Figura 153. Museu de Mineralogia e Arte Sacra. Amostras de minerais mais comuns nas bancadas no hall de entrada.................................................206 Figura 154. Museu de Mineralogia e Arte Sacra. Vista geral do salão expositivo com as vitrines modulares de vidro e bases de madeira...................................207 Figura 155. Museu de Mineralogia e Arte Sacra. Vista geral do salão expositivo. Detalhe da iluminação.........................................................................207 Figura 156. Museu de Mineralogia e Arte Sacra. Mobiliários clássicos com minerais expostos na parte superior e gavetas contendo a reserva técnica na parte inferior. 208 
Figura 157. Museu de Mineralogia e Arte Sacra. Detalhe da gaveta contendo as amostras da reserva técnica. Nota-se a falta de organização das amostras.....208 Figura 158. Museu de Mineralogia e Arte Sacra. Minerais colocados de forma aleatória, misturando amostras brutas, polidas e lapidadas sem nenhuma classificação 208

Figura 159. Museu de Mineralogia e Arte Sacra. Amostra de ouro nativo proveniente da região de Congonhas, MG. Percebe-se a simplicidade da etiqueta e de suas informações e a base em que a amostra está colocada, não dando destaque para as pequenas pepitas 209

Figura 160. Museu de Mineralogia e Arte Sacra. Vitrine com amostras misturadas de minerais e corais, ambas sem classificação. 209 Figura 161. Museu de Mineralogia e Arte Sacra. Detalhe da vitrine modular. Ao fundo vitrines clássicas com vidrarias e ao lado amostras de minerais. 209 Figura 162. Museu de Minerais e Rochas da UFES. Vitrine simples de madeira e vidro com fundo de feltro verde. Minerais comuns formadores das rochas........214 Figura 163. Museu de Minerais e Rochas da UFES. Minerais didáticos da reserva técnica. 214

Figura 164. Museu de Minerais e Rochas da UFES. Amostras de minerais lapidados e polidos. Detalhe das etiquetas simples e sem muitas Informações. 214

Figura 165. Museu de Minerais e Rochas da UFES. Amostras de minerais comuns com tamanhos grandes dispostos em prateleiras de vidro em armações metálicas.

Figura 166. Museu de Minerais e Rochas da UFES. Bancadas com amostras didáticas para aulas. Detalhe do mobiliário com exposição de minerais na parte superior e gavetas contendo a reserva técnica na parte inferior 215 Figura 167. Museu de Minerais e Rochas da UFES. Vitrine com amostras de minerais detríticos (areias) de várias localidades.

Figura 168. Museu IHGPC "Coleção Resk Frayha". Vista geral do salão expositivo.

Figura 169. Museu IHGPC "Coleção Resk Frayha". Detalhe da homenagem ao pesquisador Resk Frayha 221

Figura 170. Museu IHGPC "Coleção Resk Frayha". Vitrine com várias amostras 
minerais de Terras Raras

Figura 171. Museu IHGPC "Coleção Resk Frayha". Detalhe da iluminação interna das vitrines.

Figura 172. Museu IHGPC "Coleção Resk Frayha". Detalhe da etiqueta com informações simples e com alguns erros de digitação.

Figura 173. Museu IHGPC "Coleção Resk Frayha". Amostra de uma espécie rara encontrada na famosa pedreira Bortolan. Detalhe da base da amostra mineral. 223

Figura 174. Museu IHGPC "Coleção Resk Frayha". Amostra rara e antiga coletada na década de 60 de eudialita com zoneamento de outros minerais do mesmo grupo

Figura 175. Museu IHGPC "Coleção Resk Frayha". Testemunho de sondagem contendo pirofanita 223

Figura 176. Museu IHGPC "Coleção Resk Frayha". Amostras raras de baddeleyita e zircão do Maciço Alcalino de Poços de Caldas 224 Figura 177. Museu IHGPC "Coleção Resk Frayha". Amostra rara de natrolita em cavidade no tinguaito .224

Figura 178. Museu de Geociências IGc/USP. Vista geral do salão Expositivo 232

Figura 179. Museu de Geociências IGc/USP. Vitrine com minerais classificados segundo Dana. Abaixo Minerais grandes sem sistematização preferencial......232 Figura 180. Museu de Geociências IGc/USP. Vitrines modulares com amostras diversas e temas específicos. .232

Figura 181. Museu de Geociências IGc/USP. Vitrine dedicada aos minerais brasileiros descobertos no século XXI. .233

Figura 182. Museu de Geociências IGc/USP. Vitrine temática que ilustra os espeleotemas 233

Figura 183. Museu de Geociências IGc/USP. Iluminação interna das vitrines dos minerais. 233

Figura 184. Museu de Geociências IGc/USP. Vitrines e painel temático sobre minerais de cavernas .234

Figura 185. Museu de Geociências IGc/USP. Vista dos tipos de vitrines do museu. 234 
Figura 186. Museu de Geociências IGc/USP. Vitrines clássicas contendo a coleção Schnyder.

Figura 187. Museu de Geociências IGc/USP. Amostras de crisoberilo geminado.

Figura 188. Museu de Geociências IGc/USP. Amostra de esmeralda (variedade de berilo).... 235

Figura 189. Museu de Geociências IGc/USP. Detalhe da etiqueta com informações importantes como o nome da espécie, composição química e localidade geográfica.

Figura 190. MUGEO - CENTRO MUSEU GEOLÓGICO. Vista geral da entrada do prédio onde o MUGEO fica localizado....

Figura 191. MUGEO - CENTRO MUSEU GEOLÓGICO. Vista geral do salão expositivo com todas as vitrines. .242

Figura 192. MUGEO - CENTRO MUSEU GEOLÓGICO. Vitrine temática da coleção mineralógica Krantz.

Figura 193. MUGEO - CENTRO MUSEU GEOLÓGICO. Detalhe da vitrine temática da coleção mineralógica Krantz.

Figura 194. MUGEO - CENTRO MUSEU GEOLÓGICO. Vitrine com amostras didáticas sobre a importância dos recursos minerais. .243

Figura 195. MUGEO - CENTRO MUSEU GEOLÓGICO. Vitrine com os minerais sistematizados em classes químicas

Figura 196. MUGEO - CENTRO MUSEU GEOLÓGICO. Amostra de Cobre nativo no basalto de localidade histórica em São Simão, SP

Figura 197. MUGEO - CENTRO MUSEU GEOLÓGICO. Amostra de mineral raro hussakita. Espécie desacreditada, na verdade é um xenotímio-(Y). .244

Figura 198. MUGEO - CENTRO MUSEU GEOLÓGICO. Área dedicada a Comissão Geográfica e Geológica de São Paulo

Figura 199. MUGEO - CENTRO MUSEU GEOLÓGICO. Setor lúdico e interativo, onde as oficinas e atividades educativas são realizadas. 244

Figura 200. MUGEO - CENTRO MUSEU GEOLÓGICO. Reserva técnica com diversas amostras sem classificação. 245

Figura 201. MUGEO - CENTRO MUSEU GEOLÓGICO. Detalhe das gavetas da reserva técnica com as amostras desorganizadas e sem nenhuma 
classificação

Figura 202. Museu Alexis Dorofeef. Vitrine com amostras minerais sem classificação sistemática. Bancada com amostras comuns de minerais. Detalhe da janela aberta e entrada de luz solar, melhorando a iluminação da sala, porém prejudicando o acervo mineralógico expositivo.

Figura 203. Museu Alexis Dorofeef. Amostras de tipos de solos do mundo.....249

Figura 204. Museu Alexis Dorofeef. Amostras minerais sem ordenação. 249

Figura 205. Museu Alexis Dorofeef. Amostras minerais sem uma classificação mais específica 250

Figura 206. Museu Alexis Dorofeef. Os minerais estão colocados de forma aleatória, misturando as classes químicas. 250

Figura 207. Museu Alexis Dorofeef. Detalhe das etiquetas pouco Explicativas. .250

Figura 208. Museu Alexis Dorofeef. Detalhe na nomenclatura dos minerais. Somente o nome das variedades sem levar em conta a quais espécies pertencem....... 251

Figura 209. Museu Alexis Dorofeef. Minerais colocados em bancadas sem proteção. 251 


\section{LISTA DE QUADROS}

Quadro 1 - Instituições pesquisadas no Sudeste brasileiro com coleções mineralógicas. 36

Quadro2 - Classificação Química segundo Dana........................................53

Quadro 3 - Classificação Cristaloquímica de Nickel-Strunz...............................55

Quadro 4 - Minerais tipo do Brasil........................................................60

Quadro 5 - Dezesseis espécies minerais brasileiras aprovadas entre 1959 e 2000 seguem sendo válidas - (0,43 por ano)

Quadro 6 - Os 29 novos minerais que foram descritos entre 2004 e 2013 (2,1 por ano).

Quadro 7 - Relação de minerais tipo brasileiros com fotos. .65

Quadro 8 - Instituições pesquisadas no Sudeste brasileiro e os profissionais entrevistados. 103

Quadro 9 - Quadro de minerais tipo brasileiros pertencentes ao acervo do Museu de Minerais e Rochas "Heinz Ebert" com suas respectivas ocorrências (exemplos). 110

Quadro 10 - Quadro de minerais brasileiros pertencentes ao acervo do Museu de Minerais e Rochas "Heinz Ebert" com suas respectivas ocorrências (exemplos) 110

Quadro 11 - Quadro de minerais tipo brasileiros pertencentes ao acervo do Museu da Geodiversidade/UFRJ com suas respectivas ocorrências (exemplos).

Quadro 12 - Quadro de minerais brasileiros pertencentes ao acervo do Museu da Geodiversidade/UFRJ com suas respectivas ocorrências (exemplos). 122

Quadro 13 - Quadro de minerais tipo brasileiros pertencentes ao acervo do Museu de Ciências da Terra do DNPM-RJ, com suas respectivas ocorrências (exemplos).....

Quadro 14 - Quadro de minerais brasileiros pertencentes ao acervo do Museu de Ciências da Terra do DNPM-RJ com suas respectivas ocorrências (exemplos).

Quadro 15 - Quadro de minerais tipo brasileiros pertencentes ao acervo do Museu de Mineralogia de Aitiara, com suas respectivas ocorrências 
(exemplos)

Quadro 16 - Quadro de minerais brasileiros pertencentes ao acervo do Museu de Mineralogia de Aitiara com suas respectivas ocorrências (exemplos). 154

Quadro 17 - Quadro de minerais tipo brasileiros pertencentes ao acervo do Museu de Ciência e Técnica da Escola de Minas, com suas respectivas ocorrências (exemplos).

Quadro 18 - Quadro de minerais brasileiros pertencentes ao acervo do Museu de Ciência e Técnica da Escola de Minas com suas respectivas ocorrências (exemplos).

Quadro 19 - Quadro de minerais tipo brasileiros pertencentes ao acervo do Museu da GEOSOL com suas respectivas ocorrências (exemplos)... 176

Quadro 20 - Quadro de minerais brasileiros pertencentes ao acervo do Museu da GEOSOL com suas respectivas ocorrências (exemplos).

Quadro 21 - Quadro de minerais tipo brasileiros pertencentes ao acervo do Museu das Minas e do Metal com suas respectivas ocorrências (exemplos)....192 Quadro 22 - Quadro de minerais brasileiros pertencentes ao acervo do Museu das Minas e do Metal com suas respectivas ocorrências (exemplos). 192

Quadro 23 - Quadro de minerais brasileiros pertencentes ao acervo do Museu de Mineralogia e Arte Sacra com suas respectivas ocorrências (exemplos). 205

Quadro 24 - Quadro de minerais brasileiros pertencentes ao acervo do Museu Histórico e Geográfico de Poços de Caldas - "Coleção Resk Fraia" com suas respectivas ocorrências (exemplos). 220

Quadro 25 - Quadro de minerais tipo brasileiros pertencentes ao acervo do Museu de Geociências IGc/USP com suas respectivas ocorrências (exemplos). 230

Quadro 26 - Quadro de minerais brasileiros pertencentes ao acervo do Museu de Geociências IGc/USP com suas respectivas ocorrências (exemplos). 231

Quadro 27 - Tópicos de relevância para cada instituição pesquisada, com características, e indicação dos problemas e possíveis soluções. .253 


\section{LISTA DE SIGLAS}

CAPES Coordenação de Aperfeiçoamento de Pessoal de Nível Superior

CCHN Centro de Ciências Humanas e Naturais

CGG Comissão Geográfica e Geológica de São Paulo

CNMNC Commission on New Minerals, Nomenclature and Classification

CNPq Conselho Nacional de Desenvolvimento Científico e Tecnológico

DNPM Departamento Nacional de Produção Mineral

DOC Departamento de Oceanografia

DPS Departamento de Solos

DRM Departamento de Recursos Minerais

EMOP-UFOP Escola de Minas de Ouro Preto-Universidade Federal de Ouro Preto

ESAV Escola Superior de Agricultura e Veterinária do Estado de Minas

Gerais

FAPERJ Fundação de Amparo à Pesquisa do Estado do Rio de Janeiro

FAPESP Fundação de Amparo à Pesquisa do Estado de São Paulo

FUNCULT Fundação Municipal de Cultura, Lazer e Turismo

FUNDAP Fundação de Desenvolvimento Administrativo do Governo de São

Paulo

FNDE Fundo Nacional de Desenvolvimento da Educação

FVD Fundação Victor Dequech

GEOSOL Geologia e Sondagens S/A

GPS Global Positioning System (Sistema de Navegação por Satélite)

ICOM International Concil of Museum - (Conselho Internacional de Museus)

IEPHA Instituto Estadual do Patrimônio Histórico e Artístico

IMA International Mineralogical Association (Associação Mineralógica Internacional)

IBRAM Instituto Brasileiro de Museus

MAST Museu de Astronomia e Ciências Afins

MCT Museu de Ciência e Técnica

MCTAD Museu de Ciências da Terra Alexis Dorofeef

MMM Museu das Minas e do Metal 
PET Programa de Treinamento de Estagiários

ProAc Programa de Ação Cultural

SBG Sociedade Brasileira de Geologia

SISEM Sistema Estadual de Museus

SPHAN Serviço do Patrimônio Histórico e Artístico Nacional

UFES Universidade Federal do Espírito Santo

UFOP Universidade Federal de Ouro Preto

UFRJ Universidade Federal do Rio de Janeiro

UNESP Universidade Estadual Paulista

UNIRIO/MAST Universidade do Rio de Janeiro/Museu de Astronomia e Ciências Afins

USP Universidade de São Paulo

UFV Universidade Federal de Viçosa 


\section{SUMÁRIO}

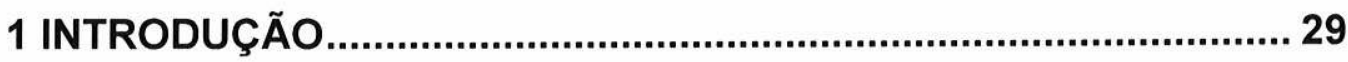

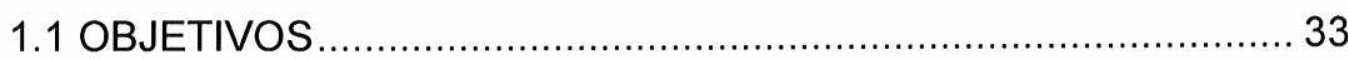

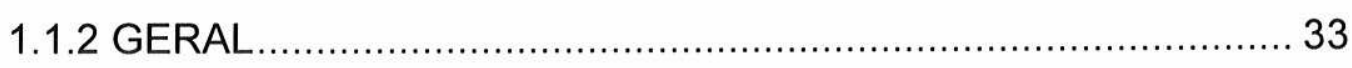

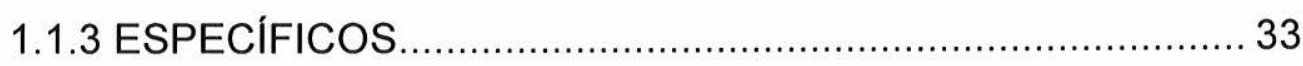

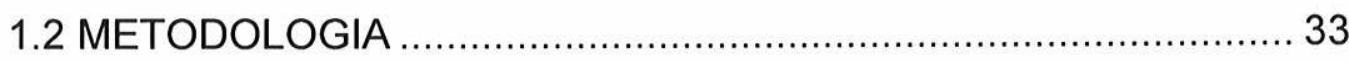

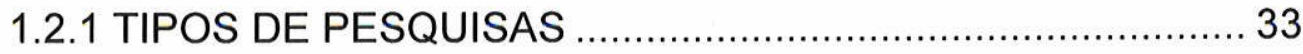

1.2.2 PROCEDIMENTOS TÉCNICOS UTILIZADOS....................... 35

1.2.3 COLETA DE DADOS: MÉTODOS E INSTRUMENTOS.......... 35

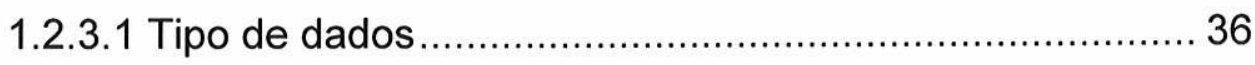

1.2.3.2 Técnicas utilizadas ......................................................... 37

2 CAPÍTULO 1 - A coleção e os colecionadores ...............................40

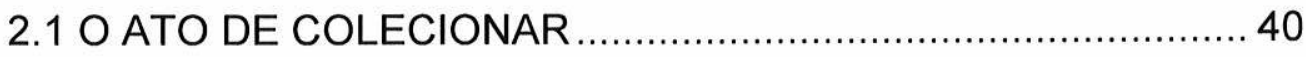

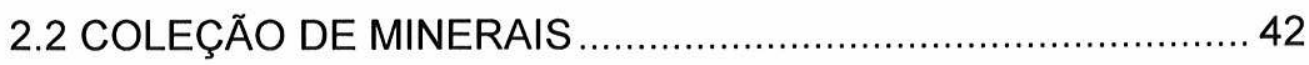

2.2.1 Por que colecionar minerais? ......................................... 42

2.2.2 Como podemos colecionar minerais? .............................. 47

2.3 COLEÇÕES MINERALÓGICAS INSTITUCIONAIS ................... 50

2.4 CLASSIFICAÇÕES DAS COLEÇÕES MINERALÓGICAS......... 51

2.4.1 Classificação por Dana....................................................... 52

2.4.2 Classificação por Strunz ...................................................... 54

3 CAPÍTULO 2 - Os minerais tipo brasileiros e os principais mineralogistas que atuaram no Brasil...........................................5 57

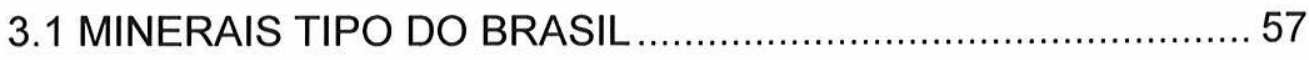

3.2 OS PRINCIPAIS MINERALOGISTAS QUE ATUARAM NO BRASIL 80

4 CAPÍTULO 3 - A história dos museus 87

5 CAPÍTULO 4 - Descritivo histórico e análise individual das instituições pesquisadas. 101 
5.1 Museu de Minerais e Rochas Heinz Ebert........................... 106

5.2 Museu da Geodiversidade/UFRJ ..................................... 118

5.3 Museu Amsterdan Sauer de Minerais Raros e Pedras

Preciosas ......................................................................... 126

5.4 Museu de Ciências da Terra / DNPM .................................. 132

5.5 Museu Nacional ............................................................. 147

5.6 Museu de Mineralogia de Aitiara ......................................... 149

5.7 Museu de Ciências e Técnica da Escola de Minas / UFOP..... 156

5.8 Museu de Mineralogia Vitor Dequech/GEOSOL.................... 172

5.9 Museu das Minas e do Metal ............................................... 186

5.10 Museu de Mineralogia e Arte Sacra................................... 201

5.11 Museu de Minerais e Rochas da UFES ............................. 210

5.1 Museu Histórico e Geográfico de Poços de Caldas

"Coleção Resk Fraia"............................................................ 216

5.13 Museu de Geociências do IGc/USP ................................. 225

5.14 Museu Geológico Valdemar Lefrève - MUGEO ................... 236

5.15 Museu de Ciências da Terra Alexis Dorofeef....................... 246

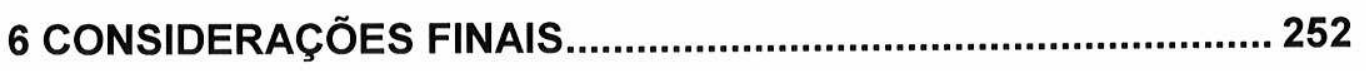

7 REFERÊNCIAS BIBLIOGRÁFICAS ......................................... 259 


\title{
INTRODUÇÃO
}

\begin{abstract}
"As coisas têm peso, massa, volume, tamanho, tempo, forma, cor, posição, textura, duração, densidade, cheiro, valor, consistência, profundidade, contorno, temperatura, função, aparência, preço, destino, idade, sentido. As coisas não têm paz". (ARNALDO ANTUNES, 1998)
\end{abstract}

A maneira como o homem se relaciona com a natureza está ligada ao estágio de desenvolvimento sócio-cultural da humanidade, que deixou como herança os conhecimentos adquiridos da cultura material, sendo estes preservados como documentos históricos (PEREIRA, 2006).

Essa relação está na capacidade de selecionar (separar o que deve ser guardado), estabelecer relacionamentos entre a materialidade e si mesmo, produzir conhecimentos e difundi-los, acumular informações e inserir-se culturalmente em sociedade.

Desde os primórdios do processo da civilização, o homem exerce a capacidade de se relacionar com a natureza e observá-la, coletá-la, tratá-la e, ao guardá-la e protegê-la, estimula a consistência às ideias e práticas do colecionismo; ao mesmo tempo, promove estas coleções para o início dos debates sobre cultura, ciência, poder, hegemonia, colonização, espoliação, tecnologia, biodiversidade, produção científica e artística, o fazer popular, entre muitos outros temas que mobilizam há muito tempo as gerações e grupos de intelectuais (BRUNO, s.d.).

Colecionar e reunir materiais de cunho natural ou cultural faz parte da própria natureza do ser humano, pois se torna imprescindivel para a formação da cultura e do conhecimento do próprio colecionador (NEVES, 1997).

As coleções existem graças aos colecionadores; eles são como "guardas dos tesouros", pois, com sua paixão, proporcionam à história o conhecimento de civilizações, de suas culturas, de onde viemos e como tudo no planeta começou.

O Planeta Terra é todo formado por elementos químicos encontrados de forma ordenada, de acordo com as leis naturais que constituem os minerais. Estudar estas substâncias que formam a matéria, como são formados, o que são e como ocorrem é chamada de Mineralogia, uma área da Geologia.

Os minerais eram vistos como parte dos produtos da natureza. A sua diversidade e o conhecimento de que constituiam as rochas proporcionaram que considerável esforço fosse dedicado à sua coleção, catalogação e nomenclatura. A 
mineralogia como ciência surgiu com o Renascimento e até o início do século $X X$ foi conhecida por História Natural (UNIVERSIDADE ESTADUAL PAULISTA, 2014).

A saída aos mares, os novos interesses econômicos e a descoberta de outras terras e civilizações são algumas das consequências maiores desse fenômeno histórico que, a partir dos séculos XVI e XVII, permitiram o surgimento dos famosos e requisitados "Gabinetes de Curiosidades".

Estes Gabinetes eram salões repletos de coleções dos mais variados e exóticos objetos provenientes dos mais variados lugares do "Novo Mundo". Reis, príncipes, nobres, burgueses e cientistas colecionavam e se dedicavam a estas coleções buscando conservar a memória do mundo desconhecido. Como se cada objeto tivesse uma história pra contar, uma linguagem a ser decifrada. Estudá-los, pesquisá-los e experimentá-los é como unir peças de um quebra-cabeça, pois tudo na natureza está interligado e começa a fazer sentido.

Conforme Guimaraens (2007) o fim do Renascimento, no final do séc. XVII surge o lluminismo, com suas ideias de liberdade do conhecimento, de educação para todos e de igualdade. Assim, surgiram os primeiros museus na Europa, com o objetivo de conservar as coleções doadas, que provinham dos gabinetes de curiosidades. O Ashmolean Museum de Oxford, Inglaterra, é o mais antigo de todos que se tem registro, tendo sido fundado em 1683 (LEWIS, 2004).

O museu é uma instituição permanente, sem fins lucrativos, a serviço da
sociedade e do seu desenvolvimento, aberta ao público e que adquire,
conserva, investiga, difunde e expõe os testemunhos materiais do homem e
de seu entorno, para educação e deleite da sociedade. (INSTITUTO
BRASILEIRO DE MUSEUS, 2013).

A presente dissertação foi desenvolvida com base em pesquisa explicativa, objetivando analisar algumas instituições museológicas que possuem coleções na área da mineralogia, situadas na região sudeste do Brasil, com o delineamento em estudo de caso. Foi feito um levantamento e escolhidos 15 museus nas áreas das geociências.

De forma a enriquecer com conhecimentos variados o corpo teórico utilizado para embasar a presente pesquisa, foram consultadas obras literárias das áreas de Museologia, Mineralogia, Geologia e Educação. Além destas fontes, utilizou-se a biblioteca eletrônica de periódicos científicos brasileiros e sites das instituições pesquisadas. Foram elencados três eixos principais que reforçaram a argumentação 
das pesquisas desenvolvidas nos principais Museus de Ciências da Terra e Ciências Naturais da Região Sudeste Brasileira dissertados no último capítulo do presente trabalho.

O Capítulo 1, A Coleção e os Colecionadores, explica a importância do colecionismo e seu surgimento. No sentido prático da palavra, colecionar significa reunir, juntar, classificar, objetos de mesma categoria ou biotipo/geotipo. Esta é uma atividade praticada desde os primórdios dos tempos, pelas primeiras civilizações humanas.

Além de sua importância cultural, educativa e científica, foi através do ato de colecionar que surgiram os primeiros Gabinetes de Curiosidades e depois em seguida foram formados os primeiros Museus do mundo.

Ênfase foi dada às coleções de minerais. Este trabalho de pesquisa analisa e investiga os diferentes tipos de coleções mineralógicas e todas as características relacionadas a esta atividade.

No Capítulo 2, Os minerais tipo brasileiros e os principais mineralogistas que atuaram no Brasil, foram pesquisados os mineralogistas deste país, de maneira ilustrada e bibliográfica, com toda sua atuação colaborativa para a difusão da Mineralogia, bem como os minerais tipo brasileiros que foram descritos e relatados por estes mesmos cientistas, relacionados no presente trabalho. Grandes cientistas da mineralogia brasileira como José Bonifácio de Andrada e Silva, Claude Henri Gorceix, Eugene Hussak, Djalma Guimarães, Octavio Barbosa, Rui Ribeiro Franco, entre outros.

O Capítulo 3, A História dos Museus, apresenta a Instituição Museu, e seu surgimento histórico mundial, que se inicia nos tempos remotos da Grécia Antiga, com os Templos das Musas onde se origina a palavra Museu (Mouseion). Trata-se de uma viagem pelo tempo, que apresenta historicamente, o desenvolvimento cultural da sociedade e finaliza com a criação dos museus brasileiros e sua importância educacional, cultural, científica e econômica para o país, dando maior destaque aos museus naturalistas.

No Capítulo 4, Descritivo Histórico e Análise Individual das Instituições Pesquisadas, estão relacionadas as 15 instituições, que foram analisadas com base no levantamento de informações históricas, organização estrutural, ação educativa e cultural, e principalmente, sobre o acervo mineralógico em sua exposição, conservação, utilização e relevância para a mineralogia brasileira. As descrições 
foram baseadas nos questionários e entrevistas realizados com alguns diretores, curadores, coordenadores e atendentes dos museus, que se prontificaram em colaborar com esta pesquisa.

Com o objetivo de revelar a grande diversidade de tipos de museus que contêm coleções mineralógicas, foram selecionados diversos perfis de museus, desde os que funcionam por iniciativa privada como o Museu de Mineralogia Aitiara em Botucatu - SP, como museus públicos centenários onde se inclui o Museu de Ciências da Terra do Departamento Nacional de Produção Mineral (DNPM), além de outros de grande importância para a mineralogia no Brasil, como o Museu de Ciência e Técnica da Escola de Minas de Ouro Preto, fundado por Claude Henry Gorceix ${ }^{1}$, a pedido do Imperador D. Pedro II.

Existem os museus que foram criados pelos esforços de professores universitários, se tornando referência no Brasil como o Museu de Geociências da Universidade de São Paulo (USP), os de caráter misto (público/privado) como o Museu das Minas e do Metal (MMM), e até museus criados por empresas, com intuito comercial, sem registro de museu e que possui coleções expressivas para a mineralogia brasileira como o Museu de Mineralogia da empresa de Geologia e Sondagens S/A (GEOSOL).

$\mathrm{Na}$ maior parte dos museus mineralógicos visitados, a classificação dos minerais se dá segundo Dana ou Strunz, que classificam os minerais de acordo com a classe química (composição química do mineral). Em alguns casos, as coleções mineralógicas estão expostas segundo a beleza estética, por seu tamanho e beleza que chamam a atenção do público como o Museu Amsterdam Sauer. Existem também, coleções fechadas por alguma temática específica, como a coleção estrangeira do famoso comerciante europeu Krantz que se encontra no Centro Museu Geológico em São Paulo.

Pretende-se que este trabalho proporcione reflexões e diretrizes aos profissionais que atuam nestes museus, para que com pequenas condutas, e algumas reformulações, possam valorizar as riquezas que se encontram depositadas em suas instituições.

\footnotetext{
${ }^{1}$ Geólogo francês convidado por D. Pedro II a ser um dos principais responsáveis pela geologia do Brasil e criação da Escola de Minas em Ouro Preto.
} 


\subsection{OBJETIVOS}

\subsubsection{GERAL}

Analisar Museus de Ciências da Terra e Ciências Naturais da região do sudeste brasileiro, em específico seus acervos mineralógicos, no que tange a exposição ao público, a difusão da mineralogia brasileira e o estado de conservação das coleções.

\subsubsection{ESPECÍFICOS}

- Investigar e avaliar as principais amostras de suas coleções didático-científicas pela importância desses exemplares para a memória da Mineralogia no Brasil;

- Revelar a grande diversidade de tipos de museus que contêm coleções mineralógicas na região Sudeste do Brasil;

- Observar e analisar o que as instituições (públicas e privadas) estão fazendo na prática para divulgar a importância dos recursos minerais e da mineralogia no país, quais atividades científicas e educacionais essas instituições estão desenvolvendo com o público em geral, dentro de suas ações educativas, como: oficinas de identificação de rochas e minerais; palestras; cursos; visitas guiadas a minerações; descrição de minerais; pesquisa de campo; coleta de amostras; doação de kits de rochas e minerais para escolas, entre outros;

- Pesquisar, investigar e documentar o papel dessas instituições para a memória da Mineralogia no Brasil;

- Desenvolver um levantamento dos principais problemas de cada instituição visitada e analisada, bem como relacionar as possíveis soluções para cada uma.

\subsection{METODOLOGIA}

\subsubsection{TIPOS DE PESQUISAS}


A presente dissertação foi desenvolvida com base em pesquisa explicativa, objetivando uma melhor compreensão sobre o tema abordado neste trabalho. Segundo Gil (2008), a pesquisa explicativa tem como objetivo primordial identificar fatores que determinam ou que contribuem para a ocorrência de fenômenos. Este tipo de pesquisa é a que mais aprofunda o conhecimento da realidade e, por isso mesmo, está embasada em métodos experimentais.

Foram escolhidos os procedimentos metodológicos para conduzir a pesquisa. O delineamento de pesquisa bibliográfica foi desenvolvido com livros, periódicos e trabalhos científicos, de forma a enriquecer com conhecimentos variados o corpo teórico utilizado para embasar a presente pesquisa nas áreas de Mineralogia, Museologia, Ciências, História e Educação.

Todo o material selecionado foi resenhado e revisado, sendo a leitura, releitura, interpretação e elaboração de resenha com as informações relevantes e apropriadamente explicadas em seu contexto.

Dos artigos resenhados, extraíram-se todas as informações mais importantes concernentes aos temas abordados no presente estudo, que colaboraram para o enriquecimento do conhecimento aplicado.

Grande parte da pesquisa desenvolvida sobre os mineralogistas que atuaram no Brasil foram baseados na publicação de Rui Ribeiro Franco no livro "História das Ciências no Brasil", mais precisamente no capítulo A Mineralogia e a Petrologia no Brasil.

Foram consultados os principais trabalhos publicados pela pesquisadora Maria Margaret Lopes, que é livre docente nas áreas das geociências e publicou diversos trabalhos com foco na história das ciências da terra no Brasil. Sua tese de mestrado, bem como publicações em periódicos científicos e livros, embasaram a estrutura dissertativa do capítulo que remete à história dos museus.

Também foi analisado o compêndio Museus - dos Gabinetes de Curiosidades à Museologia Moderna, uma fonte de pesquisa muito utilizada devido ao assunto pertinente ao tema do estudo. Analisando outras publicações de mestrado, foi possível constatar que esta publicação é muito bem referenciada, principalmente pela autora Helga Possas, no artigo Classificar e ordenar: os gabinetes de curiosidade e a história natural. 


\subsubsection{PROCEDIMENTOS TÉCNICOS UTILIZADOS}

O delineamento principal desta pesquisa foi o estudo de caso que, na definição de Yin (1987), é o mais adequado ao examinarmos eventos contemporâneos cujo comportamento que se deseja mensurar não pode ser manipulado. O estudo de caso é uma investigação empírica que estuda o fenômeno contemporâneo em seu contexto real, onde avaliamos a situação atual.

- O problema da pesquisa: o objetivo principal do estudo de caso é tecer, com base no objeto de análise, generalizações teóricas que consolidem um modelo. Uma revisão que siga a ordem teoria - dados - teoria auxiliará nesse propósito;

- Nível de controle que o pesquisador possui sobre os eventos: no método em questão, o pesquisador não pode manipular eventos e comportamentos;

- Foco temporal da pesquisa: por não permitir o controle dos eventos, o método somente pode ser aplicado a estudos de fenômenos contemporâneos e suas variadas fontes de evidência.

A escolha da abordagem estudo de caso atende às características acima descritas: revisou-se constantemente a conformidade entre os dados coletados e a literatura utilizada como referência para a interpretação; os resultados qualitativos não podem ser separados do contexto onde se originaram, mas agregam conhecimento a um corpo teórico existente.

\subsubsection{COLETA DE DADOS: MÉTODOS E INSTRUMENTOS}

\subsubsection{Tipo de dados}

Os dados coletados são de natureza qualitativa, que se caracteriza por um maior foco na compreensão dos fatos do que propriamente na sua mensuração. Nas palavras de Vianna (2001, p. 122), 
(. . . ) na pesquisa qualitativa, você analisará cada situação a partir de dados descritivos, buscando identificar relações, causas, efeitos, consequências, opiniões, significados, categorias e outros aspectos considerados necessários à compreensão da realidade estudada e que, geralmente, envolve múltiplos aspectos.

Dessa forma, buscaram-se dados de natureza primária, secundária e terciária:

a) Primária: seleção dos museus com o perfil escolhido no presente trabalho;

b) Secundária: informações extraídas de questionários respondidos em meio eletrônico e das entrevistas realizadas com os responsáveis dos museus selecionados;

c) Terciária: revisão bibliográfica de publicações referentes à temática, informações extraídas de documentos oficiais, publicações e website das instituições selecionadas.

\subsubsection{Técnicas utilizadas}

Realizada a compilação da literatura referente aos conceitos empregados no presente trabalho, passou-se às seguintes etapas da pesquisa:

a) Seleção de museus de ciências naturais e ciências da terra na região sudeste, que possuem acervos mineralógicos;

A Quadro 1 relaciona os museus visitados, datas das visitas e setores pesquisados:

Quadro 1 - Instituições pesquisadas no Sudeste brasileiro com coleções mineralógicas.

\begin{tabular}{|c|c|c|c|c|}
\hline $\begin{array}{c}\text { MUSEU } \\
\text { PESQUISA } \\
\text { DO }\end{array}$ & $\begin{array}{l}\text { INSTITUIÇÃO } \\
\text { GESTORA }\end{array}$ & LOCALIZAÇẪO & $\begin{array}{l}\text { PERÍODO } \\
\text { DA VISITA }\end{array}$ & ENTREVISTADO \\
\hline $\begin{array}{c}\text { Museu de } \\
\text { Minerais e } \\
\text { Rochas } \\
\text { Heinz } \\
\text { Ebert }\end{array}$ & $\begin{array}{c}\text { UNESP } \\
\text { Depto. de } \\
\text { Petrologia e } \\
\text { Metalogenia } \\
\text { Instituto de } \\
\text { Geociências } \\
\text { e Ciências } \\
\text { Exatas }\end{array}$ & $\begin{array}{c}\text { Universidade } \\
\text { Estadual } \\
\text { Paulista } \\
\text { Av. 24-A, 1515 - } \\
\text { 13506-900 -Rio } \\
\text { Claro (SP). }\end{array}$ & $\begin{array}{l}\text { Julho } \\
2012\end{array}$ & $\begin{array}{c}\text { Curador do } \\
\text { Museu Prof. } \\
\text { Antenor } \\
\text { Zanardo. }\end{array}$ \\
\hline $\begin{array}{l}\text { Museu da } \\
\text { Geodiversi } \\
\text { dade }\end{array}$ & $\begin{array}{c}\text { UFRJ- } \\
\text { Universidade } \\
\text { Federal do } \\
\text { Rio de } \\
\text { Janeiro }\end{array}$ & $\begin{array}{c}\text { Centro de } \\
\text { Ciências } \\
\text { Matemáticas e } \\
\text { da Natureza no } \\
\text { Instituto de }\end{array}$ & $\begin{array}{l}\text { Julho } \\
2012\end{array}$ & $\begin{array}{c}\text { Museóloga } \\
\text { Aline Rocha de } \\
\text { Souza F. de } \\
\text { Castro. }\end{array}$ \\
\hline
\end{tabular}




\begin{tabular}{|c|c|c|c|c|}
\hline & $\begin{array}{l}\text { Instituto de } \\
\text { Geociências } \\
\text { Depto.de } \\
\text { Geologia }\end{array}$ & $\begin{array}{c}\text { Geociências } \\
\text { Av.: Athos da } \\
\text { Silveira Ramos, } \\
\text { 274, Cidade } \\
\text { Universitária - } \\
\text { Ilha do Fundão } \\
\text { Rio de Janeiro, } \\
\text { RJ. }\end{array}$ & & \\
\hline $\begin{array}{l}\text { Museu } \\
\text { Amsterdam } \\
\text { Sauer de } \\
\text { Minerais } \\
\text { Raros e }\end{array}$ & $\begin{array}{l}\text { Amsterdam } \\
\text { Sauer }\end{array}$ & $\begin{array}{c}\text { Rua Garcia } \\
\text { D`Ávila } 105, \text { em } \\
\text { Ipanema, Rio de } \\
\text { Janeiro }\end{array}$ & $\begin{array}{l}\text { Julho } \\
2012\end{array}$ & $\begin{array}{c}\text { Promotor de } \\
\text { Vendas Richard } \\
\text { Carvalho. } \\
\text { (contato } \\
\text { telefônico) }\end{array}$ \\
\hline $\begin{array}{c}\text { Pedras } \\
\text { Preciosas }\end{array}$ & & & & \\
\hline $\begin{array}{l}\text { Museu de } \\
\text { Ciências } \\
\text { da Terra }\end{array}$ & $\begin{array}{c}\text { DNPM - } \\
\text { Departament } \\
\text { o Nacional de } \\
\text { Pesquisa } \\
\text { Mineral. }\end{array}$ & $\begin{array}{c}\text { Av.: Pasteur, } \\
404 \text { - Urca } \\
\text { Rio de Janeiro, } \\
\text { RJ. }\end{array}$ & $\begin{array}{l}\text { Julho } \\
2012\end{array}$ & $\begin{array}{c}\text { Chefe de } \\
\text { Divisão } \\
\text { Diógenes de } \\
\text { Almeida } \\
\text { Campos. }\end{array}$ \\
\hline $\begin{array}{l}\text { Museu } \\
\text { Nacional }\end{array}$ & $\begin{array}{l}\text { Universidade } \\
\text { Federal do } \\
\text { Rio de } \\
\text { Janeiro }\end{array}$ & $\begin{array}{c}\text { Quinta da Boa } \\
\text { Vista, s/n - São } \\
\text { Cristóvão, } \\
\text { Rio de Janeiro, } \\
\text { RJ. }\end{array}$ & $\begin{array}{l}\text { Julho } \\
2012\end{array}$ & $\begin{array}{c}\text { Não houve } \\
\text { atendimento } \\
\text { Acervo } \\
\text { mineralógico em } \\
\text { reserva técnica. }\end{array}$ \\
\hline $\begin{array}{l}\text { Museu de } \\
\text { Mineralo- } \\
\text { gia Aitiara }\end{array}$ & $\begin{array}{c}\text { Associação } \\
\text { Amigos do } \\
\text { Museu Aitiara }\end{array}$ & $\begin{array}{c}\text { Rodovia Gastão } \\
\text { Dal Farra, km } 4 \\
\text { Demétria } \\
\text { Botucatu, SP. }\end{array}$ & $\begin{array}{c}\text { Agosto } \\
2012\end{array}$ & $\begin{array}{c}\text { Diretora } \\
\text { Berenice } \\
\text { Pereira } \\
\text { Balsalobre. } \\
\end{array}$ \\
\hline $\begin{array}{l}\text { Museu de } \\
\text { Ciência } \\
\text { e Técnica } \\
\text { da Escola } \\
\text { de Minas }\end{array}$ & $\begin{array}{l}\text { UFOP - } \\
\text { Universidade } \\
\text { Federal de } \\
\text { Ouro Preto. }\end{array}$ & $\begin{array}{c}\text { Praça } \\
\text { Tiradentes, } 20- \\
\text { Centro } \\
\text { Ouro Preto, MG. }\end{array}$ & $\begin{array}{c}\text { Novembro, } \\
2013\end{array}$ & $\begin{array}{l}\text { Diretora Maria } \\
\text { Paula Delício. }\end{array}$ \\
\hline $\begin{array}{l}\text { Museu de } \\
\text { Mineralo- } \\
\text { gia Victor } \\
\text { Dequech }\end{array}$ & GEOSOL & $\begin{array}{c}\text { Rua São } \\
\text { Vicente, } 255 \text { - } \\
\text { Olhos D'água, } \\
\text { Belo Horizonte } \\
\text { Minas Gerais. }\end{array}$ & $\begin{array}{c}\text { Novembro, } \\
2013\end{array}$ & $\begin{array}{c}\text { Estagiário de } \\
\text { Geologia } \\
\text { Gabriel } \\
\text { Teodoro. }\end{array}$ \\
\hline $\begin{array}{l}\text { Museus } \\
\text { das Minas } \\
\text { e do Metal }\end{array}$ & $\begin{array}{l}\text { Governo do } \\
\text { Estado de } \\
\text { MG / Grupo } \\
\text { GERDAL }\end{array}$ & $\begin{array}{c}\text { Praça da } \\
\text { Liberdade, s/n. } \\
\text { Centro, Belo } \\
\text { Horizonte - } \\
\text { Minas Gerais. }\end{array}$ & $\begin{array}{c}\text { Novembro, } \\
2013\end{array}$ & $\begin{array}{c}\text { Curadora } \\
\text { Márcia Regina } \\
\text { Carvalho dos } \\
\text { Santos } \\
\text { Guimarães. }\end{array}$ \\
\hline $\begin{array}{l}\text { Museu de } \\
\text { Mineralo- } \\
\text { gia e de } \\
\text { Arte Sacra }\end{array}$ & $\begin{array}{l}\text { Prefeitura } \\
\text { Municipal de } \\
\text { Congonhas } \\
\text { FUNCULT - } \\
\text { Fundação }\end{array}$ & $\begin{array}{c}\text { Alameda } \\
\text { Cidade } \\
\text { Matozinhos de } \\
\text { Portugal, 153, } \\
\text { Basílica }\end{array}$ & $\begin{array}{c}\text { Novembro, } \\
2013\end{array}$ & $\begin{array}{l}\text { Atendentes } \\
\text { Guilherme } \\
\text { Souza Costa } \\
\text { Filho e Gláucio } \\
\text { Andrade de }\end{array}$ \\
\hline
\end{tabular}




\begin{tabular}{|c|c|c|c|c|}
\hline & $\begin{array}{c}\text { Municipal de } \\
\text { Cultura, } \\
\text { Lazer e } \\
\text { Turismo }\end{array}$ & $\begin{array}{c}\text { Congonhas, } \\
\text { MG. }\end{array}$ & & Jesus. \\
\hline $\begin{array}{c}\text { Museu de } \\
\text { Minerais e } \\
\text { Rochas da } \\
\text { Universida- } \\
\text { de Federal } \\
\text { do Espírito } \\
\text { Santo }\end{array}$ & $\begin{array}{c}\text { UFES - } \\
\text { Universidade } \\
\text { Federal do } \\
\text { Espírito } \\
\text { Santo } \\
\text { Centro de } \\
\text { Ciências } \\
\text { Humanas e } \\
\text { Naturais } \\
\text { Instituto de } \\
\text { Geociências }\end{array}$ & $\begin{array}{c}\text { Av. Fernando } \\
\text { Ferrari, 514 - } \\
\text { Goiabeiras, } \\
\text { Vitória - Espírito } \\
\text { Santo. No } \\
\text { prédio IC-II, } 2^{\circ} \\
\text { andar do } \\
\text { Departamento } \\
\text { de } \\
\text { Oceanografia. } \\
\text { Centro de } \\
\text { Ciências } \\
\text { Humanas e } \\
\text { Naturais - } \\
\text { CCHN - UFES. }\end{array}$ & $\begin{array}{c}\text { Dezembro } \\
2013\end{array}$ & $\begin{array}{c}\text { Coordenador } \\
\text { do Museu } \\
\text { Professor Luiz } \\
\text { Machado Filho. }\end{array}$ \\
\hline $\begin{array}{c}\text { Museu } \\
\text { Histórico e } \\
\text { Geográfico } \\
\text { de Poços } \\
\text { de Caldas } \\
\text { "Coleção } \\
\text { de } \\
\text { Minerais } \\
\text { Resk } \\
\text { Frayha" }\end{array}$ & $\begin{array}{c}\text { Prefeitura } \\
\text { Municipal de } \\
\text { Poços de } \\
\text { Caldas } \\
\text { Secretaria de } \\
\text { Cultura e } \\
\text { Turismo }\end{array}$ & $\begin{array}{c}\text { Praça Martinho } \\
\text { de Freitas } \\
\text { Mourão, Poços } \\
\text { de Caldas, MG. }\end{array}$ & $\begin{array}{c}\text { Dezembro, } \\
2013\end{array}$ & $\begin{array}{c}\text { Coordenador de } \\
\text { Divisão Haroldo } \\
\text { Paes Gessoni. }\end{array}$ \\
\hline $\begin{array}{l}\text { Museu de } \\
\text { Geociên- } \\
\text { cias } \\
\text { IGc/USP }\end{array}$ & $\begin{array}{l}\text { Instituto de } \\
\text { Geociências } \\
\text { da USP }\end{array}$ & $\begin{array}{c}\text { Universidade } \\
\text { Estadual de São } \\
\text { Paulo } \\
\text { Rua do Lago, } \\
562 \text { - Cidade } \\
\text { Universitária } \\
\text { São Paulo, SP }\end{array}$ & $\begin{array}{c}\text { Dezembro } \\
2013\end{array}$ & $\begin{array}{l}\text { Chefe Técnico } \\
\text { Ideval Souza } \\
\text { Costa. }\end{array}$ \\
\hline $\begin{array}{c}\text { Museu } \\
\text { Geológico } \\
\text { Valdemar } \\
\text { Lefèvre } \\
\text { (MUGEO) }\end{array}$ & $\begin{array}{c}\text { Instituto } \\
\text { Geográfico e } \\
\text { Geológico } \\
\text { Secretaria do } \\
\text { Meio } \\
\text { Ambiente do } \\
\text { Governo do } \\
\text { Estado de SP }\end{array}$ & $\begin{array}{c}\text { Av. Francisco } \\
\text { Matarazzo, } 455 \\
\text { - Parque da } \\
\text { Água Branca - } \\
\text { Perdizes, São } \\
\text { Paulo - SP. }\end{array}$ & $\begin{array}{c}\text { Janeiro } \\
2014\end{array}$ & $\begin{array}{c}\text { Diretor do } \\
\text { Museu } \\
\text { Fernando Alves } \\
\text { Pires. }\end{array}$ \\
\hline $\begin{array}{l}\text { Museu de } \\
\text { Ciências } \\
\text { da Terra }\end{array}$ & $\begin{array}{l}\text { Departament } \\
\text { o de Solos da } \\
\text { Universidade }\end{array}$ & $\begin{array}{c}\text { Vila Giannetti, } \\
\text { casa } 31 \text { - } \\
\text { Campus }\end{array}$ & $\begin{array}{c}\text { Janeiro, } \\
2014\end{array}$ & $\begin{array}{c}\text { Estagiária } \\
\text { Fernanda } \\
\text { Márcia Souza. }\end{array}$ \\
\hline
\end{tabular}




\begin{tabular}{|c|c|c|}
\hline $\begin{array}{c}\text { Alexis } \\
\text { Dorofeef }\end{array}$ & $\begin{array}{c}\text { Federal de } \\
\text { Viçosa }\end{array}$ & $\begin{array}{c}\text { da Universidade } \\
\text { Federal de } \\
\text { Viçosa, Viçosa, } \\
\text { MG. }\end{array}$ \\
\hline
\end{tabular}

b) Pesquisa nos websites das instituições para realização dos contatos e posteriores agendamentos das visitas;

c) Realização das visitas às instituições, com análise de observação do atendimento e do espaço, registro fotográfico, bem como a aplicação dos questionários com os responsáveis nos setores.

Vale ressaltar que o questionário não é um instrumento de pesquisa eficiente, a não ser quando aplicado a um grupo de informantes altamente selecionados (GOODE, 1952) o que legitima a utilização desse instrumento para a obtenção de informações objetivas. Ainda segundo o autor, é um instrumento muito útil para certas situações nas quais os informantes e suas instituições estão geograficamente muito dispersos, assim sua colocação se aplica ao caso, por ser em toda região Sudeste do Brasil.

Quanto aos dados coletados, foram descritos por instituição no capítulo 4 desta pesquisa; como os procedimentos foram desenvolvidos no período de junho de 2012 a janeiro de 2014, poderão apresentar alguns dados defasados. 


\section{CAPÍTULO 1 - A COLEÇÃO E OS COLECIONADORES}

\subsection{O ATO DE COLECIONAR}

Desde os primórdios do processo da civilização, o homem exerce a capacidade de se relacionar com a natureza e observá-la, coletá-la, tratá-la e, ao guardá-la e protegê-la, estimula a consistência às ideias e práticas do colecionismo e, ao mesmo tempo, promove estas coleções para o início dos debates sobre cultura, ciência, poder, hegemonia, colonização, espoliação, tecnologia, biodiversidade, produção científica e artística, o fazer popular, entre muitos outros temas que mobilizam há muito tempo as gerações e grupos de intelectuais que se dedicam sobre estas questões e assim delas desenvolvem programas de ensino e pesquisa para constituírem os museus (BRUNO, s.d.).

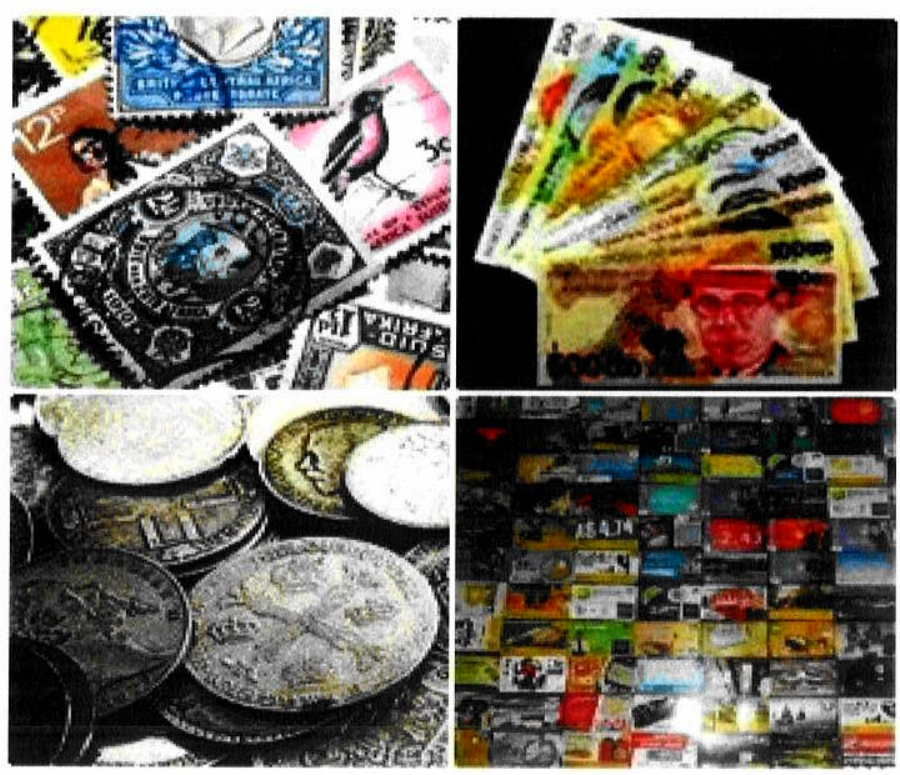

Figura 1. Ilustrando Coleções de Numismática e Filatelia.

Fonte:http://blog.correios.com.br/filatelia/encontro-de-colecionadores-em-belo-horizonte/

Colecionar e reunir materiais de cunho natural ou cultural faz parte da própria natureza do ser humano, pois se torna imprescindível para formação da cultura e do conhecimento do próprio colecionador (NEVES,1997). Nos dicionários da língua portuguesa a palavra coleção significa reunir objetos da mesma natureza, compilação, ajuntamento. 
Essa atividade remonta desde os primórdios dos tempos com registro de homens primitivos chamados de "Caçadores e Coletores", onde foram constatados e observados, por artefatos arqueológicos e ossadas encontradas associadas a diversos materiais como adornos e utensílios. Levou-se em conta que esses homens primitivos separavam rochas, conchas, sementes, dentes, ossos, entre outros materiais em suas cavernas ou moradias, muitas vezes dando status de superioridade e demonstrando liderança e hierarquia dentro de seu grupo, assim como esses materiais eram muito úteis para se produzirem ferramentas e muitas vezes eles apenas separavam e guardavam os objetos por curiosidade, sendo atraídos por sua beleza e formas curiosas (COLEÇÃO DE MINERAIS, 2009).

Em alguma fase do desenvolvimento humano, principalmente na infância, ainda que sem nenhuma metodologia específica de organização ou sistematização, muitas pessoas acabam guardando, ajuntando e colecionando alguns objetos, que podem ser desde uma lembrança de uma viagem até o presente de alguém especial (LOPES, J. 2010).

Colecionar não é apenas juntar. Uma coleção, seja do que for, deve ser um conjunto de peças bem classificadas e ordenadas. Quem assim não fizer não será propriamente um colecionador, mas apenas um ajuntador.

[...] uma coleção, isto é, qualquer conjunto de objetos naturais ou artificiais, mantido temporariamente ou definitivamente fora do circuito das atividades econômicas, sujeitos a uma proteção especial num local fechado preparado para esse fim, e exposto ao olhar do público (Pomian, 1984, p. 53).

Ser um colecionador pode contribuir para enriquecer o conhecimento geral, tanto científico, quanto cultural dos seres humanos. Colecionar dinheiro (cédulas e moedas), selos e cartões postais, conchas, chaveiros, miniaturas, discos, figurinhas, caixas de fósforo, etc. são alguns dos muitos tipos de colecionismos que existem, e dos mais "colecionáveis" desde os princípios dos tempos. De acordo com Benjamim (1984, p.79-80), é na infância que o ser humano começa a ampliar sua percepção do todo, que por sua curiosidade nata, constrói e desconstrói seu mundo pelo ato de organizar objetos:

"Toda pedra que ela encontra, toda flor colhida e toda borboleta apanhada é, para ela, já o começo de uma coleção e tudo aquilo que possui representa-lhe uma única coleção. Na criança, essa paixão revela seu verdadeiro rosto[...]" 


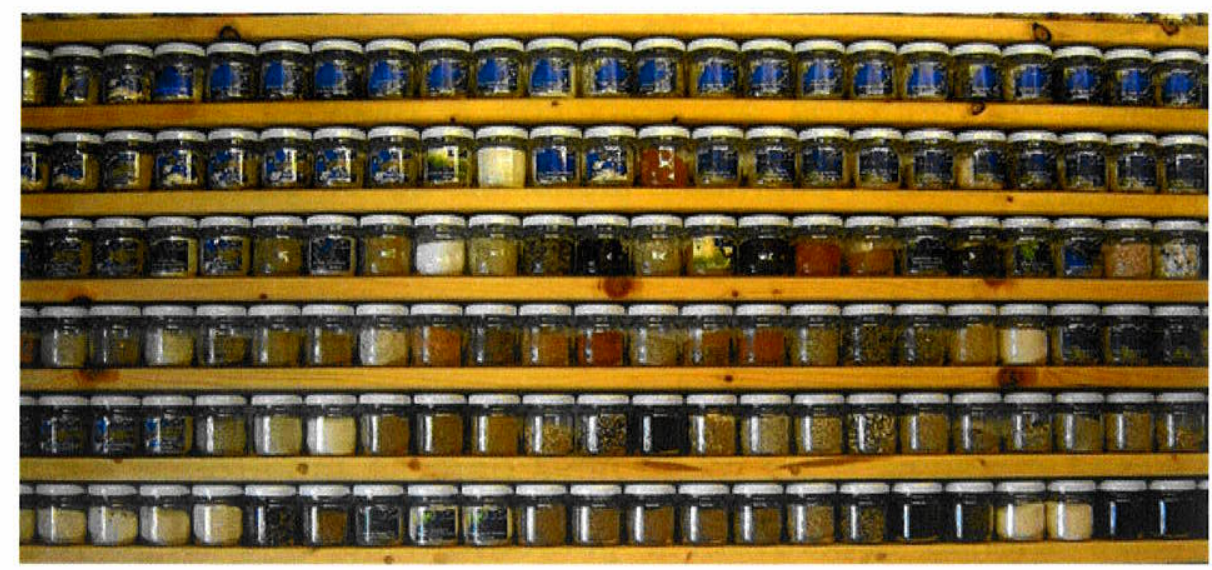

Figura 2. Coleção de Areias do Mundo (Arenofilia). Fonte: http://www.sand-atlas.com/en/yetanother-sand-collector/

As coleções de minerais e seus respectivos colecionadores, mesmo que nessas últimas décadas estejam crescendo, ainda são pouco expressivas, perto de outros itens colecionáveis, como selos, cédulas e moedas, principalmente no Brasil. Um dos motivos deve-se a ser um hobby muito caro e com um nível de especialidade e conhecimento científico muito específico. Não existe ainda um registro de uma nomenclatura específica para o ato de se colecionar minerais ou materiais correlatos de origem geológica (rochas, fósseis etc), o mais próximo disso está no ato de se colecionar areias que se chama de arenofilia.

\subsection{COLEÇÃO DE MINERAIS}

\subsubsection{Por que colecionar minerais?}

Os minerais, por definição, são compostos químicos de um ou mais tipos de e elementos, sólidos, naturais, inorgânicos, formados por processos geológicos tanto na Terra, quanto em corpos extraterrestres, e possuem uma composição química definida dentro de certos limites, com estrutura cristalina ordenada, o que acarreta características físico-químicas que os caracterizam, como cor, brilho, dureza, densidade, traço, hábito cristalino, entre outros (NEVES, 2003). 


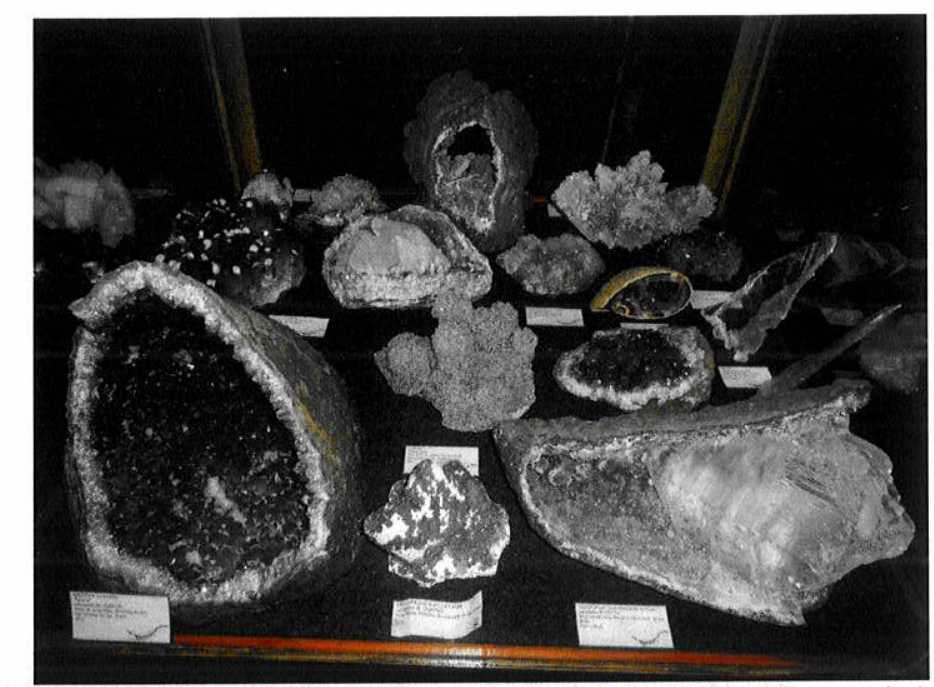

Figura 3. Minerais formados em cavidades de rochas vulcânicas Fonte: Paulo Anselmo Matioli.

Atualmente, são conhecidas cerca de 5.000 espécies minerais válidas segundo a Associação Mineralógica Internacional (IMA) e cerca de 130 novas espécies são descritas e acrescidas nesta lista nos últimos anos, devido às pesquisas de mineralogistas e geólogos em todo o mundo.

Os exemplares minerais são objetos da natureza altamente colecionáveis, pois, em geral não se deterioram facilmente (são constituídos por elementos químicos, que são mais duráveis que qualquer coisa produzida pelo homem), são comumente muito coloridos, estéticos, com suas formas curiosas e de beleza incomparável. Esta é uma das atividades mais lúdicas, interessantes e científicas que existe, pois colecionar minerais é obter um pedacinho de toda base da história da criação e formação de nosso planeta e do Sistema Solar, pois é geralmente comum colecionadores de minerais também possuírem em suas coleções amostras de meteoritos (rochas provenientes do espaço).

Segundo Neves (1997), um dos mais importantes mineralogistas norteamericanos, Frederick H. Pough ${ }^{2}$ (1906-2006) relata que entre as ciências básicas, somente a mineralogia é um agradável passatempo educativo, cultural e científico, pois, além de ser um hobby, é uma atividade científica multidisciplinar, que combina conhecimentos importantes de ciências como a Química, Física, Matemática, e ainda podem-se incluir, outras áreas do conhecimento como a Geografia, a História e o Turismo.

\footnotetext{
${ }^{2}$ Pough, descreveu e batizou uma nova espécie mineral em homenagem ao Brasil, chamado brazilianita, um hidroxifosfato de sódio e alumínio, encontrado no pegmatito de Córrego Frio, no distrito de Linópolis, pertencente ao município de Divino das Laranjeiras, no estado de Minas Gerais (na época o nome do país se escrevia com " $z$ " e não com "s")
} 
Ao pesquisar e coletar minerais, tanto para a pesquisa científica quanto para as coleções particulares, os colecionadores, sejam eles especialistas na área ou não, estão sempre querendo aumentar os seus acervos mineralógicos, passando a visitar os mais remotos e longínquos locais do planeta sempre em busca de novidades e raridades, além de se orientarem muitas vezes através de Global Position in System ${ }^{3}$ (GPS) e mapas, relacionando, assim, as localidades onde os minerais são encontrados e em muitas vezes desenvolvendo os planos de viagem com base em quais minerais conseguirão coletar.

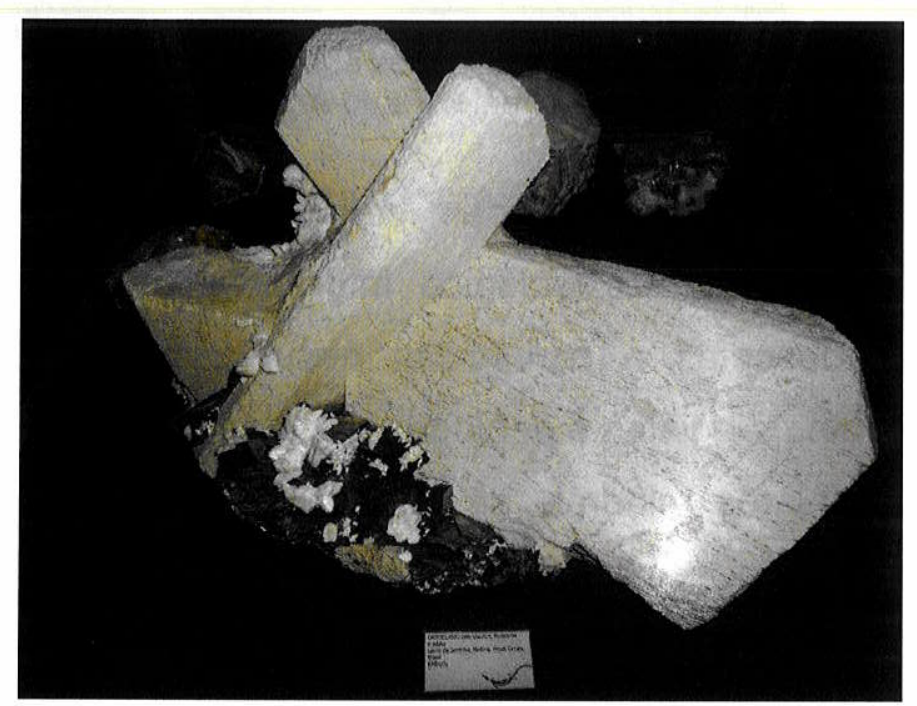

Figura 4. Ortoclásio com muscovita, albita e quartzo. Fonte: Paulo Anselmo Matioli.

Todos os anos, novos minerais são descobertos e colecioná-los se torna um grande desafio para seus colecionadores. Principalmente os que são sistemáticos, pois são aqueles que querem obter todas as espécies descritas no mundo, uma tarefa impraticável que ninguém obteve até hoje.

De uma forma geral, colecionar minerais, por sua diversidade e abundância, é um hobby muito comum em países como os Estados Unidos, Canadá, Alemanha, Itália, Espanha, França, Inglaterra, Noruega, Rússia, Austrália, Japão, entre outros. No Brasil, são poucas as pessoas que se interessam por colecionar minerais, mesmo o país sendo um dos principais produtores de minerais gemas e minerais de coleção do mundo. Porém, com as novas tecnologias, como a internet, esta área de colecionismo cresceu bastante nos últimos anos, e realizar intercâmbios com colecionadores de outros países ficou mais interessante, informativo e rápido.

\footnotetext{
${ }^{3}$ Tradução: Sistema de Navegação por Satélite
} 


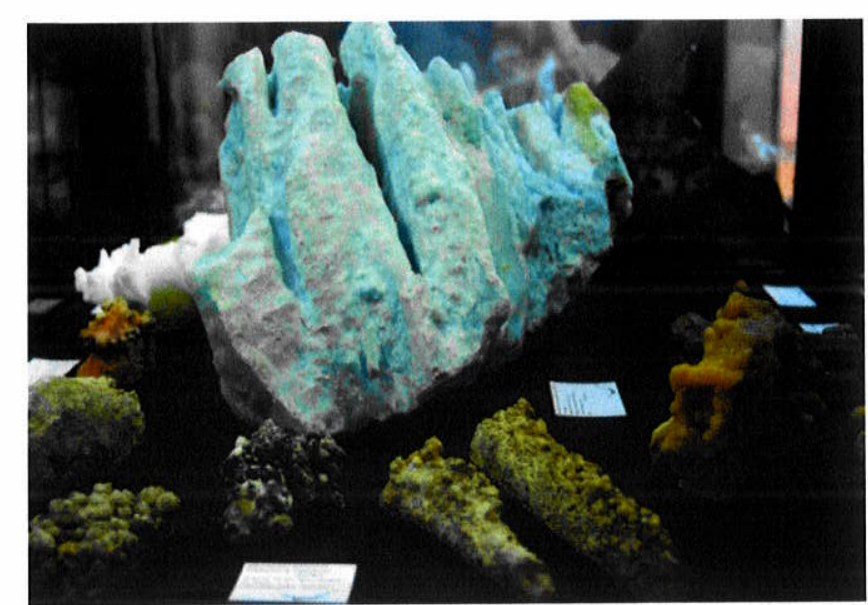

Figura 5. Minerais formados em cavernas (espeleotemas). Fonte: Paulo Anselmo Matioli.

Abaixo estão relacionadas as duas principais características que estimulam o colecionismo de minerais:

- Beleza e Estética - é o fator predominante que leva este tipo de colecionador, a desejar adquirir um exemplar e também é um dos aspectos determinantes do valor e do preço de uma amostra. A beleza e a estética de uma amostra mineral dependem da combinação de várias características específicas e particulares dos exemplares, como por exemplo, a cor (minerais em geral coloridos ou multicoloridos são muito mais atraentes, como turmalina, topázio, berilo, quartzo, espodumênio etc), brilho, transparência, forma geométrica (com hábitos cristalinos diferenciados e com formas curiosas), associação mineralógica (paragênese) e a presença da matriz rochosa, que em geral é o mais importante, pois demonstra a qual gênese pertence o mineral.

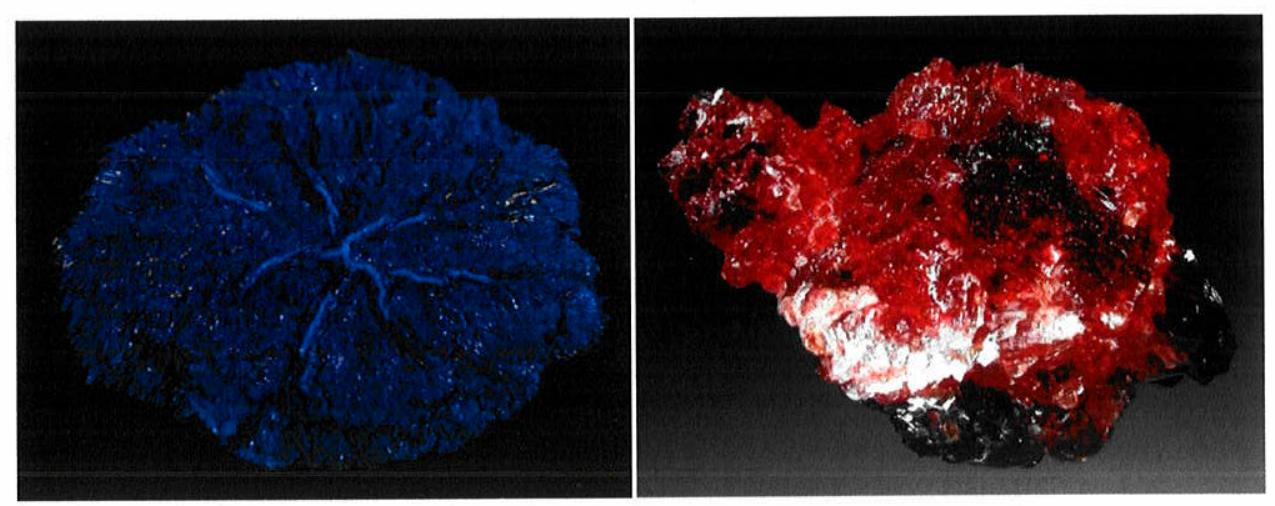

Figura 6. Minerais estéticos - azurita (esquerda) e rodocrosita (direita).

Fonte: Paulo Anselmo Matioli. 
- Raridade - é um fator que para muitos colecionadores se torna mais importante do que a própria beleza e a estética do exemplar, mesmo sendo esses minerais em muitos casos de tamanhos diminutos e na visão dos leigos serem amostras pouco atrativas.
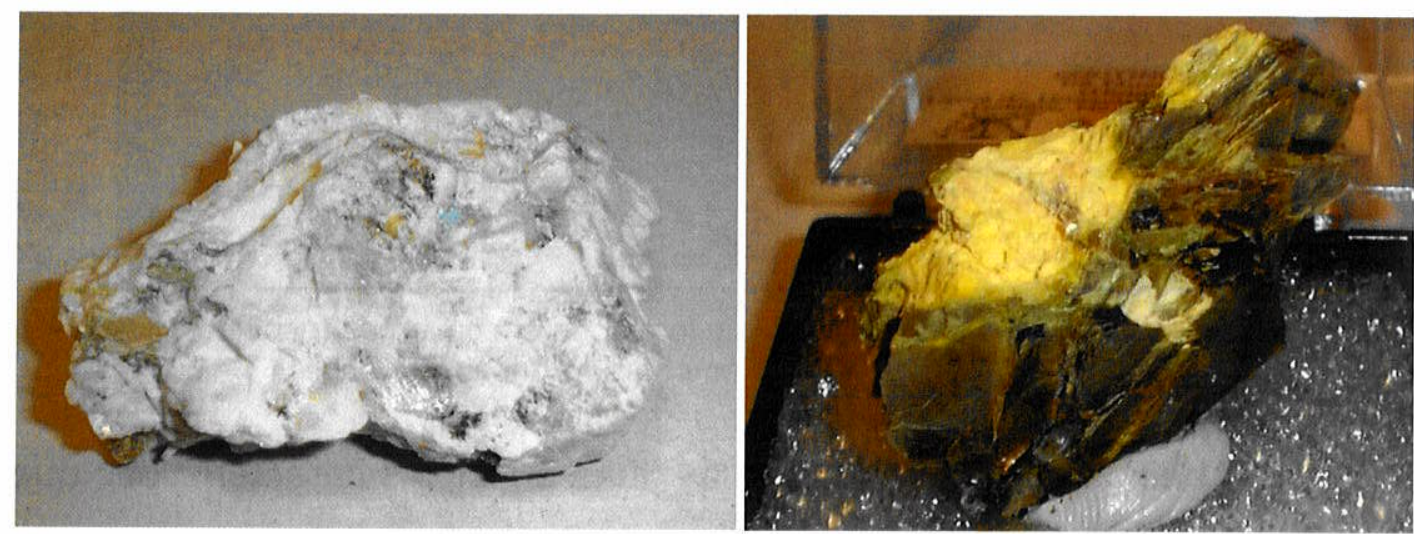

Figura 7. Minerais raros matiolíta (esquerda) e coutinhoíta (direita). Fonte: Paulo Anselmo Matioli.

Minerais estéticos como quartzo, topázio, turmalina, berilo, crisoberilo etc, mesmo bonitos e interessantes, podem valer muito menos do que minerais raríssimos de ocorrências restritas e únicas na natureza, a exemplo da coutinhoíta $\mathrm{Th}_{\mathrm{x}} \mathrm{Ba}_{(1-2 \mathrm{x})}\left(\mathrm{UO}_{2}\right)_{2} \mathrm{Si}_{5} \mathrm{O}_{13} \cdot\left(\mathrm{H}_{2} \mathrm{O}\right)_{1+y}$ (silicato hidratado de tório, bário e urânio) descoberto no ano de 2003 no pegmatito de Urucum, no município de Galiléia, no estado de Minas Gerais. Mesmo esses minerais não ocorrendo em amostras excepcionais de grande beleza ou estética, podem ser muito valorizados, por serem espécies muito raras que ocorrem apenas em uma única localidade no mundo e isso, tornaram-se um grande atrativo para um tipo específico de colecionadores e para os museus de mineralogia.

As características demonstradas anteriormente como Beleza/Estética e Raridade, são apenas dois parâmetros que norteiam os colecionadores e que de alguma maneira estabelecem uma possível meta de se atingir. Muitos museus e até mesmo colecionadores particulares, em geral, não estipulam limites aos seus acervos. Seus objetivos são tentar reunir o maior número possível de exemplares e de espécies diferentes, bem como obter amostras de várias localidades de uma mesma espécie, devido às diferenças de hábitos cristalinos, cores, associações mineralógicas, gêneses, etc. 


\subsubsection{Como podemos colecionar minerais?}

Ao adquirir minerais para o início de uma coleção, ainda classificada de forma amadora, as amostras são mais comuns e fáceis de encontrar. Quando o colecionador quer atingir níveis profissionais, começa a ficar com um custo mais alto e se torna cada vez mais difícil conseguir espécies para o seu acervo.

São necessários alguns requisitos básicos para se iniciar uma coleção mineralógica, como disponibilização de espaço, de tempo e investimento financeiro. Porém, o mais importante é a dedicação. Algumas características diferem os tipos de coleções e os seus respectivos colecionadores.

Uma coleção de minerais pode ser iniciada com peças mais comuns e de diversificadas classes mineralógicas, por exemplo, o quartzo e suas variedades como, ametista, ágata, citrino, quartzo verde, quartzo rosa, quartzo vermelho etc, o berilo e suas variedades famosas como a esmeralda, água marinha, morganita, heliodoro e goshenita, o mineral coríndon e as suas duas variedades históricas e famosas, o rubi vermelho e a safira azulada. Ainda têm-se os minerais do grupo da granada, como almandina, piropo, spessartita, uvarovita, andradita etc, minerais do grupo da mica como muscovita, biotita, lepidolita, flogopita etc.

De acordo com o espaço disponível, pode-se definir o tamanho padrão das amostras. A medida da peça, em muitos casos, pode definir seu valor financeiro, mas possuir amostras de tamanhos variados, não restringe a aquisição de peças raras, que em muitos dos casos, não passam de $1 \mathrm{~cm}$.

O tempo necessário está na dedicação para conservá-las, mas principalmente em, estudá-las e aprender a classificá-las de forma correta. As amostras da coleção de minerais devem ser catalogadas e possuírem as seguintes informações na sua etiqueta: nome da espécie, classe mineralógica, composição química, sistema cristalino e procedência.

Como alternativa, e uma maneira muito prazerosa e dinâmica e que muitos colecionadores preferem, pode-se sair para estudos de campo e coleta de minerais. Existem muitos tipos de afloramentos, como pedreiras, minerações, garimpos, lavras etc, que permitem o acesso aos minerais. Desta forma, o colecionador treina o seu olhar clínico e estimula a pesquisa e o conhecimento tanto da Mineralogia, quanto de áreas correlatas de conhecimento como Geologia, Paleontologia, Biologia etc. 
Os minerais são objetos duráveis, mas, sem alguns cuidados básicos de conservação, podem se deteriorar e se decompor em poucos anos ou até meses. $O$ manuseio deve ser bastante cuidadoso e cauteloso, pois existem minerais radioativos, tóxicos, venenosos etc, e ainda por causa dos cristais bem formados (delicados) de determinadas espécies, as condições de higiene do local e das mãos são imprescindíveis para não haver nenhum tipo de reação química com a amostra. Algumas espécies como a halita e a carnallita, encontradas em depósitos evaporíticos, precisam ficar hermeticamente fechadas para não se perder em poucos dias a amostra, se perde devido à umidade relativa do ar e por possuírem a característica de serem minerais higroscópicos.

Condições climáticas e iluminação afetam os minerais e modificam suas cores e formas originais. Um exemplo é o realgar que em exposição à luz branca modifica sua cor de vermelho para amarelo claro, muitas vezes alterando e modificando a própria espécie mineral, outro caso é a calcantita que quando exposta à luz natural fica branca alterando a sua aparência.

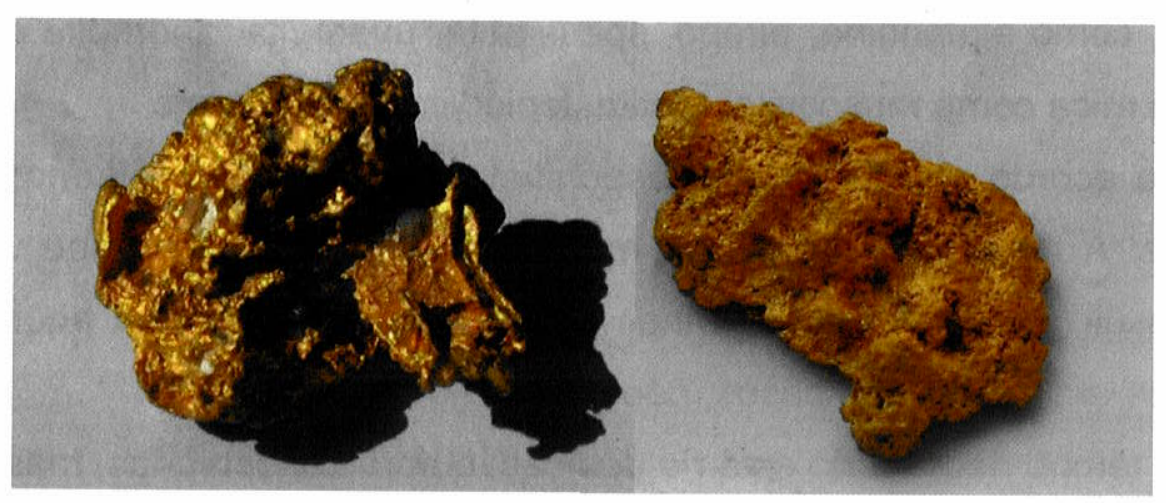

Figura 8. Elementos nativos (pepitas de ouro). Fonte: Paulo Anselmo Matioli.

$\mathrm{Na}$ maior parte das vezes, as coleções podem ser classificadas com características especificas como (MENEZES; CHAVES, 2007):

- Espécies minerais, grupos minerais ou classes minerais - muitos colecionadores buscam conhecer a composição química dos minerais e sua classificação em determinados grupos ou classes particulares, e podem ainda se interessar em adquirir certas espécies que, mesmo não sendo espetaculares ou atraentes, constituam membros raros de grupos importantes. Por outro lado, outros se dedicam a colecionarem minerais (como quartzo, topázio, calcita, fluorita, gipsita etc.) que mostrem abundância de formas cristalográficas e cores diferentes, ou ainda 
membros de um grupo (como granadas, zeólitas, micas, turmalinas, espinélios etc.), classes químicas (como elementos nativos, sulfetos, óxidos, carbonatos, arsenatos, silicatos, etc.), ou então apenas minerais contendo elementos químicos específicos (como minerais de $\mathrm{Au}, \mathrm{Ag}, \mathrm{Cu}, \mathrm{Hg}, \mathrm{In}, \mathrm{Pt}, \mathrm{Zn}, \mathrm{Pb}$ etc.);

Figura 9. Mineral raríssimo, única amostra na matriz existente no mundo de brumadoita. Fonte: Paulo Anselmo Matioli.

- Todas as espécies minerais - somente a minoria dos museus e principalmente dos colecionadores ditos "Sistemáticos" se dedica a essa tarefa árdua e a missão de tentar conseguir o maior número possível de espécies minerais descritas e aprovadas no mundo e as suas variedades. Em muitos dos casos, são pouquíssimas as amostras disponíveis de certas espécies minerais descritas em várias localidades no mundo e essa tarefa se torna quase impossível para qualquer coleção do mundo possuir todas as espécies minerais conhecidas. Por exemplo, a brumadoita $\mathrm{Cu}_{3}\left(\mathrm{Te}^{6+} \mathrm{O}_{4}\right)(\mathrm{OH})_{4} .5 \mathrm{H}_{2} \mathrm{O}$ (telurato básico hidratado de cobre) - descoberta em 2008, na Mina Pedra Preta, Serra das Éguas, Brumado, Bahia, produziu somente uma única amostra até o momento;

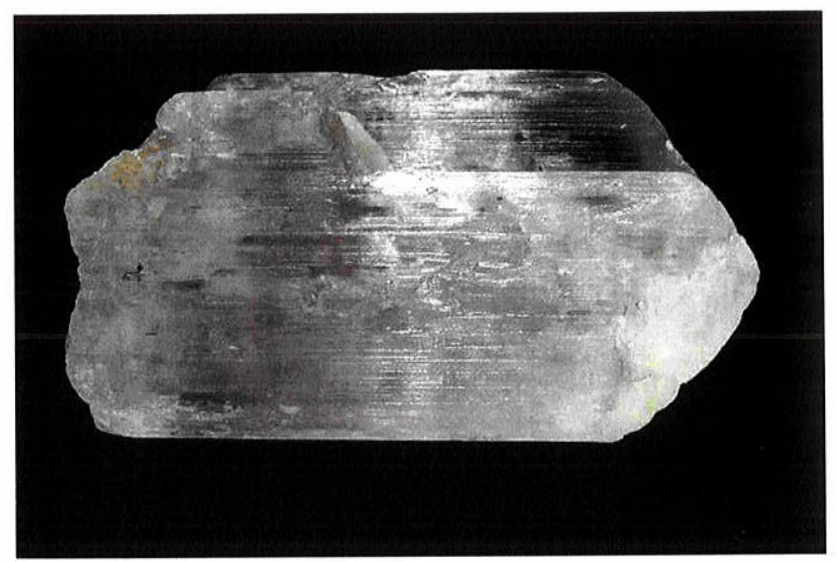

Figura 10. Mineral estético (kunzita). Fonte: Paulo Anselmo Matioli. 
- Estética - a grande maioria dos colecionadores é atraída pela beleza dos minerais, que para esses será o principal atributo;
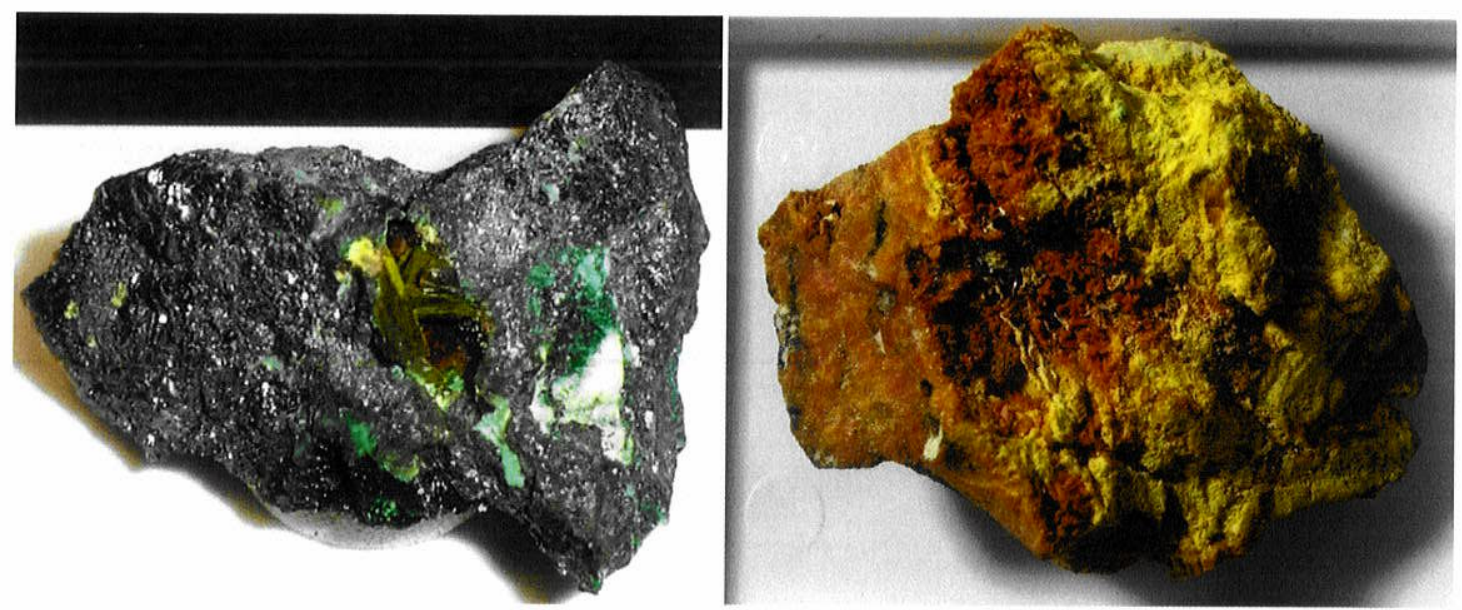

Figura 11. Minerais de urânio (marthozita e curita) da Mina Shinkolobwe, República Democrática do Congo. Fonte: Paulo Anselmo Matioli.

- Distribuição Geográfica-muitos museus e colecionadores podem restringir os seus acervos com enfoques no caráter geográfico. Podem ser minerais provenientes de um continente, de um país, às vezes de um estado ou região específica, ou até mesmo de alguma mina ou pedreira famosa. Um bom exemplo típico deste tipo de acervo é o de colecionadores que se dedicam exclusivamente a terem minerais do famoso conjunto de pedreiras Poudrette, localizada em Mt. Saint Hilaire, La Valléedu-Richelieu, Rouville Co, Montérégie, Québec, Canadá, onde foram descritas mais de 400 espécies diferentes, sendo 59 espécies novas para a ciência;

Existem ainda muitos outros tipos de coleções de minerais que levam em considerações outros fatores, como tamanho, dureza, brilho etc.

\subsection{COLEÇÕES MINERALÓGICAS INSTITUCIONAIS}

Existem museus que possuem coleções antigas e buscam investir na conservação e catalogação de seu acervo, mas muito dificilmente investem em profissionais da área ou na aquisição de novas espécies ou amostras estéticas.

Também há grandes mineradoras que possuem espaços expositivos com peças únicas em estética, e que possuem profissionais como geólogos e mineralogistas. 


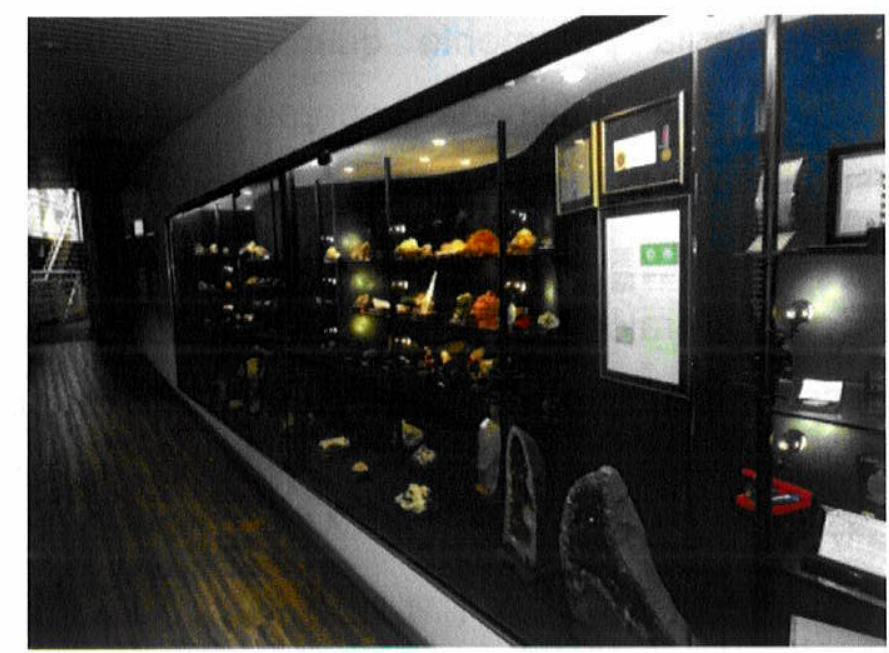

Figura 12. Museu da Empresa GEOSOL - Belo Horizonte - MG.

Muitos comerciantes nacionais e internacionais especializados nesta área de minerais de coleção são facilmente encontrados pela Internet e em algumas cidades brasileiras como São Paulo, Belo Horizonte, Ouro Preto, Governador Valadares, Teófilo Otoni, Araçuaí etc. Em geral, são antigos garimpeiros ou especialistas que possuem excelentes exemplares, incluindo muitas amostras estéticas e outras espécies raras. A compra dessas amostras dependerá exclusivamente do poder aquisitivo do colecionador.

As coleções e os colecionadores são os primórdios e o inicio de todos os museus naturalistas. A importância de se colecionar minerais está muito além da conservação ou contemplação de exemplares, está na salvaguarda de amostras históricas e importantes para a mineralogia brasileira. A grande maioria dos museus é formada por uma ou diversas coleções, que ao longo do tempo foram sendo absorvidas tanto através de doações quanto aquisições.

\subsection{CLASSIFICAÇÕES DAS COLEÇÕES MINERALÓGICAS}

Os minerais, assim como os animais e vegetais, necessitam de uma classificação de acordo com princípios científicos para melhorar e aprimorar o seu estudo e pesquisa. O princípio básico das classificações taxonômicas e sistemáticas foi elaborado pelo naturalista sueco Carl Von Linné (1758) no seu celebre livro "In Nature", que serviu de base para todas as outras classificações naturalistas que vieram a seguir. Assim com Linné, outros cientistas desenvolveram classificações semelhantes no campo da mineralogia, como Berzelius (1827), que estabeleceu 
primeiramente o sistema puramente químico; Niggli se baseou no sistema cristalográfico, onde preferencialmente separou os principais grupos minerais com base na sua estrutura cristalina (cúbico, hexagonal, tetragonal, ortorrômbico etc.); entre outros ${ }^{4}$.

As coleções mineralógicas tanto particulares quanto em exposições nos museus, sejam esses de pequeno, médio ou grande porte, podem obedecer a certos critérios que em geral serão determinantes para o caráter que o museu ou coleção quer se especializar.

Enfim, os minerais podem ser ordenados, sistematizados e classificados de acordo com diversos critérios. O mais importante, porém é a espécie mineral possuir informações corretas quanto a sua identificação e classificação, assim como a sua associação mineralógica e sua ocorrência geográfica.

Podemos ter coleções minerais com ênfase em sua classificação, nas localidades geográficas, desde uma mina ou pedreira famosa, uma região esp ecífica, um país e até um continente.

Ainda existem sistematizações de coleções mineralógicas interessantes, que levam em conta um elemento químico específico e suas aplicações na indústria. Há poucos museus que não obedecem a nenhum critério específico, que dispõem os seus exemplares de forma aleatória, muitas vezes só tendo a beleza e a estética como item necessário para a exposição.

A grande maioria dos museus científicos sistemáticos e didáticos classificam suas coleções principais na ordenação dos minerais de acordo com sua classificação química, e essa sistemática está fundamentada em dois grandes mineralogistas, o norte-americano Dana e o alemão Strunz.

\subsubsection{Classificação por Dana}

James Dwight Dana nasceu em Utica, New York, em 12 de fevereiro de 1813 e faleceu em 14 de abril de 1895 em New Haven, Connecticut, nos Estados Unidos da América. Foi um grande geólogo, mineralogista, vulcanólogo e zoólogo norteamericano, que se dedicou ao longo da vida em diversos ramos das ciências naturais (PIRSSON, 1919).

\footnotetext{
${ }^{4}$ Universidade Estadual Paulista. Introdução para o banco de dados de minerais. Disponível em: http://www.rc.unesp.br/museudpm/banco/introducao.html. Acesso em: 10 dez. 2014.
} 
Dana é conhecido, até hoje, como um dos mineralogistas sistemáticos mais importantes de todos os tempos. Em 1837, publicou o seu mais famoso e célebre tratado em mineralogia, "System of Mineralogy".

O sistema de classificação mineralógica de Dana é baseado em seus principais radicais aniônicos em sua formula química.

Abaixo, a classificação química sugerida por Dana (DANA; DANA, 1997):

Quadro 2 - Classificação Química segundo Dana.

\begin{tabular}{|c|c|}
\hline CLASSE QUIIMICA & COMPOSIÇÃO QUÍMICA \\
\hline ELEMENTOS NATIVOS E LIGAS & $\begin{array}{l}\text { Minerais compostos por um único } \\
\text { elemento como } \mathrm{Au}, \mathrm{Ag}, \mathrm{Cu}, \mathrm{Pt}, \mathrm{Pd} \text {, Ir, } \\
\text { Os, } \mathrm{Hg}, \mathrm{Fe}, \mathrm{As}, \mathrm{Te}, \mathrm{Se}, \mathrm{S}, \mathrm{C} \text { etc. }\end{array}$ \\
\hline SULFETOS & $\mathrm{S}^{2-}$ ou $\mathrm{As}^{3-}$ \\
\hline ÓXIDOS & $\mathrm{O}^{2-}$ \\
\hline HALOGENETOS & $\mathrm{Cl}^{-}, \mathrm{Br}^{-}, \mathrm{F}^{-}$e I- \\
\hline CARBONATOS & $\left(\mathrm{CO}_{3}\right)^{2-}$ \\
\hline NITRATOS & $\left(\mathrm{NO}_{3}\right)^{-}$ \\
\hline IODATOS & $\left(\mathrm{IO}_{3}\right)^{-}$ \\
\hline BORATOS & $\left(\mathrm{BO}_{3}\right)^{3-}$ \\
\hline SULFATOS & $\left(\mathrm{SO}_{4}\right)^{2-}$ \\
\hline SELENATOS E TELURATOS & $\left(\mathrm{SeO}_{4}\right)^{2-}$ e $\left(\mathrm{TeO}_{4}\right)^{2-}$ \\
\hline SELENITOS E TELURITOS & $\left(\mathrm{SeO}_{3}\right)^{2-}$ e $\left(\mathrm{TeO}_{3}\right)^{2-}$ \\
\hline CROMATOS & $\left(\mathrm{CrO}_{4}\right)^{2-}$ \\
\hline $\begin{array}{c}\text { FOSFATOS, ARSENATOS } \\
\text { E VANADATOS }\end{array}$ & $\left(\mathrm{PO}_{4}\right)^{3-},\left(\mathrm{AsO}_{4}\right)^{3-},\left(\mathrm{VO}_{4}\right)^{3-}$ \\
\hline $\begin{array}{c}\text { ANTIMONATOS, ANTIMONITOS } \\
\text { E ARSENITOS }\end{array}$ & $\left(\mathrm{Sb}_{2} \mathrm{O}_{6}\right)^{2-},\left(\mathrm{SbO}_{3}\right)^{-},\left(\mathrm{AsO}_{3}\right)^{-}$ \\
\hline MOLIBDATOS E TUNGSTATOS & $\left(\mathrm{MoO}_{4}\right)^{2-},\left(\mathrm{WO}_{4}\right)^{2-}$ \\
\hline NESOSSILICATOS & $\left(\mathrm{SiO}_{4}\right)^{4-}$ (tetraedros isolados) \\
\hline SOROSSILICATOS & $\begin{array}{c}\left(\mathrm{Si}_{2} \mathrm{O}_{7}\right)^{6-} \text { (duplas isoladas de } \\
\text { tetraedros) }\end{array}$ \\
\hline CICLOSSILICATOS & $\left(\mathrm{SiO}_{3}\right)^{2-}$ (anéis de tetraedros) \\
\hline INOSSILICATOS & $\left(\mathrm{SiO}_{3}\right)^{2-},\left(\mathrm{Si}_{4} \mathrm{O}_{11}\right)^{6-}$ (tetraedros em \\
\hline
\end{tabular}




\begin{tabular}{|c|c|}
\hline & cadeias simples e em cadeias duplas) \\
\hline FILOSSILICATOS & $\left(\mathrm{Si}_{2} \mathrm{O}_{5}\right)^{2-}$ (tetraedros em folhas) \\
\hline TECTOSSILICATOS & $\begin{array}{c}\left(\mathrm{SiO}_{2}\right) \text { (tetraedros em redes } \\
\text { tridimensionais) }\end{array}$ \\
\hline SAIS DE ÁCIDOS ORGÂNICOS & \\
\hline
\end{tabular}

\subsubsection{Classificação por Strunz}

A classificação mais utilizada na mineralogia e praticada nas coleções mineralógicas mundiais, por melhor atender às necessidades científicas, uma vez que leva em consideração tanto a estrutura cristalina e a composição química dos minerais, foi desenvolvida e elaborada pelo mineralogista alemão Strunz em 1935.

Esta classificação ao longo dos anos sofreu algumas pequenas alterações e atualmente se subdivide em 10 grandes grupos, baseando-se na composição química, sendo que esses grupos são subdivididos com base na organização estrutural. Dessa forma tem-se: 1 . elementos nativos; 2 . sulfetos e sulfossais; 3. óxidos e hidróxidos; 4 . halogenetos; 5 . carbonatos e nitratos; 6 . boratos; 7 . sulfatos e cromatos; 8. fosfatos, arsenatos, vanadatos, tungstatos e molibdatos, 9. Silicatos (nesossilicatos, sorossilicatos, ciclossilicatos, inossilicatos, filossilicatos e tectossilicatos) e 10. compostos orgânicos.

Karl Hugo Strunz ${ }^{5}$ nasceu em Weiden in der Oberpfalz, Bavaria,em 24 de fevereiro de 1910 e faleceu em 19 de abril de 2006 em Unterwössen, na região da Bavaria, na Alemanha. Foi um grande mineralogista um dos membros fundadores da IMA. Em 1941, publicou o seu trabalho mais famoso, "Mineralogische Tabellen", que consiste na classificação cristaloquímica dos minerais. Porém, desde a sua primeira edição, o trabalho recebeu várias modificações e alterações e é atualmente objeto de atualização constante, em vista de dados mais recentes sobre estruturas cristalinas. Este tipo de sistematização é a utilizada pela Associação Mineralógica Internacional.

\footnotetext{
${ }^{5}$ Webacademia- Conocemos todo. Karl Hugo Strunz, Vida, Trabajar, Honores, Selección de publicaciones. Disponível em: http://centrodeartigos.com/articulos-utiles/article_104782.html
} 
Ao longo de sua vida, publicou mais de 200 trabalhos científicos, com ênfase em classificação mineralógica e estudo de estruturas cristalinas e descreveu cerca de 14 novas espécies minerais. Em sua honra, foi batizado o mineral strunzita, um fosfato básico hidratado de manganês e ferro, descoberto no famoso pegmatito de Hagendorf, na região da Bavaria, na Alemanha.

Abaixo, a classificação sugerida por Strunz (STRUNZ; NICKEL, 2001):

Quadro 3 - Classificação Cristaloquímica de Nickel-Strunz.

\begin{tabular}{|c|c|}
\hline CLASSE MINERAL & COMPOSIÇÃO QUÍMICA \\
\hline 1) ELEMENTOS NATIVOS & $\begin{array}{l}\text { Metais e Ligas Intermetálicas; } \\
\text { Metalóides e Não Metais; Carbetos, } \\
\text { Silicietos, Nitretos e Fosfetos. }\end{array}$ \\
\hline 2) SULFETOS E SULFOSSAIS & $\begin{array}{c}\text { Sulfetos, Selenetos, Teluretos; } \\
\text { Arsenietos, Antimonídeos, } \\
\text { Bismutídeos; Sulfoarsenietos, } \\
\text { Sulfoantimonietos, Sulfobismutietos, } \\
\text { etc. }\end{array}$ \\
\hline 3) HALOGENETOS & Íons Halogêneos (Cl, B, F, I). \\
\hline 4) ÓXIDOS & $\begin{array}{c}\text { Óxidos, Hidróxidos, Vanadatos, } \\
\text { Arseniatos, Antimoniatos, Bismutiatos, } \\
\text { Sulfitos, Selenatos, Teluratos, } \\
\text { lodatos. }\end{array}$ \\
\hline 5) CARBONATOS (NITRATOS) & Carbonatos e Nitratos. \\
\hline 6) BORATOS & Boratos. \\
\hline 7) SULFATOS & $\begin{array}{l}\text { Sulfatos, Selenatos, Teluratos, } \\
\text { Cromatos, Molibdatos, Volframatos. }\end{array}$ \\
\hline $\begin{array}{l}\text { 8) FOSFATOS, ARSENATOS, } \\
\text { VANADATOS }\end{array}$ & Fosfatos, Arsenatos, Vanadatos. \\
\hline
\end{tabular}


9) SILICATOS (GERMANATOS)

10) COMPOSTOS ORGÂNICOS
Silicatos e Germanatos.

Sais de Ácidos Orgânicos, Hidrocarbonetos e Minerais Orgânicos diversos. 


\section{CAPÍTULO 2 - MINERAIS TIPO BRASILEIROS E PRINCIPAIS MINERALOGISTAS DO BRASIL}

\subsection{MINERAIS TIPO DO BRASIL}

A mineralogia no Brasil destaca-se tanto pela diversidade quanto pela quantidade excepcional de espécies minerais, tornando o país uma referência internacional em minerais gemas e em minerais raros, ambos muito procurados por museus e colecionadores.

O Brasil, notoriamente, é um dos países mais expressivos em relação à ocorrência de minerais raros, em nível mundial. Novas descobertas para a ciência são recorrentes em relação a essas substâncias minerais, inclusive, com dezenas de "minerais tipo", provenientes de nossos depósitos e jazimentos minerais (ATENCIO, 2000).

Os minerais tipo são aqueles que foram descritos pela primeira vez no país, assim sendo, possuem uma grande importância para a pesquisa científica e para a memória da mineralogia brasileira.

Dezoito novas espécies minerais foram descritas por Daniel Atencio e colaboradores (J.M.V. Coutinho, Marcelo B. Andrade, Paulo A. Matioli, J. Ellena, entre outros) nos últimos anos (coutinhoíta, lindbergita, matiolíta, ruifrancoíta, menezesita, guimarãesita, brumadoíta, bendadaíta, manganoeudialita, hidroxicalcioromeíta, carlosbarbosaíta, hidrokenomicrolita, fluorcalciomicrolita, almeidaíta, pauloabibita, cesarferreraíta, hidroxicalciomicrolita e waimirita-(Y)), o que vem dando um novo incremento e colocando esta ciência no patamar em que nunca deveria ter saído no Brasil.

Antes de 1959, quando a IMA criou uma comissão especial, havia mais de 100 minerais tidos como descobertos aqui, sem contar com variações ortográficas ou atribuição de vários nomes a uma mesma espécie mineral.

Seguindo regras e diretrizes básicas que a comissão estipulou para validar os nomes, verificou-se que cerca de 80 minerais deviam ser rejeitados, ou porque não eram realmente espécies novas, ou porque o estudo mineralógico não tinha dados conclusivos ou estavam faltando dados importantes. Assim, a lista brasileira reduzse hoje a apenas 63 minerais. 
A quantidade de minerais descritos no país certamente não condiz com a riqueza mineral brasileira, que muitos comparam às dos Estados Unidos e da Rússia. Cada um desses países tem mais de 600 minerais descritos e no mundo todo já foram descobertos cerca de 5 mil espécies minerais. Isso sugere que o solo brasileiro é pouco explorado, ao menos cientificamente.

Um exemplo clássico é a região do Maciço Alcalino de Poços de Caldas (MG), rica em rochas especiais como nefelina sienito, rocha alcalina onde se desenvolvem minerais raros, como os de zircônio e titânio. Na Rússia e no Canadá foram encontrados nessa rocha cerca de 200 minerais. No Brasil, só cerca de 20 .

Não é só por falta de especialistas que as descobertas não proliferam no país. Nas pedreiras, um procedimento comum é tratar os minerais-gemas, que incluem possíveis novidades mineralógicas, com banho de ácido, para remover as impurezas, Os pesquisadores interessados em novos minerais às vezes conseguem chegar antes do banho de ácido. Outro problema é a transformação do espaço geográfico, como é o caso de muitas pedreiras que além de estarem fechadas, suas cavas são utilizadas para várias utilidades como é o exemplo das famosas pedreiras Bortolan e da Prefeitura, ambas fechadas.

Um grande feito mineralógico foi o resgate de estudos dispersos. O maior volume foi efetuado pelo belga Jacques Jedwab, da Universidade de Bruxelas. Localizaram-se estudos raros, como os originais sobre o paládio, de William Hyde Wollaston (1766-1828), e o trabalho de 1833 de Lampadius e Plattner sobre a paladinita. O paládio é um metal encontrado em Minas Gerais, na forma de grãos opacos, de branco a cinza-aço pálido em geral associado a platina. A paladinita é um óxido de paládio em forma de grãos de cor cinza.

Antes da interveniência da IMA, os erros eram comuns porque as análises se faziam por via úmida: volumes relativamente grandes de minerais eram dissolvidos, de modo que muitas vezes os resultados não se referiam a um só mineral, mas a misturas. Já com as novas tecnologias como a microssonda eletrônica, é possível obter composições químicas para áreas muito pequenas. Um dos equívocos constatados na mineralogia brasileira envolve a harbortita da ilha de Trauíra (MA), descrita em 1932 por F. Brandt: Ao determinar a composição do mineral, o autor desprezou o sódio e o designou como um fosfato de alumínio hidratado. Atencio descobriu um estudo meio perdido nos Anais do $31^{\circ}$ Congresso Brasileiro de Geologia (1980): "Era de pesquisadores brasileiros, Marcondes L. Costa et al., que 
já haviam comprovado que o mineral coletado na ilha de Trauíra era, na verdade, um fosfato de alumínio e sódio, ou seja, era outro mineral, já conhecido como wardita. Resultado o nome harbortita foi banido.

A chernikovita, que forma placas de cor verde-limão, fora descrita na Rússia por Andrey Chernikov (1927-), mas era chamada anteriormente de hidrogênio autunita. Havia uma segunda ocorrência deste mineral, no distrito de Perus em São Paulo, na forma de cristais placóides que preenchem cavidades de turmalina granito. As análises posteriormente revelaram que o mineral não era do grupo da autunita, e sim da meta-autunita, e que continha íons $\left(\mathrm{H}_{3} \mathrm{O}\right)^{+}$e não simplesmente $\mathrm{H}^{+}$como se acreditava. O mineral foi renomeado como chernikovita por Atencio (1988), em homenagem ao mineralogista russo.

Um mineral coletado em Poços de Caldas, descrito em 1948 por Djalma Guimarães (1894-1973), ocorre na forma de cristais prismáticos que preenchem cavidades de rochas fonolíticas e era chamado de giannettita. Depois de análises precisas da estrutura cristalina por difratometria de raios $\mathrm{X}$ e por análise química de microssonda eletrônica: descobriu que se tratava da hainita, uma espécie já descrita em 1893 na República Tcheca. A djalmaíta - em octaedros pardo-amarelados, pardo-esverdeados ou negro-pardacentos - também foi descrita por Guimarães e em 1957 teve o nome mudado para uranomicrolita e foi desacreditada por Atencio (2010).

Para comprovar os erros do passado, é preciso ter amostras nas mãos, das quais muitas são difíceis de obter, sobretudo de minerais descritos quando não era obrigatório enviá-las para um museu formando um depositório científico dessas amostras tipos do Brasil.

Ouro preto e brazilianita, outro dois casos curiosos da mineralogia brasileira, principalmente como o do "ouro preto". Esse curioso metal recoberto por uma crosta escura é um equívoco histórico. De tão abundante em Vila Rica (atual Ouro Preto, $M G)$, as autoridades deram o seu nome à cidade. Descrito pela primeira vez em 1711, pelo padre jesuíta André João Antonil (1649-1716), que relatava as riquezas minerais do Brasil para a corte portuguesa, era o mineral mais antigo descrito no país. Até que, no ano de 1995, foi desmascarado por estudos do mineralogista belga Jacques Jedwab, o mineral trata-se na verdade de uma mistura de óxidos de ferro, paládio, platina, ouro, cobre e manganês, porém essas amostras hoje são 
muito raras e dificilmente encontras nas coleções tanto dos museus quanto dos colecionadores.

Com a invalidação do ouro preto, que era considerado o mineral mais antigo do país, esse lugar de mais antigo passou para um mineral descrito em 1789 por D.L.G. Karsten, o crisoberilo, que forma cristais tabulares ou prismáticos curtos em várias tonalidades de verde ou amarelo. Outro equívoco mineralógico resultou de uma tentativa de homenagear o país: em 1818, deu-se o nome de brazilianita a um mineral fibroso de tonalidades pardas provenientes do Córrego Carmo, entre Ouro Preto e Mariana (MG). Depois, viu-se que se tratava da espécie gibbsita, já descrita. Em 1945, o nome brazilianita foi merecidamente dado a uma valiosa gema de cristais amarelo-esverdeados, realmente inédita, descoberta em Divino das Laranjeiras (MG), mais precisamente no Córrego Frio.

Atualmente, apenas 63 minerais são considerados espécies tipo válidas do Brasil. A pesquisa mineralógica continua, porém, mesmo que incipiente no país, devido à escassez de profissionais militantes deste ramo tão importante da Geologia, que é a Mineralogia.

Destes 63 minerais tipo do Brasil, 18 foram publicados antes de 1959, quando a Commission on New Minerals, Nomenclature and Classification (CNMNC) / IMA foi estabelecida:

Quadro 4 - Minerais tipo do Brasil:

\begin{tabular}{|c|c|c|}
\hline ANO & ESPÉCIE & AUTORES \\
\hline 1789 & Crisoberilo & $\begin{array}{c}\text { D.L.G.Karsten, } \\
\text { A.G.Werner }\end{array}$ \\
\hline 1792 & Euclásio & R.J.Haüy \\
\hline 1809 & Paládio & W.H.Wollaston \\
\hline 1884 & Goyazita & A.Damour \\
\hline 1895 & Derbylita & E.Hussak e G.T.Prior \\
\hline 1897 & Tripuhyíta & E.Hussak e G.T.Prior \\
\hline 1898 & Senaíta & E.Hussak e G.T.Prior \\
\hline 1899 & Florencita-(Ce) & E.Hussak e G.T.Prior \\
\hline 1906 & Gorceixita & E.Hussak \\
\hline 1945 & Brazilianita & $\begin{array}{r}\text { F.H.Pough e } \\
\text { E.P.Henderson }\end{array}$ \\
\hline 1947 & Souzalita & W.T.Pecora e J.J.Fahey \\
\hline 1947 & Scorzalita & W.T.Pecora e J.J.Fahey \\
\hline 1949 & Frondelita & M.L.Lindberg \\
\hline 1953 & Faheyita & $\begin{array}{c}\text { M.I.Lindberg e } \\
\text { K.J.Murata }\end{array}$ \\
\hline 1953 & Moraesita & $\begin{array}{c}\text { M.L.Lindberg, } \\
\text { W.T.Pecora, e }\end{array}$ \\
\hline
\end{tabular}




\begin{tabular}{|c|c|c|}
\hline & & A.L.M.Barbosa \\
\hline 1954 & Barbosalita & $\begin{array}{c}\text { M.L.Lindberg e } \\
\text { W.T.Pecora }\end{array}$ \\
\hline 1954 & Tavorita & $\begin{array}{c}\text { M.L.Lindberg e } \\
\text { W.T.Pecora }\end{array}$ \\
\hline 1955 & Arsenopaladinita & M.H.Hey \\
\hline
\end{tabular}

Quadro 5 - Dezesseis espécies minerais brasileiras aprovadas entre 1959 e 2000 seguem sendo válidas $(0,43$ por ano):

\begin{tabular}{|c|c|c|}
\hline ANO & ESPÉCIE & AUTORES \\
\hline 1974 & Atheneíta & $\begin{array}{c}\text { A.M.Clark, A.J.Criddle, } \\
\text { E.E.Fejer }\end{array}$ \\
\hline 1974 & Isomertieíta & $\begin{array}{c}\text { A.M.Clark, A.J.Criddle, } \\
\text { E.E.Fejer }\end{array}$ \\
\hline 1976 & Bahianita & P.B.Moore, T.Iraki \\
\hline 1977 & Palladseíta & $\begin{array}{l}\text { R.J.Davis, A.M.Clark, } \\
\text { A.J.Criddle }\end{array}$ \\
\hline 1978 & Whiteíta-(CaFeMg) & P.B.Moore, J.Ito \\
\hline 1978 & Whiteíta-(MnFeMg) & P.B.Moore, J.Ito \\
\hline 1980 & Lantanita-(Nd) & $\begin{array}{c}\text { A.C.Roberts, G.Y.Chao, } \\
\text { F.Cesbron }\end{array}$ \\
\hline 1986 & Minasgeraisita-(Y) & $\begin{array}{l}\text { E.E.Foord, R.V.Gaines, } \\
\text { J.G.Crock, } \\
\text { W.B.Simmons, Jr., } \\
\text { C.P.Barbosa }\end{array}$ \\
\hline 1986 & Parabariomicrolita & $\begin{array}{c}\text { T.S.Ercit, } \\
\text { F.C.Hawthorne, P.Cerny }\end{array}$ \\
\hline 1988 & Lantanita-(La) & $\begin{array}{l}\text { E.H.Nickel, } \\
\text { J.A.Mandarino }\end{array}$ \\
\hline 1990 & Arupita & V.F.Buchwald \\
\hline 1990 & Zanazziíta & $\begin{array}{l}\text { P.B.Leavens, J.S.White, } \\
\text { J.A.Nelen }\end{array}$ \\
\hline 1994 & Yanomamita & $\begin{array}{c}\text { N.F.Botelho, G.Roger, } \\
\text { F.d'Yvoire, Y.Moëlo, } \\
\text { M.Volfinger }\end{array}$ \\
\hline 1997 & Quintinita & G.Y.Chao, R.A.Gault \\
\hline 2000 & Dukeíta & $\begin{array}{c}\text { J.A.R.Stirling, } \\
\text { A.C.Roberts, P.C.Burns, } \\
\text { A.J.Criddle, } \\
\text { M.N.Feinglos }\end{array}$ \\
\hline 2000 & Serrabrancaíta & $\begin{array}{c}\text { Th.Witzke, R.Wegner, } \\
\text { Th.Doering, H.Pöllmann, } \\
\text { W.Schuckmann }\end{array}$ \\
\hline
\end{tabular}


Quadro 6 - Os 29 novos minerais que foram descritos entre 2004 e 2013 (2,1 por ano):

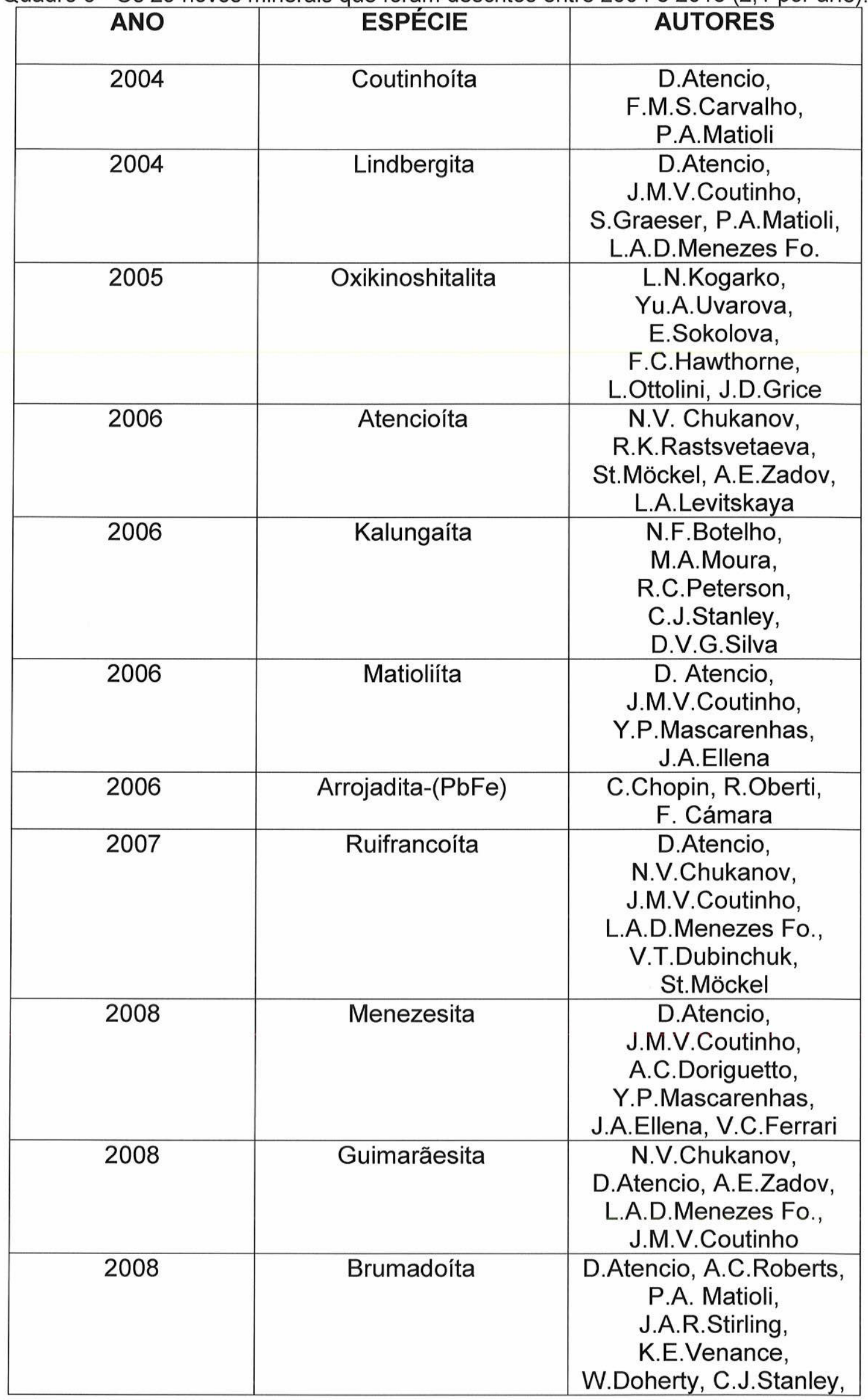




\begin{tabular}{|c|c|c|}
\hline & & $\begin{array}{l}\text { R.Rowe, } \\
\text { G.J.C.Carpenter, } \\
\text { J.M.V.Coutinho }\end{array}$ \\
\hline 2010 & Qingheiíta- $\left(\mathrm{Fe}^{2+}\right)$ & $\begin{array}{c}\text { F.Hatert, M.Baijot, } \\
\text { S.Philippo, J.Wouters }\end{array}$ \\
\hline 2010 & Bendadaíta & $\begin{array}{l}\text { U.Kolitsch, D.Atencio, } \\
\text { N.V.Chukanov, } \\
\text { N.V.Zubkova, } \\
\text { L.A.D.Menezes Fo., } \\
\text { J.M.V.Coutinho, } \\
\text { W.D.Birch, J.Schlüter, } \\
\text { D.Pohl, A.R.Kampf, } \\
\text { I.M.Steele, G.Favreau, } \\
\text { L.Nasdala, G.Giester, } \\
\text { D.Yu.Pushcharovsky }\end{array}$ \\
\hline 2010 & Manganoeudialita & $\begin{array}{l}\text { S.F.Nomura, D.Atencio, } \\
\text { N.V.Chukanov, } \\
\text { R.K.Rastsvetaeva, } \\
\text { J.M.V.Coutinho, } \\
\text { T.K.Karipidis }\end{array}$ \\
\hline 2010 & Hidroxicalcioromeíta & $\begin{array}{c}\text { D.Atencio, } \\
\text { M.B.Andrade, } \\
\text { A.G.Christy, R.Gieré, } \\
\text { P.M.Kartashov }\end{array}$ \\
\hline 2011 & Carlosbarbosaíta & $\begin{array}{c}\text { D.Atencio, A.C.Roberts, } \\
\text { M.A.Cooper, } \\
\text { L.A.D.Menezes Fo., } \\
\text { J.M.V.Coutinho, } \\
\text { J.A.R. Stirling, N.A.Ball, } \\
\text { E.Moffatt, } \\
\text { M.L.S.C.Chaves, } \\
\text { P.R.G.Brandão, } \\
\text { A.W.Romano. }\end{array}$ \\
\hline 2011 & Jacutingaíta & $\begin{array}{c}\text { A.Vymazalová, } \\
\text { F.Laufek, M.Drábek, } \\
\text { A.R.Cabral, J.Haloda, } \\
\text { T.Sidorinová, } \\
\text { B.Lehmann, } \\
\text { H.F.Galbiatti, } \\
\text { J.Drahokoupil }\end{array}$ \\
\hline 2011 & Fluornatromicrolita & $\begin{array}{c}\text { T.Witzke, M.Steins, } \\
\text { T.Doering, } \\
\text { W.Schuckmann, } \\
\text { R.Wegner, H.Pöllmann }\end{array}$ \\
\hline 2012 & Uvita & $\begin{array}{c}\text { C.M. Clark, F.C. } \\
\text { Hawthorne, J.D.Grice }\end{array}$ \\
\hline 2012 & Hidrokenomicrolita & $\begin{array}{c}\text { M.B. Andrade, D. } \\
\text { Atencio, N.V. Chukanov, } \\
\text { J. Ellena }\end{array}$ \\
\hline 2012 & Fluorcalciomicrolita & M.B.Andrade, \\
\hline
\end{tabular}




\begin{tabular}{|c|c|c|}
\hline & & $\begin{array}{c}\text { D.Atencio, H.Yang, } \\
\text { R.T.Downs, } \\
\text { A.I.C.Persiano, J.Ellena }\end{array}$ \\
\hline 2012 & Fluor-elbaíta & $\begin{array}{l}\text { F.Bosi, G.B.Andreozzi, } \\
\text { H.Skogby, A.Lussier, } \\
\text { N.A.Ball, F.C.Hawthorne }\end{array}$ \\
\hline 2013 & Pauloabibita & $\begin{array}{c}\text { L.A.D.Menezes Fo., } \\
\text { D.Atencio, } \\
\text { M.B.Andrade, } \\
\text { R.T.Downs, } \\
\text { M.L.S.C.Chaves, } \\
\text { A.W.Romano, R.Scholz, } \\
\text { A.C.Persiano }\end{array}$ \\
\hline 2013 & Almeidaíta & $\begin{array}{l}\text { L.A.D.Menezes Fo., } \\
\text { N.V.Chukanov, } \\
\text { R.K.Rastsvetaeva, } \\
\text { S.M.Aksenov, } \\
\text { I.V.Pekov, } \\
\text { M.L.S.C.Chaves, } \\
\text { R.Scholz, D.Atencio, } \\
\text { P.R.G.Brandão, } \\
\text { A.W.Romano, } \\
\text { L.C.A.Oliveira, } \\
\text { J.D.Ardisson, } \\
\text { K.Krambrock, } \\
\text { R.L.Moreira, } \\
\text { F.S.Guimarães, } \\
\text { A.C.Persiano, } \\
\text { R.P.Richards }\end{array}$ \\
\hline 2013 & Cesarferreiraíta & $\begin{array}{c}\text { R.Scholz, } \\
\text { N.V.Chukanov, I.Pekov, } \\
\text { L.A.D.Menezes Fo., } \\
\text { D.Atencio, L.Lagoeiro, } \\
\text { F.M.Belotti, } \\
\text { M.L.S.C.Chaves, } \\
\text { A.W.Romano }\end{array}$ \\
\hline 2013 & Correianevesita & $\begin{array}{c}\text { N.V.Chukanov, } \\
\text { R.Scholz, N.V.Zubkova, } \\
\text { I.V.Pekov, } \\
\text { D.I.Belakovskiy, } \\
\text { K.V.Van, L.Lagoeiro, } \\
\text { L.M.Graça, } \\
\text { K.Krambrock, } \\
\text { L.C.A.Oliveira, } \\
\text { L.A.D. Menezes Fo., } \\
\text { D.Y.Pushcharovsky }\end{array}$ \\
\hline 2013 & Hidroxicalciomicrolita & $\begin{array}{l}\text { M.B.Andrade, H.Yang, } \\
\text { D.Atencio, R.T.Downs, } \\
\text { N.V.Chukanov, } \\
\text { M.-H.Lemée-Cailleau, }\end{array}$ \\
\hline
\end{tabular}




\begin{tabular}{|c|c|c|}
\hline & & A.I.C.Persiano, J.Ellena \\
\hline 2013 & Fluorlamprofilita & M.B.Andrade, H.Yang, \\
& & R.T.Downs, G.Färber, \\
& & R.R.Contreira Fo., \\
& & S.H.Evans, C.W.Loenn, \\
& & B.N.Schumer \\
\hline 2013 & Waimirita-(Y) & A.C.Bastos Neto, \\
& & V.P.Pereira, D.Atencio, \\
& & J.T.M.M.Ferron, \\
& & J.M.V.Coutinho. \\
\hline
\end{tabular}

Abaixo a relação de todos os minerais tipo brasileiros e suas respectivas ocorrências geográficas tipo e suas composições químicas:

Quadro 7 - Relação de minerais tipo brasileiros com foto:

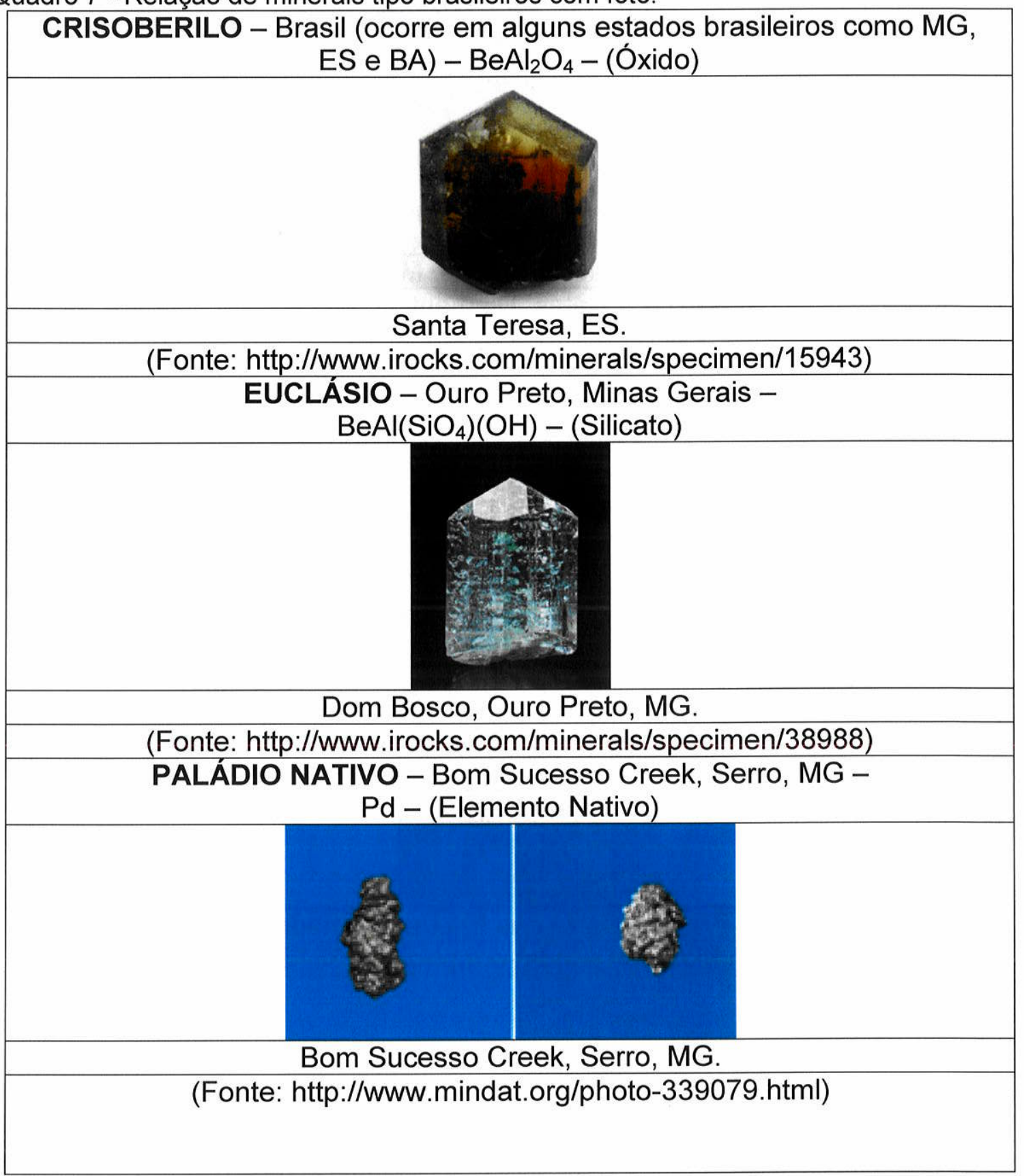




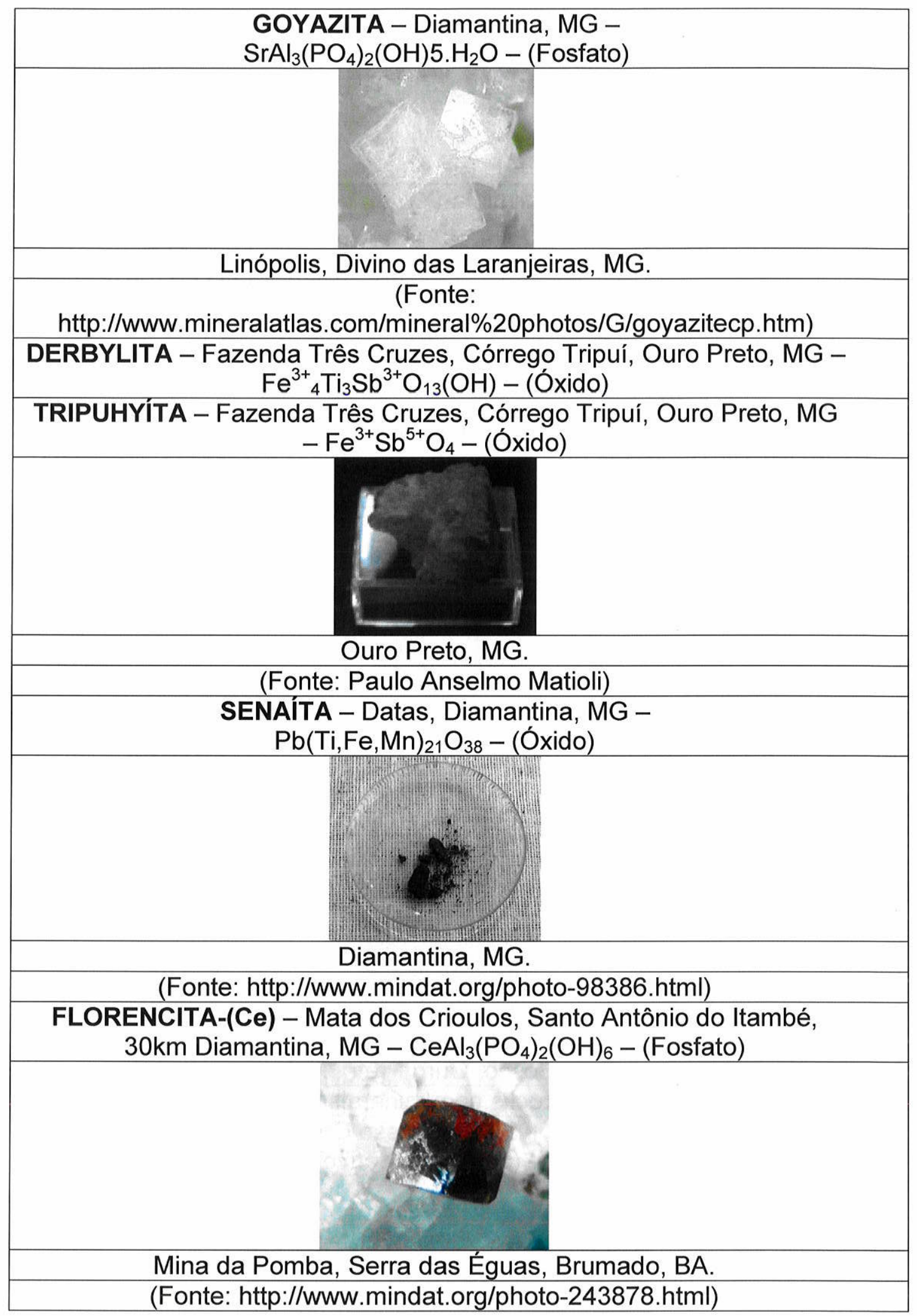




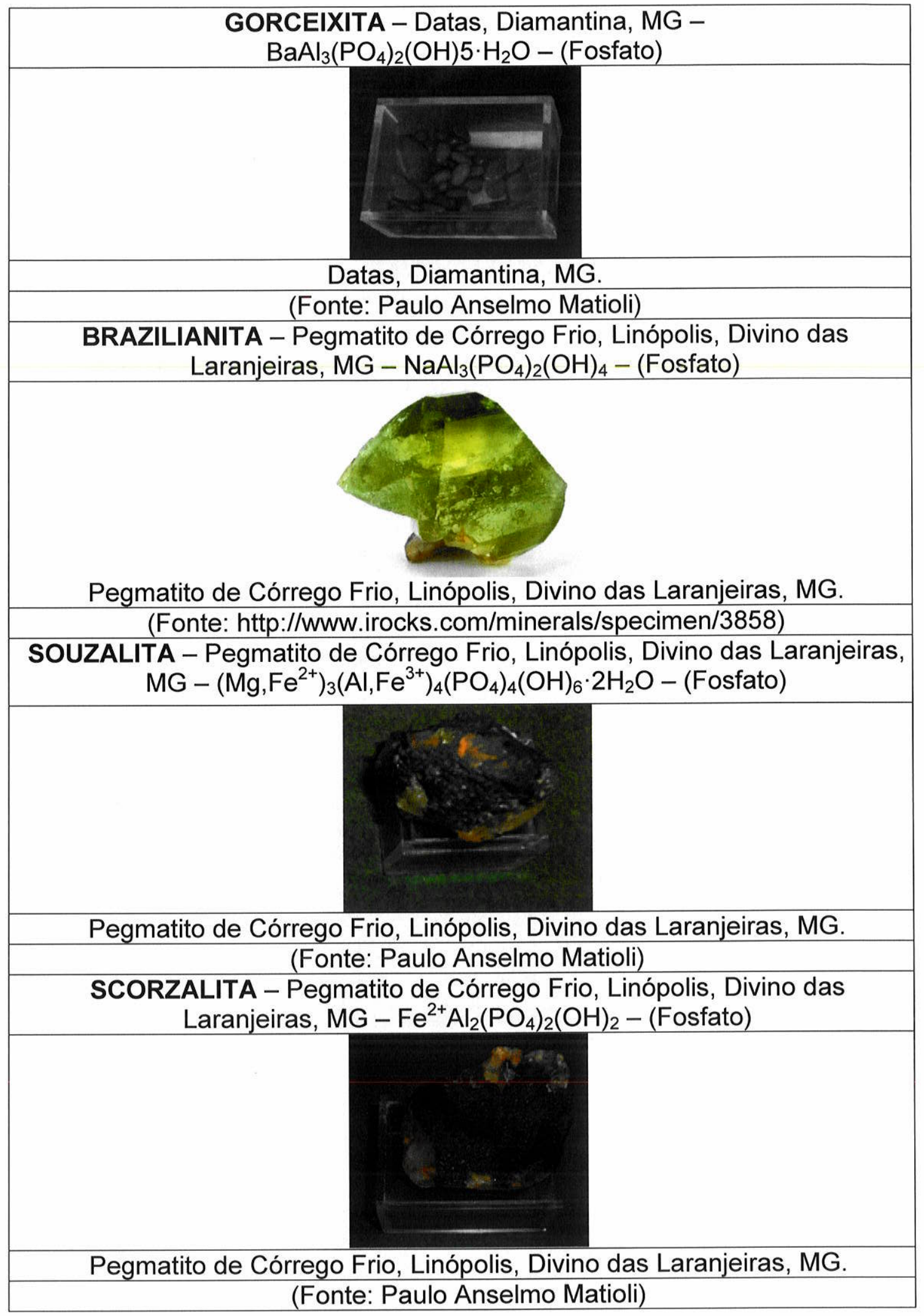




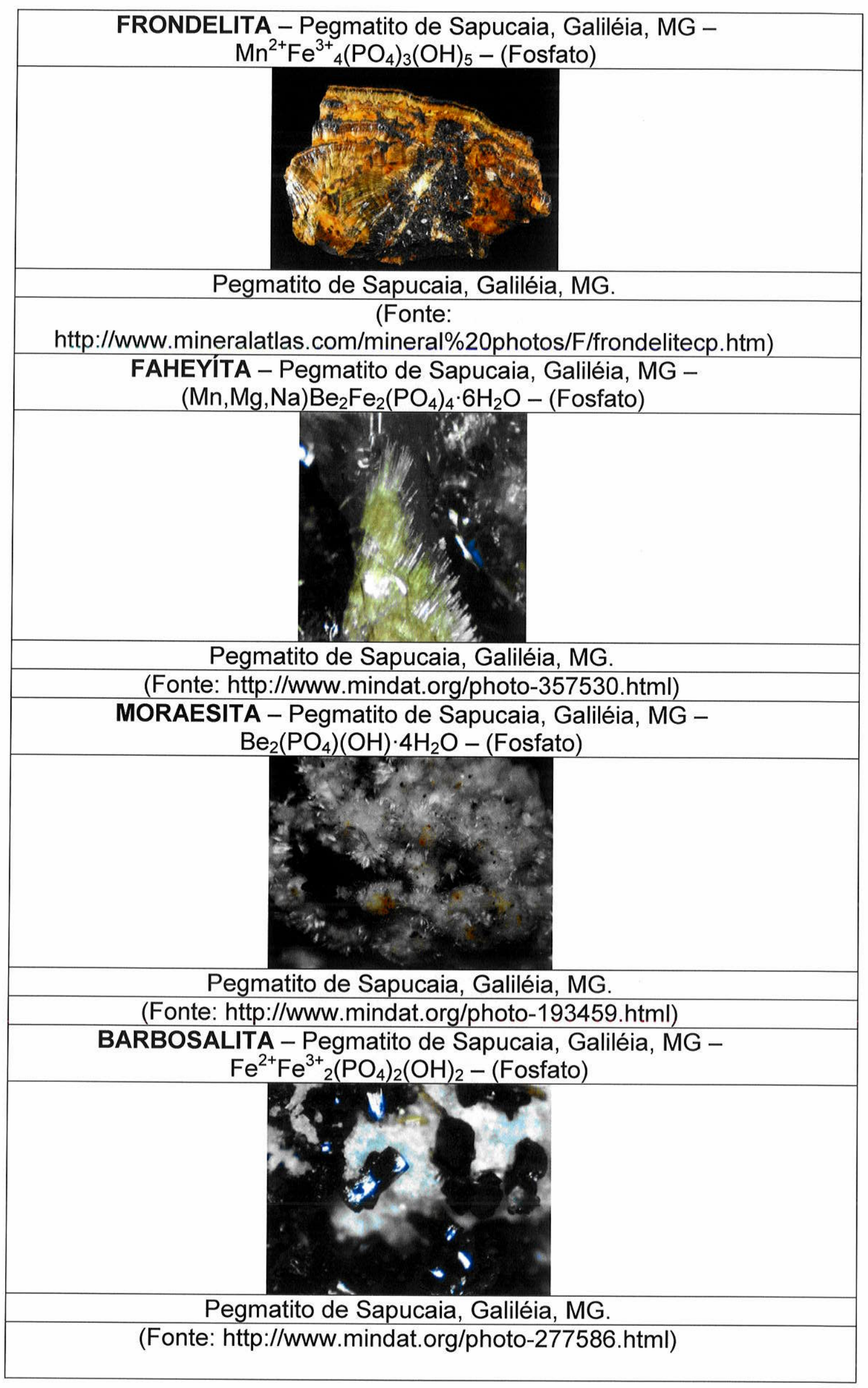




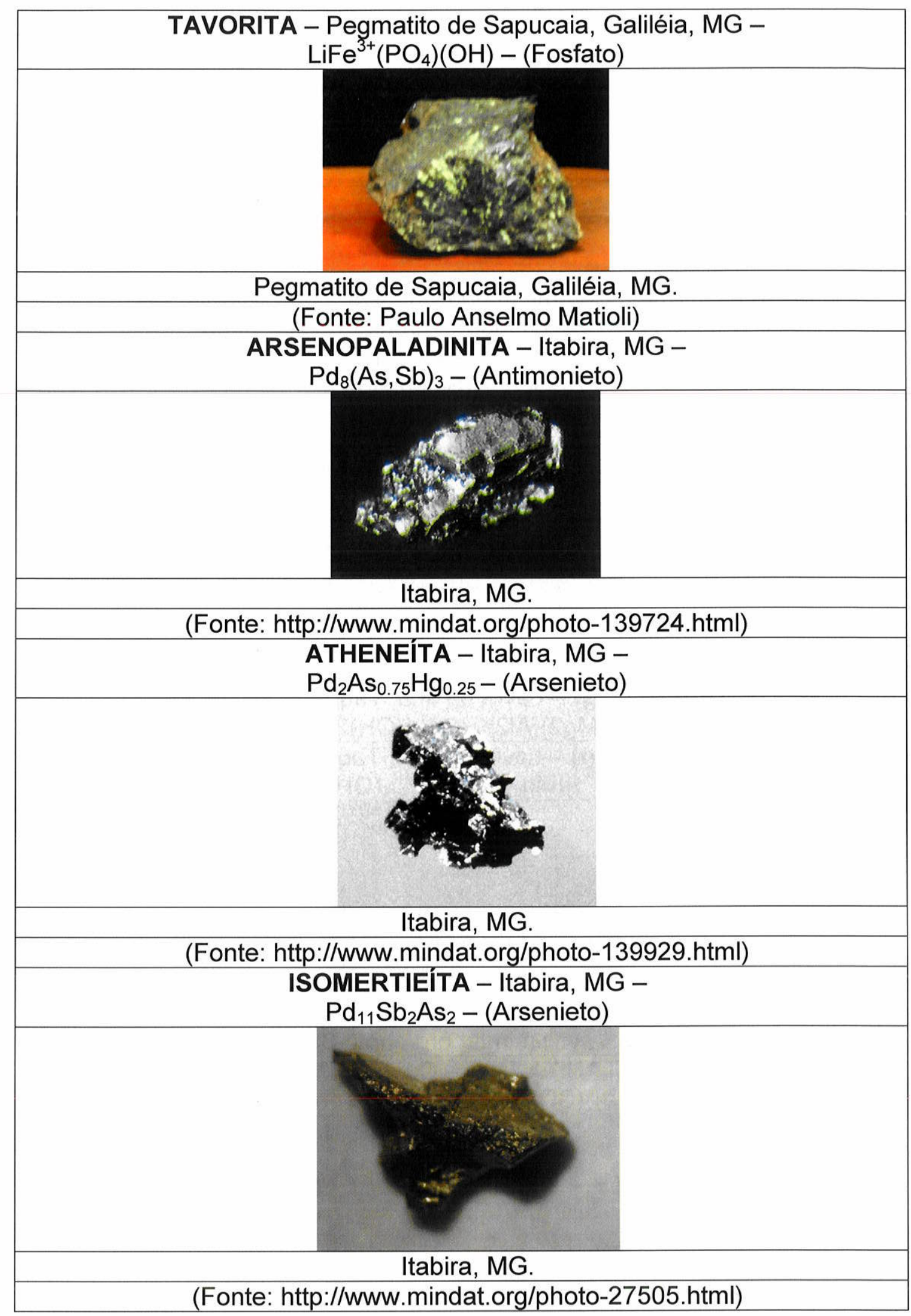




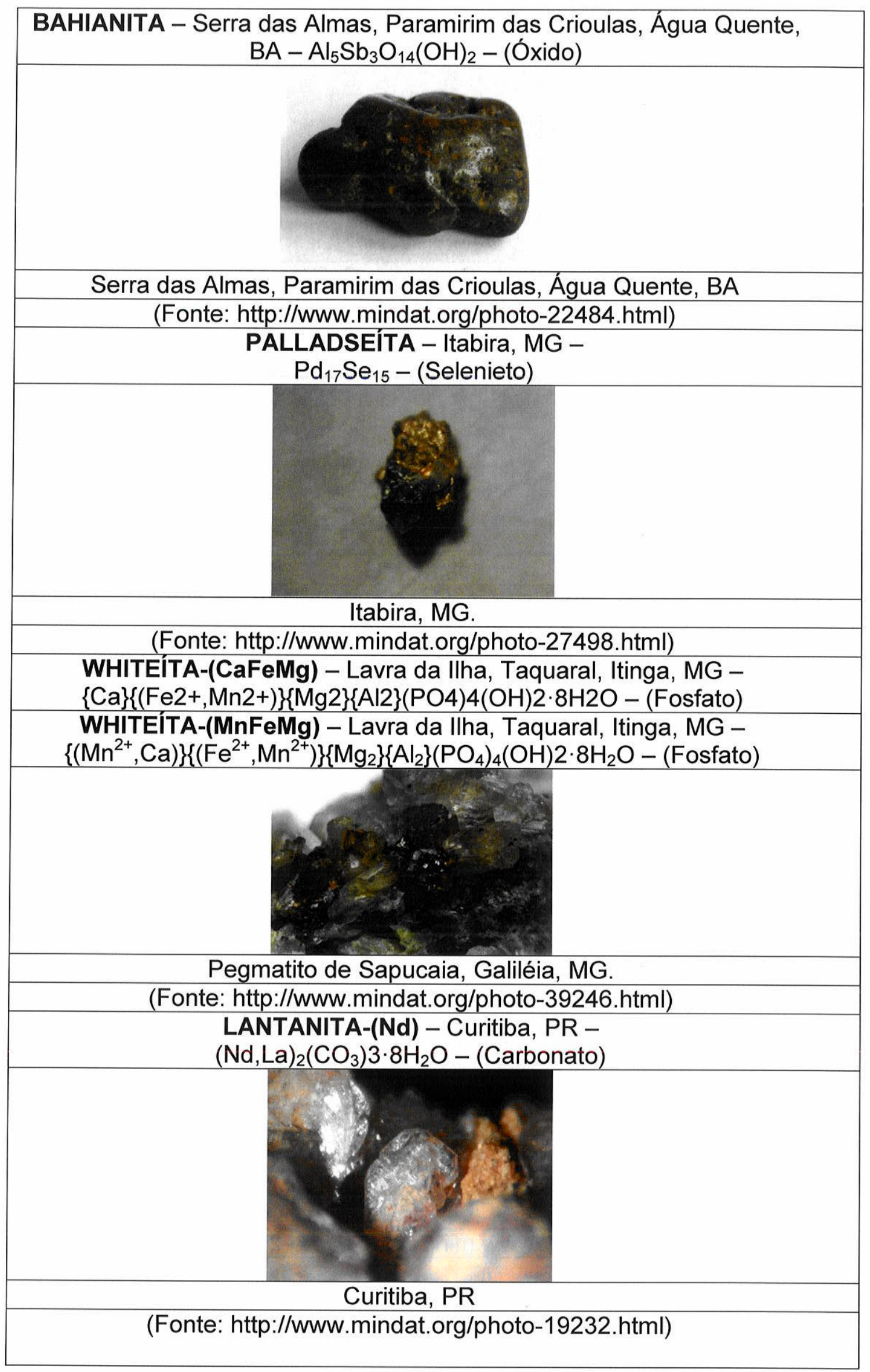




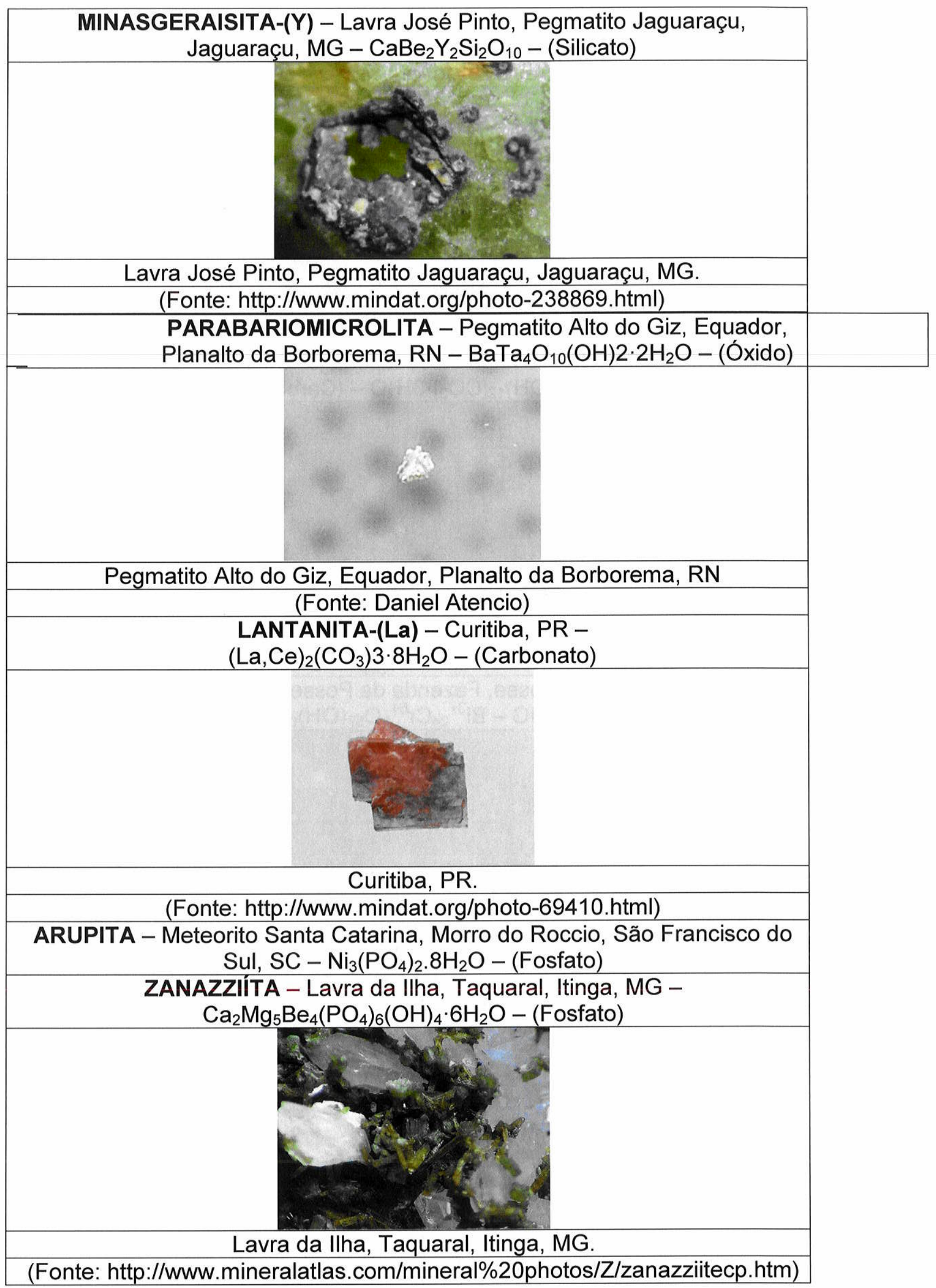




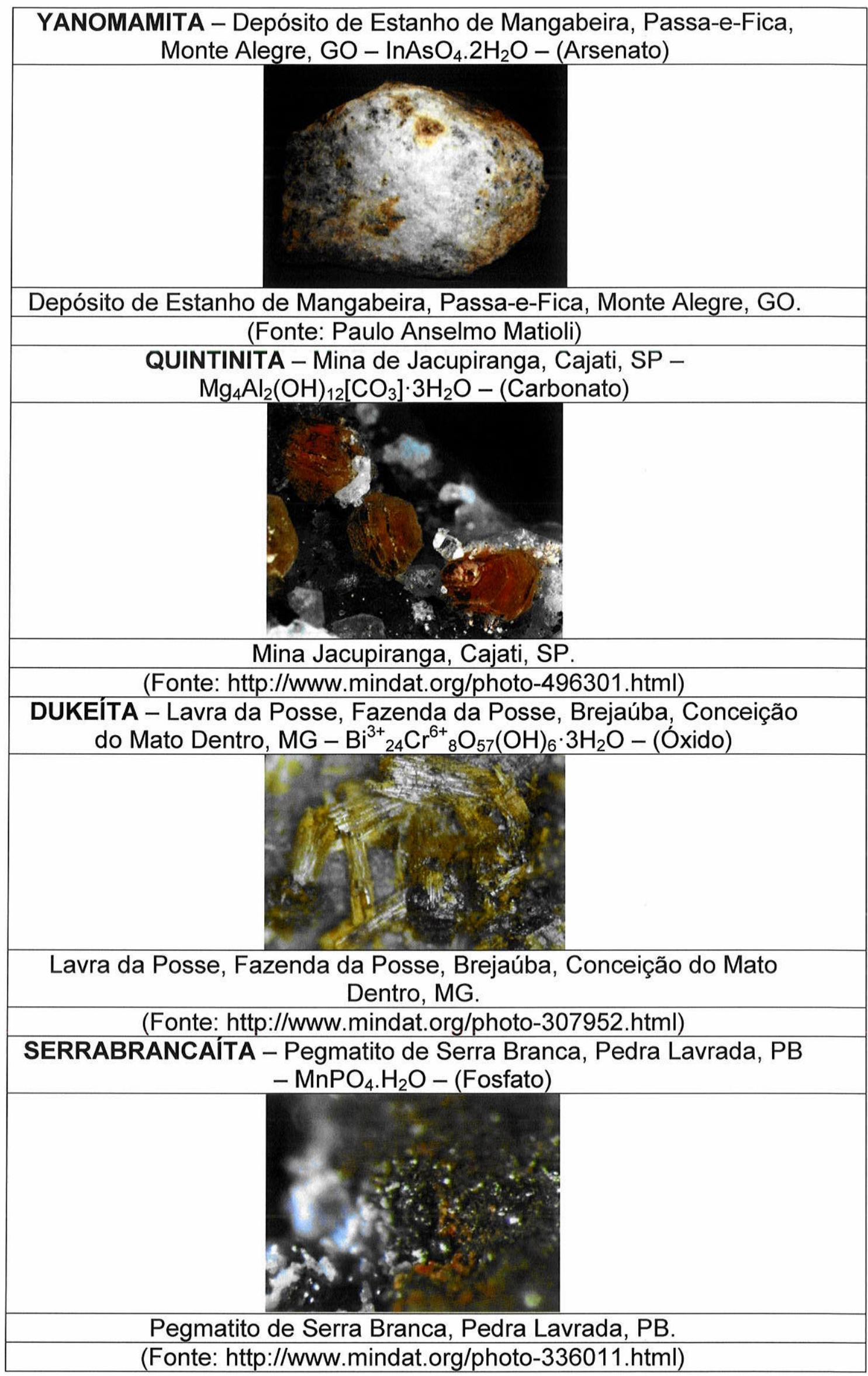




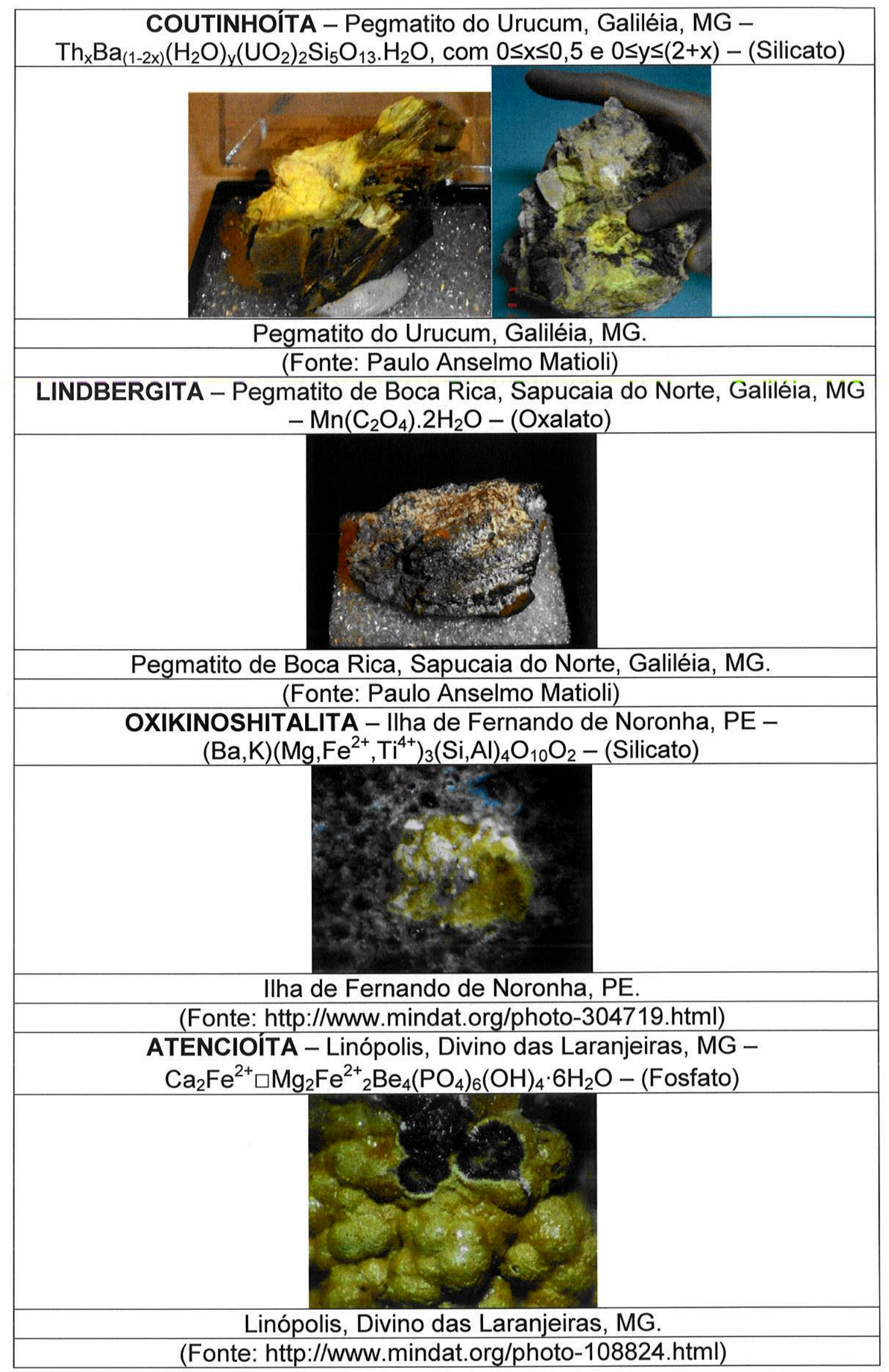




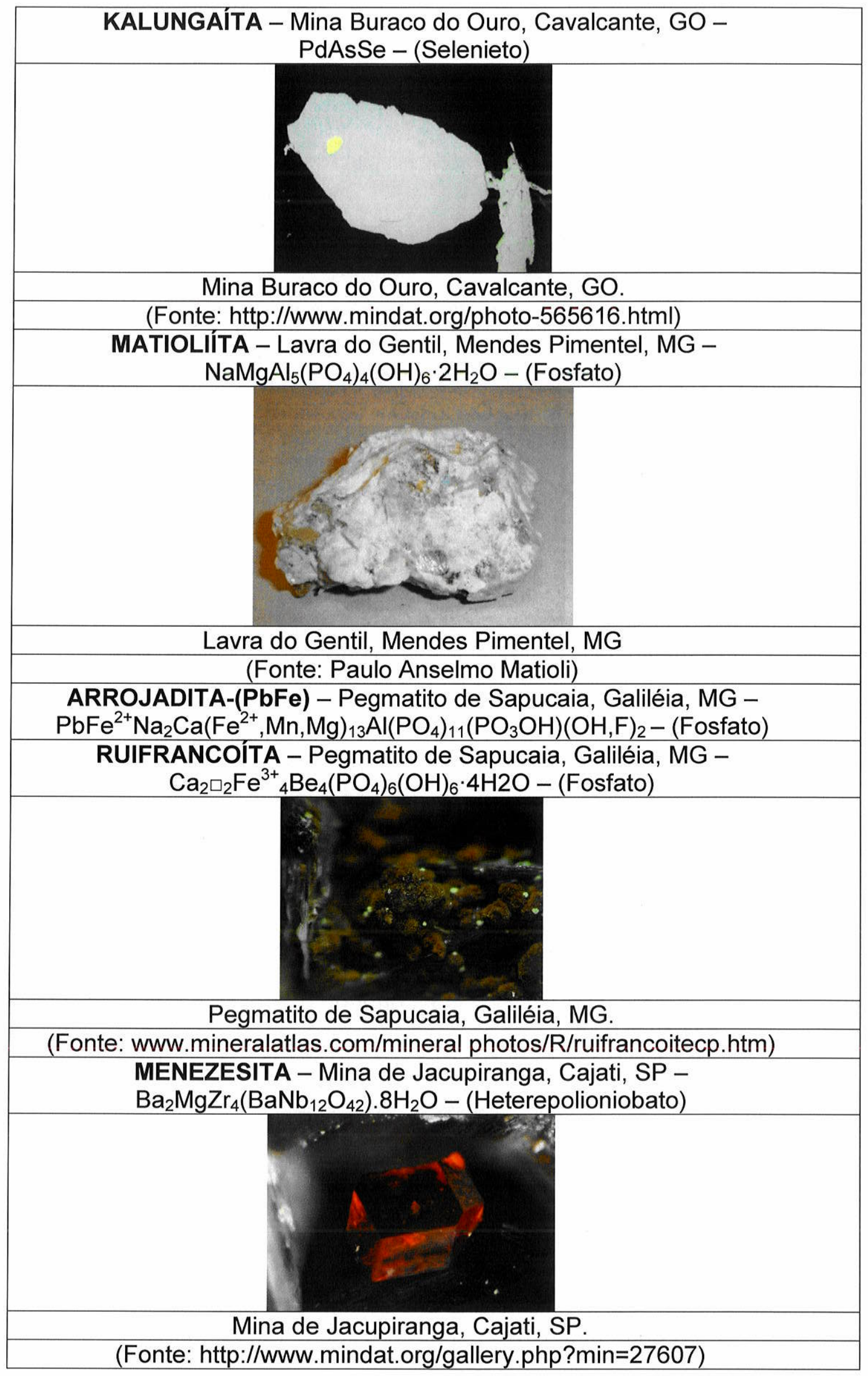




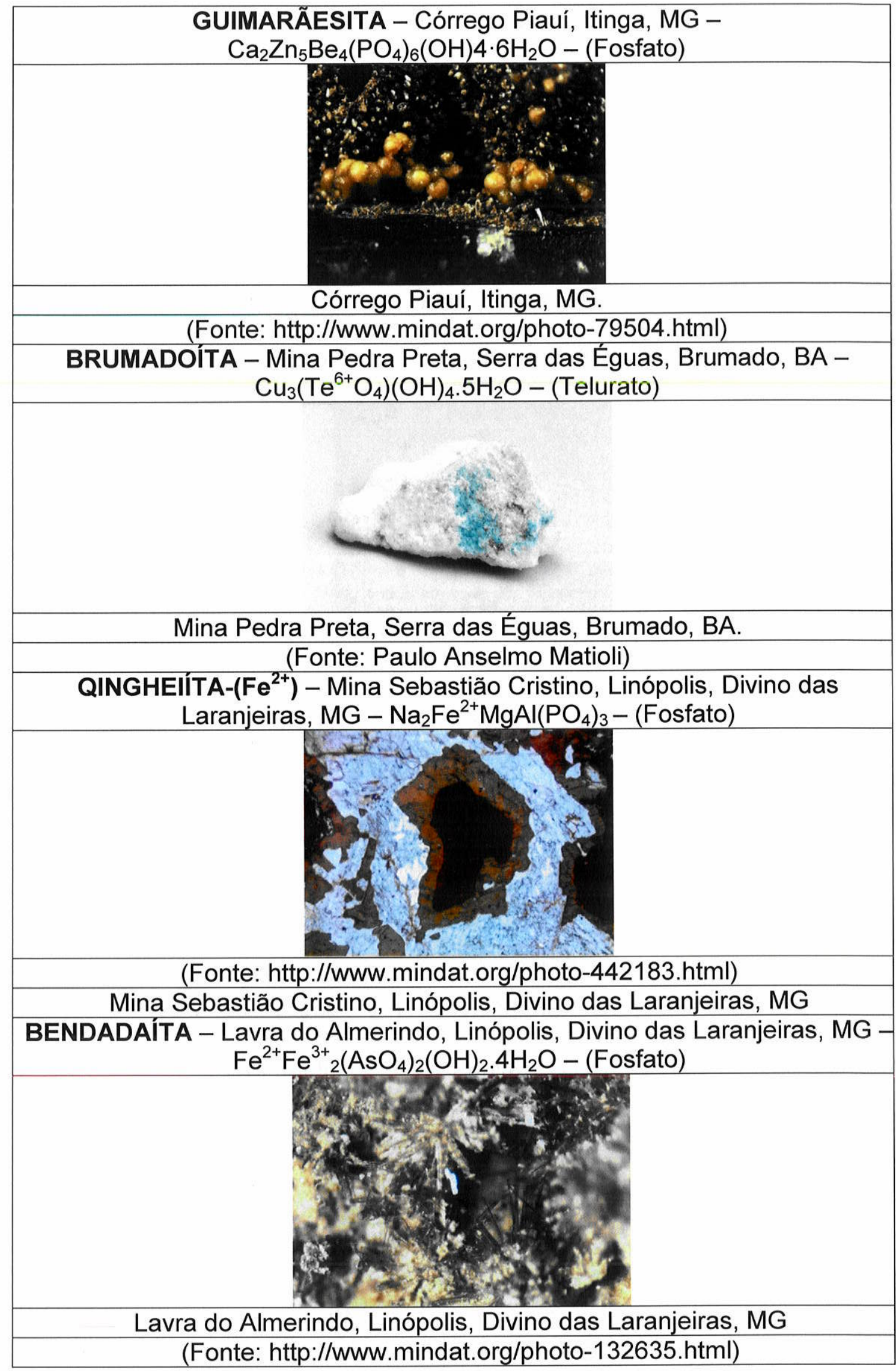




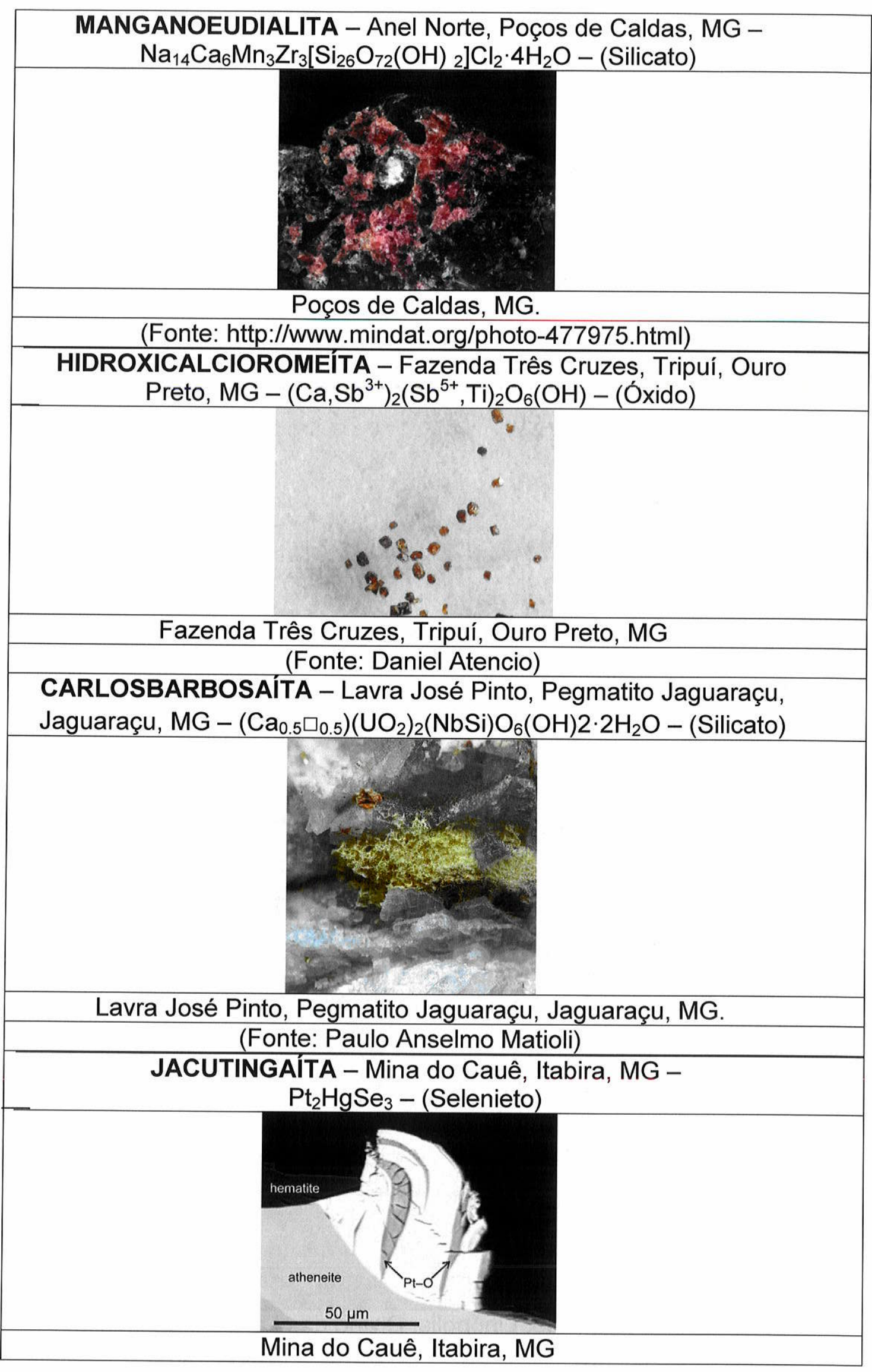




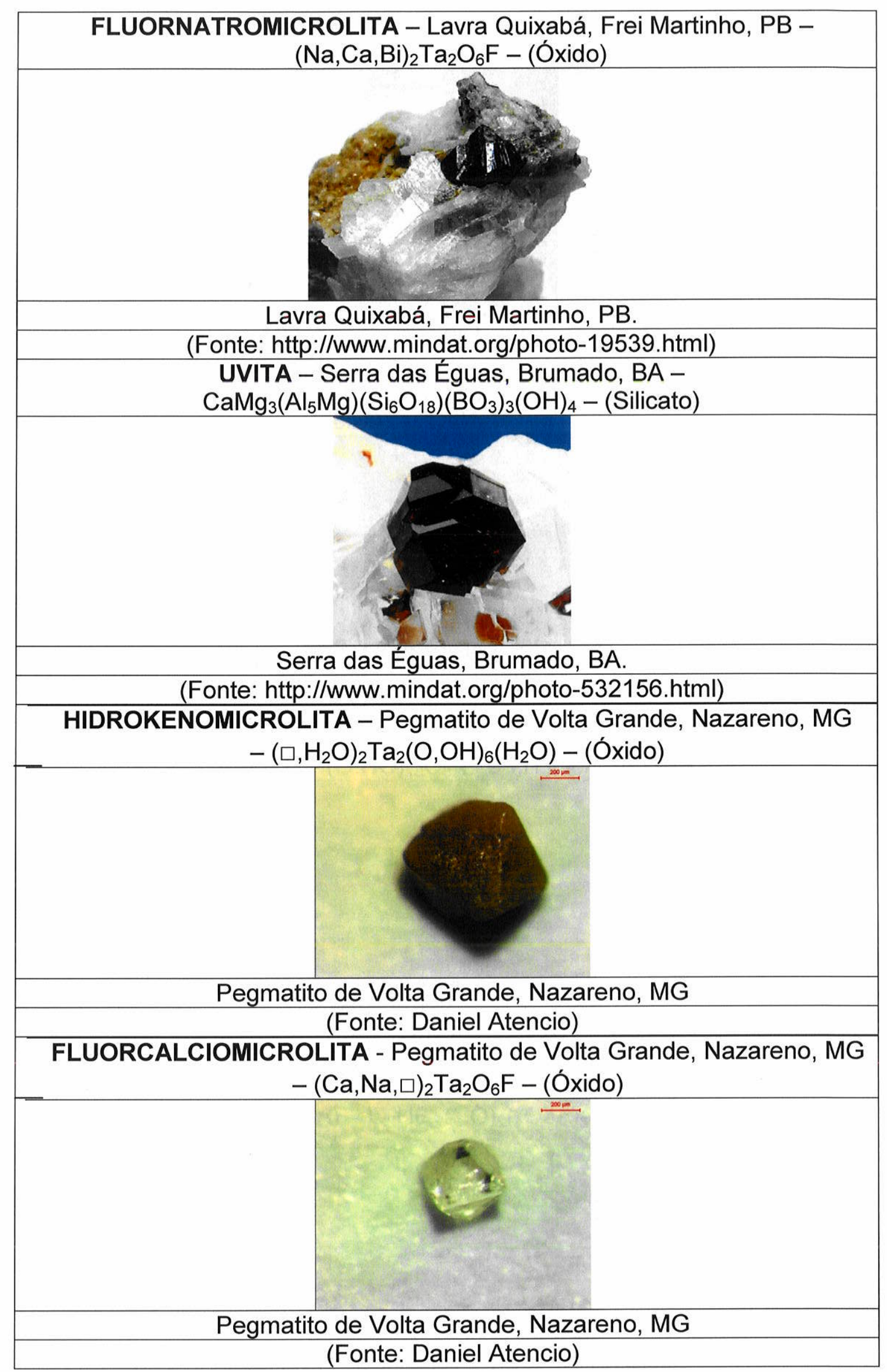




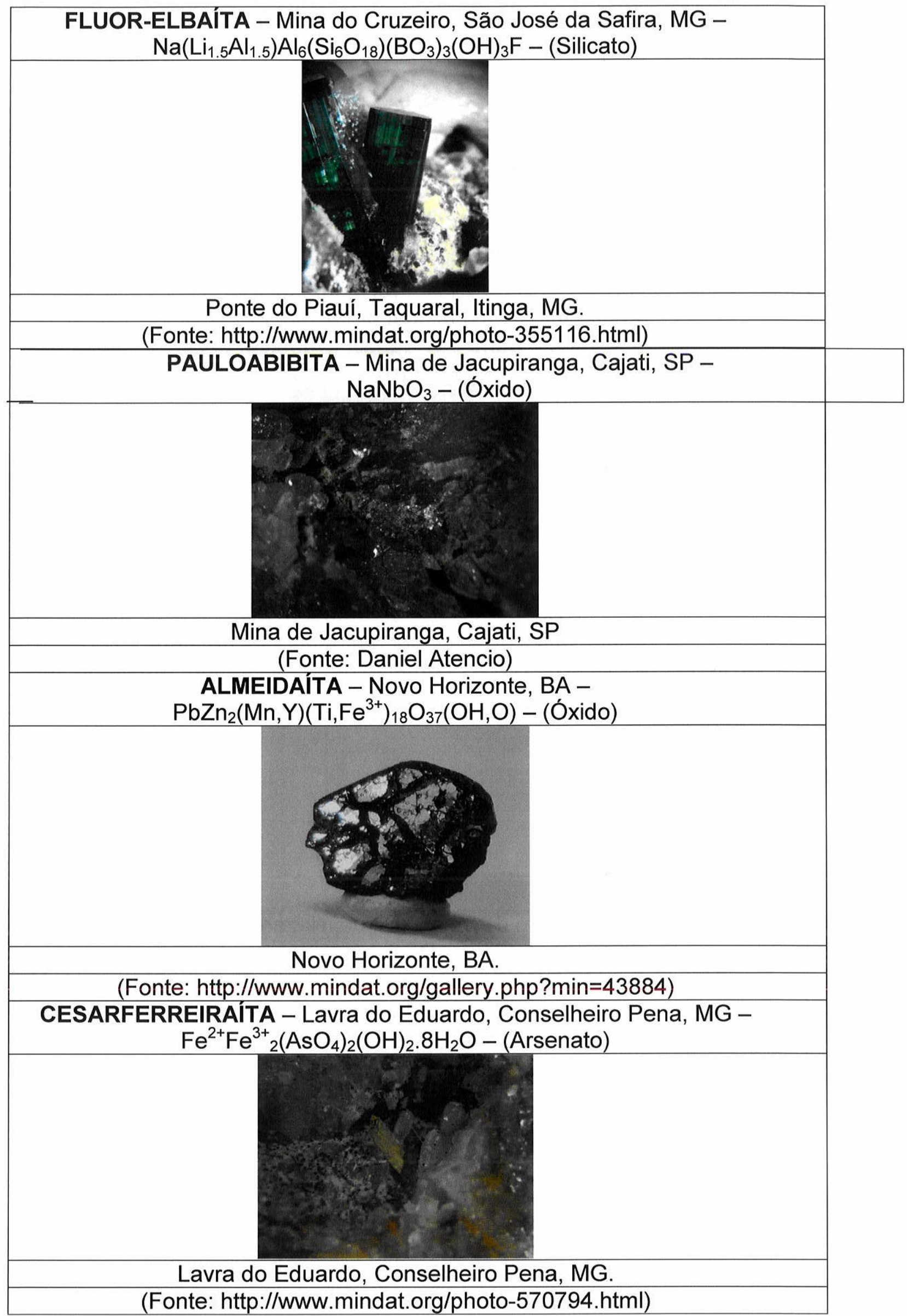




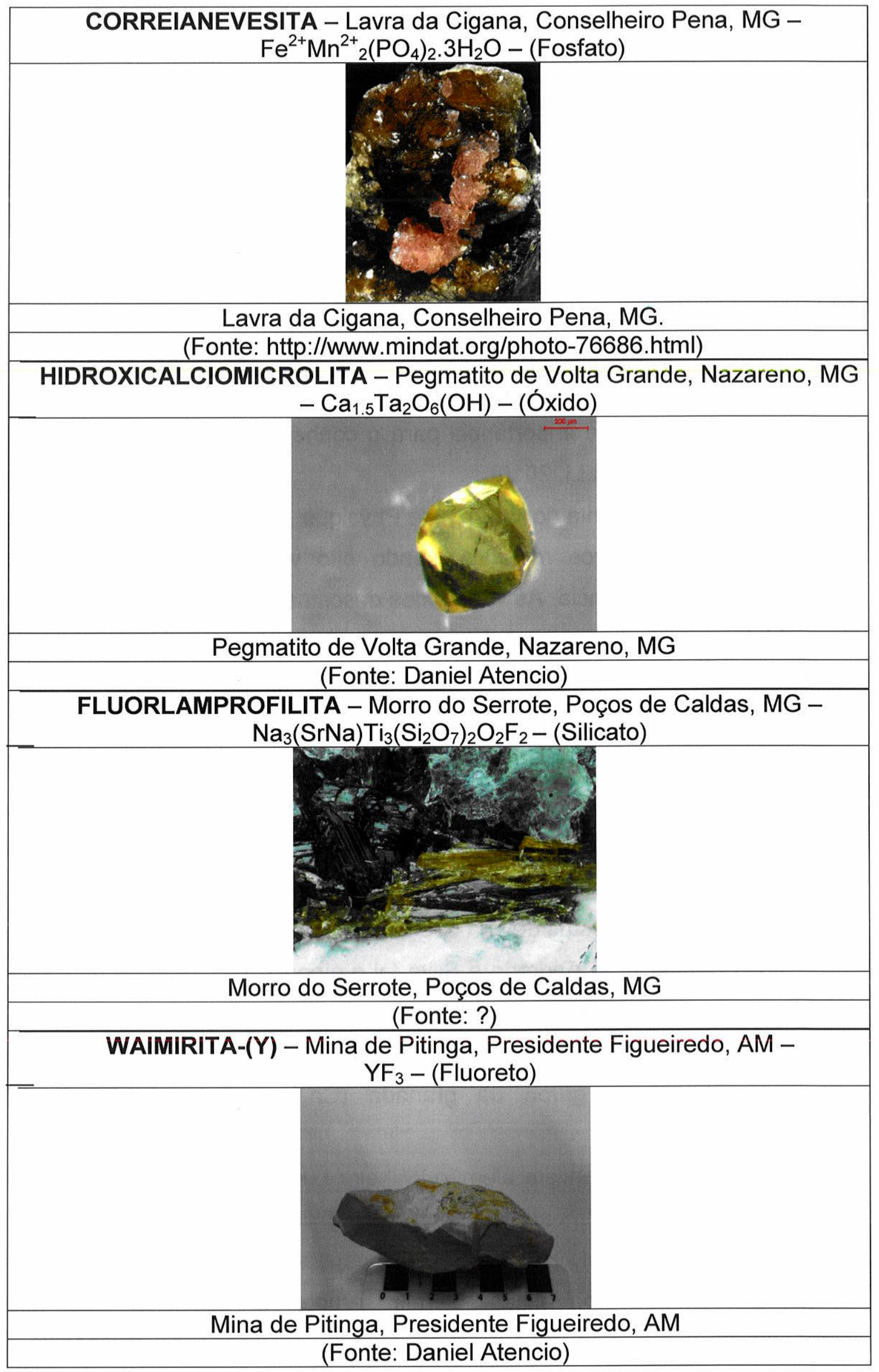




\subsection{OS PRINCIPAIS MINERALOGISTAS QUE ATUARAM NO BRASIL}

Os minerais, em nosso país, começaram a ter utilidade desde os sambaquis (O Homem de Sambaqui), em inúmeras regiões do Brasil, também tendo sido utilizados por povos indígenas de diversas etnias (Guarani, Tupinambá, Tupiniquim etc.), desde antes da invasão portuguesa, o que pode ser constatado, por exemplo, através de diversos objetos líticos e afrescos encontrados em cavernas (CORNEJO; BARTORELLI, 2010).

A história da mineralogia do país começa a ser escrita por José Bonifácio de Andrada e Silva (1765-1838). Reconhecido como patriarca da Independência no Brasil, apresenta grande importância para o conhecimento da mineralogia do país (CORNEJO; BARTORELLI, 2010).

Em 1800, apresenta no 'Journal de Physique' seu trabalho de maior destaque, descrevendo doze novos minerais, sendo oito variedades e quatro até então desconhecidos pela ciência. As variedades descritas foram o acanticônio (variedade de epídoto), salita (um piroxênio), cocolita (também um piroxênio), ictioftalmo (apofilita), indicolita (variedade azul de elbaíta, um mineral do grupo da turmalina), afrizita (turmalina negra; já descrita em 1524 por J. Mathesius e conhecida como schörl), wernerita (escapolita), alocroíta (variedade de granada entre andradita e grossulária) (VARELA; LOPES; FONSECA, 2004). As novas descobertas incluíam o espodumênio, a petalita, a criolita e a escapolita. Além de observar as características externas, José Bonifácio também forneceu dados químicos, sendo reconhecido junto aos principais mineralogistas de sua época.

José Bonifácio de Andrada e Silva foi o pioneiro das ciências geológicas nas Américas e graças a importância de suas descobertas recebeu em 1868 uma homenagem do mineralogista americano James $\mathrm{D}$. Dana, que batizou de andradita um novo mineral do grupo da granada $\left(\mathrm{Ca}_{3} \mathrm{Fe}_{2}\left(\mathrm{SiO}_{4}\right)_{3}\right)$ (VARELA; LOPES; FONSECA, 2004).

Em 1810 o geocientista alemão Wilhelm Ludwig von Eschwege (1771-1855) chega ao Brasil, e é nomeado tenente coronel do Real Gabinete de Mineralogia (CORNEJO; BATORELLI, 2010). Em 1811 constrói uma metalúrgica de ferro em Congonhas do Campo, Minas Gerais. Atuou na pesquisa dos depósitos diamantíferos e auríferos da região do Alto do Jequitinhonha (BRANCO, 2013). (ATENCIO, 2000). 
Os alemães Karl Friederich Phillip von Martius (1794-1868) e Johann Baptiste von Spix (1781-1826) empreenderam uma longa viagem pelo interior do Brasil, percorrendo mais de $10.000 \mathrm{~km}$. Relataram a presença de topázio imperial em Vila Rica (atual Ouro Preto) e, foram os primeiros cientistas a visitarem o meteorito siderítico Bendegó, encontrado na região de Monte Santo-Uauá, sertão da Bahia, em 1784. Ainda nesta excursão naturalista visitaram a região da Chapada do Araripe, fazendo um dos primeiros relatos sobre os fósseis brasileiros (HENRIQUES, 2008). As memórias de suas viagens foram registradas no livro Reise in Brasilien (1817-1820) (SPIX; MARTIUS, 1824).

O francês Claude Henri Gorceix (1842-1919) aparece no cenário brasileiro em meados de 1870, indicado ao imperador Dom Pedro II para realizar pesquisas no país e fundar a Escola de Minas em Ouro Preto (1876). Aceitando a proposta, Gorceix chega ao país trazendo inovações ao mundo acadêmico, como exigência de seleção, bolsas de estudos, ano letivo de dez meses, salários elevados, além de inovações na metodologia pedagógica, inserindo o trabalho de campo e o aspecto empírico, método transformado em lema gravado no escudo da escola "Cum mente et malleo", ou seja, "Com a cabeça e o martelo", o lema da geologia brasileira (BIBLIOTECA NACIONAL, s.d.).

Gorceix publicou mais de 50 trabalhos sobre jazidas de ouro, diamantes, topázio, ferro e terras raras, contribuindo significativamente para o conhecimento da mineralogia brasileira (BRANCO, 2013). Deixou um grande legado tanto no desenvolvimento da ciência, da geologia, mineralogia e siderurgia do país, além da Escola de Minas, que até hoje forma profissionais e engenheiros na área. É homenageado com um mineral secundário, gorceixita, um fosfato básico hidratado de bário e alumínio, descrito pela primeira vez por Hussak em 1906 (JELINEK et al., 2003).

O geólogo canadense Charles Frederick Hartt (1840-1878) fez parte da Comissão Geológica do Brasil (1875) e juntamente com Jean Louis Agassiz, desenvolveu uma excursão naturalista, a Expedição Thayer. Nesse mesmo ano, 0 geólogo norte-americano Orville Adelbert Derby inicia suas funções na Comissão (SILVA, 2011).

Orville Adelbert Derby (1851-1915) foi geólogo e geógrafo estadunidense naturalizado brasileiro. Além de fazer parte da Comissão Geológica do Império, organizou as coleções de mineralogia e paleontologia do Museu Nacional. Com mais 
de 170 trabalhos, dentre eles, estudos sobre diamante, ouro e manganês, contribuiu significativamente para a geologia e mineralogia do país (BRANCO, 2013).

Derby ainda participou de outra expedição chefiada por Hartt, a Expedição Morgan. Essas expedições eram incursões geológicas por várias regiões do Brasil, com intuito de coletar, pesquisar e conhecer diversas minas, lavras e garimpos (TOSSATO, 2001). Foi homenageado por seus feitos na área, com o batismo da derbylita, um óxido de ferro, titânio e antimônio, descrito por Hussak em 1895 (HUSSAK; PRIOR, 1895).

O petrólogo austríaco Eugen Hussak (1856-1911), juntamente com o mineralogista inglês George Thurland Prior, descreveu em 1895 os minerais-tipo brasileiros derbylita (já citada), tripuhyíta, "lewisita" e florencita-(Ce) (todos procedentes de Tripuí, Ouro Preto, Minas Gerais), senaíta nos satélites diamantíferos de Diamantina, Minas Gerais, e zirkelita nas rochas ultramáficas de Cajati, São Paulo, e a gorceixita (já citada) (BRANCO, 2013).

A partir de 1876, o mineiro Francisco de Paula Oliveira (1857-1935) obteve grande destaque na mineralogia brasileira, estudando galena, ouro, amianto, diamante, cinábrio, cobre e molibdenita (BRANCO, 2013).

A partir de 1879, outro mineiro, Luiz Felipe Gonzaga de Campos (1856-1925) incrementou os estudos sobre o diamante, ouro, ferro, e foi o precursor para a criação do Instituto Nacional de Tecnologia (BRANCO, 2013), além de contribuições para pesquisas das reservas siderúrgicas do Brasil (ABREU, 1937).

O neto de Dom Pedro II, Príncipe Dom Pedro Augusto de Saxe-CoburgoGotha (1866-1934), interessou-se por mineralogia, e também deixou algumas contribuições na área, como estudos sobre albita, apatita e scheelita do filão aurífero de Morro Velho e o quartzo brasileiro (FERRI; MOTOYAMA, 1979-1981).

A partir de 1880, o mineiro Joaquim Cândido da Costa Sena (1852-1919) estudou o bismuto e o fosfato no Brasil (BRANCO, 2013). Tem seu nome referendado a outra descoberta de Hussak, a senaíta, um óxido de ferro, titânio de chumbo em 1898 (INSUGEO, s.d.).

No ano de 1890, João Pandiá Calógeras (1870-1935) formou-se na Escola de Minas. Estudou o siderito Santa Catarina, além de ouro, ferro e diamante de Minas Gerais, sendo um dos seus trabalhos mais importantes "As Minas do Brasil e sua legislação" (BRANCO, 2013). A calogerasita, desacreditado como simpsonita, foi 
nomeado em sua homenagem em 1944 por Caio Pandiá Guimarães (THE PHILADELPHIA MINERALOGICAL SOCIETY, 1945).

Em 1894, Miguel Arrojado Ribeiro Lisboa (1872-1932) começou a estudar o ouro da região da Bacia de Gurupi, no atual estado de Tocantins, além da jazida de manganês do Morro da Mina em Conselheiro Lafaiete, Minas Gerais. Em 1907, destaca a ocorrência de ferro e manganês de Urucum, próximo a Corumbá, Mato Grosso do Sul. Foi considerado em sua época o maior geólogo brasileiro (FERRI; MOTOYAMA, 1979-1981). Em 1924, Djalma Guimarães batiza em sua homenagem a arrojadita, um fosfato de ferro, manganês e cálcio, encontrado na Serra Branca, Paraíba (GUIMARÃES, 1925).

Em meados de 1919, Avelino Ignácio de Oliveira (1891-1991) desenvolve estudos sobre a ocorrência de barita em Araxá em Minas Gerais, cobre no estado do Rio Grande do Sul. Atuou no SGM, em estudo de carvão e petróleo na região amazônica. Seus trabalhos nos campos da Mineralogia e Petrologia, quase sempre são voltados à economia dos bens minerais (FERRI; MOTOYAMA, 1979-1981).

O primeiro brasileiro a formular um mineral-tipo para o Brasil foi o eminente professor geólogo Djalma Guimarães (1894-1973), que em 1925 determinou o mineral arrojadita, hoje um grupo de minerais, além da eschwegeíta (1926) e giannettita (1948), ambos inválidos. Foi um grande especialista em nióbio-tantalatos de Araxá e estudou pegmatitos de Minas Gerais e de Roraima. Esteve envolvido nas descobertas de jazidas de apatita (fosfato) e pirocloro (nióbio) de Araxá, o que levou sua projeção nacional e internacional, tornando o Brasil o maior produtor de nióbio do mundo. Foi indicado para a criação do Instituto de Pesquisas Radioativas, hoje Centro de Desenvolvimento de Tecnologia Nuclear (CDTN). Dirigiu os mais importantes órgãos nacionais e estaduais das Geociências. Descreveu o meteorito da Serra do Magé (PE), em 1927 e o Patos de Minas (MG), em 1958. A djalmaita (desacreditada) e a guimarãesita (nome utilizado duas vezes, a primeira vez referente a um mineral desacreditado) foram referendadas em seu nome como homenagem (BRANCO, 2013; MINISTÉRIO DA CIÊNCIA, TECNOLOGIA E INOVAÇÃO, 2013).

A partir de 1919, o engenheiro Othon Henry Leonardos (1899-1977) iniciou suas contribuições significativas à mineralogia brasileira, na qual se encontram o reconhecimento geológico do rio Xingu, os garimpos diamantíferos do Triângulo 
Mineiro, além do estudo do ferro, chumbo, prata, tântalo, nióbio, urânio e rádio (BRANCO, 2013).

O engenheiro de minas, Luciano Jacques de Moraes (1896-1968) formado em 1922, pela Escola de Minas é responsável por uma produção respeitável na área da mineralogia. Realizou o primeiro mapeamento sistemático do Brasil e produziu cerca de 170 trabalhos, dentre eles estudos sobre o ouro no centro de Minas Gerais, possibilidades de petróleo no Rio Grande do Norte, serras e montanhas do Nordeste, recursos minerais no Espírito Santo, entre tantos outros, tendo grande contribuição na área (FERRI; MOTOYAMA, 1979-1981). Em 1953 tem seu nome batizado por M.L.Lindberg, William T. Pecora e colaboradores, em um novo mineral, a moraesita (BACK, 2008).

Evaristo Penna Scorza (1899-1969), engenheiro de minas e metalurgia, atuou na área de petrologia e entrou para o Serviço Geológico e Mineralógico do Brasil em 1924, estabelecendo-se em Santa Catarina, onde direcionou seus trabalhos para a pesquisa de carvão na região de Nova Veneza e Trevisto/SC, bem como para a geologia no Rio Grande do Sul, na fronteira com o Uruguai (FERRI; MOTOYAMA, 1979-1981). William T. Pecora e J. J. Fahey homenagearam the com o nome do mineral scorzalita, em 1947 (BLACK, 2008)

Em 1933, o geólogo e engenheiro de minas Octávio Barbosa (1907-1997) trabalhou na Divisão de Fomento da Produção Mineral (DNPM). Publicou mais de 200 trabalhos, sobre mineralogia, petrografia, geologia econômica, estratigrafia, paleontologia e geologia aplicada, como o trabalho de destaque "Diamante no Brasil". Atuou no antigo Serviço Geológico e Mineralógico do Brasil (SGM) e em 1977 ingressou para o Serviço Geológico do Brasil - CPRM. O acervo de suas obras encontra-se na biblioteca da CPRM no Rio de Janeiro (CPRM, 2012).

Em 1934, o alemão Heinz Ebert (1907-1983), contratado para o Departamento Nacional de Produção Mineral (1934) instalou-se no Brasil. Mapeou a região de São João Del Rei a Juiz de Fora e Barbacena (1950/1956). Apresentou importantes trabalhos sobre o Cristalino Brasileiro (1959), sendo conselheiro da SUDENE (MUSEU DE MINERAIS E ROCHAS “HEINZ EBERT”, s.d).

O geólogo alemão Viktor Leinz (1904-1983) teve grande destaque mineralógico vindo para o Brasil em 1935. Incrementou a exploração do cobre das Minas do Camaquã, no Rio Grande do Sul, tendo participação ativa em 1957 na fundação do curso de Geologia da Universidade de São Paulo (BRANCO, 2013). 
Em 1945, o geólogo norte-americano Frederick Harvey Pough (1907-2006) descreveu uma nova espécie brasileira, o fosfato brazilianita, no pegmatito de Córrego Frio, na região de Galiléia, Minas Gerais. Em 1968 o mineral, poughita recebeu seu nome como homenagem (FERRI; MOTOYAMA, 1979-1981).

Ainda na década de 40, William T. Pecora (1913-1972) e J.J. Fahey (1949) descrevem duas novas espécies de fosfatos - scorzalita e souzalita, no mesmo pegmatito onde a brazilianita havia sido descoberta (FERRI; MOTOYAMA, 19791981). A relevância dos trabalhos de Pecora levou a NASA e o USGS a criar um prêmio de reconhecimento a indivíduos ou grupos que tenham contribuído para a compreensão do planeta Terra por intermédio de sensoriamento remoto. Trata-se do William T. Pecora Awards (U.S. Geological Survey, 2014).

Nas décadas de 40 e 50, Marie Louise Lindberg (1918-?), pesquisadora da U.S Geological Survey em Washington, descreveu novos minerais, contribuindo para o conhecimento da mineralogia do país, como a avelinoita (=cyrilovita), frondelita, faheyíta, moraesita, tavorita e barbosalita no pegmatito Sapucaia, Minas Gerais (LINDBERG, 1954; 1957). Foi homenageada por um novo mineral de Galiléia, Minas Gerais, batizado de lindbergita (ATENCIO et al., 2004).

O geólogo Rui Ribeiro Franco (1916-2008) também tem grande destaque, publicando mais de oitenta trabalhos sobre geologia e mineralogia. Em 1972, em colaboração com outros geocientistas, publicou o livro "Minerais do Brasil". Rui Ribeiro Franco se dedicou ao ensino de geociências e a práticas pedagógicas sempre ligadas a mineralogia (FERRI; MOTOYAMA, 1979-1981).

Nos anos 80, o geólogo francês Jacques Pierre Cassedanne se destaca no cenário da pesquisa mineralógica brasileira. Desenvolveu trabalhos em Minas Gerais, em especial na descrição de pegmatitos, como os Jaguaraçu e Sapucaia (CASSEDANNE, ALVES, 1994; CASSEDANNE; BAPTISTA, 1999). Possui um mineral batizado em sua homenagem, a cassedanneíta, um cromato-volframato hidratado de chumbo, monoclínico, que forma uma série isomórfica com a embreyita, descoberto nos Urais (Rússia) (MINDAT, s.d.)

Daniel Atencio, do Instituto de Geociências, Universidade de São Paulo, associado a vários pesquisadores, descreveu 29 minerais novos, sendo 18 do Brasil [coutinhoíta, lindbergita, matioliíta, ruifrancoíta, menezesita, guimarãesita, brumadoíta, bendadaíta, manganoeudialita, hidroxicalcioromeíta, carlosbarbosaíta, hidrokenomicrolita, fluorcalciomicrolita, pauloabibita, cesarferreiraíta, almeidaíta, 
hidroxicalciomicrolita e waimirita-(Y)] e 11 estrangeiros. Atencio, desde 1991, é membro representante do Brasil na CNMNC - IMA (Associação Mineralógica Internacional). Em sua homenagem, foi referendado um mineral do grupo da roscherita, a atencioíta (Chukanov et al., 2006). 


\section{CAPÍTULO 3 - A HISTÓRIA DOS MUSEUS}

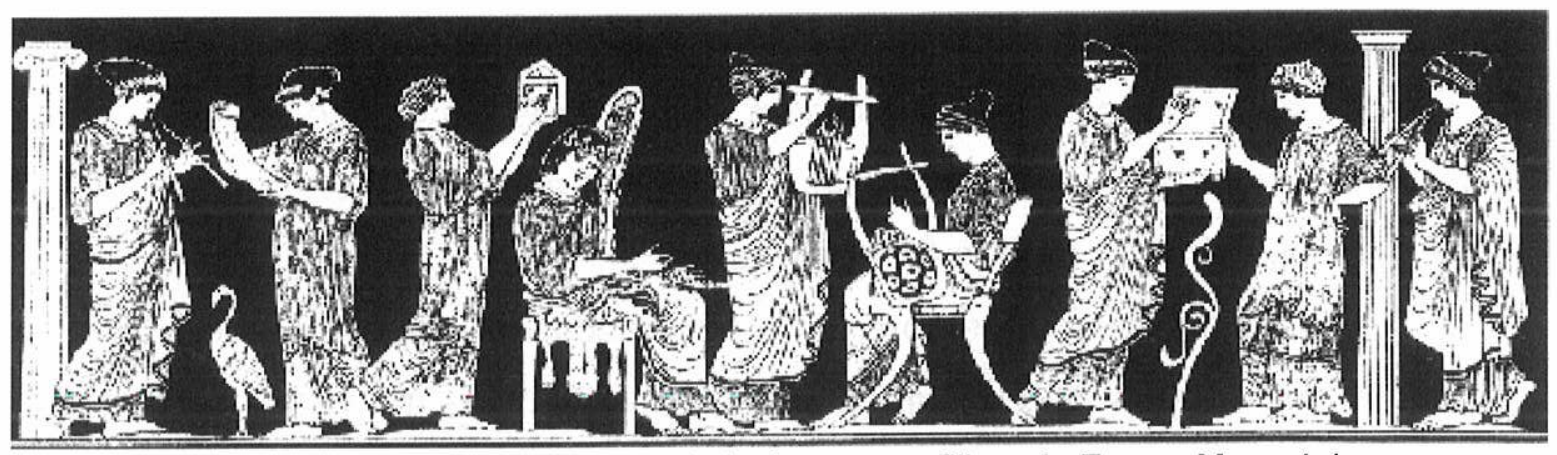

Figura 13. As nove musas da mitologia grega - filhas de Zeus e Mnemósine. Fonte: http://dc367.4shared.com/doc/H_m_wm-/preview.html.

A história dos museus tem origem em tempos remotos da Grécia Antiga, a começar pelo significado de seu nome, que vem de Mouseiom - templo das nove musas, filhas de Zeus com Mnemósine (Deusa da Memória). Este templo era um local dedicado à contemplação e aos estudos científicos, literários e artísticos, artes e ciências (GUIMARAENS, 2007).

Em Alexandria, no século III a.C., o primeiro museu de que se tem registro era considerado um centro de pesquisa e convívio cultural que reunia materiais sobre o conhecimento da época (LOPES, 1988,p.14), esculturas, instrumentos cirúrgicos e astronômicos, pedras e minérios de terras distantes. Foi considerada a primeira universidade do mundo, mas acessível somente às classes dominantes.

De acordo com Campos (2005 p. 131-160), durante a Idade Média, a maioria da produção e criação artística, cultural e científica na Europa ficou estagnada pela influência da Igreja Católica. Nos principais países de sua atuação, somente os clérigos e parte da realeza possuíam acesso ao conhecimento e à sua produção. Desta forma, este período teve um maior investimento em grandes construções, como castelos e catedrais, e na agricultura, que era o principal meio de sobrevivência de todos que viviam nos feudos.

No final da Idade Média, o reaquecimento comercial e o crescimento da classe social chamada burguesia trouxeram uma série de transformações na economia e na sociedade europeia como um todo. A integração comercial com os países do Oriente sedimentou a formação de um amplo mercado consumidor interessado na compra de produtos manufaturados e especiarias provenientes de 
países como Índia e China. No entanto, esse comércio era caracterizado por alguns entraves que impediam sua expansão, por estar dominado pelos árabes.

A necessidade de obter recursos minerais e especiarias com maior facilidade e custos baixos fez com que surgissem as Grandes Navegações, empreendimento marítimo patrocinado pela burguesia com todo o apoio da monarquia e da Igreja, o que inseriu a Europa no período moderno.

A saída aos mares, os novos interesses econômicos e a descoberta de outras terras e civilizações são algumas das consequências maiores desse fenômeno histórico que, a partir dos séc. XVI e XVII permitiram o surgimento dos famosos e requisitados "Gabinetes de Curiosidades".

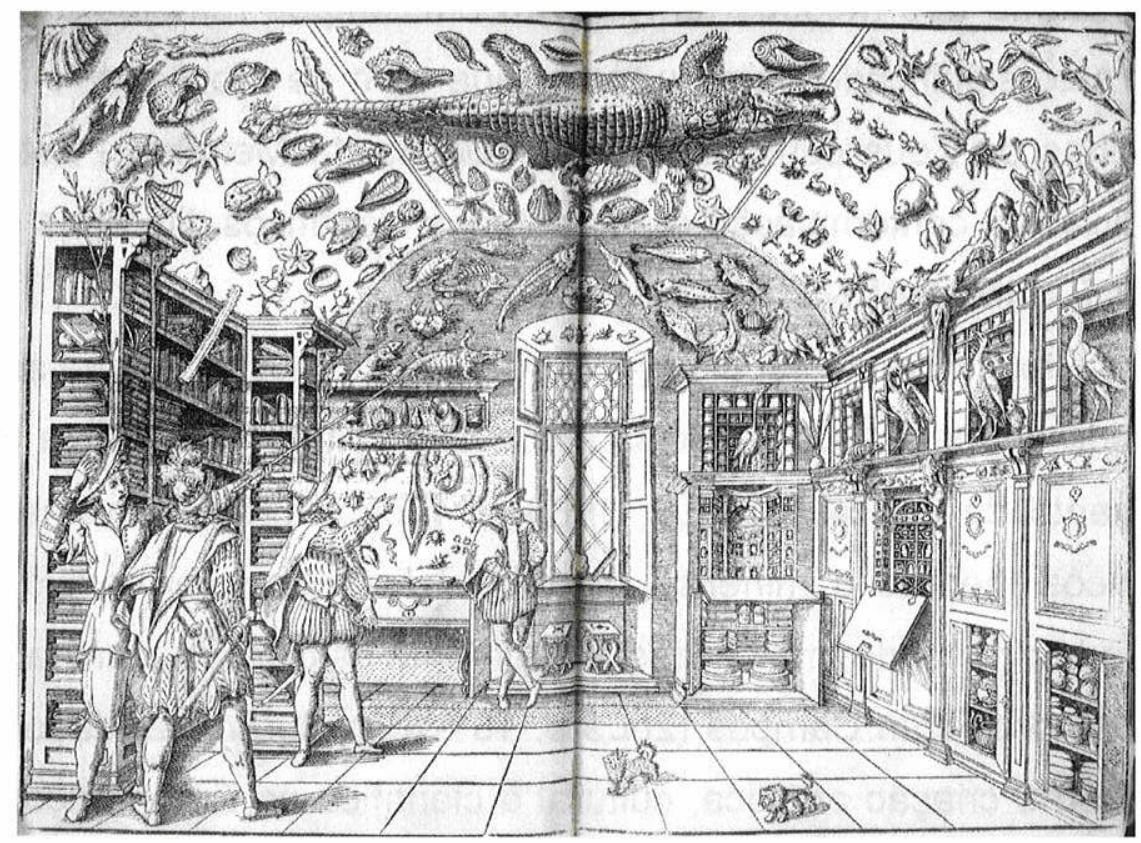

Figura 14. Esta é uma das mais antigas representações do gabinete de curiosidades do Boticário Ferrante Imperato,1599.Fonte: http://bibliodyssey.blogspot.com.br/2007/01/exploring-galaxy.html

Os gabinetes de curiosidades ou "os quartos de maravilhas", conhecidos como "Cabinets de Curiosités" na França, "Wunderkammern" na Alemanha e Áustria, "Wonder Chambers" na Grã-Bretanha e "Kunstkammer" na Dinamarca, existiam em quase todos os países da Europa.

A exploração mercantilista desvelou as maravilhas do Novo Mundo, com as produções humanas em sua pluralidade cultural, mas principalmente as riquezas naturais. A curiosidade humana e a preocupação em conservar a criação divina representada pela natureza fizeram com que surgissem estes gabinetes, locais que 
reuniam o maior número possível de objetos, considerados verdadeiros baús de tesouros (PEREIRA, 2006).

Os exploradores que retornavam com os frutos da empreitada traziam consigo diversos objetos que comprovavam suas incursões: artefatos indígenas, animais exóticos, como aves (penas), moluscos (conchas) e corais, além de diversos tipos de minerais, rochas e alguns fósseis. Muitos nobres e burgueses adquiriam estes objetos para suas coleções.

De acordo com Lopes (1988, p. 15-17), estas coleções particulares recebiam o nome de "gabinetes", o que derivou de um móvel onde se guardavam e preservavam pequenos objetos, para ser empregado no sentido de pequenas salas com objetos raros e de grande valor, nas áreas de zoologia, botânica, mineralogia, petrologia, paleontologia, história, física, química, literatura e artes.

Os "Quartos das Maravilhas" eram reconhecidos pela sociedade como 0 caminho para o progresso, pois difundiam a razão com o conhecimento. Seus acervos eram obras de arte, documentos históricos, animais, plantas, rochas, conchas, fósseis, minerais, moedas, selos, armas, móveis, vestuários, artefatos culturais e arqueológicos, etc. Estas coleções eram um símbolo de estatuto social e também expressão da ânsia pelo saber dos seus proprietários. Estiveram, desde muito cedo, à disposição de um maior número de visitantes (KRAUS, 2008).

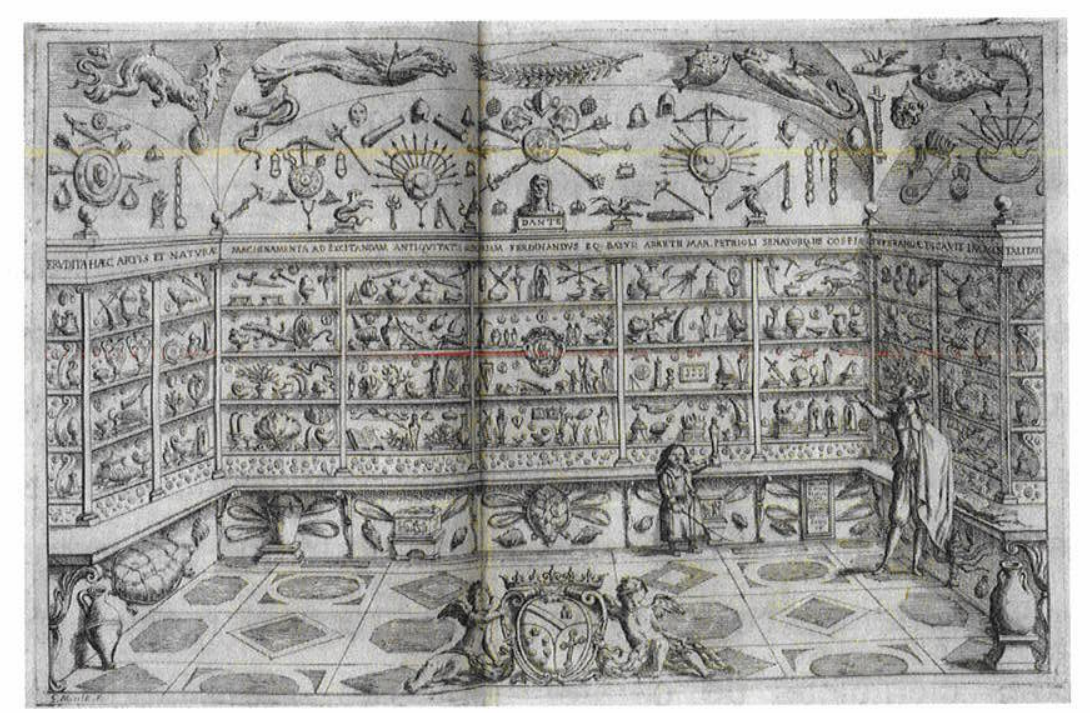

Figura 15. Ilustração retirada da publicação Museu Cospiano - o gabinete de curiosidades do príncipe Ferdinando Cospide Toscana anexado ao de Ulisse Aldrovandi - por Lorenzo Legati ,1677. Fonte: Watson Antiquarianemhttp://bibliodyssey.blogspot.com.br/2007/01/exploring-galaxy.html 
Segundo Possas (2005, p. 151-162), estes gabinetes possuíam um caráter enciclopedista a princípio, pois seus guardiões queriam ter ao alcance dos olhos as belezas culturais e naturais destes novos mundos tão distantes e desconhecidos. A autora expõe um ponto muito curioso, pois estes gabinetes eram lugares de memória que ampliavam a sensação de poder e conhecimento, e também de pertencer e compreender a criação de Deus, a grandiosidade divina em suas mãos.

\begin{abstract}
"Nos gabinetes, a tradição divina e sagrada abriga o novo, evidenciando uma articulação entre o que se conhece e o que se está por conhecer, a ciência que se conhecia e o que se está por construir." (POSSAS, 2005)
\end{abstract}

Possas também coloca em seu trabalho que existiam dois grandes eixos que dividiam as coleções nos gabinetes, a Naturalia e o Mirabilia (conforme estudo de Adalgisa Lugli). A Naturalia era composta por exemplares naturalistas (mineral, vegetal e animal); já a Mirabilia possuía produções humanas, bem como produtos de consumo (POSSAS, 2005).

De acordo com Lopes (1988, p.17), a difusão dos estudos sobre as riquezas naturais do Oriente e do Ocidente enriqueceu os Gabinetes de Curiosidade e, pelo acréscimo gradativo de suas coleções, esses gabinetes se transformaram em núcleos importantes de investigação e pesquisa para a época, apoiados em seus acervos curiosos que mais tarde originaram os principais museus europeus de história natural.

Tantos os nobres, que possuíam coleções grandiosas e fantásticas, quanto os pesquisadores naturalistas da época, que tinham suas coleções mais voltadas para o raro e único, começaram a se especializar para classificar cuidadosamente seus acervos e a se preocupar com a apresentação dos mesmos, ou seja, uma correta conservação dos exemplares. Os objetos passaram a ter importância em si, como elementos de pesquisa e não só por sua beleza ou raridade.

Torrens (1985 apud LOPES, 1988, p. 16-17) afirma que entre os séculos XVI e XVII existiam importantes coleções geológicas, consideradas o marco inicial para as classificações científicas de caráter geológico. Aldrovandi de Bologna(15221605), naturalista e colecionador, publicou em 1600 o trabalho "Museum Metallicum", que continha todo o conhecimento dos objetos geológicos da época. 
Em meados do século XVII, as coleções naturalistas eram organizadas de maneira sistemática, o que se mantém até hoje pela influência de Carl Von Linné, com critérios para coleta, informações e ilustrações (POSSAS, 2005, p. 151-162).

As coleções de minerais possuiam inicialmente um interesse mais farmacológico do que por sua beleza; nos gabinetes se misturavam diversas áreas do conhecimento. Quando recebiam minerais com uma qualidade gemológica ou raridade, eram agregados às coleções familiares para serem preservados na família.

De acordo com Guimaraens (2007), com o fim do Renascimento, no final do séc. XVII surge o lluminismo, com suas ideias de liberdade do conhecimento, de educação para todos e de igualdade. Assim surgiram os primeiros Museus na Europa, com o objetivo de conservar as coleções doadas e que provinham dos gabinetes de curiosidade.

O Ashmolean Museum de Oxford, criado em 1683, o mais antigo de todos, possuía as coleções ecléticas de várias partes do mundo. Uma das principais coleções doadas foi a da família Tradescant. O museu contava com uma estrutura com laboratórios, salas de aula com o propósito de investigação, catalogação, conservação, educação e exibição. Seu principal propósito era ser um órgão público em benefício público (LEWIS, 2004).

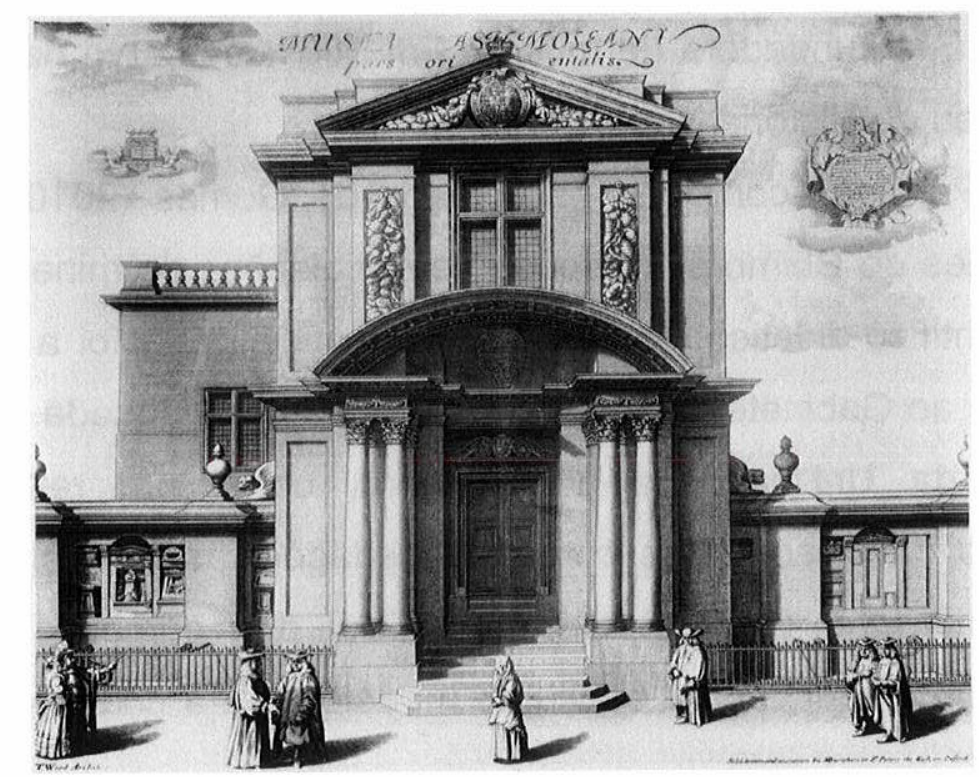

Figura 16. Frente do Ashmolean Museum em seu edifício original em Broad Street (gravura feita por Michael Burgueses 1685). Fonte: http://britisharchaeology.ashmus.ox.ac.uk/collections/collection-index.html

O estilo enciclopédico com a influência iluminista fortaleceu a união do conhecimento com a razão, a ordem e a moral, favorecendo a formação de acervos 
sistemáticos e a atuação de instituições culturais com objetivos educativos e públicos. Outro importante museu fundado na Inglaterra no século XVIII foi o British Museum, aberto em Londres em 1759, estabelecido por ato parlamentar, para o benefício público.

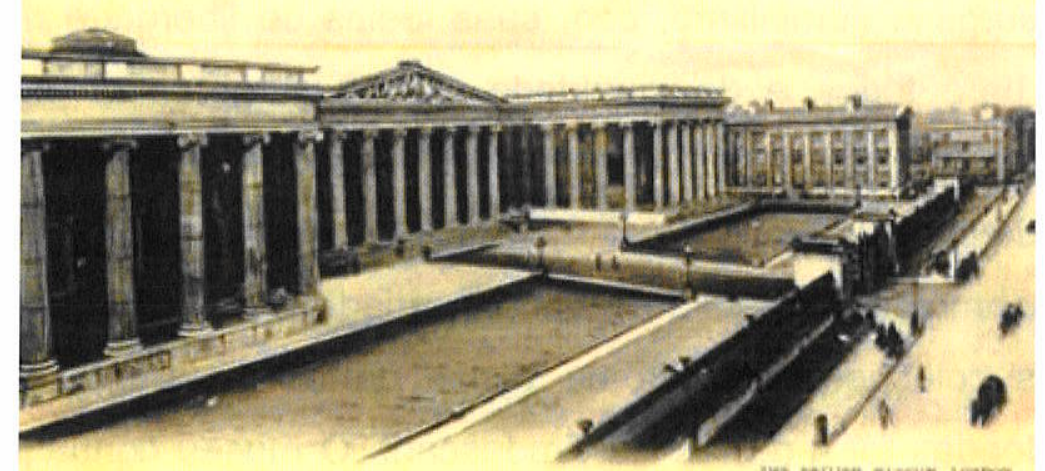

Figura 17. Museu Britânico em 1768. Fonte:

http://blogillustratus. blogspot.com.br/p/museus-e-fundacoes.html

Seu acervo possuía antiguidades clássicas, manuscritos, numismática e espécimes de história natural, pois "todas as artes e ciências estão ligadas entre si", como dizia a lei fundadora do museu. Em 1881, o acervo naturalista foi transferido para o Museu de História Natural de Londres.

Em Portugal, conforme os estudos de Gomes (2010, p. 250), existiam as Universidades de Coimbra, Lisboa e Porto coleções de minerais que serviam como recurso científico-didático. A primeira a ser oficializada foi a Coleção Mineralógica, pertencente ao Gabinete de História Natural, que foi fundada em 1772 pela Reforma Pombalina da Universidade de Coimbra, como um reflexo da evolução do pensamento científico e das correntes pedagógicas que iam surgindo na Europa com o lluminismo. Este foi o ponto inicial dos primeiros Museus de Ciências Universitários, que inclusive serviu de modelo para a criação dos primeiros museus brasileiros.

O Museu do Louvre surgiu em Paris, em 1793, por um ato de democratização das coleções reais e por iniciativa do próprio governo. Seu acervo, diferente dos outros museus, possuía um caráter artístico e era aberto ao público por alguns dias da semana (LEWIS, 2004). 
O Museu de Mineralogia de Paris (Musée de Minéralogie), criado pela Escola Superior de Minas de Paris, foi fundado em 1794, um ano depois do Louvre, e se tornou um dos maiores e mais importantes museus de Mineralogia do mundo. Seu fundador, René Just Haüy (um dos mais renomados e importantes mineralogistas do mundo), possuía um Gabinete de Mineralogia com uma coleção única, que reunia amostras de todo o mundo, além da produção mineral de toda a república francesa.

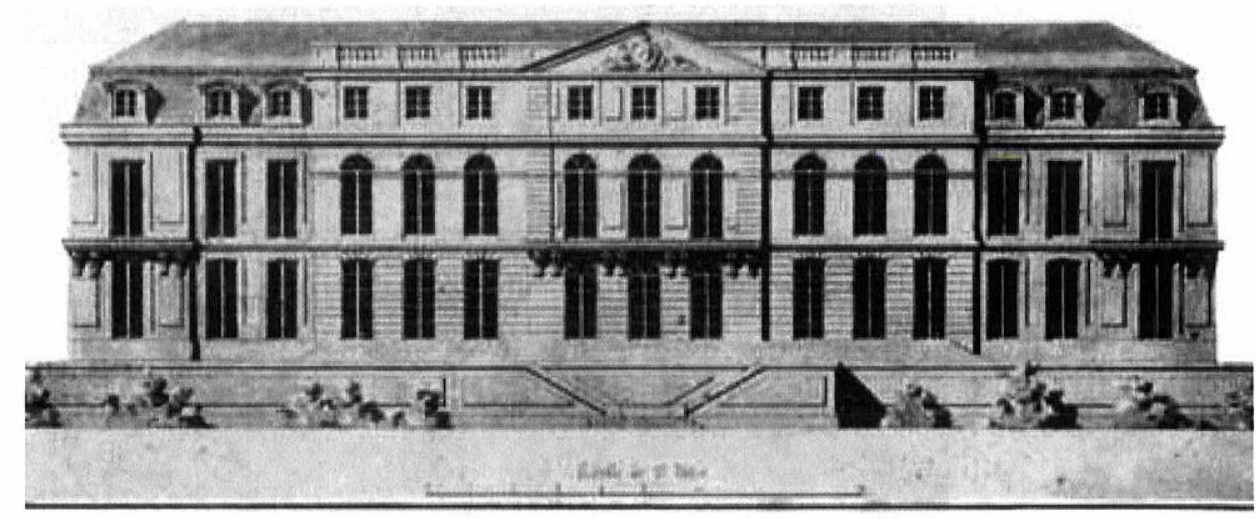

Figura 18. Museu de Mineralogia de Paris (construção original). Fonte: http://www.gegmfrance.org/nouveau_fichier_15.htm

Ele ainda conseguiu diversas coleções particulares adquiridas do mundo todo. Trata-se de uma coleção que nunca ficou estática e que propicia a produção de diversos trabalhos científicos para o mundo. Hoje a coleção do museu está entre as dez maiores e melhores de todo o mundo, com mais de 100.000 amostras (MUSEU DE MINERALOGIA DE PARIS).

O exemplo europeu, por força do colonialismo, se expandiu também para outros países do Oriente e da América. A sociedade mais intelectual da época se uniu para expor coleções em museus que enfocavam as artes e ciências e se dedicavam ao fomento do conhecimento sobre seus próprios países. Como exemplo, cita-se a Sociedade de Artes e Ciência de Batavia em Jacarta, a qual iniciou uma coleção em 1778, que evoluiu para se tornar o Museu Central da Cultura da Indonésia. Na Índia ocorreu o mesmo, sendo o primeiro museu, o Museu Indiano em Calcutá, fundado em 1784 a partir das coleções reunidas pela Sociedade Asiática de Bengal (LEWIS, 2004).

Nos Estados Unidos, em 1773, a Charleston Library Society da Sociedade da Carolina do Sul formou uma coleção naturalista de objetos com origem animal, vegetal e mineral, com o propósito de estimular a medicina e agricultura. 
Ainda nos Estados Unidos, surgiram mais dois importantes museus de história natural, com coleções naturalistas que incluíam minerais de importantes coleções particulares, o American Museum of Natural History (AMNH), fundado em 1869, e o Smithsonian Institute - National Museumof Natural History (NMNH), fundado em 1910.

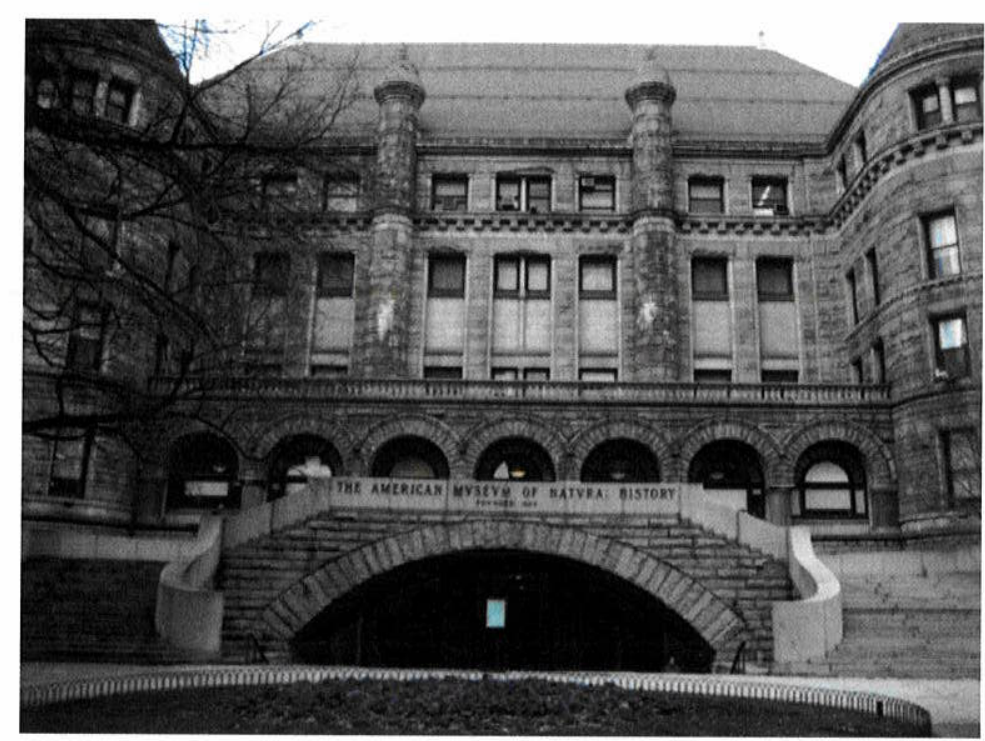

Figura 19. American Museumof Natural History (AMNH) - Museu de História Natural Americano. Fonte: http://www.skyscrapercity.com/showthread. php?t=560712

Na América do Sul, um dos primeiros museus fundados no continente foi o Museu de Ciências Naturais da Argentina, em 1812, mas só foi aberto ao público em 1823. O acervo é muito rico e variado e suas principais áreas do conhecimento são paleontologia, antropologia e entomologia.

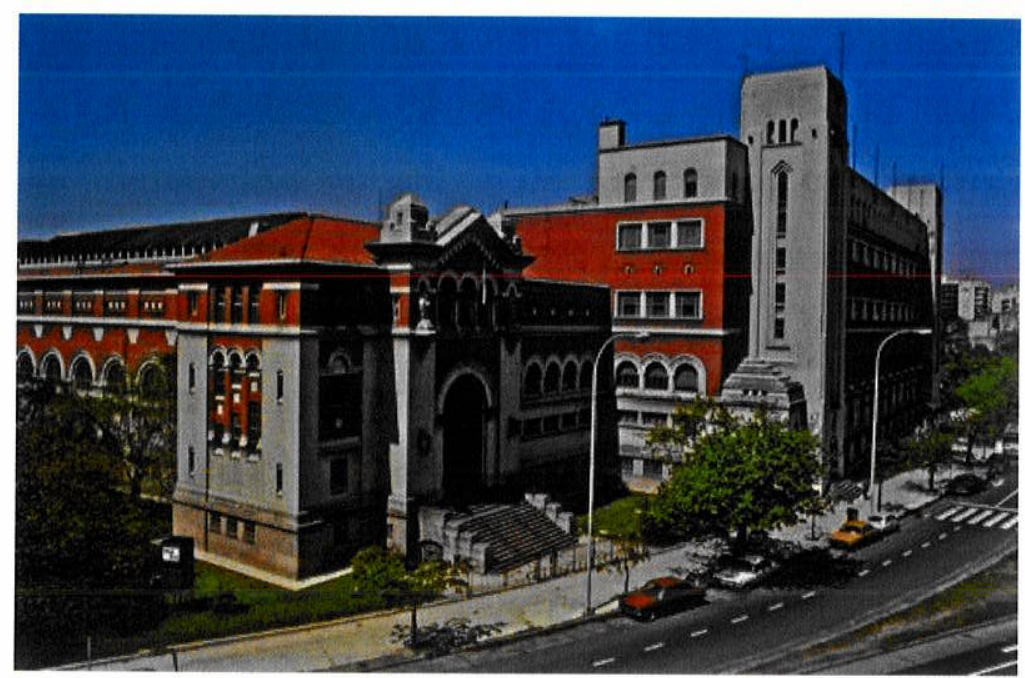

Figura 20. Museu de Ciências Naturais da Argentina. Fonte:

http://caballitotequiero.com.ar/portal/2012/09/30/concierto-en-el-museo-de-ciencias-naturales/ 
De acordo com Lopes, (1988) também surgiram os Museus de Bogotá em 1823, Santiago do Chile em 1830 e La Plata em 1880, todos os museus nacionais de história natural, com coleções naturalistas (mineralógicas, fossilíferas e zoológicas) e etnográficas.

Pode-se dizer que, como primeira instituição museal do Brasil, tivemos a que foi precursora do Museu Nacional no Rio de Janeiro, a "Casa dos Pássaros". Este local data de 1784, como Casa de História Natural, fundada pelo Vice-Rei Dom Luiz de Vasconcelos e Sousa. Recebia este nome pela quantidade de aves empalhadas expostas no local. Seu responsável era Francisco Xavier Cardoso Caldeira, conhecido como Xavier dos Pássaros (CORNEJO; BARTORELLI, 2010, p.78-79).

Conforme Machado (2005 p. 138), este local serviu de intermediador de materiais naturalistas durante quase 30 anos. Suas coleções eram separadas por áreas, estudadas e enviadas a Portugal com o intuito de abastecer as coleções da Coroa e Instituições de toda Europa.

Com a estrutura que possuía em 1811, se tornou local de lapidação de diamantes da Coroa e em 1813, a mando do Príncipe Regente Dom João, todas as suas coleções naturalistas, inclusive as mineralógicas, foram transferidas para a Academia Real Militar, sendo incorporadas ao Museu Real em sua inauguração em 06 de junho de 1818. Entre as principais coleções da Família Real, também vinculadas ao novo Museu, estavam as mais de 3.200 amostras de minerais da mundialmente famosa Coleção Werner, que, na época, possuía todas as espécies minerais descritas pela mineralogia mundial.

O Museu Real possuía como finalidade "propagar os conhecimentos e os estudos das ciências naturais no Reino do Brasil", com a função de "identificar os produtos naturais únicos dessa parte do mundo, para proveito das ciências e das Artes, e deles prover museus do mundo" (LOPES, 1997, P. 38) 


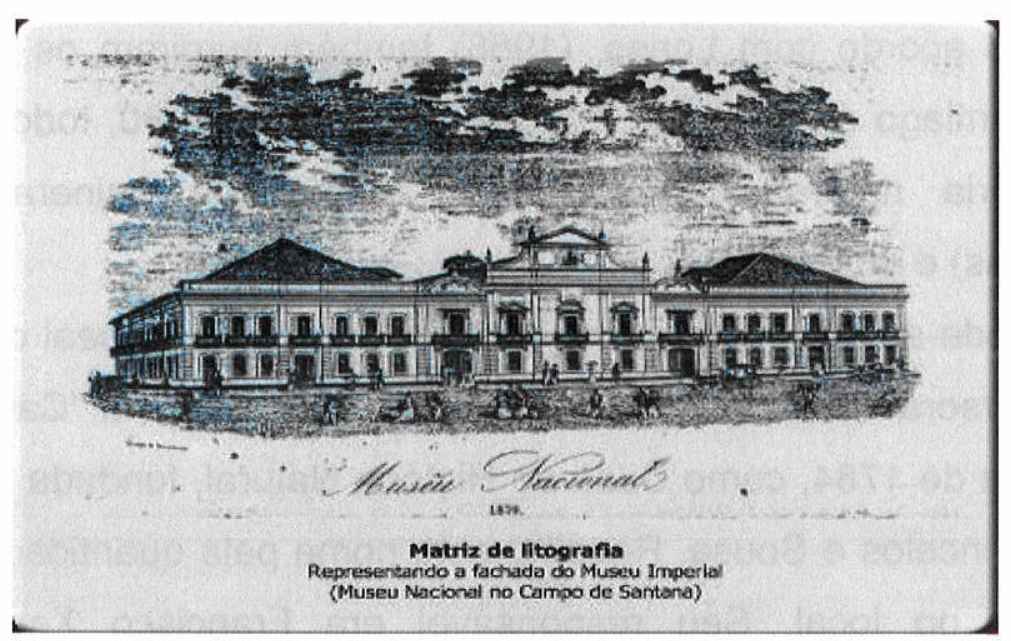

Figura 21. Museu Nacional do Rio de Janeiro. Fonte:

http://www.museunacional.ufrj.br/site2/MuseuNacional/Principal/omuseu.htm

O Museu Real recebeu diversas coleções enviadas pelos governadores das províncias coloniais e tinha uma grande quantidade e qualidade de acervos da mesma espécie. Depois de catalogados e organizados, os acervos ficavam em exposição sem muito critério. Só em 24 de outubro de 1821, este museu passou a ser aberto ao público. Ele ficava dividido em quatro áreas: antropológica, zoológica, botânica e mineralógica.

Conforme Rezende, (1982apud LOPES, 1988, p.27), o Museu Real foi o primeiro órgão a se encarregar da Geologia no Brasil, com o setor de "Mineralogia, Geologia e Ciências Exatas", que surgiu em 1875, e por mais de 50 anos atuou no país, dando origem ao Departamento Nacional da Produção Mineral. Depois surgiram órgãos pelo Brasil todo e cada um possui em seus departamentos, coleções de minerais que representam suas regiões e abastecem muitas universidades e instituições de ensino.

Com toda essa propagação cultural trazida pela família real, e induzida pelas influências europeias com a liberdade do pensamento e o ideário de educação para todos, o século XIX no Brasil ficou conhecido como "a era dos museus"; em seguida ao Museu Real, vieram o Museu Paraense Emilio Goeldi, fundado em 1866, e o Museu Paulista, em 1894, ambos com coleções importantes de petrologia, mineralogia e paleontologia para o país.

O Museu Emilio Goeldi tem seu nome em homenagem ao pesquisador naturalista suíço que trabalhou no Museu Nacional e foi convidado a trabalhar no Museu Paraense por suas grandes contribuições a zoologia brasileira. O museu possuía um dos acervos mineralógicos mais exuberantes do país, além de trabalhos 
geológicos pioneiros na Amazônia, com os cientistas mais importantes da época, Orville Derby, H. Smith e Charles F. Hartt. Passou por diversos problemas financeiros e, pela falta de interesse público, ficou inativo por diversos períodos do século XIX. Atualmente, o museu passou por um processo de modernização e deu enfoque ao acervo etnográfico da Amazônia e de sua zoologia, destacando- se os animais endêmicos da região amazônica.
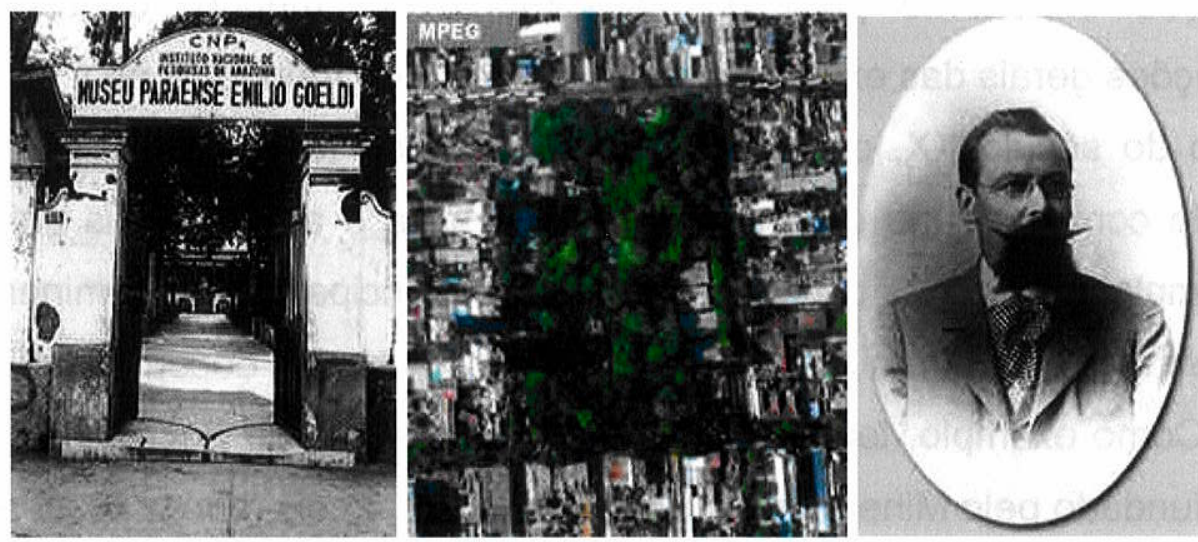

Figura 22. Museu Paraense Emílio Goeldi. Ao centro vista panorâmica e à direita retrato de Emílio Goeldi, fundador do museu. Fonte: http://www.girafamania.com.br/introducao/zoo_goeldi.htm

O Museu Paulista, que também possuía um acervo constituído pelas mesmas áreas do Museu Emilio Goeldi, foi fundado por Orville Derby, e objetivava contribuir para as várias áreas do conhecimento naturalista, geologia, mineralogia e botânica. Muito desenvolvido no setor de pesquisa e desenvolvimento, deixou muitos trabalhos publicados.

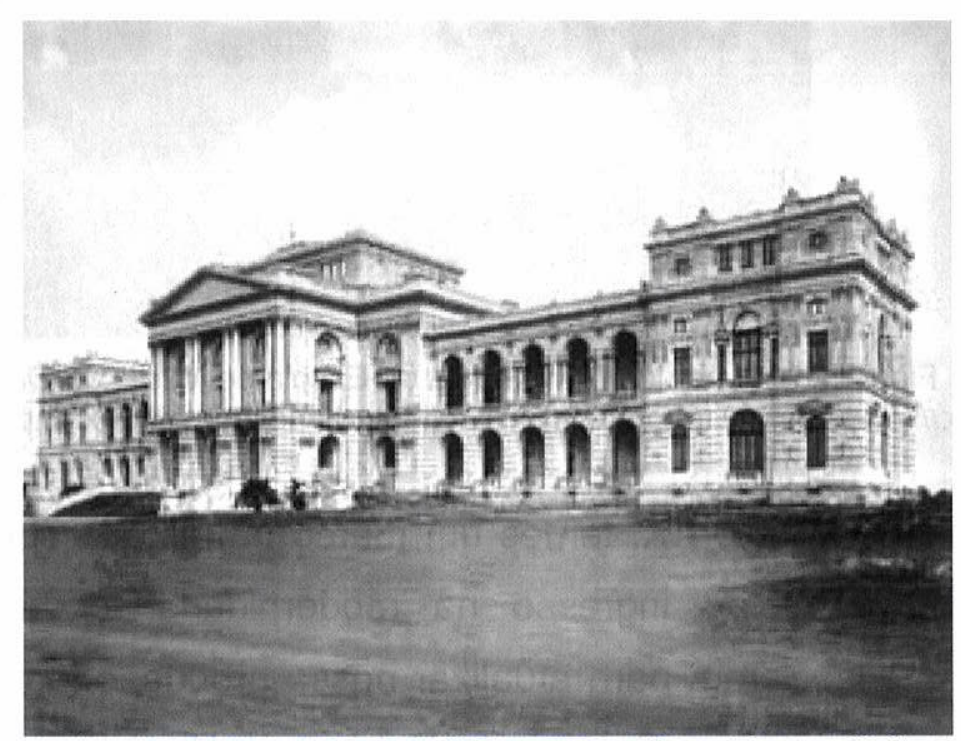

Figura 23. Museu do Ipiranga, 1902, atual Museu Paulista. Fonte: Guilherme Gaensly, em http://www.aprenda450anos.com.br/450anos/vila_metropole/2-3_museu_ipiranga.asp 
Em 1939, o Museu Paulista ficou mais conhecido como Museu do Ipiranga e se especializou em etnografia e história. Seu acervo geológico, incluindo toda a documentação produzida, foi transferido em 1969 para o Museu Geológico Valdemar Lefévre - MUGEO(LOPES, 1988, p. 34).

A visão iluminista, em que passado, presente e futuro, possuem uma integração importante para o entendimento de mundo, estava exposta nas concepções gerais das exposições museais de todo mundo. E no final do século XIX e início do século $X X$, os museus de ciências da terra e ciências naturais foram surgindo com o ideário de unir a teoria à prática e as principais universidades do Brasil implantaram suas coleções naturalistas, principalmente as mineralógicas, para ilustrarem e estimularem a pesquisa científica entre seus docentes e discentes.

Como exemplo, temos o Museu de Mineralogia da Escola de Minas de Ouro Preto, fundado pelo Mineralogista Henry Claude Gorceix, em 1876. O acervo era sua própria coleção, um material muito rico e variado, objeto de estudo que originou uma grande contribuição científica para o país.

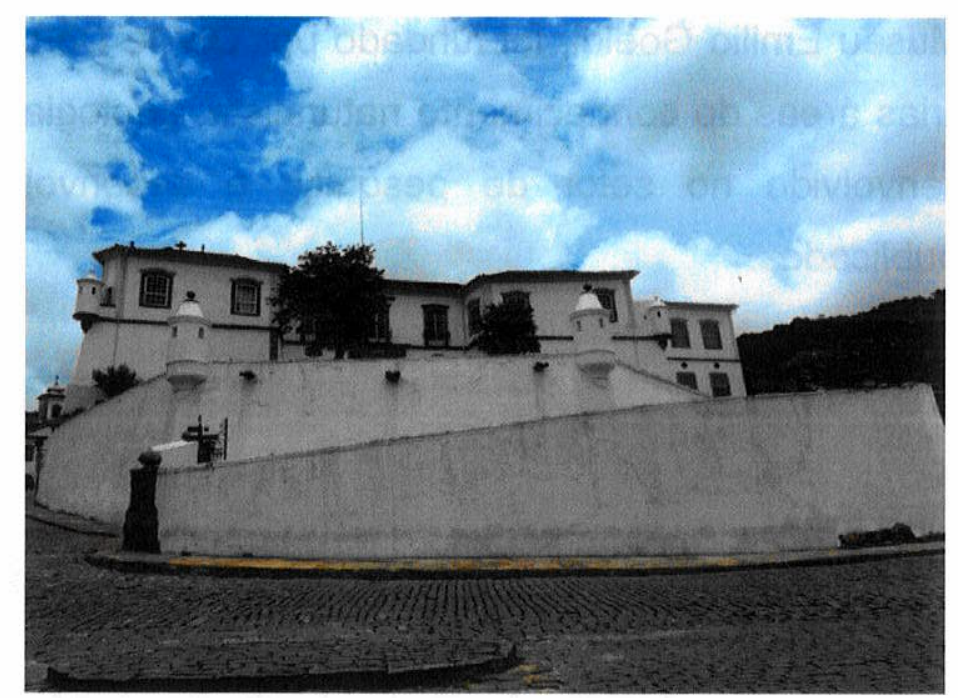

Figura 24. Museu de Mineralogia da Escola de Minas de Ouro Preto. Fonte: http://www. ouropreto.mg.gov. br/portaldoturismo/index/index. php?pag=9\&\&id=134

No início do século $\mathrm{XX}$, temos um marco na história cultural do país, com a superação do atraso ao ingresso na modernidade, onde muitos intelectuais modernistas se associaram para atualizar nossa produção local com as tendências europeias. Surgiu, então, o Serviço do Patrimônio Histórico e Artístico Nacional - 
SPHAN, criado em 1937 para institucionalizar uma política para o patrimônio cultural do país (JULIÃO, 2008).

Este órgão começou a atuar na preservação e conservação de monumentos e edificações históricas e também de alguns dos museus mais importantes e antigos do país. De acordo com Santos (1997), "Não se tratava apenas de celebrar a história, mas de definir o passado a ser recuperado, o passado que deveria ter direito à perpetuidade e direito à visibilidade".

Surge a mais importante organização que institui leis e regras para conciliar e ajudar museus do mundo todo, o Internacional Council of Museums (ICOM), criado em 1946 por profissionais de museus que registram e integram as ações relacionadas à difusão, conservação e preservação do patrimônio mundial - cultural, material e imaterial do passado, presente e futuro.

E mesmo com a criação do ICOM, os museus brasileiros, de uma forma geral, passaram por uma estagnação de quase 50 anos; somente nas décadas de 70 e 80 iniciaram-se mudanças significativas na abordagem do público visitante e na modernização de seus espaços. Em linhas gerais, promoveram-se reformulação de espaços físicos e exposições, implantação de serviços educativos, conservação e segurança de acervos. Com a influência norte-americana que idealizou as exposições interativas, com os Dioramas (baseados em recursos cinematográficos que reconstroem ambientes artificiais para ilustrarem os acervos), onde, principalmente, os museus de ciências começaram a se modernizar para atrair o público geral (LOPES, 1988, p.22).

Ainda segundo Lopes, grandes universidades brasileiras reformularam suas exposições de coleções didáticas, antes restritas aos alunos e professores, que passaram a se adaptar a este novo modelo de museus. Surgiram instituições como a Estação Ciência, em São Paulo, e o Museu de Astronomia e Ciências Afins do Rio de Janeiro (MAST - RJ).

"No universo da cultura, o museu assume funções as mais diversas e envolventes. Uma vontade de memória seduz as pessoas e as conduz à procura de registros antigos e novos, levando-as ao campo dos museus, no qual as portas se abrem sempre mais. A museologia é hoje compartilhada como uma prática a serviço da vida" (PORTAL DO INSTITUTO BRASILEIRO DE MUSEUS). 
Muitos órgãos, leis e decretos passaram a ser criados e colocados em prática a partir do século XXI. Os mais importantes foram decretados em 2009, como o Estatuto dos Museus e o Instituto Brasileiro de Museus. Pelo estatuto, os museus são definidos desta forma:

[...]"são instituições sem fins lucrativos que conservam, investigam, comunicam, interpretam e expõem, para fins de preservação, estudo, pesquisa, educação, contemplação e turismo, conjuntos e coleções de valor histórico, artístico, científico, técnico ou de qualquer outra natureza cultural, abertas ao público, a serviço da sociedade e de seu desenvolvimento" (BRASIL. LEI No 11.904, DE 14 DE JANEIRO DE 2009)".

Pensar a trajetória histórica e teórica dos museus no mundo e no Brasil, buscando compreender sua importância social, torna-se essencial neste momento em que as sociedades vivem diferentes crises e expectativas de renovação social, tecnológica, estética e relacional. Os modelos desta análise indicam um confronto com a realidade e com seu contexto. Repensar significa, para o campo do museu, da mineralogia e do colecionismo, a necessidade de outros embates, incertezas e riscos intelectuais, políticos, gerenciais e científicos. 


\section{CAPÍTULO 4 - DESCRITIVO HISTÓRICO E ANÁLISE INDIVIDUAL DAS INSTITUIÇÕES VISITADAS}

Os museus de Ciências Naturais e Ciências da Terra analisados foram selecionados com base no levantamento de informações históricas, organização estrutural, ação educativa e cultural, e, principalmente, no acervo mineralógico em sua exposição, conservação, utilização e relevância para a mineralogia brasileira.

Com o objetivo de revelar a grande diversidade de tipos de museus que contêm coleções mineralógicas, foram selecionados diversos perfis de museus, incluindo-se os que funcionam por iniciativa privada e os museus públicos centenários.

As descrições foram baseadas em questionário elaborado especialmente para esta pesquisa. Através do contato telefônico elou meios eletrônicos, foram agendadas visitas com alguns diretores, curadores, coordenadores e atendentes dos museus, que se prontificaram em colaborar com esta pesquisa.

As respostas foram obtidas por entrevistas gravadas em meio eletrônico e escritas manualmente no dia da visita. Segue abaixo o modelo do questionário aplicado:

\section{Instituição}

1. Nome da Instituição Museal Pesquisada.

2. Nome do Responsável pelo acervo. Formação acadêmica. Idade. Área de Atuação.

3. Qual é o seu cargo no museu? Há quantos anos você trabalha nesta instituição?

4. Quantos funcionários trabalham no museu?

5. Quando o museu foi inaugurado? E há quanto tempo recebe o público?

6. Quais são as principais áreas de atuação do museu? Qual é a principal especialidade do museu?

7. Qual o principal objetivo da instituição?

8. É cobrado algum valor para entrar no museu?

9. Como o museu se mantém financeiramente? Quais órgãos governamentais e/ou privados estão envolvidos com o museu?

10. O museu está bem localizado?

11. Como é feita a divulgação do museu?

12. Vocês possuem monitores e estagiários para o atendimento ao público? Como eles são capacitados?

13. Qual é o público alvo do museu? E o principal perfil deste público? 
14. Quantos visitantes passam por mês no museu? Qual é a media de idade dos visitantes?

15. Qual o tempo de visitação mínimo para se conhecerem todos os espaços do museu?

16.A instituição desenvolve avaliações específicas sobre a opinião do público?

17. Qual é a importância deste museu para a cidade? E para a preservação do patrimônio natural?

\section{Estrutura Física}

1) Você acha que as instalações são suficientes para abrigar todo o acervo exposto? Em sua opinião, o que está faltando?

2) O museu possui aparelhos de climatização e de segurança?

3) O museu possui acessibilidade?

4) O museu possui algum centro de conveniência, como loja e lanchonete?

\section{Acervo Museológico}

1. O museu possui reserva técnica?

2. Vocês realizam pesquisas sobre o acervo?

3. Quantas amostras existem atualmente em exposição no museu? Qual sua área total?

4. Quem classificou o acervo? Que métodos foram utilizados para fazer a classificação. Seguiu algum critério preferencial?

5. Existem no acervo exemplar da mineralogia tipo brasileira? Quais?

6. Quais minerais se destacam no acervo por serem amostras importantes para a mineralogia do Brasil?

7. Quem manuseia e faz a manutenção do acervo?

8. Como é realizada a aquisição de acervo?

9. O museu tem política de intercâmbio com outras instituições e/ou colecionadores particulares?

10. Existe a preocupação do museu em estar ampliando o seu acervo?

\section{Ação Educativa e Cultural}

1. Vocês possuem ação educativa no museu? Quais são as principais atividades desenvolvidas pela instituição?

2. O museu possui espaços interativos e lúdicos?

3. A instituição possui espaços físicos, para palestras, oficinas, cursos, vídeos educativos, etc.? Qual é a importância destes espaços para o museu?

4. Quais ações o museu desenvolve para divulgar e fomentar a mineralogia do Brasil? 
Foram desenvolvidos o descritivo histórico e a análise individual dos museus pesquisados, com base na compilação das informações obtidas pelo questionário, e por meio de pesquisa nos sites das instituições ou registros das mesmas.

Na quadro abaixo, estão descritos os museus por ordem cronológica da visita efetuada:

Quadro 8 - Lista dos museus pesquisados por ordem cronológica da visita efetuada

\begin{tabular}{|c|c|c|c|c|}
\hline $\begin{array}{l}\text { MUSEU } \\
\text { PESQUISA- } \\
\text { DO }\end{array}$ & $\begin{array}{c}\text { INSTITUIÇÃO } \\
\text { GESTORA }\end{array}$ & LOCALIZAÇÃO & $\begin{array}{l}\text { PERÍODO } \\
\text { DA VISITA }\end{array}$ & ENTREVISTADO \\
\hline $\begin{array}{l}\text { Museu de } \\
\text { Minerais e } \\
\text { Rochas } \\
\text { Heinz Ebert }\end{array}$ & $\begin{array}{c}\text { UNESP } \\
\text { Departamento } \\
\text { de Petrologia e } \\
\text { Metalogenia } \\
\text { Instituto de } \\
\text { Geociências e } \\
\text { Ciências Exatas }\end{array}$ & $\begin{array}{c}\text { Universidade } \\
\text { Estadual Paulista } \\
\text { Av. 24-A, 1515 - } \\
\text { 13506-900 -Rio } \\
\text { Claro (SP). }\end{array}$ & $\begin{array}{l}\text { Julho } \\
2012\end{array}$ & $\begin{array}{l}\text { Curador do } \\
\text { Museu Prof. } \\
\text { Antenor } \\
\text { Zanardo. }\end{array}$ \\
\hline $\begin{array}{l}\text { Museu da } \\
\text { Geodiversi- } \\
\text { dade }\end{array}$ & $\begin{array}{c}\text { UFRJ - } \\
\text { Universidade } \\
\text { Federal do Rio } \\
\text { de Janeiro } \\
\text { Instituto de } \\
\text { Geociências - } \\
\text { Departamento } \\
\text { de Geologia }\end{array}$ & $\begin{array}{c}\text { Centro de Ciências } \\
\text { Matemáticas e da } \\
\text { Natureza no } \\
\text { Instituto de } \\
\text { Geociências Av.: } \\
\text { Athos da Silveira } \\
\text { Ramos, } 274, \\
\text { Cidade } \\
\text { Universitária - Ilha } \\
\text { do Fundão } \\
\text { Rio de Janeiro, RJ. }\end{array}$ & $\begin{array}{l}\text { Julho } \\
2012\end{array}$ & $\begin{array}{l}\text { Museóloga } \\
\text { Aline Rocha de } \\
\text { Souza F. de } \\
\text { Castro. }\end{array}$ \\
\hline $\begin{array}{c}\text { Museu } \\
\text { Amsterdam } \\
\text { Sauer de } \\
\text { Minerais } \\
\text { Raros e } \\
\text { Pedras } \\
\text { Preciosas }\end{array}$ & $\begin{array}{c}\text { Amsterdam } \\
\text { Sauer }\end{array}$ & $\begin{array}{c}\text { Rua Garcia } \\
\text { D`Ávila 105, em } \\
\text { Ipanema, Rio de } \\
\text { Janeiro }\end{array}$ & $\begin{array}{l}\text { Julho } \\
2012\end{array}$ & $\begin{array}{c}\text { Promotor de } \\
\text { Vendas Richard } \\
\text { Carvalho. } \\
\text { (contato } \\
\text { telefônico) }\end{array}$ \\
\hline $\begin{array}{l}\text { Museu de } \\
\text { Ciências da } \\
\text { Terra }\end{array}$ & $\begin{array}{c}\text { DNPM - } \\
\text { Departamento } \\
\text { Nacional de } \\
\text { Pesquisa } \\
\text { Mineral. }\end{array}$ & $\begin{array}{c}\text { Av.: Pasteur, } 404 \text { - } \\
\text { Urca } \\
\text { Rio de Janeiro, RJ. }\end{array}$ & $\begin{array}{l}\text { Julho } \\
2012\end{array}$ & $\begin{array}{l}\text { Chefe de } \\
\text { Divisão } \\
\text { Diógenes de } \\
\text { Almeida } \\
\text { Campos. }\end{array}$ \\
\hline $\begin{array}{l}\text { Museu } \\
\text { Nacional }\end{array}$ & $\begin{array}{l}\text { Universidade } \\
\text { Federal do Rio } \\
\text { de Janeiro }\end{array}$ & $\begin{array}{c}\text { Quinta da Boa } \\
\text { Vista, sn - São } \\
\text { Cristóvão, } \\
\text { Rio de Janeiro, RJ. }\end{array}$ & $\begin{array}{l}\text { Julho } \\
2012\end{array}$ & $\begin{array}{c}\text { Não houve } \\
\text { atendimento } \\
\text { Acervo } \\
\text { mineralógico em } \\
\text { reserva técnica. }\end{array}$ \\
\hline
\end{tabular}




\begin{tabular}{|c|c|c|c|c|}
\hline $\begin{array}{c}\text { Museu de } \\
\text { Mineralogia } \\
\text { Aitiara }\end{array}$ & $\begin{array}{c}\text { Associação } \\
\text { Amigos do } \\
\text { Museu Aitiara }\end{array}$ & $\begin{array}{c}\text { Rodovia Gastão } \\
\text { Dal Farra, km } 4 \\
\text { Demétria } \\
\text { Botucatu, SP. }\end{array}$ & $\begin{array}{c}\text { Agosto } \\
2012\end{array}$ & $\begin{array}{c}\text { Diretora } \\
\text { Berenice } \\
\text { Pereira } \\
\text { Balsalobre. }\end{array}$ \\
\hline $\begin{array}{l}\text { Museu de } \\
\text { Ciência } \\
\text { e Técnica } \\
\text { da Escola } \\
\text { de Minas }\end{array}$ & $\begin{array}{c}\text { UFOP - } \\
\text { Universidade } \\
\text { Federal de Ouro } \\
\text { Preto. }\end{array}$ & $\begin{array}{c}\text { Praça Tiradentes, } \\
20 \text { - Centro } \\
\text { Ouro Preto, MG. }\end{array}$ & $\begin{array}{c}\text { Novembro, } \\
2013\end{array}$ & $\begin{array}{l}\text { Diretora Maria } \\
\text { Paula Delício. }\end{array}$ \\
\hline $\begin{array}{l}\text { Museu de } \\
\text { Mineralogia } \\
\text { Victor } \\
\text { Dequech }\end{array}$ & GEOSOL & $\begin{array}{l}\text { Rua São Vicente, } \\
255 \text { - Olhos } \\
\text { D'água, Belo } \\
\text { Horizonte Minas } \\
\text { Gerais. }\end{array}$ & $\begin{array}{c}\text { Novembro, } \\
2013\end{array}$ & $\begin{array}{c}\text { Estagiário de } \\
\text { Geologia } \\
\text { Gabriel } \\
\text { Teodoro. }\end{array}$ \\
\hline $\begin{array}{l}\text { Museus das } \\
\text { Minas e do } \\
\text { Metal }\end{array}$ & $\begin{array}{c}\text { Governo do } \\
\text { Estado de MG / } \\
\text { Grupo GERDAL }\end{array}$ & $\begin{array}{c}\text { Praça da } \\
\text { Liberdade, s/n. } \\
\text { Centro, Belo } \\
\text { Horizonte - Minas } \\
\text { Gerais. }\end{array}$ & $\begin{array}{c}\text { Novembro, } \\
2013\end{array}$ & $\begin{array}{c}\text { Curadora } \\
\text { Márcia Regina } \\
\text { Carvalho dos } \\
\text { Santos } \\
\text { Guimarães. }\end{array}$ \\
\hline $\begin{array}{l}\text { Museu de } \\
\text { Mineralogia } \\
\text { e de Arte } \\
\text { Sacra }\end{array}$ & $\begin{array}{c}\text { Prefeitura } \\
\text { Municipal de } \\
\text { Congonhas } \\
\text { FUNCULT - } \\
\text { Fundação } \\
\text { Municipal de } \\
\text { Cultura, Lazer e } \\
\text { Turismo }\end{array}$ & $\begin{array}{c}\text { Alameda Cidade } \\
\text { Matozinhos de } \\
\text { Portugal, 153, } \\
\text { Basílica } \\
\text { Congonhas, MG. }\end{array}$ & $\begin{array}{c}\text { Novembro, } \\
2013\end{array}$ & $\begin{array}{c}\text { Atendentes } \\
\text { Guilherme } \\
\text { Souza Costa } \\
\text { Filho e Gláucio } \\
\text { Andrade de } \\
\text { Jesus. }\end{array}$ \\
\hline $\begin{array}{c}\text { Museu de } \\
\text { Minerais e } \\
\text { Rochas da } \\
\text { Universida- } \\
\text { de Federal } \\
\text { do Espírito } \\
\text { Santo }\end{array}$ & $\begin{array}{c}\text { UFES - } \\
\text { Universidade } \\
\text { Federal do } \\
\text { Espírito Santo } \\
\text { Centro de } \\
\text { Ciências } \\
\text { Humanas e } \\
\text { Naturais } \\
\text { Instituto de } \\
\text { Geociências }\end{array}$ & $\begin{array}{c}\text { Av. Fernando } \\
\text { Ferrari, } 514- \\
\text { Goiabeiras, Vitória } \\
\text { - Espírito Santo. } \\
\text { No prédio IC-II, } 2^{\circ} \\
\text { andar do } \\
\text { Departamento de } \\
\text { Oceanografia. } \\
\text { Centro de Ciências } \\
\text { Humanas e } \\
\text { Naturais - CCHN } \\
\text { - UFES. }\end{array}$ & $\begin{array}{c}\text { Dezembro } \\
2013\end{array}$ & $\begin{array}{c}\text { Coordenador } \\
\text { do Museu } \\
\text { Professor Luiz } \\
\text { Machado Filho. }\end{array}$ \\
\hline $\begin{array}{c}\text { Museu } \\
\text { Histórico e } \\
\text { Geográfico } \\
\text { de Poços de } \\
\text { Caldas } \\
\text { "Coleção de } \\
\text { Minerais } \\
\text { Resk } \\
\text { Frayha" } \\
\end{array}$ & $\begin{array}{l}\text { Prefeitura } \\
\text { Municipal de } \\
\text { Poços de } \\
\text { Caldas } \\
\text { Secretaria de } \\
\text { Cultura e } \\
\text { Turismo }\end{array}$ & $\begin{array}{c}\text { Praça Martinho de } \\
\text { Freitas Mourão, } \\
\text { Poços de Caldas, } \\
\text { MG. }\end{array}$ & $\begin{array}{c}\text { Dezembro, } \\
2013\end{array}$ & $\begin{array}{c}\text { Coordenador de } \\
\text { Divisão Haroldo } \\
\text { Paes Gessoni. }\end{array}$ \\
\hline
\end{tabular}




\begin{tabular}{|c|c|c|c|c|}
\hline $\begin{array}{l}\text { Museu de } \\
\text { Geociências } \\
\text { IGc/USP }\end{array}$ & $\begin{array}{c}\text { Instituto de } \\
\text { Geociências da } \\
\text { USP }\end{array}$ & $\begin{array}{c}\text { Universidade } \\
\text { Estadual de São } \\
\text { Paulo } \\
\text { Rua do Lago, } 562 \\
\text { - Cidade } \\
\text { Universitária São } \\
\text { Paulo, SP }\end{array}$ & $\begin{array}{c}\text { Dezembro } \\
2013\end{array}$ & $\begin{array}{c}\text { Chefe Técnico } \\
\text { Ideval Souza } \\
\text { Costa. }\end{array}$ \\
\hline $\begin{array}{l}\text { Museu } \\
\text { Geológico } \\
\text { Valdemar } \\
\text { Lefèvre } \\
\text { (MUGEO) }\end{array}$ & $\begin{array}{c}\text { Instituto } \\
\text { Geográfico e } \\
\text { Geológico } \\
\text { Secretaria do } \\
\text { Meio Ambiente } \\
\text { do Governo do } \\
\text { Estado de SP }\end{array}$ & $\begin{array}{c}\text { Av. Francisco } \\
\text { Matarazzo, } 455 \text { - } \\
\text { Parque da Água } \\
\text { Branca - Perdizes, } \\
\text { São Paulo - SP. }\end{array}$ & $\begin{array}{c}\text { Janeiro } \\
2014\end{array}$ & $\begin{array}{c}\text { Diretor do } \\
\text { Museu } \\
\text { Fernando Alves } \\
\text { Pires. }\end{array}$ \\
\hline $\begin{array}{l}\text { Museu de } \\
\text { Ciências da } \\
\text { Terra } \\
\text { Alexis } \\
\text { Dorofeef }\end{array}$ & $\begin{array}{l}\text { Departamento } \\
\text { de Solos da } \\
\text { Universidade } \\
\text { Federal de } \\
\text { Viçosa }\end{array}$ & $\begin{array}{c}\text { Vila Giannetti, } \\
\text { casa } 31 \text { - Campus } \\
\text { da Universidade F } \\
\text { ederal de Viçosa, } \\
\text { Viçosa, MG. }\end{array}$ & $\begin{array}{c}\text { Janeiro, } \\
2014\end{array}$ & $\begin{array}{c}\text { Estagiária } \\
\text { Fernanda } \\
\text { Márcia Souza. }\end{array}$ \\
\hline
\end{tabular}




\section{MUSEU DE MINERAIS E ROCHAS “HEINZ EBERT”}

(análise realizada em julho de 2012)

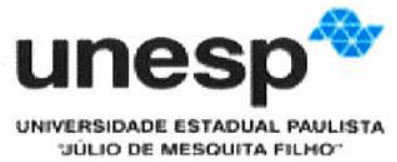

HISTÓRICO DA INSTITUIÇÃO

O Museu de Minerais e Rochas "Heinz Ebert" fica no Departamento de Petrologia e Metalogenia da Universidade Estadual Paulista (UNESP), na Avenida 24-A, no 1515- Bela Vista, Rio Claro - SP.

Segundo a pesquisa desenvolvida com o Curador e responsável pelo museu há 36 anos, o Prof. Antenor Zanardo (Doutor em Geologia, especializado em Petrologia Metamórfica), a história do museu começou em 1968, quando o Prof. Heinz Ebert, especialista e pesquisador nas áreas das Geociências, com a colaboração de professores, alunos e funcionários deu sequência a montagem de várias coleções didáticas, incluindo seções delgadas e polidas, para serem utilizadas nas aulas práticas das disciplinas de Geologia, Mineralogia e Petrografia dos cursos de Geologia, Geografia e Biologia.

Além das coleções didáticas, o museu passou a abrigar os materiais utilizados nas pesquisas dos professores e alunos do Curso de Geologia, adquirindo também caráter científico. Em 1976, o Museu foi oficialmente denominado de "Museu Didático de Minerais, Minérios e Rochas Prof. Dr. Heinz Ebert". No período de 1999 a 2000, o Museu foi restaurado e toda a sua infra-estrutura física foi modernizada, tendo sido reinaugurado em setembro de 2000.

\section{ORGANIZAÇÃO E FUNCIONAMENTO}

A gestão do museu pertence ao Departamento de Mineralogia e Petrologia do Instituto de Geociências e Ciências Exatas da UNESP. As verbas destinadas ao museu não são regulares, pois necessitam de projetos que são submetidos à Fundação de Amparo à Pesquisa do Estado de São Paulo (FAPESP), como no caso de sua reinauguração em 2000. A entrada ao público é gratuita, mas grupos escolares devem agendar a visita com antecedência.

O museu possui dois funcionários, um técnico e um curador. Os monitores são estudantes, geralmente alunos de geologia que recebem bolsa da Coordenação 
de Aperfeiçoamento de Pessoal de Nível Superior (CAPES), quando existe disponibilidade do Programa de Treinamento de Estagiários (PET), que desenvolvem um atendimento aos visitantes.

O principal objetivo da instituição é preservar o patrimônio natural, gerar material didático fundamental para o ensino de varias disciplinas das ciências naturais (Mineralogia; Mineralogia Óptica; Geologia Geral; Petrologias: Magmática, Metamórfica e Sedimentar; Geologia Econômica; Geologia Estrutural, etc.); fomentar e/ou possibilitar pesquisas acadêmicas e aplicadas, divulgar as geociências e promover atividades de extensão. O museu serve de elo entre os pesquisadores, com suas atividades acadêmicas e de pesquisa, e a coletividade, mostrando o espírito e a mentalidade científica, incentivando a inclinação para a ciência e informando sobre seu progresso, incutindo o desejo de entender, apreciar, participar e conservar a natureza (MUSEU DE MINERAIS E ROCHAS “HEINZ EBERT”, 2014).

A divulgação do museu é feita principalmente pela internet através do site oficial de geociências e a indicação de professores e alunos. O acesso ao museu é um pouco restrito, pois o mesmo localiza-se no interior da universidade, o que inibe o público transeunte de visitá-lo. O tempo médio de visita é de uma hora. O público alvo são estudantes do ensino fundamental e universitários. Em média, 200 pessoas são recebidas por mês.

A principal área de atuação do museu é a Geologia Geral, com ênfase em Mineralogia e Petrologia. Sua relevância para a mineralogia brasileira está no seu acervo, que contém coleções diversificadas e antigas, com peças únicas. A coleção do cientista e pesquisador Heinz Ebert, torna-o um dos museus mais importantes do país, pois sua contribuição para a mineralogia brasileira é inestimável. Só por manter a memória deste grande geólogo, especialista em praticamente todas as áreas de geociências, destaca-se como uma das instituições que fomentam a Mineralogia no país.

\section{ESTRUTURA FÍSICA}

A área total do museu possui $340 \mathrm{~m}^{2}$, que inclui salão expositivo, reserva técnica, laboratório e litoteca. As coleções do salão expositivo variam entre amostras estéticas e didáticas, com cerca de 5.600 amostras de minerais e rochas. O museu possui acessibilidade, por ser todo em piso térreo. A segurança é realizada pelos 
guardas da universidade, que controlam o acesso. A climatização está adequada, com ar-condicionado em todas as áreas do museu.

\section{AÇÃO EDUCATIVA E CULTURAL}

De acordo com o curador do museu, este possui uma ação educativa geralmente interna, para os próprios alunos da universidade de diversos cursos. Mas também recebem escolas que agendam visita e/ou o público geral, um acolhimento diferenciado, com atividades interativas e lúdicas. Os monitores desenvolvem a monitoria com o público, e algumas vezes levam as coleções didáticas para as áreas arborizadas do campus, realizando algumas atividades diferenciadas. A realização de palestras, oficinas, cursos especiais, exposições itinerantes e saídas de campo, são desenvolvidas com os alunos da universidade pela programação existente na grade curricular.

\section{ACERVO MINERALÓGICO}

O Museu de Minerais e Rochas "Heinz Ebert" possui um acervo geológico importante, com ênfase na Mineralogia, de aproximadamente 6.000 amostras minerais, dividindo-se no setor expositivo com mais de 2.000 amostras e em reserva técnica em dois locais distintos com mais de 4.000 amostras. Entretanto, em seu acervo geral, há ainda importantes coleções de rochas, fósseis, e alguns meteoritos.

As principais amostras minerais raras e estéticas do ponto de vista do curador já estão em exposição. As amostras estão dispostas em vitrines modulares de vidro, muito bonitas, com iluminação pouco eficiente, pois não é pontual, mas sim, de forma central, em cada um dos módulos, cuja base é de madeira com fórmica.

A coleção mineralógica foi classificada e organizada segundo o sistema de Dana, e contém algumas amostras interessantes e raras. Quem classificou o acervo em sua maioria foi o próprio professor Dr. Heinz Ebert, pois a grande maioria deste acervo fazia parte de sua coleção particular, que foi a origem deste museu pesquisado. A identificação das amostras em exposição não possui uma etiqueta muito bem representativa e explicativa, com apenas algumas informações simples. Em alguns casos, a identificação dos exemplares está equivocada, tanto a sua nomenclatura quanto a sua ocorrência. As informações das localidades são em geral 
simples e sem muitos detalhes, o que dificulta a obtenção de maiores informações sobre as jazidas de onde os minerais são provenientes. Em algumas amostras, as etiquetas possuem nomes em desuso e nomes de variedades sem o apontamento de a quais espécies pertencem aquelas variedades minerais. As etiquetas são transparentes, o que também dificulta a visualização das informações.

Uma grande quantidade de espécies raras, e até mais importantes do ponto de vista mineralógico para a história da mineralogia brasileira, está armazenada na reserva técnica nas próprias vitrines modulares e em outro setor, onde preferencialmente se armazenam amostras mais didáticas. Faz-se necessário um trabalho minucioso de pesquisa, revisão e classificação mineralógica desta importante reserva técnica.

Conforme já mencionado, a reserva técnica dispõe-se em dois locais distintos, o primeiro na parte de baixo das próprias vitrines modular e, onde os minerais são dispostos em caixas individuais de papelão e colocados em caixas maiores de plástico. Alguns exemplares estão soltos, sem nenhuma separação preferencial. Já no segundo local destinado para as amostras da reserva técnica, que se localiza ao lado da litoteca (na litoteca existe um número muito grande de rochas vinculadas a diversos projetos de pesquisa da UNESP), há amostras importantes de minerais brasileiros e estrangeiros. Em geral, estas amostras estão mal armazenadas, em etiquetas ou as informações das etiquetas não coincidem com as dos exemplares correspondentes.

Uma grande parte do acervo da primeira reserva técnica se encontra identificada por números que correspondem a um antigo livro de registros, mas muitas informações estão errôneas.

A intenção do curador do museu Dr. Antenor Zanardo, assim como do responsável técnico Laerte Martins, que são os responsáveis pela manutenção e obtenção de acervo, é que sempre que possível o acervo seja ampliado tanto com espécies raras, quanto com minerais estéticos (dando preferência para essas amostras). Entretanto o espaço ainda é insuficiente. Essa ampliação poderá será feita através do intercâmbio de amostras e doações de alunos, ex-alunos e visitantes.

O acervo mineralógico do Museu de Minerais e Rochas "Heinz Ebert" é um acervo importante do país no que se diz respeito à preservação da mineralogia brasileira, sendo uma das maiores referências do interior de São Paulo. A sua 
importância se deve ao fator de possuir uma grande quantidade de amostras brasileiras e de ocorrências históricas, muitas delas exauridas.

Quadro 9 -Quadro de minerais tipo brasileiros pertencentes ao acervo do Museu de Minerais e Rochas "Heinz Ebert" com suas respectivas ocorrências (exemplos):

\begin{tabular}{|c|}
$\begin{array}{c}\text { Quadro de minerais tipo brasileiros pertencentes ao acervo do } \\
\text { Museu de Minerais e Rochas “Heinz Ebert” com suas respectivas } \\
\text { ocorrências (exemplos): }\end{array}$ \\
\hline Crisoberilo - Rio das Pratinhas, Arataca, BA. \\
\hline Frondelita - Pegmatito de Sapucaia, Galileia, MG. \\
\hline Uvita - Mina Pedra Preta, Serra das Éguas, Brumado, BA. \\
\hline Euclásio - Fm. Equador, RN. \\
\hline
\end{tabular}

Quadro 10. Quadro de minerais brasileiros pertencentes ao acervo do Museu de Minerais e Rochas "Heinz Ebert" com suas respectivas ocorrências (exemplos):

\begin{tabular}{|c|}
\hline $\begin{array}{c}\text { Quadro de minerais brasileiros importantes pertencentes ao } \\
\text { acervo do Museu de Minerais e Rochas “Heinz Ebert” e suas } \\
\text { respectivas ocorrências (exemplos): }\end{array}$ \\
\hline Enstatita - Vale do Mandioca, Petúnia, Nova Resende, MG. \\
\hline Tremolita - Fazenda Cristália, Lindóia-Itapira, SP, Brasil \\
\hline Malaquita e wollastonita - Mina do Juca, Itaoca, SP. \\
\hline Rodocrosita e rodonita - Mina Morro da Mina, Conselheiro Lafaiete,MG. \\
\hline Wolframita - Mina Inhandjara, Jundiaí, SP. \\
\hline Pirolusita, lithioforita, manganita, romanechita - Serra do Navio, AP. \\
\hline Pirolusita (var.polianita) - Serra dos Carajás, Paraupebas, PA. \\
\hline Gibbsita - Lagoa Gambá, Ouro Preto, MG. \\
\hline Ouro Nativo - Mina Salamangone, Distrito Aurífero de Lourenço, \\
\hline Fluorita - Morro da Fuma, PA; Antônio Pereira, Ouro Preto, MG. \\
\hline
\end{tabular}




\section{RELAÇÃO DE FOTOS DO MUSEU HEINZ EBERT}

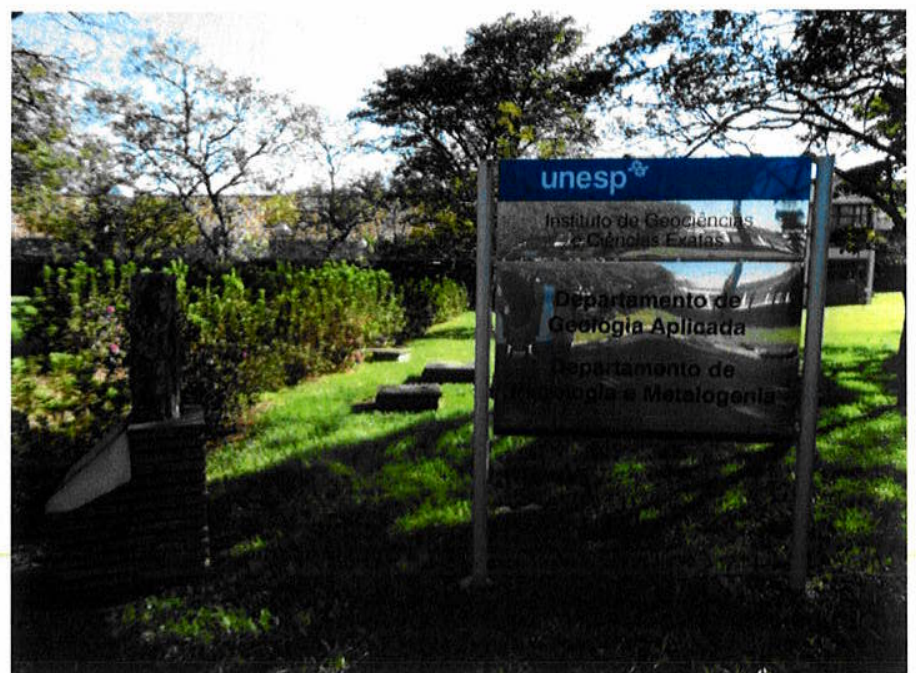

Figura 25. Museu de Minerais e Rochas Heinz Ebert. Entrada do Campus de Geologia da Unesp em Rio Claro

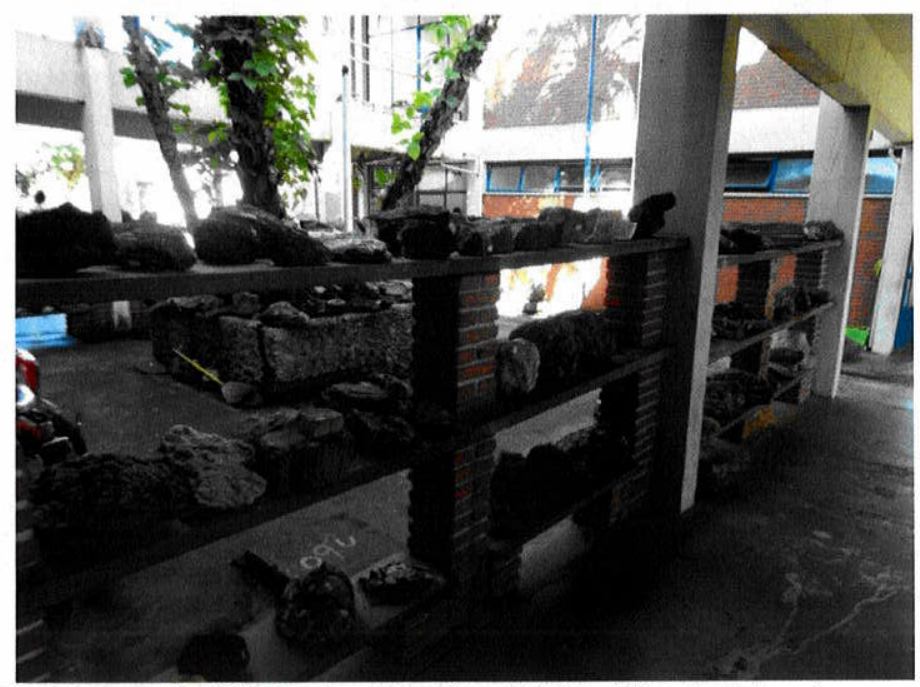

Figura 26. Museu de Minerais e Rochas Heinz Ebert. Amostras geológicas didáticas na entrada do campus de geologia da Unesp em Rio Claro.

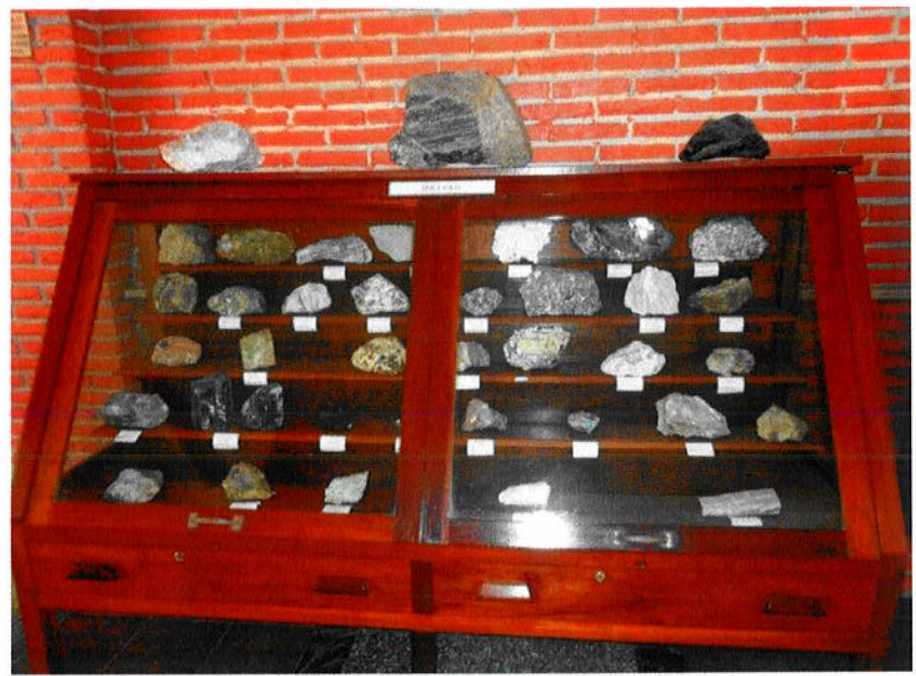

Figura 27. Museu de Minerais e Rochas Heinz Ebert. Vitrine clássica de madeira com vidro contendo amostras didáticas, localizados no saguão de entrada do museu. 


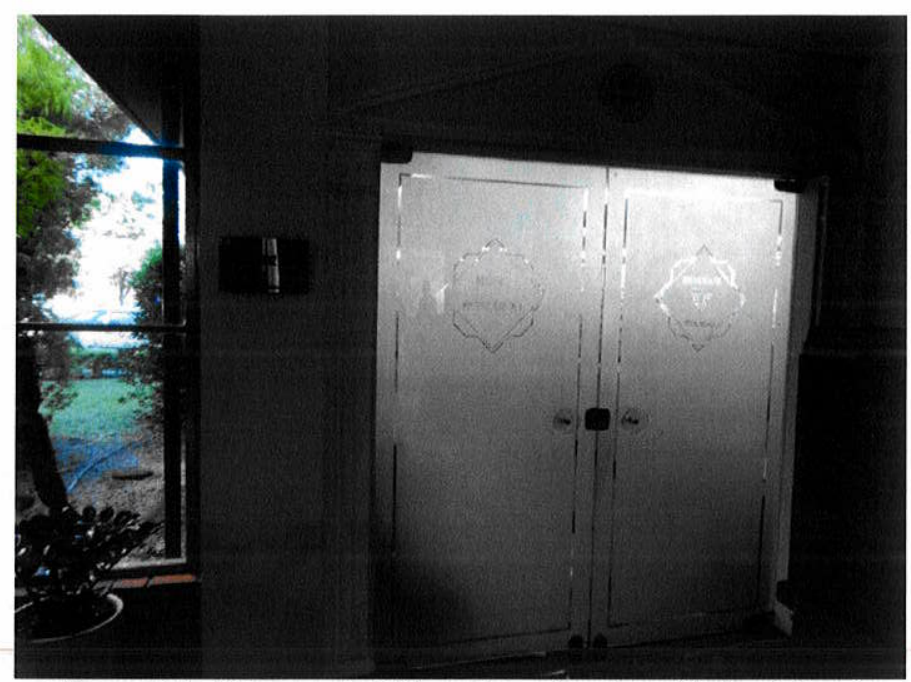

Figura 28. Museu de Minerais e Rochas Heinz Ebert. Vista da entrada do Museu Heinz Ebert.

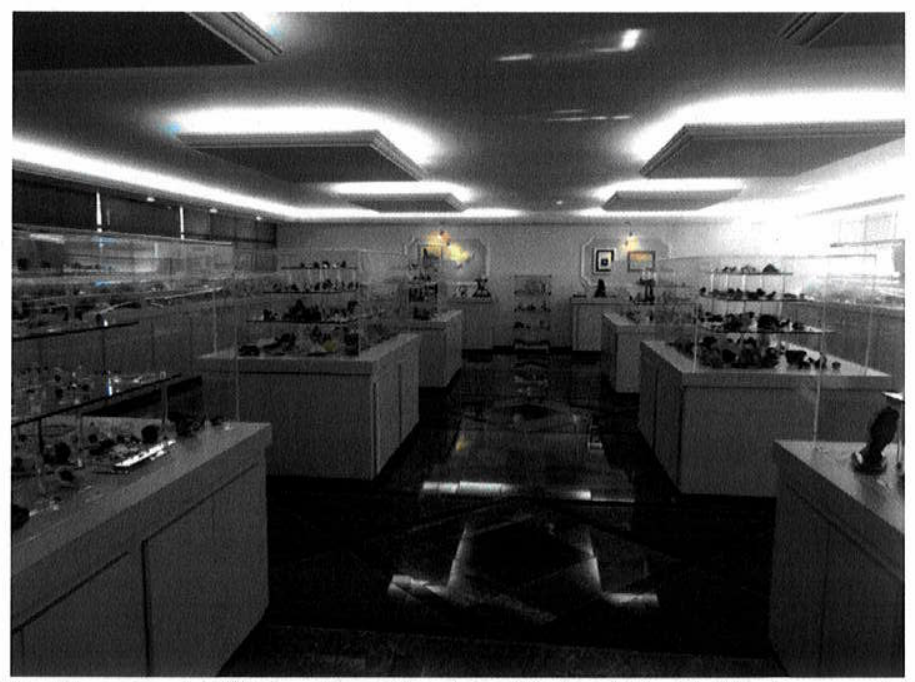

Figura 29. Museu de Minerais e Rochas Heinz Ebert. Vista geral do salão expositivo com as vitrines contendo os minerais.

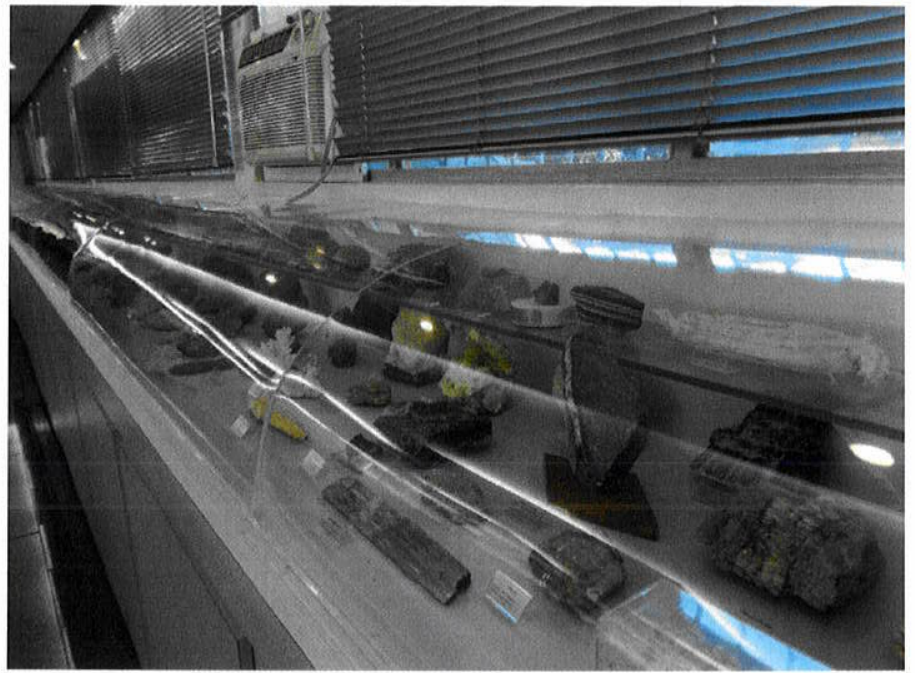

Figura 30. Museu de Minerais e Rochas Heinz Ebert. Vitrines com amostras didáticas em exposição. 


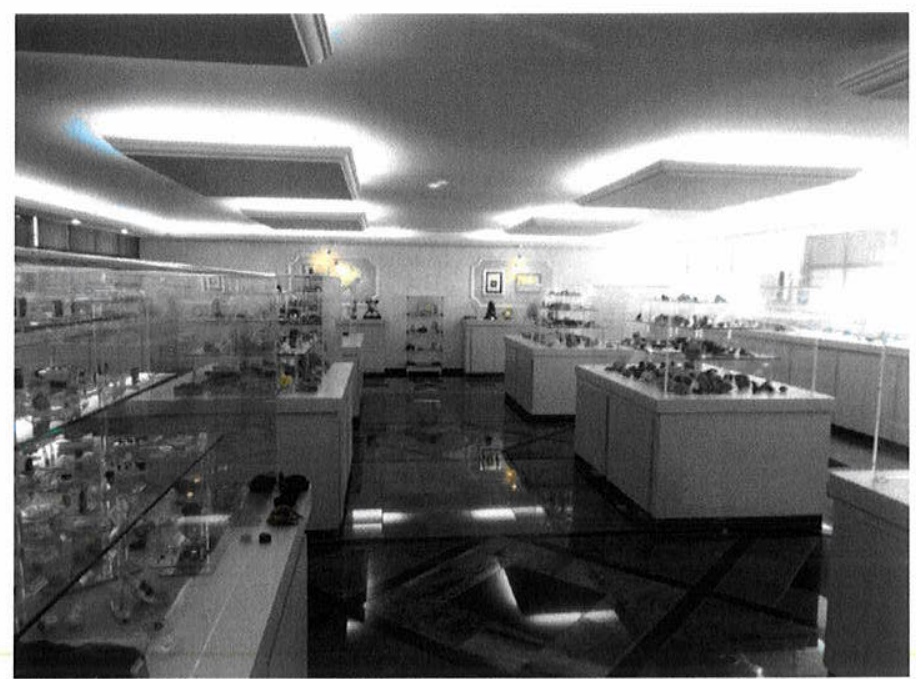

Figura 31. Museu de Minerais e Rochas Heinz Ebert. Vista das vitrines com detalhes da iluminação central no teto do salão expositivo.

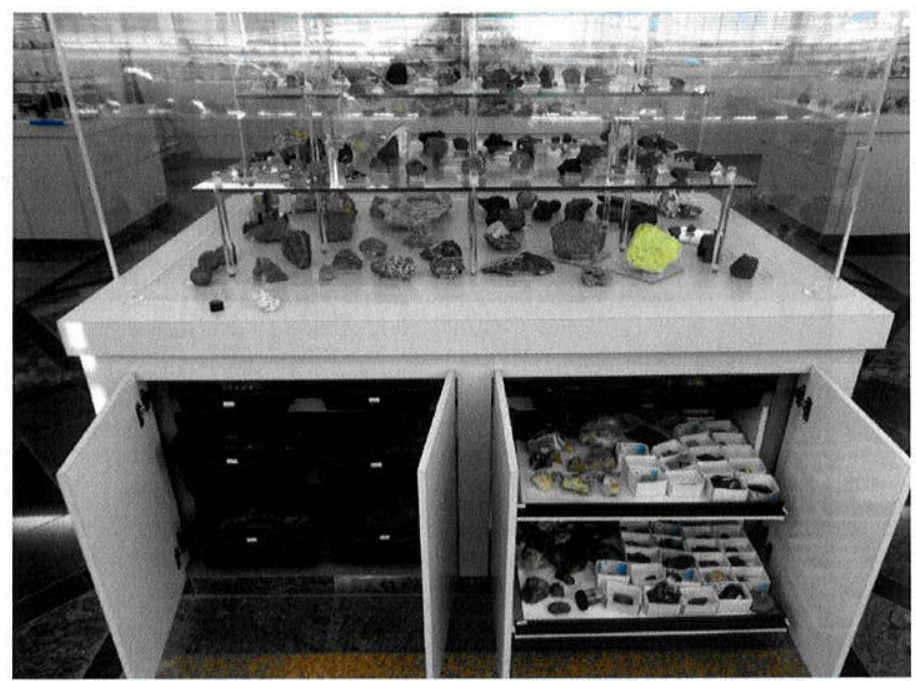

Figura 32. Museu de Minerais e Rochas Heinz Ebert. Vitrine expositiva na parte superior e reserva técnica na parte inferior.

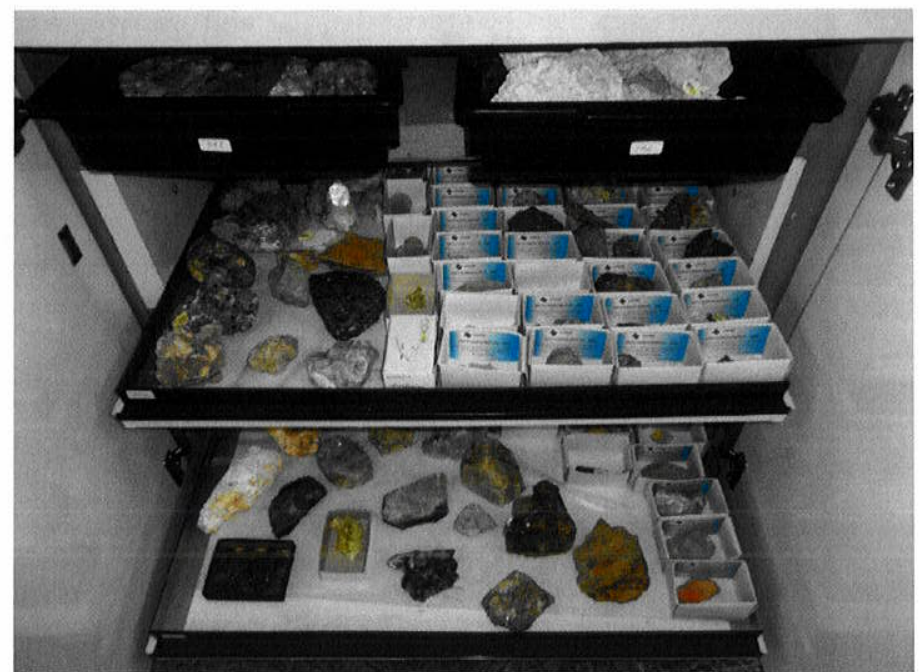

Figura 33. Museu de Minerais e Rochas Heinz Ebert. Detalhe das amostras da reserva técnica. 


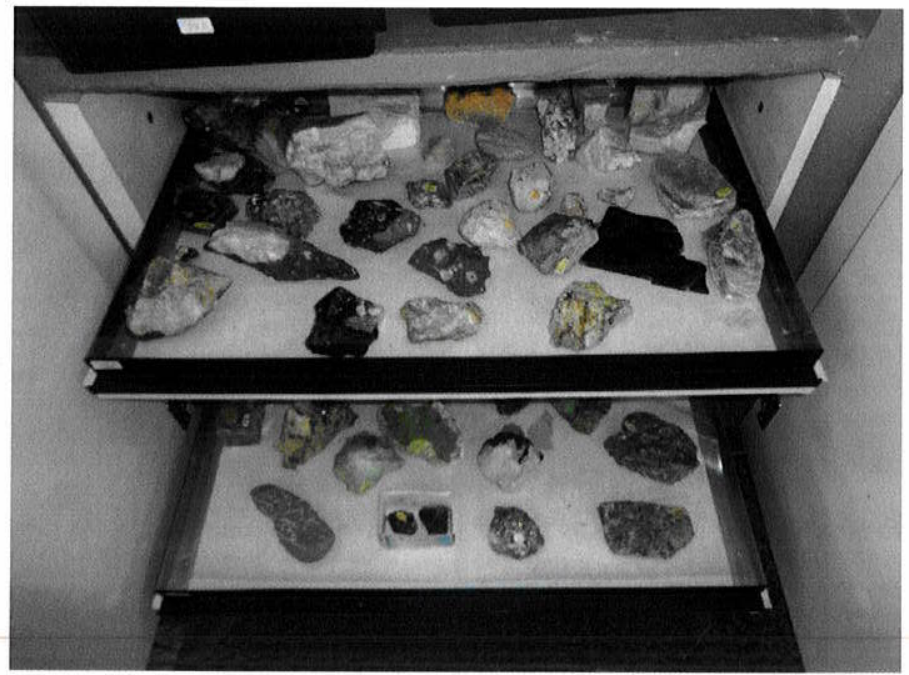

Figura 34. Museu de Minerais e Rochas Heinz Ebert. Amostras da reserva técnica sem organização.

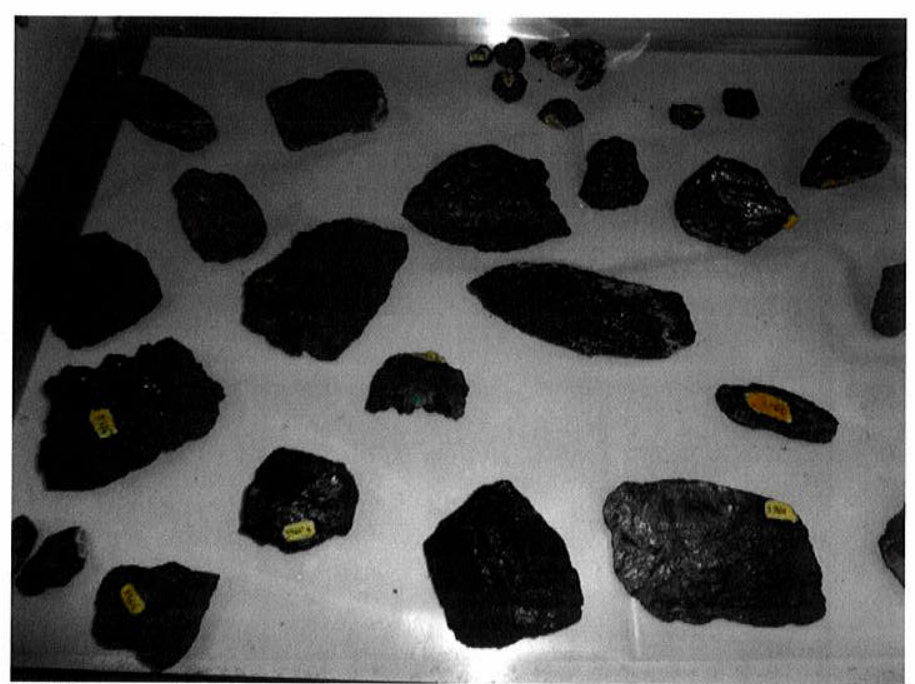

Figura 35. Museu de Minerais e Rochas Heinz Ebert. Amostras da reserva técnica com uma numeração desproporcional e que danifica os exemplares.

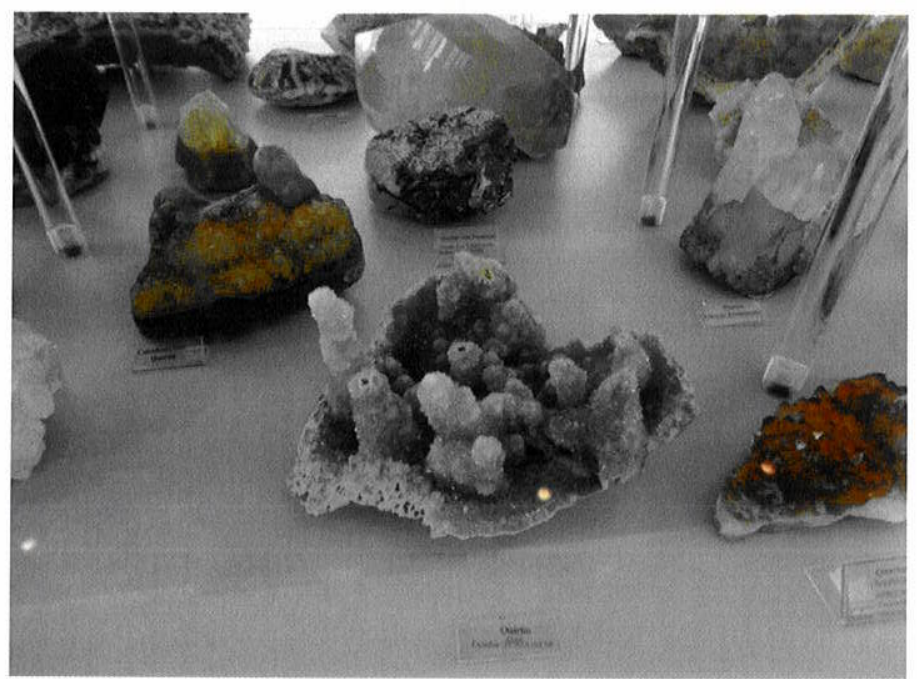

Figura 36. Museu de Minerais e Rochas Heinz Ebert. Amostras de minerais estéticos comuns e detalhe da etiqueta em acrílico contendo informações simples e pouco informativa. 


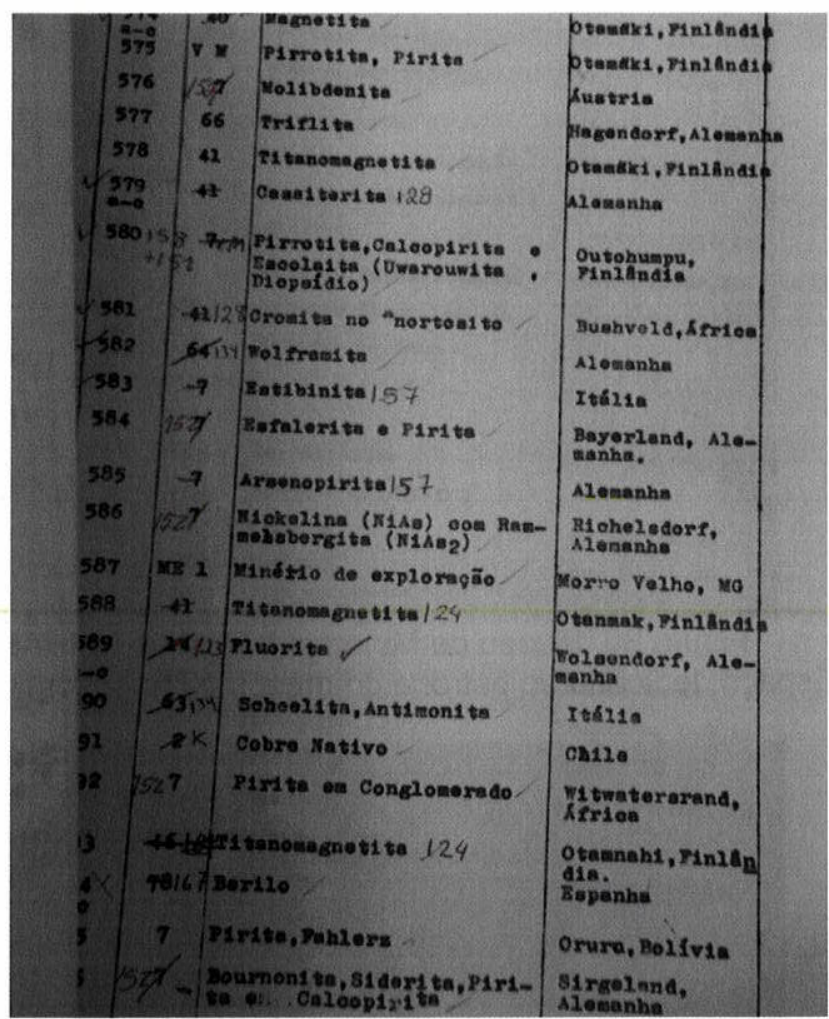

Figura 37. Museu de Minerais e Rochas Heinz Ebert. Catalogo antigo de minerais da reserva técnica.

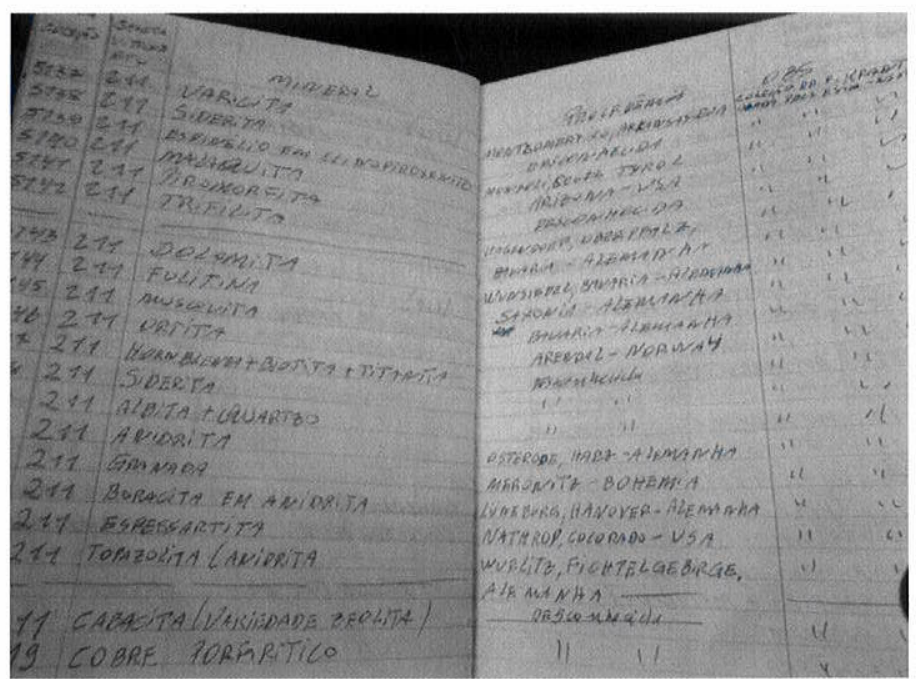

Figura 38. Museu de Minerais e Rochas Heinz Ebert. Catalogo antigo de minerais da reserva técnica. 


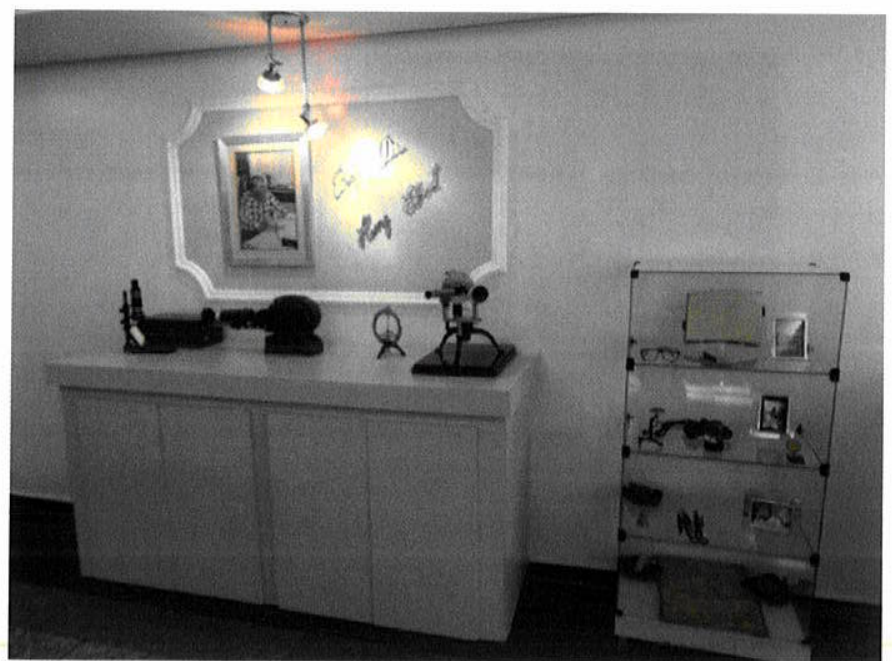

Figura 39. Museu de Minerais e Rochas Heinz Ebert. Espaço dedicado ao patrono do museu o professor Heinz Ebert.

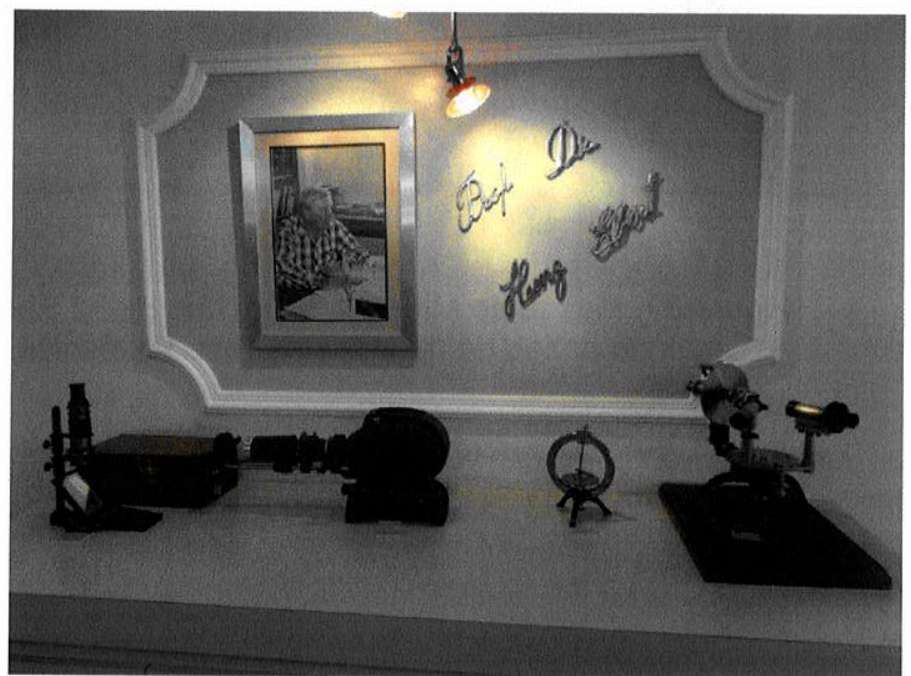

Figura 40. Museu de Minerais e Rochas Heinz Ebert. Espaço dedicado ao patrono do museu o professor Heinz Ebert.

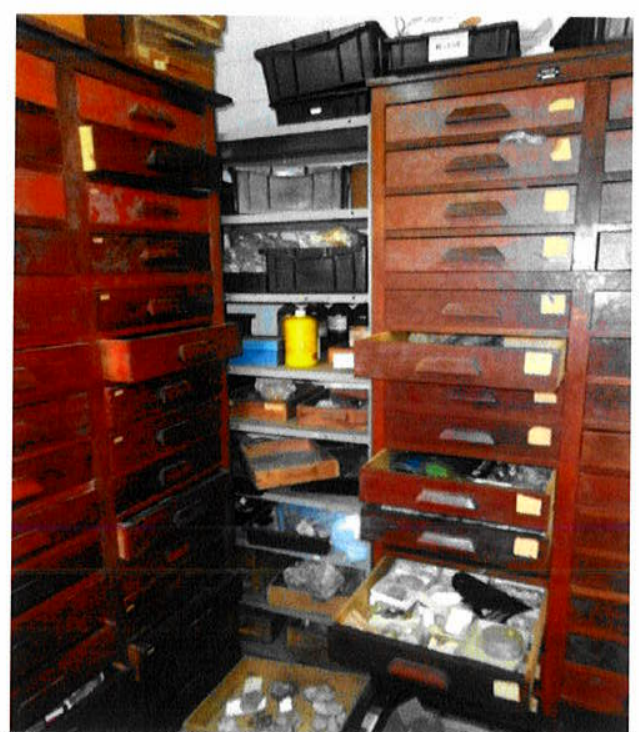

Figura 41. Museu de Minerais e Rochas Heinz Ebert. Reserva Técnica, mostrando as diversas gavetas com as amostras. 


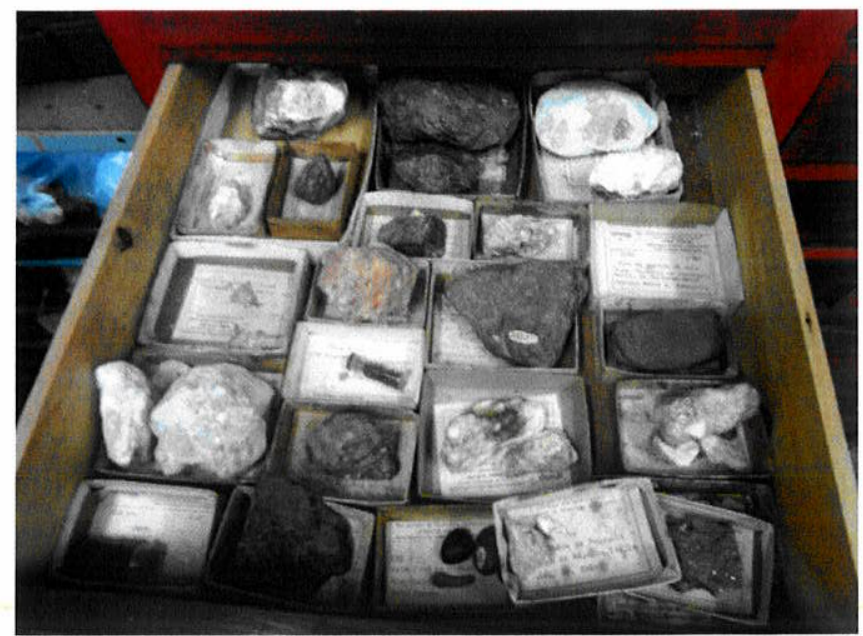

Figura 42. Museu de Minerais e Rochas Heinz Ebert.

Detalhe da gaveta com as amostras minerais da reserva técnica. Nota-se falta de cuidado com os exemplares.

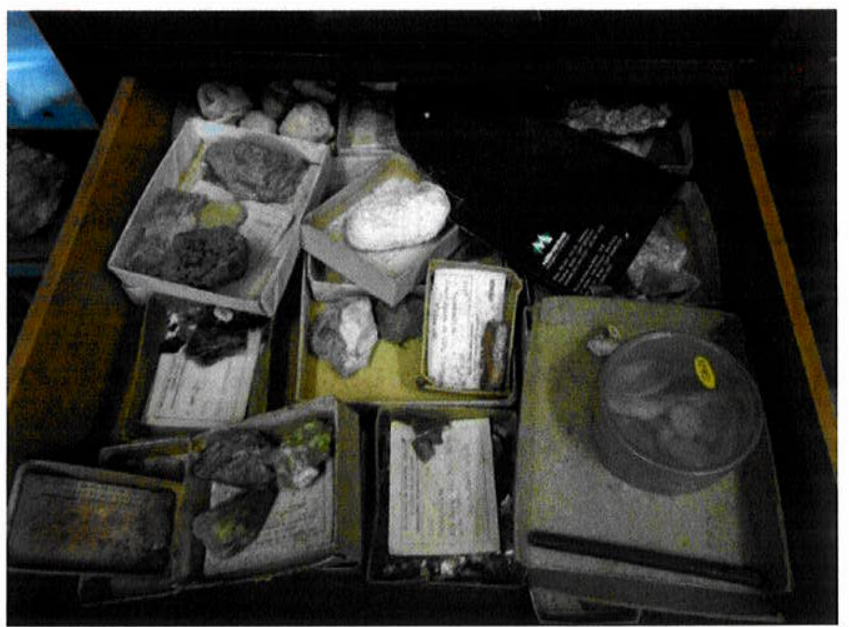

Figura 43. Museu de Minerais e Rochas Heinz Ebert. Detalhe da gaveta com as amostras minerais da reserva técnica. Nota-se a falta de cuidado com os exemplares e a desorganização das amostras. 


\section{MUSEU DA GEODIVERSIDADE}

(análise realizada em julho de 2012)

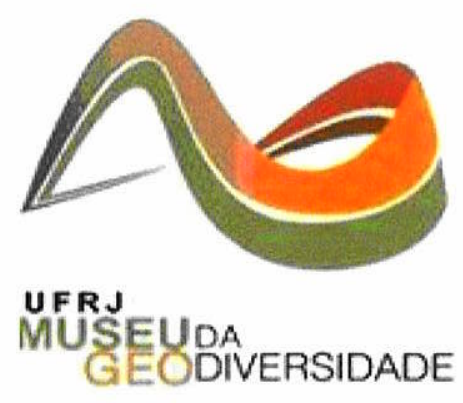

HISTÓRICO DA INSTITUIÇÃO

O Museu da Geodiversidade fica localizado no Centro de Ciências Matemáticas e da Natureza no Instituto de Geociências - Departamento de Geologia, na Av. Athos da Silveira Ramos, 274, Cidade Universitária - Ilha do Fundão, Rio de Janeiro.

Segundo a pesquisa desenvolvida com a museóloga Aline Rocha de Souza F. de Castro, Mestre em Museologia e Patrimônio - Universidade do Rio de Janeiro/Museu de Astronomia e Ciências Afins - UNIRIO/MAST e Doutoranda em Geologia - Universidade Federal do Rio de Janeiro - UFRJ, a coleção começou a ser formada por professores e alunos da universidade, há cinquenta anos. O museu foi criado em 2007. Em 2008, inaugurou sua primeira exposição, que ficou aberta ao público por quase um ano. Devido a problemas estruturais, passou por uma longa reforma e uma nova exposição foi inaugurada em setembro de 2011.

\section{ORGANIZAÇÃO E FUNCIONAMENTO}

A gestão do museu pertence ao Instituto de Geociências da Universidade Federal do Rio de Janeiro. Ele é mantido basicamente através de projetos, que são submetidos aos órgãos de apoio à pesquisa e empresas privadas, como o Departamento de Recursos Minerais - DRM do Governo do RJ, a Fundação de Amparo à Pesquisa do Estado do Rio de Janeiro - FAPERJ, a CPRM e a PETROBRAS. Mas de qualquer forma, não há um apoio contínuo, deve ser renovado periodicamente. $A$ entrada é gratuita.

A curadoria do museu é setorizada e de responsabilidade dos docentes. A coleção de Paleontologia tem a curadoria dos professores Ismar de Souza Carvalho e Lílian Berqvist. A coleção de minerais tem a curadoria da Profa . Cícera Neysi de Almeida. Ainda compõem a estrutura de recursos humanos, dois docentes - direção e vice direção; um docente - coordenação de capacitação de Pessoal; cinco técnicos 
de curso superior - educadores e museólogos (que são os curadores mencionados acima, além da museóloga entrevistada); três técnicos de nível médio e três funcionários terceirizados - portaria e limpeza.

Os monitores que atendem o público são alunos da própria universidade que recebem uma bolsa de extensão. Eles são capacitados pelo Núcleo de Capacitação, composto por docentes da universidade.

Os principais objetivos da instituição são: estimular a preservação do patrimônio cultural e natural constituído pela Universidade Federal do Rio de Janeiro; realizar exposições para divulgação do conhecimento acadêmico das Geociências produzido e disseminado no âmbito universitário; desenvolver atividades educativas voltadas para o ensino das Ciências da Terra na Educação Básica e na sociedade em geral (UNIVERSIDADE FEDERAL DO RIO DE JANEIRO, 2013).

A divulgação do museu é feita principalmente pela internet, através de blogs de professores, do site oficial do Instituto de Geociências, página nas redes sociais e mala direta (e-mails). O acesso ao museu acaba sendo um pouco restrito, pois fica dentro da universidade, o que inibe o público transeunte. O tempo médio de visita é de uma hora. O público alvo são estudantes do ensino fundamental e universitários. O museu recebe uma média de 800 pessoas por mês.

O museu possui duas áreas principais, geologia (rochas e minerais) e paleontologia (fósseis). O Museu busca uma integração das geociências e do entendimento do por que, onde e como ocorrem os desastres naturais, tais como terremotos, furacões, vulcões, mudanças climáticas, retratando a história geológica da Terra. O museu abriga a terceira maior coleção de fósseis no país, catalogada pelo sistema paleontológico do Serviço Geológico do Brasil, disponível pela internet.

A importância para a preservação do patrimônio natural é afirmada pela entrevistada que assegurou que o recorte e a proposta expositiva são únicos. O museu da geodiversidade contribui para a preservação e divulgação do Patrimônio Geológico. É um dos poucos museus que já trabalha com esses termos novos (geodiversidade, geoconservação).

\section{ESTRUTURA FÍSICA}

A área total do museu é de 700 metros quadrados, inclui salões expositivos, auditório e reserva técnica. Em sua estrutura física possui acessibilidade, por ser 
todo térreo, e algumas informações estão sendo convertidas para braile. Há um stand pequeno para venda de produtos e as lanchonetes estão distribuídas pela universidade. A segurança é realizada pelos guardas da universidade, que controlam o acesso. A climatização está inadequada, segundo a museóloga Aline, pois o equipamento de ar-condicionado não possui alcance e posicionamentos corretos para atender o espaço.

\section{AÇÃO EDUCATIVA E CULTURAL}

De acordo com a entrevistada, dá-se uma ação educativa muito bem desenvolvida. Dentre suas ações estão: realizar visitas monitoradas, seguidas de atividades lúdicas e pedagógicas, realizar Olimpíada Científica, participar de Eventos Científicos Externos, e também desenvolver e distribuir materiais sobre Geociências. Além disso, dentro da monitoria de visitantes que realizam o circuito expositivo, estão espaços próprios para experimentos, oficinas, vídeos educativos e manipulação de materiais.

As ações que contribuem para a divulgação da mineralogia no Brasil estão na exposição que apresenta um módulo específico sobre minerais. Também são produzidos materiais (jogos e folhetos) sobre o tema, que foi inserido nas questões da Olimpíada Científica realizada em 2011.

\section{ACERVO MINERALÓGICO}

O acervo consiste em algumas poucas amostras (porém em tamanhos grandes), cerca de 80 exemplares em exposição e a grande maioria de seu acervo mineralógico está armazenada na reserva técnica.

O que foi constatado é que o acervo tem função somente didática e está disposto em algumas vitrines de madeira e vidro, com boa iluminação, porém sem nenhuma sistematização ou classificação preferencial. O critério principal utilizado para seleção das amostras expostas foi a qualidade visual (estética), relevância científica (minerais comuns formadores de rochas) e contextualização no tema da exposição, que eles intitularam "Memórias da Terra".

As amostras possuem uma etiqueta com a identificação básica/simples (nome: da espécie ou grupo mineral / ocorrência: às vezes está colocado o nome da 
cidade, mas em geral observa-se somente o estado em que o mineral foi encontrado uso: principal utilização do mineral). Em muitos casos, a identificação do exemplar está equivocada. Esta classificação ficou a encargo dos professores do Departamento de Mineralogia, que são os responsáveis e os curadores pelo setor dos minerais.

Não foi observada nenhuma espécie tipo brasileira em exposição, somente algumas espécies famosas como berilo (var. esmeralda), quartzo (var. ametista e ágata), gipsita (var. selenita), entre outras amostras comuns.

No setor expositivo de minerais, consta ainda uma pequena exposição didática e temática da utilização dos bens minerais com alguns minerais, representado alguns elementos químicos importantes como o carbono, ouro, prata, titânio, ferro, etc. Neste acervo, destacam-se somente algumas poucas amostras de ouro nativo e diamante no metaconglomerado.

A grande maioria dos exemplares que estão em exposição foi obtida através de compra e algumas poucas amostras foram doadas.

Este museu cumpre a sua função perante a sociedade, pois tem um acervo naturalista interessante composto por minerais, rochas e fósseis (destaque para o setor da paleontologia) e seu acervo está disposto de maneira lúdica e atraente, o que desperta o interesse nos visitantes.

Porém, nada de muito expressivo foi evidenciado ou encontrado em exposição no que se diz respeito ao setor de mineralogia tenha melhor material. $A$ reserva técnica não pôde ser visitada e talvez contenha melhor material.

Atualmente este museu não representa um local importante para a preservação da memória da mineralogia brasileira, pois contém em sua coleção expositiva apenas um dos minerais descritos no país (brazilianita), somente tem função didática e educativa no fomento da mineralogia e geologia do Brasil, pois mostra algumas espécies famosas brasileiras.

Quadro 11 - Quadro de minerais tipo brasileiros pertencentes ao acervo do Museu da Geodiversidade/UFRJ com suas respectivas ocorrências (exemplos):

Quadro de minerais tipos brasileiros pertencentes ao acervo do Museu
da Geodiversidade com suas respectivas ocorrências (exemplos):
Brazilianita - Pegmatito de Córrego Frio, Linópolis, Divino das Laranjeiras,
MG.


Quadro 12 - Quadro de minerais brasileiros pertencentes ao acervo do Museu da Geodiversidade/UFRJ com suas respectivas ocorrências (exemplos):

Quadro de minerais importantes brasileiros pertencentes ao acervo do Museu da Geodiversidade e suas respectivas ocorrências (exemplos):

Ouro Nativo - Serro, MG.

Diamante - Rio Jequitinhonha, Maria Nunes, MG.

Berilo (var. esmeralda) - BA

Berilo (var. água marinha) - MG

Espodumênio (var.kunzita) - MG

Espodumênio (var.hiddenita) - MG

Topázio (var. imperial) - MG

Quartzo (var. ametista) - RS

Quartzo (pseudomorfo de anidrita) - RS

Gipsita (var. selenita) - RS

\section{RELAÇÃO DE FOTOS DO MUSEU DA GEODIVERSIDADE/UFRJ}

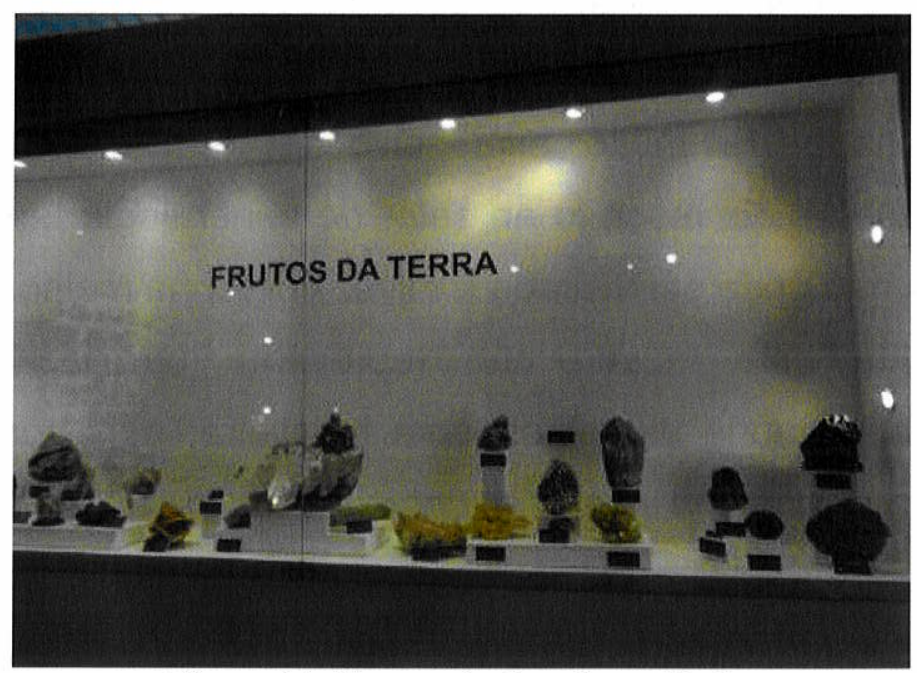

Figura 44. Museu da Geodiversidade.

Vitrine com amostras de minerais comuns. 


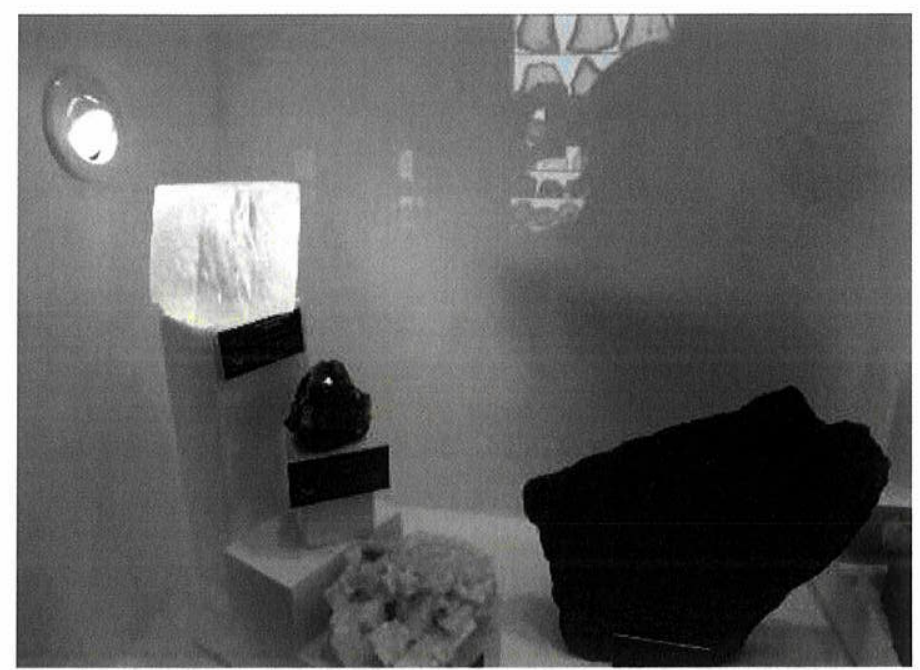

Figura 45. Museu da Geodiversidade. Vitrine com amostras de minerais comuns. Detalhe da iluminação direcionada aos minerais.

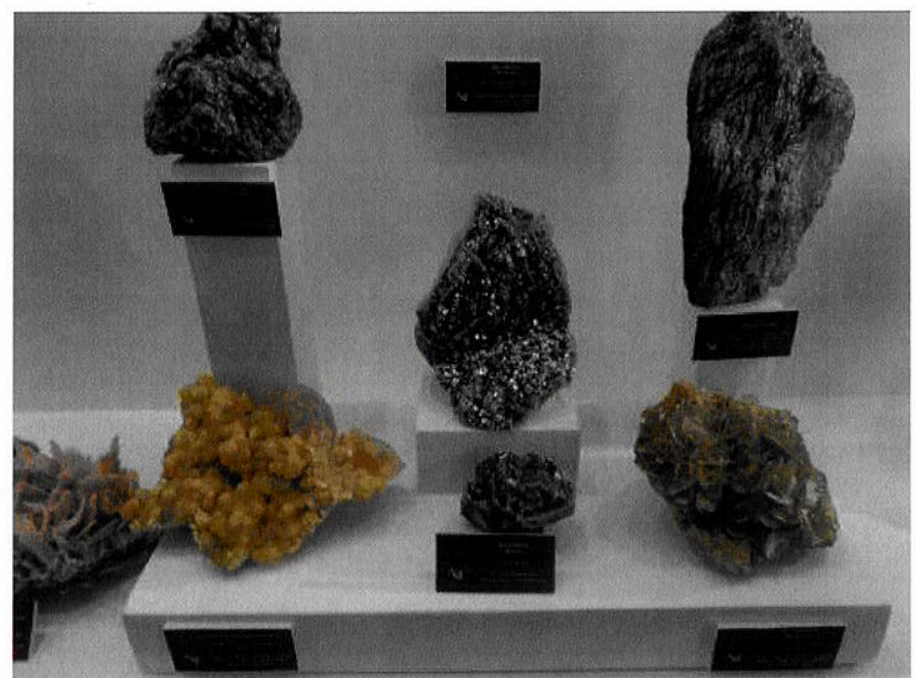

Figura 46. Museu da Geodiversidade. Vitrine com as amostras separadas em grupos, no caso o grupo das Micas.

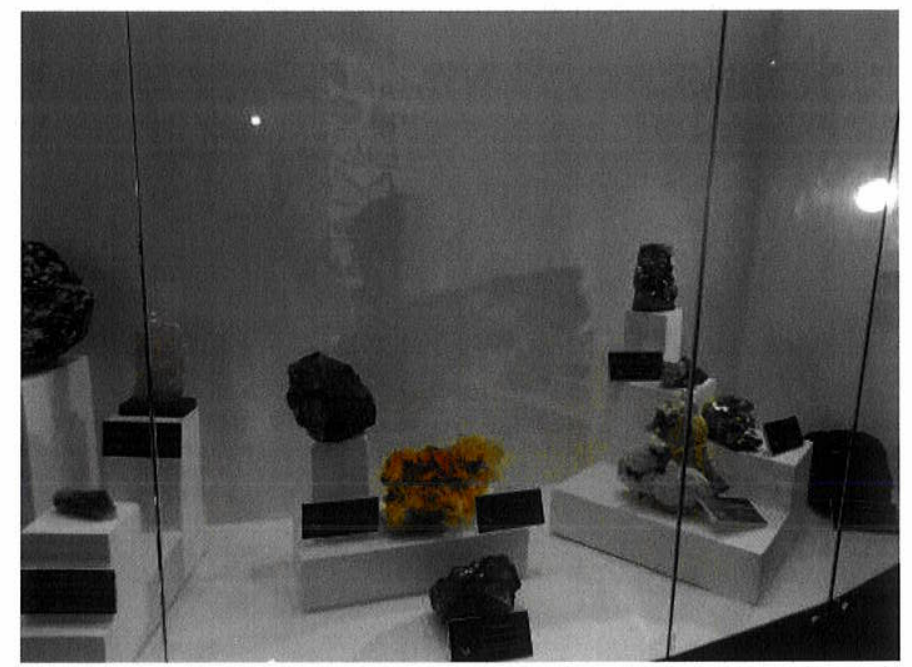

Figura 47. Museu da Geodiversidade. Vitrine de minerais colocados aleatoriamente, sem nenhuma classificação preferencial. 


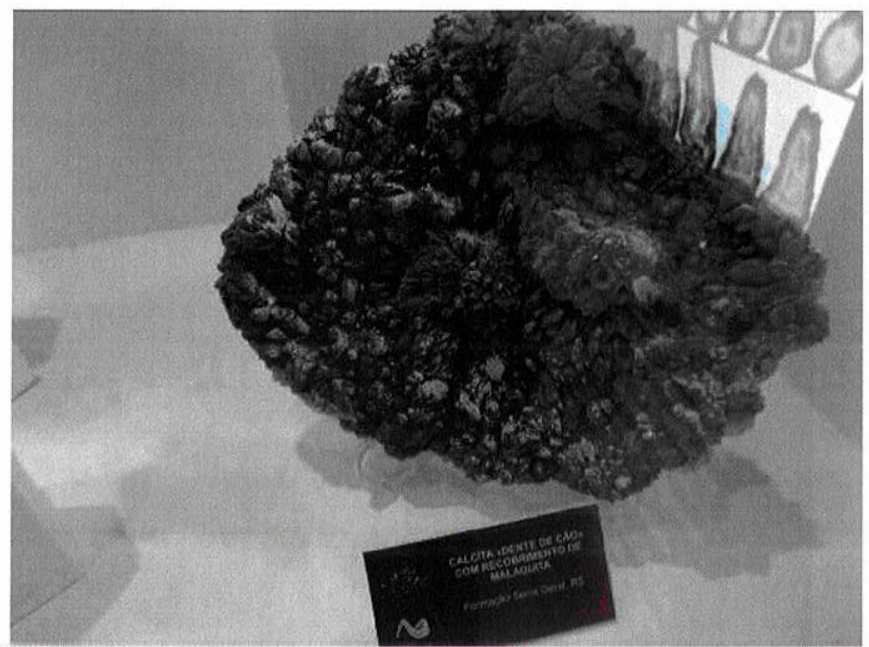

Figura 48. Museu da Geodiversidade. Detalhe da etiqueta do mineral contendo informações simples equivocadas enquanto a sua classificação mineralógica. No caso a malaquita é na verdade um mineral do grupo da clorita.

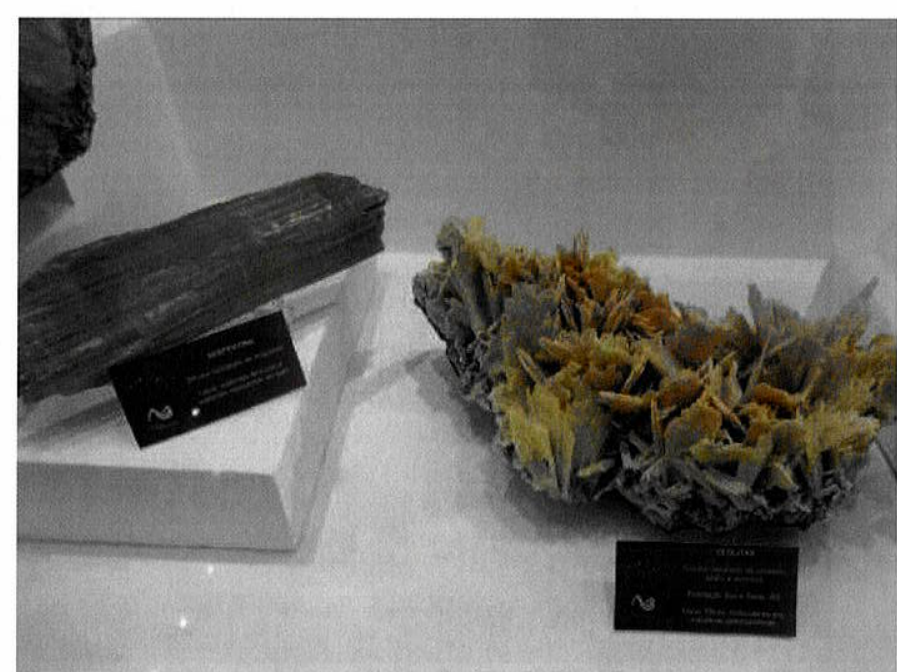

Figura 49. Museu da Geodiversidade. Amostras estéticas em exposição na vitrine. Detalhe da etiqueta que possui informações equivocadas em relação a sua classificação.

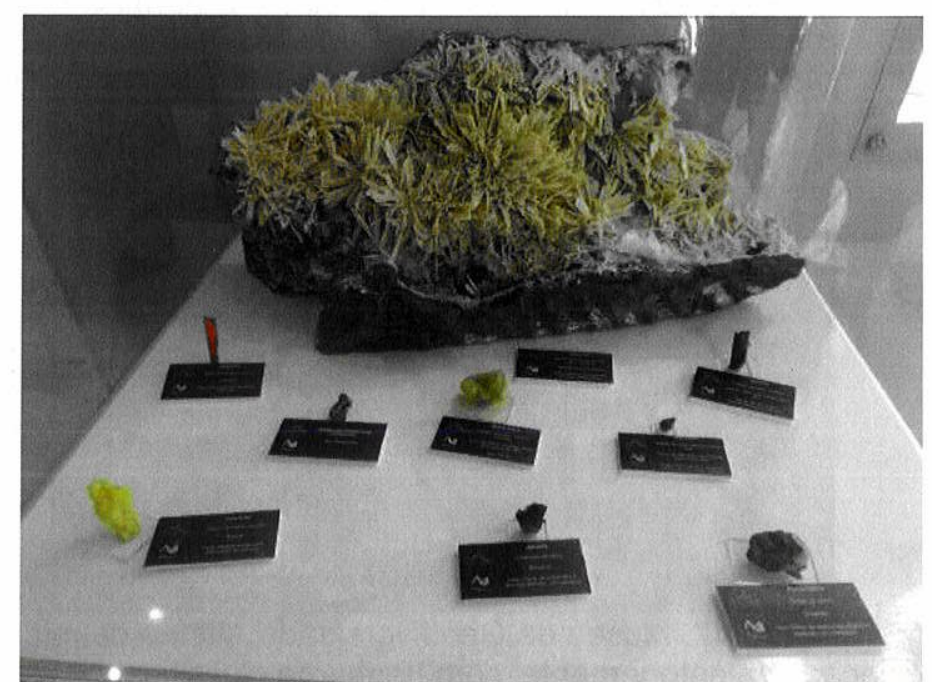

Figura 50. Museu da Geodiversidade. Vitrine com minerais diversos, sem classificação e organização. 


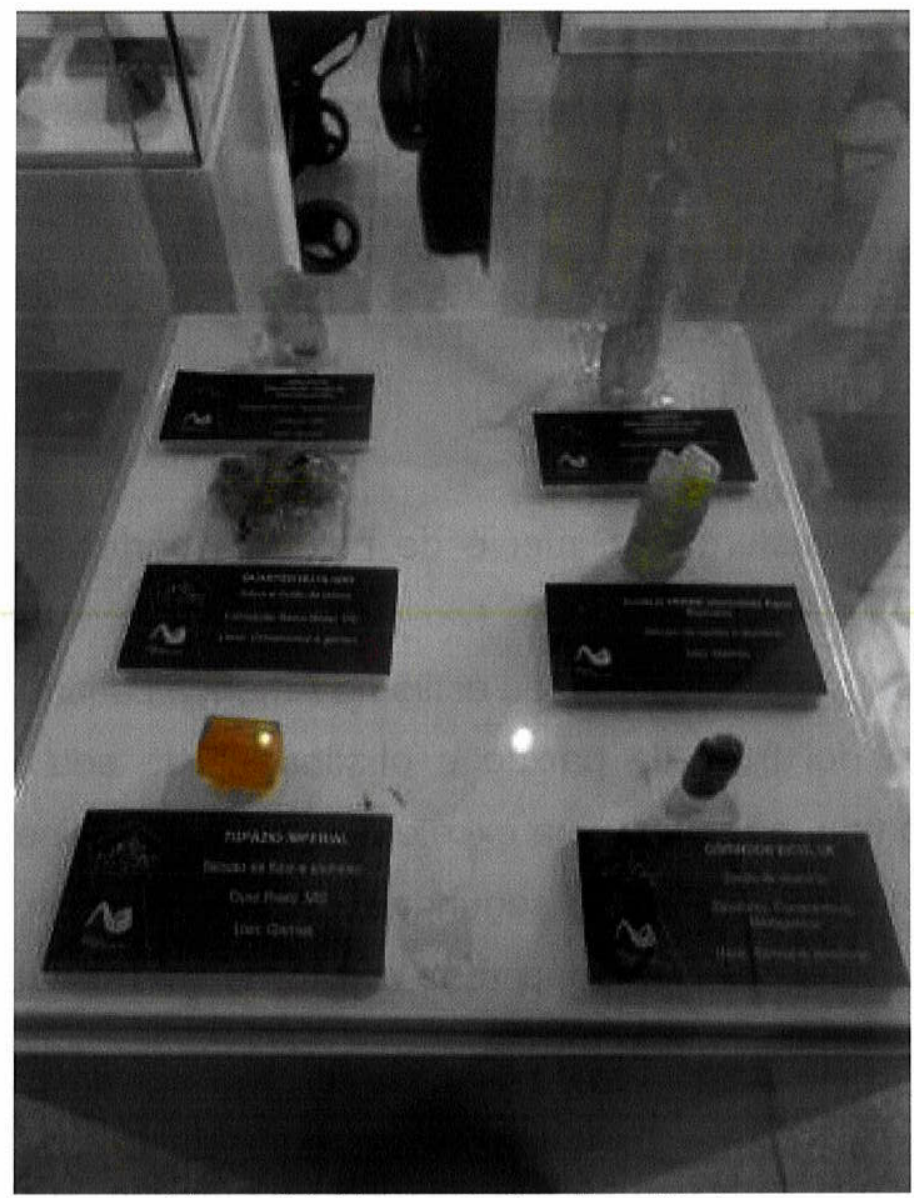

Figura 51. Museu da Geodiversidade. Vitrine com minerais estéticos. 


\section{MUSEU AMSTERDAM SAUER \\ DE PEDRAS PRECIOSAS E MINERAIS RAROS}

(análise realizada em julho de 2012)

\section{HISTÓRICO DA INSTITUIÇÃO}

O Museu Amsterdam Sauer é de natureza particular e localiza-se na Rua Garcia D’Ávila, 105, em Ipanema, Rio de Janeiro. Foi inaugurado em 1989, por iniciativa privada e é o único em seu estilo na América Latina.

O museu foi fruto da paixão e obstinação de seu fundador, Jules Roger Sauer, que montou, em 1941 uma excelente coleção de minerais-gemas brasileiros, que vem sendo enriquecida pela segunda geração da família. Ao longo de sua vida, Jules Sauer, um francês que nasceu na região de Alsácia - Lorena emigrou para o Brasil, foi pesquisador, minerador, lapidador, exportador, colecionador, atacadista e varejista, uma lenda viva na história da joalheria brasileira, que percorreu as mais importantes minas de gemas do planeta, colhendo experiências e histórias fantásticas (MUNDO DAS MARCAS, 2014).

Em suas viagens, dedicou-se principalmente a visitar e pesquisar diversas ocorrências minerais em todo o país, coletando e adquirindo amostras para a sua própria coleção, ênfase nos minerais estéticos. Este acervo mais tarde se transformaria no Museu Amsterdam Sauer (AMSTERDAM SAUER, 2014).

No dia da visita programada, o Diretor Daniel Sauer estava ausente. Desta forma alguns detalhes da descrição deste museu estão comprometidos. O Promotor de Vendas, Richard Carvalho, respondeu algumas perguntas por contato telefônico.

\section{ORGANIZAÇÃO E FUNCIONAMENTO}

O Museu Amsterdam Sauer possui uma réplica de uma mina em tamanho natural que transporta todos os visitantes através de um ambiente cenográfico das típicas minas do interior do Brasil. 
Recentemente, o prédio, que abriga o museu, recebeu mais um pavimento. $A$ nova área, localizada no terceiro andar, funciona como um misto de espaço cultural e de eventos (palestras, cursos e treinamento).

O museu recebe turistas, clientes, e eventualmente visitas monitoradas de escolas. Não existe uma ação educativa direcionada e nem mensuração de visitantes, apesar de o museu possuir um potencial educativo excelente.

A divulgação é feita por catálogos, revistas de joias e de turismo, redes sociais, site, distribuição de folders em hotéis e em alguns pontos estratégicos do Rio de Janeiro.

\section{ACERVO MINERALÓGICO}

Em exposição, observa-se mais de 3.000 minerais-gemas brutos e lapidados expostos em vitrines modulares de vidro, onde os visitantes vivem um momento de grande deslumbramento, admiração e fascínio com a riqueza do mundo mineral. Diversos minerais como turmalina (de todas as cores), berilo (água-marinha, esmeralda), topázio (imperial, azul, incolor), diamante e outros minerais importantes, de diversas formas e tamanhos, são alguns exemplos do rico acervo deste museu.

No museu, podem ser vistos também cristais gigantes, como um topázio de 68 quilos, um dos maiores já encontrados no mundo, e um aglomerado de cristais de quartzo transparente, de $64,5 \mathrm{~kg}$, que lembra uma fantástica escultura. Um exemplar de água marinha com 635 quilates, destaque no Guinness Book - O Livro dos Recordes, por sua grande raridade e beleza (AMSTERDAM SAUER, 2014).

Neste museu, é possível visualizar os minerais brutos que ilustram o "antes" (produzido pela natureza), e o "depois" (gemas e joias manufaturadas).

A coleção mineralógica do Museu Amsterdam Sauer não apresenta sistematização ou classificação, a menos de uma ordenação de acordo com alguns grupos ou espécies minerais específicos ou pela estética das amostras. O principal critério utilizado para a aquisição e para o seu agrupamento está na beleza e estética dos minerais.

Cerca de 3 mil amostras estão dispostas em vitrines modulares de vidros, com iluminação geral do ambiente reduzida, mas com iluminação pontual na parte superior de cada vitrine ou amostra em bases de madeira, possibilitando uma observação eficiente dos detalhes dos exemplares. As etiquetas são de acrílico e 
possuem informações muito simples, incluindo, apenas os nomes (muitas vezes de variedades) das amostras, sem informação de suas localizações geográficas.

O salão expositivo contém, além das vitrines e bases com os minerais, uma réplica de mineração artesanal, típica do interior do Brasil. Neste ambiente, percebem-se amostras de minerais incrustados na parede, tornando-o mais lúdico e interessante.

O acervo do Museu Amsterdam Sauer, apesar de ser uma coleção mineralógica com fins mais comerciais do que científicos ou didáticos, possui em seu acervo importantes amostras de minerais-gemas brasileiros, como um dos maiores cristais de água-marinha do mundo e uma fabulosa coleção de diamantes, de cores e formados diferentes. Portanto, é um acervo importante e com certa relevância para a preservação da memória da mineralogia brasileira.

\section{RELAÇÃO DE FOTOS DO MUSEU AMSTERDAN SAUER}

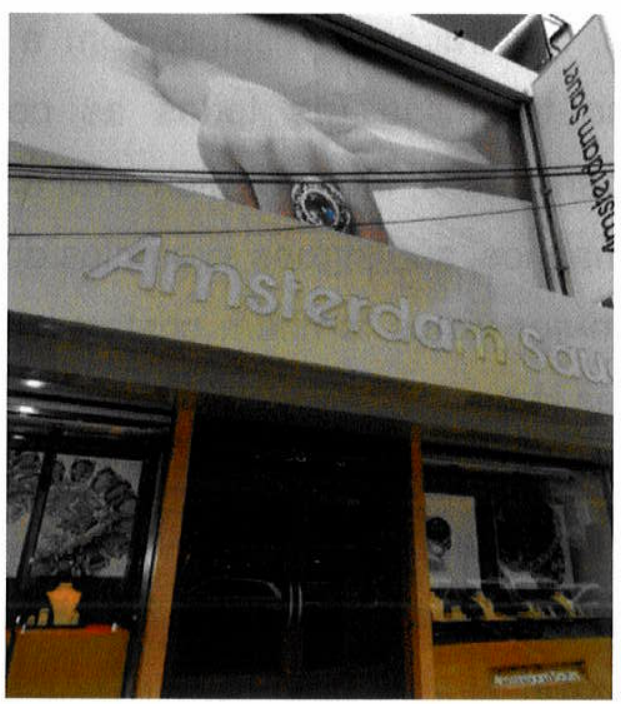

Figura 52. Museu Amsterdam Sauer. Vista da entrada do museu.

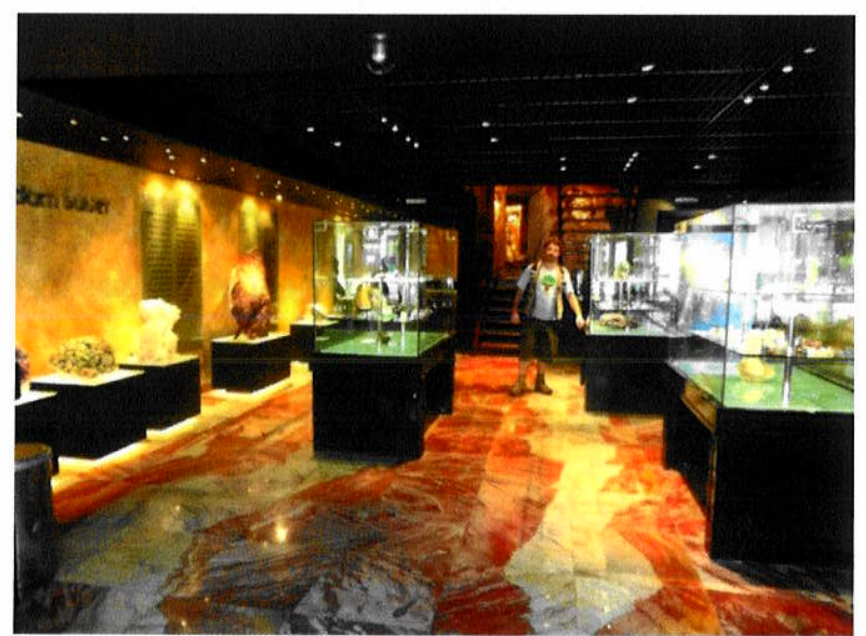

Figura 53. Museu Amsterdam Sauer. Vista geral do salão expositivo. 


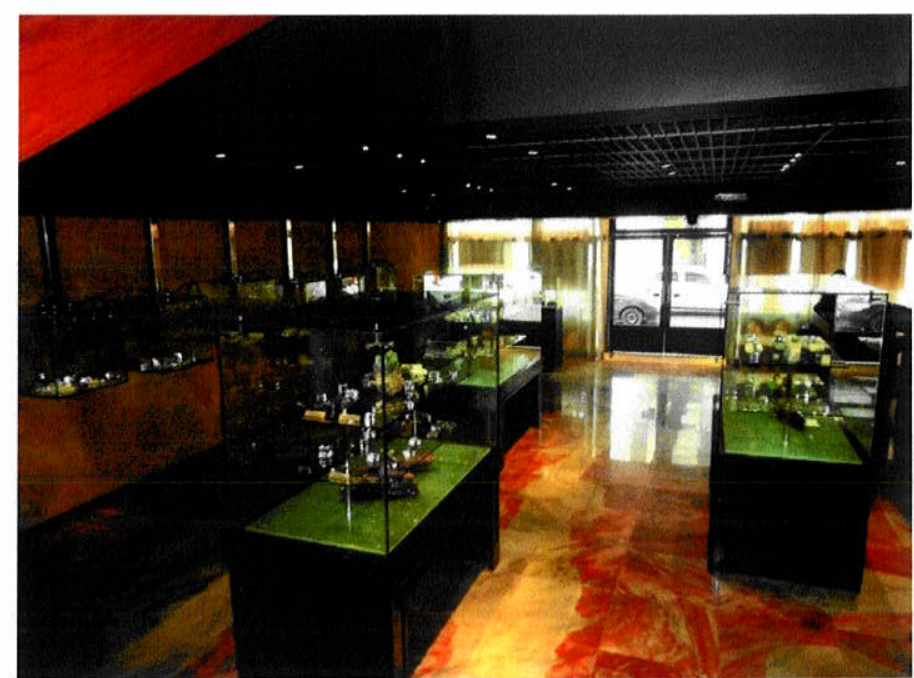

Figura 54. Museu Amsterdam Sauer. Vista geral do salão expositivo com as vitrines modulares, com iluminação pontual e reduzida.

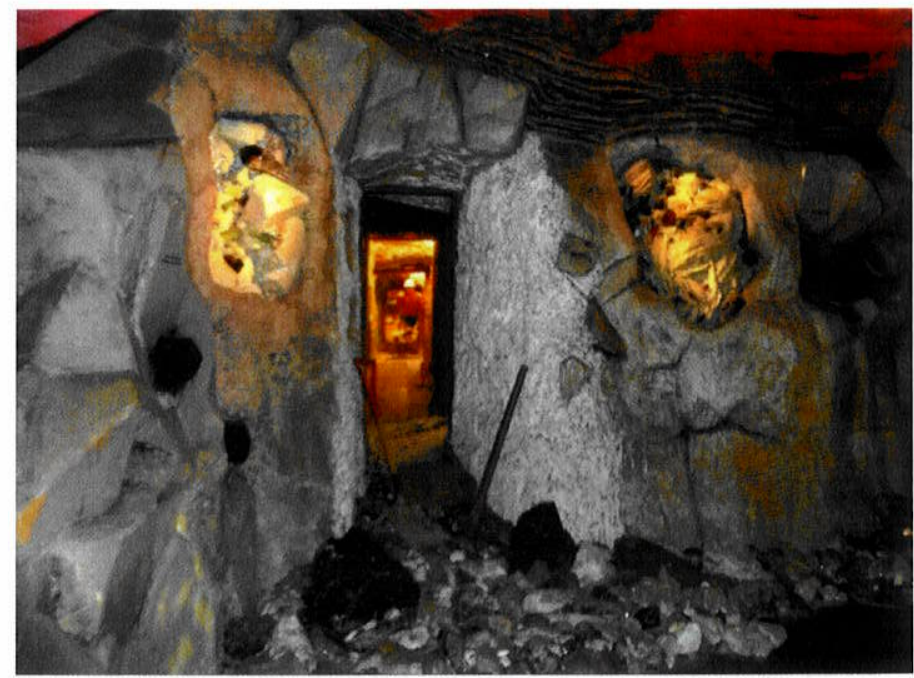

Figura 55. Museu Amsterdam Sauer. Réplica de um garimpo realizado em pegmatitos brasileiros.

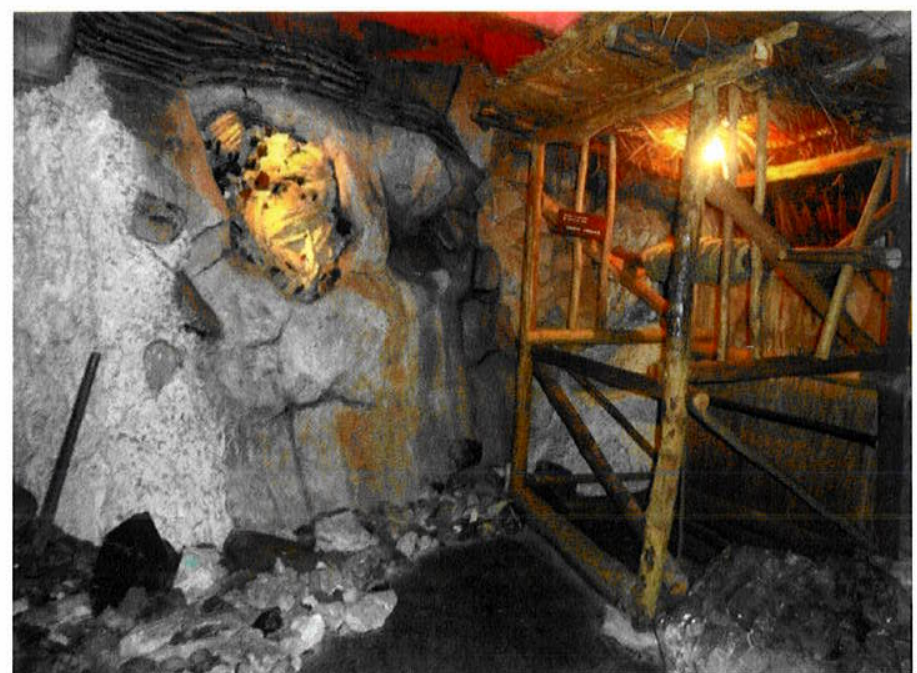

Figura 56. Museu Amsterdam Sauer. Réplica de um garimpo realizado em pegmatitos brasileiros. 


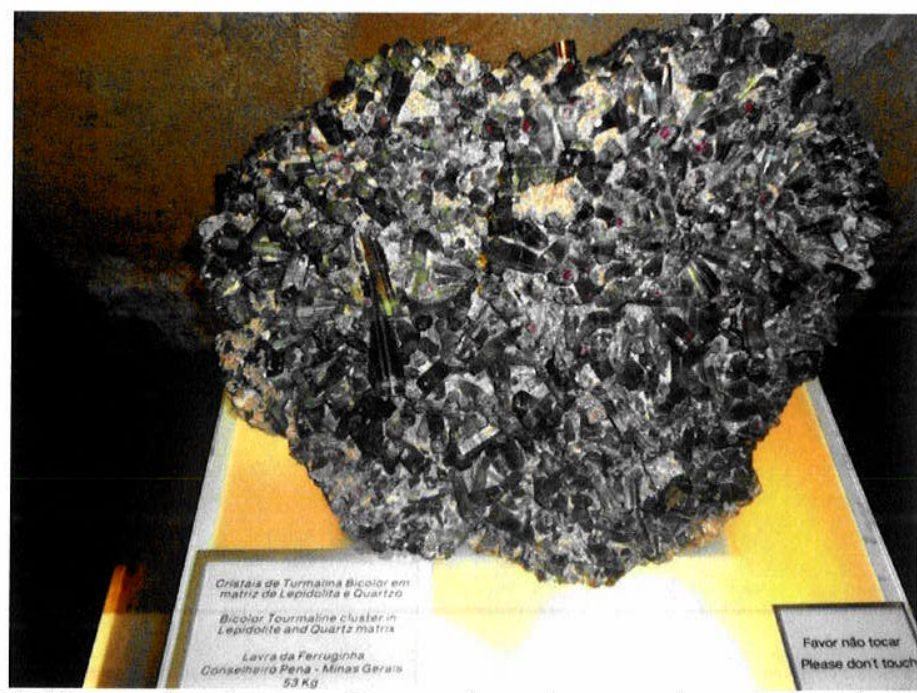

Figura 57. Museu Amsterdam Sauer. Amostra grande estética de Turmalina bicolor colocada em pedestais com iluminação pontual, para valorizar a amostra.

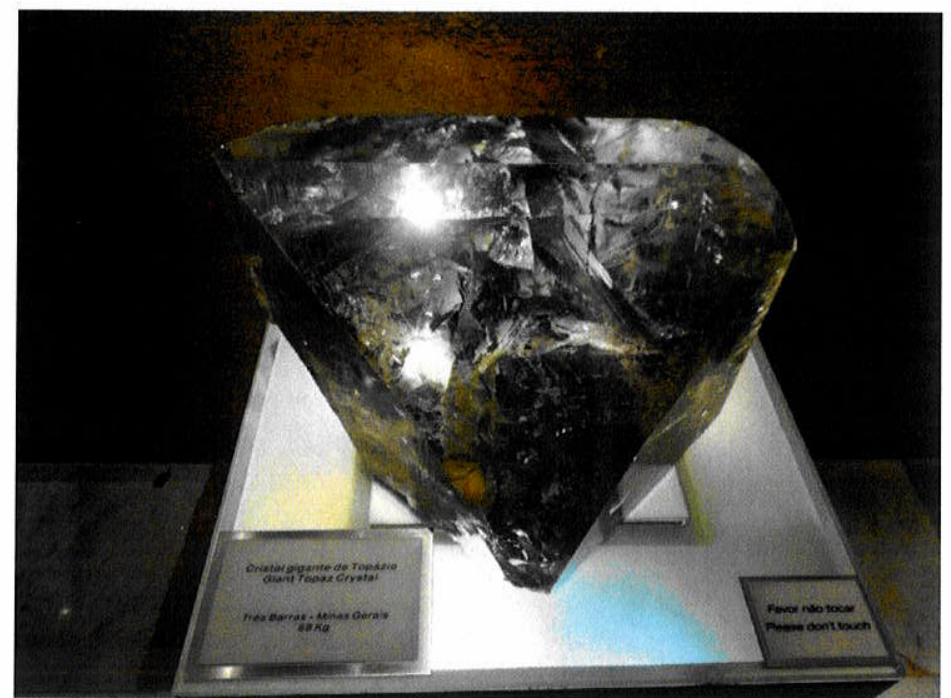

Figura 58. Museu Amsterdam Sauer. Amostra grande estética de Topázio incolor.

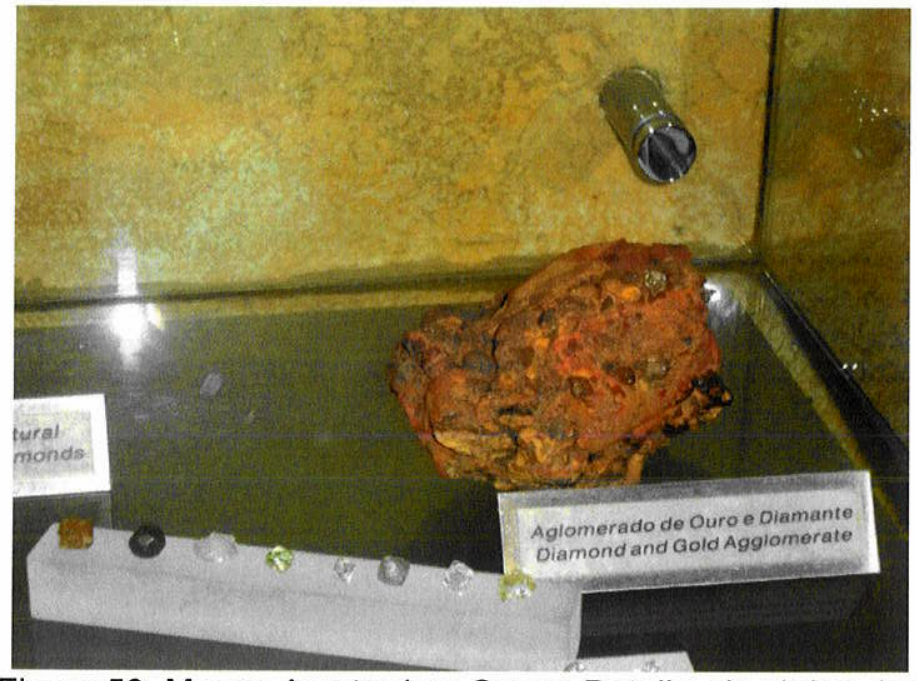

Figura 59. Museu Amsterdam Sauer. Detalhe da vitrine dos diamantes, contendo uma das melhores coleções do país. 


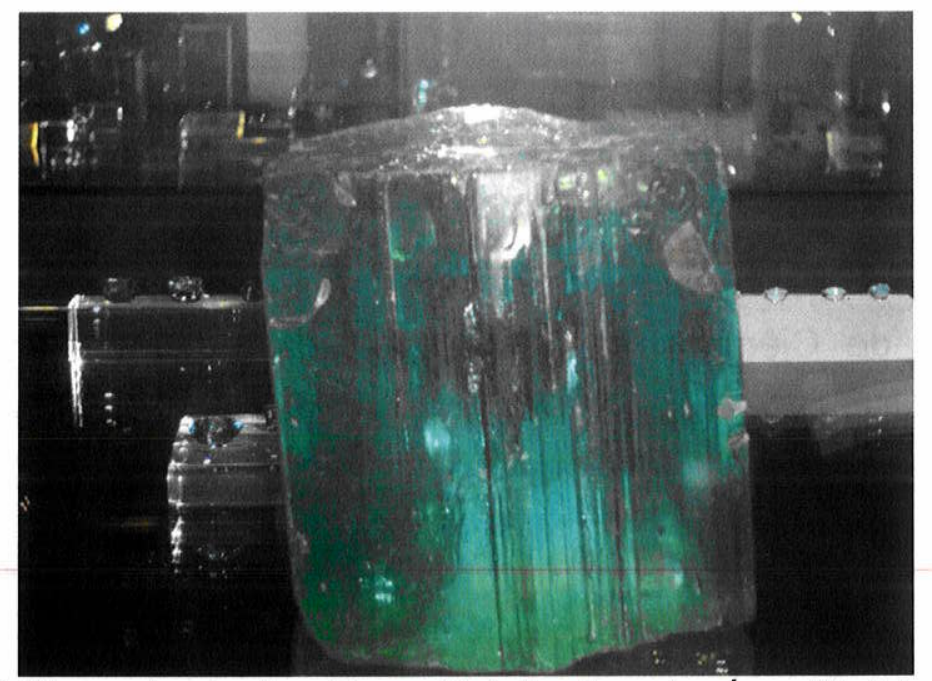

Figura 60. Museu Amsterdam Sauer. Detalhe da maior Água Marinha do país.

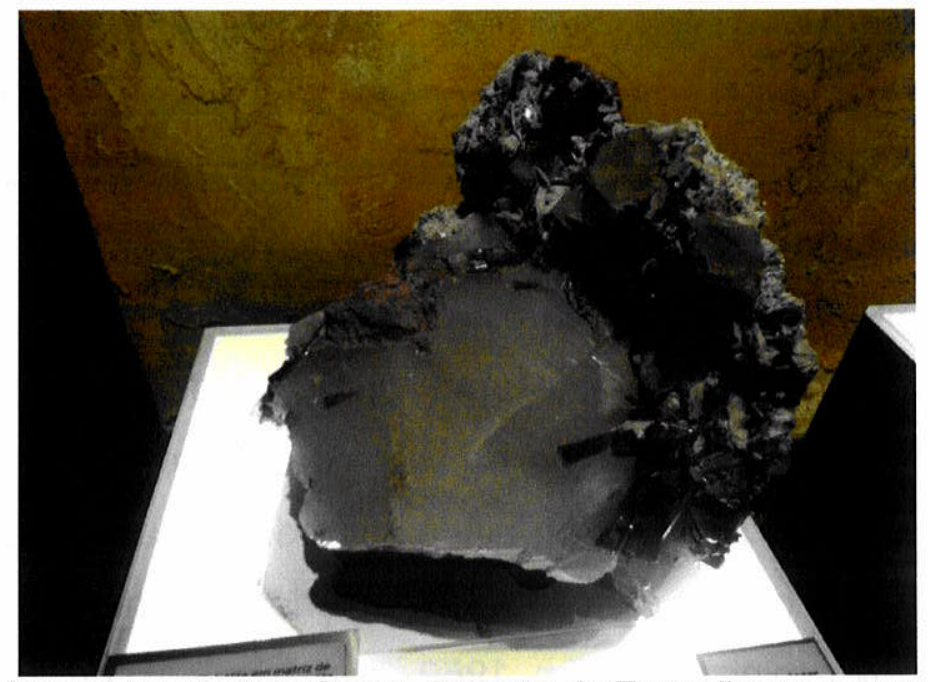

Figura 61. Museu Amsterdam Sauer. Amostra de Turmalina rosa proveniente da famosa lavra do Jonas, em Conselheiro Pena, Minas Gerais.

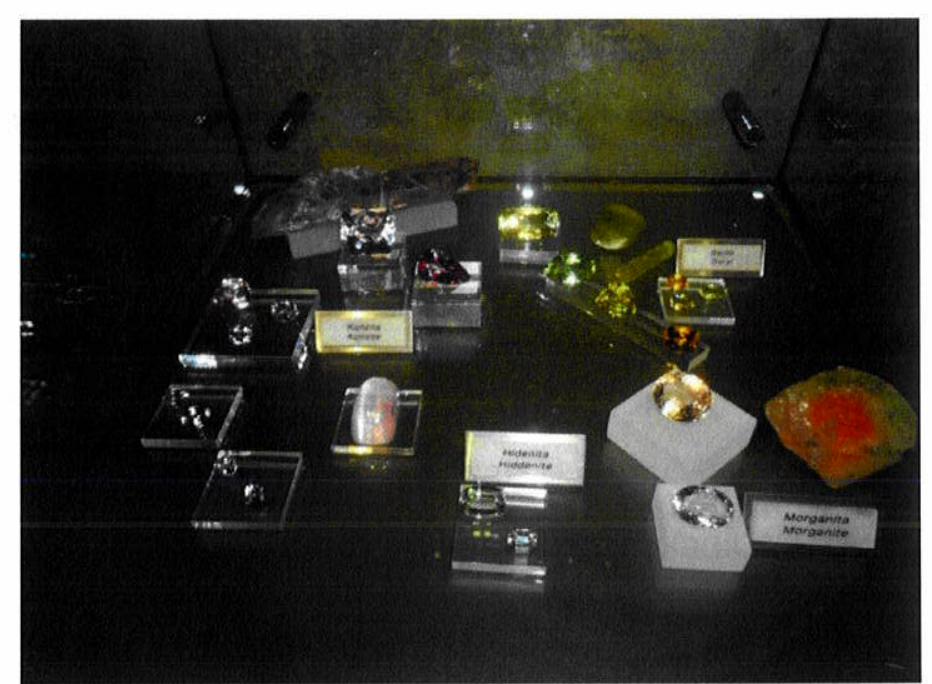

Figura 62. Museu Amsterdam Sauer. Vitrine com minerais brutos e lapidados. 


\section{MUSEU DE CIÊNCIAS DA TERRA/DNPM/CPRM}

(análise realizada em julho de 2012)

HISTÓRICO DA INSTITUIÇÃO

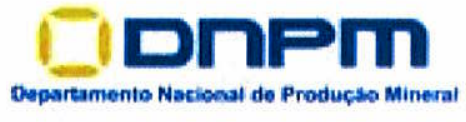

O Museu de Ciências da Terra do Departamento Nacional de Produção Mineral fica localizado no antigo Palácio dos Estados, na Avenida Pasteur, 404, Urca, Rio de Janeiro.

Sua história começa pelo Palácio dos Estados, que foi construído exclusivamente para a Exposição Nacional de 1908, em comemoração ao centenário da "Abertura dos Portos". Todos os estados da Federação organizaram pavilhões ou estandes exibindo seus avanços culturais e econômicos em álbuns, fotografias ou catálogos, o mais importante foi este no Rio de Janeiro. Sua exposição durou três meses e recebeu visitantes do mundo todo (UNIVERSIDADE FEDERAL DO RIO GRANDE DO SUL, 2013).

Em novembro de 1909, um ano após o término da Exposição Nacional, - Serviço Geológico instalou-se, junto com outros órgãos do Ministério da Agricultura, neste majestoso prédio da Avenida Pasteur. Em 1934, foi extinto o Serviço Geológico e criado o DNPM, ainda subordinado ao Ministério da Agricultura. Finalmente, em 1960, com a criação do Ministério de Minas e Energia, o DNPM foi absorvido pelo novo ministério. Em 1969, o prédio passou para o patrimônio do Centro de Pesquisa dos Recursos Minerais (CPRM) e hoje abriga além de diversas áreas técnicas do Serviço Geológico do Brasil (como hoje é denominado o CPRM), o Museu de Ciências da Terra do DNPM. Na década de 70 , o prédio todo sofreu com um incêndio, que resultou em uma grande perda de documentos. Em 1992, foi tombado como patrimônio histórico, onde foi reorganizada toda a sua exposição para receber o público.

Dr. Diógenes de Almeida Campos, geólogo e paleontólogo, que trabalha como Chefe de Divisão do Museu e está na instituição há mais de 45 anos, relatou na entrevista que as coleções geológicas começaram em 1906, e desde sua implantação no Palácio dos Estados, já colocava muitos destes materiais em exposição ao público. Quando o prédio e toda coleção foram tombados em 24/11/1992, iniciou-se um processo de reestruturação do acervo, para no ano de 
2000, conseguir adequar em seus 1500 metros quadrados, as coleções setorizadas em história do CPRM, Petrologia, Meteorítica e Mineralogia, e Paleontologia.

As coleções do Museu de Ciências da Terra resultam dos trabalhos realizados por várias gerações de geocientistas que passaram pelo Serviço Geológico e, mais tarde, pelo DNPM. No seu valioso acervo, destaca-se a exposição permanente de coleções de minerais, rochas, fósseis e meteoritos.

\section{ORGANIZAÇÃO E FUNCIONAMENTO}

A gestão do museu pertence ao DNPM, que anualmente prevê os gastos com energia, água, materiais de consumo, bem como serviços terceirizados, como limpeza e segurança. Existe uma Associação de Amigos do Museu que também colabora com materiais e reparos emergenciais, e os projetos inscritos para a modernização dos espaços, com verbas privadas como a Petrobrás, o Conselho Nacional de Desenvolvimento Científico e Tecnológico - CNPq e a Fundação de Amparo à Pesquisa do Estado do Rio de Janeiro - FAPERJ, que executaram os projetos no setor da Paleontologia. O salão expositivo da Mineralogia, Petrologia e Meteorítica continuam sem apoio.

O principal responsável pelo acervo e sua curadoria é o Prof. Diógenes, mas como ele relatou, existem mais 11 pessoas que trabalham para o museu e que são funcionários públicos de diversas áreas. Para a segurança e limpeza, o museu conta com um serviço terceirizado para todo o prédio, incluindo o DNPM e a CPRM.

Os monitores que atendem o público são alunos das Universidades do Rio de Janeiro, que fazem estágio nas áreas da Geologia e Paleontologia, mas por serem voluntários, torna esta atividade muito rotativa. Em entrevista, Dr. Diógenes relatou que o museu contrata pessoas terceirizadas para receberem o público escolar, sendo as mesmas capacitadas, mas também se torna muito rotativo e trabalhoso mantê-las.

O principal objetivo da instituição é conservar e difundir o acervo histórico e seus documentos, para promover a relação com o público visitante e o pesquisador, divulgando as áreas da Paleontologia e Geologia.

A divulgação não é muito boa, pois o museu não possui verba prevista, mas encontram-se informações pela internet e pela divulgação e indicações de professores e alunos. O museu também se encontra no roteiro turístico da cidade e 
é muito bem localizado, pois fica próximo à praia, aos pés do Pão de Açúcar, na Urca. O museu não possui um público específico, pois recebe pessoas de todas as idades, desde turmas escolares, universitários, pesquisadores e turistas. O tempo médio de visita é de uma hora e, em média, 800 visitantes são recebidos por mês, conforme o registro no livro de presença.

O Museu de Ciências da Terra conta com quatro exposições permanentes (SERVIÇO GEOLÓGICO BRASILEIRO, 2013):

- No Tempo dos Dinossauros - acervo de vertebrados fósseis que viveram no Brasil durante a Era Mesozóica, suas origens e descendentes até os dias de hoje.

- LewellynlvorPrice + 10 um Paleontólogo - uma mostra contando a vida de um dos maiores paleontólogos do DNPM, com o seu legado cientifico e cultural deixado para o Brasil.

- Dinossauros do Triângulo - acervo de vertebrados fósseis encontrados no Triângulo Mineiro.

- Mostra Mineralógica e Petrográfica.

De acordo com o entrevistado, a cidade do Rio de Janeiro ainda não soube reconhecer o seu valor, pois existem atitudes como disponibilizar transporte para os alunos, divulgação na Secretaria de Educação, entre outras, que poderiam melhorar a visitação e o reconhecimento da população sob este patrimônio inestimável para a humanidade. Seu acervo é inestimável e conta toda história da mineralogia e sua exploração em território brasileiro.

\section{ESTRUTURA FÍSICA}

A área total dos salões expositivos e reserva técnica fica em 1.500 metros quadrados (800 metros quadrados somente para a exposição dos minerais). O museu possui áreas, que ainda passarão por reformas, e que criarão acessibilidade (atualmente não possui), desta forma, podendo expor adequadamente muita parte deste acervo que atualmente está em reserva técnica ou nos gaveteiros dos atuais expositores, que também serve como uma reserva técnica de importantes amostras históricas. O setor de geologia é muito rico, só que mal exposto. As vitrines são altas demais e a maioria do acervo está trancada nas gavetas. A climatização está inadequada e necessita ser substituída. Não existem áreas de convivência como espaço para lanche ou lanchonete. 


\section{AÇÃO EDUCATIVA E CULTURAL}

O museu possui uma pessoa que desenvolve atividades especiais com as turmas escolares e que realiza a divulgação nas escolas, através de e-mail. Ela faz o acolhimento de visitantes e após a visita pelas exposições, realiza oficinas de fósseis, de rochas e minerais. Passa vídeos educativos e faz algumas experiências com os grupos. Mas não promove ações culturais e educativas para o público geral.

O museu acredita que, com a aprovação de um dos projetos que visam dar ênfase ao setor de Mineralogia, poderão ser contratadas pessoas que façam a catalogação e conservação mais adequada do acervo mineralógico, pois o mesmo será repassado para a CPRM.

\section{ACERVO MINERALÓGICO}

O Museu de Ciências da Terra do DNPM possui com certeza um dos acervos geológicos e paleontológicos mais importantes do país. O seu setor de Mineralogia conta com mais de 7500 amostras de minerais somente no salão expositivo principal e em reserva técnica, além de existirem muitas amostras raras como as da coleção Hussak. Ainda não foi feito nenhum levantamento ou pesquisa sobre esse acervo. De acordo com o diretor do museu, Dr. Campos, estudos apontam cerca de 1800 a 2000 espécies minerais distintas, sendo uma das maiores coleções mineralógicas do país.

A coleção mineralógica foi sistematizada e organizada segundo a classificação química de Dana. As amostras estão colocadas em mobiliários antigos de madeira com vidros, relembrando muito os antigos "Gabinetes de Curiosidades". Além de a coleção principal estar classificada de acordo com as classes químicas, existe, em outras vitrines, agrupamentos de minerais segundo as principais propriedades físicas.

As vitrines, apesar de históricas, não possuem uma boa visibilidade para os visitantes, principalmente as crianças ou os caderantes, pois são vitrines altas. A iluminação das vitrines e insuficiente para valorizar e destacar as importantes amostras mineralógicas deste acervo, pois a maioria das luminárias não está funcionando. 
As amostras de minerais, em muitas vitrines, não estão bem alinhadas e, em geral, estão um pouco desorganizadas, dando a impressão de falta de manutenção.

Destacam-se neste acervo, além de minerais históricos doados por grandes vultos da mineralogia brasileira e de ocorrências exauridas e/ou fechadas, amostras estéticas e raras, como um cristal grande de brazilianita da localidade tipo (pegmatito de Córrego Frio, Linópolis, Divino das Laranjeiras); um cristal biterminado de columbita-(Fe) da lavra da Golconda, Governador Valadares; topázio Incolor da lavra do Funil, Santa Maria de Itabira; fenacita do Rio Piracicaba, São Miguel de Piracicaba, todas ocorrências de Minas Gerais, entre outras.

Existem também, ao longo de todo o salão expositivo principal, pedestais de madeira e outras vitrines de madeira e vidro com amostras grandes de minerais de ocorrências interessantes brasileiras.

As etiquetas das amostras, em geral, são antigas e estão muito desatualizadas quando se leva em consideração as novas nomenclaturas dos minerais. Muitos nomes em desuso são utilizados, além de, em muitos casos, as etiquetas mostrarem informações confusas, misturando nome da espécie, com o grupo a que pertence este mineral e a sua localidade geográfica. Não existe também um padrão nas etiquetas dos minerais.

Um dos fatores mais prejudiciais deste acervo é a deterioração de alguns exemplares de minerais de grupos específicos como sulfetos (oxidação) e sulfatos (deliqüescência) e esses minerais estão se perdendo dia após dia por falta de cuidados especiais.

Atualmente, a direção do museu não possui políticas de intercâmbio de amostras, pela falta de conhecimento de seu próprio acervo, salvo algumas exceções. Apesar de poucas as doações, o acervo recebe exemplares de muitos profissionais ligados às áreas das geociências e colecionadores particulares.

O acervo de minerais, apesar de apresentar alguns problemas de conservação, classificação e revisão mineralógica, apresenta uma das coleções mais interessantes e importantes para a memória de mineralogia do país. Impressionam além da grande quantidade de minerais importantes e minerais tipos brasileiros, amostras provenientes de ocorrências históricas, além dos principais vultos da mineralogia brasileira terem doados amostras raras para a composição deste museu. Cientistas e mineralogistas como Eugene Hussak, William Pecora, Costa Sena, Djalma Guimarães, Evaristo Scorza, Orville Derby, Jacques Moraes, 
Octavio Barbosa, Jacques Cassedanne, entre outros, são dos muitos colaboradores deste museu.

Quadro 13 - Quadro de minerais tipo brasileiros pertencentes ao acervo do Museu de Ciências da Terra do DNPM-RJ, com suas respectivas ocorrências (exemplos):

\begin{tabular}{|c|}
\hline $\begin{array}{l}\text { Quadro de minerais tipo brasileiros pertencentes ao acervo do } \\
\text { Museu de Ciências da Terra do DNPM com suas respectivas ocorrências } \\
\text { (exemplos): }\end{array}$ \\
\hline Arrojadita - Alto do Boqueirão, Parelhas, RN. \\
\hline $\begin{array}{c}\text { Bahianita - Serra das Almas, Paramirim das Crioulas, Água Quente, } \\
\text { Paramirim, BA. }\end{array}$ \\
\hline Barbosalita - Pegmatito de Sapucaia, Galileia, MG. \\
\hline $\begin{array}{c}\text { Brazilianita - Pegmatito de Córrego Frio, Linópolis, } \\
\text { Divino das Laranjeiras, MG. }\end{array}$ \\
\hline Crisoberilo - Pancas, ES. \\
\hline Frondelita - Pegmatito de Sapucaia, Galiléia, MG. \\
\hline Gorceixita - Dattas, Diamantina, MG. \\
\hline Hidroxicalcioromeita (ex-lewisita) - Córrego Tripuhy, Ouro Preto, MG. \\
\hline Moraesita - Pegmatito de Sapucaia, Galiléia, MG. \\
\hline $\begin{array}{c}\text { Scorzalita - Pegmatito de Córrego Frio, Linópolis, } \\
\text { Divino das Laranjeiras, MG. }\end{array}$ \\
\hline Senaíta - Dattas, Diamantina, MG. \\
\hline $\begin{array}{l}\text { Souzalita - Pegmatito de Córrego Frio, Linópolis, } \\
\text { Divino das Laranjeiras, MG. }\end{array}$ \\
\hline Tavorita - Pegmatito de Sapucaia, Galiléia, MG. \\
\hline Tripuhyíta - Córrego Tripuhy, Ouro Preto, MG. \\
\hline Uvita - Mina Pedra Preta, Serra das Éguas, Brumado, BA. \\
\hline
\end{tabular}

Quadro 14 -Quadro de minerais brasileiros pertencentes ao acervo do Museu de Ciências da Terra do DNPM-RJ com suas respectivas ocorrências (exemplos):

\begin{tabular}{|}
$\begin{array}{c}\text { Quadro de minerais brasileiros importantes pertencentes ao acervo do } \\
\text { Museu de Ciências da Terra do DNPM e suas respectivas ocorrências } \\
\text { (exemplos): }\end{array}$ \\
\hline Anglesita - Mina de Panelas, Paranavaí, PR. \\
\hline Bindheimita (espécie questionável) - Ouro Preto, MG. \\
\hline Bismuto nativo - Brejaúba, Conceição do Mato Dentro, MG;
\end{tabular}




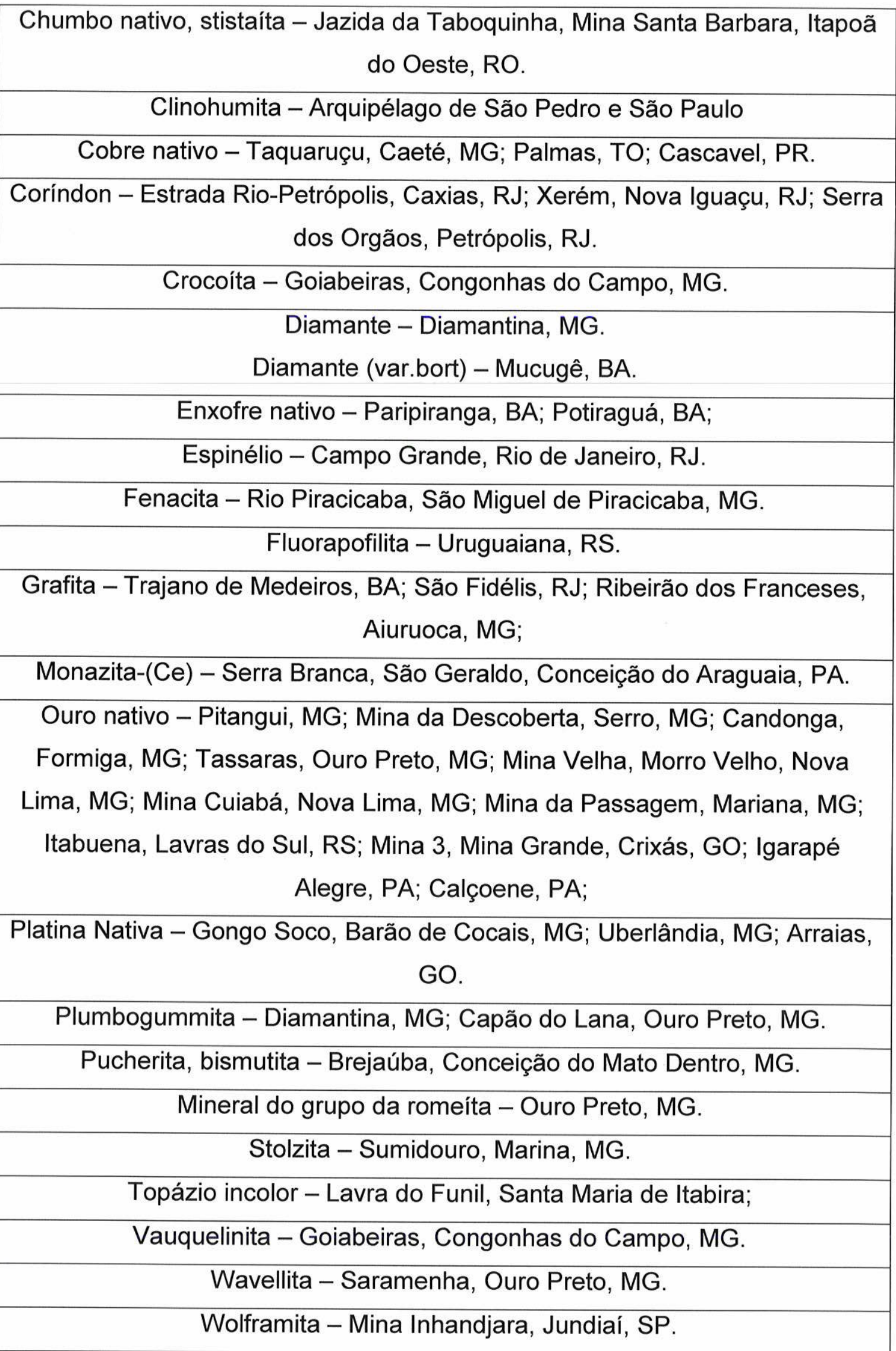




\section{RELAÇÃO DE FOTOS DO MUSEU CIÊNCIAS DA TERRA DO DNPM}

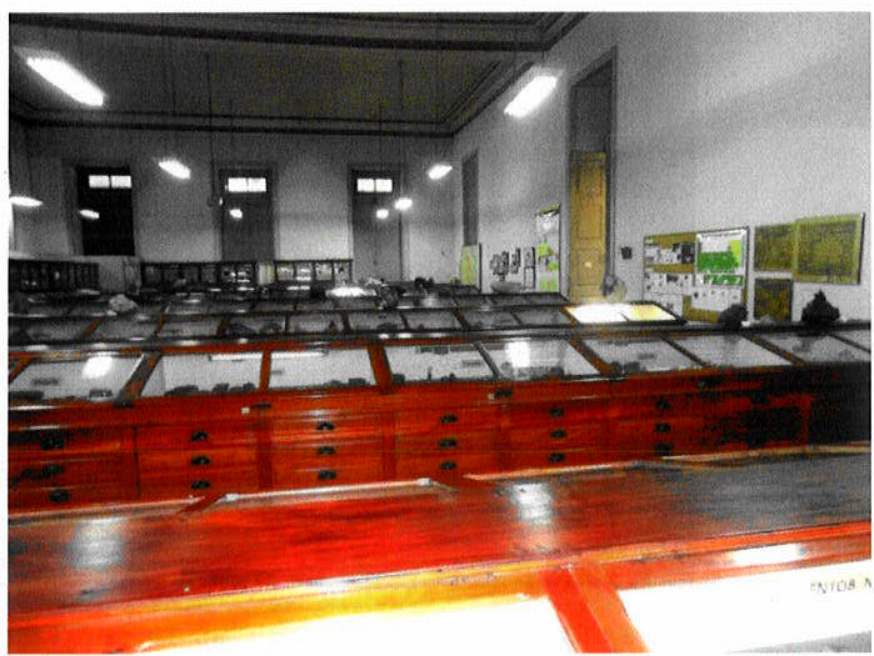

Figura 63. Museu de Ciências da Terra do DNPM-RJ. Vista geral do salão expositivo com as vitrines clássicas de madeira e vidro. lluminação geral do ambiente.

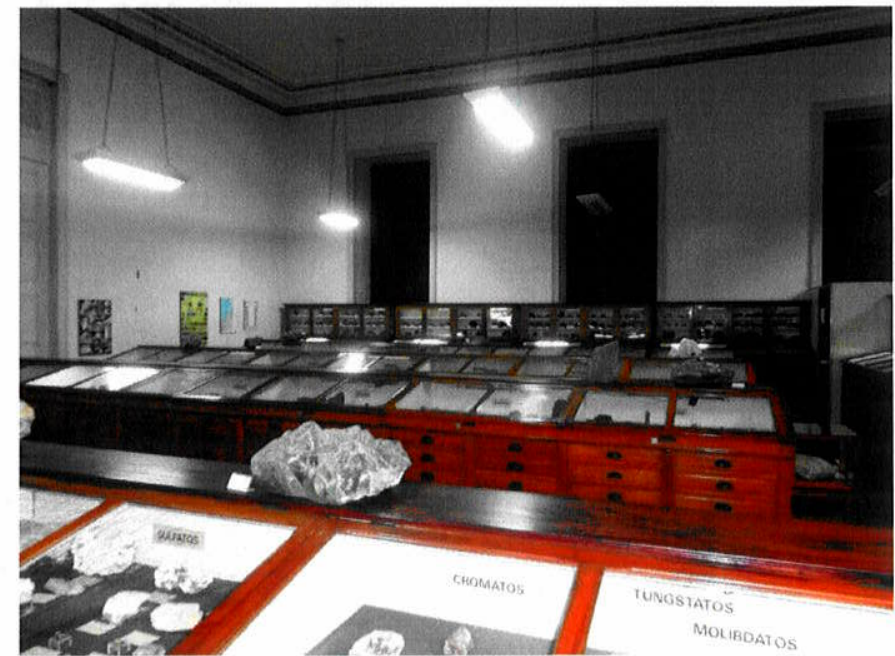

Figura 64. Museu de Ciências da Terra do DNPM-RJ. Vista geral do salão expositivo com as vitrines clássicas de madeira e vidro. Iluminação geral do ambiente.

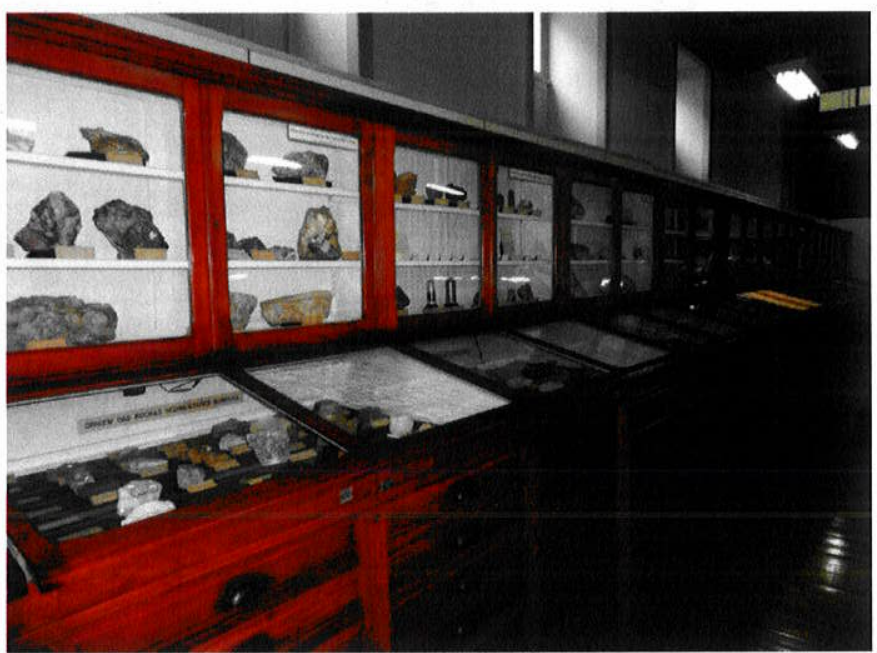

Figura 65. Museu de Ciências da Terra do DNPM-RJ. Vista geral das vitrines clássicas de madeira e vidro nas laterais do salão expositivo. Observam-se as gavetas na parte inferior do mobiliário da reserva técnica. 


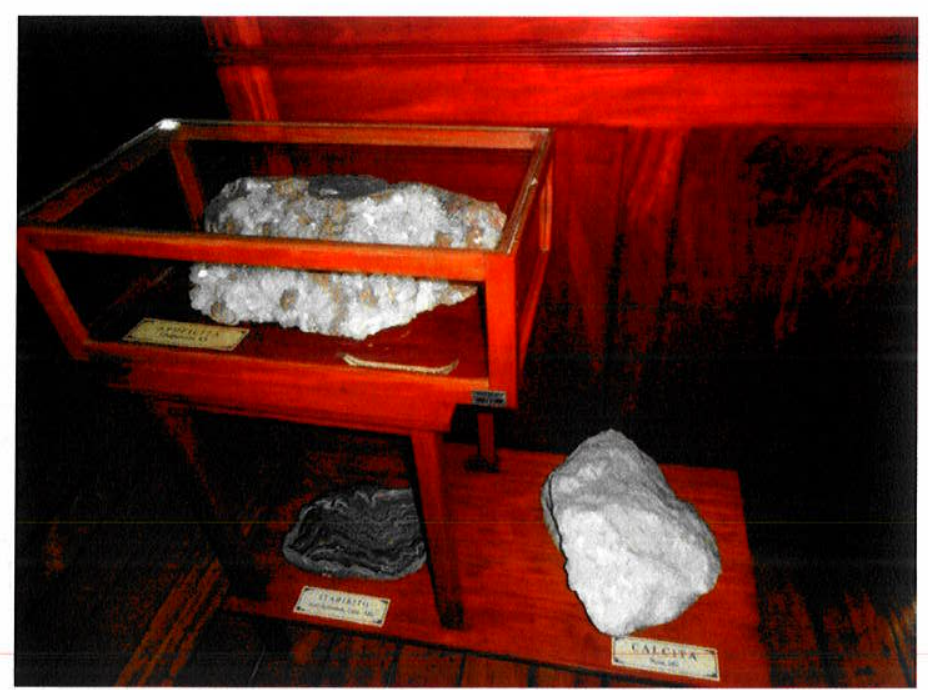

Figura 66. Museu de Ciências da Terra do DNPM-RJ. Amostras maiores colocadas em bases de madeira.

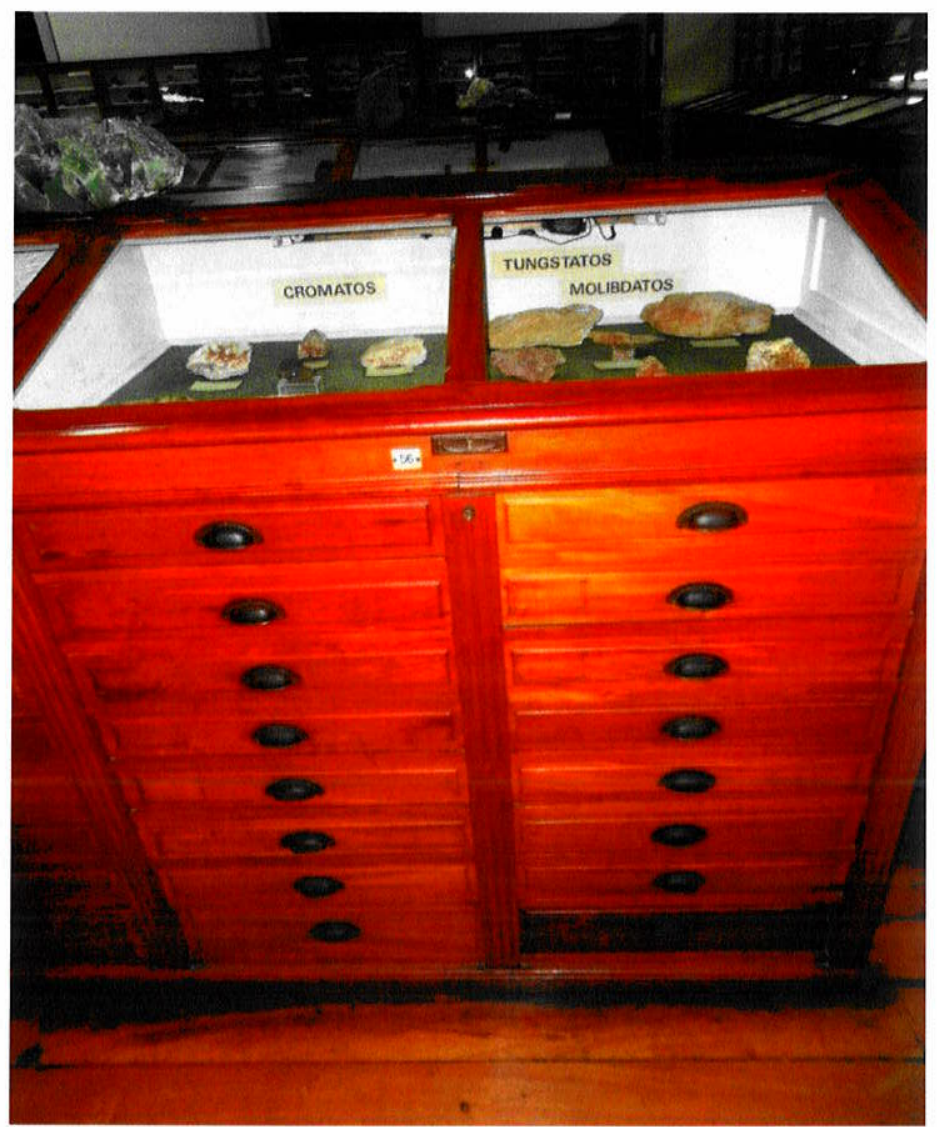

Figura 67. Museu de Ciências da Terra do DNPM-RJ. Detalhe da vitrine - parte superior: exposição / parte inferior (gavetas): reserva técnica. 


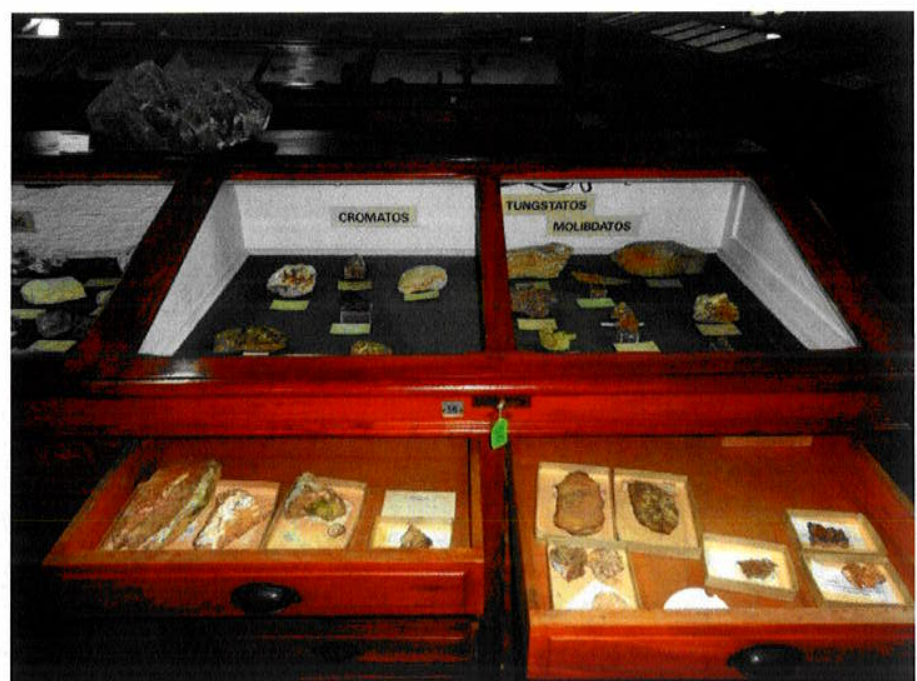

Figura 68. Museu de Ciências da Terra do DNPM-RJ. Detalhe das gavetas da reserva técnica, contendo amostras raras.

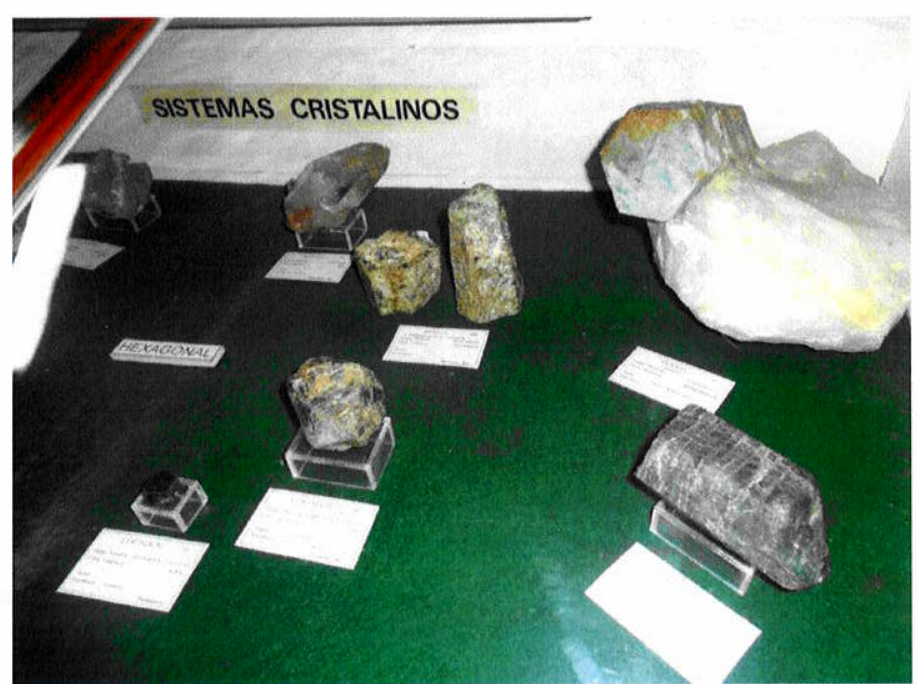

Figura 69. Museu de Ciências da Terra do DNPM-RJ. Vitrine com minerais expostos segundo ao sistema cristalino.

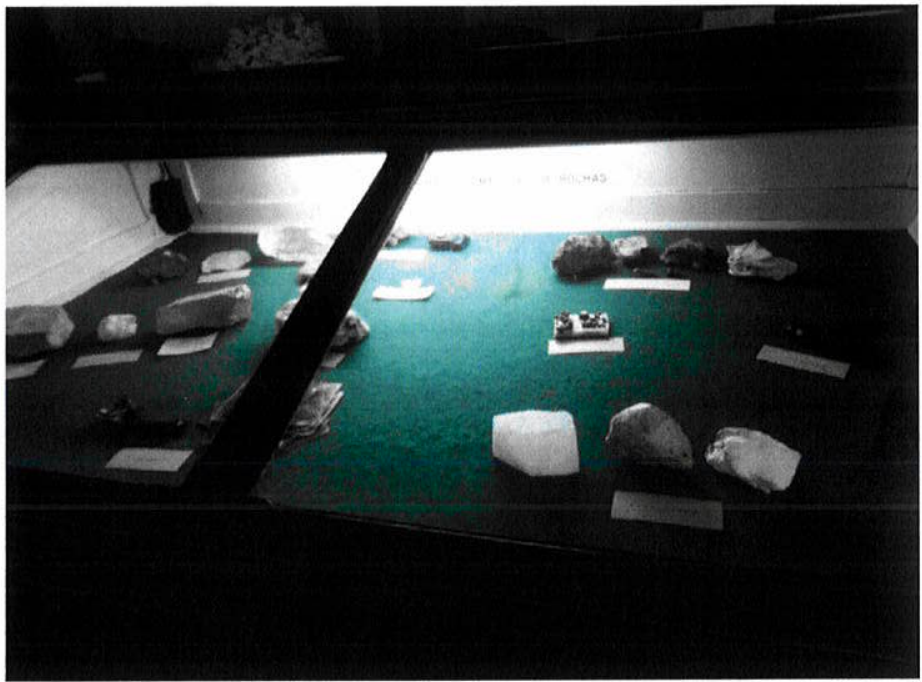

Figura 70. Museu de Ciências da Terra do DNPM-RJ. Vitrine com minerais comuns formadores das rochas. 


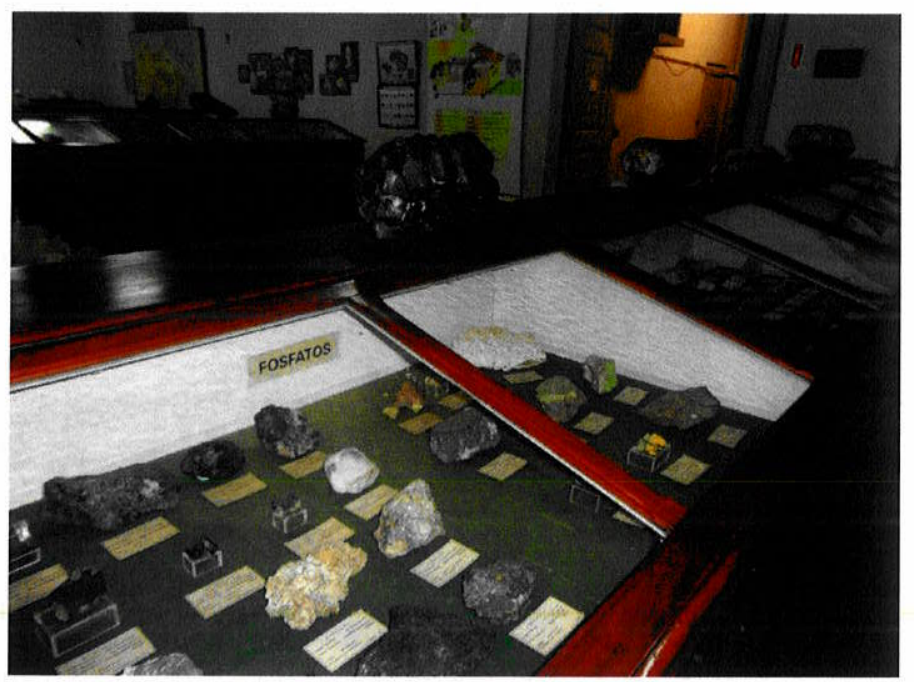

Figura 71. Museu de Ciências da Terra do DNPM-RJ.

Vitrine com minerais expostos segundo a classificação química.

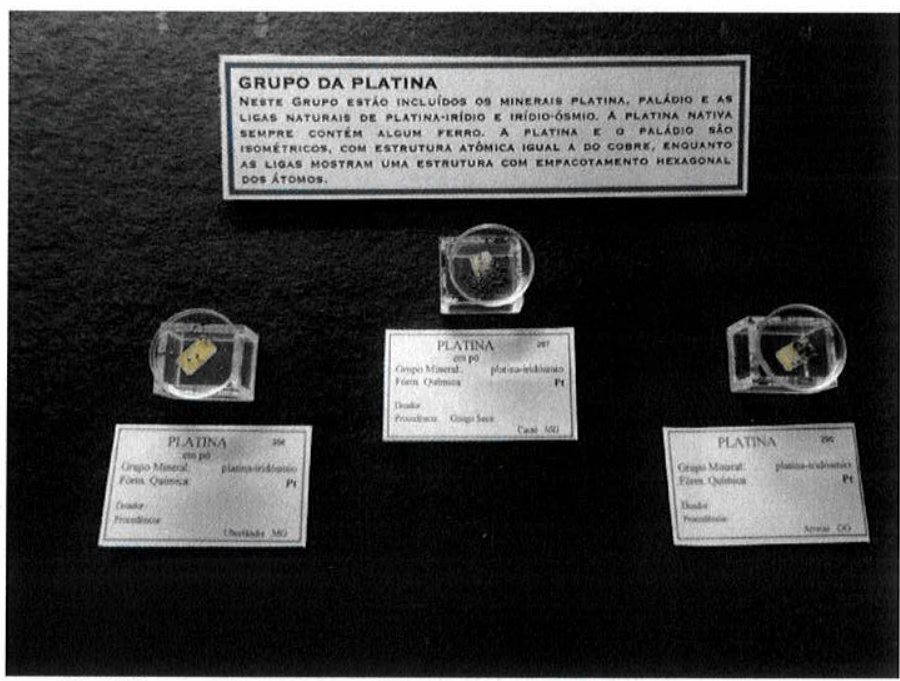

Figura 72. Museu de Ciências da Terra do DNPM-RJ. Detalhe de três amostras raras de platina nativa de algumas ocorrências brasileiras

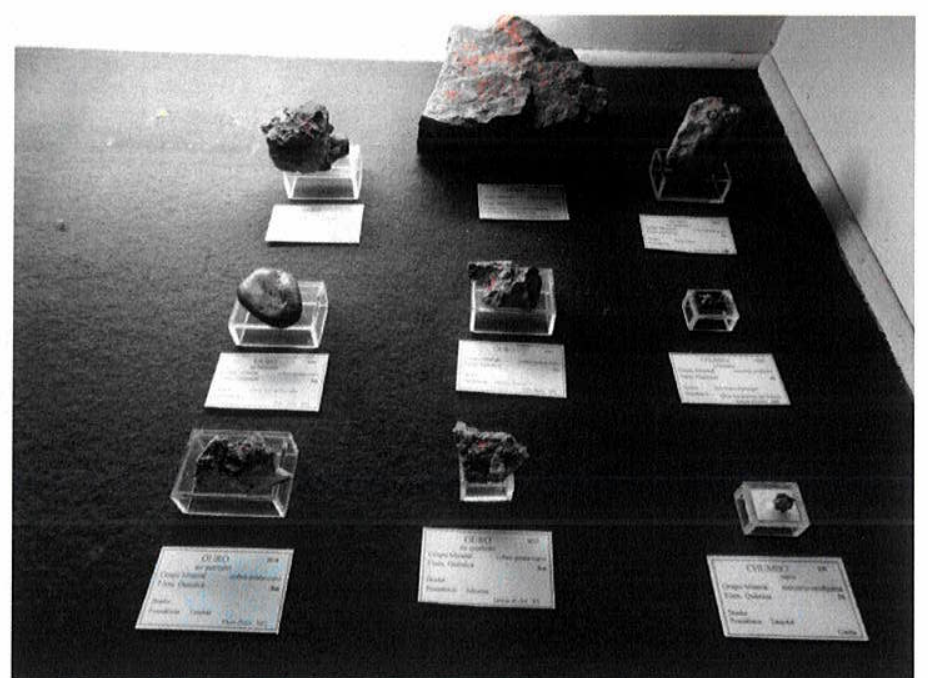

Figura 73. Museu de Ciências da Terra do DNPM-RJ. Amostras de elementos nativos. 


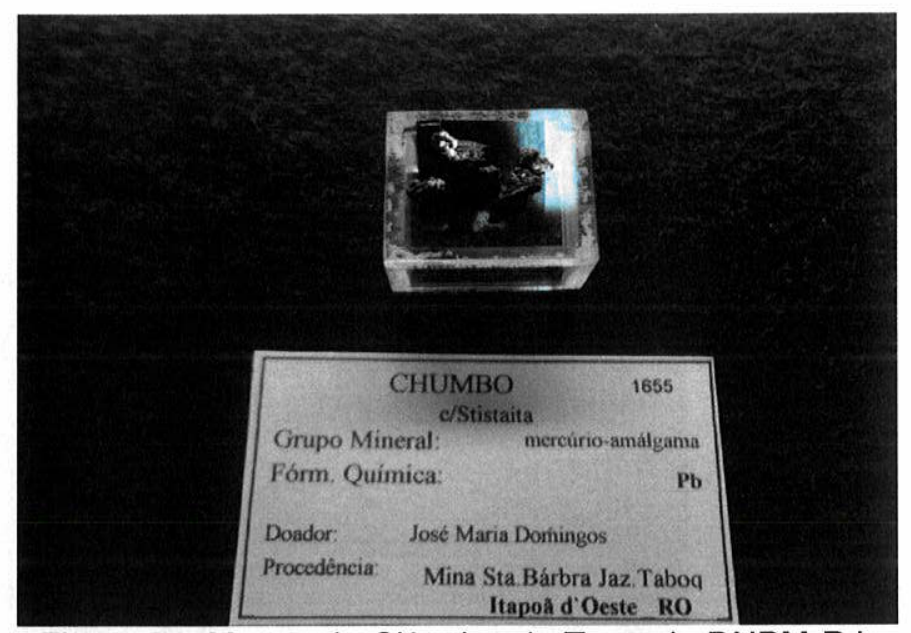

Figura 74. Museu de Ciências da Terra do DNPM-RJ.

Detalhe da amostra de chumbo nativo com

stistaita proveniente do estado de Rondônia.

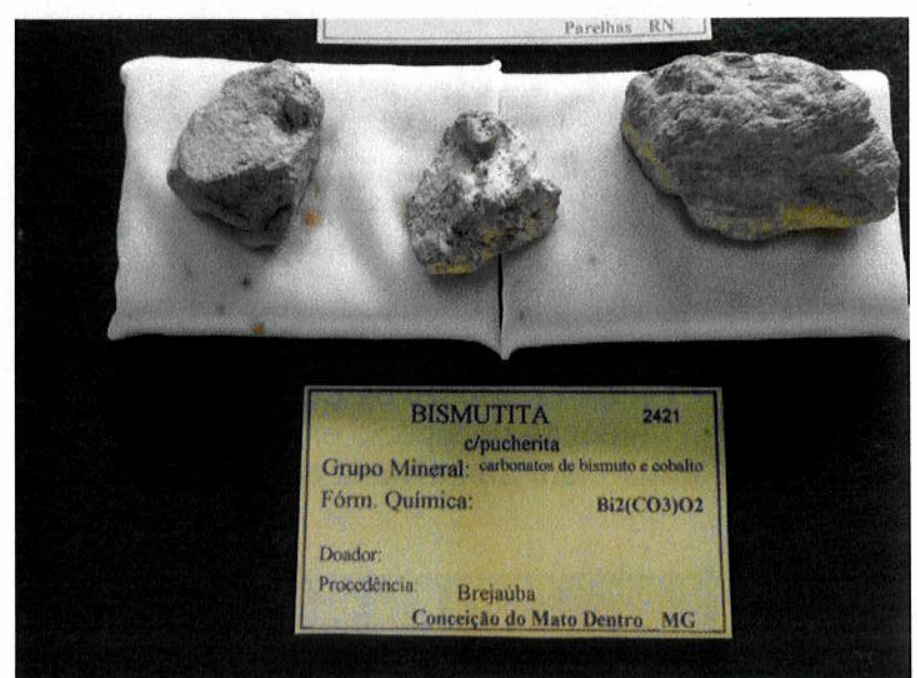

Figura 75. Museu de Ciências da Terra do DNPM-RJ. Amostras de bismutita com rara associação de pucherita de uma ocorrência famosa e atualmente exaurida. Percebe-se a falta de uma maior sinalização na etiqueta apontando quais são os minerais.

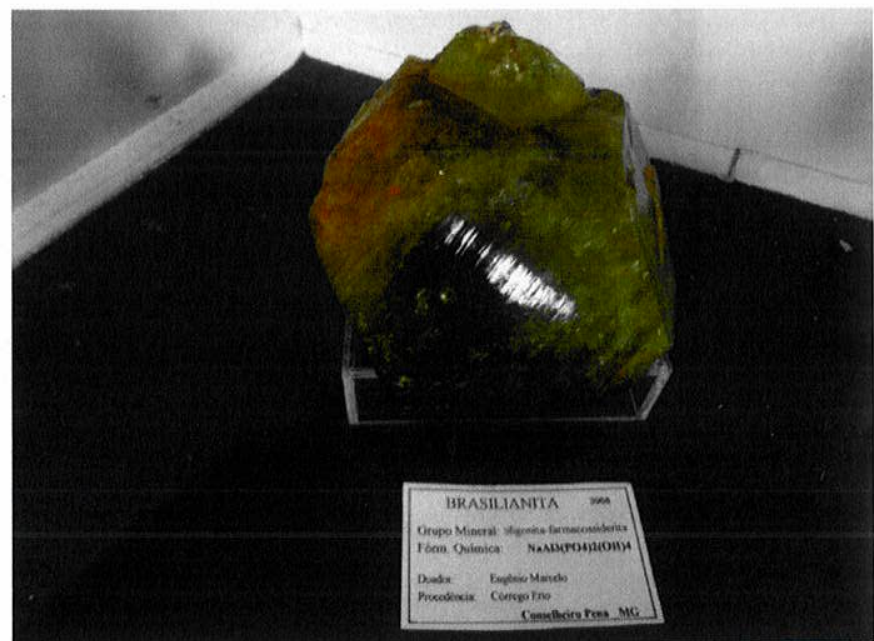

Figura 76. Museu de Ciências da Terra do DNPM-RJ. Amostra de brazilianita, um cristal fantástico da localidade tipo do estado de Minas Gerais. 

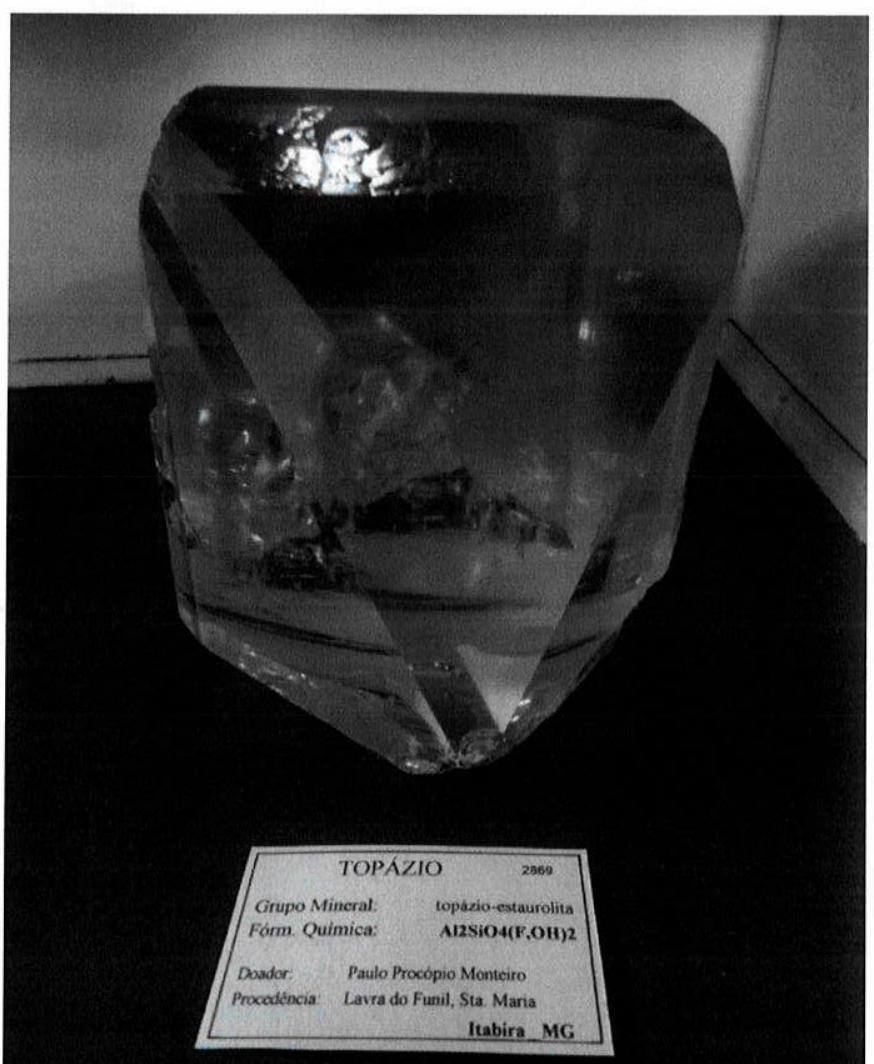

Figura 77. Museu de Ciências da Terra do DNPM-RJ. Amostra de topázio proveniente da Lavra do Funil, em Santa Maria de Itabira, Minas Gerais.

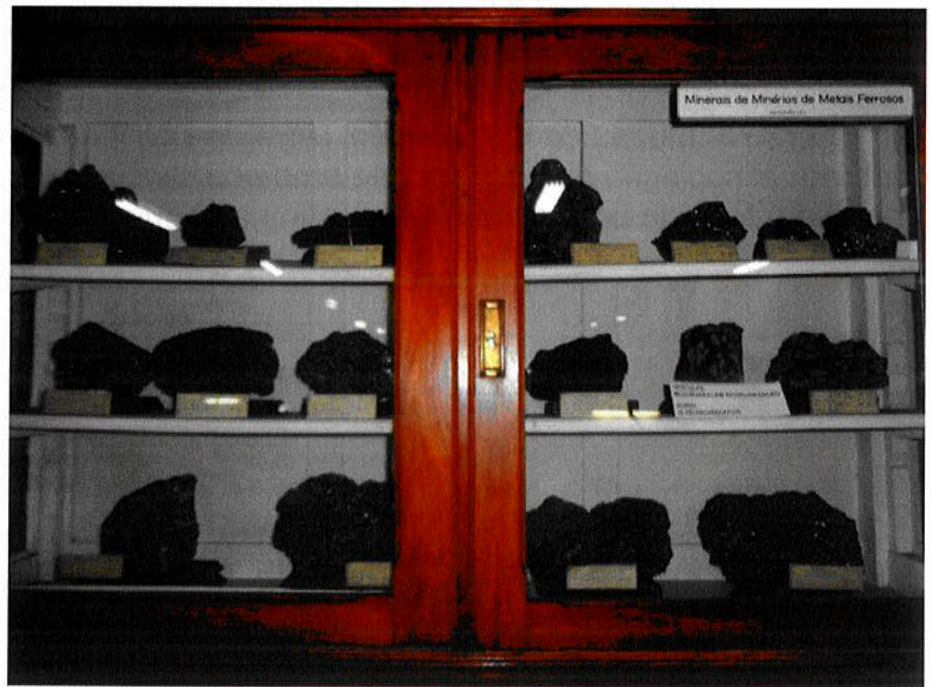

Figura 78. Museu de Ciências da Terra do DNPM-RJ. Vitrine com minerais de ferro e manganês. Vitrine lateral do salão expositivo. 


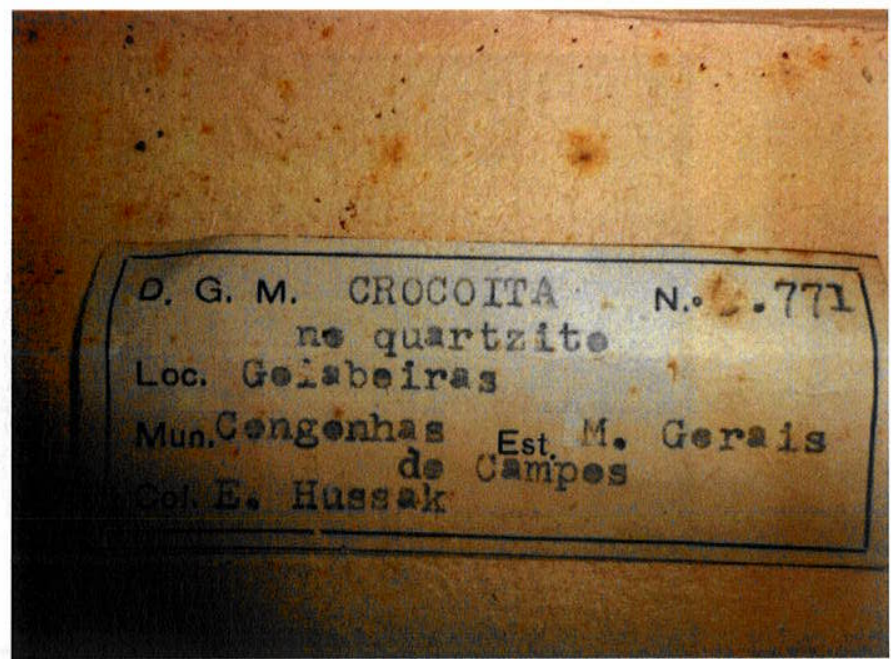

Figura 79. Museu de Ciências da Terra do DNPM-RJ. Etiqueta em estado ruim de conservação.

Amostra proveniente da famosa coleção Hussak.

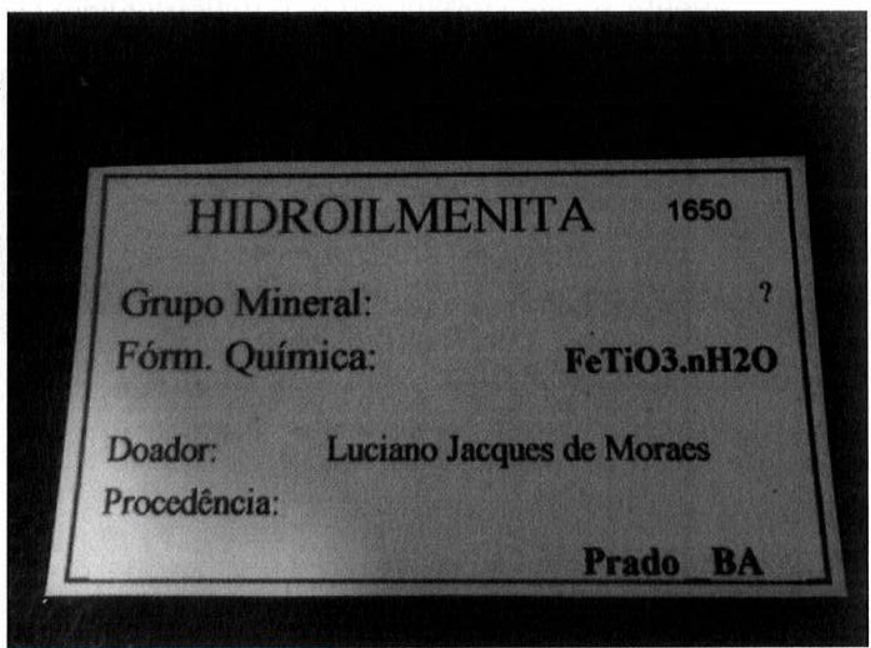

Figura 80. Museu de Ciências da Terra do DNPM-RJ. Etiqueta com informações simples. Nomenclatura em desuso, por se tratar de uma variedade. Detalhe da doação do famoso mineralogista Luciano Jacques de Moraes.

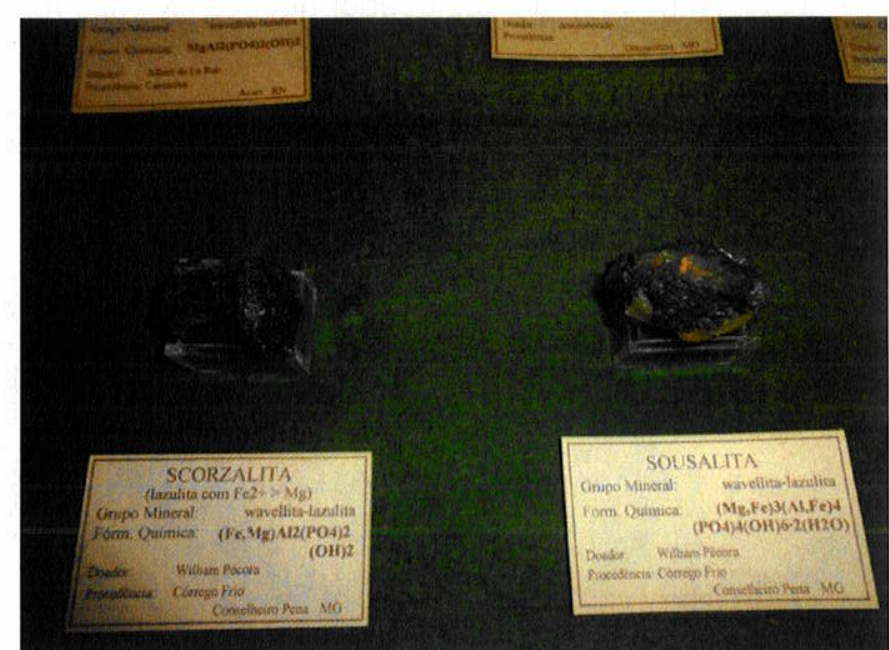

Figura 81. Museu de Ciências da Terra do DNPM-RJ. Detalhe de dois minerais tipo brasileiro, a scorzalita e a souzalita. Nota-se o famoso doador desses exemplares, o mineralogista William Pecora. 


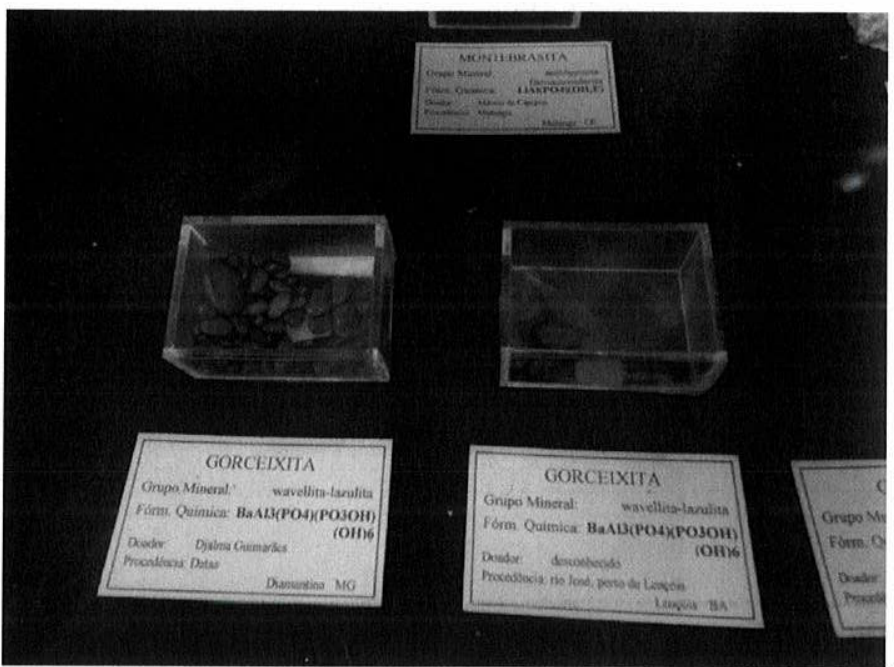

Figura 82. Museu de Ciências da Terra do DNPM-RJ. Minerais expostos em caixas de plástico, dificultando um pouco a visualização das espécies. Nota-se o famoso doador desses exemplares, o mineralogista Djalma Guimarães.

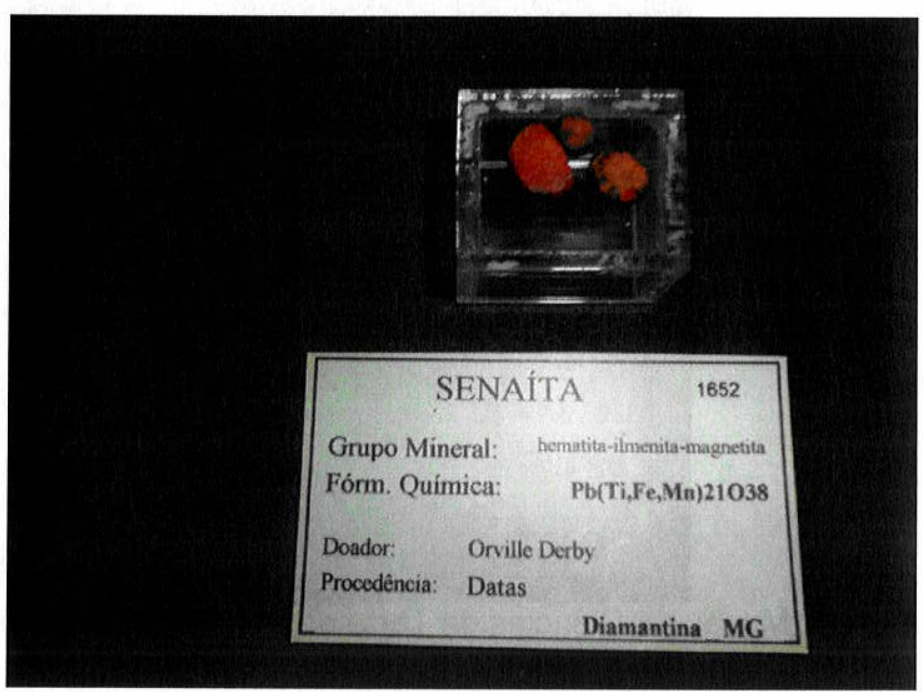

Figura 83. Museu de Ciências da Terra do DNPM-RJ. Detalhe de uma espécie tipo brasileira, a senaita. Nota-se o famoso doador desses exemplares, o geólogo Orville Derby.

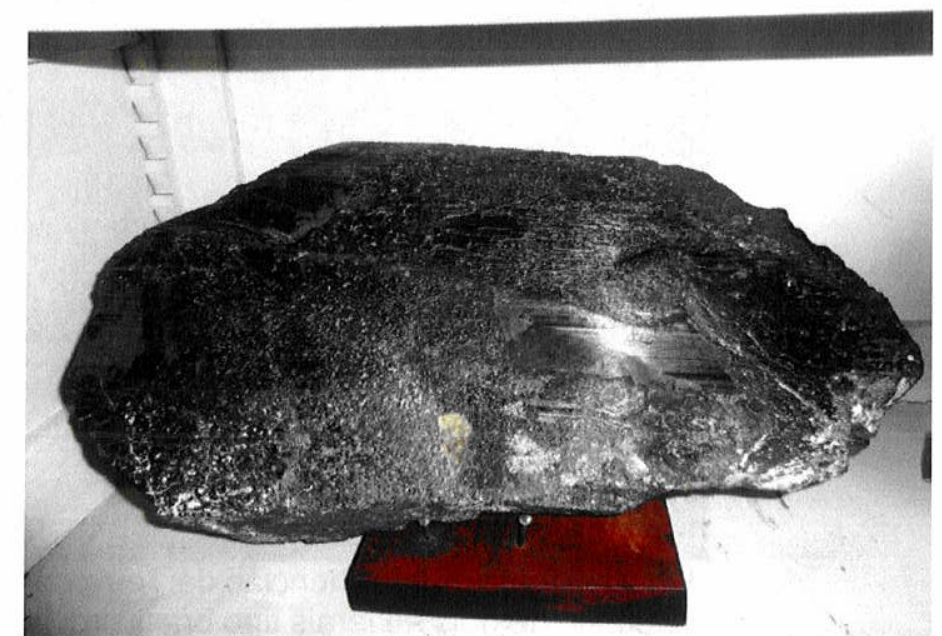

Figura 84. Museu de Ciências da Terra do DNPM-RJ. Cristal biterminado de tantalita- $(\mathrm{Fe})$ proveniente do estado de Minas Gerais. 


\section{MUSEU NACIONAL - RIO DE JANEIRO}

(instituição visitada em julho de 2012)

O Museu Nacional faz parte da pesquisa, tanto por ser o primeiro museu a ser fundado no Brasil, como pela relevância de seu acervo geológico e naturalista, mais específico o mineralógico. Porém este acervo não está exposto e se encontra depositado em reserva técnica. Somente uma excelente coleção de meteoritos (incluindo o famoso meteorito Bendegó) e uma importante coleção paleontológica (com destaque para os fósseis da Chapada do Araripe) se encontram atualmente em exposição.

No dia da visita ao Museu Nacional, infelizmente, o curador responsável pelo acervo, Dr. Ciro Alexandre Ávila, não estava disponível. Sendo assim, não houve análise de seu acervo na reserva técnica.

O Museu Nacional/UFRJ está vinculado ao Ministério da Educação. É a mais antiga instituição científica do Brasil e o maior museu de história natural e antropológico da América Latina.

A história do Museu Real, hoje conhecido por Museu Nacional, remonta à antiga Casa de História Natural, que tinha um nome pitoresco de "Casa dos Passaros", isso devido à grande quantidade de aves taxidermizadas em exposição. Esta instituição foi criada em 1784, pelo Vice-Rei Dom Luiz de Vasconcelos e Sousa, pela qual o responsável era Francisco Xavier Cardoso Caldeira. Em 1811, a mando da Coroa, abrigou os lapidadores de diamantes. Consta nos registros que "em 22 de junho de 1813, o Príncipe Regente Dom João extinguiu todos os cargos daquela instituição e suas coleções de mineralogia e de história natural foram para a Academia Real Militar". (CORNEJO \& BARTORELLI, 2010, p.84)

No dia da criação do Museu Nacional em 06 de junho de 1818, inicialmente, sediado no Campo de Sant'Anna, Dom João solicita a transferência de todo o acervo da antiga Casa dos Pássaros. O museu serviu para atender aos interesses de promoção do progresso cultural e econômico no país.

Instalou-se no Paço de São Cristóvão na Quinta da Boa Vista, a partir de 1892, que foi residência da Família Imperial brasileira até 1889. Isso deu ao Museu um caráter ímpar frente às outras instituições do gênero. Principalmente por estar localizada no casarão que serviu de moradia a família real por vários anos (onde 
nasceu D. Pedro II e se realizou a $1^{\text {a }}$ Assembléia Constituinte Republicana), hoje, atua na interface memória e produção científica. (MUSEU NACIONAL/UFRJ)

O primeiro diretor do museu foi o frei franciscano José Batista de Costa Azevedo, que era o diretor do Gabinete Mineralógico e Físico da Academia Real Militar. A coleção inicial do Museu Real foi constituída, principalmente, pelo acervo reunido pelo mineralogista alemão Abraham Gottlob Werner, que ficou conhecida por "Coleção Werner". (CORNEJO \& BARTORELLI, 2010)

José Bonifácio de Andrada e Silva, como Ministro do Império e dos Estrangeiros, estimulou expedições científicas, patrocinando parte delas, em troca de amostras que deveriam ser coletadas, tanto geológicas quanto da fauna e flora.

A Imperatriz Leopoldina, por ser uma naturalista nata, também colaborou com o acervo do Museu Nacional doando diversas amostras.

E assim, o acervo do museu foi aumentando, por sua relevância e por ser referência nacional nas áreas naturalistas.

Dentro da área mineralógica, uma das maiores contribuições foi a doação da Coleção José Bonifácio que, após sua morte, foi doada por sua família á seu pedido.

Existe uma estimativa de que o acervo geral seja constituído por 20 milhões de peças. De acordo com o curador Dr. Ciro, não existe espaço físico suficiente para expor o acervo mineralógico. Existem planos futuros, mas por enquanto, este acervo, de grande relevância para a mineralogia brasileira, continuará em reserva técnica, sendo deteriorado pelo tempo. 


\section{MUSEU DE MINERALOGIA AITIARA}

(análise realizada em julho de 2012) museu de mineralogia aitiara

\section{HISTÓRICO DA INSTITUIÇÃO}

O Museu Aitiara fica localizado na Rodovia Gastão Dal Farra, km 4, na cidade de Botucatu em São Paulo, mais precisamente no bairro Demétria, distante $12 \mathrm{~km}$ do centro da cidade, um espaço geográfico que cresceu com a iniciativa de pessoas preocupadas com a agricultura orgânica e biodinâmica, com uma vida espiritual tranquila e com valores humanos para a conservação da terra, da propriedade, da natureza e baseado na filosofia antroposófica.

Esta comunidade começounos anos 1970, quando nasceram várias atividades ligadas à agricultura e à educação; hoje, quase 1.000 pessoas fazem parte da comunidade.

Quando a Escola Aitiara, de Pedagogia Waldorf ${ }^{6}$ foi fundada, um de seus professores e fundadores, o professor de artes alemão Erich Otto Blaich, decidiu montar uma coleção didática composta por minerais, rochas e fósseis para a escola. Ele também ajudou a fundar outras escolas com sistema Waldorf pelo Brasil, Argentina e Chile. Com os minerais, uma de suas especializações, conseguiu levantar dinheiro para ajudar diversas destas escolas. Com o passar do tempo, decidiu se instalar em Botucatu e sua coleção particular virou o Museu de Mineralogia Aitiara, fundado em 06/12/2008 na própria Escola Aitiara. Desde 2006, a coleção estava disposta para utilização dos alunos, mas depois de oficializar sua fundação, foi organizada pela geóloga Valéria Teixeira e pelo próprio Prof. Blaich, levando em conta a estética e beleza dos exemplares.

\section{ORGANIZAÇÃO E FUNCIONAMENTO}

A mantenedora do Museu é a Associação Museu de Mineralogia Aitiara e a pessoa entrevistada foi a tesoureira Berenice Pereira Balsalobre, que, além deste cargo em estatuto, também exerce a curadoria, monitoria e assuntos jurídicos da

\footnotetext{
${ }^{6} \mathrm{~A}$ Pedagogia Waldorf é baseada na Antroposofia - palavra de origem grega que significa "sabedoria humana". Este sistema de ensino incentiva e encoraja a criatividade, nutre a imaginação e conduz os alunos a um pensamento livre e autônomo. Escola Waldorf São Paulo. Disponível em: http://www.waldorf.com.br/quem-somos-58/a-pedagogia.html. Acesso em: 11 jan. 2013
} 
instituição. O Museu não possui funcionários, ela e o filho do Prof. Blaich, Hans Jorge Blaich são voluntários.

A Associação Museu de Mineralogia Aitiara tem por finalidade desenvolver e estimular o conhecimento da geologia e mineralogia através de amostras de rochas e minerais do Brasil e do mundo, para os cursos do ensino médio e fundamental na cidade de Botucatu, no estado de São Paulo. O museu também é referência para cidades próximas localizadas em outros estados, principalmente grupos de escolas com o sistema Waldorf. Atua diretamente nas áreas pedagógica e cultural para a complementação na formação da compreensão relacionada com a mineralogia e geologia geral do planeta.

Outro objetivo da associação é tornar o museu referência no estudo e pesquisa da geologia e mineralogia na região, conscientizando sobre a preservação dos recursos naturais da Terra.

A principal área de atuação do museu é a mineralogia, mas há exemplares de rochas, fósseis e conchas (moluscos), com função didática.

A instituição é mantida financeiramente por contribuições livres de escolas com sistema Waldorf e turmas de outras instituições - são cobrados $\mathrm{R} \$ 3,00$ por pessoa. Existe também uma loja que vende minerais para os grupos visitantes. A associação pretende desenvolver parcerias com a Secretaria de Educação de Botucatu e com o Estado de São Paulo.

A divulgação é feita pelas redes sociais e pelo famoso "boca-a-boca". Toda monitoria é agendada com antecedência e os grupos são de faixas etárias variadas, desde o ensino fundamental até o universitário. Alguns pais de alunos da região, pesquisadores e curiosos visitam o museu esporadicamente. A visita dura em média $1 \mathrm{~h} 30 \mathrm{~m}$ e a média mensal de visitação é de 200 pessoas.

A importância do museu para a cidade e para a preservação do patrimônio natural está na exclusividade em um raio de $200 \mathrm{~km}$ no entorno de Botucatu, pois não existe nenhuma outra instituição que ofereça a possibilidade de conhecimento e observação que o museu oferece. O patrimônio cultural e científico que está exposto pode ser um importante fator de interação, de aprofundamento das relações geográficas e geológicas do planeta e um apoio importante para o sistema educacional da cidade e da região. 


\section{ESTRUTURA FÍSICA}

O museu possui uma sala de aula adaptada para a exposição dos minerais. Conta também com uma loja e uma sala que serve de reserva técnica e depósito da loja. Sua área total é de 80 metros quadrados, possui acessibilidade, pois a sala expositiva é ampla e térrea, mas não possui segurança e climatização adequada para o acervo.

\section{AÇÃO EDUCATIVA E CULTURAL}

O Museu de Mineralogia Aitiara possui função didática, mas não possui ação educativa direcionada ao público geral, por não ter funcionários para colaborarem com sua execução. As visitas de grupos agendados externos não possuem suporte pedagógico da instituição, e os próprios professores é que utilizam o museu como recurso didático.

A Diretora Berenice apresenta a exposição de uma maneira básica, os tipos de rocha, a formação dos fósseis, os tipos de minerais e sua fluorescência. Entre os experimentos apresentados, destaca-se a clivagem da calcita, mas sem muito embasamento técnico.

Algumas vezes são realizadas palestras na Escola Aitiara e saídas de campo, mas só quando existe uma solicitação da própria escola. Pode-se dizer que o museu divulga a mineralogia com suas pequenas, mas significativas ações, pois o museu é referência em sua região, e conserva a coleção de minerais de uma importante personalidade artística que, além de deixar obras muito apreciadas, contribuiu para difundir a mineralogia entre as escolas com o sistema Waldorf.

\section{ACERVO MINERALÓGICO}

\section{Julho de 2012}

O Museu de Mineralogia Aitiara possui aproximadamente 1.000 exemplares expostos, divididos em 800 amostras em seu acervo geral de minerais e outras 200 de rochas, fósseis e conchas. O museu não possui nenhuma sistematização ou classificação específica e as amostras estão colocadas nas vitrines aleatoriamente obedecendo somente ao critério estético, da beleza e da cor, dando destaque aos 
minerais mais coloridos e com formas mais curiosas, como o enxofre nativo e as fluorita. Não apresenta, assim, nenhuma classificação científica das amostras tanto em exposição quanto na reserva técnica.

A maior parte da coleção mineralógica é composta por exemplares de minerais brasileiros, incluindo uma grande coleção de variedades do quartzo, como a ametista e a ágata.

A identificação das amostras não possui uma etiqueta muito explicativa e em muitos casos a identificação dos exemplares está equivocada.

Todos os exemplares de minerais, rochas, fósseis e conchas, estão dispostos em bonitas vitrines de madeira branca com portas de vidro e com iluminação interna.

\section{Agosto de 2012}

Depois da visita técnica ao Museu de Mineralogia Aitiara, a convite da Diretora e Curadora Berenice, recebi uma proposta para desenvolver toda a classificação e sistematização deste museu, assim como estimular a aquisição de minerais raros brasileiros para compor o acervo.

O acervo mineralógico está atualmente classificado dentro das normas técnicas e científicas utilizadas pela maioria dos museus mineralógicos, que sistematiza os minerais de acordo com a sua classificação química, neste caso segundo Strunz.

As etiquetas foram desenvolvidas para conter as principais informações como: nome da espécie, localidade e composição química. Dentro das vitrines estão os nomes das classes químicas para apoiar a informação da classificação química.

O museu possui ainda duas coleções estéticas centrais temáticas sobre ametista. As amostras, neste caso, foram dispostas de acordo com sua beleza. Tanto o prof. Blaich quanto seu filho Jorge e a diretora Berenice organizam constantemente viagens para o Rio Grande do Sul, com o intuito de comprar amostras para o museu e para serem vendidos em sua loja e angariar fundos para melhorias da instituição.

O museu realizou uma excursão mineralógica, tendo visitado vários garimpos e minas, e conheceu os principais comerciantes de minerais do estado de Minas Gerais. Neste trabalho de campo, o museu conseguiu diversos exemplares de minerais, incluindo algumas espécies raras brasileiras. 
Merece destaque, dentro do acervo, uma excelente amostra de estalactite proveniente da China, que o museu recebeu de doação. A amostra está colocada separadamente do restante dos outros minerais, pois se destaca tanto por sua beleza quanto pelo seu tamanho.

Depois da renovação, o museu passou a ser uma das referências de mineralogia do interior de São Paulo, ganhando ainda um edital da Secretaria de Cultura do Estado de São Paulo pelo Programa de Ação Cultural - ProAc, para melhorias no sistema de iluminação e exposição.

Atualmente, o Museu de Mineralogia Aitiara apresenta um bom acervo mineralógico, composto por algumas importantes espécies tipos-brasileiras, assim como outros exemplares famosos de minerais-gemas brasileiros. No acervo, são encontrados ainda diversos exemplares de minerais provenientes de vários países.

O acervo mineralógico que compõe o Museu de Mineralogia Aitiara contribui para a difusão da mineralogia no Brasil para a preservação de sua história, pois apresenta espécies raras e de localidades geográficas importantes do país.

Quadro15 - Quadro de minerais tipo brasileiros pertencentes ao acervo do Museu de Mineralogia de Aitiara, com suas respectivas ocorrências (exemplos):

\begin{tabular}{|c|}
\hline $\begin{array}{c}\text { Quadro de minerais tipos brasileiros pertencentes ao acervo do } \\
\text { Museu de Aitiara com suas respectivas ocorrências (exemplos): }\end{array}$ \\
\hline Barbosalita - Pegmatito de Sapucaia, Galileia, MG. \\
\hline $\begin{array}{c}\text { Brazilianita - Pegmatito de Córrego Frio, Linópolis, } \\
\text { Divino das Laranjeiras, MG. }\end{array}$ \\
\hline Coutinhoíta - Pegmatito de Urucum, Galileia, MG. \\
\hline Crisoberilo - Rio das Pratinhas, Arataca, BA. \\
\hline Frondelita - Pegmatito de Sapucaia, Galileia, MG \\
\hline Matioliíta - Lavra do Gentil, Mendes Pimentel, MG. \\
\hline Scorzalita - Pegmatito de Córrego Frio, Linópolis, \\
Divino das Laranjeiras, MG. \\
\hline Tavorita - Pegmatito de Sapucaia, Galiléia, MG. \\
\hline Uvita - Mina Pedra Preta, Serra das Éguas, Brumado, BA. \\
\hline Yanomamita - Depósito de Sn de Mangabeira, Monte Alegre, GO. \\
\hline Zanaíta - Lavra da Ilha, Taquaral, Itinga, MG. \\
\hline
\end{tabular}


Quadro 16 -Quadro de minerais brasileiros pertencentes ao acervo do Museu de Mineralogia de Aitiaracom suas respectivas ocorrências (exemplos):

\begin{tabular}{|c|}
\hline $\begin{array}{c}\text { Quadro de minerais brasileiros importantes pertencentes ao acervo do } \\
\text { Museu de Aitiara e suas respectivas ocorrências (exemplos): }\end{array}$ \\
\hline Diamante (no metaconglomerado) - Lavrinha, Guinda, \\
Vale do Jequitinhonha, Diamantina, MG. \\
\hline Fluorapofilita - Túnel das Antas, Veranópolis, RS. \\
\hline $\begin{array}{c}\text { Ludlamita - Rio Cauaburi, Cabeça do Cachorro, Parque Nacional do Pico da } \\
\text { Neblina, São Gabriel da Cachoeira, Floresta Amazônica, AM. }\end{array}$ \\
\hline Ouro nativo (pepitas) - Ribeirão do Carmo, Passagem de Mariana, \\
Mariana, MG. \\
Vivianita - Rio Cauaburi, Cabeça do Cachorro, Parque Nacional do Pico da \\
Neblina, São Gabriel da Cachoeira, Floresta Amazônica, AM.
\end{tabular}

\section{RELAÇÃO DE FOTOS DO MUSEU AITIARA}

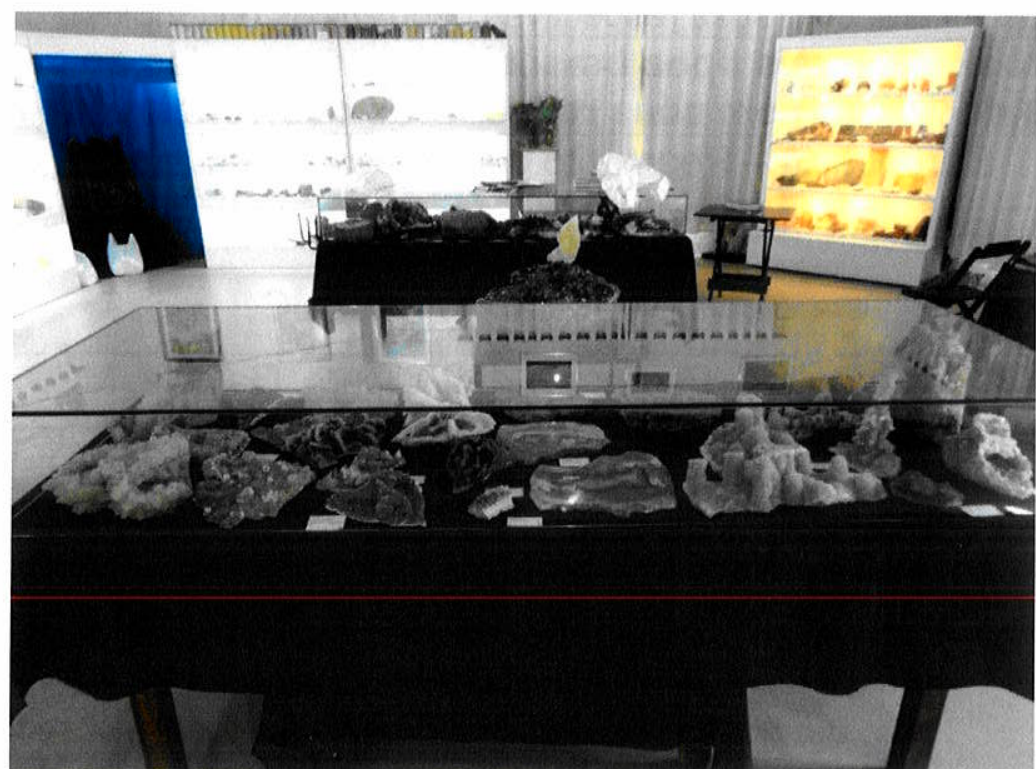

Figura 85. Museu de Mineralogia de Aitiara. Vista geral das vitrines do museu. Nota-se ao centro uma exposição temática de variedades de quartzo (ametista). 


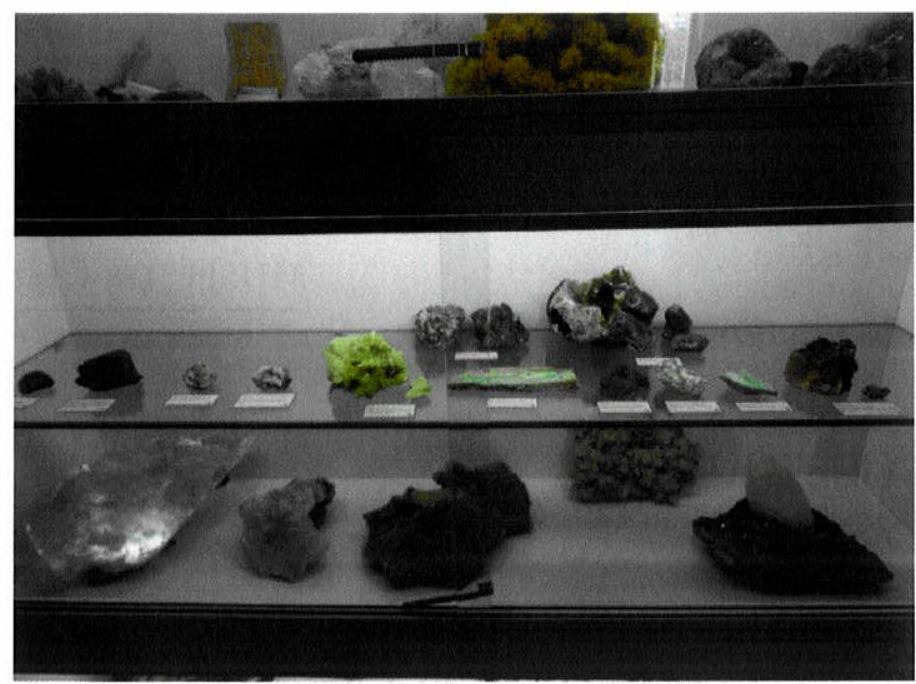

Figura 86. Museu de Mineralogia de Aitiara. Detalhe da vitrine na parte superior de fosfatos, incluindo algumas espécies tipo brasileiro.

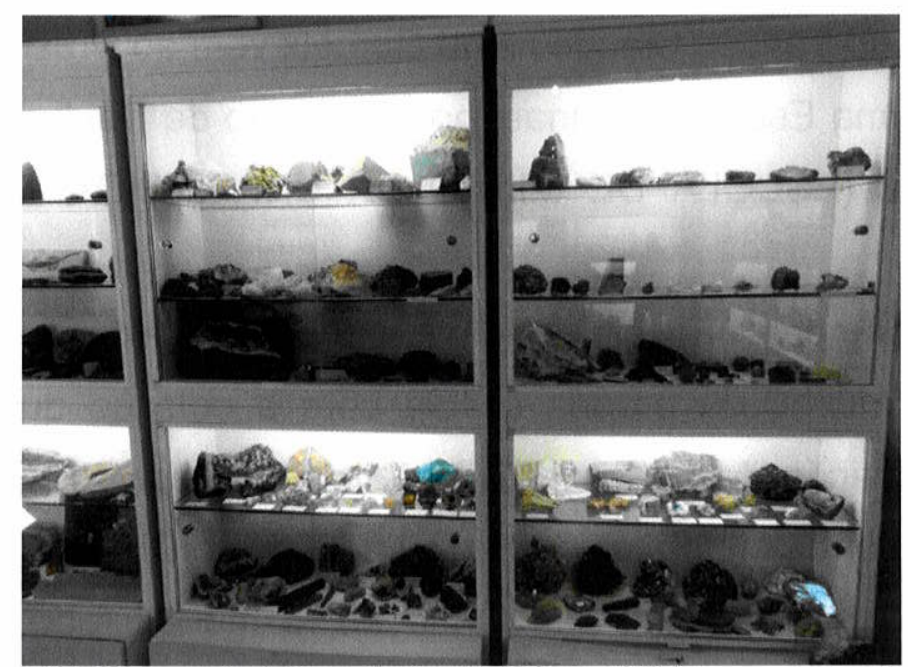

Figura 87. Museu de Mineralogia de Aitiara. Vitrine com os minerais sistematizados por classes químicas segundo Strunz. lluminação interna, valorizando a visualização dos exemplares.

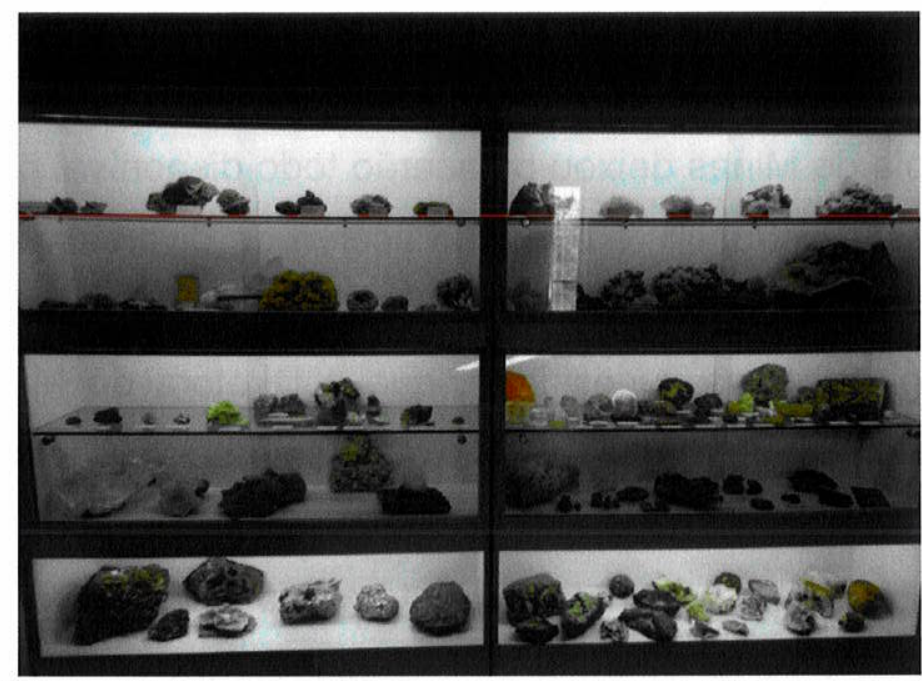

Figura 88. Museu de Mineralogia de Aitiara. Vitrine com os minerais sistematizados por classes químicas segundo Strunz. Nota-se na parte de baixo das vitrines, amostras de tamanhos maiores com temas diferenciados. 


\section{MUSEU DE CIÊNCIA E TÉCNICA DA ESCOLA DE MINAS DA UNIVERSIDADE FEDERAL DE OURO PRETO}

(análise realizada em novembro de 2012)

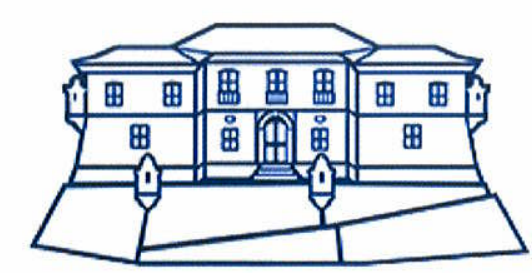

MUSEU de CIÈnCIA E TÉCNICA

Escola de Minas / UFOP - Ouro Preto

\section{HISTÓRICO DA INSTITUIÇÃO}

O Museu de Ciência e Técnica - MCT da Escola de Minas fica em Ouro Preto, Minas Gerais, na Praça Tiradentes, $n^{\circ} 20$, Centro.

Sua história começa no final do século XIX, mais precisamente em 1874, quando o geólogo francês Claude Henri Gorceix vem ao Brasil à convite de D. Pedro II para fundar uma Escola de Minas, por indicação de Daubré, Diretor da Escola de Minas de Paris (ESCOLA DE MINAS DA UNIVERSIDADE DE OURO PRETO, 2013).

Além de fundar a Escola de Minas em Ouro Preto em 1876, Gorceix também inaugurou um museu da própria escola com a coleção que ele mesmo formou, adicionada a doação de parte da Coleção de D. Pedro II. Gorceix foi o fundador, diretor e professor de Mineralogia, Geologia, Física e Química.

Todos os anos, desde sua fundação, o museu recebe doações de acervo geológico de ex-alunos, professores, colecionadores, alunos e amigos da Escola de Minas. Assim, sua coleção é considerada hoje uma das maiores do mundo.

Em 1979, com o crescimento dos cursos e novos investimentos, foi criada a Universidade Federal de Ouro Preto - UFOP. Com a construção de um Campus próprio, a Escola de Minas deixou o casarão todo disponível para o museu, cresceu, modernizando sua estrutura, e expondo acervo de diversas áreas do conhecimento ligadas aos cursos da universidade.

Vale registrar uma curiosidade, que a Diretora do Museu Dra. Maria Paula Delício relatou em entrevista. O ilustre aviador Alberto Santos Dumontfoi aluno de Henri Gorceix no ano de fundação da escola, no Curso de Nivelamento, mas não chegou a ingressar na faculdade. Estas informações foram encontradas nas documentações e fotos da fundação da Escola de Minas.

A Diretora Maria Paula trabalha há 15 anos no museu. É formada em Engenharia Geológica, com mestrado em Micropaleontologia e doutorado em 
Educação em Museus. De acordo com as informações prestadas à entrevista, a Escola de Minas formou grandes mineralogistas e dentre suas especialidades ligadas às Geociências, possui como pilar o resguardo e divulgação da mineralogia brasileira.

Cada salão conta toda história de sua fundação, das áreas de conhecimento como, física, química, metalurgia, mineração, ferrovia, engenharias, desenho técnico, bem como salas históricas com o Pantheon de Claude Henri Gorceix que, além de seus despojos, possui raridades em objetos como afrescos e um lustre com lâmpadas criadas por Thomas Alva Edison, feitas de bambu calcinado, considerado uma raridade histórica.

\section{ORGANIZAÇÃO E FUNCIONAMENTO}

A gestão do museu pertence à UFOP, que disponibiliza os recursos financeiros para subsidiar os custos administrativos, físicos e recursos humanos. Para atividades extras, como confecção de novos painéis, exposições itinerantes e materiais de divulgação, são desenvolvidos projetos especiais para captar os recursos, como editais públicos ou apoio direto de empresas como a GEOSOL ${ }^{7}$ que sempre auxilia o museu, principalmente com os materiais de divulgação.

O quadro de funcionários do museu conta com três especialistas contratados diretamente pela UFOP, dez funcionários terceirizados (oito atendentes, uma secretária e um conservador), além de dez estudantes bolsistas que realizam tarefas diversas no museu, como classificação de acervo, recuperação de documentos e fotografias, marketing e atendimento no setor de astronomia noturno.

Os estudantes que atendem o público são capacitados pela Diretora do MCT e pelo Prof. Luciano Gandini, que ensinam a monitoria nos setores e como desenvolver o acolhimento de visitantes.

Os objetivos gerais da instituição estão pautados nos princípios gerais da museologia, de conservar, preservar, salvaguardar e divulgar o acervo. Cada setor do museu possui objetivos específicos. Abaixo foram relacionados os do setor de Mineralogia (MUSEU DA ESCOLA DE MINAS/UFOP, 2013):

- coletar, preservar e expor minerais ou peças que estejam diretamente relacionadas com a mineralogia;

\footnotetext{
${ }^{7}$ Empresa Nacional de Geologia e Sondagens LTDA
} 
- contribuir para o aprimoramento do ensino da mineralogia na Universidade;

- atender a um público diverso: alunos da Universidade, técnicos, cientistas, pesquisadores e visitantes em geral;

- divulgar e tornar conhecida a coleção de minerais da Escola de Minas e as riquezas naturais do Brasil e do exterior.

A divulgação do museu é feita pelo site da UFOP, pelo site próprio do museu, redes sociais, bem como folders e pelo circuito turístico da cidade. A Diretora Maria Paula, nos relatou que o MCT atende diretamente o publico geral, pois o museu está bem localizado em uma cidade turística, o queproporciona a visitação de um público diversificado (tanto brasileiros, como estrangeiros). A entrada é cobrada com valores diferentes conforme os tipos de visitantes: $R \$ 6,00$ por pessoa, sendo $R \$ 3,00$ para estudantes. Alunos em grupos agendados da rede pública pagam $R \$ 1,50$ e moradores das cidades de Ouro Preto e Mariana, bem como estudantes da UFOP, tem isenção na entrada.

O museu desenvolve programas educativos para escolas de $1^{\circ}$ e $2^{\circ}$ graus, para as quais são oferecidas oficinas e atividades lúdicas, além de sua utilização por estudantes universitários. As visitas têm duração média de duas horase são direcionadas conforme o interesse do educador que agendou a visita.

O público estimado é de 4.200 pessoas, nos meses de turismo mais intenso. Em média são 50.000 visitantes por ano.

Na parte expositiva, o museu inova com as coleções de Geociências: há o setor de Mineralogia I com minerais estéticos e uma expografia nos padrões arquitetônicos do Museu da Escola de Paris. O setor de Mineralogia II, mais didáticocientífico, se divide com a formação do planeta, ciclo das rochas, ciclo hídrico, aplicabilidade dos minerais e uma parte que ilustra os "Gabinetes de Curiosidade" do século XVII.

A criação da Escola de Minas deu visibilidade e colaborou com o crescimento e preservação de uma das cidades mais importantes e históricas do Brasil. O reconhecimento está no turismo que toda a cidade usufrui para o seu próprio crescimento.

Por fazer parte do Sistema de Museus e Patrimônios da cidade, existe uma integração e incentivo de atividades turísticas que são executadas pela Secretaria de Cultura e Patrimônio da Prefeitura de Ouro Preto. O MCT se torna relevante pela ação educativa que desenvolve. 


\section{ESTRUTURA FÍSICA}

Os ambientes do setor de mineralogia são climatizados e com iluminação e segurança adequados para a conservação do acervo. Não possuem acessibilidade para deficientes físicos, por ser uma construção antiga demais para adaptações, mas quando necessário, realizam-se oficinas na parte térrea do museu. O MCT está desenvolvendo um trabalho inicial com deficientes visuais. Existe uma lojinha com lembranças do museu e todo lucro reverte para a UFOP.

\section{AÇÃO EDUCATIVA E CULTURAL}

Uma das principais atividades do MCT é a ação educativa, pois seus espaços foram projetados para receber grupos educativos. Há o Espaço Multimídia onde se realiza oficinas, palestras, cursos com um público diversificado. Abaixo estão relacionados os principais projetos que são realizados todos os anos (Museu da Escola de Minas):

- Projeto de Produção Associada ao Turismo;

- Projeto "Arte, Cultura, Ciência e Patrimônio: ações educativas complementares" do Fundo Nacional de Desenvolvimento da Educação FNDE;

- Projeto DINAMIZAÇÃO EDUCATIVA DO MCT/EM/UFOP: Criação de Kits para o Ensino de Ciências - financiado pelo CNPq;

- Projeto "Organização, Restauração e Difusão do Acervo Técnico-Científico da UFOP - Novos Elementos Para a História da Ciência no Brasil";

- Projeto Dinamização educativa do MCT/EM/UFOP: Criação de ambientes didáticos - financiado pelo CNPq;

- Programa de apoio à educação básica - Projeto de educação patrimonial Programa Integrado de extensão para o ensino da divulgação da ciência MCT/EM/UFOP;

- Projeto Astronomia na Comunidade;

- Projeto Astronomia Itinerante;

- Projeto Museu Educa;

- Projeto Programas de Rádio de Divulgação Científica. 
Cada projeto é direcionado para um público específico, mas todos estão pautados, direta ou indiretamente, em difundir a mineralogia.

\section{ACERVO MINERALÓGICO}

O Museu de Ciência e Técnica da Escola de Minas da Universidade de Ouro Preto possui sem dúvida um dos melhores acervos mineralógicos brasileiros do país, no requisito amostras estéticas e em minerais raros.

O museu se divide em dois núcleos distintos e com propostas diferentes: Mineralogia I e Mineralogia II.Na entrada da exposição da Mineralogia I, que se localiza no primeiro andar, existem vitrines clássicas de madeira e vidro, com amostras de minerais-gemas e pedras lapidadas; ainda no espaço encontram-se amostras grandes de minerais do estado de Minas Gerais. Destaca-se,no hall de entrada, uma grande amostra de itabirito e de uma grande raiz de árvore típica da região de Ouro Preto, onde parte desta raiz envolveu cristais de hematita, fato incomum de ocorrer.

Este setor da Mineralogia I possui um belo salão expositivo climatizado e com iluminação direcionada nas vitrines modulares, dando grande destaque para os minerais e todos seus detalhes. Os minerais estão ordenados em classes químicas segundo Dana. As amostras minerais estão dispostas em belíssimas vitrines modulares de vidro. Todo o piso é confeccionado em mármore.

As etiquetas dos minerais são de acrílico e transparente e possuem informações simples como o nome da espécie, composição química e localidade geográfica.

Em muitos casos, as localidades não estão muito bem especificadas e notamse ainda alguns nomes de variedades de minerais como martita, octaedrita, kaemmererita e amazonita sem as devidas referências das espécies às quais pertence cada.Em alguns casos, utiliza-se apenas o nome de grupos minerais, sem citar a espécie.

Concentram-se neste ambiente uma quantidade de minerais, cuja beleza e estética é o mais importante requisito, além de algumas amostras históricas de diamante e ouro preto (ouro de cor escura rico em óxido de paládio e óxido de ferro que deu nome a cidade) e de amostras incríveis como topázio Imperial, euclásio e hematita,todas as amostras provenientes da região de Ouro Preto. 
No salão expositivo além das 10 vitrines principais com os minerais em sistematização química, há algumas vitrines com temas específicos como: os minerais encontrados na região de Ouro Preto; ametista do Rio Grande do Sul; calcita; minerais fluorescentes; pedras lapidadas e meteoritos. Neste local, ainda se pode observar uma das mais importantes e raras coleções de meteoritos do país.

Mesmo sendo este primeiro setor dedicado a exposição de belas amostras, sendo algumas com importante valor histórico, nota-se uma repetição exagerada de certos minerais comuns, em exposições didáticas, científicas e sistemáticas, mostrando localidades geográficas diferentes, associações mineralógicas distintas, padrões de cores, entre muitas outras características que são interessantes de serem observadas. No ambiente a luz está reduzida dando destaque somente aos minerais.

Já o setor da Mineralogia II, localizado no segundo andar, tem o principal objetivo de resgatar os antigos "Gabinetes de Curiosidades", mais especificamente os gabinetes de mineralogia que eram comuns nos séculos passados.

Os minerais estão sistematizados de acordo com a classificação química de Dana e estão dispostos em vitrines clássicas de madeira e vidro, com prateleiras internas. É uma viagem ao mundo mineralógico do Brasil e de vários países do mundo. São mais de 20 mil amostras, incluindo algumas raras, coletadas por grandes cientistas do passado como o próprio fundador da Escola de Minas, Claude Henri Gorceix.

A iluminação neste setor é insuficiente, mesmo estando presente no interior de cada vitrine, pois não são pontuais. As etiquetas dos minerais neste ambiente, não possuem uma padronização, mas a grande maioria é igual às do setor da Mineralogia I, de acrílico transparente. As etiquetas possuem informações simples como o nome das espécies, composição química e localidade geográfica. Neste ambiente, nota-se grande quantidade de exemplares com nomes antigos e em desuso. Em adição as localidades estão.

Junto às vitrines com classificação química tradicional, existem vitrines com temas específicos como as propriedades físicas dos minerais (traço, cor, dureza relativa, brilho, clivagem).

Neste setor, além dos gabinetes de minerais, existem salas temáticas discorrendo sobre a formação do planeta Terra, ciclo das rochas, aplicação dos bens minerais e os ciclos da mineração do país. Esses espaços são muito importantes no 
trabalho pedagógico da instituição, principalmente no recebimento de turmas escolares.

A reserva técnica está localizada em dois setores diferentes, o primeiro em fase de classificação e revisão mineralógica e os exemplares sendo recatalogados, fotografados e higienizados. Possui bons armários e estrutura para o armazenamento das amostras. No segundo local, as amostras estão ainda sem nenhuma organização, separação ou revisão mineralógica, porém nota-se uma grande quantidade de espécies raras e amostras importantes para o acervo.

O acervo está sempre aberto à pesquisa dos alunos, de profissionais das áreas das geociências que queiram investigar e estudar o acervo expositivo e de reserva técnica. A direção tem interesse em desenvolver alguns intercâmbios no futuro, depois de sua reserva técnica ser totalmente analisada e reclassificada. $O$ acervo geralmente é acrescido por novas amostras devido a doações, pois o museu não possui verba para a compra de exemplares. A manutenção do acervo fica a cargo dos curadores do museu e dos estagiários.

No acervo mineralógico geral (Mineralogia I e II) pertencente a Escola de Minas, há uma grande quantidade de minerais pertencentes a espécies raras e tipos brasileiras, mas o que impressiona é a quantidade de ocorrências geológicas que hoje se encontram exauridas ou ainda minerações fechadas ou fora de operação, constituindo um dos acervos mais significativos para a mineralogia brasileira. Com certeza é uma das melhores coleções mineralógicas do país e de todo o mundo e apresenta grande relevância para a preservação da memória da mineralogia do Brasil.

Quadro 17 - Quadro de minerais tipo brasileiros pertencentes ao acervo do Museu de Ciência e Técnica da Escola de Minas, com suas respectivas ocorrências (exemplos):

\begin{tabular}{|c|}
$\begin{array}{c}\text { Quadro de minerais tipo brasileiros pertencentes ao acervo da } \\
\text { Escola de Minas de Ouro Pretocom suas respectivas ocorrências } \\
\text { (exemplos): }\end{array}$ \\
Arrojadita - Parelhas, RN. \\
\hline Bahianita - Serra das Almas, Paramirim das Crioulas, Água Quente, \\
Paramirim, BA. \\
\hline Brazilianita - Pegmatito de Córrego Frio, Linópolis, \\
Divino das Laranjeiras, MG. \\
\hline Cesarferreiraíta - Pegmatito do Eduardo, Conselheiro Pena, MG.
\end{tabular}




\begin{tabular}{|c|}
\hline Crisoberilo - Santa Teresa, ES. \\
\hline Derbylita - Córrego Tripuhy, Ouro Preto, MG. \\
\hline Euclásio - Saramenha, Dom Bosco, Miguel Burnier e Rodrigo Silva, Ouro \\
Preto, MG. \\
\hline Florencita-(Ce) - Ouro Preto, MG. \\
Gorceixita - Abaeté, MG. \\
\hline Hidroxicalcioromeita (ex-lewisita) - Córrego Tripuhy, Ouro Preto, MG. \\
\hline Minasgeraisita-(Y) - Pegmatito de Jaguaraçu, Jaguaraçu, MG. \\
\hline Tripuhyíta - Córrego Tripuhy, Ouro Preto, MG. \\
\hline Uvita - Mina Pedra Preta, Serra das Éguas, Brumado, BA. \\
\hline
\end{tabular}

Quadro 18-Quadro de minerais brasileiros pertencentes ao acervo do Museu de Ciência e Técnica da Escola de Minas com suas respectivas ocorrências (exemplos):

\begin{tabular}{|c|}
\hline $\begin{array}{l}\text { Quadro de minerais importantes brasileiros pertencentes ao acervo da } \\
\text { Escola de Minas de Ouro Preto e suas respectivas ocorrências } \\
\text { (exemplos): }\end{array}$ \\
\hline Almandina - Serra da Sapateira, RJ. \\
\hline Andradita - Valença, RJ; Barbacena, MG. \\
\hline Antimônio Nativo - Patos, PB. \\
\hline $\begin{array}{l}\text { Berilo (var.água Marinha) - Galileia, MG; Governador Valadares, MG; } \\
\text { Pedra Azul, MG. }\end{array}$ \\
\hline Berilo (var.esmeralda) - Ferros, MG; Brumado, BA. \\
\hline Berilo (var.heliodoro) - Belo Oriente, MG. \\
\hline Berilo (var.morganita) - Galileia, MG; \\
\hline Bismuto nativo - Bonfim, MG; Mariana, MG; Equador, RN. \\
\hline Brucita - Minaçu, GO. \\
\hline Cinábrio - Tripuí e Dom Bosco, Ouro Preto, MG. \\
\hline Clinocloro (var.kaemererita) - Serro, MG. \\
\hline Coríndon - Mata Azul, GO; Petrópolis, RJ. \\
\hline $\begin{array}{c}\text { Diamante - Ouro Preto, MG; Itacambirussu, MG; Coromandel, MG; } \\
\text { Diamantina, MG; São João del Rei, MG; Grão Mogol, MG; Rio Quilombo, MT; } \\
\text { Chapada Diamantina, BA. }\end{array}$ \\
\hline Enxofre nativo - Antônio Pereira, Ouro Preto, MG. \\
\hline Epídoto - Rio Casca, MG. \\
\hline Escorodita - Antônio Pereira, Ouro Preto, MG. \\
\hline
\end{tabular}




\begin{tabular}{|c|}
\hline Euxenita - Ubá, MG. \\
\hline Farmacosiderita - Ouro Preto, MG. \\
\hline Fenacita - Rio Piracicaba, São Miguel de Piracicaba, MG. \\
\hline Gibbsita - Ouro Preto, MG. \\
\hline Hematita - Miguel Burnier e Dom Bosco, Ouro Preto, MG. \\
\hline Litioforita - Serra do Navio, AP. \\
\hline Malaquita - Mina Santa Blandina, Itapeva, SP. \\
\hline Mercúrio nativo - Tripuí, Ouro Preto, MG. \\
\hline Mitridatita - Traguatam, PR. \\
\hline Novacekita - Brumado, BA. \\
\hline $\begin{array}{l}\text { Ouro Nativo - Ouro Preto, MG; Santa Rita Durão, Mariana, MG; São João del } \\
\text { Rei, MG; Nova Lima, MG; Jaraguá, GO; Serra da Jacobina, BA; Rio Gurupi, } \\
\text { PA; Piancó, PB; Montes Áureos, MA; Itabira, MG; Barão de Cocais, MG; Santa } \\
\text { Bárbara, MG; Ribeirão das Varas, MG; Serro, MG; Grão Mogol, MG. }\end{array}$ \\
\hline Perovskita - Mina Jacupiranga, Cajati, SP. \\
\hline Pirolusita - Jaboticatuba, MG; Serra do Cipó, MG. \\
\hline Platina nativa - Conceição, MG; Morro do Pilar, MG. \\
\hline Prehnita - Marilac, MG. \\
\hline Romeíta (var.atopita) - Tripuí, Ouro Preto, MG. \\
\hline Rutilo - Santa Quitéria, CE. \\
\hline Saleeíta - São Geraldo do Baixio, MG. \\
\hline Sellaíta - Serra das Éguas, Brumado, BA. \\
\hline Simpsonita - Parelhas, RN. \\
\hline Stibnita - Ouro Preto, MG. \\
\hline Stolzita - Sumidouro e Jambeiro, Mariana, MG. \\
\hline Tantalita-(Mn) - Junco do Sideró, PB. \\
\hline Tapiolita-(Fe) - Galileia, MG; Picuí, PB. \\
\hline $\begin{array}{c}\text { Topázio - Teófilo Otoni, MG; Caraí, MG; Salinas, MG. } \\
\text { Topázio imperial - (Antônio Pereira, Dom Bosco, Rodrigo Silva, Miguel } \\
\text { Burnier) Ouro Preto, MG. }\end{array}$ \\
\hline Turquesa - Itatiaíussu, MG. \\
\hline Valentinita - Ouro Preto, MG. \\
\hline Villiaumita - Pedreira da Bortolan, Poços de Caldas, MG. \\
\hline Wavellita - Tripuí, Ouro Preto, MG. \\
\hline
\end{tabular}




\section{RELAÇÃO DE FOTOS DO MUSEU DA ESCOLA DE MINAS DE OURO PRETO}

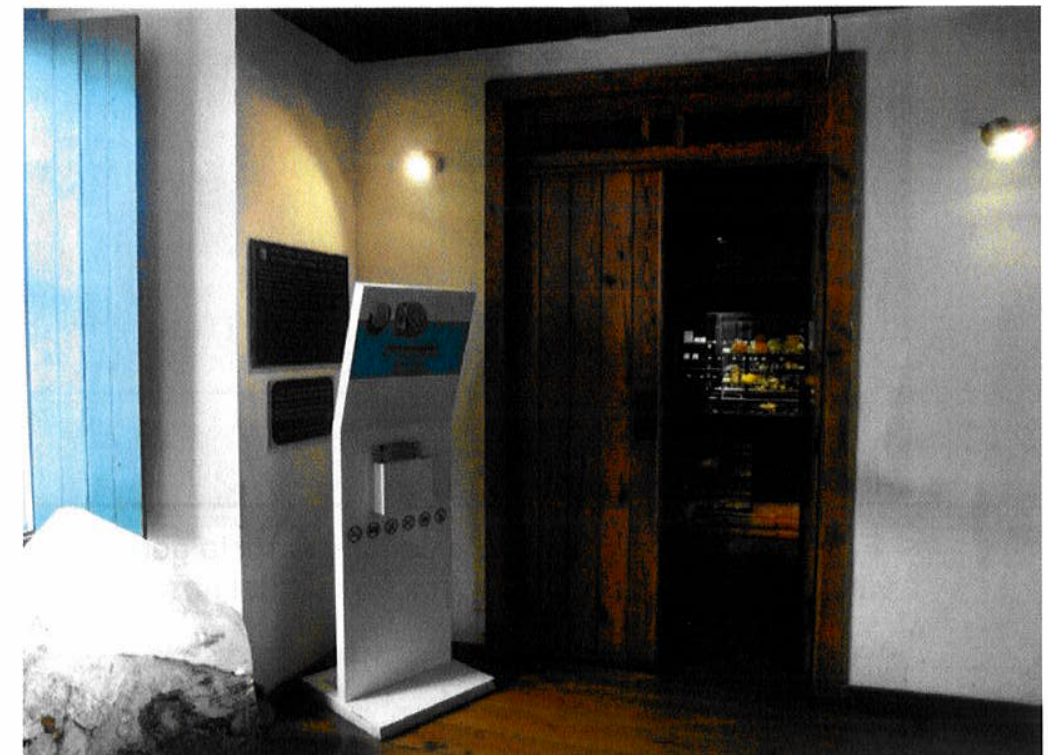

Figura 89. Museu da Escola de Minas. Entrada do setor de mineralogia I.

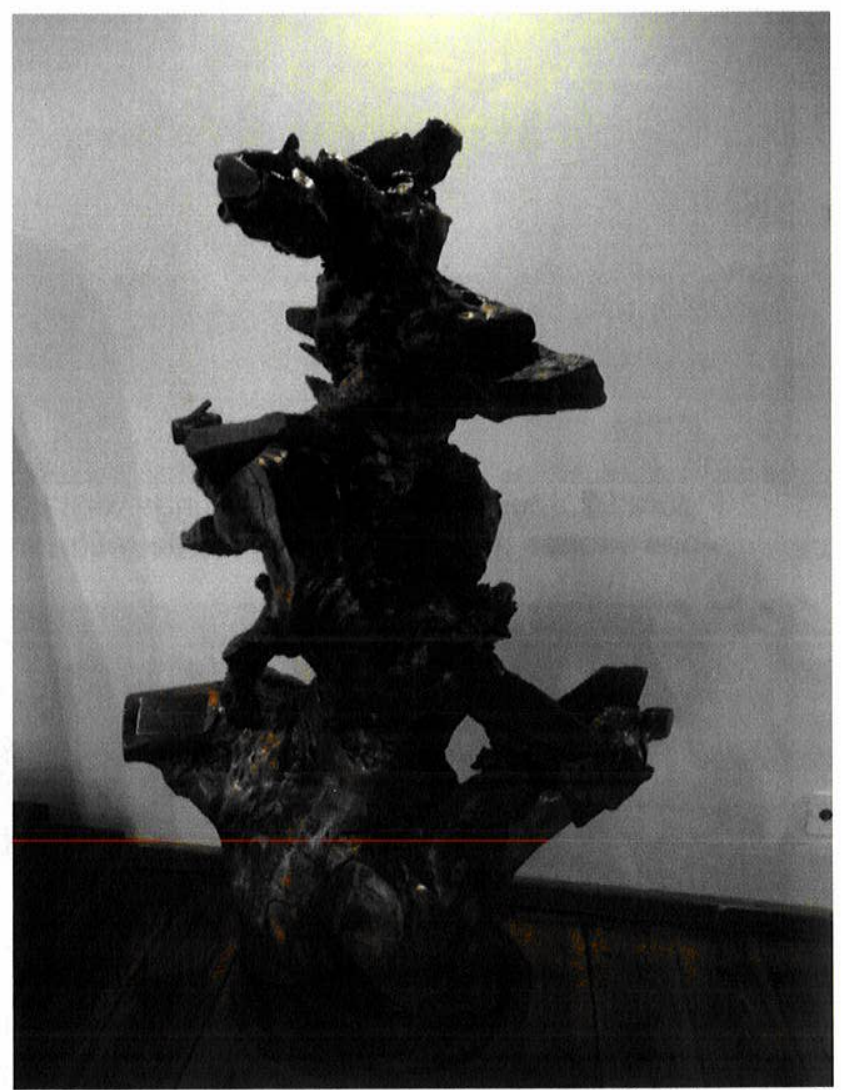

Figura 90. Museu da Escola de Minas. Detalhe da amostra de raiz de planta envolvendo cristais de hematita (itabirito). 


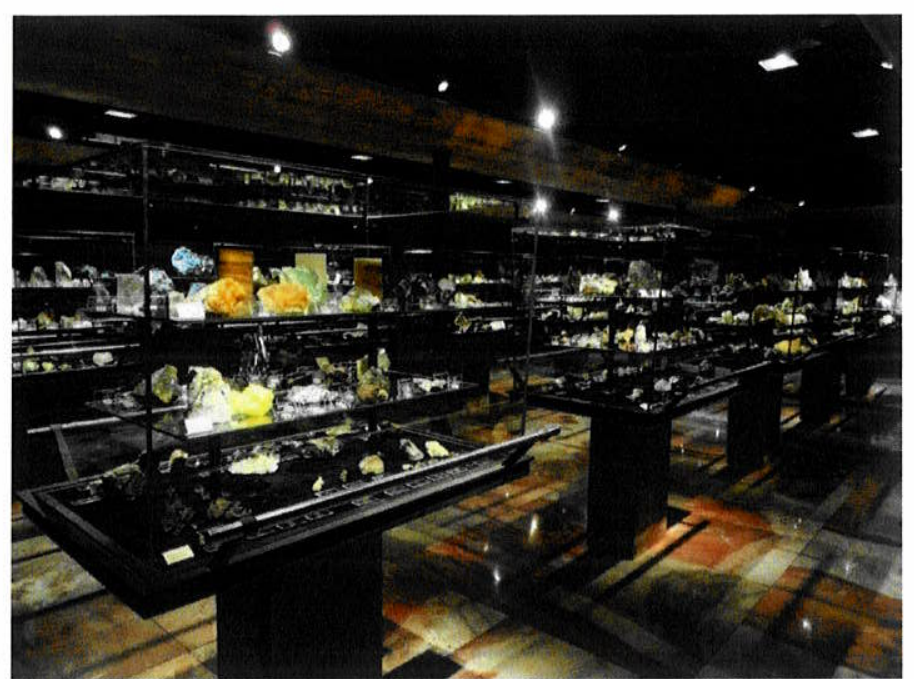

Figura 91. Museu da Escola de Minas. Vista geral das vitrines modulares e da iluminação pontual nas vitrines.

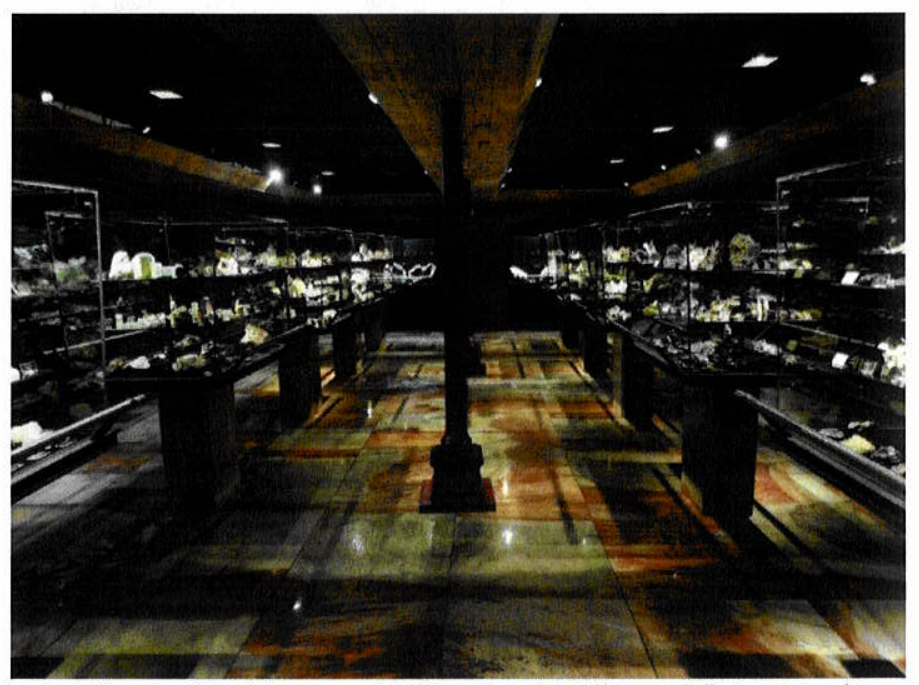

. Figura 92. Museu da Escola de Minas. Vista geral das vitrines modulares e do piso de mármore

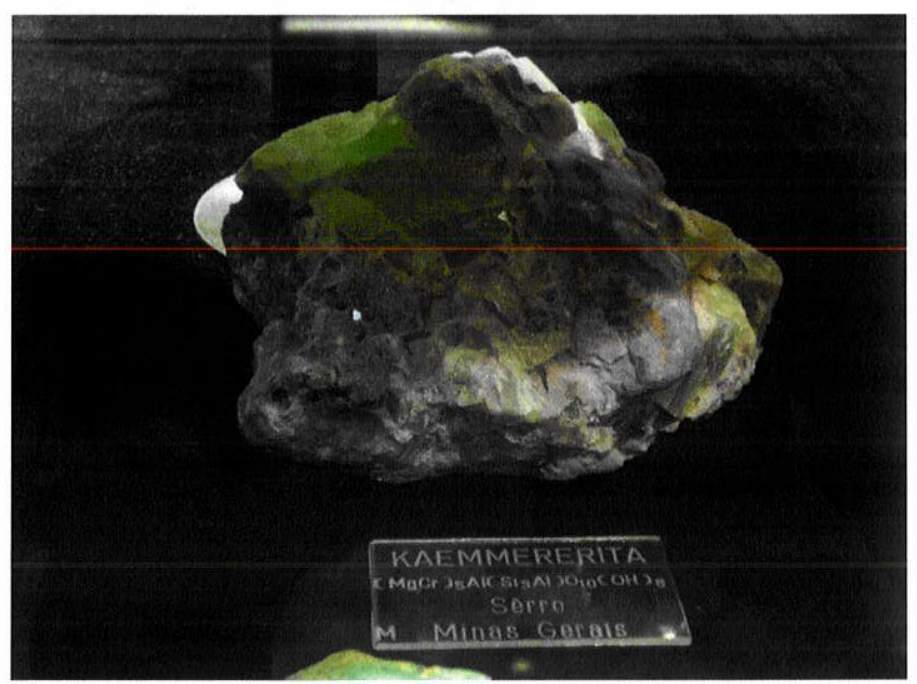

Figura 93. Museu da Escola de Minas. Foto de umavariedade de clinocloro, porém sem a devida explicação de qual espécie pertence. Detalhe da etiqueta sem as informações necessárias. 


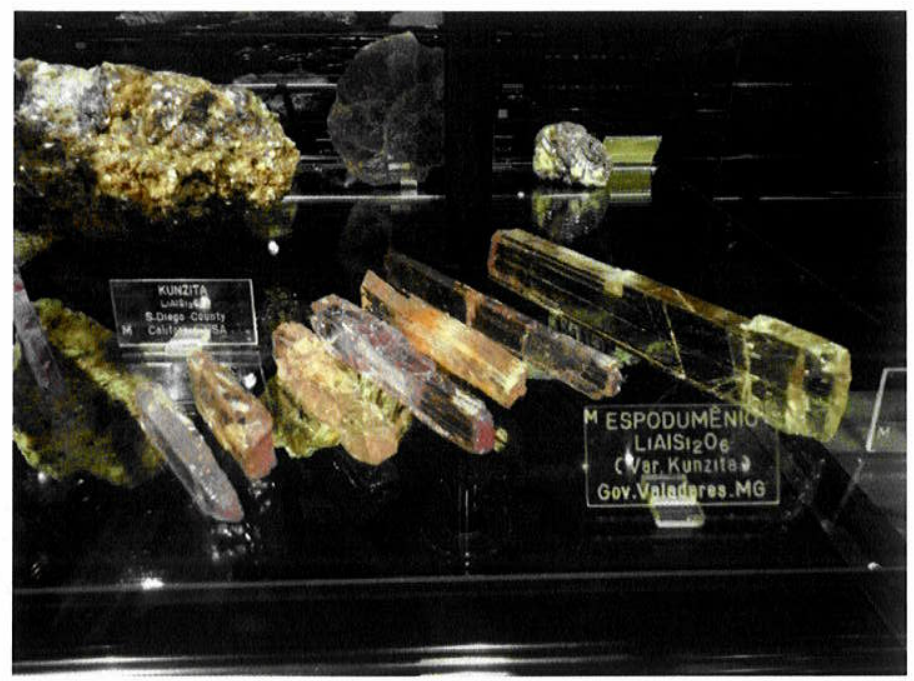

Figura 94. Museu da Escola de Minas. Detalhe das etiquetas sem padronização das informações sobre a variedade kunzita.

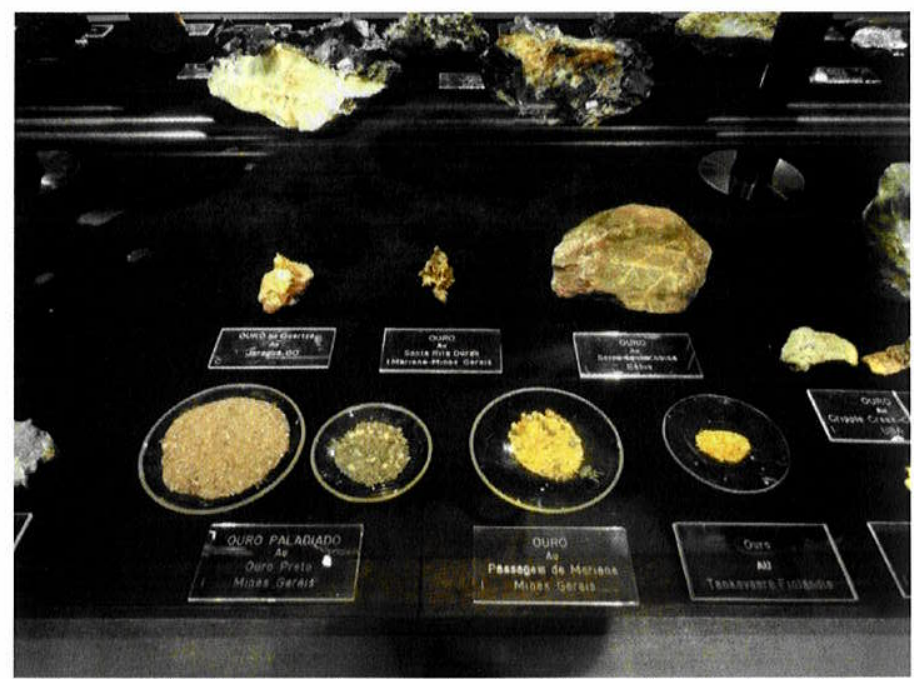

Figura 95. Museu da Escola de Minas. Vista da vitrine com amostras de elementos nativos: ouro.

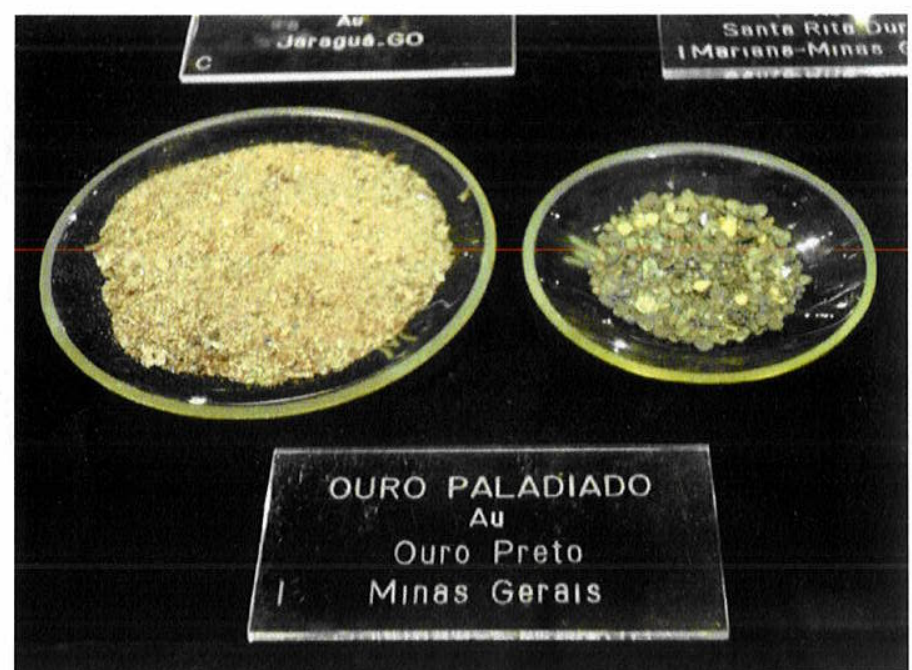

Figura 96. Museu da Escola de Minas.Detalhe das amostras raras de ouro preto (ouro paladiado). 


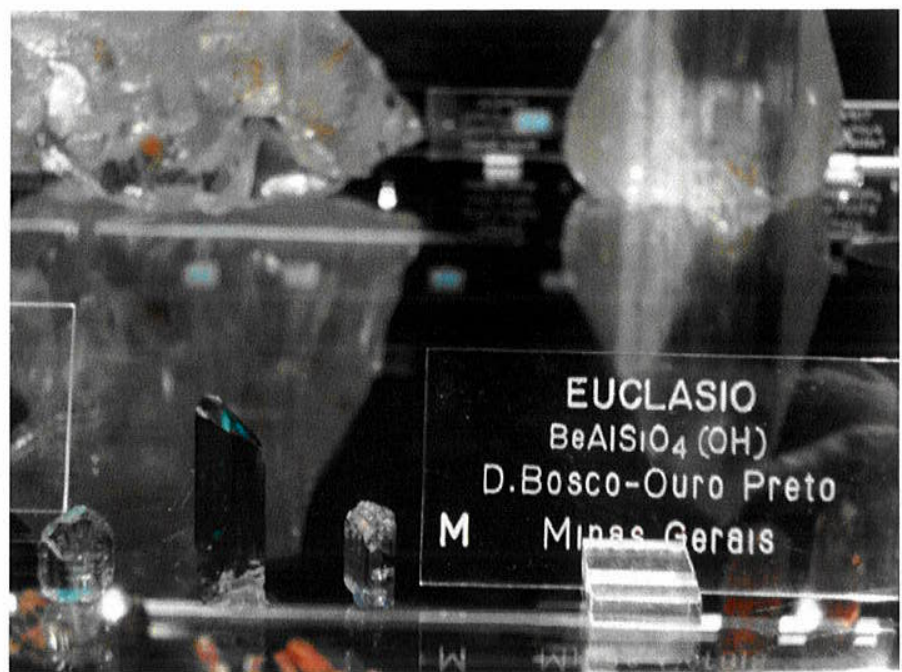

Figura 97. Museu da Escola de Minas. Amostras raras e estéticas de euclásio de Ouro Preto.

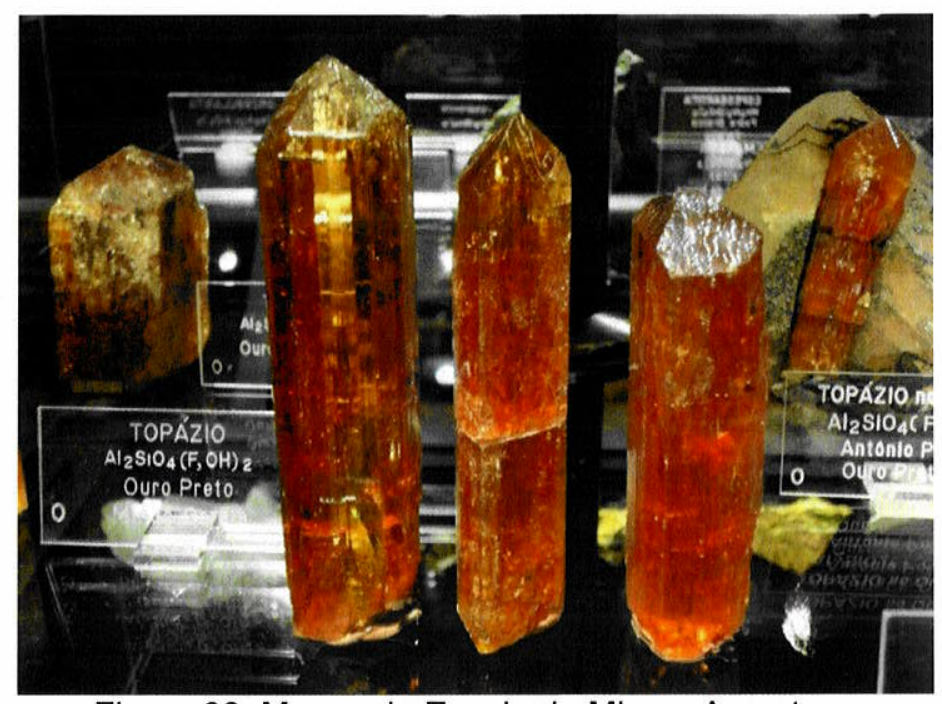

Figura 98. Museu da Escola de Minas. Amostras raras e estéticas de topázio Imperial de Ouro Preto.

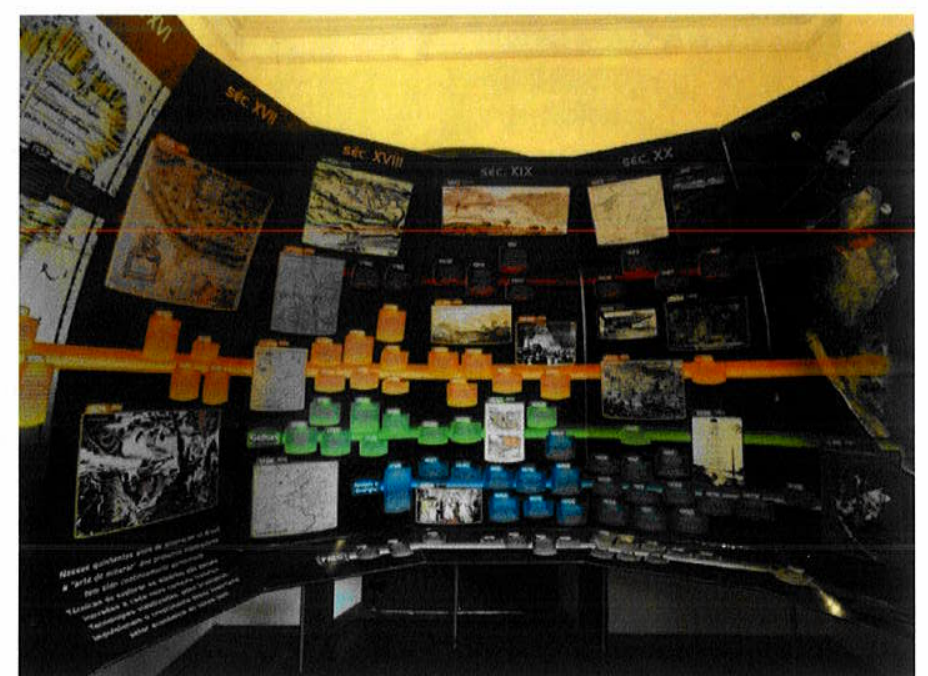

Figura 99. Museu da Escola de Minas.Setor educativo: Ciclos das Minerações do Brasil. 


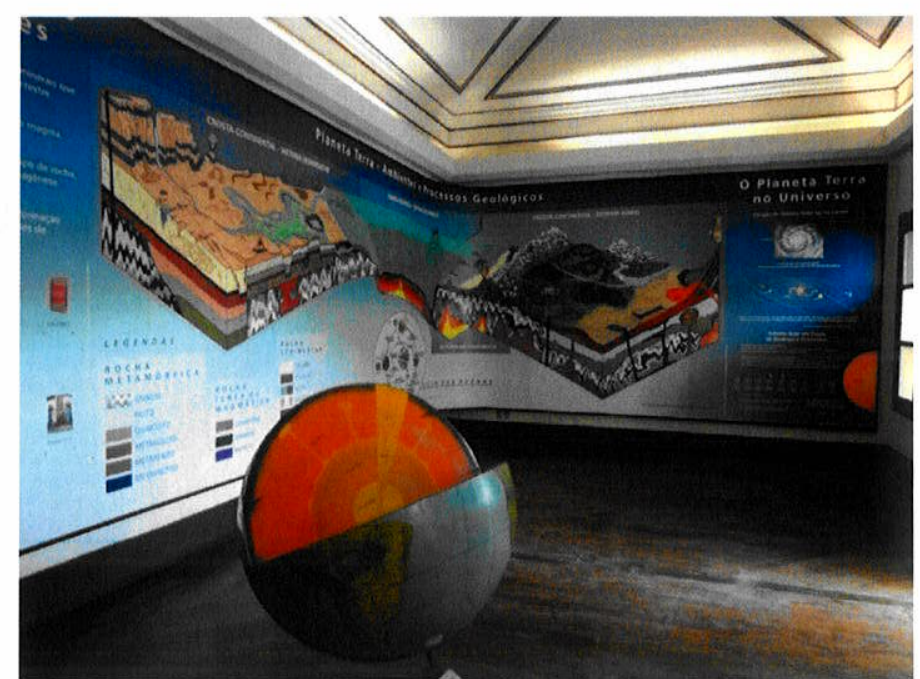

Figura 100. Museu da Escola de Minas.

Setor educativo: Ciclo das Rochas.

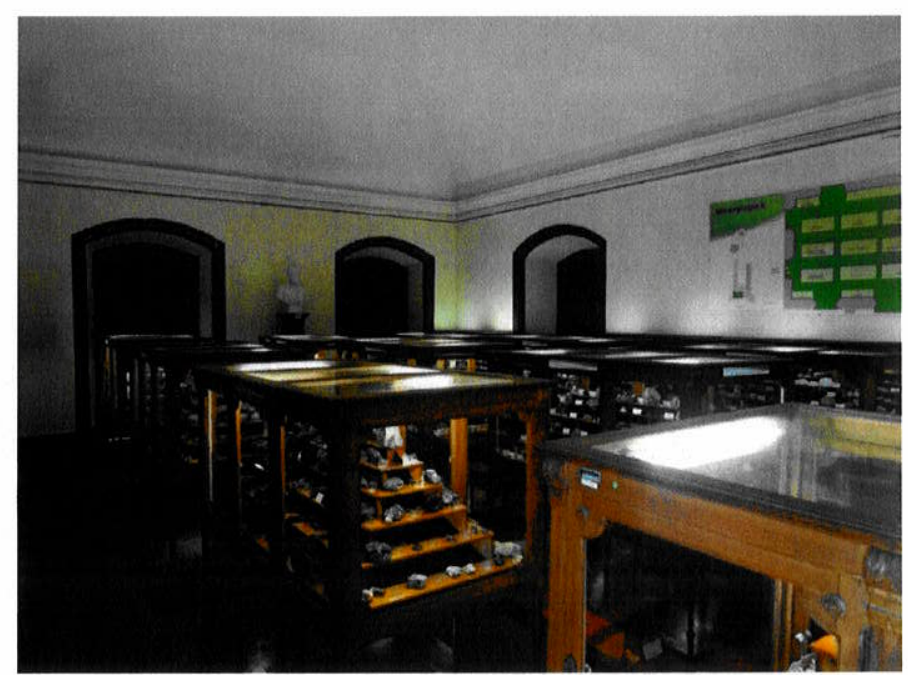

Figura 101. Museu da Escola de Minas. Vista geral das vitrines clássicas. Falta iluminação.

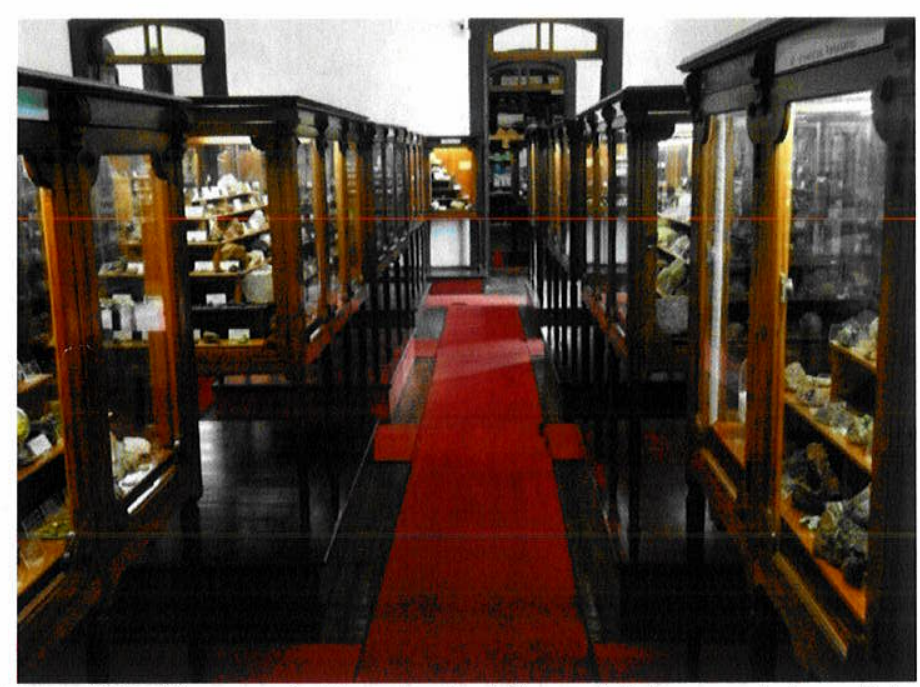

Figura 102. Museu da Escola de Minas. Vista geral das vitrines clássicas e dos corredores estreitos, dificultando o acesso aos deficientes físicos com baixa mobilidade ou cadeirantes. 


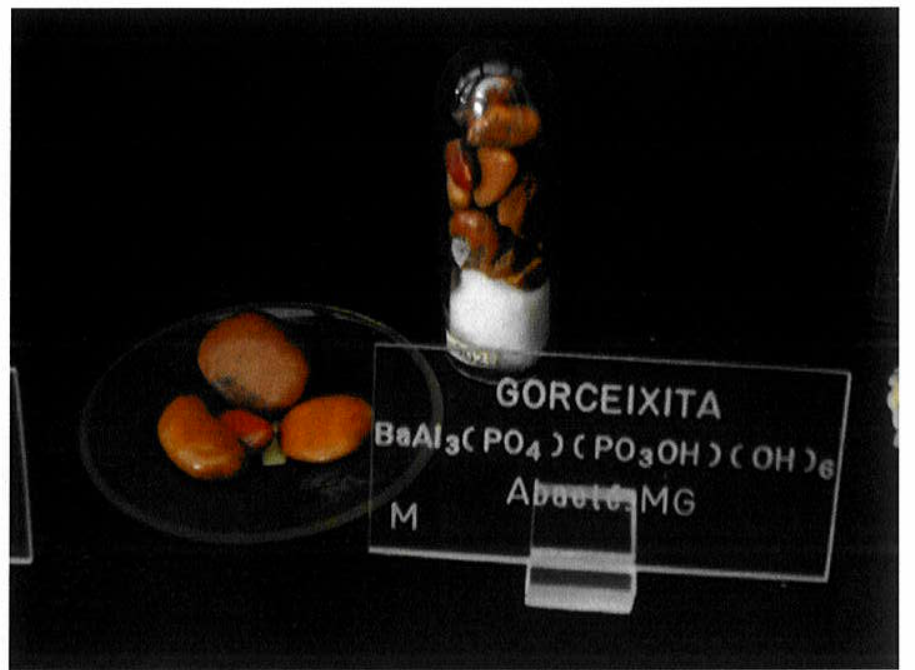

Figura 103. Museu da Escola de Minas. Detalhe de espécie rara descoberta em Minas Gerais em homenagem ao patrono do Museu de Mineralogia da UFOP, a gorceixita.

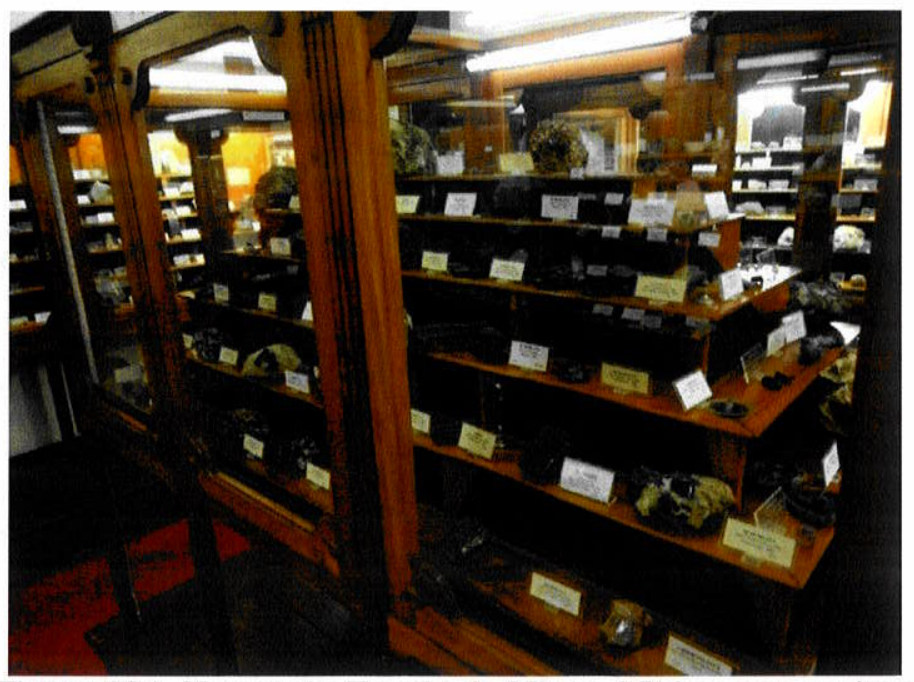

Figura 104. Museu da Escola de Minas. Vitrine com muitas amostras minerais classificados segundo Dana.

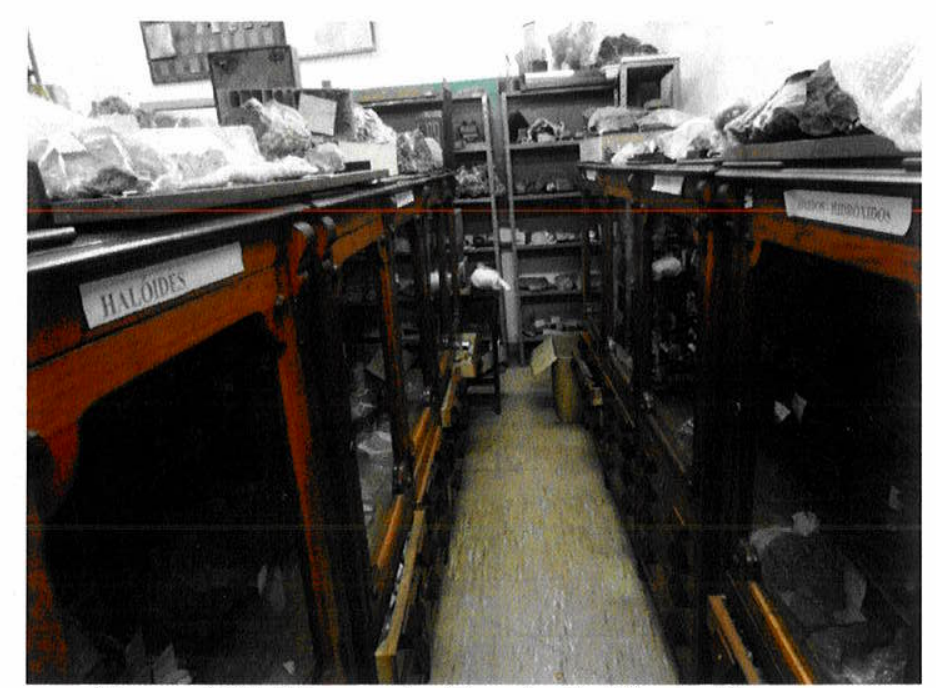

Figura 105. Museu da Escola de Minas. Reserva Técnica com várias vitrines de minerais. 


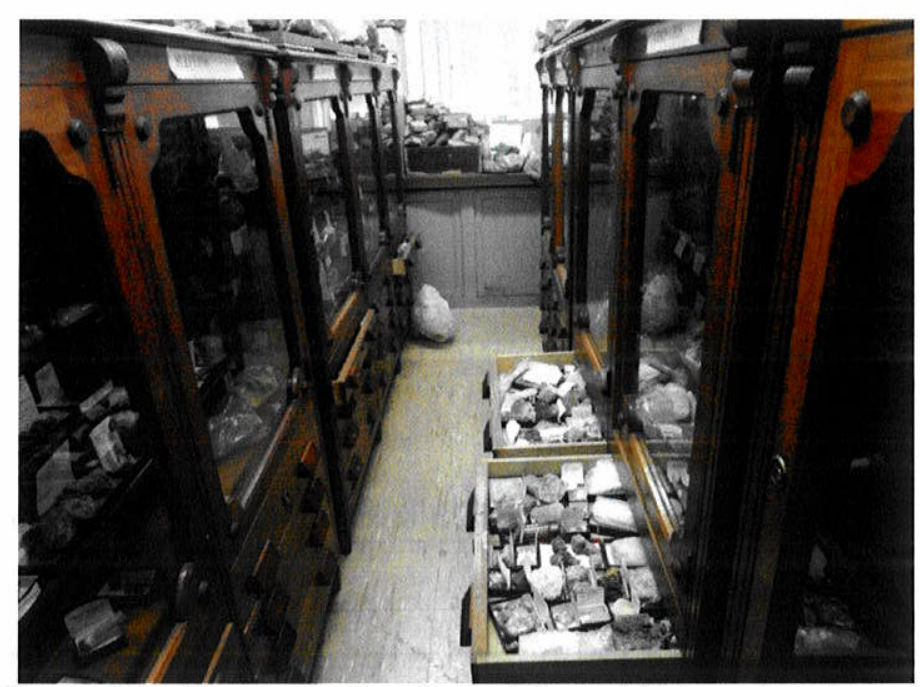

Figura 106. Museu da Escola de Minas. Vitrines de minerais e detalhe nas gavetas completamente lotadas de amostras minerais. Em muitas ocasiões foi constatado melhores amostras na reserva técnica.

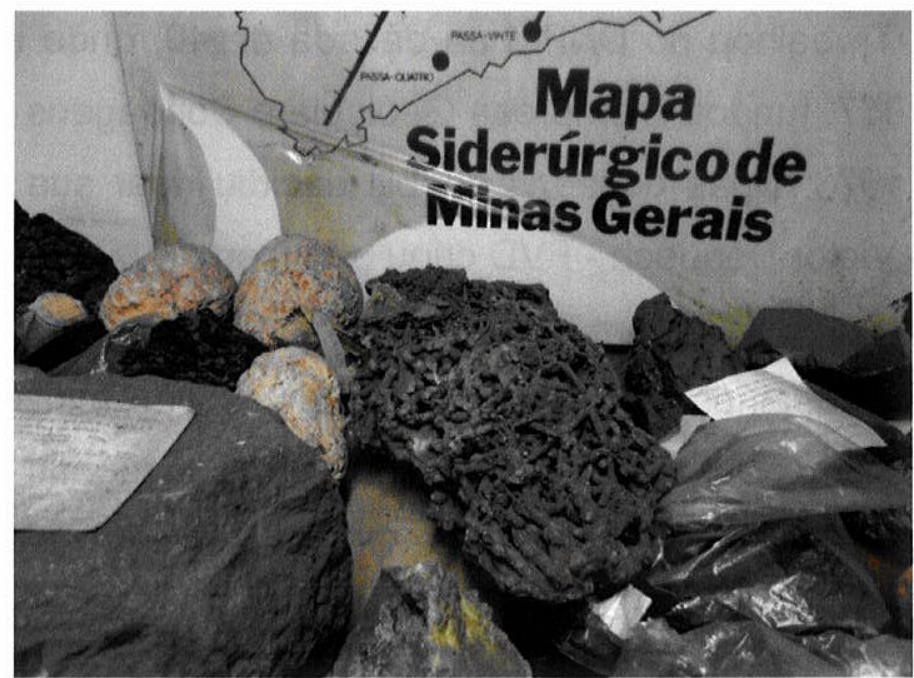

Figura 107. Museu da Escola de Minas. Amostras raras e interessantes sem cuidados de manutenção ou conservação.

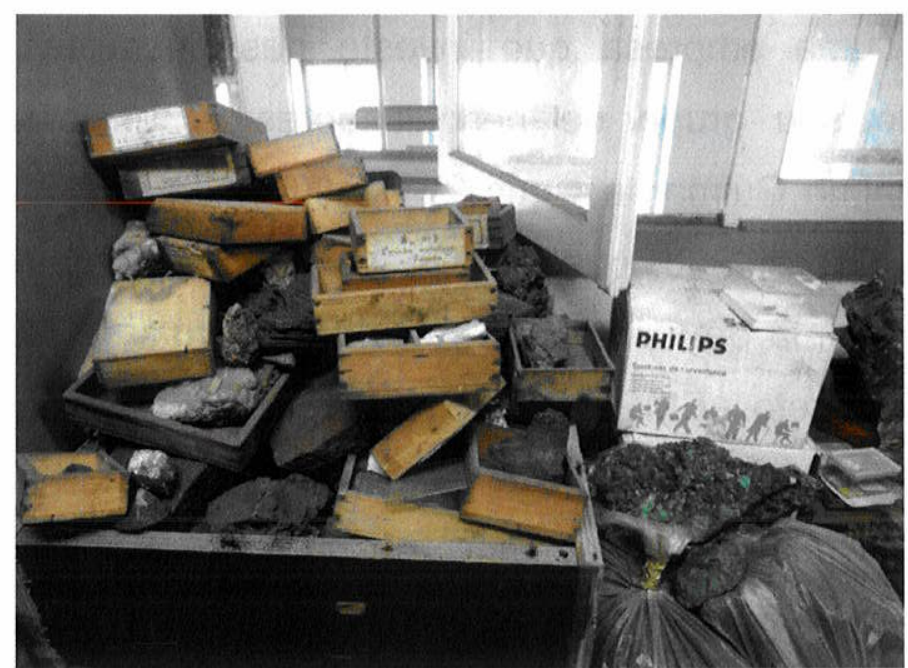

Figura 108. Museu da Escola de Minas. Amostras raras e interessantes sem cuidados especiais. 
MUSEU DE MINERALOGIA VITOR DEQUECH/ GEOSOL GEOLOGIA E SONDAGENS SIA

(pesquisa realizada em 18/11/2013)

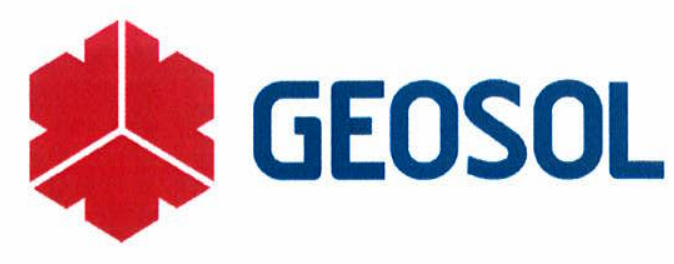

HISTÓRICO DA INSTITUIÇÃO

O Museu da GEOSOL fica localizado na Rua São Vicente, 255 - Olhos D'Água, Belo Horizonte - Minas Gerais.

A Empresa GEOSOL foi fundada em 1953 sob a denominação de Geologia e Sondagens S/A. pelo Engenheiro Civil e de Minas Victor Dequech. Victor foi estudante de Engenharia de Minas e Civil da Escola de Minas de Ouro Preto na década de 30. Trabalhou no DNPM na década de 40 , onde iniciou sua coleção de minerais. Em 1957, fundou a empresa Geologia e Sondagens S/A - GEOSOL até se aposentar em 1978. Duas décadas depois decidiu doar sua coleção à empresa e pela Fundação Victor Dequech - FVD criou o Museu de Mineralogia da GEOSOL.

Sua primeira sede foi em Criciúma, Santa Catarina, e a empresa desenvolveu seus primeiros trabalhos realizando sondagens em minas de carvão mineral localizadas no sul do país (GEOSOL - Geologia e Sondagens S/A., 2013).

Quase dez anos depois, a GEOSOL passou a ter atuação nacional, executando trabalhos de sondagens em diversas regiões do Brasil. Entre 1967 e 1978, foi criado o laboratório de análises químicas e geoquímicas, voltado para clientes do setor mineral, que acaba por se tornar o maior do ramo no Brasil.

Por ser uma empresa que investe nas pesquisas e estudos da área, participaram de seu grupo de pesquisadores e funcionários, dois nomes da mineralogia, Djalma Guimarães, que foi consultor da empresa na década de 60, e João Henrique Grossi Sad, que se tornou diretor da empresa. João Henrique foi formado na $1^{\text {a }}$ Turma de Geologia e Escola de Minas de Ouro Preto-Universidade Federal de Ouro Preto - EMOP-UFOP em 1961, e foi nomeado através de decreto, pelo então Presidente Juscelino Kubitschek, em fevereiro de 1961, como assistente de professorda Cadeira de Geologia. Foi um dos mais atuantes profissionais da primeira geração de geólogos brasileiros, tanto no setor empresarial de mineração como no setor acadêmico e na Sociedade Brasileira de Geologia - SBG, tendo atuado durante várias décadas na Geosol. 
Em 2002, foi criada a Fundação Victor Dequech - FVD, entidade sem fins lucrativos, que controla um terço do capital da GEOSOL. Os principais objetivos são o desenvolvimento técnico e científico da atividade mineral, além da melhoria de qualidade de vida dos profissionais da GEOSOL.

A FVD investe em desenvolvimento tecnológico, oferecendo bolsas de mestrado e doutorado para os pesquisadores que, de alguma forma, se envolvem com atividades relacionadas ao setor mineral.

Por estar direcionada ao setor da pesquisa e desenvolvimento, a Fundação decidiu criar a Biblioteca João Henrique Grossi Sad e o Museu de Mineralogia Vitor Dequech, que possuem um acervo dedicado às ciências minerais. A biblioteca compreende desde trabalhos recentes, de autoria do próprio professor João Henrique Grossi Sad, a obras escritas há quase 300 anos, oriundas de diversos países.

As obras científicas se encontram em condições ideais de acondicionamento, e suas instalações contam com três salas climatizadas que relembram a tradicional biblioteca da Escola de Minas da Universidade Federal de Ouro Preto.

O Museu de Mineralogia Vitor Dequech foi inaugurado em novembro de 2003 para valorizar a mineralogia no Brasil e oferecer subsídio técnico para as pessoas interessadas. Toda coleção que o fundador da empresa formou, foi com este intuito, pois contempla minerais de beleza ímpar do Brasil todo, além de minérios provenientes de minas em atividade e de outras já exauridas, bem como rochas e fósseis.

\section{ORGANIZAÇÃO E FUNCIONAMENTO}

A presente pesquisa foi desenvolvida com o estagiário do Museu de Mineralogia, o estudante de Geologia Gabriel, pois o responsável técnico, Paulo Roberto Amorim dos Santos Lima, não pôde colaborar por estar ausente no momento da visita.

De acordo com seu relato, o Museu da GEOSOL, não é registrado como um museu, pois não está cadastrado pelo IBRAM e pelo Sistema Estadual de Museus (SISEM), e também não está aberto ao público em geral.

O objetivo principal do museu é colaborar com a comunidade científica, conservando a coleção de minerais do fundador da empresa Vitor Dequech em sua 
riqueza e diversidade de amostras brasileiras. Além disso, o museu se torna uma vitrine que representa o trabalho da GEOSOL para clientes e para grupos universitários e de cursos técnicos.

Seu funcionamento é diário e eles recebem clientes e visitantes da empresa que utilizam o museu como passagem, pois está localizado na entrada. Alguns grupos universitários e de cursos técnicos nas áreas das geociências e engenharias, solicitam visita monitorada pelo museu e por toda a empresa.

A Fundação mantenedora do museu produziu um "Guia de Mineralogia" em 2004, com o intuito de homenagear o fundador da empresa GEOSOL, contando sua história, de sua coleção de minerais e do Museu de Mineralogia GEOSOL.

Esta publicação possui a maior parte do acervo catalogada, com fotos e descrições químicas de cada peça, um livro que teve distribuição gratuita e que além de colaborar com o conhecimento científico da área da mineralogia, também é um material de divulgação muito importante para a empresa.

Dentro de suas ações de divulgação estão às redes sociais e um site que possui todo o catálogo fotográfico do museu.

Não existe um reconhecimento da comunidade ou da cidade quanto ao museu, pois ele não é de caráter público. Sua importância para a mineralogia está na conservação de um acervo rico em raridades de importantes espécies brasileiras.

\section{ESTRUTURA FÍSICA}

O Museu da GEOSOL possui três ambientes expositivos, todos bem iluminados, climatizados e com segurança. Um dos espaços fica dividido com a biblioteca, sendo este sem acessibilidade para pessoas com dificuldade de mobilidade como cadeira de rodas. Por não ser aberto ao público geral, também não possui áreas de convivência como loja e lanchonete.

\section{AÇÃO EDUCATIVA E CULTURAL}

De acordo com o entrevistado, o museu não possui ações educativas diretas e planejadas, com divulgação em instituições de ensino. Quando existe o interesse, um grupo agenda a visita à empresa e recebe atendimento com monitoria no museu, 
vídeo institucional com palestra da área no auditório, e visita às instalações da empresa.

\section{ACERVO MINERALÓGICO}

O Museu da GEOSOL possui um acervo mineralógico bem significativo, composto por 900 amostras, em sua grande maioria de exemplares brasileiros.

As coleções de minerais estão em duas áreas centrais que se localiza bem na entrada da Empresa da GEOSOL, sendo um dos cartões postais da empresa. Os exemplares, em geral, possuem um porte médio a grande e em geral são exemplares muito estéticos e de grande beleza.

Os minerais são classificados segundo Dana em classes químicas, onde algumas das principais classes estão bem representadas. As amostras estão dispostas em vitrines de vidro, com uma iluminação geral na parte de cima das vitrines, porém não muito eficaz. Os minerais estão colocados em bases de madeira para dar destaque às peças.

A etiqueta dos minerais contém informações precisas como o nome da espécie e a localidade geográfica. As ocorrências são muito bem descritas com importantes informações sobre a proveniência das espécies minerais.

Além da exposição seguindo a sistematização por classes químicas, ocorrem ainda algumas outras exposições que se misturam à exposição sistemática, como é o caso de vários minérios dos principais elementos metálicos, como ferro, manganês etc., destacando-se amostras do estado de Minas Gerais. Uma das exposições mais importantes está dedicada aos minerais tipo brasileiros, onde algumas raridades pode ser observadas como matiolíta, coutinhoíta, lindbergita, yanomamita, entre outras.

Existe outra parte do acervo expositivo que está localizada dentro da biblioteca, disposta em vitrines tradicionais, onde também se destacam e se concentram amostras de minérios dos principais elementos metálicos como ferro, manganês, ouro, alumínio, níquel, cobre, chumbo, etc., além de outras espécies, em geral amostras de ocorrências brasileiras.

O museu não possui reserva técnica e todo o seu acervo está exposto em três áreas principais. O acervo em geral está bem classificado e analisado e o curador do museu Paulo Amorim e o estagiário Gabriel são os únicos a serem os 
responsáveis tanto pela manutenção quanto pela classificação. A aquisição de novos exemplares é fruto de doações e de compra de comerciantes especializados, cuja verba em geral é disponibilizada pela Fundação Vitor Dequech. O museu não desenvolve intercâmbio com outras instituições ou colecionadores e a direção pretende ampliar o espaço da exposição dos minerais e fazer uma revisão mineralógica de seu acervo.

No acervo mineralógico destacam-se alguns exemplares belíssimos e algumas espécies raras, como: topázio imperial, topázio incolor, euclásio, brazilianita, berilo (var. água marinha), scheelita, montebrasita com kosnarita, hematita com quartzo, barita, vivianita, fluorita, guimarãesita etc.

O acervo de minerais do Museu da GEOSOL, mesmo não tendo um setor educativo muito atuante ou a intenção de se tornar, um museu mais pedagógico e assim divulgar a mineralogia do Brasil através de sua coleção é uma importante coleção de minerais brasileiros e com certeza é relevante para a preservação da memória da mineralogia do país, tanto pela grande quantidade de localidades históricas, quanto pela raridade de algumas espécies minerais.

Quadro 19 -Tabela de minerais tipo brasileiros pertencentes ao acervo do Museu da GEOSOL com suas respectivas ocorrências (exemplos):

\begin{tabular}{c}
$\begin{array}{c}\text { Quadro de minerais tipo brasileiros pertencentes ao acervodo Museu da } \\
\text { Geosol com suas respectivas ocorrências (exemplos): }\end{array}$ \\
Arrojadita - Alto do Boqueirão, Parelhas, RN. \\
Atencioíta - Linópolis, Divino das Laranjeiras, MG. \\
Pahianita - Serra das Almas, Paramirim das Crioulas, Água Quente, \\
Paramirim, BA. \\
\hline Barbosalita - Lavra do Tomé, Galiléia, MG. \\
Brazilianita - Pegmatito de Córrego Frio, Linópolis, \\
Divino das Laranjeiras, MG; São Geraldo do Baixio, MG; Lavra Sebastião \\
Cristino, Mendes Pimentel, MG. \\
Coutinhoíta - Pegmatito Urucum, Galileia, MG. \\
Crisoberilo - Colatina, ES. \\
\hline Euclásio - Rodrigo Silva e Dom Bosco, Ouro Preto, MG; Alto do Giz, Equador, \\
RN. \\
\hline Fluornatromicrolita - Lavra Quixabá, Frei Martinho, PB.
\end{tabular}




\begin{tabular}{|c|}
\hline Frondelita - Pegmatito de Sapucaia, Galileia, MG. \\
\hline Guimarãesita - Córrego Piauí, Taquaral, Itinga, MG. \\
\hline Lantanita-(Nd) - Curitiba, PR. \\
\hline Lindbergita - Lavra da Boca Rica, Sapucaia do Norte, Galiléia, MG. \\
\hline Matioliíta - Lavra do Gentil, Mendes Pimentel, MG. \\
\hline Menezesita - Mina Jacupiranga, Cajati, SP. \\
\hline Moraesita - Fazenda Pomaroli, Linópolis, Divino das Laranjeiras, MG; São \\
Geraldo do Baixio, MG. \\
\hline Quintinita - Mina Jacupiranga, Cajati, MG. \\
\hline Ruifrancoíta - Lavra da Proberil, Galiléia, MG. \\
\hline Tavorita - Pegmatito de Sapucaia, Galiléia, MG. \\
\hline Uvita - Mina Pedra Preta, Serra das Éguas, Brumado, BA. \\
\hline Yanomamita - Depósito de Sn Mangabeira, Monte Alegre de Goiás, GO. \\
\hline Zanazzíta - Lavra do Taquaral Seco, Itinga, MG. \\
\hline
\end{tabular}

Quadro 20 -Tabela de minerais brasileiros pertencentes ao acervo do Museu da GEOSOL com suas respectivas ocorrências (exemplos);

Quadro de minerais importantes brasileiros pertencentes ao acervo do Museu da Geosol e suas respectivas ocorrências (exemplos):

Barita - Mina 3, Estação Cocal, Morro da Fumaça, SC.

Berilonita - Lavra do Telírio, Linópolis, Divino das Laranjeiras, MG.

Berthierita - Mina Faina, Pitangui, MG.

Bismutomicrolita (desacreditado) - Alto Cajazeiras, Junco do Seridó, PB.

Bismutotantalita - Mina Saco da Onça, Carnaúba dos Dantas, RN.

Chernikovita- Pedreira Domingas Della Antônia Tosold, Perus, SP.

Cromita - Serra do Quatipuru, Conceição do Araguaia, PA.

Diamante - Diamantina, MG.

Hematita- Rodrigo Silva, Ouro Preto, MG.

Hidroxil-herderita - Lavra da Xandá, Virgem da Lapa, MG.

Humboldtina - Lavra do Vianna, Santa Maria de Itabira, MG.

Montebrasita e kosnarita - Lavra do Jenipapo, Itinga, MG.

Ouro nativo - Mina Lamego, Sabará, MG; Mina Bela Fama, Nova Lima, MG;

Mina Grande, Crixás, GO; Mina Cuiabá, Sabará, MG.

Romanechita - Mina Santa Terezinha, Serra do Navio, AP. 
Scheelita - Mina Velha, Morro Velho, Nova Lima, MG; Garimpo Carnaíba, Pindobaçu, BA; Mina Bonito, São Miguel do Jucurutu, RN; Mina Malhada dos Angico, Jardim do Seridó, RN.

Stokesita - Lavra do Urucum, Galiléia, MG.

Todorokita, nstutita, pirolusita - Mina do Azul, Serra dos Carajás, Paraupebas, PA.

Topázio imperial - Garimpo de Antônio Pereira, Ouro Preto, MG. Topázio Azul - Iço, CE.

Uranmicrolita (desacreditado) - Lavra Volta Grande, Nazareno, MG.

Vivianita - Lavra da Cigana, Galiléia, MG; Mina Catalão, Catalão, GO.

Waylandita - Alto do Giz, Equador, RN.

\section{Relação de fotos do Museu de Mineralogia da GEOSOL}

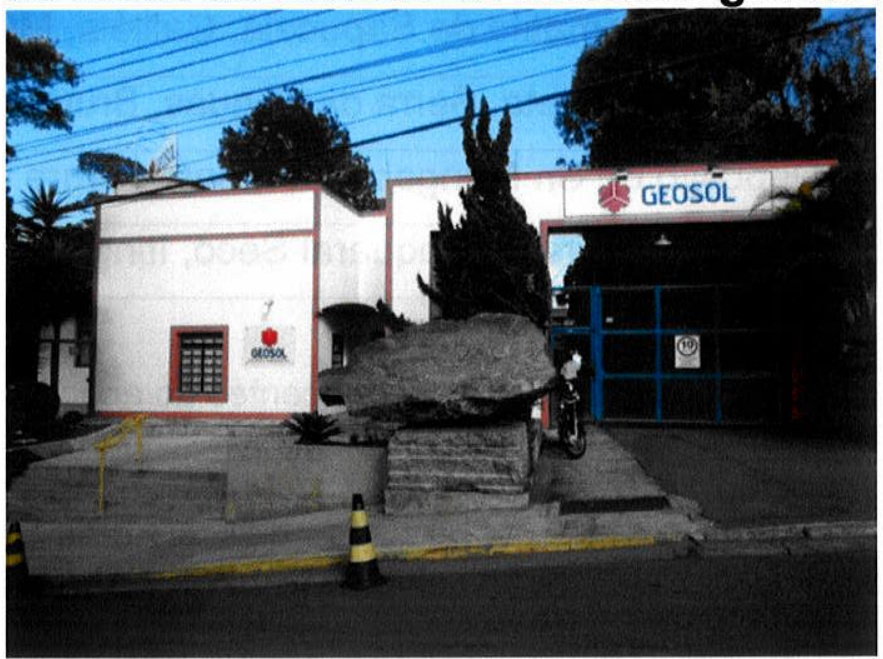

Figura 109.Museu da GEOSOL. Foto da entrada da Empresa Geosol, em detalheuma amostra muito grande de jaspilito. Não existe referência de que existe um museu dentro da instituição.

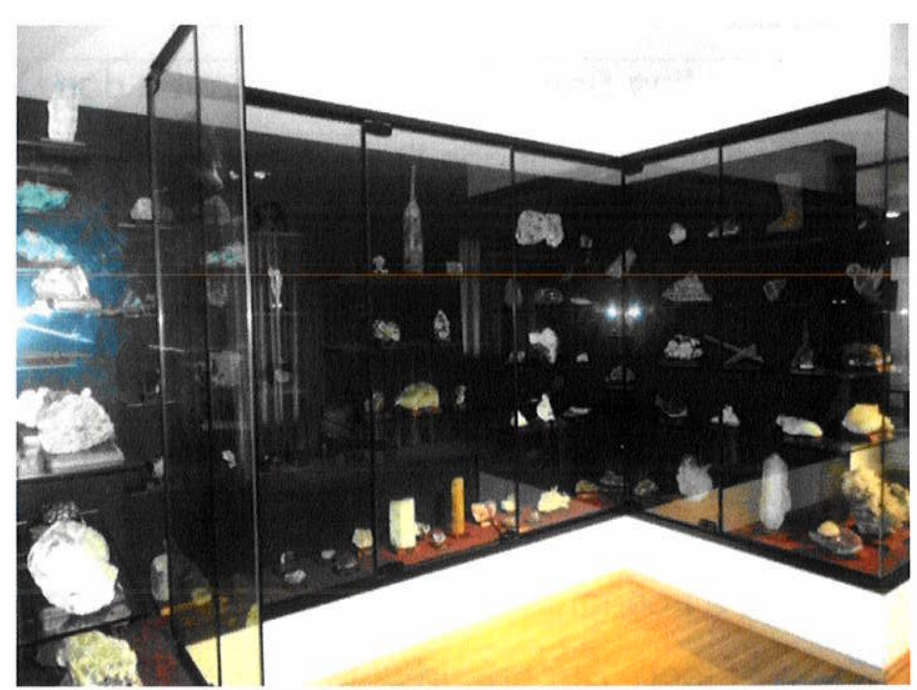

Figura 110. Museu da GEOSOL. Vitrine com diversas amostras de minerais brasileiros. Observa-se a falta de iluminação dentro das vitrines. 


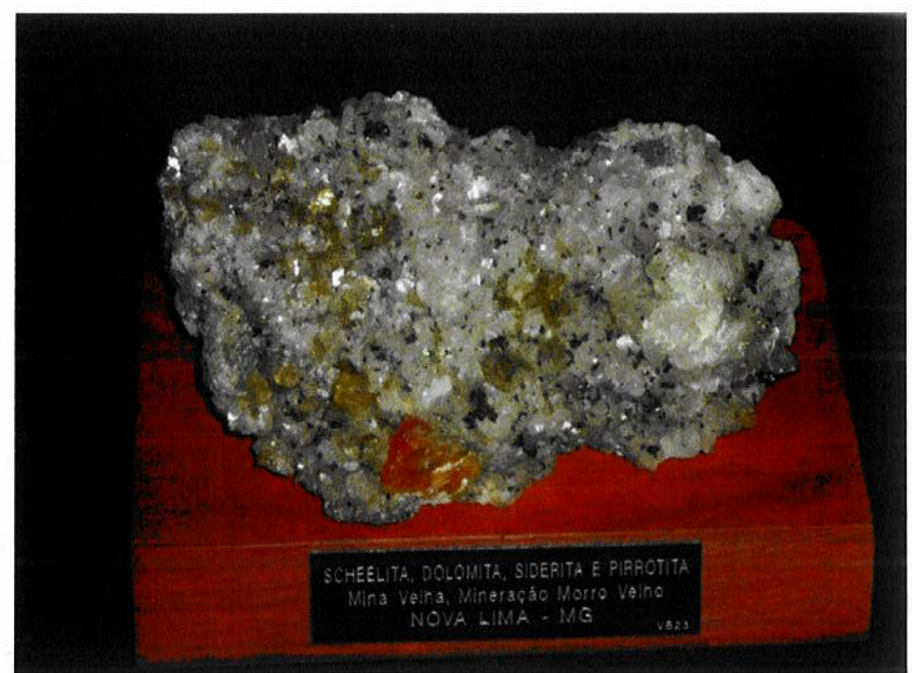

Figura 111.Museu da GEOSOL. Amostra rara e estética de scheelita proveniente da Mina Velha, Morro Velho, Nova Lima MG. Detalhe da base de madeira e da etiqueta.

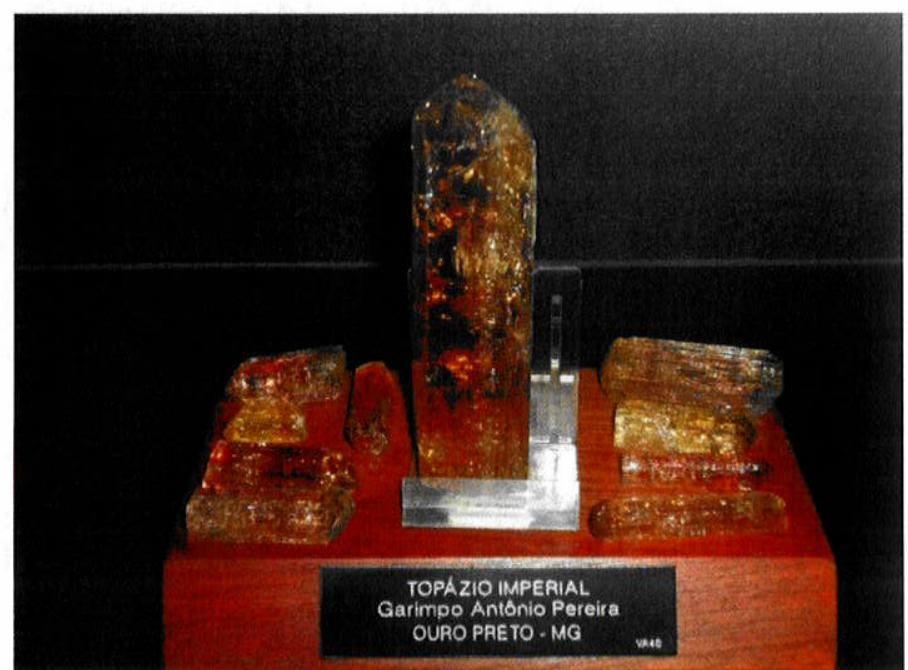

Figura 112. Museu da GEOSOL. Amostras fantásticas e estéticas de topázio imperial proveniente do Garimpo de Antônio Pereira, Ouro Preto, MG.

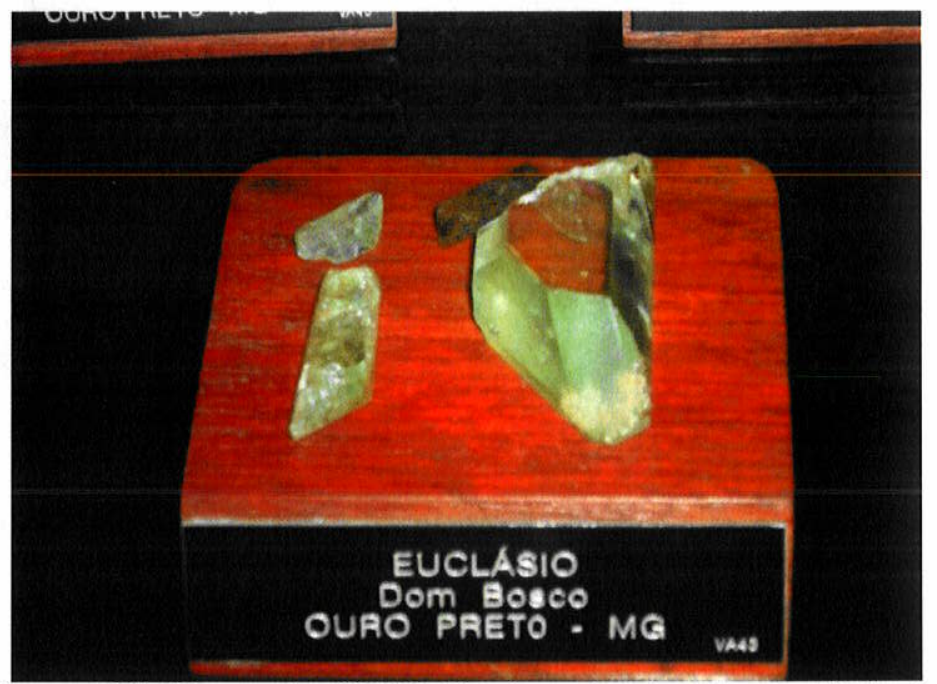

Figura 113.Museu da GEOSOL. Amostra de raro euclásio da localidade tipo provenientes de Dom Bosco, Ouro Preto, MG. 


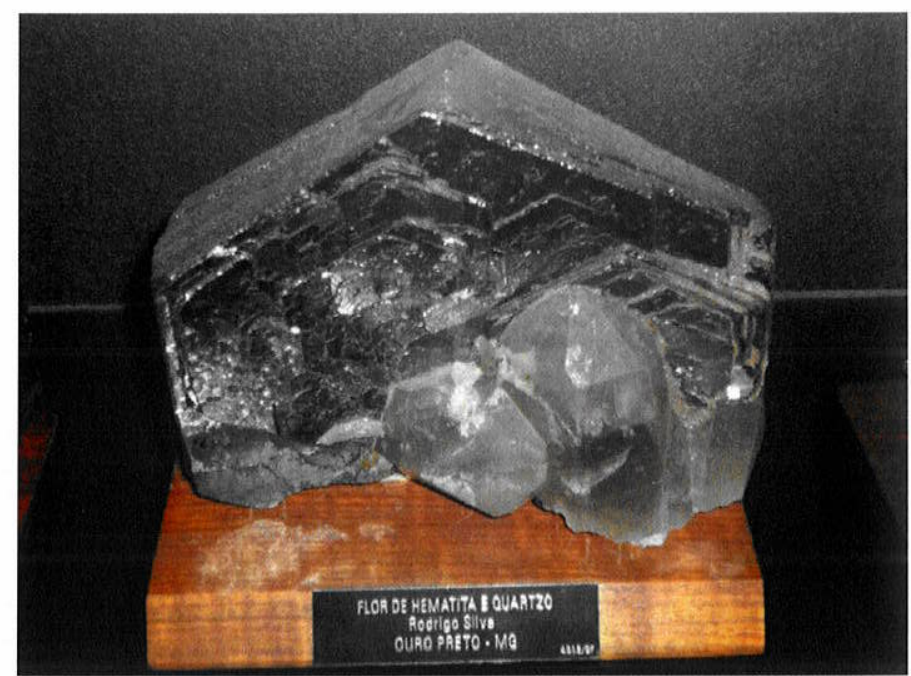

Figura 114. Museu da GEOSOL. Amostra estética de hematita de Rodrigo Silva, Ouro Preto, MG.

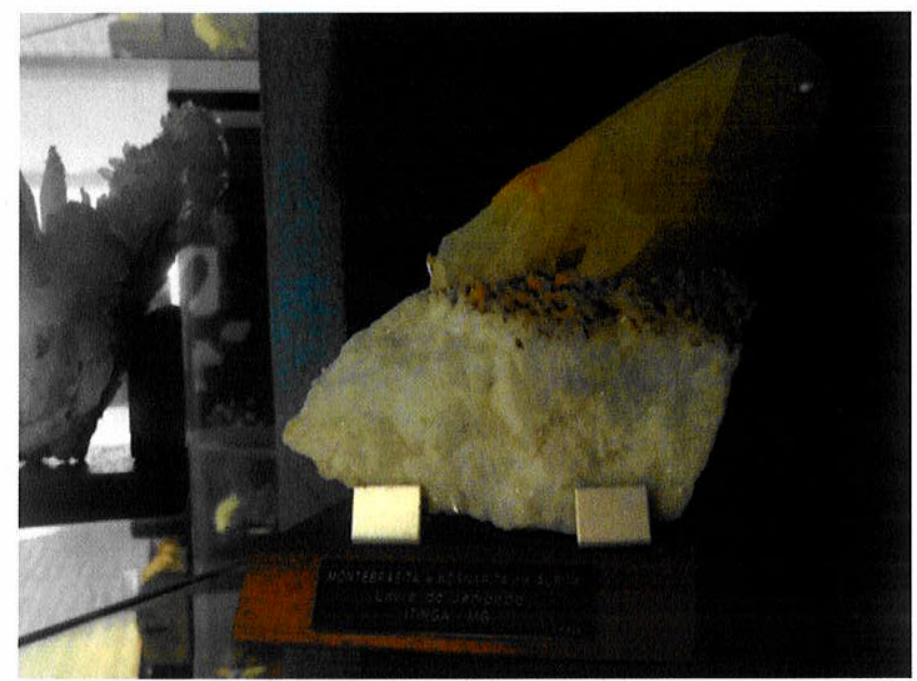

Figura 115. Museu da GEOSOL. Amostra de rara e estética montebrasita associada com kosnarita na albita do Pegmatito de Jenipapo, Itinga, MG.

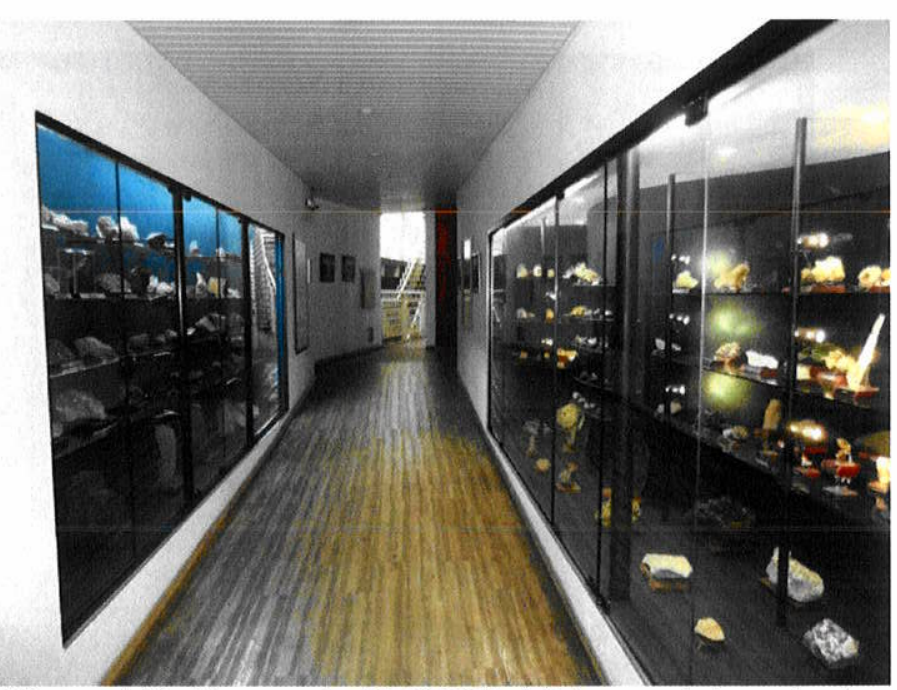

Figura 116. Museu da GEOSOL. Vista geral da entrada da empresa com as vitrines de minerais em exposição. 


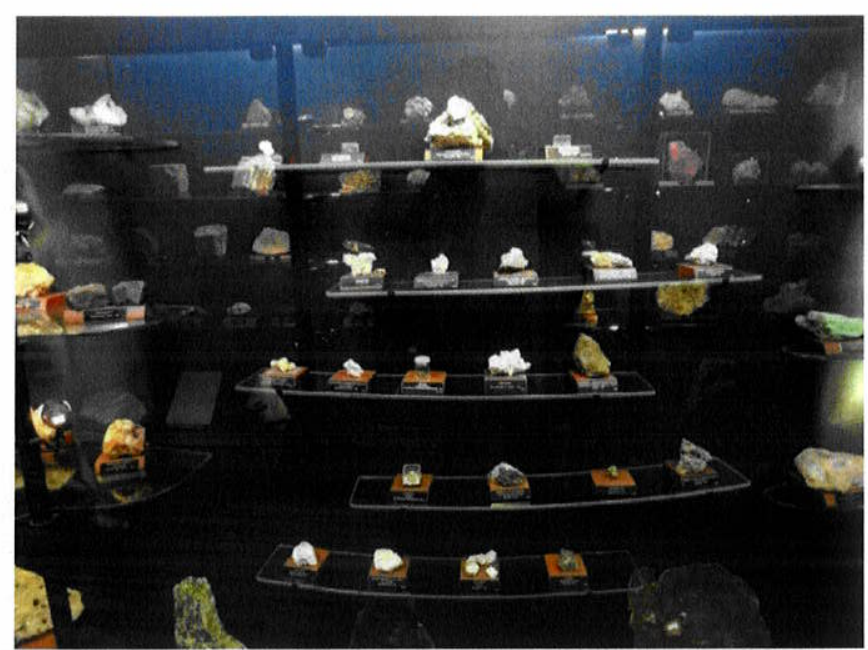

Figura 117. Museu da GEOSOL. Vitrine com dedicação especial aos minerais tipo do Brasil, expondo algumas raridades como matiolíta, atencioíta, coutinhoíta, yanomamita, entre outras.

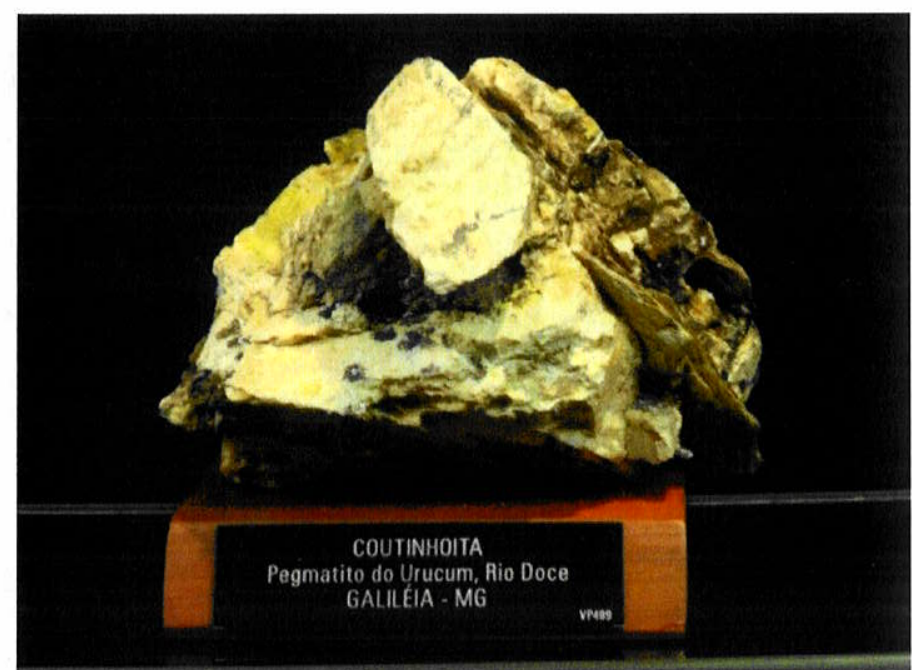

Figura 118.Museu da GEOSOL. Amostra raríssima de coutinhoíta proveniente da localidade tipo o Pegmatito de Urucum, Galileia, MG. Porém, nota-se a falta de informação na etiqueta sobre onde se observar a espécie descrita e a sua associação mineralógica.

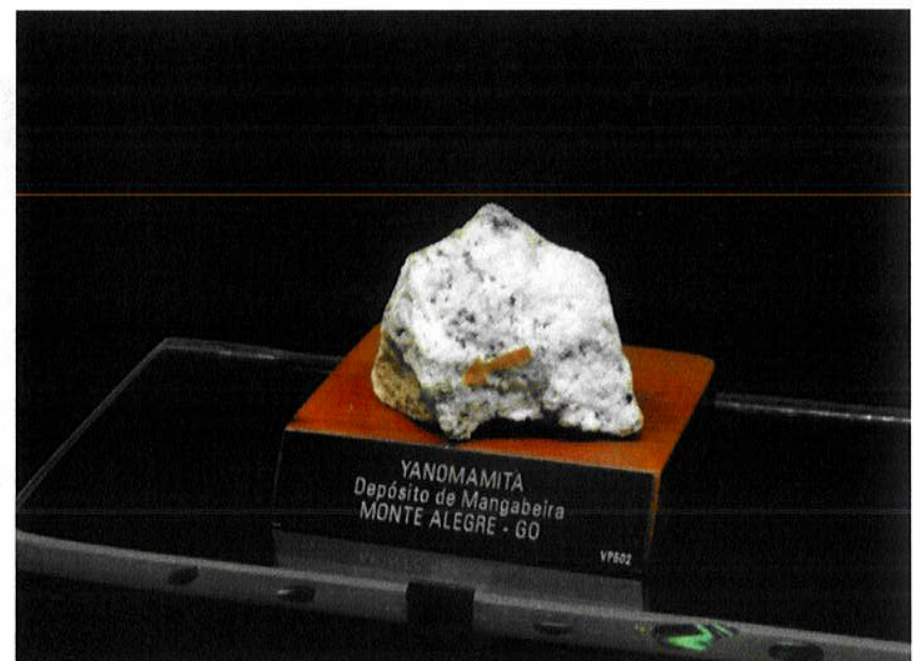

Figura 119. Museu da GEOSOL. Amostra rara de yanomamita de sua ocorrência tipo no país que é o Depósito Estanífero de Mangabeira, Monte Alegre, GO. Neste exemplar, nota-se uma seta apontando para onde o observador deve olhar, facilitando a visualização do mineral. 


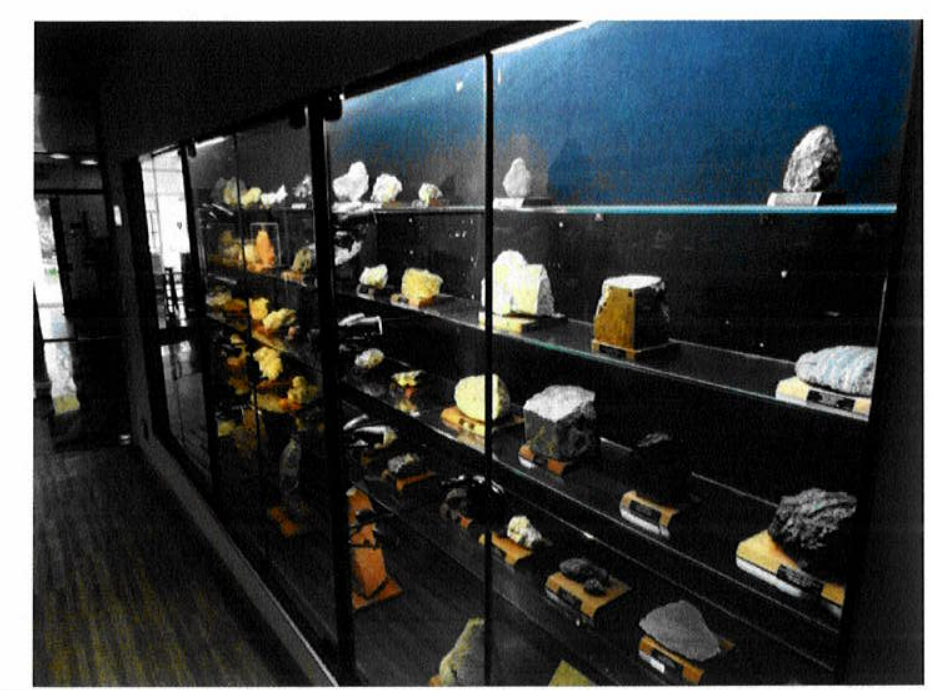

Figura 120. Museu da GEOSOL. Vitrine dedicada a diversos tipos de minérios.

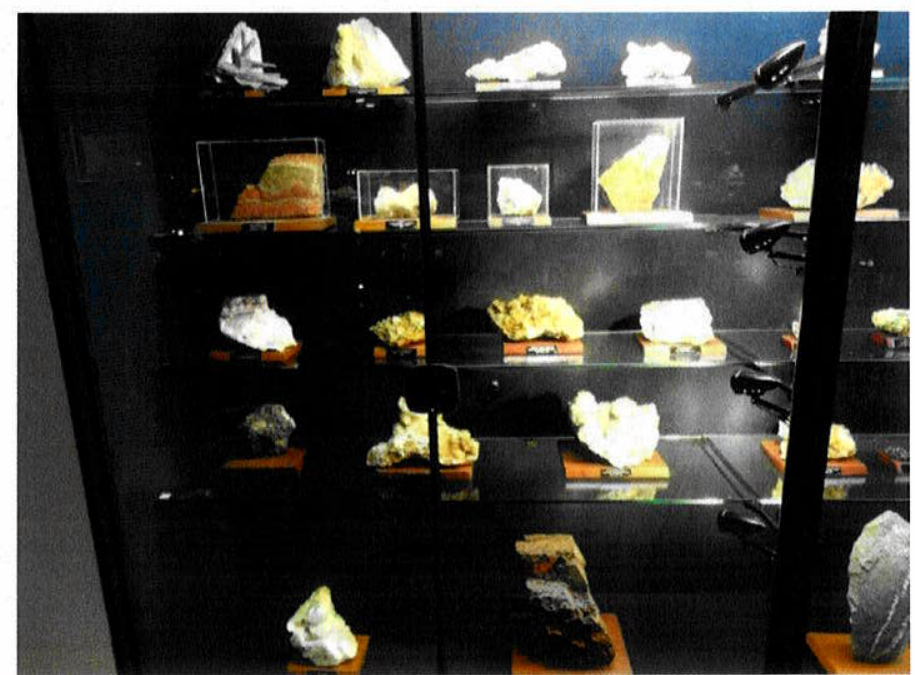

Figura 121.Museu da GEOSOL. Vitrine com vários minerais e, em detalhe, caixas hermeticamente fechadas contendo minerais higroscópicos e deliquescentes. A iluminação neste caso é pontual dentro das vitrines, melhorando a visualização das amostras.

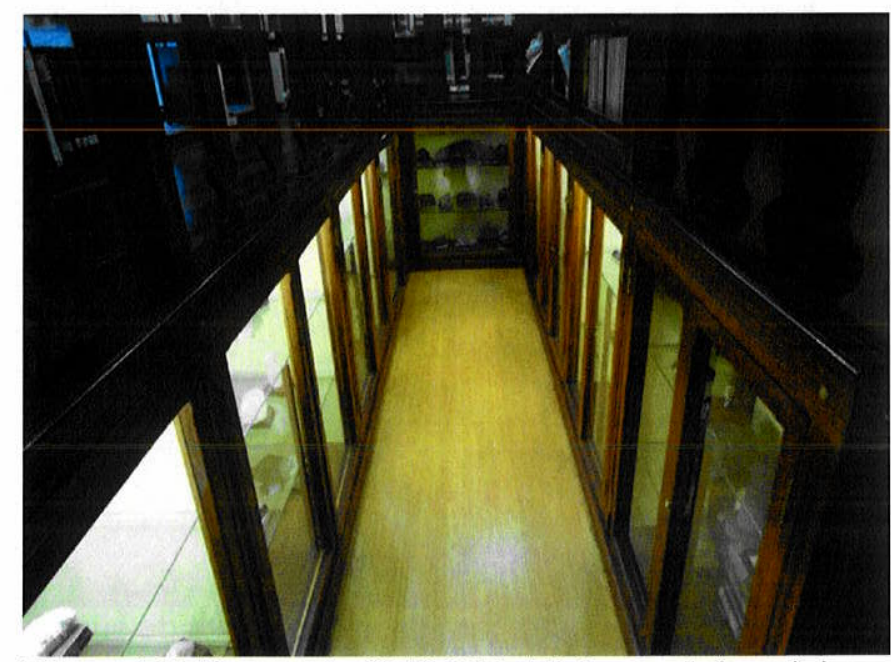

Figura 122.Museu da GEOSOL. Vista geral das vitrines com amostras minerais dentro da biblioteca. 


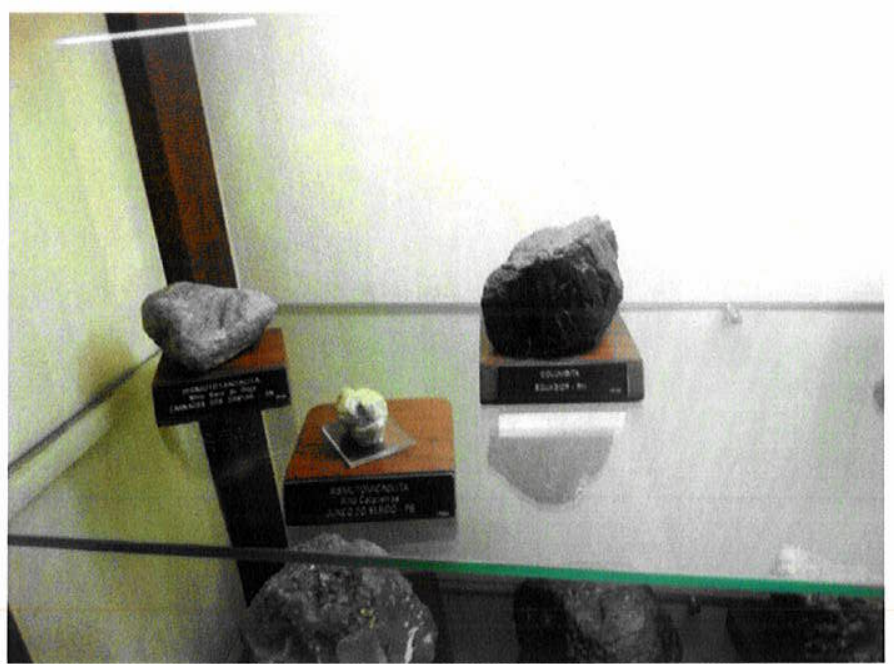

Figura 123.Museu da GEOSOL. Amostras de minerais raros brasileiros comobismutotantalita e bismutomicrolita (desacreditada).

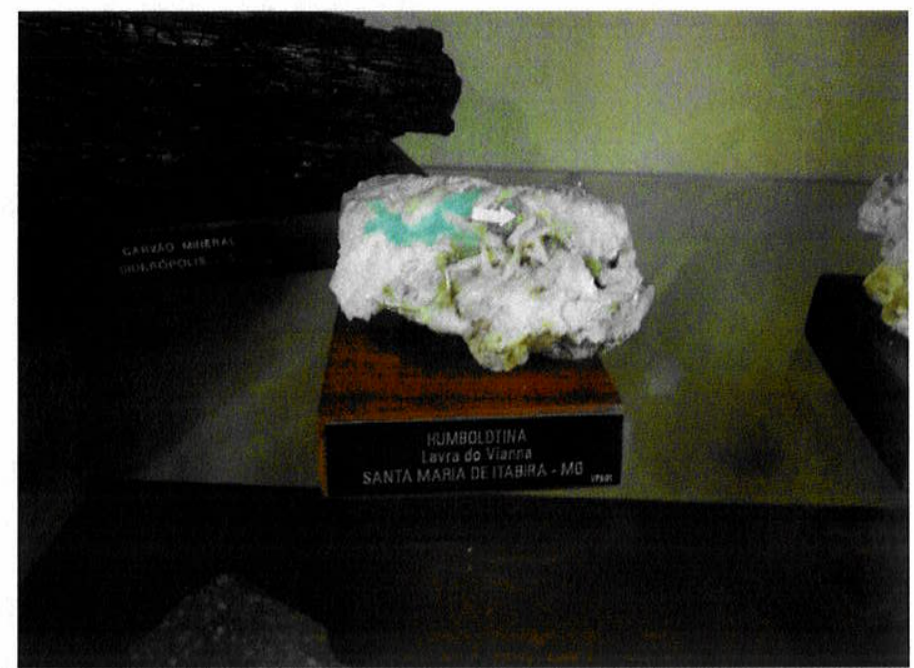

Figura 124.Museu da GEOSOL. Amostra rara de humboldtina proveniente de MG.

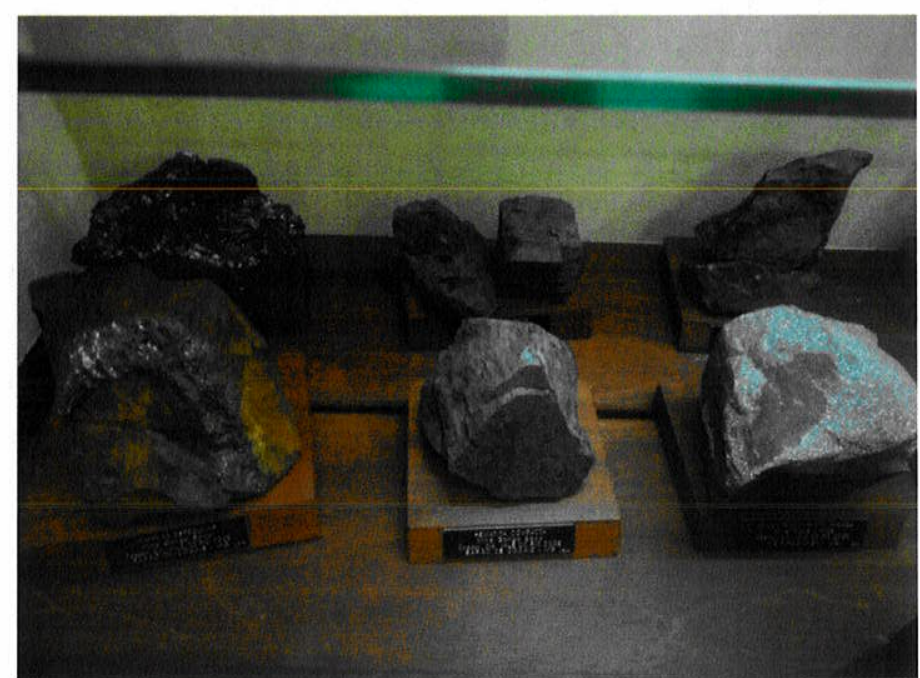

Figura 125.Museu da GEOSOL. Vitrine contendo amostras de minérios de ferro. 


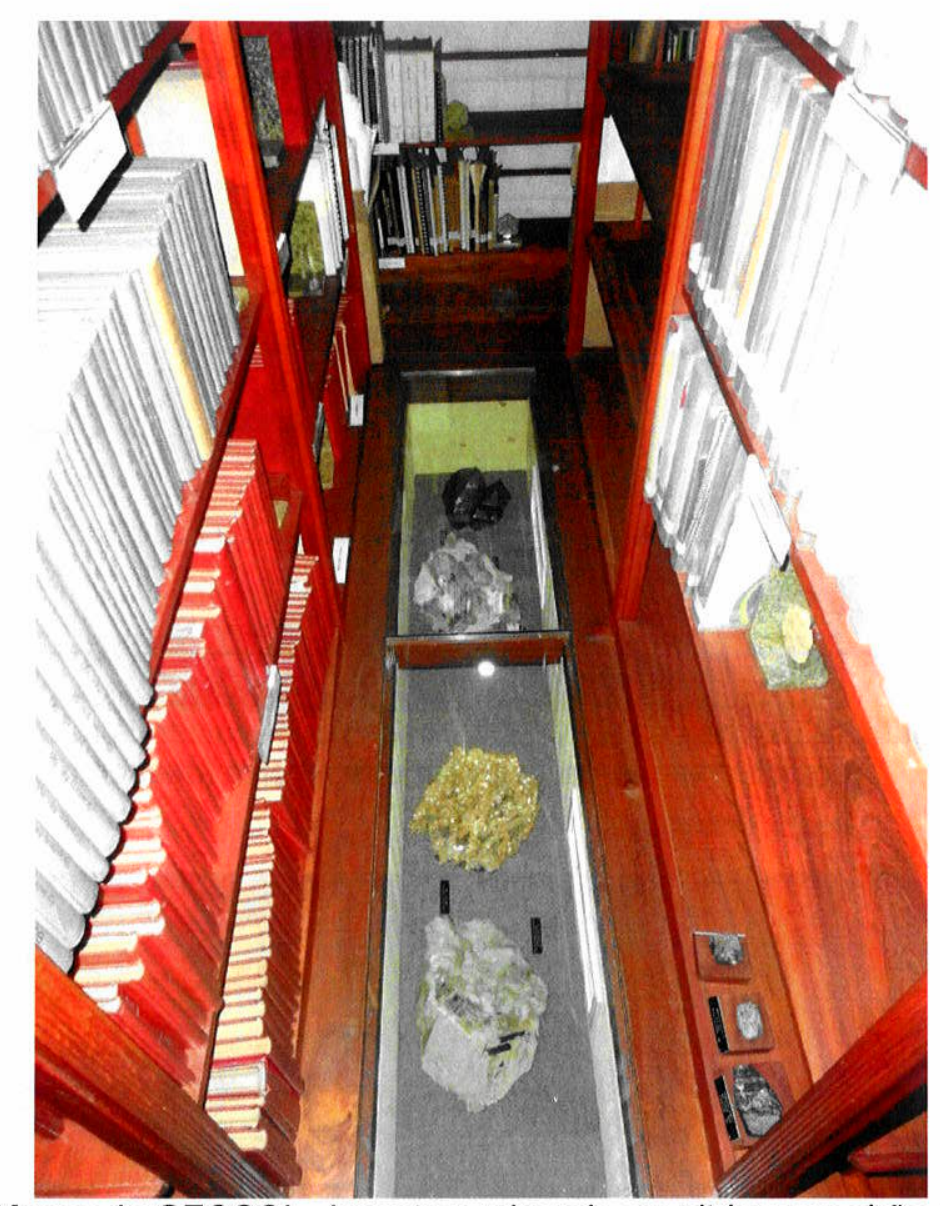

Figura 126.Museu da GEOSOL. Amostras minerais em vitrines no chão da biblioteca.

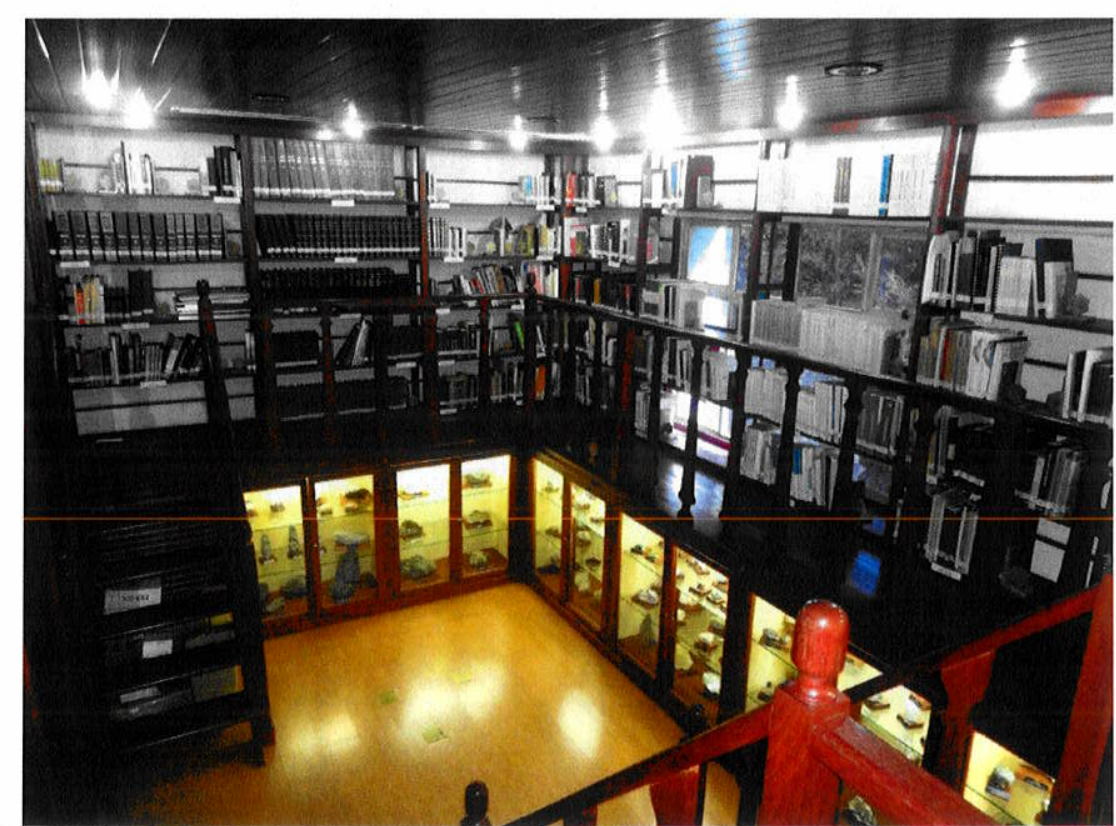

Figura 127.Museu da GEOSOL. Vista geral da biblioteca com as vitrines dos minerais. Detalhes da iluminação central do teto e da iluminação dentro de cada vitrine. 


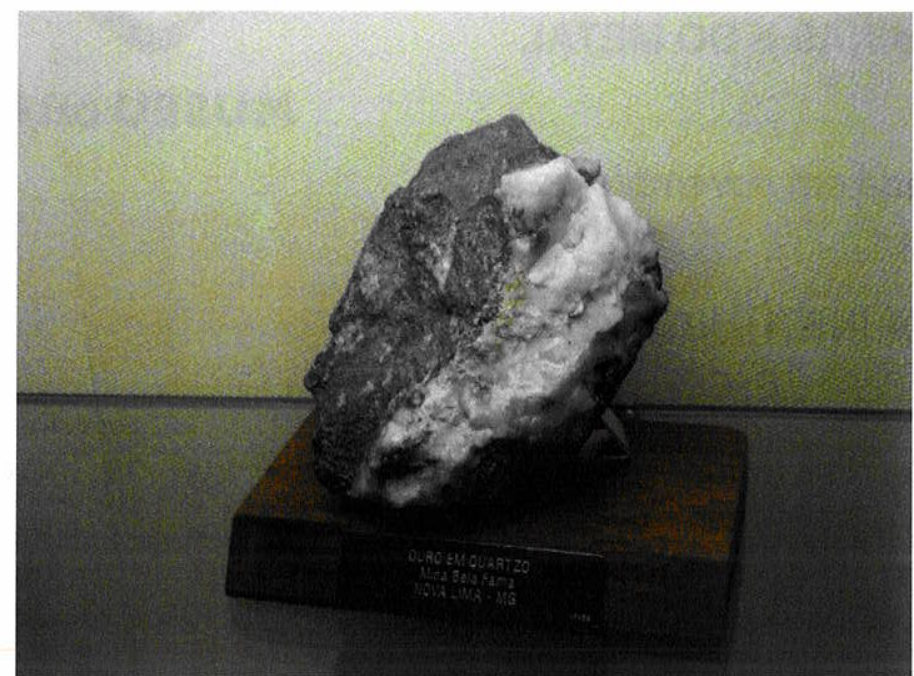

Figura 128.Museu da GEOSOL. Amostra de ouro nativo da Mina Bela Fama, Nova Lima, MG.

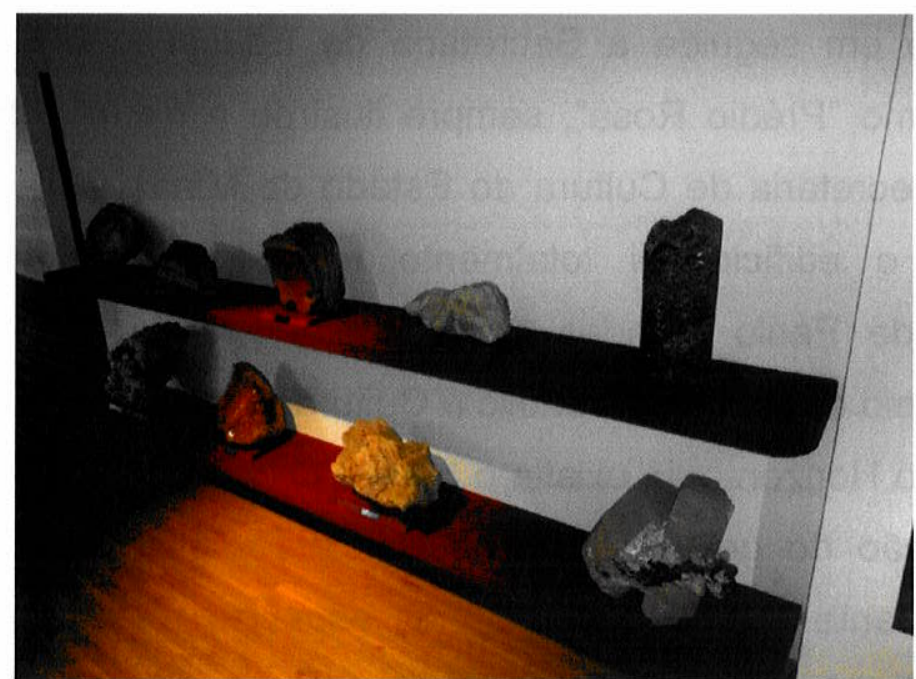

Figura 129.Museu da GEOSOL. Amostras de minerais maiscomuns, de tamanhos grandes, expostas em bancadas de madeira com feltro vermelho.

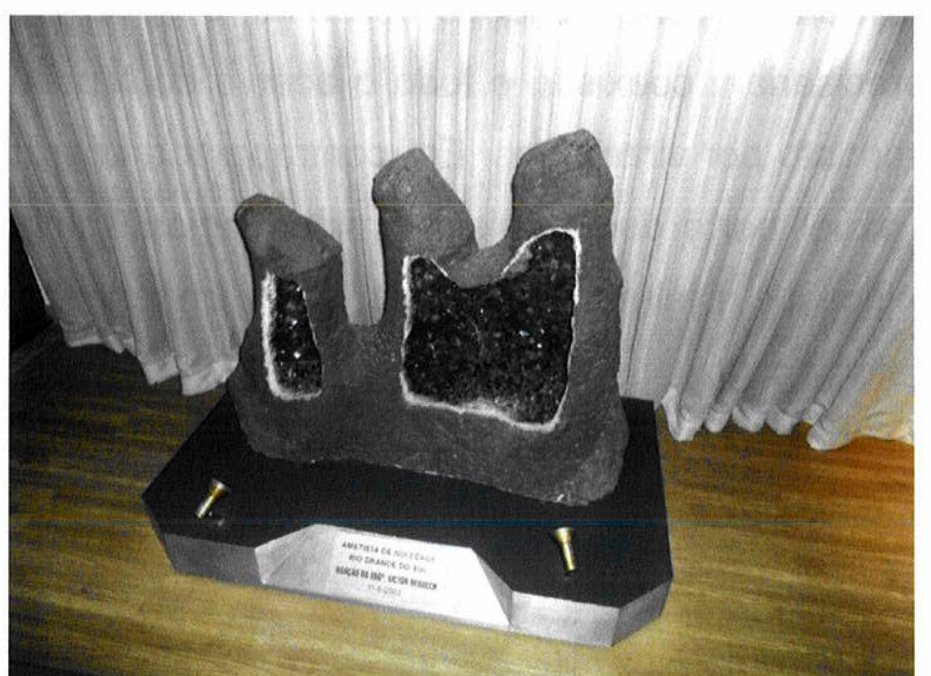

Figura 130.Museu da GEOSOL. Amostra estética de ametista (variedade do quartzo) doada pelo fundador da Geosol, Vitor Dequech. Detalhe da base com iluminação pontual. 


\section{MUSEU DAS MINAS E DO METAL}

(análise realizada em novembro de 2013)

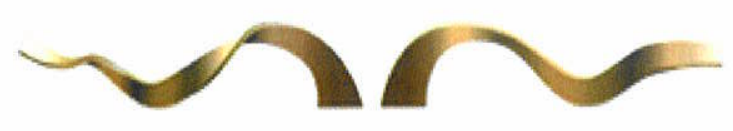

MUSEU DAS MINAS E DO METAL

\section{HISTÓRICO DA INSTITUIÇÃO}

O Museu das Minas e do Metal - MMM- fica na Praça da Liberdade, s/n. Centro, Belo Horizonte - Minas Gerais. Ele foi inaugurado em junho de 2010, localizado em uma das edificações mais antigas da cidade, que data de 12 de dezembro de 1896, no mesmo dia em que a cidade de Belo Horizonte foi fundada.

Este palácio foi construído para abrigar a primeira Secretaria de Interior do estado e logo em seguida a Secretaria de Educação e seus diversos setores. Conhecido como "Prédio Rosa", sempre ilustrou a história da cidade, e, por uma iniciativa da Secretaria de Cultura do Estado de Minas Gerais, em parceria com o Grupo EBX, o edifício foi totalmente restaurado e adequado, com projeto arquitetônico de Paulo Mendes da Rocha e projeto museográfico de Marcello Dantas, por meio de Leis de Incentivo à Cultura.

Em Belo Horizonte, já existia o Museu de Mineralogia, que possuía a coleção e documentação do geólogo e pesquisador Professor Djalma Guimarães ${ }^{8}$, uma coleção importante composta por várias espécies minerais, rochas, meteoritos e documentos históricos.

De acordo com a curadora de geociências do museu, Márcia Regina Carvalho dos Santos Guimarães, com a criação do MMM, o governo decidiu que estes dois museus não precisariam coexistir, e todo o acervo do Museu Djalma Guimarães foi cedido em comodato por vinte anos. Em contrapartida criaram uma galeria especial que, além de expor parte desta coleção mineralógica, também conta a história da trajetória científica de Djalma Guimarães e do engenheiro Eliezer Batista ${ }^{9}$, com imagens e objetos antigos.

A proposta do MMM é relatar através de ambientes modernos e interativos, a história da humanidade pelas eras do metal, apresentando um novo olhar sobre o

\footnotetext{
${ }^{8}$ Vide capítulo II p. deste trabalho.

${ }^{9}$ Engenheiro brasileiro, Ministro das Minas e Energia no mandato do presidente João Goulart (19611964) e foi ex-presidente da Companhia Vale do Rio Doce. FGV/CPDOC. Eliezer Batista. Disponível em:< http://cpdoc.fgv.br/producao/dossies/Jango/biografias/eliezer_batista>. Acesso em: 11 dez. 2013.
} 
patrimônio cultural de Minas Gerais e o desenvolvimento econômico: do ciclo do ouro à indústria de microprocessadores (BELO HORIZONTE-MINAS GERAIS, 2013). De acordo com a curadora Márcia, foram selecionadas dez minas - ferro, ouro, diamante, nióbio, zinco, gemas, grafita, alumínio e calcário - para contar a história de Minas Gerais e do país. Personagens históricos como a Imperatriz Teresa Cristina $^{10}$, Fernão Dias ${ }^{11}$; D. Pedro II e Barão de Eschwege ${ }^{12}$ e fictícios saem das páginas dos livros para receber os visitantes, com relatos sobre o Brasil nas monitorias.

\section{ORGANIZAÇÃO E FUNCIONAMENTO}

A gestão do museu é realizada pela Associação do Museu das Minas e do Metal que recebe atualmente apoio do Grupo Gerdau, e de ações desenvolvidas no próprio museu, como locação de espaços para festas, loja de souvenires, lanchonete e a bilheteria.

A curadora de geociências Márcia Guimarães relatou que o museu possui uma equipe de trabalho bem capacitada, pois a área educativa do museu é atuante em todos os setores, e possui uma rede de colaboradores muito eficiente.

Os monitores são capacitados pela equipe da ação educativa, que possui material específico para treiná-los ao atendimento ao público, bem como cursos, palestras, vídeos próprios, que deixam a equipe preparada para receber todos os tipos de público e de todas as idades. São 20 estudantes de diversas áreas como história, geografia, engenharia química, belas artes, entre outras.

\footnotetext{
10 Imperatriz Teresa Cristina foi esposa de D. Pedro II, e foi conhecida como "a Imperatriz Arqueóloga" estudiosa buscava participar de expedições de pesquisa. RAINHAS TRÁGICAS. Imperatriz Teresa Cristina. Disponível em: http://rainhastragicas.com/2013/07/22/d-teresa-cristinauma-imperatriz-silenciosal. Acesso em: 11 jan. 2014.

${ }^{11}$ Fernão Dias Paes Leme foi um bandeirante, conhecido como "Caçador de Esmeraldas" assumiu a tarefa de buscar riquezas para a Coroa Portuguesa no século XVII. Biblioteca Virtual. Disponivel em: http://www. bibliotecavirtual.sp.gov.br/turismo-interior-santanadoparn. Php. Acesso em: $11 \mathrm{dez}$. 2013.

${ }^{12}$ Alemão Wilhelm Ludwig Von Eschwege, aluno de Werner, geólogo e metalurgista foi intendente das minas de ouro e curador do gabinete de mineralogia no Rio de Janeiro entre 1808 e 1821. Deixou diversas contribuições científicas para a mineralogia no Brasil. CPRM serviço geológico do Brasil. Barão de Eschwege. Disponível em: http://www.cprm.gov.br/publique/cgi/cgilua.exe/sys/start.htm?infoid=519\&sid=8. Acesso em: $11 \mathrm{dez}$. 2013.
} 
O museu utiliza tecnologia de ponta para mostrar o universo das rochas e dos minerais, os processos de transformação dos minérios e a importância deles para a vida humana e o desenvolvimento social, econômico e cultural, o que chama a atenção do público infanto-juvenil. Em ambientes virtuais, os visitantes podem interagir com os espaços criados para permitir intensa vivência pelo mundo dos metais, contribuindo de maneira lúdica para o conhecimento nesta área. Entretanto, observa-se a ausência de minerais expostos nestes setores, o que enriqueceria os espaços.

Os objetivos da instituição são pautados na educação, como o de despertar vocações, reconhecer o trabalho da mineração como ponto inicial da economia do estado de Minas Gerais, bem como divulgar e popularizar o conhecimento científico em geociências.

Conforme as informações disponibilizadas pela curadora do museu, o MMM possui um setor de comunicação com profissionais que realizam a divulgação nas redes sociais, no site próprio do museu, release nos veículos de comunicação locais, e no principal circuito turístico da cidade. O Museu faz parte do Circuito da Praça da Liberdade, onde recebem muitos turistas.

A entrada custa $R \$ 6,00$ para o público geral e meia-entrada é disponível para professores, estudantes e terceira idade. A visita tem duração livre, conforme o interesse do público. Os roteiros educativos possuem uma média de $1 \mathrm{~h} 30 \mathrm{~m}$. O público alvo são estudantes do ensino básico, que de acordo com Márcia constitui $70 \%$ de seu público total mensal, em torno de 5.000 pessoas. Para aperfeiçoar o atendimento e conhecer o perfil de seu público, as recepcionistas aplicam pesquisas aleatórias durante todo ano, sendo controlado pelo educativo do museu.

Pelas palavras da curadora, o Museu das Minas e do Metal é referência na área das geociências para a cidade. Estão bem localizados e possuem uma média de público que está dentro de suas metas. O museu só precisa ser reconhecido pelos moradores da cidade, que ainda desconhecem seu potencial cultural, de lazer e entretenimento.

\section{ESTRUTURA FÍSICA}

O Museu tem acessibilidade para quem possui mobilidade reduzida. O local possui acesso com elevadores, bem como disponibilidade de cadeiras de roda e 
bengalas para quem necessitar. A comunicação do museu desenvolveu um aplicativo em tablets para deficientes visuais e auditivos, o que facilita o entendimento dos espaços e seus conteúdos. Todos os ambientes possuem câmeras de segurança, vigilantes e saídas de emergência. Os salões são todos climatizados, exceto as reservas técnicas.

O MMM também possui uma lanchonete e loja de souvenir abertos ao público, com acesso separado do museu, mas com toda sua temática envolvida, proporcionando segurança e conforto para seus visitantes.

\section{AÇÃO EDUCATIVA E CULTURAL}

A ação educativa e cultural do MMM é o ponto forte da instituição. Sua equipe possui profissionais altamente capacitados e uma rede de colaboradores que elaboram roteiros de visitação e conteúdos que visam colaborar com os conteúdos escolares de maneira interdisciplinar.

As visitas de grupos escolares devem ser agendadas com antecedência, e todos os professores que levam suas turmas, são obrigados a participar de uma capacitação de educadores antes da data agendada. Assim, eles possuem mais propriedade para elaborar a visita e ainda podem escolher os roteiros educativos do museu entre três sugestões (MUSEU DAS MINAS E DO METAL, 2013):

- MAMA ÁFRICA - Uma aventura através da Geologia e das mudanças ocorridas no processo da formação da Terra. O reconhecimento da fundamental importância do continente africano no desenvolvimento do "homo sapiens" e na formação da cultura brasileira;

- VIAJEIROS - Um jardim imaginário, onde se encontram viajeiros que trilharam a história do Brasil. São personagens de diferentes épocas, de Debret e Dom Pedro II a Burle Marx;

- HORIZONTE SECRETO - Explorar códigos antigos e belos que sempre intrigaram o homem, desvendar os novos mistérios do mundo, o Micro e o Macro inteligíveis de Djalma Guimarães e Eliezer Batista.

A ação educativa e cultural é direcionada para o público geral, pois a equipe promove atividades para todas as idades, desde peças de teatro, oficinas, palestras e cursos em salas especiais e dois auditórios para 100 pessoas cada. Esta parte é 
gratuita e todos os temas das atividades estão relacionados com a mineração, metalurgia e produção mineral.

\section{ACERVO MINERALÓGICO}

O Museu das Minas e do Metal (MMM) tem uma área expositiva muito bonita e moderna dentro dos novos padrões da museologia. O local tem iluminação geral reduzida, porém em cada módulo onde os minerais estão localizados e expostos, há uma iluminação pontual, sendo fácil a observação dos exemplares e de detalhes das amostras.

As vitrines são muito modernas e atrativas, além disso, em algumas delas encontra-se interatividade, como a narração sobre um mineral, grupo ou classe mineral e vídeos relacionados à temática.

Os minerais estão classificados e sistematizados de acordo com a classificação química de Dana. Apesar da ordenação dos minerais ser baseada nas classes químicas, o acervo exposto procura a busca de exemplares mais estéticos do que espécies mais raras. No setor expositivo, há vitrines com outros temas como: réplicas dos maiores e mais importantes e famosos diamantes do mundo e outra de pedras lapidadas. Encontra-se ainda neste setor expositivo uma vitrine dedicada exclusivamente aos minerais tipos brasileiros como: brazilianita, euclásio, crisoberilo, moraesita, ruifrancoita, barbosalita e guimarãesita. Nesta vitrine, ainda há a djalmaita, renomeada uranomicrolita e depois desacreditada, por tratar-se provavelmente de hidrokenomicrolita ou hidroxikenomicrolita.

As etiquetas dos minerais contêm informações simples (algumas informações são bilíngues português-inglês), compostas por: nome da espécie, composição química e localidade geográfica. As localidades possuem informações simples e incompletas, faltando informações importantes e necessárias para a melhor compreensão das ocorrências das espécies minerais. As etiquetas estão separadas dos minerais e esses estão numerados. Em geral, os minerais estão colocados em bases de metal, que por um lado são interessantes e conseguem expor as amostras com mais detalhes, mas essas bases com o tempo podem sofrer oxidação e assim alterando e reagindo quimicamente com algumas das espécies minerais.

Em todo o acervo exposto, algumas amostras se destacam pela beleza e principalmente pela raridade, como é o caso das duas amostras de fenacita que o 
museu possui em sua coleção. As amostras são muito grandes para a espécie, que é relativamente rara e em geral forma cristais de tamanhos menores, e são provenientes de uma localidade histórica e famosa brasileira que é o rio Piracicaba, em São Miguel de Piracicaba, no estado de Minas Gerais.

A reserva técnica do museu divide-se em duas áreas, uma área expositiva com parte desta reserva técnica já foi classificada e revisada, onde se podem observar bonitas e raras amostras como um octaedro de diamante negro. Neste setor expositivo pertencente a reserva técnica, observam-se ainda algumas amostras de fósseis de várias ocorrências. O grande destaque para essa área é um dos expositores estar dedicado à memória do geólogo e mineralogista Djalma Guimarães, com amostras de rochas e suas respectivas lâminas delgadas, medalhas, cartões personalizados, a sua máquina de escrever e a sua caderneta de campo,importante registro da história geológica do país. Existem ainda diversas amostras guardadas na parte não exposta do mobiliário da reserva técnica, sem classificação ou organização.

Na segunda área da reserva técnica, localizada em uma sala, encontram-se diversas caixas de plástico em estantes cheias de amostras todas misturadas e sem nenhuma classificação ou sistematização. Algumas amostras possuem uma numeração que, em geral, está danificando os próprios minerais, pois além de serem marcações grandes, estão em posições equivocadas nas amostras, pois as numerações deveriam ser pequenas e pouco visíveis nos exemplares.

O museu possui algumas áreas interativas e lúdicas que mostram minerais de formas curiosas e interessantes. O acervo do museu ainda apresenta uma boa coleção de meteoritos.

O MMM possui em seus acervos mineralógicos, algumas importantes espécies da mineralogia-tipo brasileira e isso contribui para a preservação da memória da mineralogia brasileira, sendo um local de divulgação e fomento dessa temática, mas poderia ter um acervo ainda mais significativo e importante para a mineralogia brasileira e mundial. De maneira geral possui algumas amostras importantes, pois apresenta um espaço museal moderno, amplo e atrativo, além de contar com o apoio do governo do estado de Minas Gerais e de importante empresa como a Gerdau. 
Quadro 21 - Quadro de minerais tipo brasileiros pertencentes ao acervo do Museu das Minas e do Metal com suas respectivas ocorrências (exemplos):

\begin{tabular}{|c|}
\hline $\begin{array}{c}\text { Quadro de minerais tipos brasileiros pertencentes ao acervo do } \\
\text { Museu das Minas e do Metal com suas respectivas ocorrências } \\
\text { (exemplos): }\end{array}$ \\
\hline Barbosalita - Galiléia, MG. \\
\hline $\begin{array}{c}\text { Brazilianita - Lavra do Telírio, Linópolis, } \\
\text { Divino das Laranjeiras, MG. }\end{array}$ \\
\hline Crisoberilo - Teixeira de Freitas, MG; Padre Paraíso, MG; Monte Azul, MG. \\
\hline Euclásio - Conselheiro Pena, MG. \\
\hline Guimarãesita com Zanazziita - Córrego do Piauí, Itinga, MG. \\
\hline Moraesita - São Geraldo do Baixio, MG. \\
\hline Ruifrancoíta - Lavra da Proberil, Galiléia, MG. \\
\hline
\end{tabular}

Quadro 22 - Quadro de minerais brasileiros pertencentes ao acervo do Museu das Minas e do Metal com suas respectivas ocorrências (exemplos):

Quadro de minerais importantes brasileiros pertencentes ao acervo do Museu das Minas e do Metal e suas respectivas ocorrências (exemplos): Anatásio- Tapira, MG.

Antimônio nativo - Santo Antônio de Jesus, BA.

Bismuto nativo - Conceição do Mato Dentro, MG.

Cerussita - Mina do Pelado, Boquira, BA.

Cinábrio - Ouro Preto, MG.

Descloizita - Januária, MG.

Diamante - Diamantina, MG; Abaeté, MG.

Fenacita - Rio Piracicaba, São Miguel Piracicaba, MG.

Fluorapatita - Lavra do Sapo, Goiabeiras, MG.

Gibbsita - Ouro Preto, MG.

Grafita - Jequitinhonha, MG.

Hainita - Pedreira Bortolan, Poços de Caldas, MG.

Hematita com rutilo - Novo Horizonte, BA.

Mercúrio nativo - Ouro Preto, MG.

Ouro nativo - São João del Rei, MG; Alta Floresta, MT.

Pirrotita - Mina Velha, Morro Velho, Nova Lima, MG.

Topázio - Araçuai, MG.

Uranmicrolita (djalmaita) mineral desacreditado - Nazareno, MG.

Willemita - Mina Morro da Usina, Vazante, MG. 


\section{RELAÇÃO DE FOTOS DO MUSEU DAS MINAS E DO METAL}

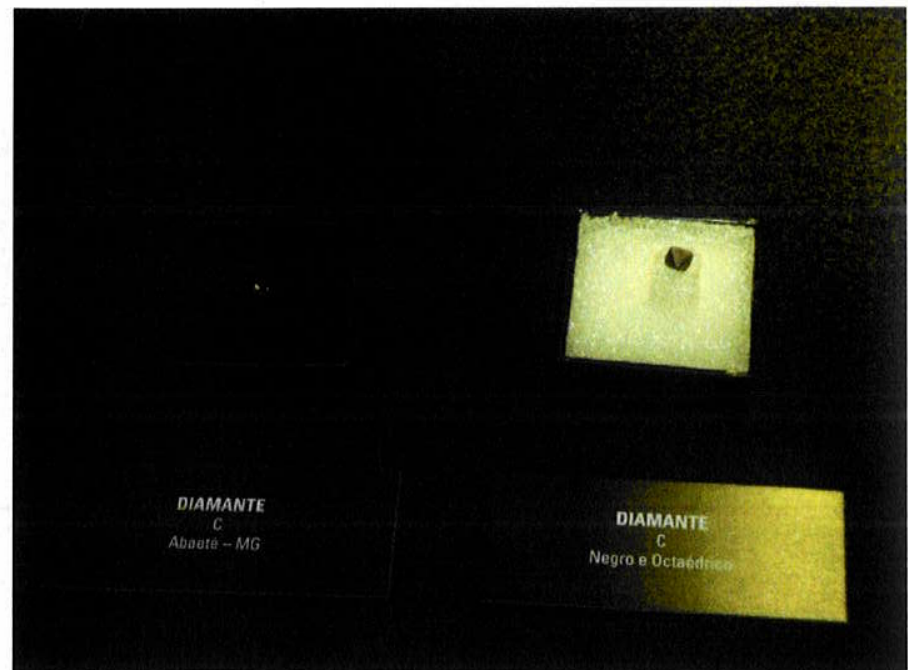

Figura 131. Museu das Minas e do Metal. Detalhes de duas amostras de diamantes com etiquetas contendo informações simples. Destaque para o belo octaedro de diamante negro.

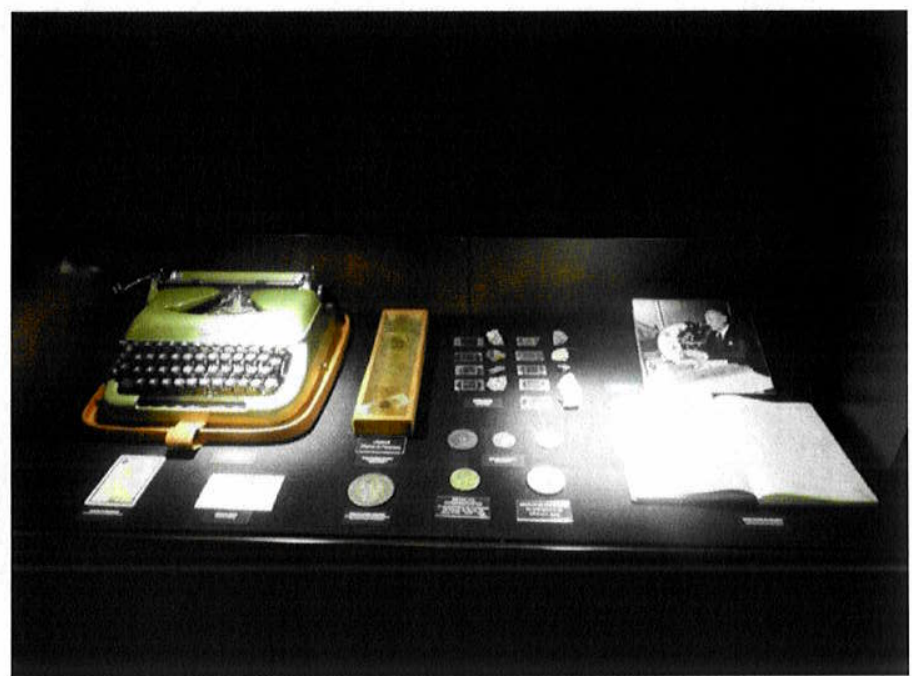

Figura 132. Museu das Minas e do Metal. Vitrine em homenagem ao geólogo e mineralogista Djalma Guimarães. 


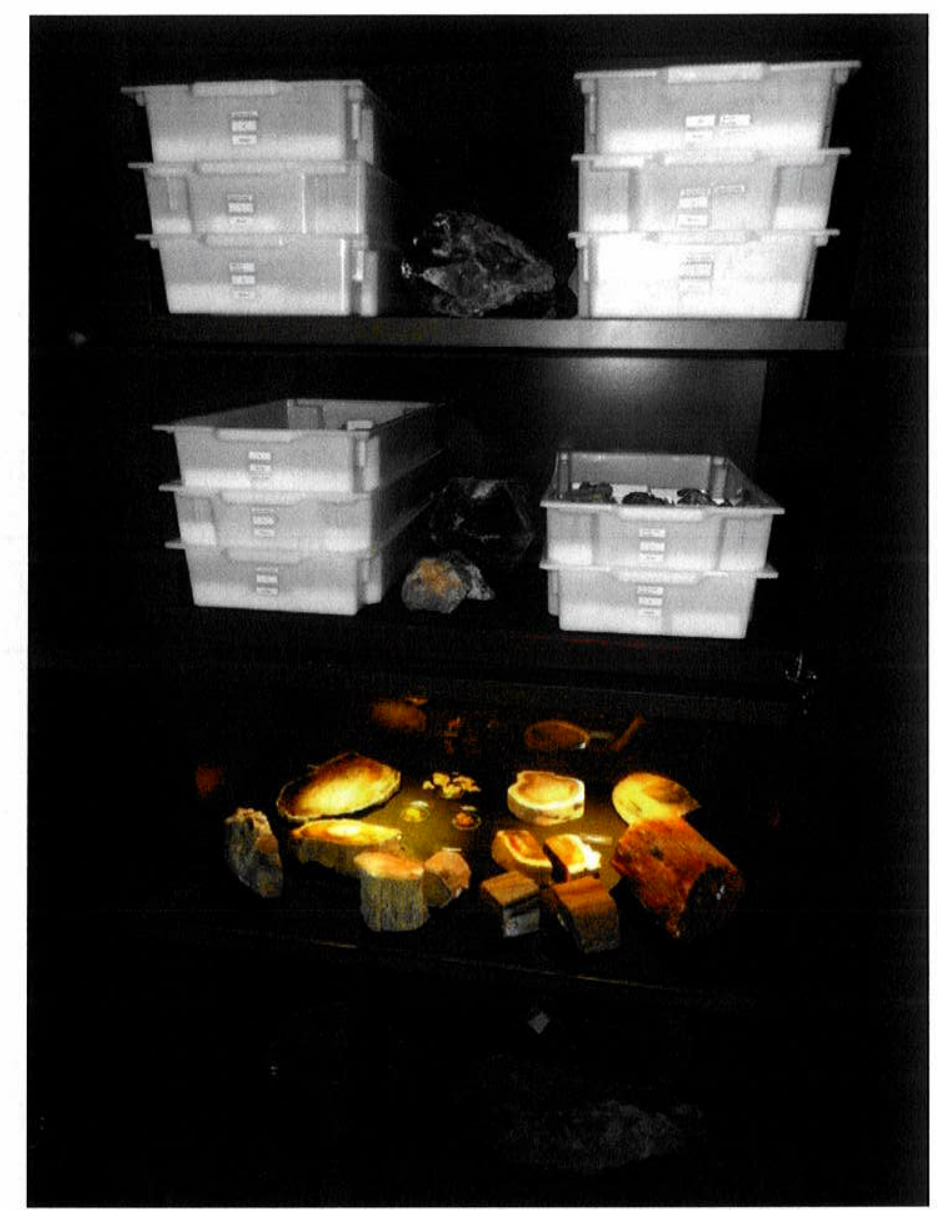

Figura 133. Museu das Minas e do Metal. Detalhes do mobiliário da reserva técnica.

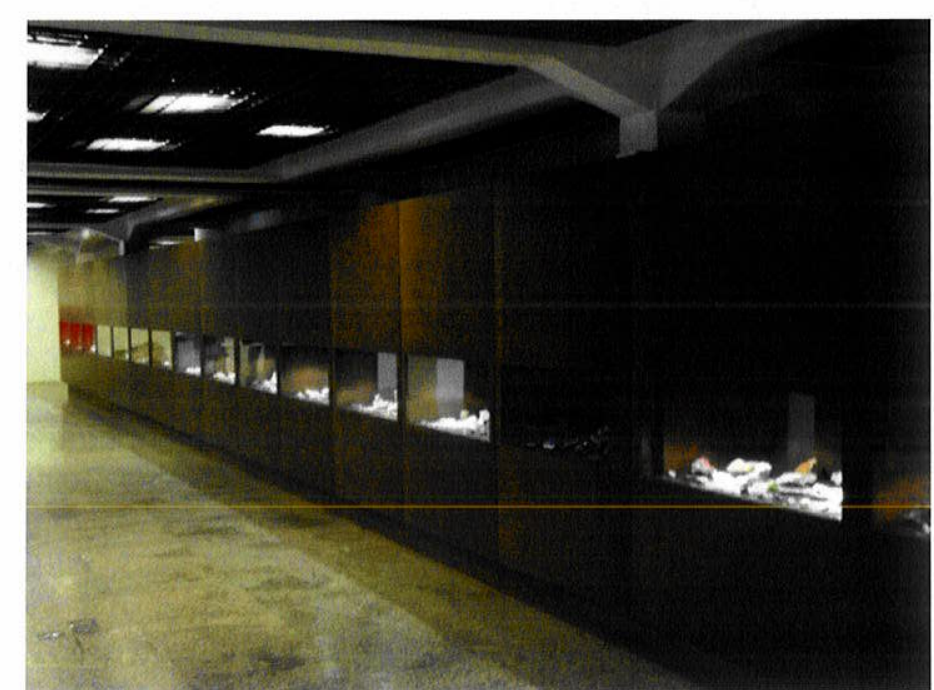

Figura 134. Museu das Minas e do Metal. Mobiliário com vitrines na parte inferior com amostras minerais da reserva técnica. 


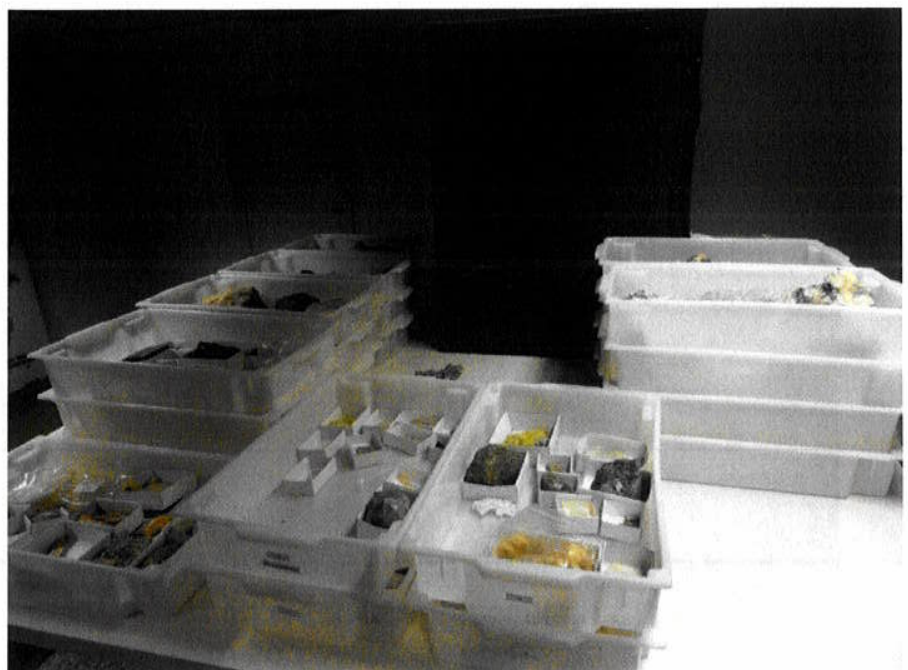

Figura 135. Museu das Minas e do Metal. Caixas de plástico contendo amostras minerais da reserva técnica.

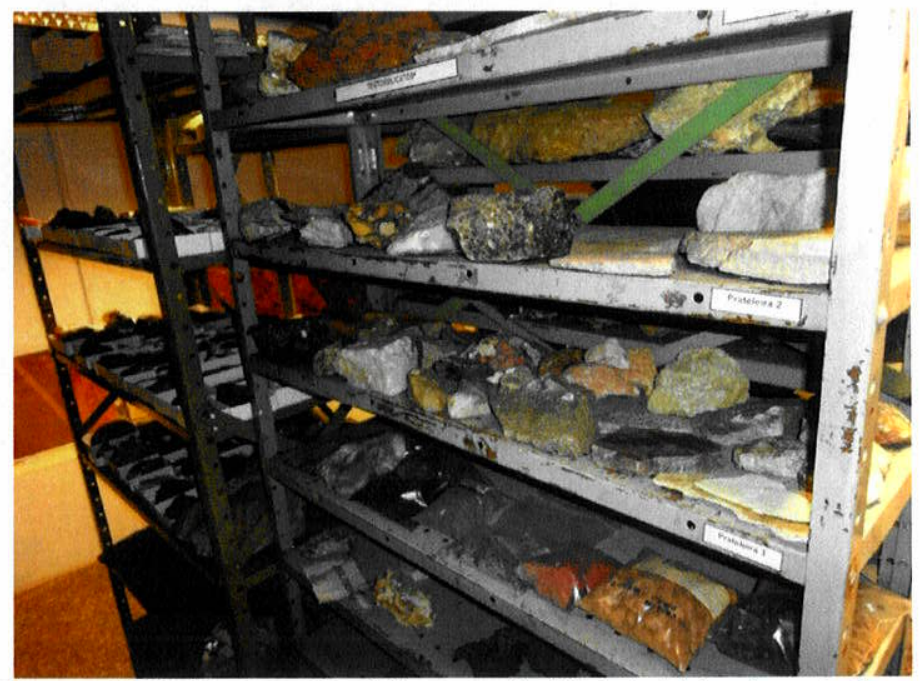

Figura 136. Museu das Minas e do Metal. Estantes de ferro contendo diversas amostras da reserva técnica sem classificação.

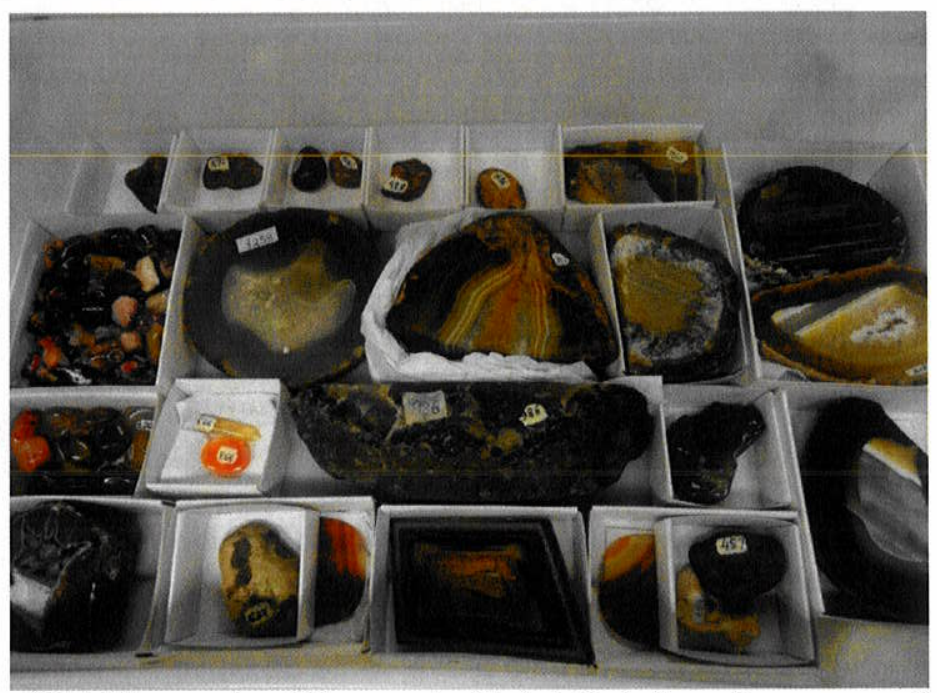

Figura 137. Museu das Minas e do Metal. Detalhes da numeração nas amostras da reserva técnica; observa-se a desproporcionalidade nas marcações. 


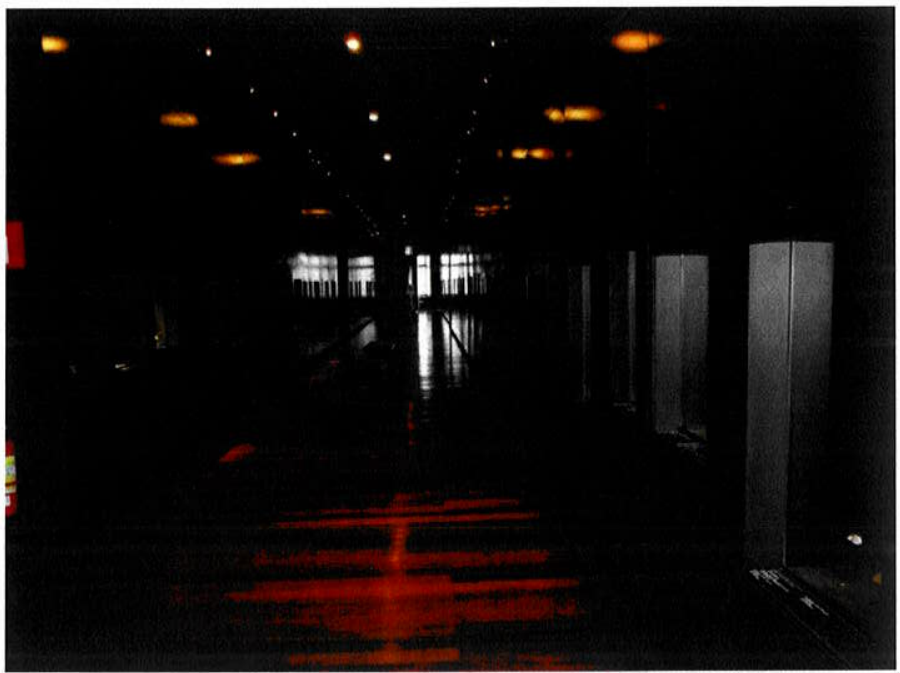

Figura 138. Museu das Minas e do Metal. Vista geral do setor expositivo dos minerais.

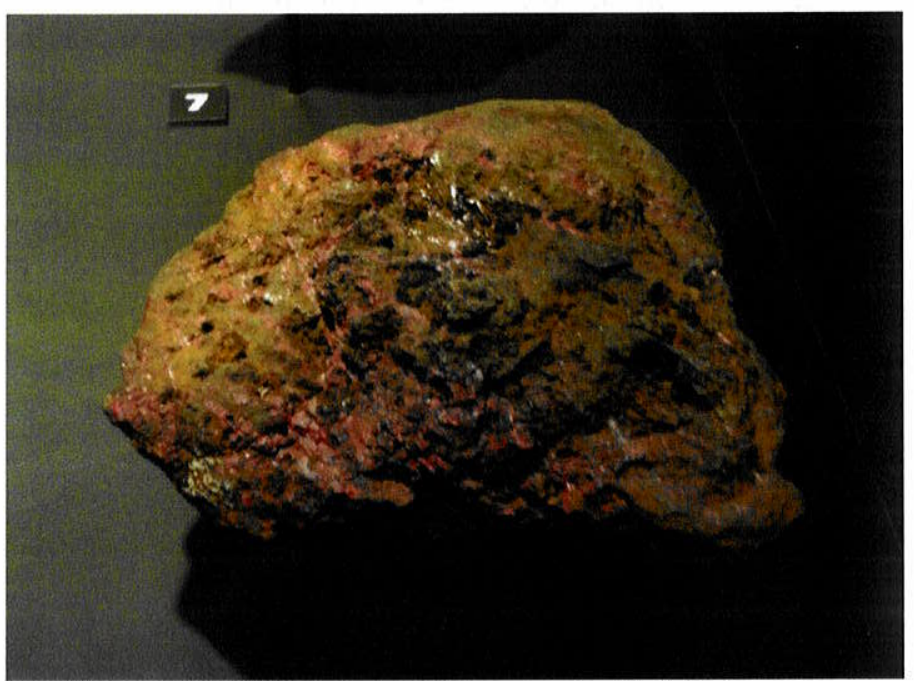

Figura 139. Museu das Minas e do Metal. Amostra rara de cinábrio de Dom Bosco, Ouro Preto, MG.

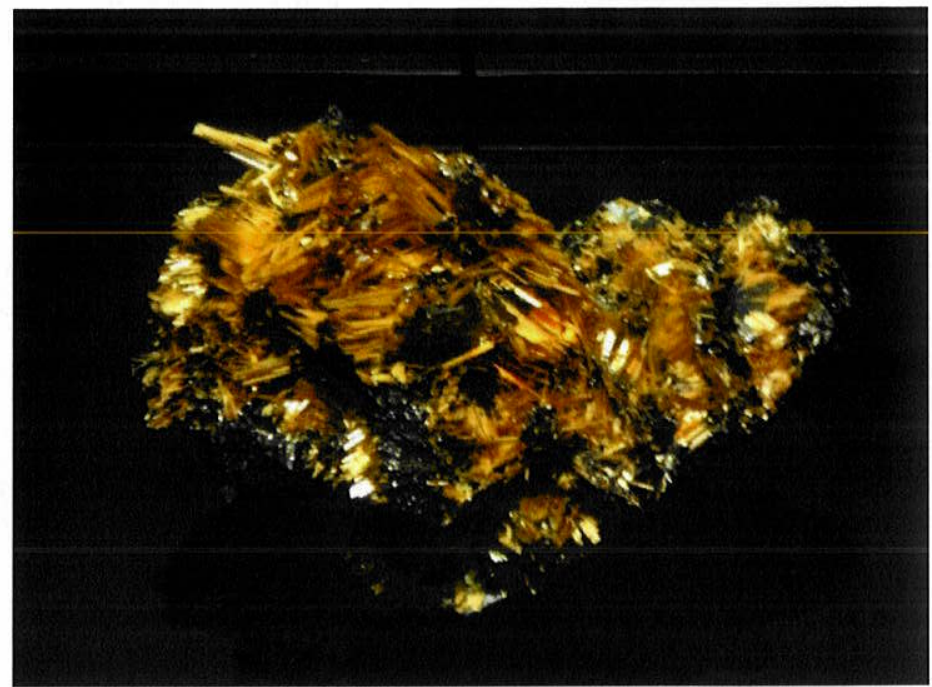

Figura 140. Museu das Minas e do Metal. Amostra estética de hematita com rutilo proveniente de Novo Horizonte, BA. 


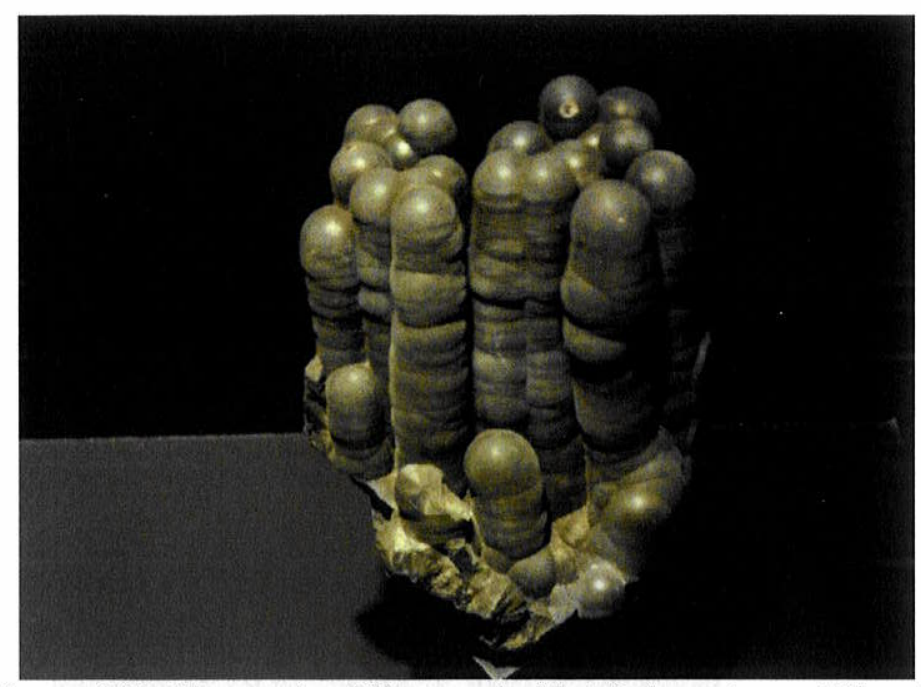

Figura 141. Museu das Minas e do Metal. Amostra estética de pirolusita proveniente da Mina Morro da Mina, Conselheiro Lafaiete, MG.

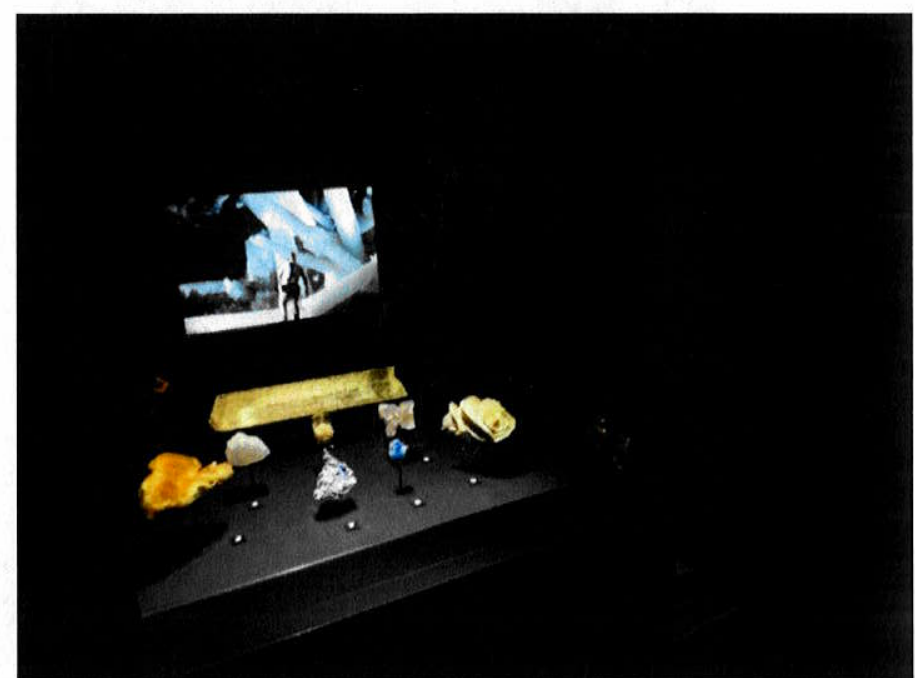

Figura 142. Museu das Minas e do Metal. Vitrine com belas amostras de minerais da classe dos sulfatos; em detalhe as tecnologias interativas como tela ao fundo ilustrando os cristais gigantes de gipsita do México.

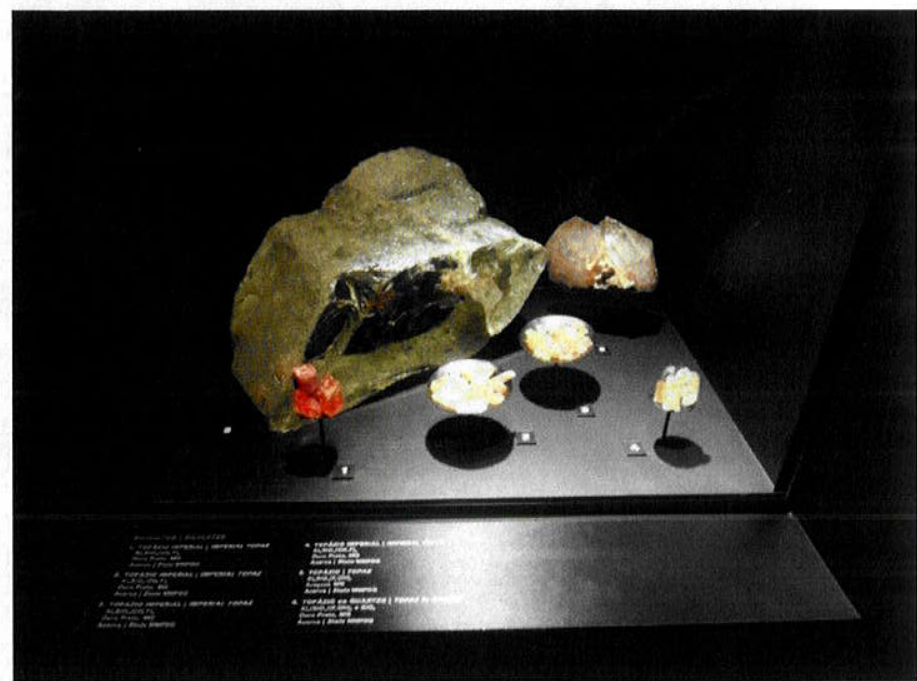

Figura 143. Museu das Minas e do Metal. Vitrine com bons exemplares de topázio, detalhe na grande e rara amostra ao fundo de topázio incolor. Notam-se as bases que seguram as amostras. 


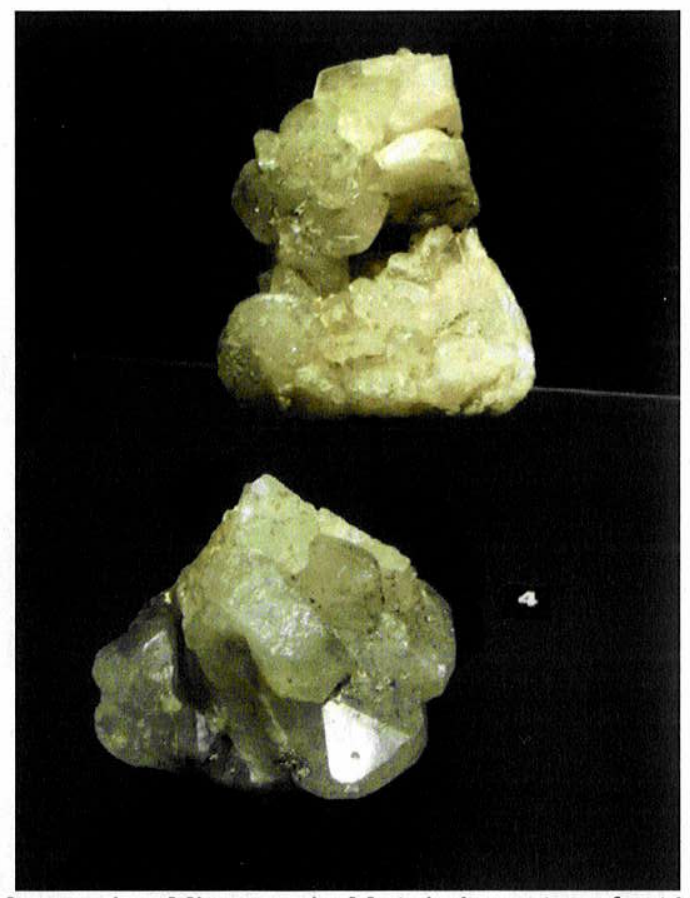

Figura 144. Museu das Minas e do Metal. Amostras fantásticas e raras defenacita provenientes do Rio Piracicaba, São Miguel de Piracicaba, MG.

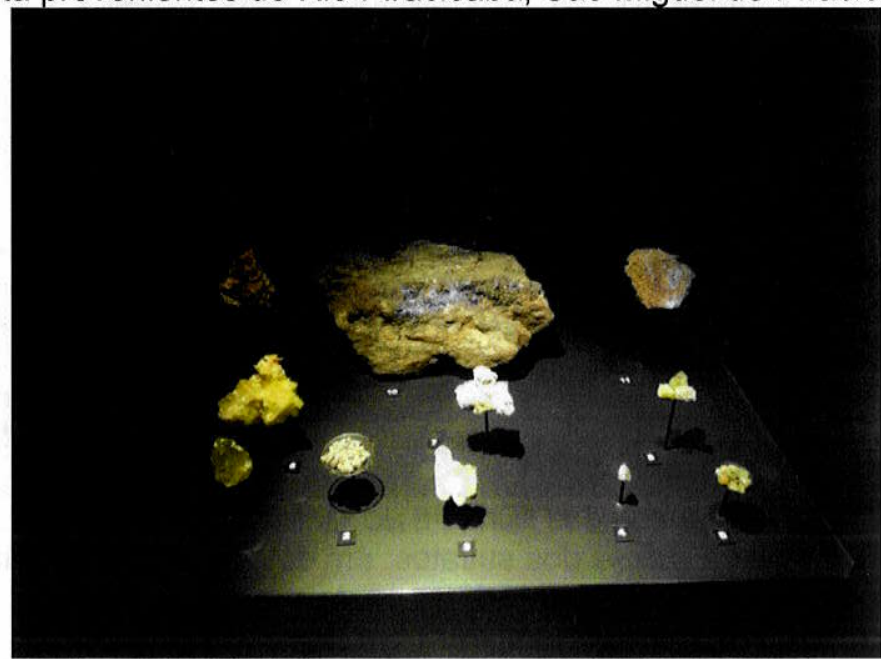

Figura 145. Museu das Minas e do Metal. Vitrine dedicada especialmente aos minerais tipo do Brasil com raridades em exposição.

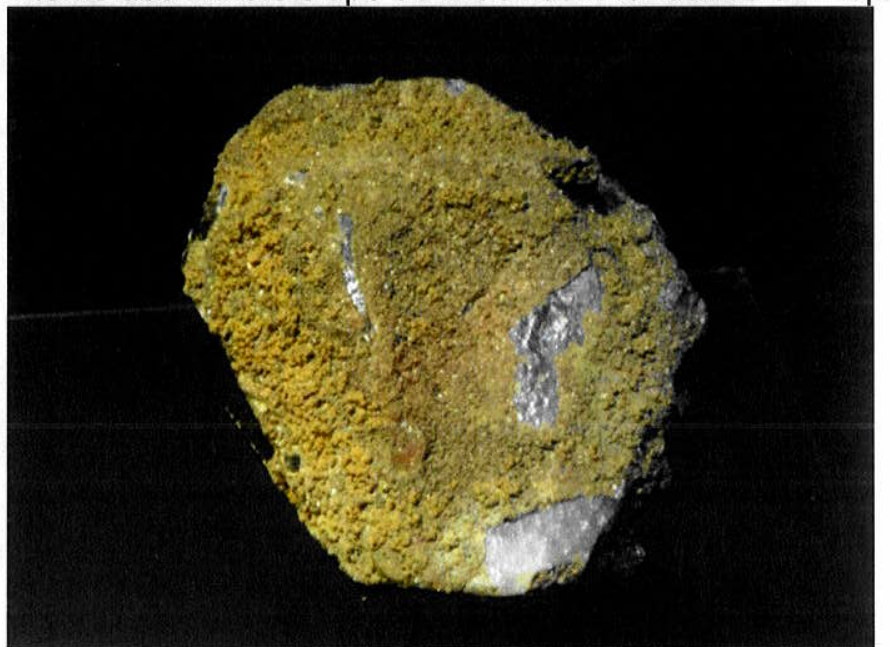

Figura 146. Museu das Minas e do Metal. Amostra deguimarãesita proveniente de Itinga, MG. 


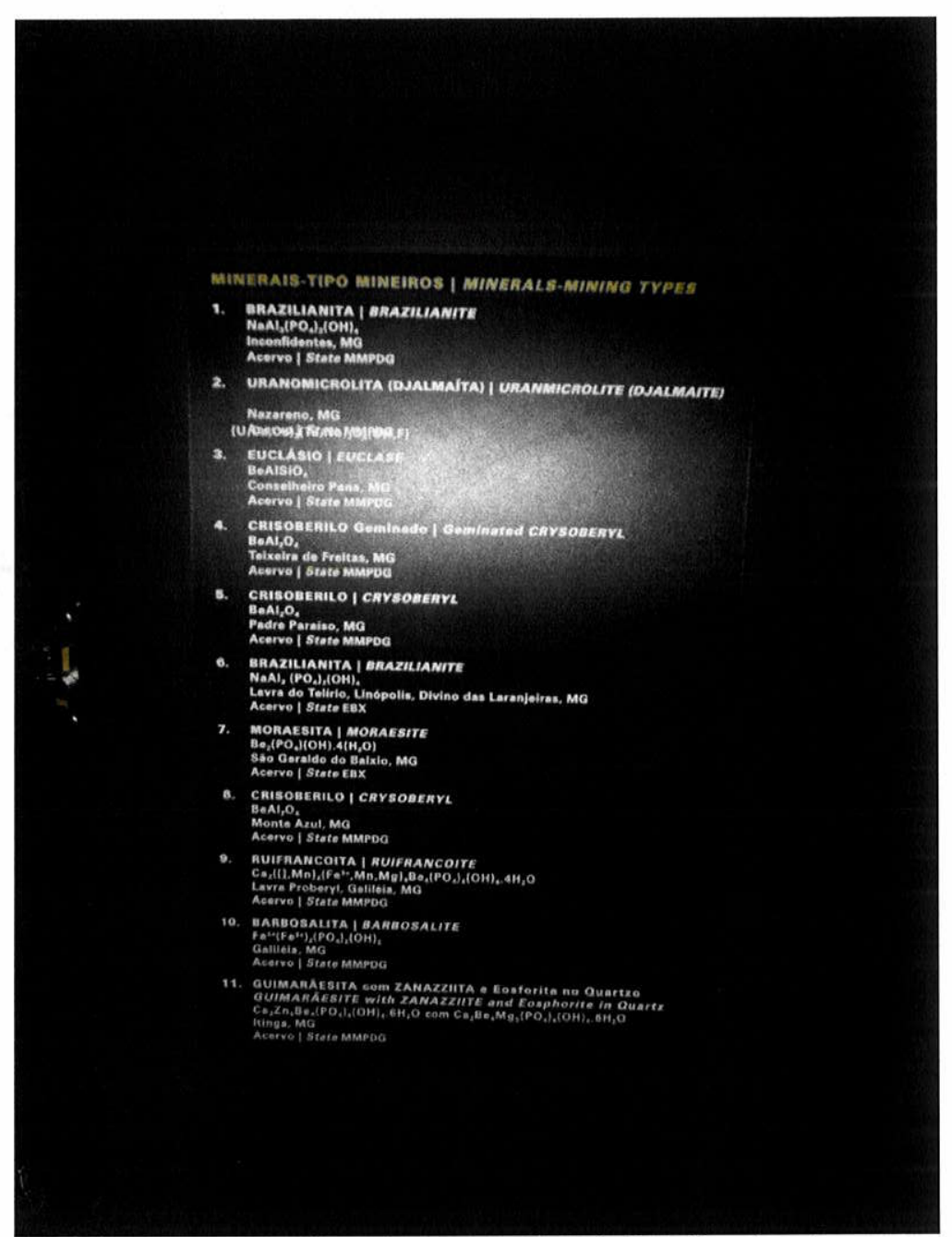

Figura 147. Museu das Minas e do Metal. Detalhe da placa com os nomes referentes aos minerais tipo brasileiros.

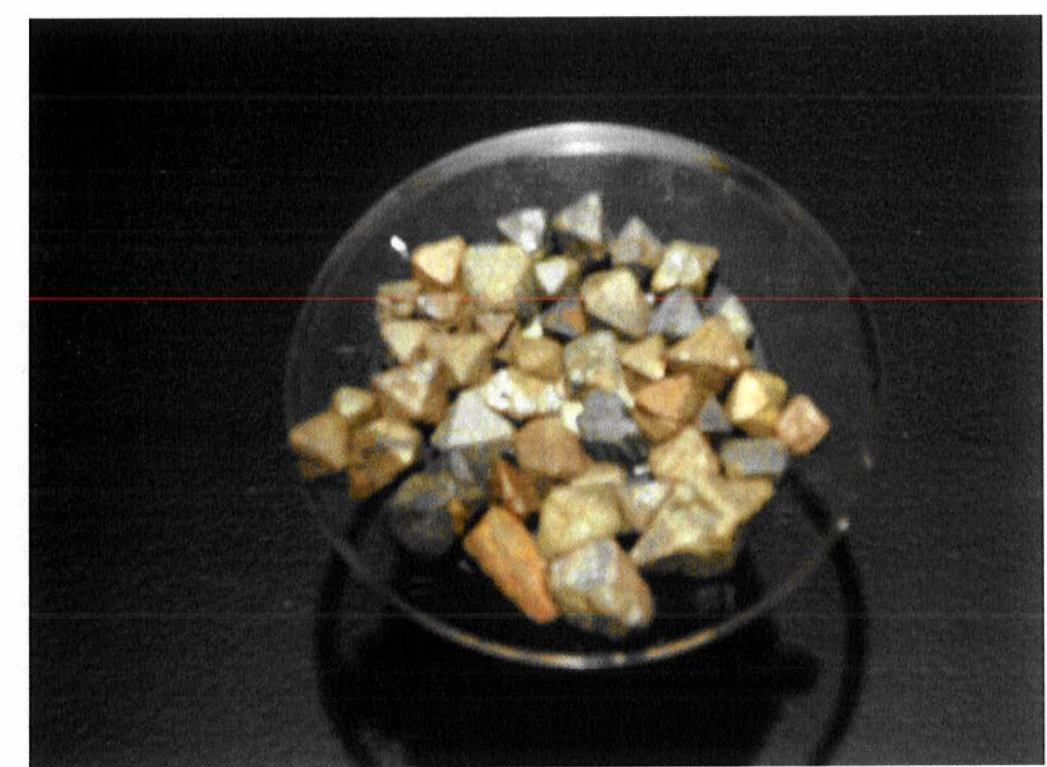

Figura 148. Museu das Minas e do Metal. Exemplares de octaedros de "djalmaita" (mineral desacreditado), provenientes do Pegmatito de Volta Grande, Nazareno, MG. 


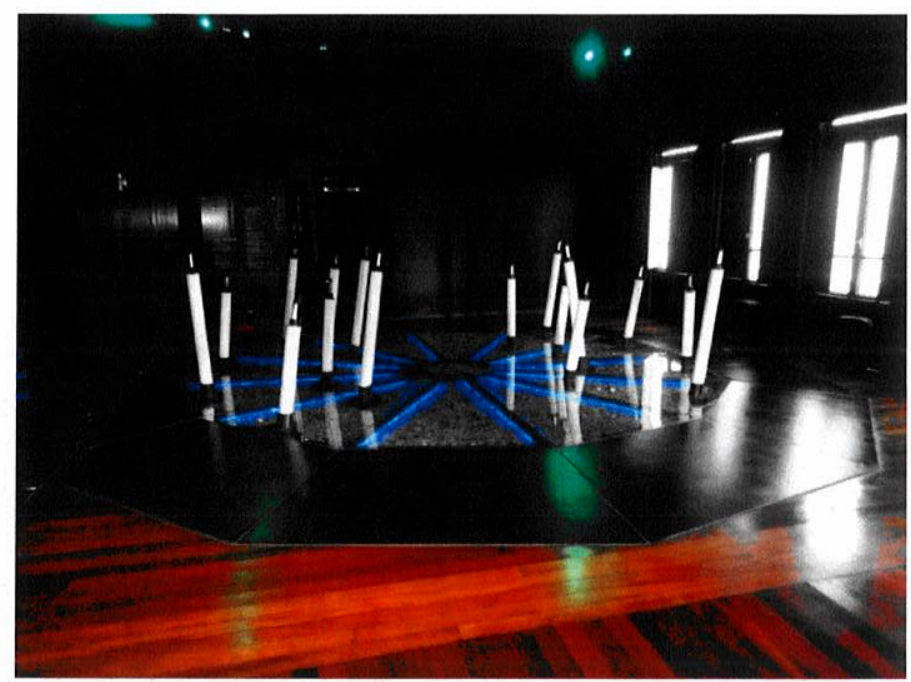

Figura 149. Museu das Minas e do Metal. Setor interativo e lúdico que mostra hologramas de minerais, chamado de Chão de Estrelas.

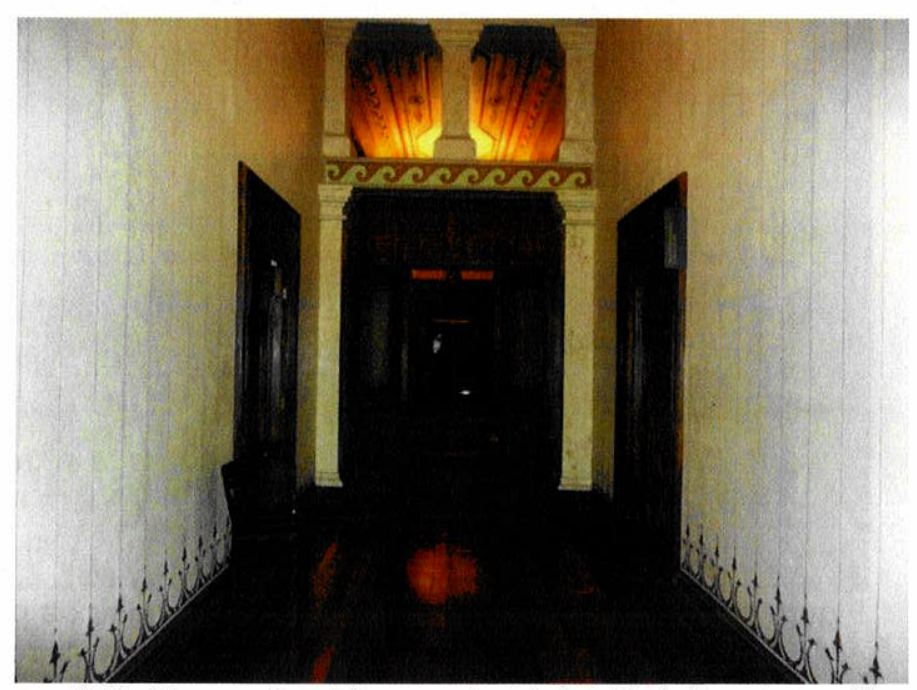

Figura 150. Museu das Minas e do Metal. Detalhe dos salões do antigo prédio histórico, onde ficam as salas expositivas.

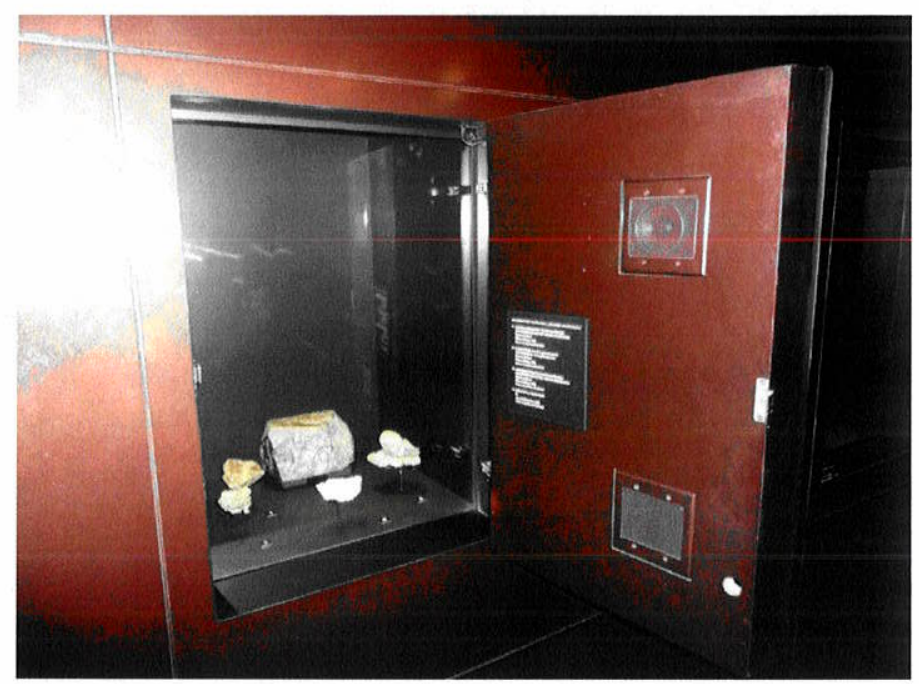

Figura 151. Museu das Minas e do Metal. Detalhes da interatividade da vitrine. 


\section{MUSEU DE MINERALOGIA E ARTE SACRA}

(análise realizada em setembro de 2013)

\section{HISTÓRICO DA INSTITUIÇÃO}

O Museu de Mineralogia fica na cidade de Congonhas em Minas Gerais. Seu endereço é Alameda Cidade Matozinhos de Portugal, 153, Basílica. Este museu faz parte do complexo histórico, cultural e turístico, que possui seu foco nas antigas construções da Igreja Católica. A cidade possui esse nome em homenagem a Nossa Senhora da Conceição de Congonhas, e foi fundada em 1734.

No século XVII, a exploração dos Bandeirantes por todo o interior brasileiro, à procura de ouro e diamante, foi intensa. O principal estado a ser desbravado foi Minas Gerais, e entre estas andanças foi construída a Estrada Real - Trecho Congonhas, que dava acesso para diversas regiões do estado (SINDCOMERCIO DE CONGONHAS, 2013).

O vilarejo começou a ser construído por mineradores que, atraídos pelos veios auríferos da região, decidiram ali se instalar para explorá-la. Conta a história que um destes mineradores, chamado Feliciano Mendes, acometido por grave moléstia, fez a promessa ao Senhor Bom Jesus de Matosinhos, que se conseguisse recuperar a saúde, se dedicaria ao serviço da Igreja. Com a graça alcançada, fincou uma cruz no alto do Morro do Maranhão e passou a angariar doações para a construção do santuário, que hoje é um dos complexos religiosos mais visitados de Minas Gerais.

Um Museu de Mineralogia, situado entre diversas construções de Arte Sacra, se justifica pela origem da própria cidade e de seus primeiros moradores. Vale destacar que neste complexo se encontram obras de Antônio Francisco de Lisboa, o Aleijadinho. Em Congonhas, o mestre Aleijadinho deixou doze profetas esculpidos em pedra sabão expostos no alto da Basílica de Bom Jesus do Matozinho. No percurso até a chegada à basílica, é possível conhecer outra marca de sua obra, os seis passos esculpidos em madeira. Toda cidade respira cultura e religiosidade. 
Todo complexo foi tombado pelo Instituto Estadual do Patrimônio Histórico e Artístico (IEPHA), em $1^{\circ}$ de agosto de 1981, mas o Museu de Mineralogia foi aberto oficialmente ao público em 30/07/1995.

\section{ORGANIZAÇÃO E FUNCIONAMENTO}

Para manter todas estas obras integradas e conservadas. Foi criada, pela Prefeitura de Congonhas, a Fundação Municipal de Cultura, Lazer e Turismo (FUNCULT). Ela gere todo o espaço e mantém o Museu de Mineralogia aberto gratuitamente ao público.

No momento da visita ao Museu, a coordenadora responsável indicou um dos atendentes para ser entrevistado. Foram entrevistados os dois atendentes de museu, que se propuseram a colaboram com a pesquisa. Para complementar as questões relacionadas neste trabalho, foi fornecido um folder que conta um pouco da história da cidade e a cópia do Cadastro de Museus elaborado pela Comissão de Patrimônio Cultural da USP, onde se encontram dados sobre a instituição, respondido pela Coordenadora Vilma L. Miranda e a Oficial Administrativo Ana da Cruz Vieira em 08/06/2000.

Os atendentes entrevistados foram o Sr. Guilherme Souza Costa Filho (62 anos), e Gláucio Andrade de Jesus (36 anos). Ambos não possuem formação técnica em mineralogia. O museu possui uma coordenadora e quatro atendentes de museu.

O principal objetivo da instituição, de acordo com o cadastro cedido para esta pesquisa, é proporcionar a participação da comunidade nas atividades promovidas pelo museu, fomentar o intercâmbio entre o museu e outras atividades congêneres e promover e ampliar o acervo do museu.

A divulgação é desenvolvida pelo site da prefeitura e por outras empresas que trabalham na promoção turística da região. Também ocorre a distribuição de folders para os visitantes e moradores. Além disso, o museu está cadastrado pelo IBRAM, participa de eventos anuais como a Semana de Museus e Primavera nos Museus. Estas atividades ficam disponíveis no site do IBRAM e são distribuídos catálogos por todo Brasil.

O museu possui como área principal a mineralogia, mas também possui exemplares expostos de petrologia, paleontologia e malacologia. 
Por fazer parte do roteiro turístico da cidade, o museu é reconhecido pelo seu valor histórico e educativo, pois recebe muitas escolas da cidade e de toda a região. O museu enriquece o turismo e conserva o patrimônio mineralógico e geológico da região.

\section{ESTRUTURA FÍSICA}

A área total do museu é de $127 \mathrm{~m}^{2}$, com três salões principais (dois salões somente expositivos e outro com exposição de amostras, reserva técnica e espaço para atividades lúdicas e oficinas educativas), além de haver um auditório para realização de atividades culturais. Todo o espaço do museu possui acessibilidade para deficientes físicos e idosos. Mas não há climatização e áreas para convivência como lanchonetes e lojas de souvenires.

\section{AÇÃO EDUCATIVA E CULTURAL}

O acolhimento de visitantes é feito pelos atendentes, que monitoram por todos os espaços em uma média de 1 hora de atendimento. Os grupos escolares, bem como turistas, visitam o museu, principalmente por causa da integração das atividades e eventos que são promovidos por todo o complexo, no pátio da Romaria. Não são realizados eventos ou atividades específicos pelo museu, exceto quando requisitado pelo grupo escolar. Há um livro de presença que registra uma média de 1000 visitantes por mês, variável conforme a época do ano.

\section{ACERVO MINERALÓGICO}

O Museu de Mineralogia de Congonhaspossui em seu acervo geralaproximadamente 900 exemplares expostos de minerais, rochas, espeleotemas, fósseis, corais, conchas e artefatos históricos (microscópios, teodolitos, bateias, etc) e arqueológicos. Existem mais 1100 amostras em reserva técnica, principalmente de minerais. O museu possui ainda um acervo de imagens e instrumentos antigos ligados amineralogia e geologia. $O$ museu, em seu setor expositivo, não possui nenhuma classificação específica. 
A maior parte da coleção mineralógica é composta por exemplares de minerais brasileiros da região e do estado de Minas Gerais, como minerais de ferro (hematita, goethita) e de manganês (pirolusita) entre outros como, por exemplo, talco, gipsita, cianita, etc.

As etiquetas são bem simples com o nome das espécies, localidades geográficas e doadores. A identificação das amostras, em muitos casos, está equivocada devido à falta de um especialista na classificação dessas amostras, ou estão faltando maiores informações. As procedências em geral não têm muitas informações, somente o nome da mina, ou do estado, não traduzindo muito bem a localidade geográfica e a proveniência geológica das amostras.

$\mathrm{Na}$ entrada do museu, o visitante e depara com amostras de grande porte de minerais comuns, e dispostas em estruturas (pedestais) de madeira branca.

Os exemplares de minerais, rochas, fósseis,corais e conchas estão dispostosem dois tipos principais de mobiliários. A maior parte em vitrines de vidro com bases de madeira e com iluminação próxima vinda de spots acoplados no teto do salão. A outra parte do material exposto está contida em vitrines tradicionais de madeira e vidro, com forramento de carpete. Muitas das etiquetas com nomes em desuso.

A reserva técnica está colocada em gaveteiros de madeira. Na parte superior, as amostras são colocadas em exposição e todas as amostras, colocadas de forma aleatória, estão protegidas por vidro.

Uma das amostras mais apreciadas e comentadas é de um material artificial, carbeto de silício, que quando formado naturalmente se denomina moissanita. Ela encontra-se em meio aos minerais e não há nenhuma informação de que se trata de material artificial.

O museu, apesar de ser uma instituição simples,é dotado de pessoas muito gentis, e que têm a intenção de fomentar e difundir o conhecimento geológico e mineralógico (mesmo certos limites) para todos os seus visitantes, sejamescolares ou turistas. A intenção da direção do museu é, sempre que possível, aumentar seu acervo através do recebimento de doações, de coletas e principalmente de intercâmbios desenvolvidos com outras instituições e colecionadores do país.

O acervo mineralógico que compõe o Museu de Mineralogia de Congonhas, apesar de possuir amostras de minerais interessantes da região, não apresenta muita relevância para a mineralogia no Brasil, pois não apresenta espécies raras 
brasileiras. O museu, porém, serve ao papel, perante a comunidade, de difundir alguns dos principais recursos minerais da sua região e do estado de Minas Gerais.

Quadro 23 - Quadro de minerais brasileiros pertencentes ao acervo do Museu de Mineralogia e Arte Sacra com suas respectivas ocorrências (exemplos):

\begin{tabular}{|c|}
\hline $\begin{array}{c}\text { Quadro de minerais importantes brasileiros pertencentes ao acervo do } \\
\text { Museu de Mineralogia de Congonhas e suas respectivas ocorrências } \\
\text { (exemplos): }\end{array}$ \\
\hline Ouro nativo - Congonhas, MG. \\
Hematita - Congonhas, MG. \\
\hline Goethita - Congonhas, MG. \\
Magnetita - Congonhas, MG. \\
\hline Topázio (imperial) - Ouro Preto, MG. \\
\hline Talco - Santa Rita, MG. \\
\hline Cianita - Belo Vale, MG. \\
\hline Pirolusita- Mina Morro da Mina, Conselheiro Lafaiete, MG. \\
\hline Hemimorfita azul - Mina Morro da Usina, Vazante, MG. \\
\hline Petalita - Itinga, MG. \\
\hline Anátasio (var. octaedrita) - Trindade, GO. \\
\hline Columbita-(Fe) - Serra da Mesa, GO. \\
\hline Berilo (var.esmeralda) - Santa Terezinha de Goiás, GO. \\
\hline Cassiterita - Mina Pitinga, Presidente Figueredo, AM. \\
\hline Criolita - Mina Pitinga, Presidente Figueredo, AM. \\
\hline Scheelita "rolada" - São João do Sabugi, RN. \\
\hline Opala no basalto - Foz do Iguaçu, PR. \\
\hline
\end{tabular}




\section{RELAÇÃO DE FOTOS DO MUSEU DE MINERALOGIA E ARTE SACRA}

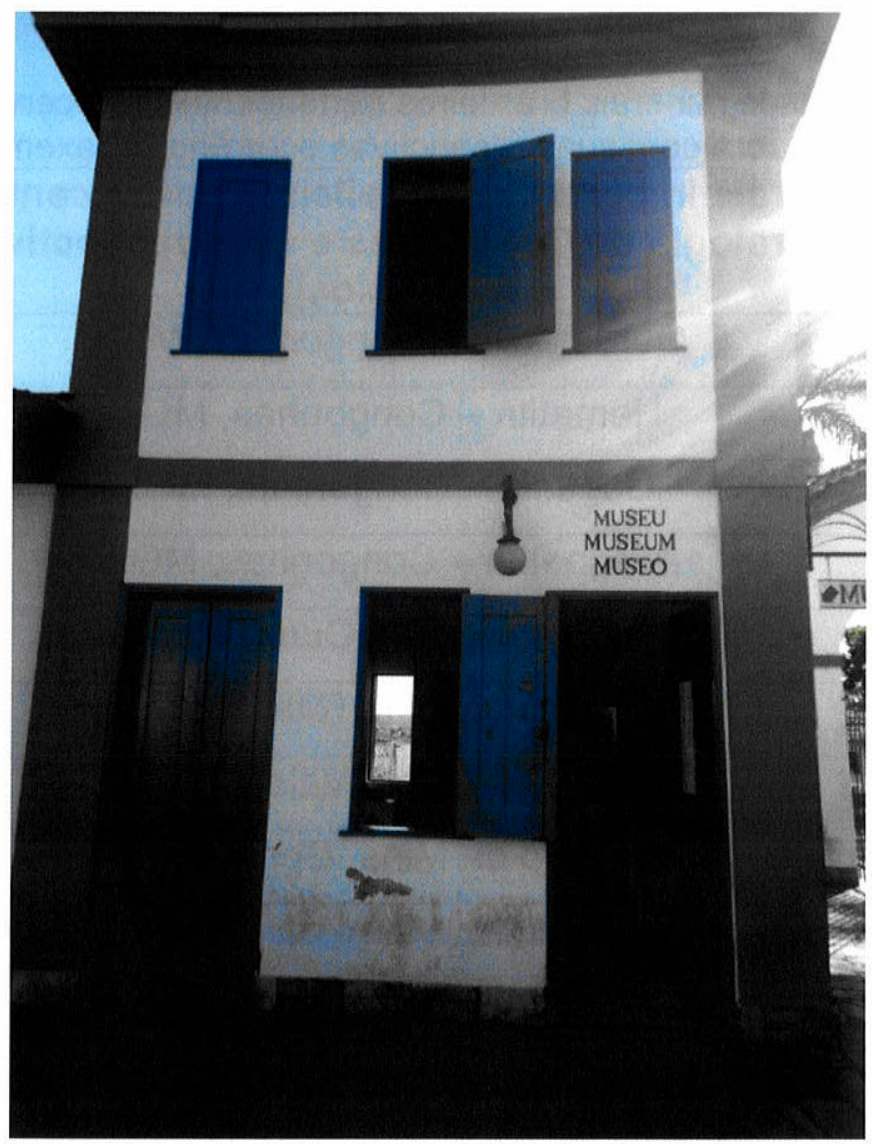

Figura 152. Museu de Mineralogia e Arte Sacra. Vista da entrada do museu.

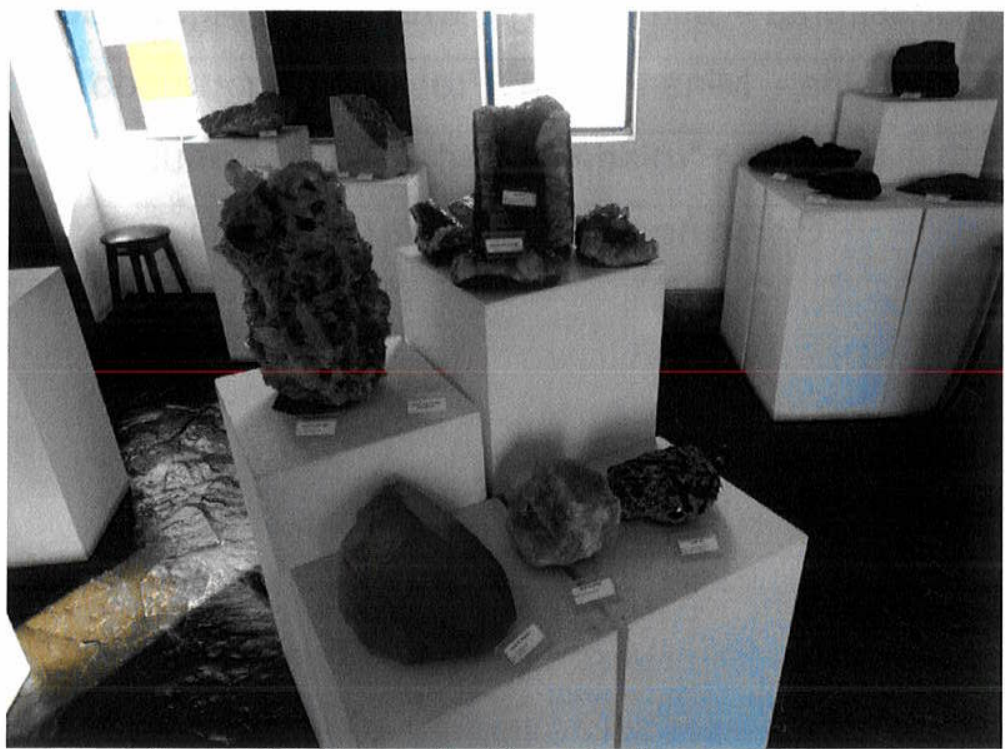

Figura 153. Museu de Mineralogia e Arte Sacra. Amostras de minerais mais comuns nas bancadas no hall de entrada. 


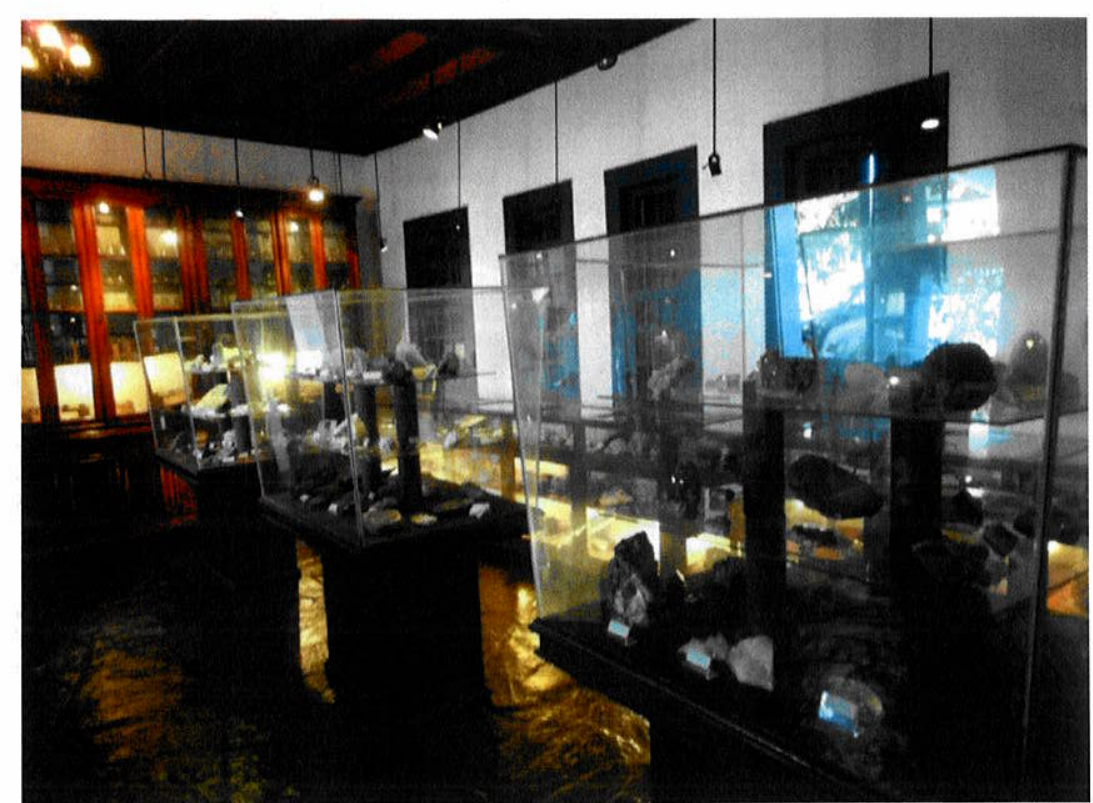

Figura 154. Museu de Mineralogia e Arte Sacra. Vista geral do salão expositivo com as vitrines modulares de vidro e bases de madeira.

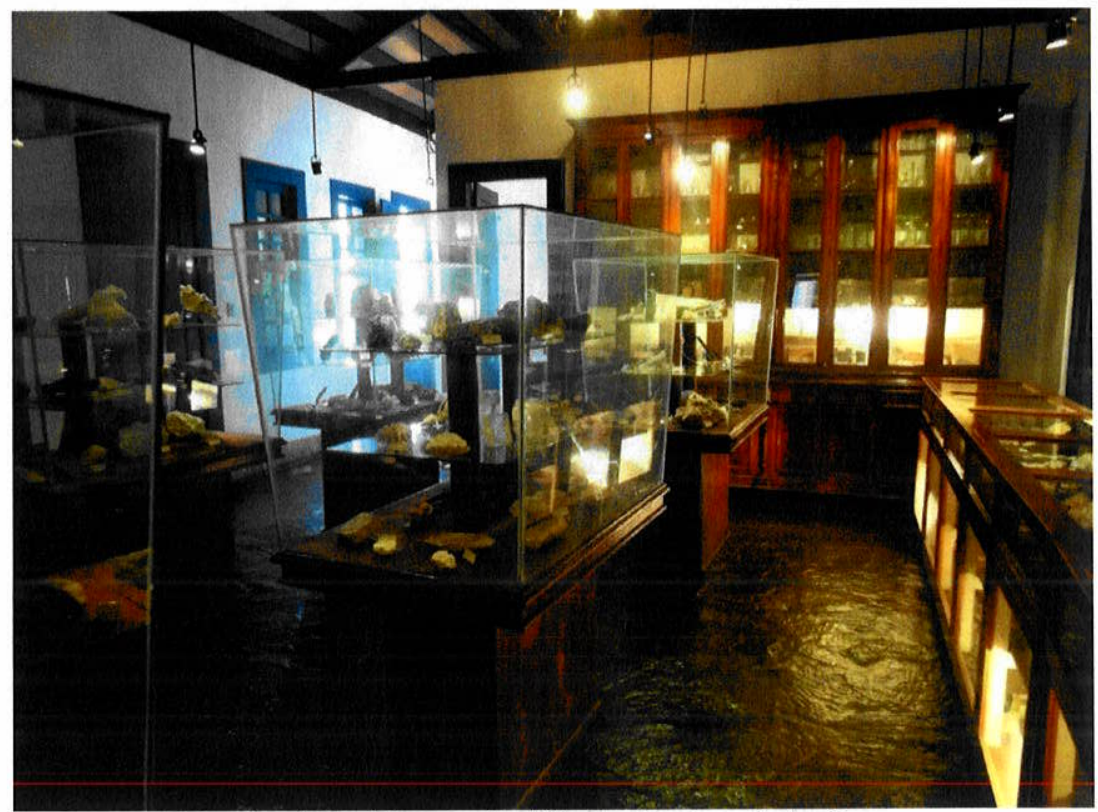

Figura 155. Museu de Mineralogia e Arte Sacra. Vista geral do salão expositivo. Detalhe da iluminação. 


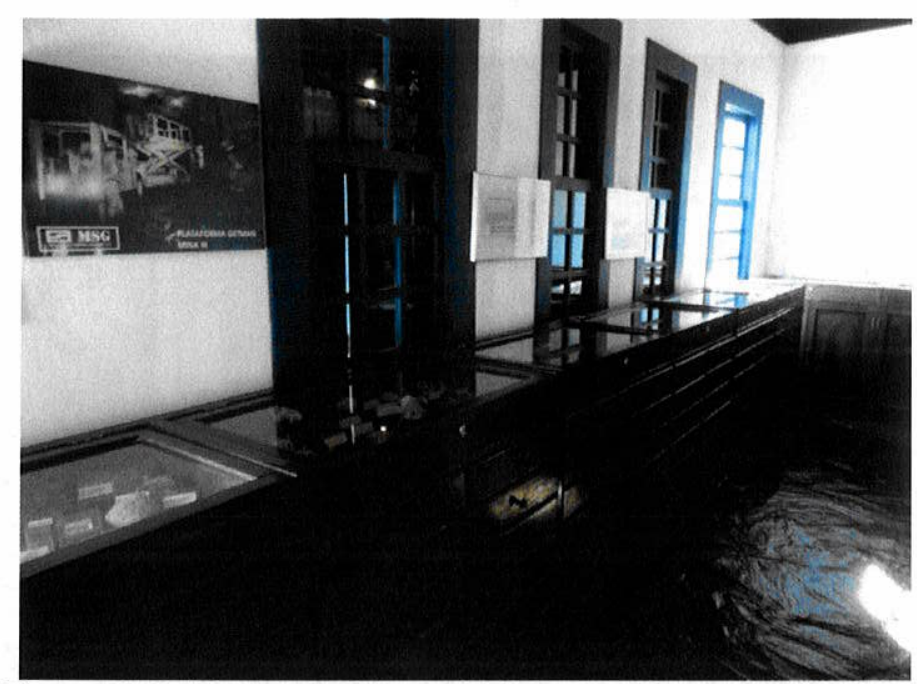

Figura 156. Museu de Mineralogia e Arte Sacra. Mobiliários clássicos com minerais expostos na parte superior e gavetas contendo a reserva técnica na parte inferior.

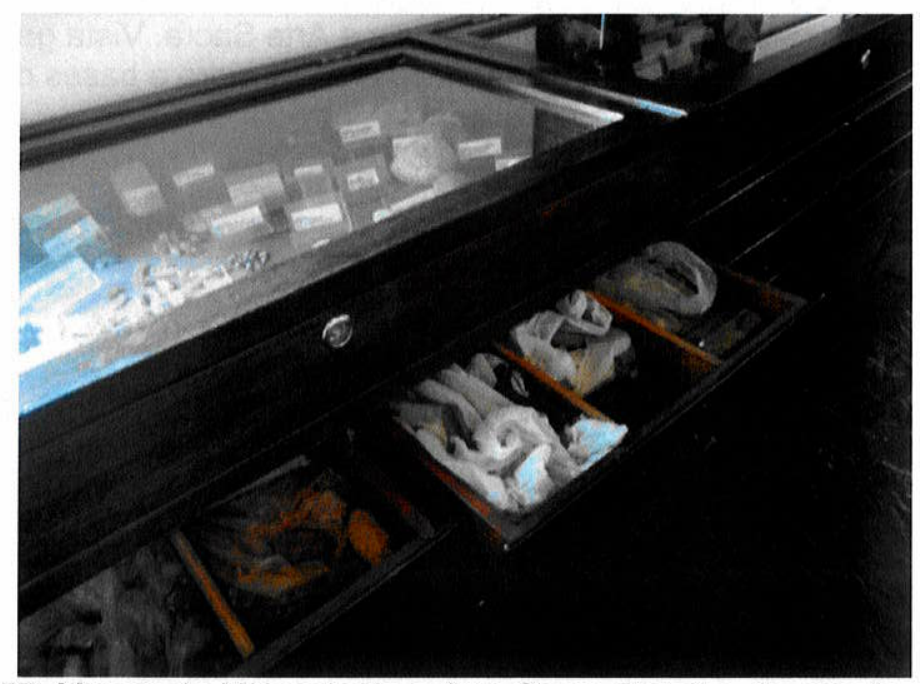

Figura 157. Museu de Mineralogia e Arte Sacra.Detalhe da gaveta contendo as amostras da reserva técnica. Nota-se a falta de organização das amostras.

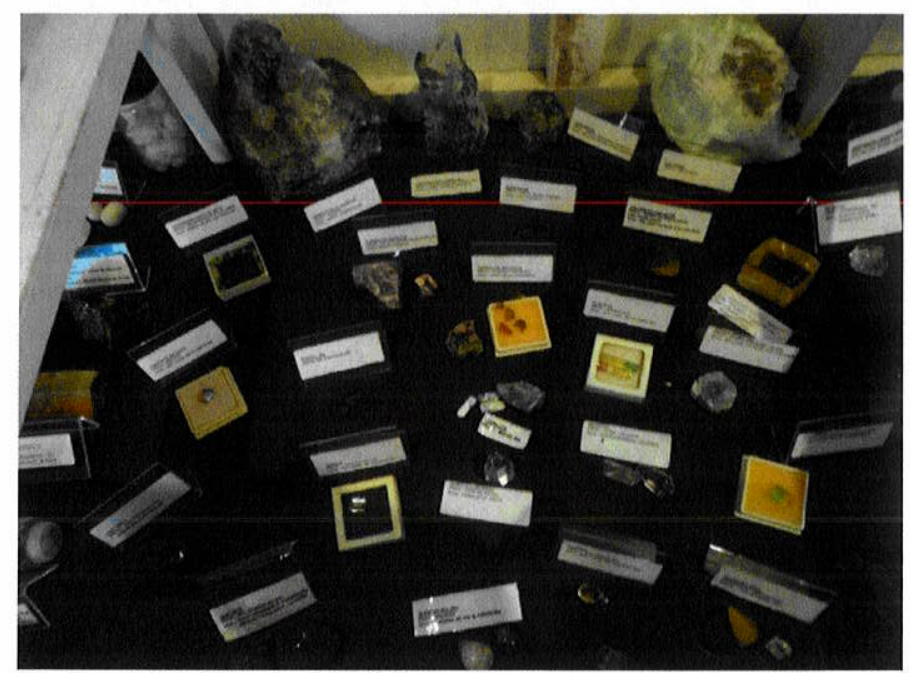

Figura 158. Museu de Mineralogia e Arte Sacra.Minerais colocados de forma aleatória, misturando amostras brutas, polidas e lapidadas sem nenhuma classificação. 


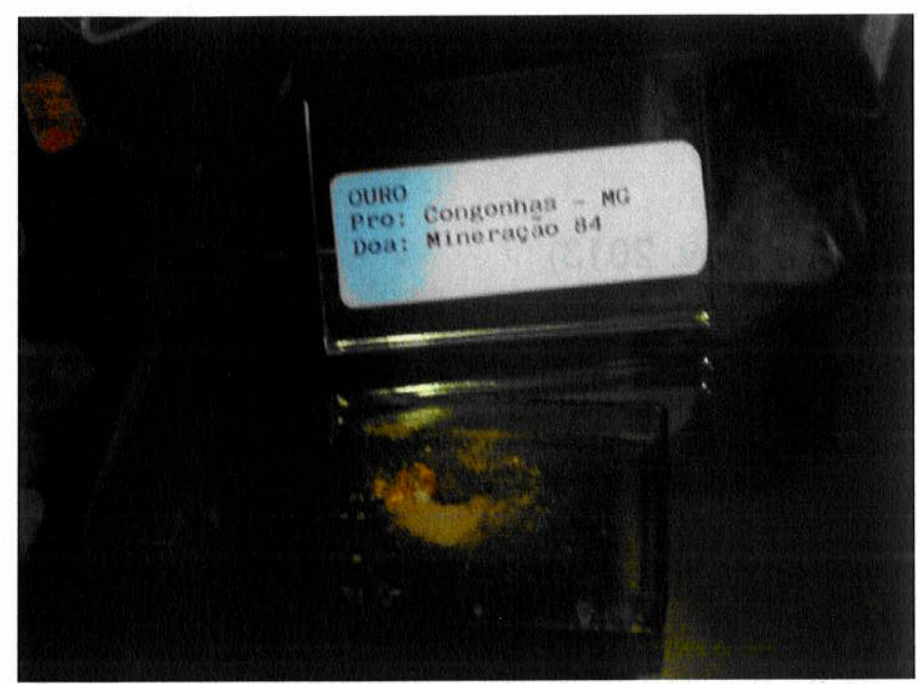

Figura 159. Museu de Mineralogia e Arte Sacra. Amostra de ouro nativo proveniente da região de Congonhas, MG. Percebe-se a simplicidade da etiqueta e de suas informações e a base em que a amostra está colocada, não dando destaque para as pequenas pepitas.

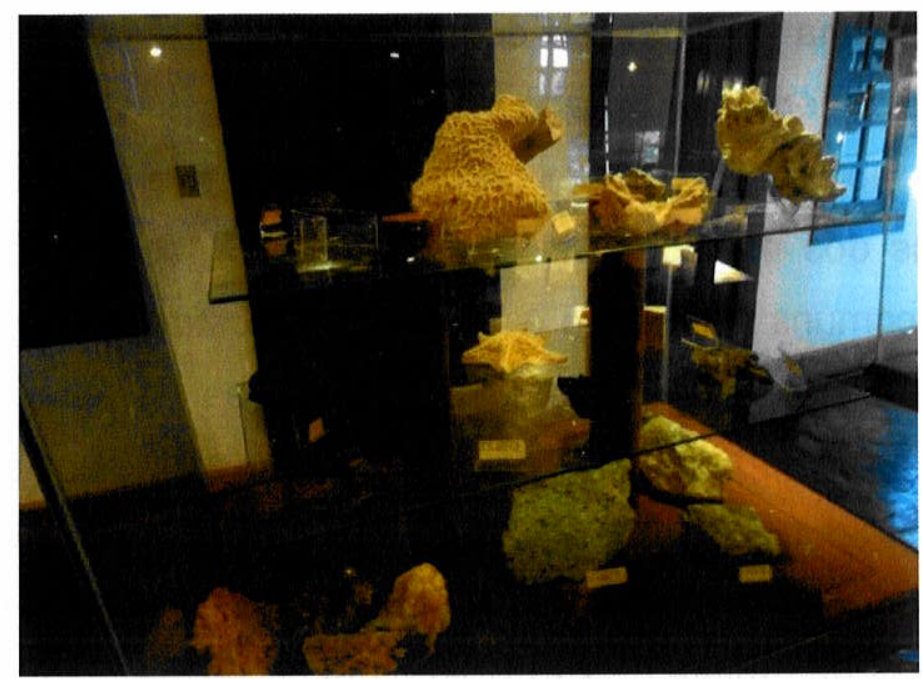

Figura 160. Museu de Mineralogia e Arte Sacra. Vitrine com amostras misturadas de minerais e corais, ambas sem classificação.

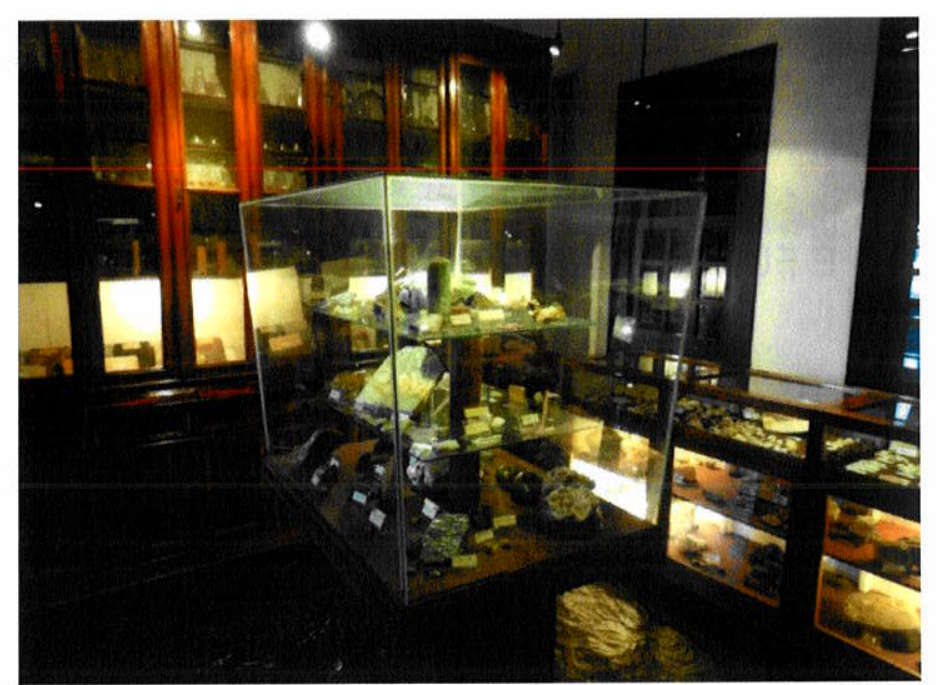

Figura 161. Museu de Mineralogia e Arte Sacra. Detalhe da vitrine modular. Ao fundo vitrines clássicas com vidrarias e ao lado amostras de minerais. 


\section{Museu de Minerais e Rochas da Universidade Federal do Espírito Santo}

(análise realizada em Nov. 2013)

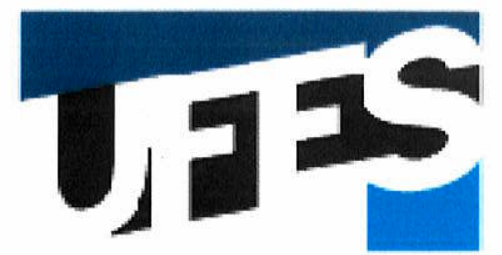

Universidade Federal do Espírito Santo

HISTÓRICO DA INSTITUIÇÃO

O Museu de Minerais e Rochas da Universidade Federal do Espírito Santo (UFES) fica localizado na Av. Fernando Ferrari, 514 - Goiabeiras, Vitória- Espírito Santo, no prédio IC-II, $2^{\circ}$ andar do Departamento de Oceanografia (DOC), Centro de Ciências Humanas e Naturais (CCHN) - UFES.

A coleção foi formada por professores do curso de geologia, com o intuito de auxiliar o programa de extensão desenvolvido no Laboratório de Geologia, que faz parte do departamento de Oceanografia, do Centro de Ciências Humanas e Naturais da UFES. O laboratório contém um acervo de minerais, rochas, areias e fósseis, com amostras dos principais minerais existentes, de vários tipos de minérios, de rochas mais comuns do Estado e do Brasil, amostras de areias interessantes, com composições diferenciadas, e alguns exemplares de fósseis. $\mathrm{O}$ museu atende a diversas disciplinas, como as de mineralogia e geologia, para os cursos de oceanografia, geografia, química, ciências biológicas e outros.

O museu está registrado no IBRAM como Núcleo de Ciências da UFES, e é parte integrante do projeto da Pró-Reitoria de Extensão. O Coordenador do Museu é o Professor Luiz Machado Filho, geólogo e especialista em rochas ornamentais e fosfatos. A presente pesquisa foi baseada nas descrições registradas pelo coordenador.

\section{ORGANIZAÇÃO E FUNCIONAMENTO}

O museu é gerido pela UFES, que mantém a estrutura do museu, subsidiando custos básicos da estrutura física e dos recursos humanos. São três funcionários, o coordenador e dois alunos estagiários (um monitor de geologia e outro bolsista de extensão). 
Para ser monitor, há o pré-requisito de ter cursado a disciplina de geologia geral e ter passado com nota boa. Os monitores recebem treinamento com o coordenador e com monitores anteriores, para atendimento ao público.

O Museu de Minerais e Rochas tem por objetivo atender a comunidade da Grande Vitória, bem como a de todo o Estado do Espírito Santo, por meio de suas atividades principais, que são (UNIVERSIDADE FEDERAL DO ESPÍRITO SANTO , 2014):

- Receber visitas de turmas de estudantes de ensino fundamental e médio para atividade pedagógica prática, complementar às informações sobre geologia que recebem em seus colégios;

- Atender a grupos de estudantes para apoio em seus trabalhos sobre minerais, rochas e outros assuntos de geologia, com classificação de amostras e fornecimento de informações;

- Ministrar cursos de pequena duração para professores como subsídio às suas atividades didáticas no campo da geologia;

- Atender a pessoas interessadas em recursos minerais, através de classificação de amostras de minerais, rochas e minérios e fornecimento de informações técnicas, econômicas e jurídicas.

A divulgação é feita através dos alunos da UFES, que cursam disciplinas no museu e que são professores ou desenvolvem outras atividades em instituições públicas e privadas da região metropolitana de Vitória. Eles participam de eventos na cidade de Vitória, como Semana Nacional de Ciência e Tecnologia, em feiras de ciências em escolas, expondo coleção de minerais e rochas e distribuindo folders do museu. Existe também uma página no site da UFES que descreve as atividades e objetivos do museu.

O museu funciona no período da tarde, pois na parte da manhã e da noite é utilizado como sala de aula. Em média 100 pessoas são recebidas por mês (visitantes externos, pois os alunos da UFES não são registrados). O tempo de visitação é de uma hora e os grupos interessados agendam a visita com antecedência. O público alvo são estudantes de ensino fundamental e universitários.

Esta é a única instituição do gênero na Região Metropolitana de Vitória, que abrange cinco municípios do Espírito Santo e é capaz de dar suporte didático prático sobre geologia, minerais e rochas às escolas, e informações sobre recursos minerais às pessoas da comunidade. 


\section{ESTRUTURA FÍSICA}

O museu localiza-se em uma sala de aula adaptada, com bancadas e gaveteiros, onde fica exposto o acervo de minerais, rochas, areias e fósseis. A segurança e climatização são da própria universidade e áreas de convivência, assim como lojas, lanchonetes e sanitários. O prédio possui elevadores, consequentemente existe acessibilidade para pessoas com dificuldade de mobilidade física.

\section{AÇÃO EDUCATIVA E CULTURAL}

De acordo com o professor Luiz, o Projeto Museu de Minerais e Rochas, desenvolvido pela instituição, tem ação educativa, através de atividade didática prática, com visitas monitoradas, complementares aos conteúdos sobre geologia, rochas e minerais trabalhados pelas escolas públicas e privadas da Região Metropolitana de Vitória. As atividades principais são as visitas didáticas e a ajuda em trabalhos escolares sobre os referidos assuntos.

\section{ACERVO MINERALÓGICO}

O acervo mineralógico do museu é simples composto por aproximadamente 500 amostras de minerais, rochas, areias e fósseis. A coleção de minerais possui espécies mais comuns como pirita, calcita, quartzo e algumas variedades (ametista, ágata, quartzo rosa etc.), sodalita, muscovita, grafita, almandina, schorlita, fluorapatita, hematita etc, porém não possuem nenhuma amostra espetacular, somente amostras didáticas, salvo algumas exceções como uma amostra de carbonado, variedade negra do Diamante.

A coleção foi classificada com base em propriedades físicas e alguns testes químicos. Alguns minerais polidos e lapidados estão juntos em uma mesma vitrine.

As vitrines onde as amostras estão dispostas são de madeira e vidro. $\mathrm{Na}$ parte inferior há gavetas, onde a reserva técnica está armazenada.

Toda a exposição ocupa uma sala de aula adaptada para o propósito com cerca de $90 \mathrm{~m}^{2}$. A reserva técnica tem o objetivo de auxiliar as aulas ministradas 
dentro do museu e da universidade e as amostras repetidas, em muitos casos são doadas para as escolas e faculdades.

A iluminação é geral da própria sala em que as vitrines estão expostas, não sendo muito eficiente e possuindo algumas janelas permitindo a luz solar entrar e podendo assim danificar e alterar as colorações dos minerais mais coloridos.

As etiquetas das amostras são muito simples, não são muito informativas, contendo apenas o nome da espécie ou do grupo mineral pertencente. Algumas etiquetas contêm, em adição, sua localidade geográfica.

Além das vitrines, existem algumas estantes com prateleiras e amostras de tamanhos maiores, expostas sem classificação ou sistematização. Ao lado, existe uma grande bancada com diversas amostras de minerais e rochas expostas para aulas didáticas sobre geologia, mineralogia e petrologia.

O museu não possui pesquisa do seu acervo didático e a manutenção é realizada tanto pelo coordenador quanto pelos estagiários. A aquisição de acervo se dá basicamente por doações e também por compras de pequeno valor, feitas pelo coordenador, com recursos próprios, pois não há verba prevista para a compra de exemplares para o museu.

A coordenação do museu não realiza intercâmbio de amostras, porém está aberta para esse tipo de atividade, desde que seja vantajoso para ambos os lados.

A coleção mineralógica do Museu de Minerais e Rochas da Universidade Federal do Espírito Santo cumpre o seu papel perante a comunidade na difusão do conhecimento geológico. Porém, o seu acervo é irrelevante para a preservação da memória da mineralogia brasileira, por não conter amostras da sua mineralogia tipo e nem possuir amostras significativas. Ressalta-se a necessidade de uma melhor identificação das espécies, classificação e revisão mineralógica sistemática dos seus exemplares. 


\section{RELAÇÃO DE FOTOS DO MUSEU DE MINERAIS E ROCHAS DA UFES}

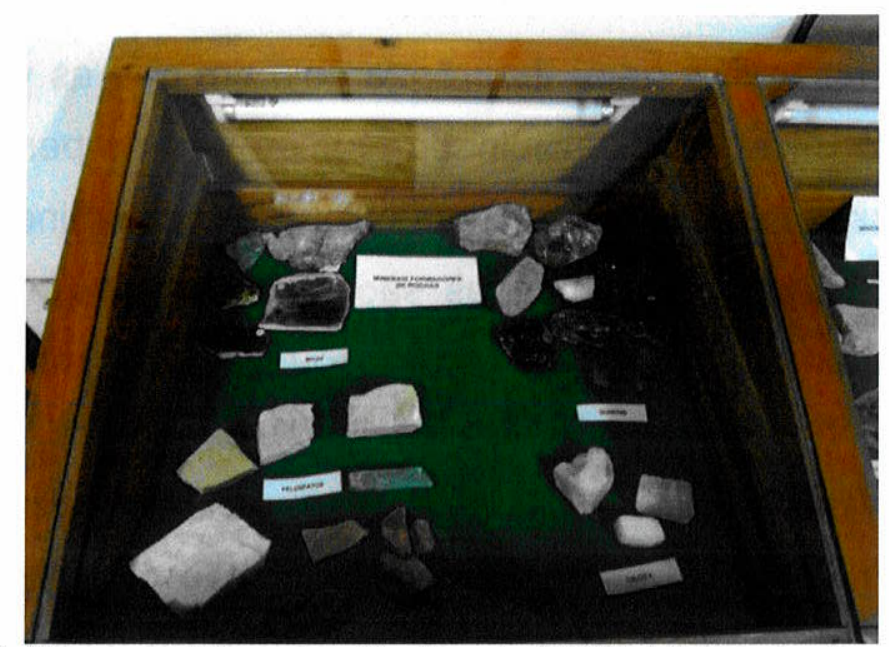

Figura 162. Museu de Minerais e Rochas da UFES. Vitrine simples de madeira e vidro com fundo de feltro verde. Minerais comuns formadores das rochas.

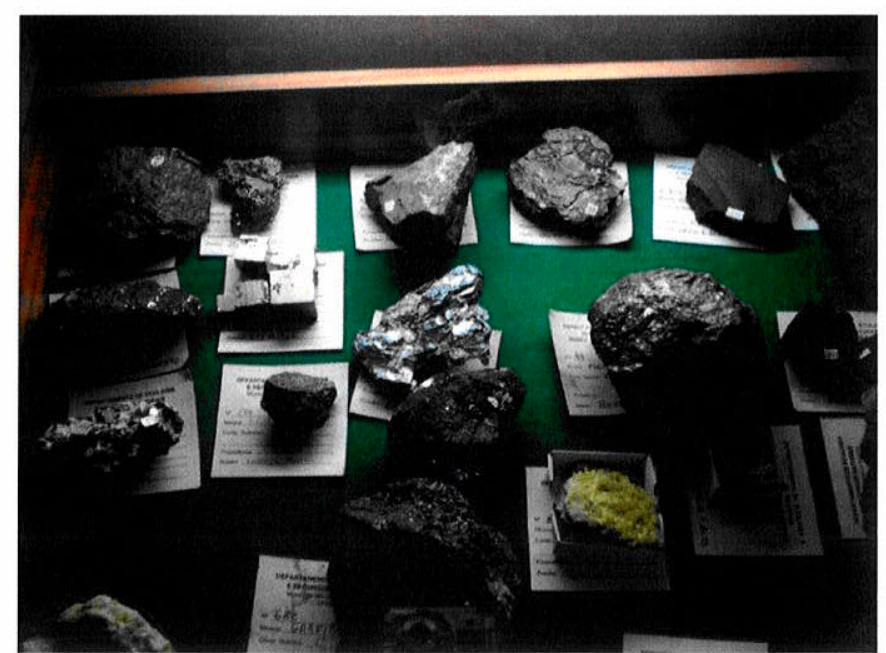

Figura 163. Museu de Minerais e Rochas da UFES. Minerais didáticos da reserva técnica.

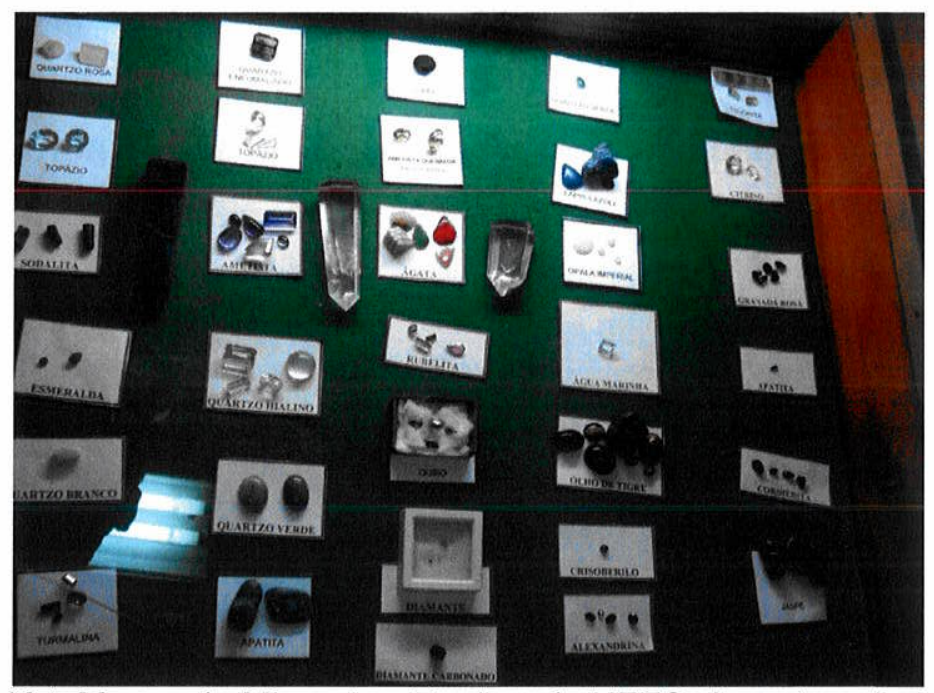

Figura 164. Museu de Minerais e Rochas da UFES. Amostras de minerais lapidados e polidos. Detalhe das etiquetas simples e sem muitas informações. 


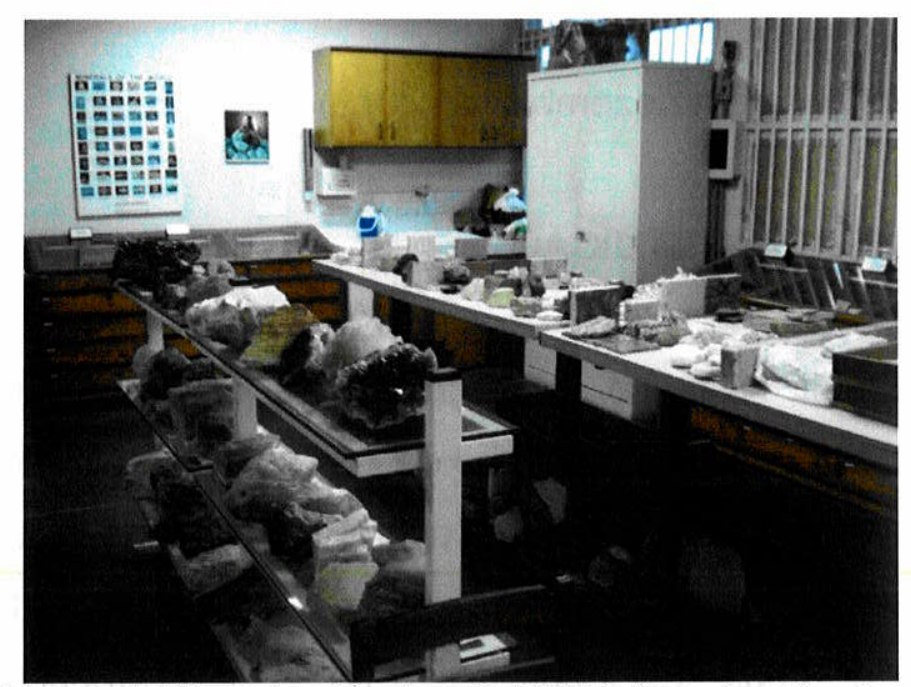

Figura 165. Museu de Minerais e Rochas da UFES. Amostras de minerais comuns com tamanhos grandes dispostos em prateleiras de vidro em armações metálicas.

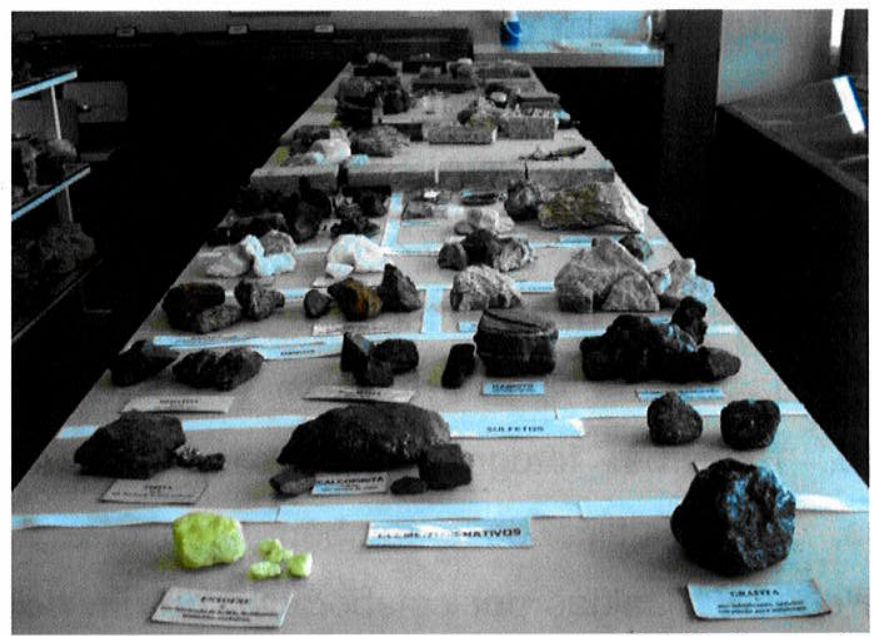

Figura 166. Museu de Minerais e Rochas da UFES. Bancadas com amostras didáticas para aulas. Detalhe do mobiliário com exposição de minerais na parte superior e gavetas contendo a reserva técnica na parte inferior.

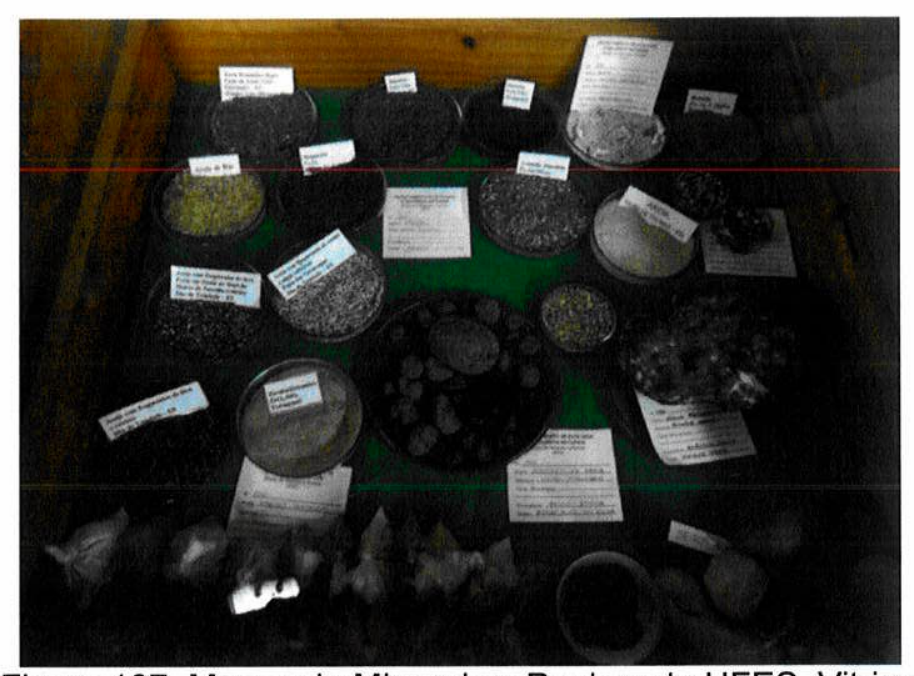

Figura 167. Museu de Minerais e Rochas da UFES. Vitrine com amostras de minerais detríticos (areias) de várias localidades. 


\section{MUSEU HISTÓRICO E GEOGRÁFICO DE POÇOS DE CALDAS}

(análise realizada em dezembro de 2013)

\section{HISTÓRICO DA INSTITUIÇÃO}

O Museu Histórico e Geográfico fica na cidade de Poços de Caldas, Minas Gerais, situado na Praça Martinho de Freitas Mourão, área central da cidade.

Sua história começa pelo casarão onde o museu se encontra instalado e que pertenceu ao Coronel Augustinho Junqueira, um dos fundadores da cidade. Foi construído no início do século $X X$ e antes de pertencer ao Coronel Junqueira, foi hospital, hotel e escola estadual até 1985, quando foi tombado como patrimônio histórico brasileiro. Passou por um processo de restauração e em 1996 abrigou o Museu e todo seu acervo para ser aberto ao público em 2002 (CIRCUITO TURÍSTICO - CAMINHOS GERAIS, 2014).

O museu foi criado em 1972, na comemoração do centenário da cidade em um dos pontos turísticos mais visitados, o Country Club. O intuito era criar um centro de memória da cidade, para registrar toda sua criação e crescimento com documentos, registros fotográficos, livros, jornais antigos, móveis, louças, vestimentas, objetos utilitários e também uma coleção de minerais e rochas da região de Poços de Caldas por colaboração de um dos mais ilustres moradores, o geólogo e pesquisador Resk Frayha.

Resk Frayha, além de ter sido um dos maiores conhecedores e pesquisadores de geologia do Maciço Alcalino de Poços de Caldas, foi prefeito uma vez e vice-prefeito duas vezes. Por muitos anos realizou diversas pesquisas em todo o planalto de Poços de Caldas coletando muitos minerais raros para a sua coleção particular.

O principal responsável pelo acervo hoje exposto no museu é o arquiteto Haroldo Paes Gessoni, que atua no museu há mais de 10 anos como Coordenador de Divisão. Todas as informações para esta pesquisa foram relatadas pelo Coordenador Haroldo. Ele também disponibilizou um vídeo de uma entrevista realizada com o Sr. Resk Frayha, que relatou um pouco de sua história e embasou a parte histórica desta pesquisa. 


\section{ORGANIZAÇÃO E FUNCIONAMENTO}

A gestão do museu pertence À Prefeitura de Poços de Caldas, através da Secretaria de Turismo e Cultura da cidade. Este departamento supre os custos de manutenção do prédio, a contratação do coordenador e a cessão de funcionários públicos de carreira como um bibliotecário, uma assessora técnica, três auxiliares administrativos e um funcionário para serviços básicos.

A instituição também participa de projetos e editais de estância estadual e federal pelas leis de incentivo á cultura, que quando aprovadas, colaboram para melhorias das exposições e para a conservação e restauro de acervos, entre outros.

Para a Exposição de Minerais Resk Frayha, inaugurada em 2006, o museu obteve apoio da Associação de Mineradores do Planalto de Poços de Caldas, e da Associação de Amigos do Museu.

O objetivo desta instituição é de reunir acervo que conte a história da cidade. Muitas famílias poçoscaldenses, desde sua inauguração, doam seus objetos pessoais para o museu. O principal trabalho do museu é inventariar, restaurar e organizar as exposições de tudo que é doado ao museu, inclusive rochas e minérios. Entretanto, falta uma pessoa capacitada para identificar e catalogar este material.

O museu apresenta dois setores, o histórico e o geográfico. O primeiro possui seis tipos de exposições, sem ligação entre si, e o segundo somente uma exposição, que é a coleção de minerais Resk Frayha.

$\mathrm{O}$ atendimento é feito pelo Haroldo e funcionários disponíveis, pois não há monitores. A entrada é gratuita e a visita demora cerca de 1 hora. A média mensal de visitação é em torno de 1200 pessoas. Muitos turistas e estudantes do ensino fundamental e universitários de todo Brasil são recebidos, principalmente pela coleção Resk Frayha, alvo de muitas pesquisas realizadas na área da geologia. Em entrevista, o coordenador lamenta não receber os trabalhos publicados para serem arquivados na biblioteca do museu.

Como o museu faz parte do roteiro turístico da cidade, a divulgação é feita por meio de folhetos e site da prefeitura. Sua localização é uma das melhores da cidade, pois fica bem no centro, próximo aos melhores comércios, restaurantes e hotéis.

Sua importância está na preservação e conservação da Memória de Poços de Caldas. Como diz o nome do museu, expõe toda a história com objetos cotidianos, além de possuir uma biblioteca que resguarda os principais documentos, registros, 
livros e jornais desde o início do século XIX. Também é geográfico, com toda referência geológica da região.

\section{ESTRUTURA FÍSICA}

O acesso externo ao museu possui rampas de várias dimensões, mas para se ter acesso aos espaços expositivos, somente é possível por uma escadaria. Há uma área térrea, que passou por reformas restauração dos objetos e para a reserva técnica do museu. O museu ainda não possui acessibilidade para pessoas impossibilitadas de subir escadas. Conforme a entrevista, a climatização ainda está inadequada e necessita ser substituída, e não existem áreas de convivência, como espaço para lanche ou lanchonete.

\section{ÁÇAO EDUCATIVA E CULTURAL}

Para obter respostas mais precisas sobre a ação educativa e cultural do museu, o questionário foi entregue para a assessora técnica do museu, Sônia Maria Sanches.

O museu possui um agendamento prévio de visitas das escolas, instituições ou grupos que o querem conhecer com orientação de um dos funcionários. Alguns estagiários também vão às escolas, orientar professores e estudantes em relação à educação patrimonial.

O local não possui áreas interativas e lúdicas, mas tem a intenção de mudar a localização da grade do pátio externo para ganhar espaço para maior interação com as escolas e melhor utilização do espaço para contação de histórias, oficinas e outras atividades educativas.

Em compensação, o museu possui uma sala de exposições temporárias, onde acontecem palestras, cursos, inaugurações e outros. Essa sala é muito importante, pois proporciona uma variedade de atividades multidisciplinares, que enriquecem as ações do museu.

A instalação da sala Dr. Resk Frayha valorizou o acervo mineralógico e tem por finalidade promover e divulgar a importância das rochas, minérios e minerais da região de Poços de Caldas. Conforme a assessora técnica, após sua inauguração, 
uma diversidade de escolas, universidades e pesquisadores já estiveram no museu com a finalidade única de conhecer a coleção.

Vale ressaltar que o museu conta com o apoio de engenheiros de minas, geógrafos e geólogos para entrevistas e atendimento escolar, quando for necessário enriquecer visitas direcionadas.

\section{ACERVO MINERALÓGICO}

O acervo mineralógico, composto por quase 300 amostras, está dispostos em vitrines de madeira com vidro e possui etiquetas com o nome das espécies (alguns minerais foram classificados erroneamente) e as localidades específicas do maciço alcalino de Poços de Caldas. Possui iluminação central e também iluminação interna, facilitando a observação dos exemplares.

Algumas espécies se destacam pela raridade e por hoje serem ocorrências exauridas e localidades históricas do planalto. São amostras coletadas há mais de 60 anos, quando as minerações estavam em plena exploração, como, por exemplo, amostras de baddeleyíta "botrioidal" do Ribeirão do Quartel, Águas da Prata, SP e villiaumita da Pedreira Bortolan, Poços de Caldas ambas as ocorrências atualmente estão inacessíveis.

Neste acervo há vários minerais de elementos terras raras e de tório e urânio como cerianita-(Ce), uraninita, autunita etc., muitas dessas amostras provenientes do famoso Morro do Ferro, uma das maiores concentrações radioativas naturais do mundo, e com uma mineralogia bem diversificada e rara.

Importantes amostras de bauxita (gibbsita+böhmita+diásporo) de diversas localidades históricas dentro do maciço alcalino são encontradas nesta coleção.

A coleção de minerais Resk Frayha que faz parte do Museu do Instituto Histórico e Geográfico de Poços de Caldas, apesar de ser pequena, tem uma importância local, regional e até nacional, devido à importância do Maciço Alcalino de Poços de Caldas para toda a geologia e mineralogia do Brasil.

A coleção mineralógica deste museu é relevante para a pesquisa e para a memória da mineralogia do Brasil, principalmente pela raridade das amostras e pela história do pesquisador e colecionador Resk Frayha, que dedicou boa parte de sua vida reunindo amostras e pesquisando a mineralogia do maciço alcalino de Poços de Caldas. 
Quadro 24. Quadro de minerais brasileiros pertencentes ao acervo do Museu Histórico e Geográfico de Poços de Caldas - "Coleção Resk Frayha" com suas respectivas ocorrências (exemplos);

Quadro de minerais brasileiros importantes pertencentes ao acervo do Museu do IHGPC e suas respectivas ocorrências (exemplos):

Autunita - Mina do Serrote, Cascata, SP.

Baddeleyíta - Ribeirão do Quartel, Águas da Prata, SP; Morro do Serrote, Cascata, SP.

Cerianita-(Ce) - Morro do Ferro, Poços de Caldas, MG.

Eudialita e manganoeudialita - Anel Norte e Pedra Balão, Poços de Caldas, MG.

Gibbsita - Campo do Saco, Campo do Cocal, Campo do Sérgio, Morro da Árvore - Poços de Caldas, MG.

Hainita e rosenbuschita - Pedreira Bortolan, Poços de Caldas, MG. Ilsemannita - Mina Osamu Utsumi, Caldas, MG; Campo do Agostinho, Poços de Caldas, MG.

Jordisita - Mina Osamu Utsumi, Caldas, MG; Campo do Agostinho, Poços de Caldas, MG.

Natrolita - Pedreira Bortolan, Poços de Caldas, MG.

Pirofanita-Campo do Cercado, Andradas, MG.

Pirolusita - Campo do Cercado, Andradas, MG.

Tuperssuatsiaíta - Pedreira Bortolan, Poços de Caldas, MG.

Uraninita - Mina Osamu Utsumi, Caldas, MG.

Villiaumita - Pedreira Bortolan, Poços de Caldas, MG.

Zircão - Mina do Serrote, Cascata, SP; Mina da Espingarda,

Poços de Caldas, MG; Morro do Taquari, Caldas, MG. 


\section{RELAÇÃO DE FOTOS DO MUSEU IHGPC/COLEÇÃO RESK FRAYHA}

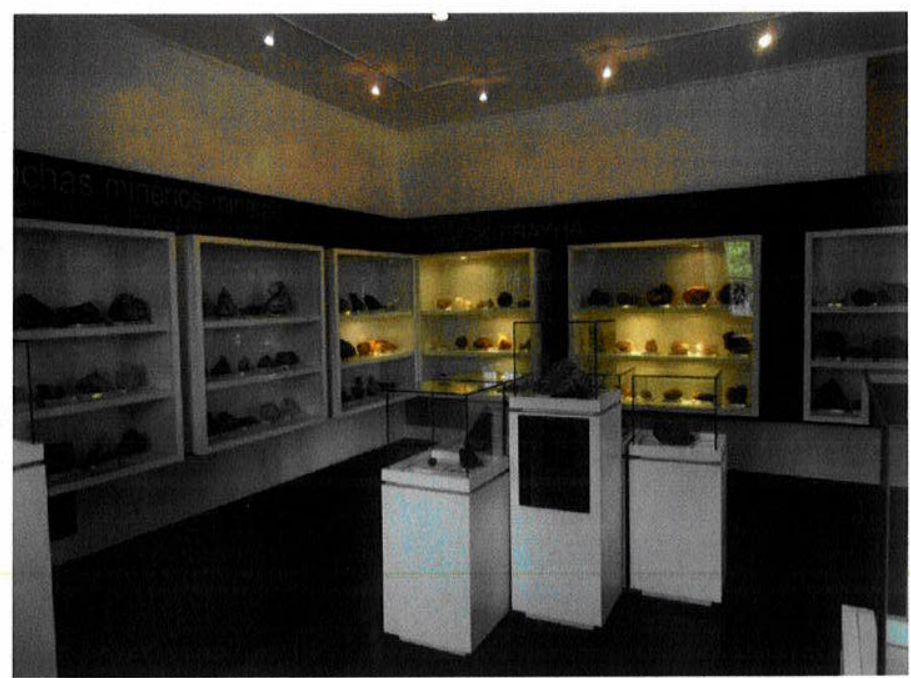

Figura 168. Museu IHGPC "Coleção Resk Frayha". Vista geral do salão expositivo.

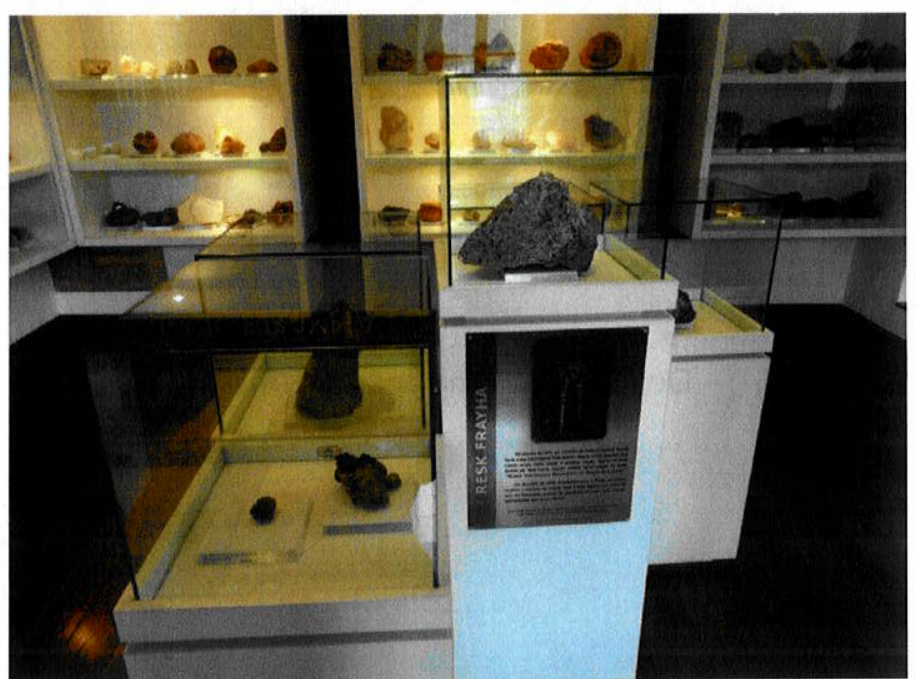

Figura 169. Museu IHGPC "Coleção Resk Frayha". Detalhe da homenagem ao pesquisador Resk Frayha.

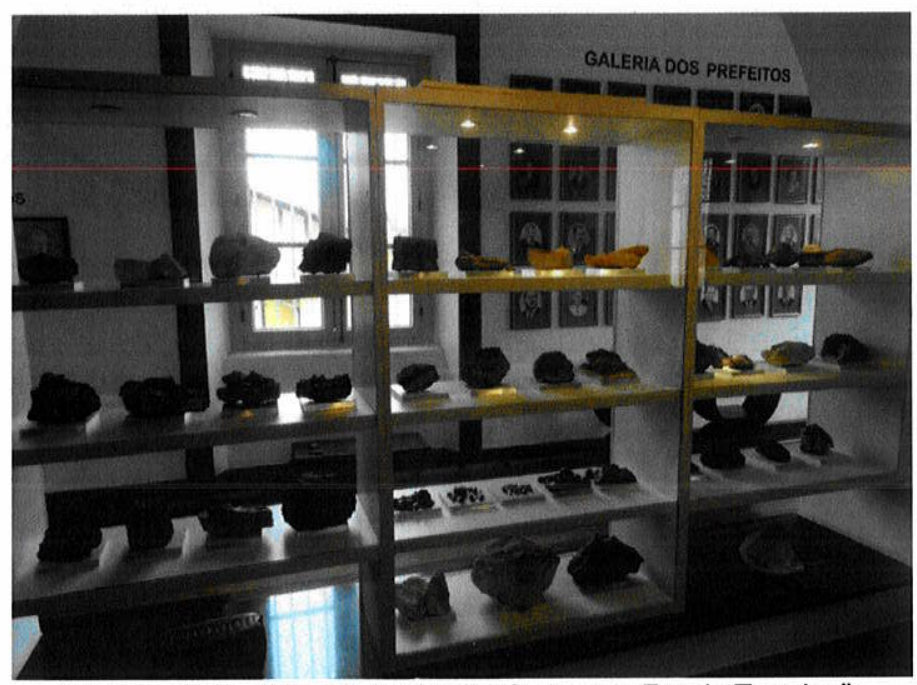

Figura 170. Museu IHGPC "Coleção Resk Frayha". Vitrine com várias amostras minerais de Terras Raras. 


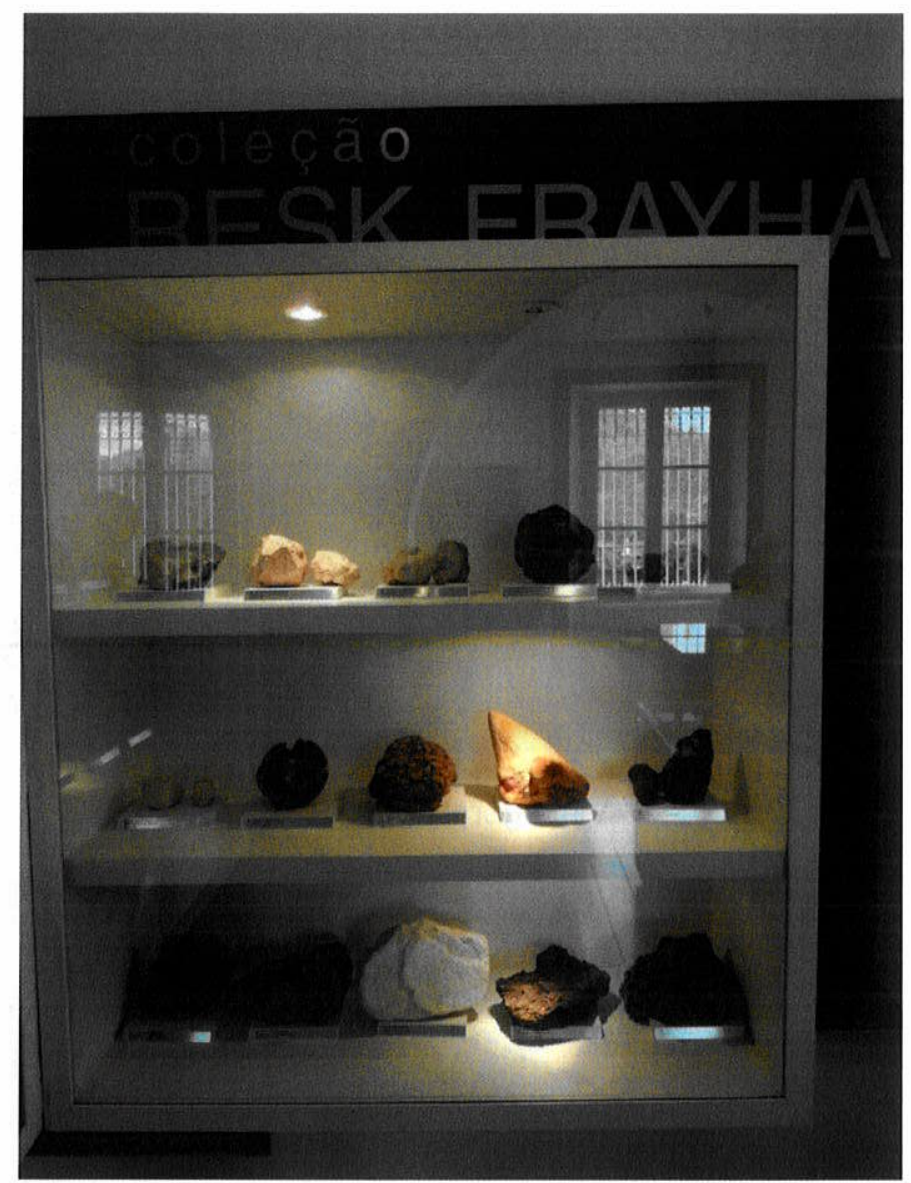

Figura 171. Museu IHGPC "Coleção Resk Frayha". Detalhe da iluminação interna das vitrines.

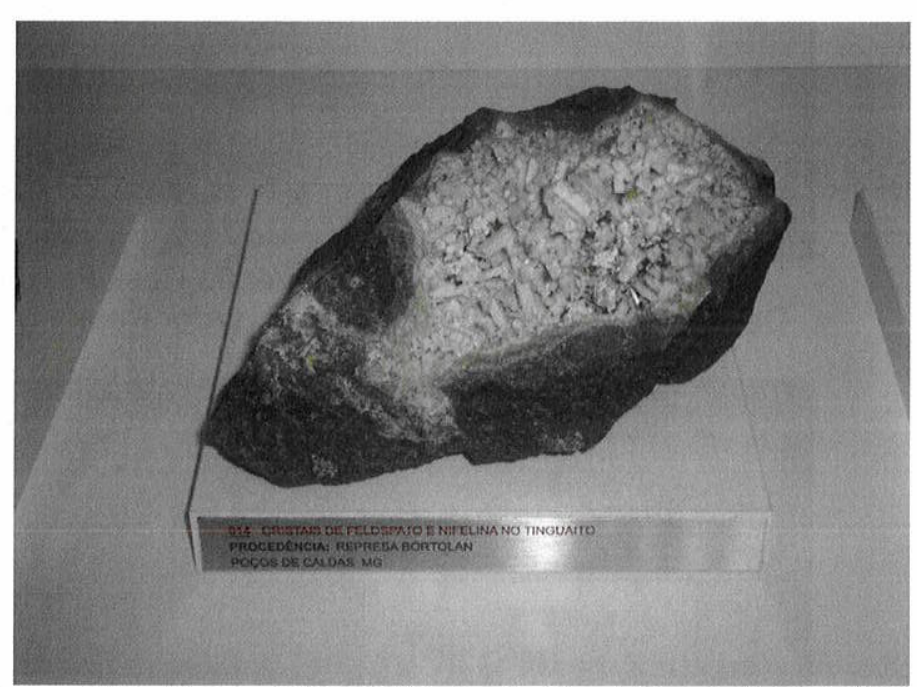

Figura 172. Museu IHGPC "Coleção Resk Frayha". Detalhe da etiqueta com informações simples e com alguns erros de digitação. 


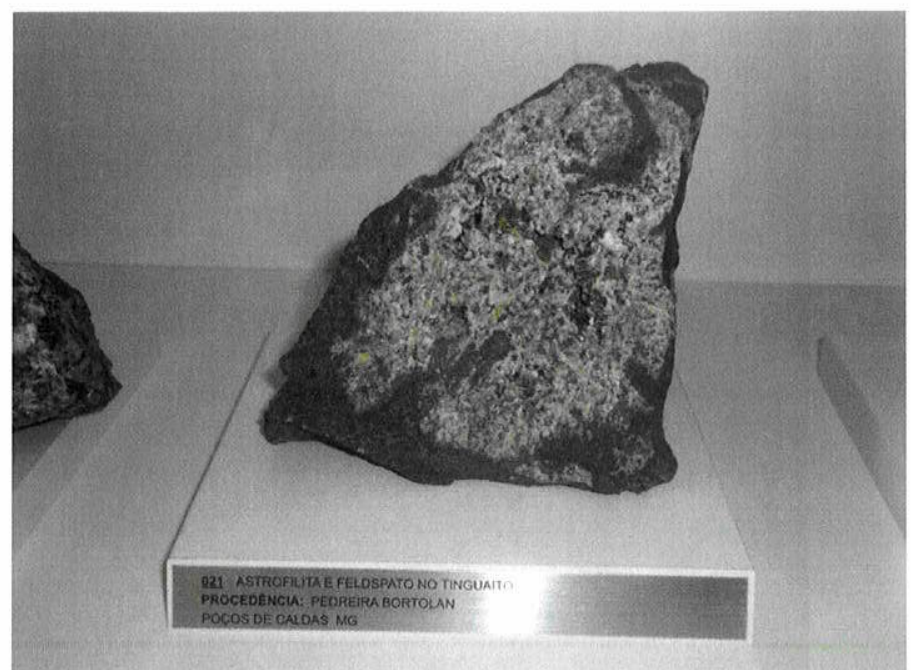

Figura 173. Museu IHGPC "Coleção Resk Frayha". Amostra de uma espécie Rara, astrofilita encontrada na famosa pedreira Bortolan. Detalhe da base da amostra mineral.

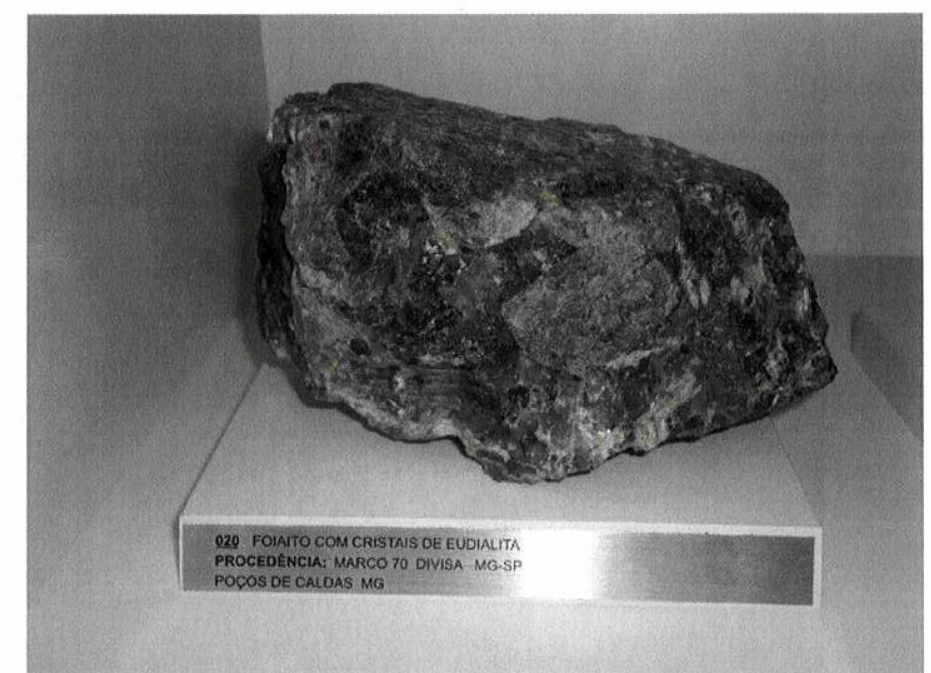

Figura 174. Museu IHGPC "Coleção Resk Frayha". Amostra rara e antiga, coletada na década de 60, de mineral (ou minerais) do grupo da eudialita.

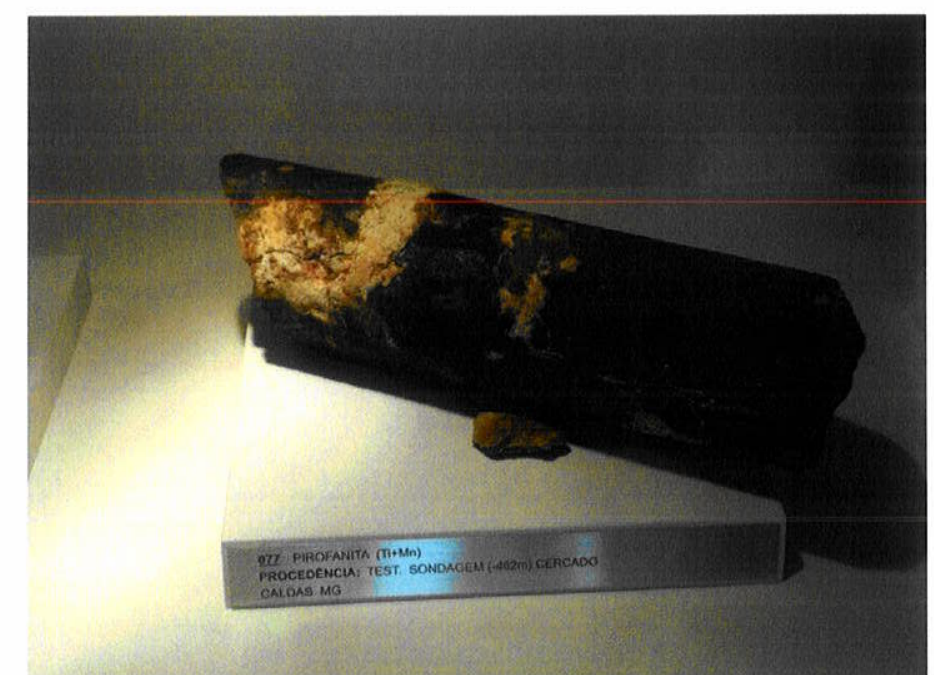

Figura 175. Museu IHGPC "Coleção Resk Frayha". Testemunho de sondagem contendo pirofanita. 


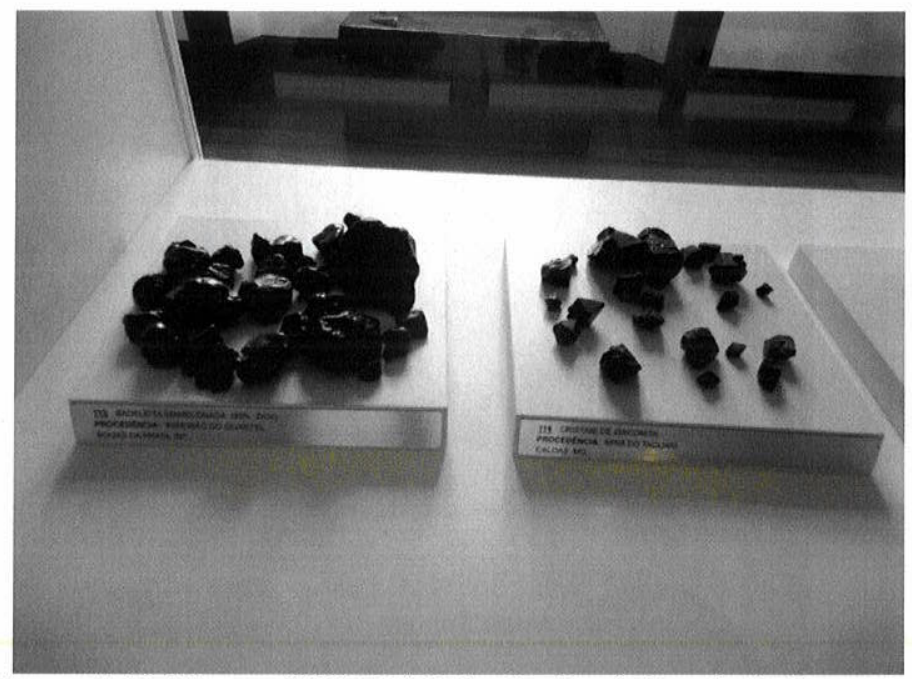

Figura 176. Museu IHGPC "Coleção Resk Frayha". Amostras raras de baddeleyíta e zircão do Maciço Alcalino de Poços de Caldas.

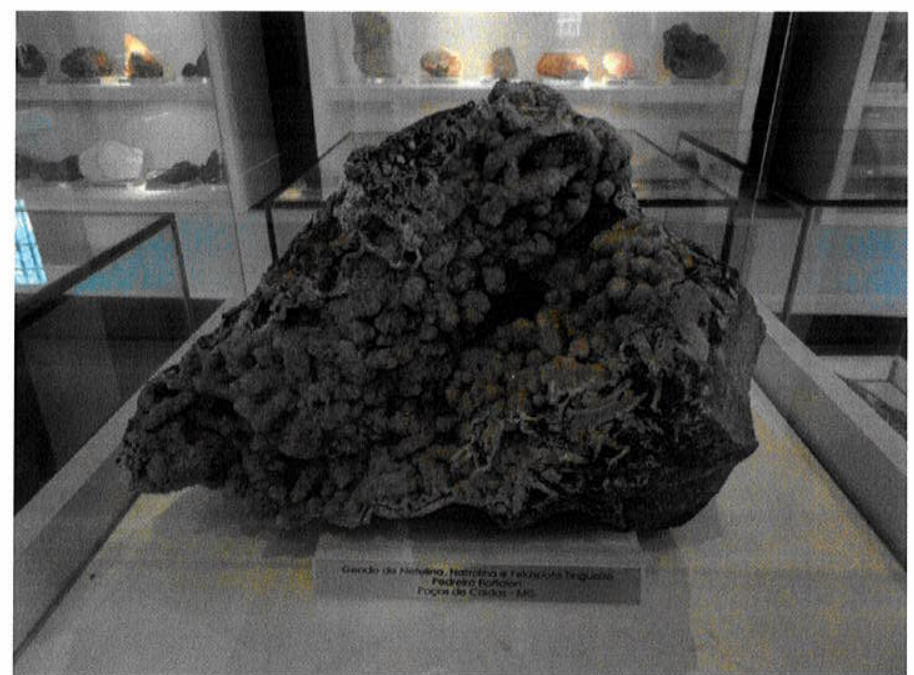

Figura 177. Museu IHGPC "Coleção Resk Frayha”. Amostra rara de natrolita em cavidade no tinguaíto. 


\section{MUSEU DE GEOCIÊNCIAS \\ IGc /USP}

(análise realizada em dezembro de 2013)

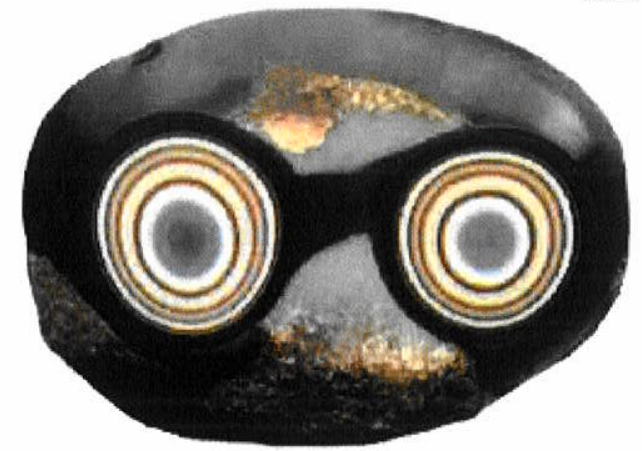

\section{HISTÓRICO DA INSTITUIÇÃO}

O Museu de Geociências fica localizado na Rua do Lago, 562 - $1^{\circ}$ andar Cidade Universitária USP - São Paulo, SP.

Sua história começou em 1934, por iniciativa do Prof. Ettore Onorato ${ }^{13}$, que o criou a partir da coleção do Departamento de Mineralogia e Petrologia da então Faculdade de Filosofia, Ciências e Letras da USP (FFCL).

$\mathrm{O}$ acervo do Museu foi formado, inicialmente, pelas doações de alunos e professores e depois pela aquisição de importantes coleções particulares, adquiridas pelo Governo de São Paulo, como a coleção Araújo Ferraz e a coleção Luiz Paixão em 1954, bem como com pela doação da coleção C .L. Schnyder em 1984. Foi também acrescida ao museu, na década de 90 , uma coleção muito importante de espécies raras e vários holótipos do mineralogista russo Eugene Semenov.

Atualmente, o acervo vem sendo aumentado, principalmente, por doações feitas por professores, colecionadores particulares, alunos do curso de geologia, e também, pela aquisição de peças individuais (MUSEU DE GEOCIÊNCIAS IGc/USP).

Relatando um pouco sobre as áreas de atuação do museu, suas ações eram voltadas para os aspectos científicos e didáticos da Mineralogia e da Cristalografia. A partir de 1957, data da criação do curso de geologia na USP, o museu passou a ser, também, um laboratório de aulas práticas para os alunos desse novo curso da Faculdade de Filosofia, Ciências e Letras.

Em 1981, houve uma grande reestruturação e diversificação no acervo, quando foram incluídas, além das amostras de minerais, amostras de rochas, gemas, meteoritos e fósseis. O museu, que antes era mais mineralógico, transformou-se no atual Museu de Geociências.

\footnotetext{
${ }^{13}$ Professor da Cadeira de Mineralogia e Petrologia da FFCL-USP, veio da Universidade de Roma, Itália no período de 1934 a 1939 e trouxe para o Brasil a técnica de difratometria de raio X para análise mineralógica. Scielo. Rui Ribeiro Franco: o início da geociências. Disponível em:http://www.scielo.br/scielo.php?pid=S0103-40141994000300009\&script=sci_arttext. Acesso em 03 dez. 2013.
} 
O responsável pelo museu é Ideval Souza Costa, Geólogo, Mestre em Mineralogia Aplicada, que trabalha no museu há dez anos. Seu cargo é de Chefe Técnico, atuando também como coordenador do setor educativo.

\section{ORGANIZAÇÃO E FUNCIONAMENTO}

A gestão do museu pertence ao Instituto de Geociências da USP, que arca com todos os gastos básicos da instituição.

Trabalham no museu três funcionários, um geólogo e dois técnicos em museu, (um bacharel em Relações Públicas e uma mestra em Mineralogia Aplicada). Para a segurança, foram contratados dois vigilantes terceirizados. A monitoria é realizada por dois monitores bolsistas e mais alunos voluntários. Todos são capacitados pelo geólogo da instituição.

As áreas de atuação são Mineralogia e Petrologia, com atendimento educativo direcionado.

O principal objetivo do museu é instigar o interesse à pesquisa dos diversos públicos sobre o Planeta Terra, através de evidências geológicas. Mais especificamente, o Museu de Geociências é um laboratório de aulas práticas para várias disciplinas, de graduação e de pós-graduação, destinadas ao curso de geologia, a cursos de outras unidades da USP, e ainda a outras instituições universitárias e, como ponto principal relacionado ao acervo, é um fiel depositário de amostras científicas pesquisadas pelos docentes do IGc/USP, e de outras universidades.

O museu é aberto ao público, dentro dos horários de funcionamento, que estão relacionados com o IGc/USP. Somente as visitas de turmas devem ser agendadas com antecedência. O museu solicita uma contribuição voluntária de $\mathrm{R} \$ 3,00$ por pessoa de grupos pertencentes a instituições privadas, e $\mathrm{R} \$ 1,00$ de grupos públicos. A monitoria pode durar até duas horas, e o público alvo são estudantes do ensino fundamental, médio e universitários.

A divulgação é feita pelo site do museu, pelas redes sociais, e por folders que são distribuídos e pela imprensa local.

O Museu de Geociências da USP atua junto à comunidade, oferecendo orientação educacional em geociências em instituições de ensino, organização de exposições em diversas localidades, orientação geológica gratuita e cursos 
relacionados a temas variados da geologia. Desta forma contribui para a disseminação do conhecimento da mineralogia e é instituição referência para a capital de São Paulo.

\section{ESTRUTURA FÍSICA}

O Museu de Geociências ocupa uma área de $550 \mathrm{~m}^{2}$, localizada no primeiro andar do edifício principal do Instituto de Geociências. Todos os ambientes são climatizados, com acessibilidade e segurança próprios. Há uma loja do museu, com livros, minerais, kits educativos, entre outros. A própria cidade universitária já é um local de convivência, com lanchonetes, restaurantes, banheiros, bebedouros, tudo com acesso ao público.

\section{AÇÃO EDUCATIVA E CULTURAL}

O museu possui uma ação educativa bem centrada nas escolas, oferecendo um atendimento monitorado, cursos e palestras (no auditório do Instituto de Geociências), além de orientação em feiras de ciências, e visitas a escolas. A monitoria é desenvolvida de forma lúdica e interativa, no próprio espaço do museu.

Além disso, são desenvolvidas ações culturais, como exposições temporárias, participação em eventos externos, tais como feiras educativas, inauguração de espaços culturais, e empréstimos de amostras, com coleções próprias para esta atividade.

De acordo com o interesse do professor, são fornecidos materiais que possam auxiliá-los na preparação da visita.

\section{ACERVO MINERALÓGICO}

O Museu de Geociências do IGc-USP possui um acervo grande, rico e raro tanto em diversidade de exemplares mineralógicos, quanto em localidades geográficas históricas. No acervo atual, conta com aproximadamente 45 mil amostras de minerais, rochas, espeleotemas, meteoritos e fósseis, todas expostas em um grande salão de $550 \mathrm{~m}^{2}$. Em exposição, são cerca de 5 mil amostras de minerais (incluem-se algumas rochas, espeleotemas e meteoritos - 
aproximadamente 300 amostras). Todos os minerais estão sistematizados e classificados de acordo com a classificação de Dana, sendo todas as classes químicas bem representadas.

O mobiliário do museu é composto por vitrines de madeira com várias prateleiras de vidros e iluminação interna. No espaço, ainda há algumas vitrines com formatos diferentes da grande maioria, onde existem exposições temáticas.

Muitos minerais estão sobre bases de metal ou acrílico, não havendo uniformidade na disposição das amostras. Alguns minerais estão em caixas de plástico hermeticamente fechados, por serem deliqüescentes.

As etiquetas são importantes, pois além dos nomes das espécies, há a composição química e a localidade geográfica. As localidades geográficas, em geral, estão bem especificadas, apesar de existirem algumas procedências incompletas. Algumas etiquetas estão em Braille e o museu tem acessibilidade através de elevador. Porém, as vitrines em geral são altas e com várias prateleiras de vidro, não permitindo assim, nem aos caderantes e nem às crianças, terem uma boa visibilidade dos minerais.

Existe no acervo erros quanto à classificação de alguns dos minerais expostos e, em muitos casos, isso se deve a falta de atenção dos responsáveis pela manutenção, pesquisa e gestão do acervo, pois às vezes observam-se minerais com etiquetas trocadas, possivelmente durante a manutenção de limpeza por estagiários com pouco conhecimento sobre os minerais ou sobre o acervo. São ainda utilizadas nomenclaturas antigas, não havendo um padrão nos nomes das espécies minerais, como é o caso de algumas espécies minerais que são comumente chamados de amianto ou asbesto, nomes utilizados para minerais fibrosos como actinolita, tremolita, antofilita, riebeckita e, principalmente, crisotila.

O acervo atual conta com 45.000 peças, das quais cerca de 5.000 estão em exposição permanente. A maior parte dos exemplares é nacional e provém de várias regiões brasileiras, enquanto o restante corresponde a amostras de diferentes partes do mundo.

Uma das amostras mais importantes do acervo geológico do museu não está em sua exposição principal dentro do salão, mas sim no hall de entrada do Instituto de Geociências da USP, que é o meteorito siderito Itapuranga pesando $628 \mathrm{~kg}$, sendo o terceiro maior meteorito brasileiro. Porém, pouco destaque se dá para essa incrível amostra. 
No acervo mineralógico, além dos minerais ordenados em classes químicas, ocorrem outras vitrines com temas específicos como, por exemplo: 1) coleção do mineralogista russo Eugene Semenov, composta por vários minerais raros e muitas espécies holótipos, que são as amostras originais que permitiram a descrição das espécies, 2) coleção dos minerais tipo do Brasil, onde se encontram espécies raríssimas das ultimas descobertas e descrições de minerais novos brasileiros como coutinhoita, matioliíta, lindbergita, menezesita, atencioíta, ruifrancoiíta, guimarãesita, carlosbarbosaíta, entre outras. Esse acervo mineralógico é um dos mais importantes de toda a coleção do museu, pois além de dar notoriedade ao museu, dá visibilidade internacional.

Ainda no salão principal, há algumas vitrines com temática sobre cavernas, onde mostra-se a formação de estalactites e estalagmites e expõe-se boa variedade de espeleotemas. Outras vitrines se destacam por serem dedicadas aos meteoritos, às rochas mais antigas do mundo, e combustíveis e resinas fósseis.

No centro do salão expositivo, concentram-se os minerais-gemas e as pedras lapidadas.

O museu ainda conta com exposições de rochas separadas por sua gênese (ígneas, metamórficas e sedimentares) e uma exposição sobre os bens minerais, mostrando alguns importantes minerais-minérios dos principais elementos químicos e a sua utilização na indústria.

O museu não possui politicas de intercâmbio e em geral recebe doações de alunos, ex-alunos, professores e colecionadores.

A reserva técnica tem aproximadamente 1000 amostras e fica próxima ao depósito geral de amostras geológicas das pesquisas de professores e pesquisadores do Instituto de Geociências da USP. A reserva não possui climatização e nenhuma proteção especial aos exemplares. As amostras estão colocadas em caixas de plásticos, em armários deslizantes de aço.

$\mathrm{O}$ acervo mineralógico do Museu de Geociencias da USP é uma das mais importantes coleções para a preservação da memória da mineralogia do país. O mais importante deste acervo é a quantidade de espécies tipos brasileiros e dos seus respectivos holótipos, além de vários minerais provenientes de localidades históricas e ocorrências exauridas. 
Quadro 25 - Quadro de minerais tipo brasileiros pertencentes ao acervo do Museu de Geociências IGc/USP com suas respectivas ocorrências (exemplos):

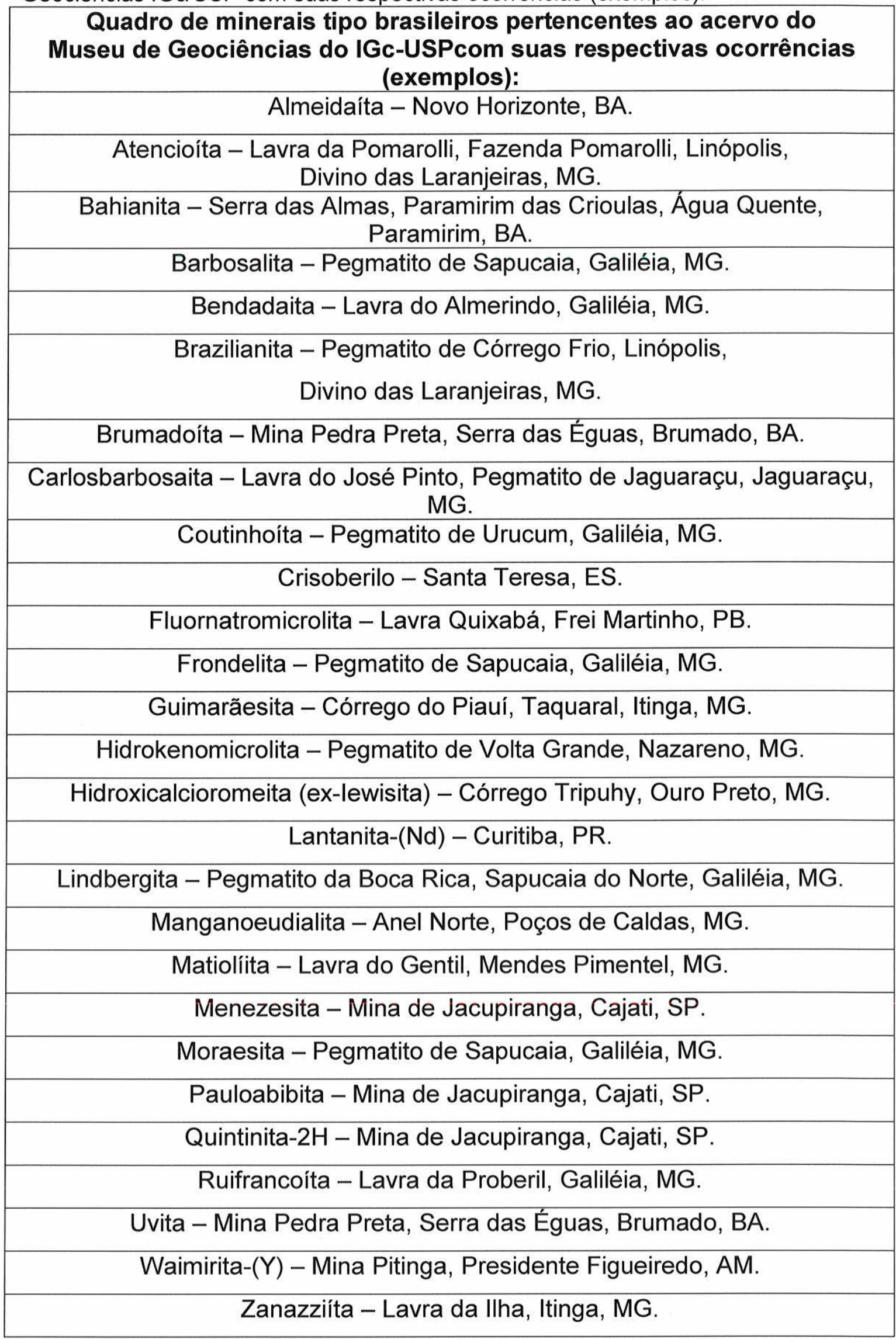


Quadro 26. Quadro de minerais brasileiros pertencentes ao acervo do Museu de Geociências IGc/USP com suas respectivas ocorrências (exemplos);

\begin{tabular}{|c|}
\hline $\begin{array}{l}\text { Quadro de minerais importantes brasileiros pertencentes ao acervo do } \\
\text { Museu de Geociências do IGc-USP e suas respectivas ocorrências } \\
\text { (exemplos): }\end{array}$ \\
\hline Antimônio nativo - Areado, MG. \\
\hline Baddeleyíta - Morro do Serrote, Cascata, SP. \\
\hline Calcosiderita - Mina do Córrego Fundo, Itatiaiuçu, MG. \\
\hline Crocoíta - Goiabeiras, Congonhas do Campo, MG. \\
\hline Cubanita (=chalmersita) - Mina Velha, Morro Velho, Nova Lima, MG. \\
\hline Diamante - Diamantina, MG. \\
\hline Edingtonita - Mina Jacupiranga, Cajati, SP. \\
\hline Fenacita - Rio Piracicaba, São Miguel de Piracicaba, MG. \\
\hline Gibbsita - Lagoa Gambá, Ouro Preto, MG. \\
\hline Hainita - Pedreira Bortolan, Poços de Caldas, MG. \\
\hline Kosnarita - Pegmatito do Jenipapo, Itinga, MG. \\
\hline Narsarsukita - Pedreira Bortolan, Poços de Caldas, MG. \\
\hline Ouro nativo - São João del Rei, MG. \\
\hline Simpsonita - Fm. Equador, Parelhas, RN. \\
\hline Stokesita - Pegmatito de Urucum, Galiléia, MG. \\
\hline Stolzita - Sumidouro, Mariana, MG. \\
\hline Turquesa - Mina do Córrego Fundo, Itatiaiuçu, MG. \\
\hline
\end{tabular}




\section{RELAÇÃO DE FOTOS DO MUSEU DE GEOCIÊNCIAS IGC/USP}

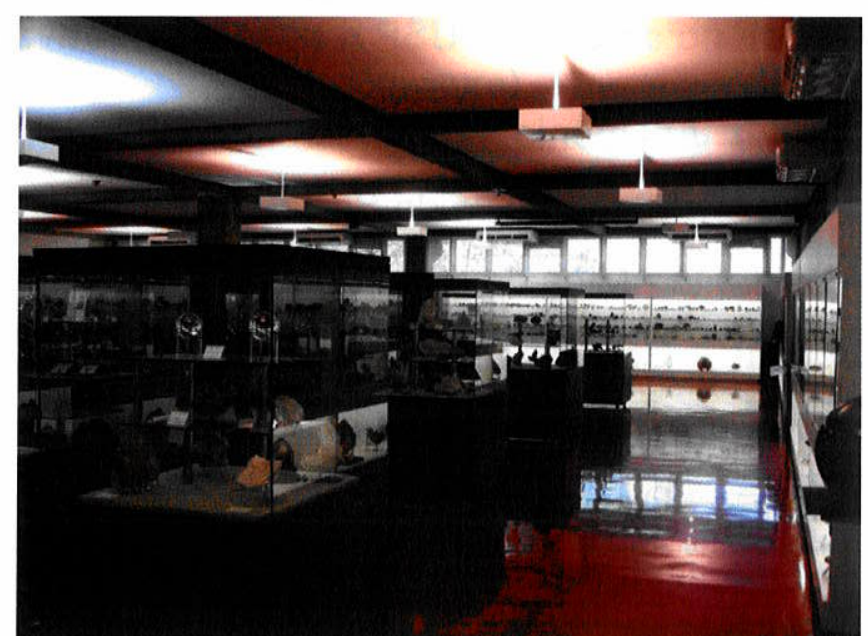

Figura 178. Museu de Geociências IGc/USP. Vista geral do salão expositivo.

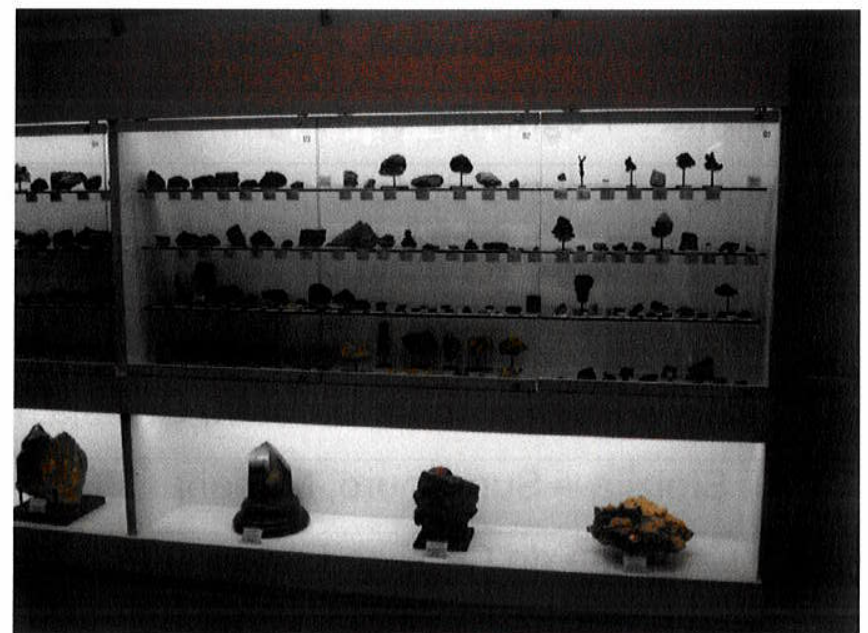

Figura 179. Museu de Geociências IGc/USP.

Vitrine com minerais classificados segundo Dana. Abaixo Minerais grandes sem sistematização preferencial.

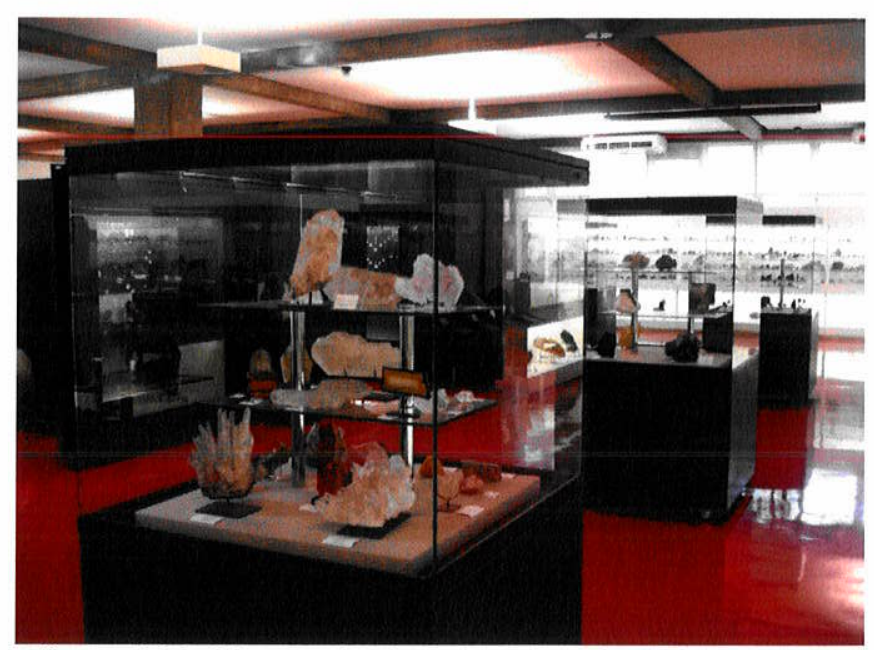

Figura 180. Museu de Geociências IGc/USP. Vitrines modulares com amostras diversas e temas específicos. 


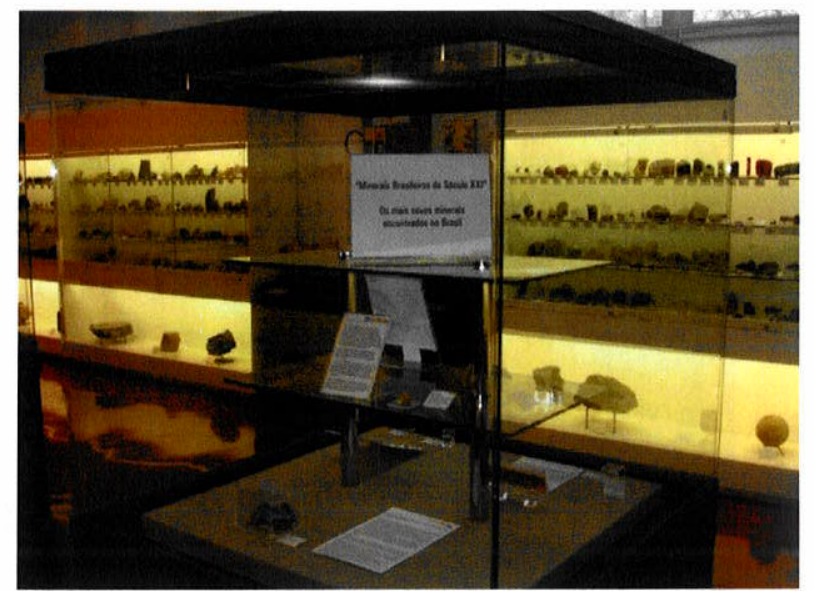

Figura 181. Museu de Geociências IGc/USP. Vitrine dedicada aos minerais brasileiros descobertos no século XXI.

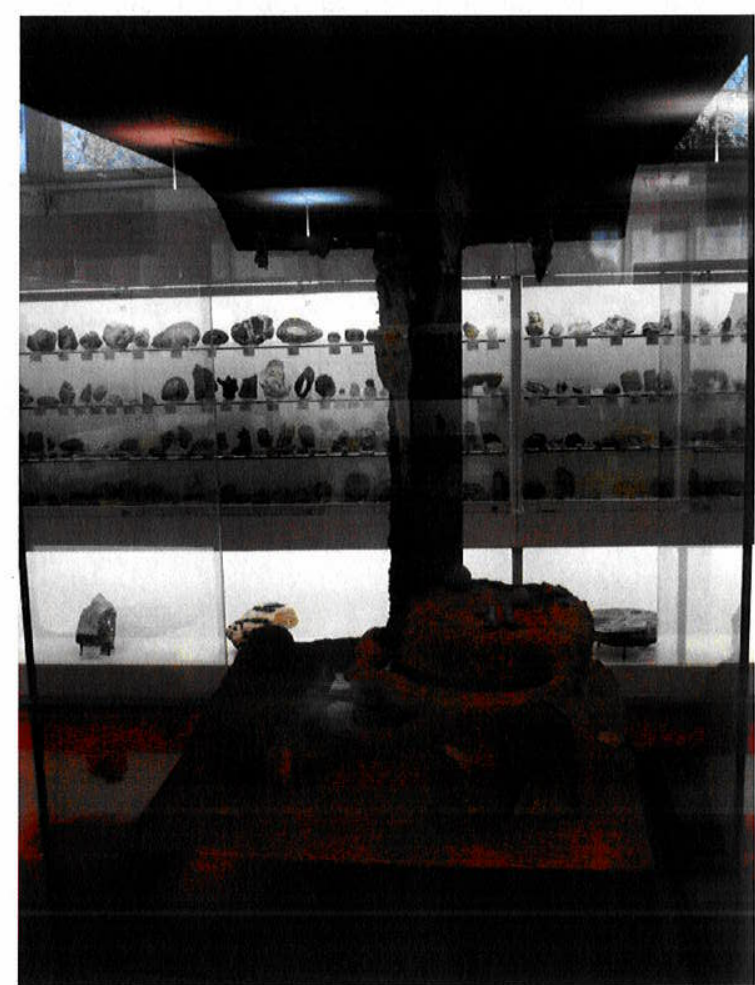

Figura 182. Museu de Geociências IGc/USP. Vitrine temática que ilustra os espeleotemas.

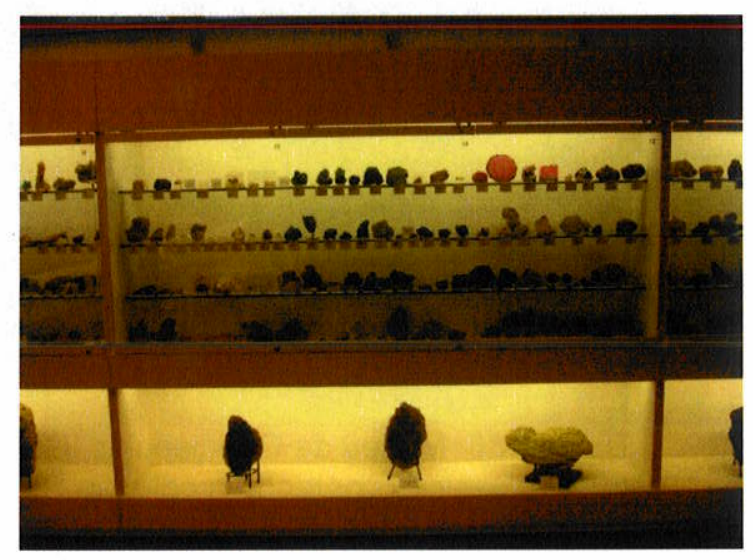

Figura 183. Museu de Geociências IGc/USP. lluminação interna das vitrines dos minerais. 


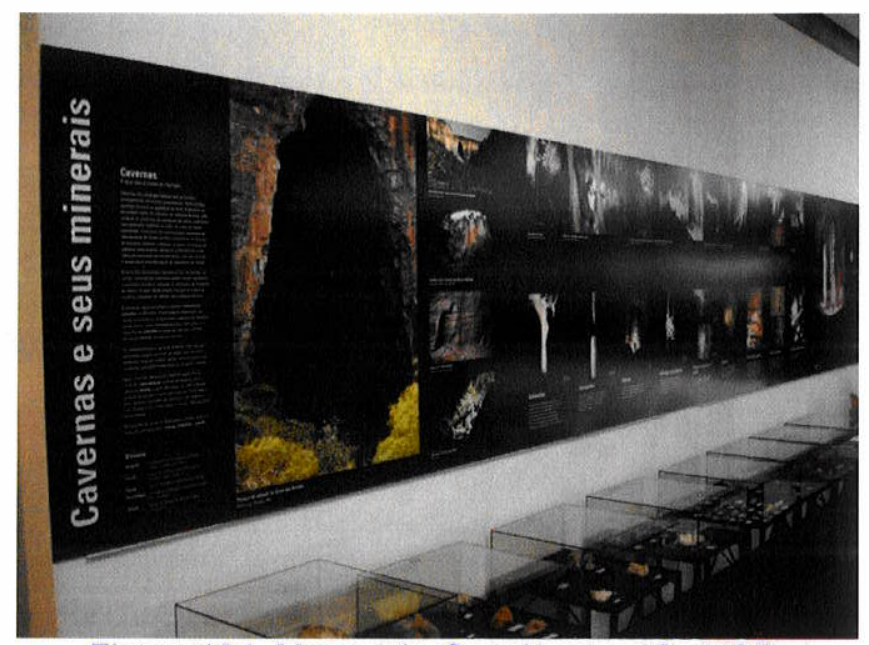

Figura 184. Museu de Geociências IGc/USP. Vitrines e painel temático sobre minerais de cavernas.

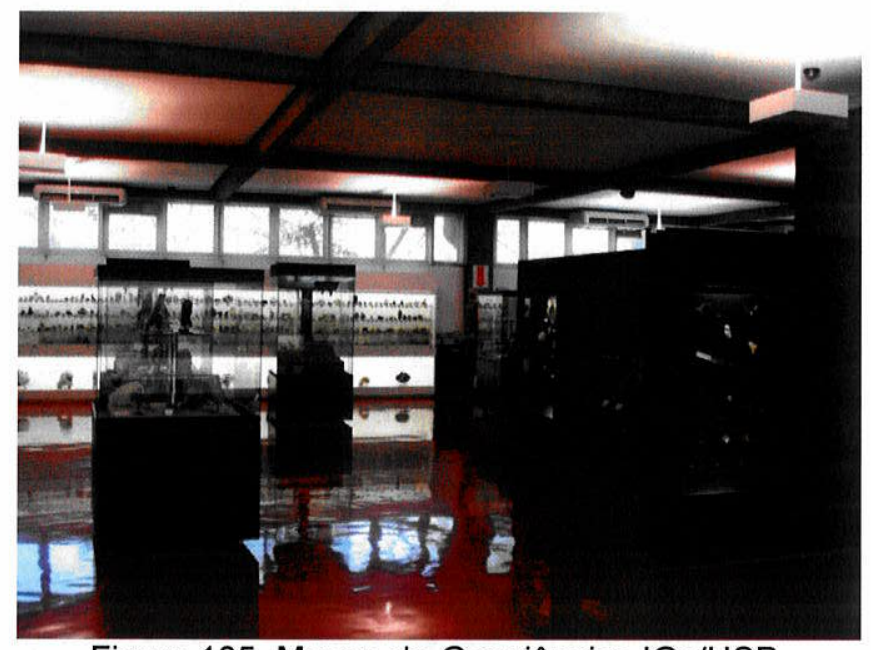

Figura 185. Museu de Geociências IGc/USP. Vista dos tipos de vitrines do museu.

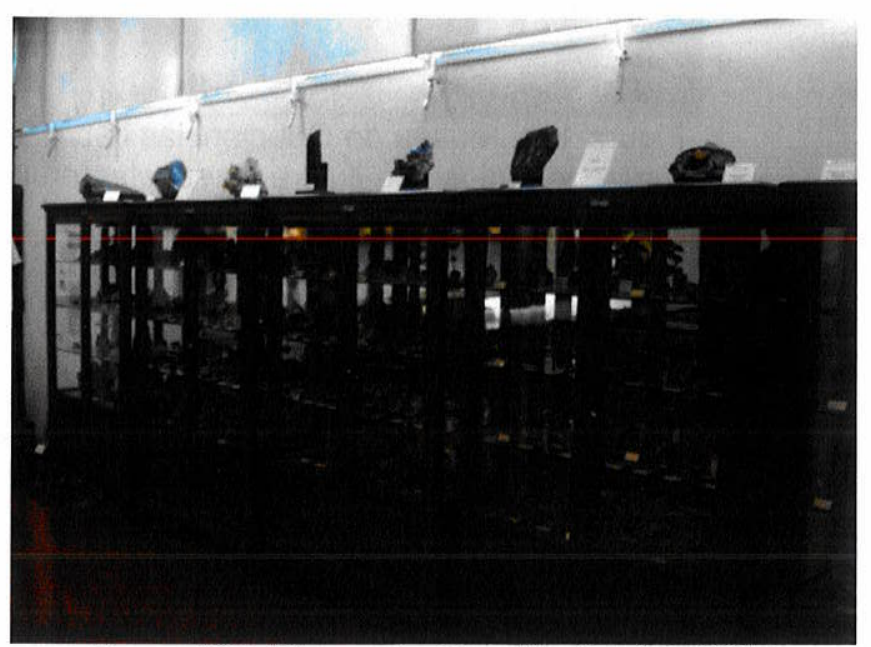

Figura 186. Museu de Geociências IGc/USP. Vitrines clássicas contendo a coleção Schnyder. 


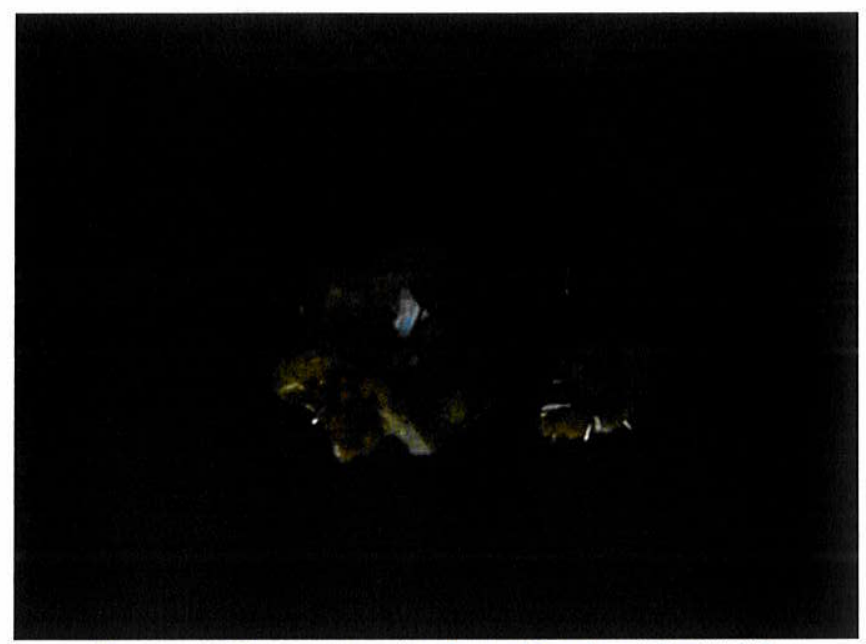

Figura 187. Museu de Geocięncias IGc/USP. Amostras de crisoberilo geminado.

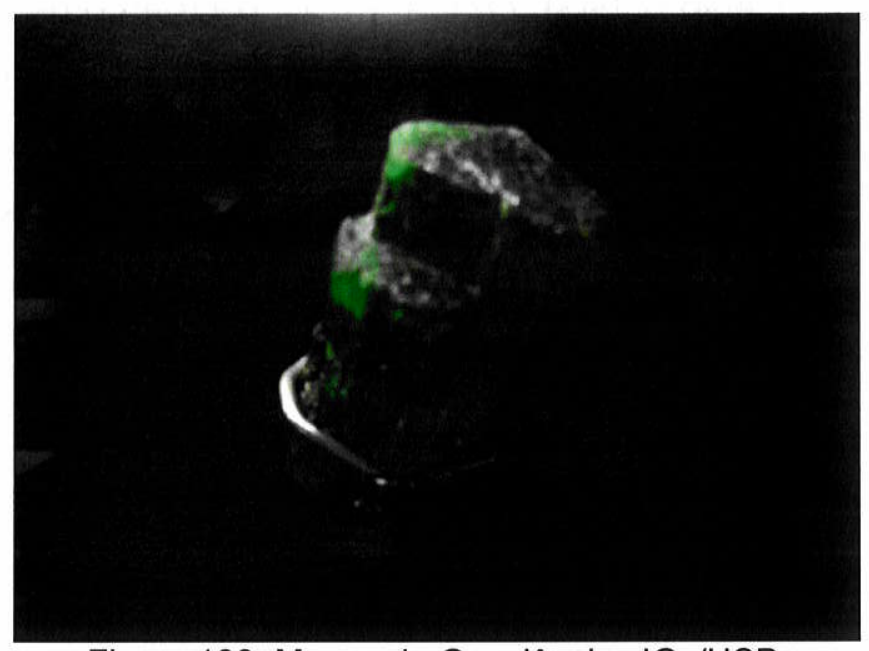

Figura 188. Museu de Geociências IGc/USP. Amostra de esmeralda (variedade de berilo).

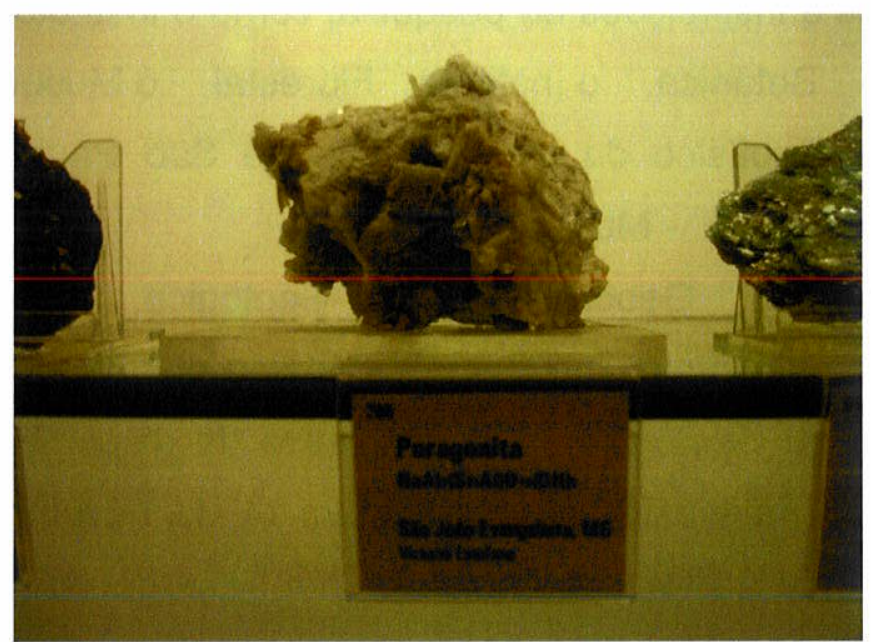

Figura 189. Museu de Geociências IGc/USP. Detalhe da etiqueta com informações importantes como o nome da espécie, composição química e localidade geográfica. 
MUGEO - CENTRO MUSEU GEOLÓGICO

(análise realizada em 17/01/2014)

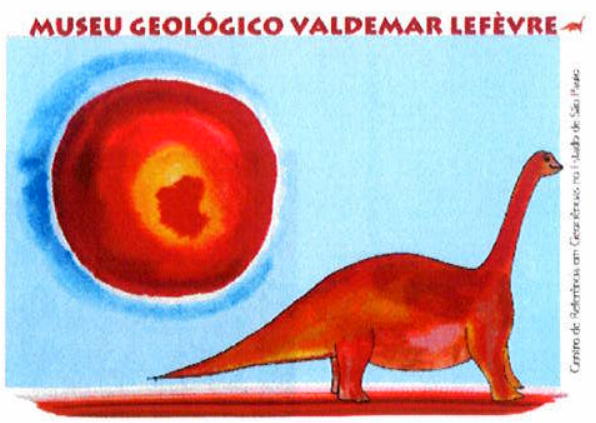

HISTÓRICO DA INSTITUIÇÃO

O MUGEO é um museu público estadual, localizado na Av. Francisco Matarazzo, 455 - Parque da Água Branca - Perdizes, São Paulo - SP.

O Museu Geológico tem sua origem na coleção da Comissão Geográfica e Geológica de São Paulo (CGG), criada em 27 de março de 1886. A comissão surgiu da necessidade de se conhecer o território paulista, em função da expansão da cafeicultura e do acelerado crescimento econômico decorrente dessa atividade (MUSEU GEOLÓGICO VALDEMAR LEFRĖVE - MUGEO, 2014).

Foi responsável por realizar as primeiras expedições modernas de mapeamento do solo, clima e hidrografia do interior paulista, levadas a cabo ao longo de quatro décadas. Colaboraram na comissão nomes como os dos engenheiros Teodoro Sampaio e Francisco de Paula Oliveira, o botânico Albert Löfgren, os geólogos Orville Adelbert Derby e Luiz Felipe Gonzaga de Campos.

Os trabalhos da Comissão Geográfica e Geológica acumularam um vasto patrimônio científico, iconográfico e documental, posteriormente dividido entre diversos órgãos e instituições de pesquisa, como o Instituto Geográfico e Geológico, o Instituto de Botânica, o Instituto Florestal, o Museu Paulista e o Instituto Astronômico e Geofísico da Universidade de São Paulo (MUSEU GEOLÓGICO VALDEMAR LEFRÈVE - MUGEO, 2014).

O Instituto Geográfico e Geológico, herdeiro das coleções de mineralogia, paleontologia e demais campos das geociências, foi o responsável por criar o Museu Geológico, com o objetivo de disponibilizar parte de acervo ao público geral. O museu foi inaugurado em 14 de novembro de 1967 e recebeu o nome de Valdemar Lefèvre, em homenagem ao engenheiro e ex-diretor do Instituto Geográfico e Geológico.

O Diretor do Museu, Fernando Alves Pires, que trabalha a 21 anos na instituição e é Geólogo Doutor em Estratigrafia e Sedimentologia, colaborou com esta pesquisa, informando grande parte do conteúdo descrito. Ele ressalta que, 
mesmo o museu sendo inaugurado em 1967, somente teve uma atuação significativa a partir de 1993, quando foi efetuada uma reestruturação em toda expografia física e no acervo exposto.

\section{ORGANIZAÇÃO E FUNCIONAMENTO}

O MUGEO é um instituto gerido pelo Instituto Geológico, centro de pesquisa vinculado à Secretaria do Meio Ambiente do Estado de São Paulo, para os custeios da estrutura física e dos recursos humanos. Melhorias e exposições itinerantes são financiadas por empresas como PETROBRAS e Fundação Vitae.

O principal responsável pelo acervo e sua curadoria é o Diretor Fernando, mas como ele relatou, existem no total 22 pessoas que trabalham para o museu e que são funcionários públicos de diversas áreas, bem como 06 estagiários cedidos pela Fundação de Desenvolvimento Administrativo do Governo de São Paulo (FUNDAP).

Estes estagiários selecionados ficam por pouco tempo no museu, e o trabalho de capacitação acaba sendo bem intenso para a equipe educativa. Eles são em sua maioria estudantes de Geografia.

O principal objetivo da instituição é conservar e difundir o acervo histórico e seus documentos, para promover a relação com o público visitante e o pesquisador, divulgando as áreas da Geografia, Geologia e Paleontologia.

O museu mantém exposições permanentes com peças selecionadas de suas coleções de minerais, rochas, fósseis e acervo histórico-documental, abordando temas como (MUSEU GEOLÓGICO VALDEMAR LEFRĖVE - MUGEO, 2014):

- "Fósseis do Estado de São Paulo" (com raridades como o fóssil de um morcego);

- "Comissão Geográfica e Geológica - documentos do passado - 1886 1931" - objetos, documentos e painéis fotográficos;

- "Coleção Internacional Krantz" - uma coleção única no Brasil com mais de 500 espécies minerais provenientes de todos os continentes do mundo. Esta coleção data do final do século XIX, e é considerada referência para estudos comparativos de identificação;

- "Coleção Classificação Sistemática dos Minerais" - possui uma média de 500 espécies em exposição, de acordo com sua filiação química; 
- "Coleção Utilização dos Minerais" - cerca de 100 amostras que expõem minerais e sua utilização pelo homem, com os produtos que são fabricados.

A divulgação é feita pelo site, pelas redes sociais, distribuição de folders e materiais educativos, além do próprio Parque da Água Branca que já faz uma divulgação entre os visitantes. A TV Cultura frequentemente faz entrevistas e vídeos do museu e suas atividades educativas.

Uma média de 5.000 pessoas são recebidas por mês (mais de $90 \%$ são estudantes). As entradas para visitantes transeuntes são gratuitas, mas para grupos agendados custa $R \$ 5,00$ por aluno das escolas particulares e $R \$ 1,00$ para alunos da rede pública. O tempo médio de visitação é de $1 \mathrm{~h} 30 \mathrm{~min}$, e para saber sobre o desempenho da instituição, são aplicadas pesquisas de público, mais voltadas aos educadores.

O MUGEO é bem localizado e possui boa visibilidade nas áreas da geologia, o que o torna referência em educação geológica. Seu valor está no trabalho desenvolvido com a educação ambiental e a conservação de acervos históricos, geográficos, geológicos e paleontológicos.

\section{ESTRUTURA FÍSICA}

O museu possui dois andares. No andar térreo, ficam as principais exposições de minerais, rochas e fósseis, e os sanitários. No andar superior, estão as salas de oficinas para escolas agendadas, exposição da Comissão Geográfica e Geológica, e administração, que não possui acessibilidade para pessoas com dificuldade de mobilidade física.

De acordo com o Diretor Fernando, já existe um projeto em andamento que vai ampliar os espaços e adaptar a acessibilidade. Todos os ambientes possuem ventilação, mas não são climatizados. A segurança é feita por câmeras de vigilância e alarme. Há uma loja, que pertence à comissão, com livros e lembranças do museu. As áreas de convivência, como espaço para lanche ou lanchonete estão no parque. 
O ponto forte do MUGEO é sua ação educativa. Uma equipe própria de trabalho recebe grupos agendados, com monitorias específicas e oficinas lúdicas interativas para todas as idades. Sempre trabalhando a educação ambiental interdisciplinar, são apresentados os espaços, desenvolvendo e estimulando a parte sensorial com os cinco sentidos.

O museu também realiza exposições itinerantes em outras instituições e exposições temporárias em sua sede, como:

- "GEOARTE - caminho das pedras" - com o objetivo de motivar, através das oficinas interativas, a importância de se preservar e conhecer o meio ambiente físico e geológico com técnicas de arteeducação;

- "Comissão Geográfica e Geológica - documentos do passado - 1886 $1910 "$ - objetos e painéis fotográficos;

As atividades educativas e culturais incluem as oficinas monitoradas de sensibilização, desenvolvidas com base nas coleções didáticas de rochas, minerais e fósseis, e as exposições institucionais realizadas durante a semana do meio ambiente, em diversos parques da capital paulista. Além de palestras e cursos que são realizados na sala de oficinas, que é adaptada para as ocasiões, utiliza-se o auditório do Parque da Água Branca, quando disponível.

\section{ACERVO MINERALÓGICO}

O MUGEO, em sua coleção de minerais, possui cerca de 1100 amostras, divididas em três eixos temáticos:

- 500 amostras pertencentes à famosa Coleção Internacional Krantz, a coleção é a mais completa e é a única do gênero em todo o Brasil. Foi comprada em 1905 pela Comissão Geográfica e Geológica de São Paulo. São minerais provenientes de todos os continentes, com ênfase no continente europeu, pois o famoso comerciante e colecionador Krantz era alemão.

Os minerais dessa coleção, apesar de não apresentar muita relação com a memória da mineralogia brasileira, são importantes, por ser a coleção utilizada como referência para a identificação e classificação de espécies minerais em todo o mundo. Os minerais estão dispostos em vitrines de vidro com madeira e as etiquetas atuais mantêm as antigas nomenclaturas originais e as localidades geográficas não 
estão muito bem descritas, dificultando muitas vezes as pessoas de conhecer a qual pais pertencem determinadas espécies minerais. Algumas amostras estão trocadas, devido à falta de manuseio e pesquisa dos exemplares. A coleção tem um grande valor didático e científico.

Neste acervo destaca-se para o Brasil o mineral "hussakita" que é um mineral em homenagem ao geólogo e mineralogista Eugene Hussak e que foi descoberto em Diamantina, Minas Gerais. Não é uma espécie valida de mineral e sim um sinônimo para outra espécie mineral já conhecida por xenotimio-(Y), um fosfato de ítrio:

- 500 amostras de várias espécies minerais, contendo alguns exemplares interessantes e provenientes de localidades diferentes, principalmente do estado de São Paulo. Os minerais neste setor estão todos dispostos em ordenação e sistematização química, segundo Dana, com algumas das classes químicas bem representadas. Os minerais estão expostos em vitrines de vidro e apresentam etiquetas com informações básicas como nome da espécie e localidade geográfica. Nota-se, em muitos casos, uma classificação mineralógica com erros tanto na nomenclatura quanto na sua ocorrência, além de muitas etiquetas possuírem somente os nomes de variedades minerais e não de suas espécies.

Neste acervo existem alguns poucos minerais tipos brasileiros como brazilianita e frondelita, ambos de suas localidades tipo em Minas Gerais.

- 100 amostras de minérios didáticos de diversos elementos químicos, mostrando a utilização dos recursos minerais e sua aplicação na indústria siderúrgica, de construção civil, farmacêutica, elétrica e alimentícia.

Vale a pena ressaltar que o museu possui uma coleção importante de fósseis brasileiros e tem em seu acervo um dos quatro fragmentos do meteorito que caiu no interior paulista, nos arredores de Avanhandava no ano de 1958. O museu ainda tem uma coleção didática de rochas do estado de São Paulo, mostrando a geologia da região.

O acervo documental do museu é muito importante, pois contém uma parte importante da história geológica e geográfica do estado de São Paulo e demonstra a importância de geólogos e mineralogistas como Orville Derby e Luiz Felipe Gonzaga de Campos para o estudo e a pesquisa da mineralogia brasileira.

O museu possui uma reserva técnica com diversos acervos de minerais, rochas e fósseis. As amostras estão dispostas em armários e prateleiras de madeira. 
Não possuem uma sistematização e a reserva serve mais como depósito, precisando de uma reorganização e reclassificação mineralógica. Não existe pesquisa sobre o acervo mineralógico, somente sobre os acervos documentais e paleontológicos. Isto decorre da falta de um especialista (mineralogista) tanto no museu quanto no Instituto Geológico.

A manutenção do acervo é feita somente pelo seu diretor e a limpeza pelos estagiários do museu, que tem acesso a todas as amostras. O museu tem o principal objetivo educativo de difundir os conhecimentos de geociências.

O museu não tem políticas de intercambio e prefere não ter esse tipo de atuação, pois não possui em seu quadro de funcionários um mineralogista para desenvolver essas trocas com outras instituições. O museu recebe raramente algumas doações, que são ou não incorporadas segundo julgamento de sua importância.

O acervo mineralógico do MUGEO, apesar de importante para as geociências de uma forma geral, mesmo contendo algumas amostras históricas e de ocorrências clássicas, não tem muita relevância para a preservação da memória da mineralogia brasileira no que se refere aos exemplares dos minerais em exposição. Porém, a documentação histórica é muito importante para a história geológica do país e o trabalho educativo do museu é muito atuante na instituição.

\section{RELAÇÃO DE FOTOS DO MUGEO - CENTRO MUSEU GEOLÓGICO}

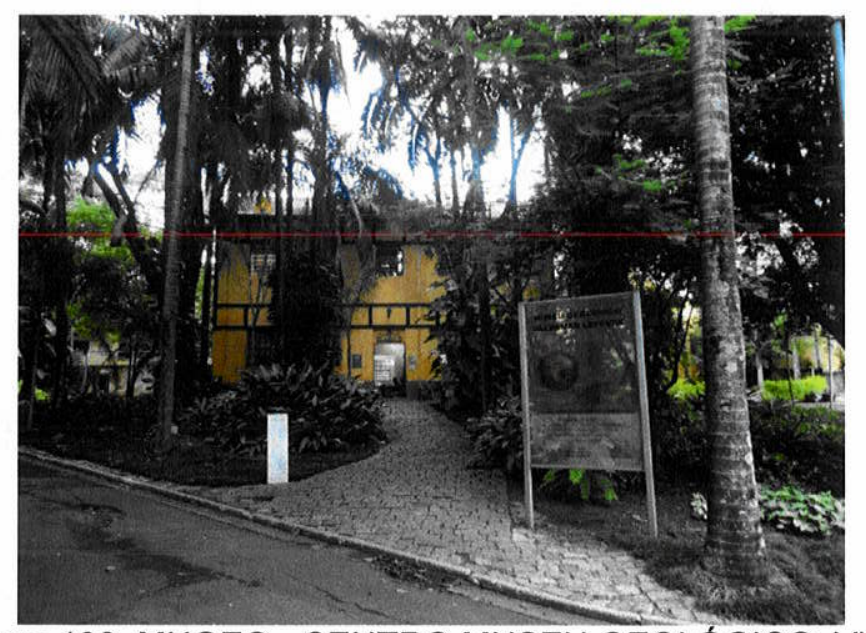

Figura 190. MUGEO - CENTRO MUSEU GEOLÓGICO. Vista geral da entrada do prédio onde o MUGEO fica localizado. 


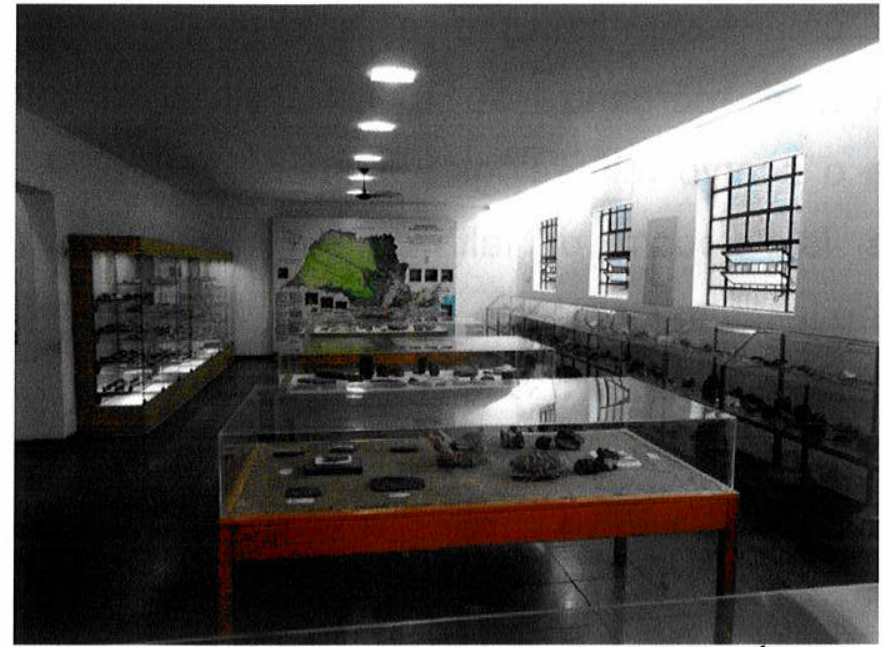

Figura 191. MUGEO - CENTRO MUSEU GEOLÓGICO. Vista geral do salão expositivo com todas as vitrines.

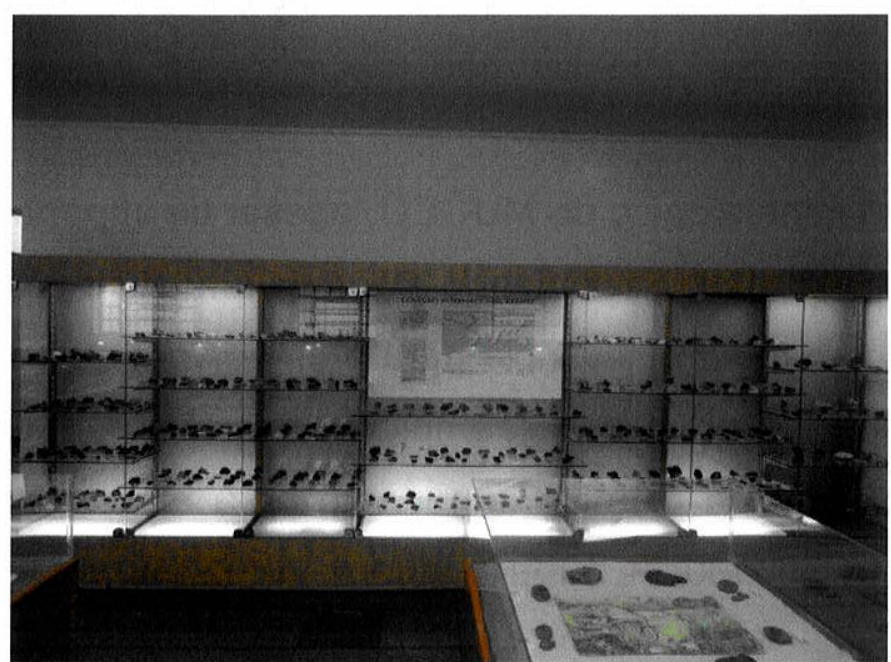

Figura 192. MUGEO - CENTRO MUSEU GEOLÓGICO. Vitrine temática da coleção mineralógica Krantz.

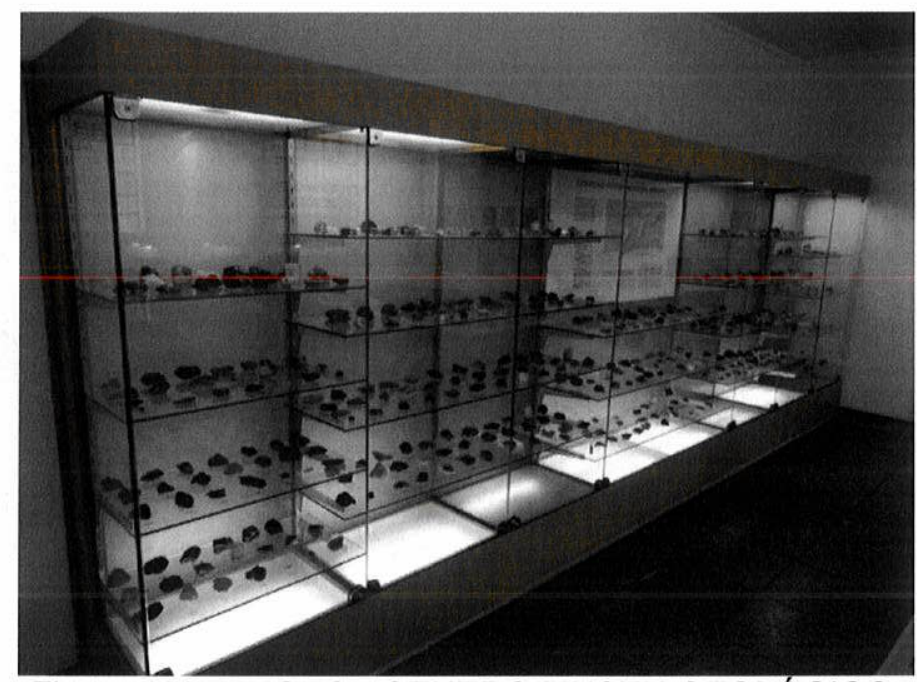

Figura 193. MUGEO - CENTRO MUSEU GEOLÓGICO. Detalhe da vitrine temática da coleção mineralógica Krantz. 


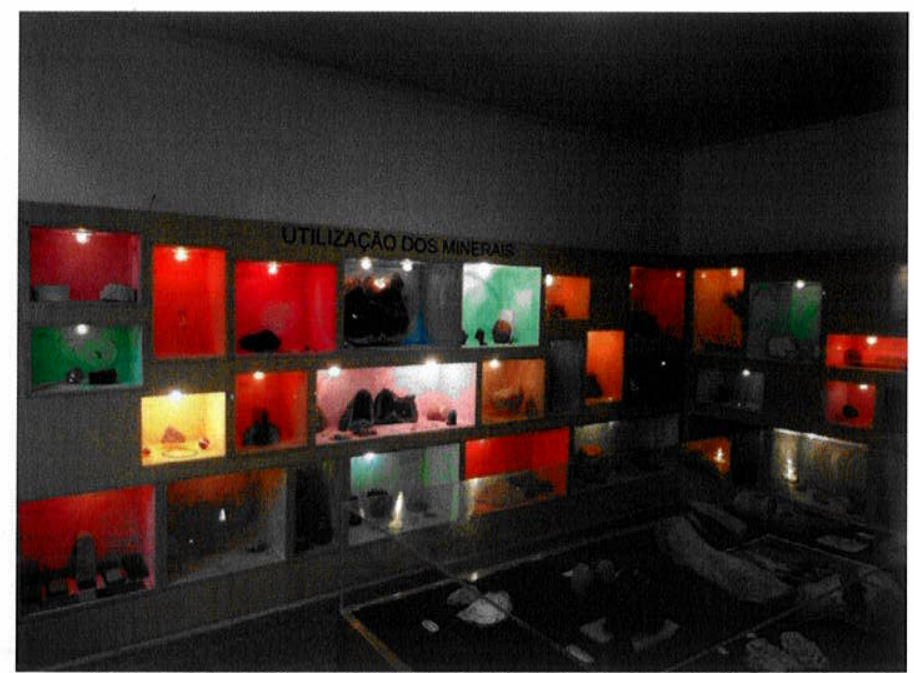

Figura 194. MUGEO - CENTRO MUSEU GEOLÓGICO. Vitrine com amostras didáticas sobre a importância dos recursos minerais.

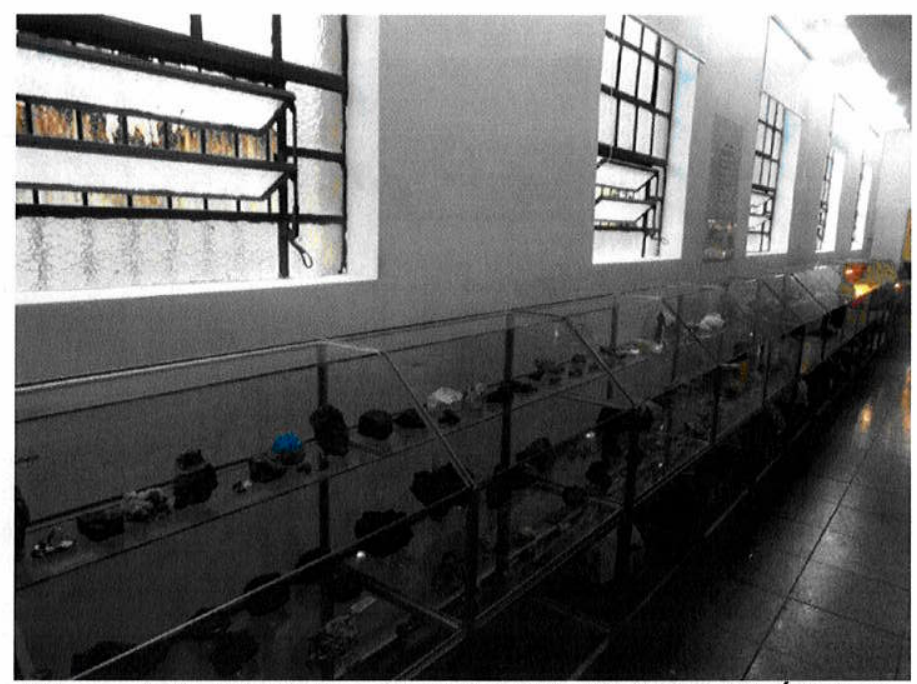

Figura 195. MUGEO - CENTRO MUSEU GEOLÓGICO.

Vitrine com os minerais sistematizados em classes químicas.

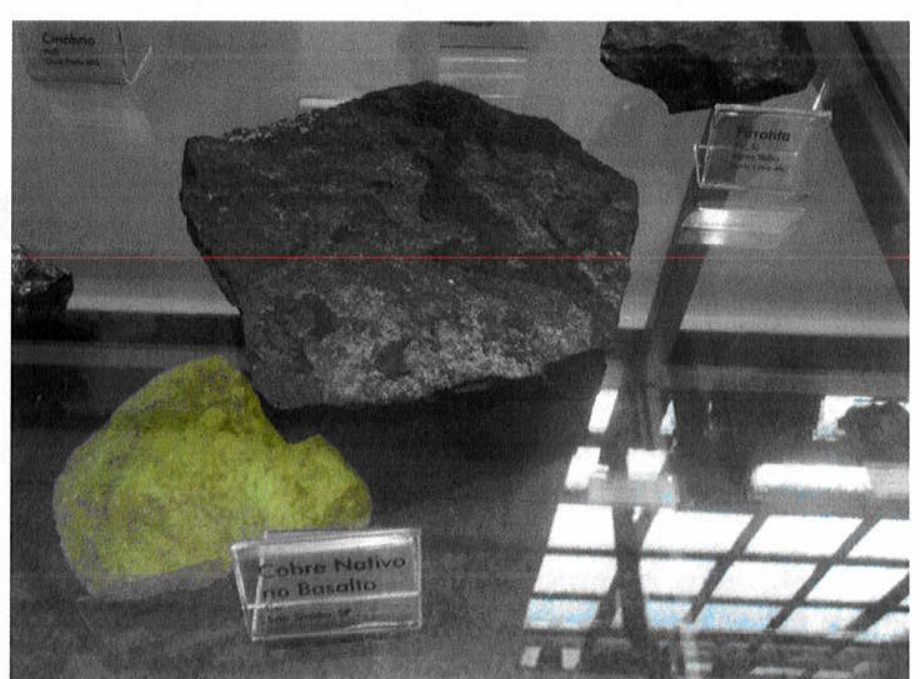

Figura 196. MUGEO - CENTRO MUSEU GEOLOGICO. Amostra de cobre nativo no basalto de localidade histórica em São Simão, SP. 


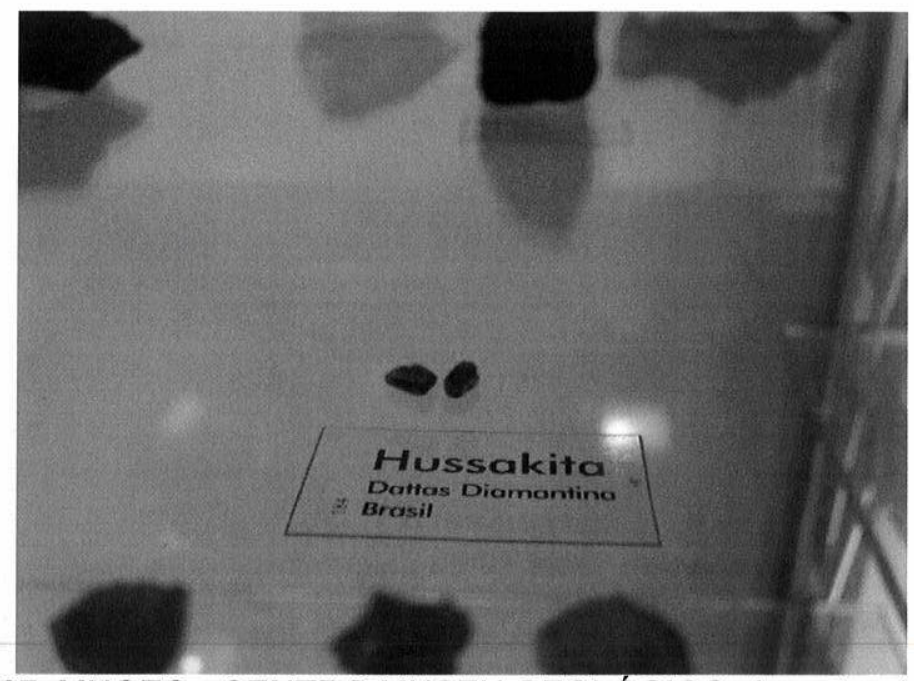

Figura 197. MUGEO - CENTRO MUSEU GEOLÓGICO. Amostra de mineral raro hussakita. Espécie desacreditada, na verdade é xenotimio-( $(Y)$.

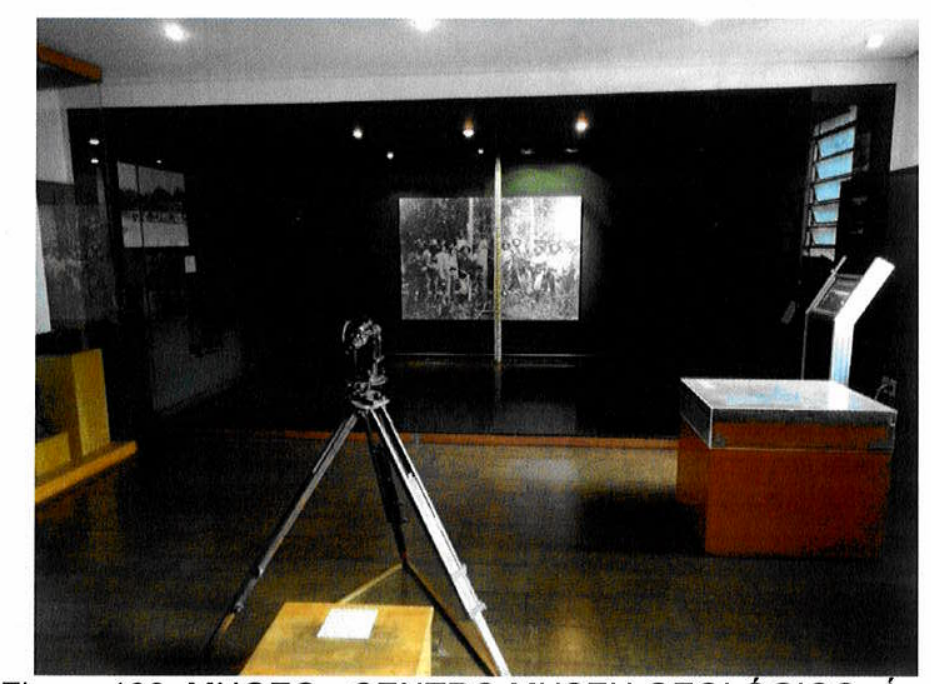

Figura 198. MUGEO - CENTRO MUSEU GEOLÓGICO. Área dedicada a Comissão Geográfica e Geológica de São Paulo.

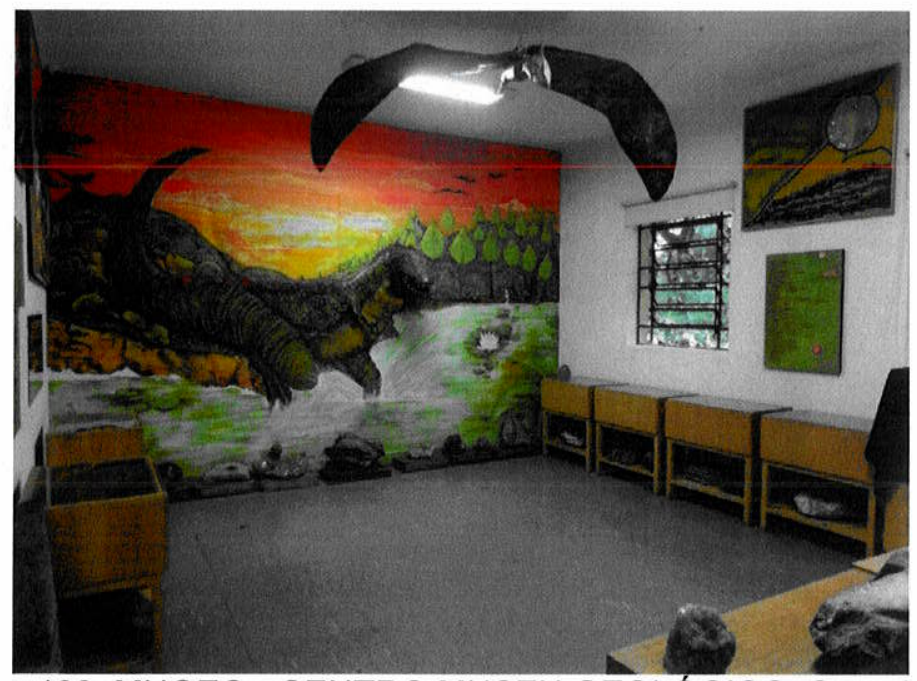

Figura 199. MUGEO - CENTRO MUSEU GEOLOGICO. Setor lúdico e interativo, onde as oficinas e atividades educativas são realizadas. 


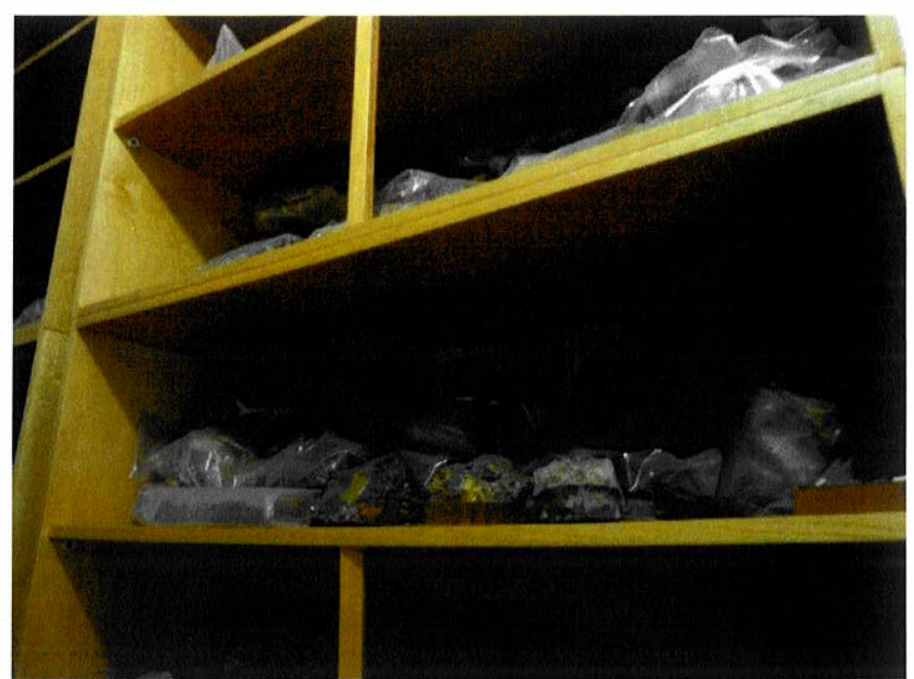

Figura 200. MUGEO - CENTRO MUSEU GEOLÓGICO. Reserva técnica com diversas amostras sem classificação.

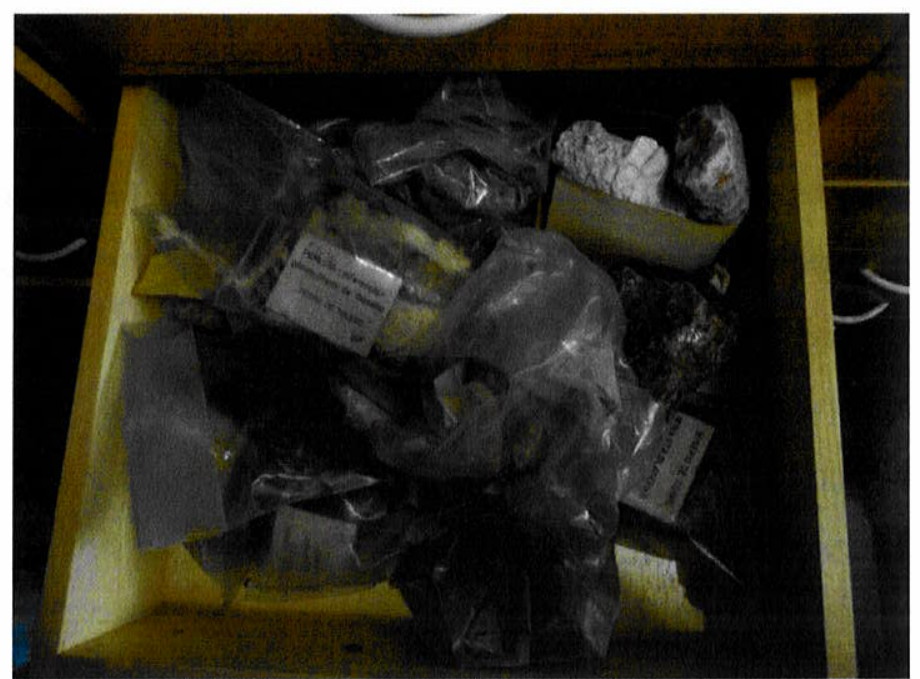

Figura 201. MUGEO - CENTRO MUSEU GEOLÓGICO. Detalhe das gavetas da reserva técnica com as amostras desorganizadas e sem nenhuma classificação. 


\section{MUSEU DE CIÊNCIAS DA TERRA ALEXIS DOROFEEF - DPS - UFV}

(análise realizada em 30 de janeiro de 2014)

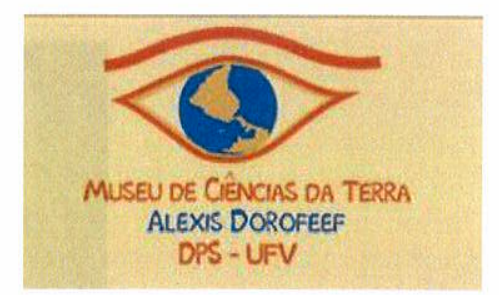

HISTÓRICO DA INSTITUIÇÃO

O Museu de Ciências da Terra Alexis Dorofeef fica localizado na Vila Giannetti, casa 31 - Campus da Universidade Federal de Viçosa (UFV), Minas Gerais.

Foi criado em 1993 por iniciativa de duas professoras da Universidade de Viçosa do Departamento de Solos (DPS), Cristine Muggler, a atual curadora do Museu, e Luciana Maria Lopes. Elas vislumbraram no acervo do laboratório, potencialidade para se criar um museu que pudesse conservar todo aquele material, e ao mesmo tempo trabalhá-lo educacionalmente com o público geral (MUSEU DE CIÊNCIAS DA TERRA ALEXIS DOROFEEF, 2014).

Sua homenagem foi ao Professor Alexis Dorofeef, professor da antiga Escola Superior de Agricultura e Veterinária do Estado de Minas Gerais (ESAV). Ele iniciou a coleção na década de 1930, recolheu e catalogou amostras em todo o país, a fim de enriquecer suas aulas práticas. Na década de 1980, quando Alexis já tinha se afastado da Universidade Federal de Viçosa, surgiu a ideia do museu (MUSEU DE CIÊNCIAS DA TERRA ALEXIS DOROFEEF, 2014).

O MCTAD tornou-se referência enquanto espaço de educação e divulgação científica, valorizando a construção e democratização dos saberes, cultivando parcerias com grupos da Universidade, como o Programa Teia, e com os Movimentos Sociais da região. Em 2000, foi criado o Programa de Educação em Solos e Meio Ambiente da Universidade e o museu tornou-se peça chave para sua execução (MUSEU DE CIÊNCIAS DA TERRA ALEXIS DOROFEEF, 2014).

Em 2005, o museu passou por algumas reformulações em seus espaços, criando três temáticas expositivas:

- O Sistema Terra: dinâmica e processos;

- Recursos Minerais: uso econômico e impactos ambientais;

- Solos: conhecer para conservar. 


\section{ORGANIZAÇÃO E FUNCIONAMENTO}

A gestão do museu é realizada pelo Departamento de Solos da Universidade Federal de Viçosa. A Curadora do MCTAD é Cristine Carole Muggler, Geóloga, $\mathrm{PhD}$ em Ciências Ambientais/Holanda, com PosDoc junto ao World Soil Museum, WUR, Holanda, Professora da UFV. Não foi possível entrevistá-la no momento da visita, mas a estagiária Fernanda Márcia Souza respondeu às perguntas dentro de seu conhecimento de dois anos de trabalho no museu.

A equipe do museu é constituída por uma coordenadora pedagógica, e dois técnicos de apoio operacional, além de 13 estagiários da UFV nas áreas de Geografia, Comunicação Social e Agronomia. Estes são capacitados por estagiários mais antigos e passam por cursos e palestras sobre a ação educativa do museu.

O museu é aberto ao público gratuitamente, e a divulgação é feita pelo site do museu, redes sociais, folders e contatos com escolas. O museu recebe uma média de 500 pessoas por mês, sendo a maior parte estudantes de toda rede de ensino. Kits didáticos de rochas e de solos podem ser adquiridos. O local é arejado e com segurança da universidade. O próprio campus possui lanchonete.

O objetivo da instituição é buscar despertar a curiosidade e o interesse das pessoas pelo que existe e acontece em nosso planeta, tendo como principais elementos os solos, as rochas e os minerais. Com a exposição de seu acervo e, principalmente, com a realização de ações educativas, o museu é um espaço de descobertas e interações.

\section{AÇÃO EDUCATIVA E CULTURAL}

O museu já é uma ação educativa, com seus espaços, sua abordagem com o público, o direcionamento das monitorias e suas atividades.

Dentro de suas ações, estão projetos que possuem abordagens diferenciadas e todas voltadas para pesquisa, educação ambiental e valorização do planeta. São realizadas palestras, filmes, cursos, oficinas e capacitações, dentro dos temas (MUSEU DE CIÊNCIAS DA TERRA ALEXIS DOROFEEF, 2014).

- Programa de Educação em Solos e Meio Ambiente;

- CONVIVERDE DE VIÇOSA - Projeto Sala Verde pela Diretoria de Educação Ambiental do Ministério do Meio Ambiente; 
- Feira do Conhecimento realizado na Semana Nacional de Ciências e Tecnologia.

\section{ACERVO MINERALÓGICO}

O acervo do museu é composto por 1500 amostras de minerais, rochas, solos e fósseis, sendo 1000 de minerais e 500 de rochas. Entretanto, apenas cerca de 300 amostras estão expostas.

As amostras estão dispostas em vitrines modulares de vidro, com bases de madeira. Os minerais estão agrupados de forma aleatória, misturando as classes químicas como sulfetos, fosfatos e silicatos (galena - fluorapatita - cianita). A iluminação das amostras é geral e as etiquetas de acrílico são muito simples e pouco informativa, ora contendo informações do nome da espécie e da sua composição química, ora contendo somente o nome da espécie. As procedências das amostras, em geral, não estão representadas nas etiquetas.

Muitas amostras não possuem nenhuma identificação e, em muitos casos, utiliza-se somente os nomes das variedades mineralógicas.

O museu possui reserva técnica com cerca de 3000 amostras ainda não catalogadas ou destinadas a coleções didáticas para escolas.

A coleção mineralógica do Museu Alexis Dorofeef cumpre o seu papel perante a sociedade divulgando e difundindo conhecimentos sobre as ciências naturais, em particular áreas da geologia e agronomia. Porém, seu acervo mineralógico pouco tem a dizer ou contribuir para a preservação da memória da mineralogia brasileira, pois o acervo além de não possuir uma classificação e sistematização científica atualizada de suas espécies, não possui também informações precisas sobre os exemplares, principalmente em relação às localidades geográficas. 


\section{RELAÇÃO DE FOTOS DO MUSEU ALEXIS DOROFEEF}

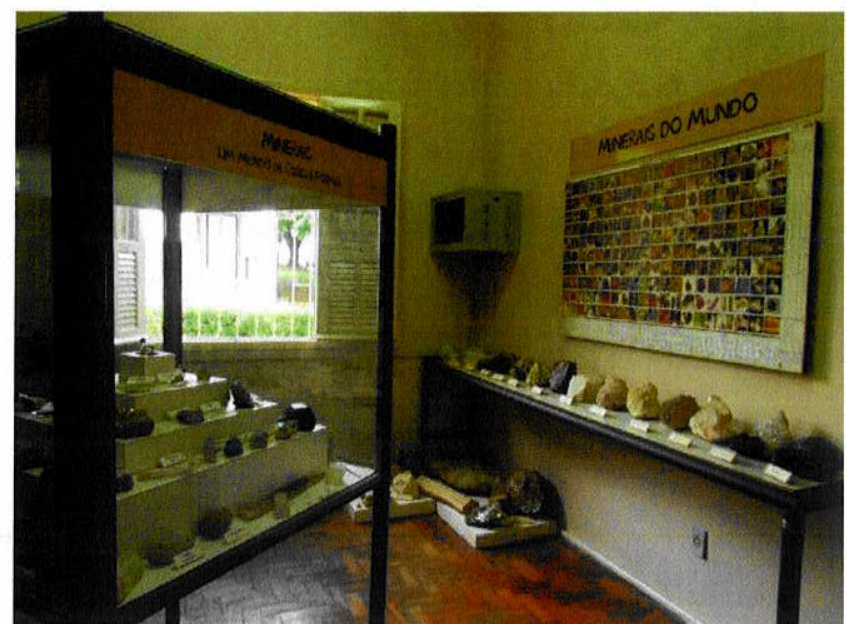

Figura 202. Museu Alexis Dorofeef. Vitrine com amostras minerais sem classificação sistemática. Bancada com amostras comuns de minerais. Detalhe da janela aberta e entrada de luz solar, melhorando a iluminação da sala, porém prejudicando o acervo mineralógico expositivo.

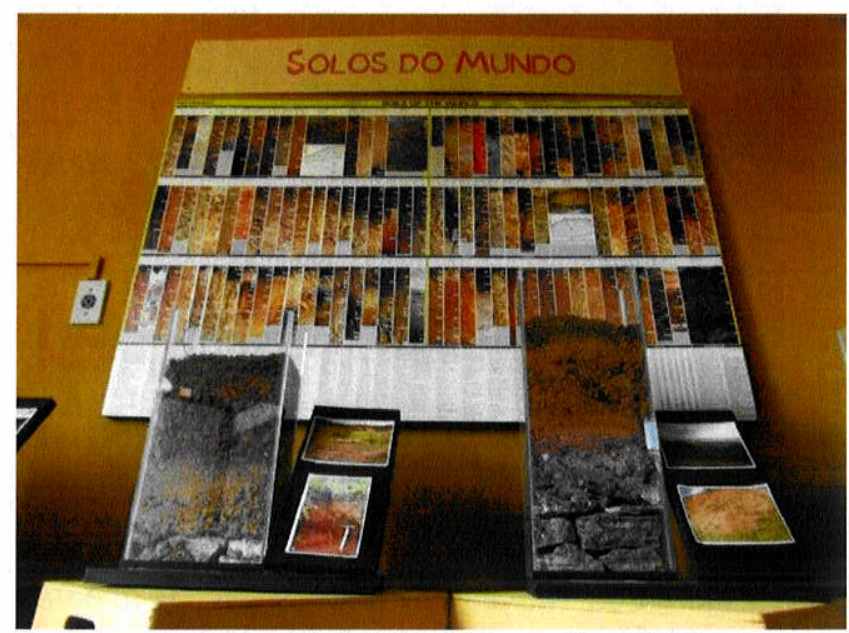

Figura 203. Museu Alexis Dorofeef. Amostras de tipos de solos do mundo.

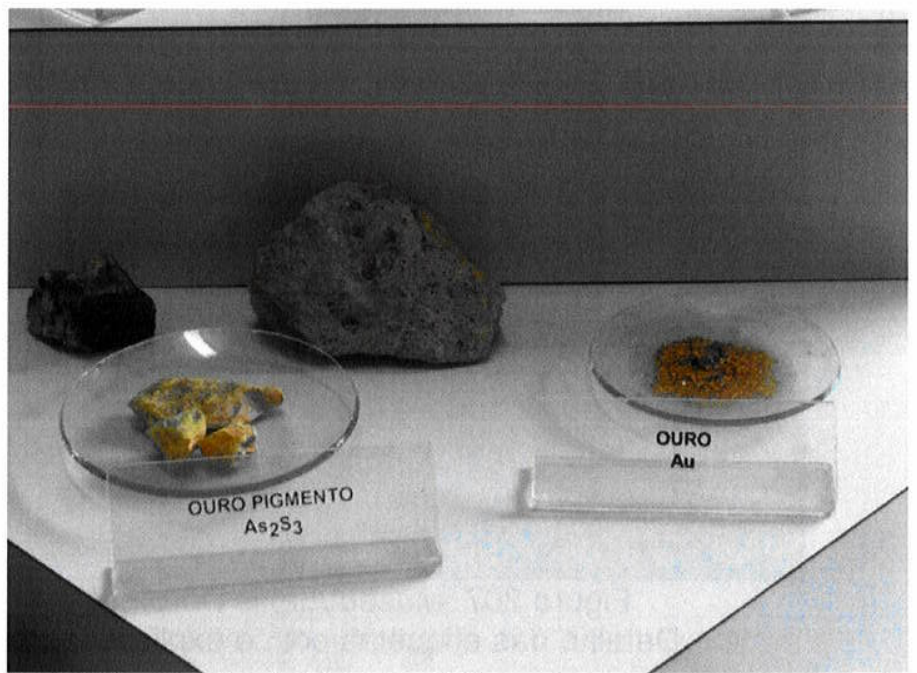

Figura 204. Museu Alexis Dorofeef. Amostras minerais sem ordenação. 


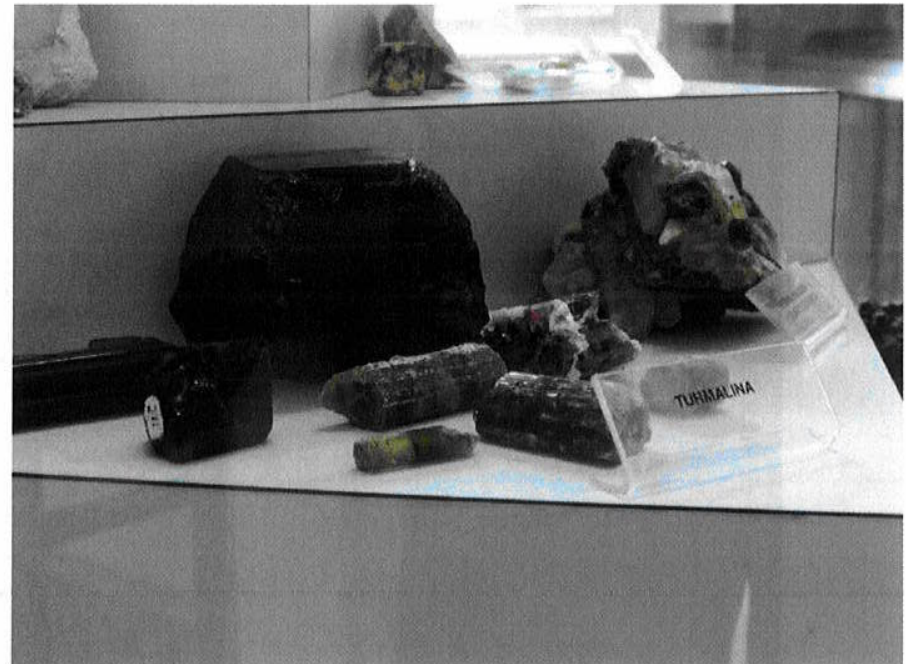

Figura 205. Museu Alexis Dorofeef. Amostras minerais sem uma classificação mais específica.

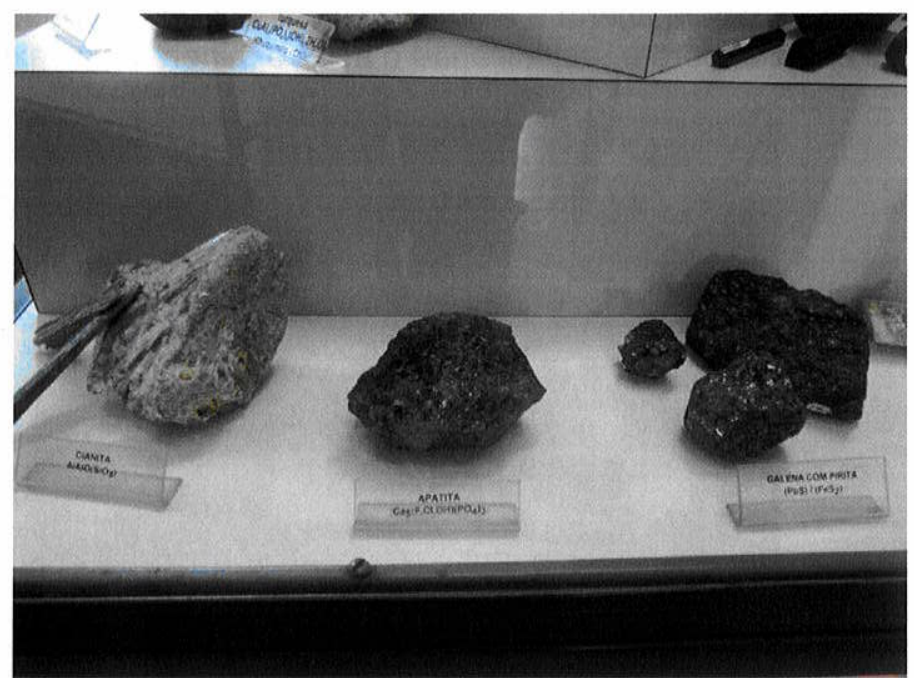

Figura 206. Museu Alexis Dorofeef. Os minerais estão colocados de forma aleatória, misturando as classes químicas.

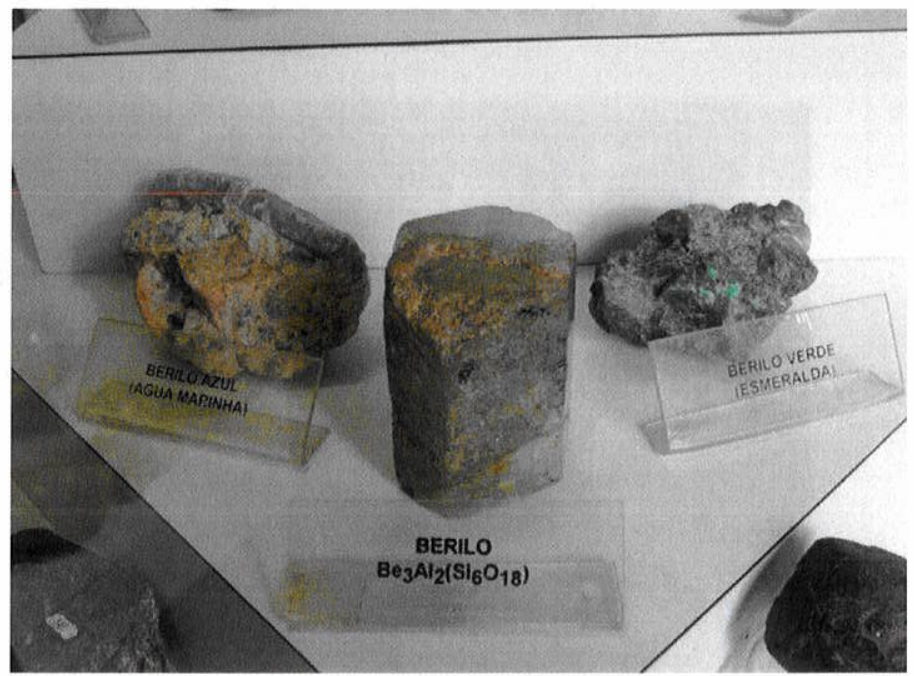

Figura 207. Museu Alexis Dorofeef.

Detalhe das etiquetas pouco explicativas. 


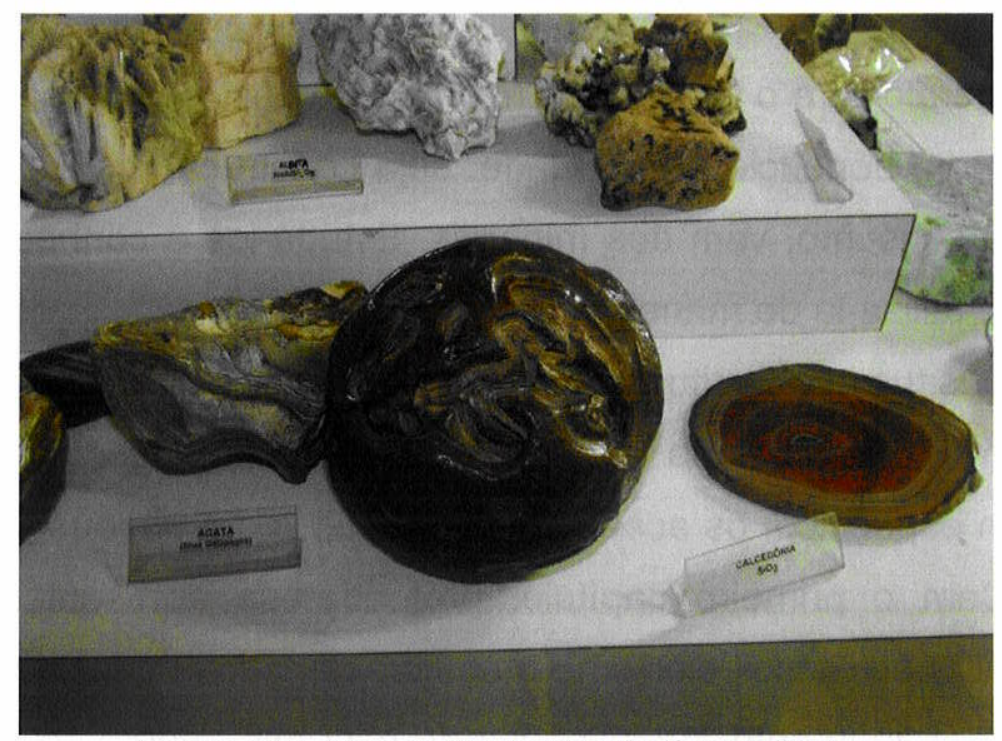

Figura 208. Museu Alexis Dorofeef. Detalhe na nomenclatura dos minerais. Somente o nome das variedades, sem levar em conta a quais espécies pertencem.

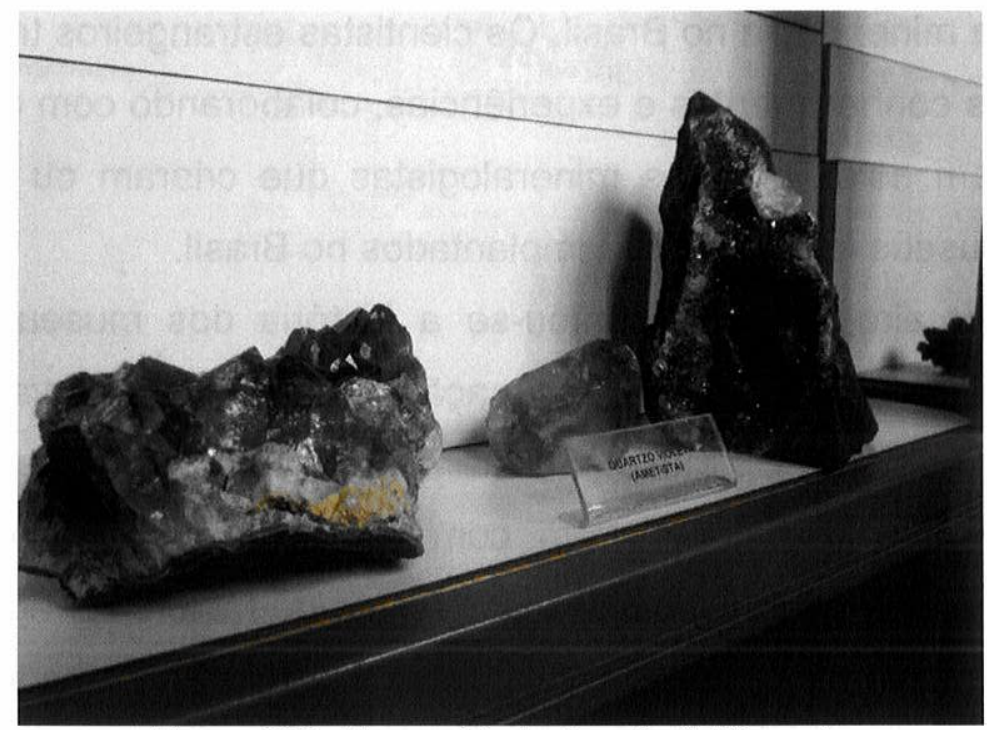

Figura 209. Museu Alexis Dorofeef. Minerais colocados em bancadas sem proteção. 


\section{CONSIDERAÇÕES FINAIS}

A mineralogia é o estudo dos minerais e suas propriedades, ou seja, tudo que é produzido em benefício à sociedade, seja construção civil, produção tecnológica, produtos de consumo, vem dos minerais. Estudá-los é conhecer a natureza, saber respeitá-la e utilizá-la de maneira útil e funcional.

Os museus são instituições de grande importância para resgatar, conservar e difundir a memória de tudo que existe. A presente pesquisa teve o objetivo de analisar, em específico, os acervos mineralógicos de museus de ciências naturais e da terra. Com o primeiro capítulo, pretendeu-se apresentar a importância das coleções, os tipos de colecionismo e as características principais para se colecionar minerais adequadamente. As coleções de minerais podem se constituir em material de estudo importante para os mineralogistas.

No segundo capítulo, foram relacionados os principais mineralogistas que difundiram a mineralogia no Brasil. Os cientistas estrangeiros trouxeram, de diversos países, seus conhecimentos e experiências, colaborando com o desenvolvimento do país. E foram estes grandes mineralogistas que criaram ou colaboraram com os primeiros museus mineralógicos implantados no Brasil.

No terceiro capítulo, contou-se a história dos museus, comprovando que desde a antiguidade existia a preocupação em obter e preservar objetos da natureza e da cultura humana. Os museus tiveram início com os gabinetes de curiosidade no século $\mathrm{XVI}$, que se aprimoraram com o passar do tempo, buscando estudar, catalogar e utilizar estas coleções naturalistas de minerais, vegetais e animais. Sem perder o princípio de conservação e pesquisa, os museus adquiriram outra função de extrema importância para as coleções, a difusão dos conhecimentos produzidos.

Existe uma grande variedade nos tipos de museus, e muitos deles necessitam colocar em prática a tríade funcional dos museus.

Os museus desempenham três funções que são os pilares de sua existência: conservar, pesquisar e difundir conhecimento. Com a pesquisa desenvolvida, foram levantados questionamentos sobre a relação dos museus pesquisados com seu acervo e com seu público, uma tríade que se completa e coexiste.

De acordo com (SOFKA, 2009), o museu que não desenvolve pesquisa, que não expõe seus acervos, ou que não difunde este conhecimento ao público, tudo ao mesmo tempo, na melhor das hipóteses: 
[...] "o museu seria uma coleção de objetos - talvez registrados, conservados e restaurados - mas não mais do que isso. Uma fonte ou reserva de conhecimento, mas sem utilização. Isto é algo que não desejamos hoje, algo que de forma alguma corresponde à ideia moderna de museu. Desejamos saber que objetos coletamos e porquê. Desejamos saber em que medida nossos objetos relacionam-se entre si e, mais que tudo, com o mundo a nossa volta - natureza e humanidade".[...]

Foi efetuado um levantamento de 15 instituições da região Sudeste, apenas dois, possuem os três princípios na prática: o Museu de Ciência e Técnica da Escola de Minas de Ouro Preto e o Museu de Geociências da USP. São referência no país e possuem as mais completas coleções de mineralogia do Brasil. Entretanto, como todas as instituições, também necessitam de profissionais especializados em mineralogia para identificar e valorizar adequadamente o acervo que possuem.

Nos quadros abaixo, foram relacionados os tópicos de relevância para cada instituição, indicando sua problemática.

Quadro 27 - Tópicos de relevância para cada instituição pesquisada, com características, e indicação dos problemas.

\begin{tabular}{|l|c|c|c|c|c|}
\hline $\begin{array}{l}\text { CARACTERISTICAS } \\
\text { DAS INSTITUIÇÕES }\end{array}$ & $\begin{array}{c}\text { Museu } \\
\text { de } \\
\text { Minerais } \\
\text { e } \\
\text { Rochas } \\
\text { Heinz } \\
\text { Ebert }\end{array}$ & $\begin{array}{c}\text { Museu da } \\
\text { Geodiversidade }\end{array}$ & $\begin{array}{c}\text { Museu } \\
\text { Amsterdam } \\
\text { Sauer de } \\
\text { Minerais } \\
\text { Raros e } \\
\text { Pedras } \\
\text { Preciosas }\end{array}$ & $\begin{array}{c}\text { Museu } \\
\text { de } \\
\text { Ciências } \\
\text { da Terra }\end{array}$ & $\begin{array}{c}\text { Museu } \\
\text { Nacional }\end{array}$ \\
\hline $\begin{array}{l}\text { PROFISSIONAIS } \\
\text { ESPECIALIZADOS } \\
\text { (MINERALOGISTAS) }\end{array}$ & Não & Não & Não & Não & $X$ \\
\hline $\begin{array}{l}\text { VALORIZAÇÃO } \\
\text { CIENTIFICA } \\
\text { DO ACERVO } \\
\text { MINERALÓGICO }\end{array}$ & Sim & Não & Não & Sim & $X$ \\
\hline $\begin{array}{l}\text { MANUTENÇÃO } \\
\text { DO ACERVO } \\
\text { MINERALÓGICO }\end{array}$ & Sim & Sim & Sim & Sim & $X$ \\
\hline $\begin{array}{l}\text { CLASSIFICAÇÃO } \\
\text { DO ACERVO } \\
\text { MINERALÓGICO }\end{array}$ & Sim & Não & Não & Sim & $X$ \\
\hline INTERCÂMBIOS & Sim & Não & Não & Sim & $X$ \\
\hline $\begin{array}{l}\text { PESQUISA } \\
\text { CIENTIFICA DO }\end{array}$ & Não & Não & Não & Não & $X$ \\
\hline
\end{tabular}




\begin{tabular}{|c|c|c|c|c|c|}
\hline ACERVO GERAL & & & & & \\
\hline $\begin{array}{l}\text { AÇÃO EDUCATIVA E } \\
\text { CULTTURAL }\end{array}$ & Sim & Sim & Não & Sim & $\mathrm{X}$ \\
\hline $\begin{array}{l}\text { AMOSTRAS TIPO } \\
\text { BRASILEIRAS } \\
\text { IMPORTANTES }\end{array}$ & Sim & Não & Não & Sim & $\mathrm{X}$ \\
\hline $\begin{array}{l}\text { AMOSTRAS } \\
\text { HISTÓRICAS } \\
\text { BRASILEIRAS }\end{array}$ & Sim & Não & Sim & Sim & $\mathrm{X}$ \\
\hline $\begin{array}{l}\text { CARACTERISTICAS } \\
\text { DAS INSTITUIÇÕES }\end{array}$ & $\begin{array}{l}\text { Museu de } \\
\text { Mineralogia } \\
\text { Aitiara }\end{array}$ & $\begin{array}{l}\text { Museu de } \\
\text { Ciência } \\
\text { e Técnica } \\
\text { da Escola } \\
\text { de Minas }\end{array}$ & $\begin{array}{l}\text { Museu de } \\
\text { Mineralogia } \\
\text { Victor } \\
\text { Dequech }\end{array}$ & $\begin{array}{l}\text { Museus } \\
\text { das } \\
\text { Minas e } \\
\text { do Metal }\end{array}$ & $\begin{array}{c}\text { Museu } \\
\text { de } \\
\text { Mineral } \\
\text { ogia e } \\
\text { de Arte } \\
\text { Sacra }\end{array}$ \\
\hline $\begin{array}{l}\text { PROFISSIONAIS } \\
\text { ESPECIALIZADOS } \\
\text { (MINERALOGISTAS) }\end{array}$ & Não & Sim & Sim & Não & Não \\
\hline $\begin{array}{l}\text { VALORIZAÇÃO } \\
\text { CIENTÍFICA } \\
\text { DO ACERVO } \\
\text { MINERALÓGICO }\end{array}$ & Sim & Sim & Sim & Sim & Não \\
\hline $\begin{array}{l}\text { MANUTENÇÃO } \\
\text { DO ACERVO } \\
\text { MINERALÓGICO }\end{array}$ & Sim & Sim & Sim & Sim & Sim \\
\hline $\begin{array}{l}\text { CLASSIFICAÇÃO } \\
\text { DO ACERVO } \\
\text { MINERALÓGICO }\end{array}$ & Sim & Sim & Sim & Sim & Não \\
\hline INTERCÂMBIOS & Sim & Não & Não & Não & Sim \\
\hline $\begin{array}{l}\text { PESQUISA } \\
\text { CIENTÍFICA DO } \\
\text { ACERVO GERAL }\end{array}$ & Não & Não & Não & Não & Não \\
\hline $\begin{array}{l}\text { AÇÃO EDUCATIVA E } \\
\text { CULTURAL }\end{array}$ & Sim & Sim & Não & Sim & Sim \\
\hline $\begin{array}{l}\text { AMOSTRAS TIPO } \\
\text { BRASILEIRAS } \\
\text { IMPORTANTES }\end{array}$ & Sim & Sim & Sim & Sim & Não \\
\hline $\begin{array}{l}\text { AMOSTRAS } \\
\text { HISTÓRICAS } \\
\text { BRASILEIRAS }\end{array}$ & Sim & Sim & Sim & Sim & Sim \\
\hline $\begin{array}{l}\text { CARACTERISTICAS } \\
\text { DAS INSTITUIÇÕES }\end{array}$ & $\begin{array}{l}\text { Museu de } \\
\text { Minerais e } \\
\text { Rochas da } \\
\text { Universidade } \\
\text { Federal do } \\
\text { Espírito Santo }\end{array}$ & $\begin{array}{c}\text { Museu } \\
\text { Histórico e } \\
\text { Geográfico } \\
\text { de Poços de } \\
\text { Caldas } \\
\text { Coleção de } \\
\text { Minerais } \\
\text { ReskFrayha }\end{array}$ & $\begin{array}{l}\text { Museu de } \\
\text { Geociênci } \\
\text { as } \\
\text { IGc/USP }\end{array}$ & $\begin{array}{c}\text { Museu } \\
\text { Geológic } \\
\text { o } \\
\text { Valdemar } \\
\text { Lefèvre } \\
\text { MUGEO }\end{array}$ & $\begin{array}{l}\text { Museu } \\
\text { de } \\
\text { Ciências } \\
\text { da Terra } \\
\text { Alexis } \\
\text { Dorofeef }\end{array}$ \\
\hline $\begin{array}{l}\text { PROFISSIONAIS } \\
\text { ESPECIALIZADOS } \\
\text { (MINERALOGISTAS) }\end{array}$ & Não & Não & Sim & Não & Não \\
\hline $\begin{array}{l}\text { VALORIZAÇÃO } \\
\text { CIENTÍFICA } \\
\text { DO ACERVO } \\
\text { MINERALÓGICO }\end{array}$ & Não & Não & Sim & Não & Não \\
\hline MANUTENÇÃO & Sim & Sim & Sim & Sim & Sim \\
\hline
\end{tabular}




\begin{tabular}{|l|c|c|c|c|c|}
\hline $\begin{array}{l}\text { DO ACERVO } \\
\text { MINERALÓGICO }\end{array}$ & Não & Não & Sim & Sim & Não \\
\hline $\begin{array}{l}\text { CLASSIFICAÇÃO } \\
\text { DO ACERVO } \\
\text { MINERALÓGICO }\end{array}$ & Sim & Não & Não & Não & Não \\
\hline $\begin{array}{l}\text { INTERCÂMBIOS } \\
\text { PESQUISA } \\
\text { CIENTÍFICA DO } \\
\text { ACERVO GERAL }\end{array}$ & Não & Não & Sim & Não & Não \\
\hline $\begin{array}{l}\text { AÇÃO EDUCATIVA E } \\
\text { CULTURAL }\end{array}$ & Sim & Sim & Sim & Sim & Sim \\
\hline $\begin{array}{l}\text { AMOSTRAS TIPO } \\
\text { BRASILEIRAS } \\
\text { IMPORTANTES }\end{array}$ & Não & Não & Sim & Não & Não \\
\hline $\begin{array}{l}\text { AMOSTRAS } \\
\text { HISTÓRICAS } \\
\text { BRASILEIRAS }\end{array}$ & Não & Sim & Sim & Sim & Não \\
\hline
\end{tabular}

${ }^{*} \mathrm{O}$ símbolo $\mathrm{X}$ significa que não houve análise do museu.

$\mathrm{Na}$ maior parte dos museus mineralógicos visitados e pesquisados, a classificação e sistematização dos exemplares minerais se dão segundo Dana ou Strunz, que classificam os minerais de acordo com sua composição química. Em alguns casos, observamos as coleções mineralógicas sem nenhum tipo de classificação, sendo colocadas as amostras aleatoriamente. Algumas coleções são agrupadas segundo a beleza estética e, às vezes, os minerais estão dispostos em diversas coleções com temáticas específicas, como a coleção estrangeira do famoso comerciante europeu Krantz ou ainda por sua ocorrência geográfica ou elemento químico.

\section{CONCLUSÕES}

Abaixo estão expostos os principais problemas encontrados nas coleções mineralógicas dos museus do sudeste brasileiro:

- amostras tipo brasileiras - em alguns museus, encontramos importantes exemplares de minerais tipo brasileiros mencionados na parte descritiva de cada museu;

- amostras históricas brasileiras - foram reconhecidos exemplares históricos, coletados por importantes cientistas, como Eugene Hussak, Orville Derby, Djalma 
Guimarães, Luciano J. Moraes, entre outros. Foram encontradas amostras de ocorrências famosas que, nos dias de hoje, são completamente exauridas e/ou impossíveis de se conseguir coletar ou até mesmo adquirir através de compra ou intercâmbio;

- falta de interesse - a maior parte dos museus pesquisados é ligada a universidades e à administração pública (municipal, estadual, federal); ainda assim, foi observado que os responsáveis (reitores, diretores, coordenadores e curadores) não se interessam muito em querer desenvolver pesquisas sobre os seus acervos mineralógicos, mesmo sendo estes ligados aos cursos de graduação e pósgraduação de geologia e ciências;

- falta de apoio financeiro - este problema ocorre, principalmente, em decorrência da falta de interesse de seus gestores e pessoal técnico, que não se preocupam em buscar verbas e/ou desenvolver projetos para captação de recursos. Um dos graves problemas ligados a este setor é que os museus mineralógicos e geológicos não possuem verbas específicas para a compra permanente de bons exemplares de minerais, sendo que, na maioria das vezes, os museus vivem exclusivamente da doação de exemplares feita por alunos, ex-alunos, professores e pessoas ligadas à instituição. Os museus mineralógicos particulares (pouquíssimos no país), funcionam, em geral, como verdadeiras "galerias de arte", que atraem turistas internacionais, os quais são estimulados a comprar pedras preciosas brasileiras. A pesquisa e a educação ficam em segundo plano;

- classificação mineralógica - muitos minerais são erroneamente classificados devido à falta de conhecimento dos responsáveis pelas coleções mineralógicas, via de regra não mineralogistas. Em geral, não se dá muita importância à paragênese mineralógica dos minerais e a sua localização geográfica;

- nomenclatura mineralógica - em sua maioria, os museus pesquisados não se preocupam em atualizar os nomes estabelecidos e propostos pela IMA (Associação Internacional de Mineralogia). Muitos utilizam nomes em desuso ou colocam sinônimos e os nomes de suas variedades mineralógicas, não informando a que espécies pertencem; 
- etiquetas - em geral as etiquetas possuem poucas informações sobre o exemplar exposto ou ainda informações imprecisas e equivocadas a respeito da classificação e da localidade das amostras;

- manutenção - problema grave encontrado em alguns museus, tanto no quesito mobiliário quanto nos exemplares expostos. Encontramos vitrines empoeiradas e sujas, luzes queimadas, falta de cuidado com as amostras expostas, amostras de minerais que estão em processo de decomposição, entre outros. Em geral, a falta de climatização e a falta de conhecimento específico sobre a mineralogia ocasionam estes problemas (oxidação, deliquescência, poeira etc);

- intercâmbio - algumas das instituições visitadas não possuem políticas de intercâmbios com outras instituições e colecionadores particulares. Desta forma seus acervos mantêm-se estagnados durante muitos anos, dependendo quase que exclusivamente da doação de exemplares;

- equipe de museológica - este foi um dos piores problemas detectados, principalmente com relação aos museus de ciências naturais. Existe uma relativa ausência de funcionários específicos e estagiários/monitores (alunos de graduação em geologia, geografia e biologia cedidos pelos cursos universitários ligados à instituição) para o atendimento e recebimento de visitantes, com exceção de quando ocorre o agendamento prévio de visitas de escolas;

- pesquisa científica do acervo exposto e da reserva técnica - quase todos os museus pesquisados não desenvolvem pesquisa sobre os seus acervos mineralógicos, nem possuem cadastros de todas as suas amostras. Isso acaba acarretando falta de conhecimento do próprio acervo, tanto o acervo expositivo quanto o de reserva técnica. Em muitos casos, foi possível observar falta de cuidados com as amostras da reserva técnica, as quais, muitas vezes, são amostras melhores do que os exemplares em exposição;

- trabalho educativo específico - quase todos os museus possuem trabalhos ligados à educação, porém poucos ou quase nenhum divulga a história da 
mineralogia no Brasil e seus principais cientistas, só trabalham em linhas gerais, mostrando o que é a geologia e suas áreas correlatas.

Nesta pesquisa, o mais importante, além de conhecer de perto as coleções mineralógicas (em exposição e em reserva técnica), foi perceber que o maior diferencial nem sempre está nas condições financeiras da instituição, no tamanho ou ainda em suas coleções mineralógicas, mas sim na falta de especialistas (mineralogistas) trabalhando e pesquisando os seus acervos mineralógicos, dando assim a devida importância aos minerais tipo do Brasil e outras ocorrências históricas do país. Em todas as instituições museais pesquisadas os seus acervos mesmo que importantes para a preservação da memória da mineralogia brasileira não está sendo trabalhada adequadamente, tanto na sua conservação, exposição e identificação.

A solução que foi pensada para se resolver todos os problemas levantados nesta pesquisa, está na capacitação dos profissionais que estão à frente gerindo esses acervos. 


\section{8 - REFERÊNCIAS BIBLIOGRAFICAS ${ }^{14}$}

ABREU, S. F. de. A riqueza mineral do Brasil. Ed. 1. Cia Editora Nacional: Coleção Brasilianas. 1937.

AGASSIZ, L.; AGASSIZ, E. C. Viagem ao Brasil. Brasília: Senado Federal, 2000. 504p. Disponível em: <http://www.livrosgratis.com.br/arquivos_livros/sf000071.pdf>. Acesso em: 09 jan. 2014.

AMSTERDAM SAUER. Museu Amsterdam Sauer. Disponível em: <http://www.amsterdamsauer.com.br/museu-amsterdam-sauer>. Acesso em: 07 jan. 2014

ANDRADE, J. Erich Otto Blaich. Edições e Produções Person, São Paulo, 2007.As obras abaixo relacionadas não foram diretamente citadas no trabalho, mas contribuíram para a compreensão dos temas que abordam.

ATENCIO, D. Memória da Mineralogia Brasileira. São Paulo: IG-USP, 1999. p. 214. Tese para concurso de Livre Docência: Mineralogia Básica e Aplicada. Instituto de Geociência - USP, São Paulo. 2000.

ATENCIO, D. Minerais brasileiros do século 21. In: Congresso Brasileiro de Geologia, 43, Aracaju. Anais. 133 p. 2006.

ATENCIO, D. Type Mineralogy of Brazil. São Paulo: Museu de Geociências IGUSP, 2000.

BACK, M. E.; MANDARINO, J. A. Fleischer's glossary of mineral species. Tucson: The Mineralogical Record, 2008.

BARBOSA, R. Oração aos moços. Rio de Janeiro: Edições Casa de Rui Barbosa, 2003. 83 p. Vida e morte no museu-casa, Aparecida M. S. Rangel. Imput - MUSAS Revista Brasileira de Museus e Museologia, n. 3, 2007. Rio de Janeiro: Instituto do Patrimônio Histórico e Artístico Nacional, Departamento de Museus e Centros Culturais, 2004 v.:il. Anual.

BASTANI, T. J. Minas e Minérios no Brasil (tesouros, cidades pré-históricas e minas abandonadas). Livraria Freitas Bastos S/A; Rio de Janeiro, 1957.

BELISÁRIO, A. Gênio Negro: Theodoro Sampaio ex-escravo e um grande cientista. Revista de História. Disponível em: <http://www.revistadehistoria.com.br/secao/reportagem/genio-negro>. Acesso em: 06 jan. 2014.

Belo Horizonte - Minas Gerais. Museu das Minas e do Metal. Disponível em: http://www.belohorizonte.mg.gov.br/local/atrativos-turisticos/culturais-lazer/museudas-minas-e-do-metal. Acesso em: 11 dez. 2013.

BENJAMIM, W. Obras escolhidas II: rua de mão única. 5. ed. São Paulo: Brasiliense, 1995. 71-141 p. Reflexões: a criança, o brinquedo e a educação. São

${ }^{14}$ De acordo com a Associação Brasileira de Normas Técnicas. NBR 6023. 
Paulo: Summus, 1984. Imput - MUSAS - Revista Brasileira de Museus e Museologia, n. 3, 2007. Rio de Janeiro: Instituto do Patrimônio Histórico e Artístico Nacional, Departamento de Museus e Centros Culturais, 2004 v.:il. Anual. O lugar da infância nos museus. 39 p.

BIBLIODISSEY. Exploring the Galaxy. 2007. Disponível em: <http://bibliodyssey.blogspot.com.br/2007/01/exploring-galaxy.html>. Acesso em: 17 dez. 2013.

BIBLIOTECA NACIONAL. A França no Brasil: Claude Henri Gorceix e a Escola de Minas de Ouro Preto. [s.d]. Disponível em: <http://bndigital.bn.br/francebr/gorceix.htm>. Acesso em: 12 jan. 2014.

BIBLIOTECA VIRTUAL. Disponível em: <http://www.bibliotecavirtual.sp.gov.br/turismo-interior-santanadoparn. Php>. Acesso em: 11 dez. 2013.

BRANCO, P. de M. Breve História da Mineralogia Brasileira. CPRM - Companhia de Pesquisa de Recursos Minerais. 2013. Disponivel em: http://www.cprm.gov.br/publique/cgi/cgilua.exe/sys/start.htm?infoid=2566\&sid=129.

Acesso em: 12 dez. 2013.

BRASIL. LEI No 11.904, DE 14 DE JANEIRO DE 2009. Institui o Estatuto de Museus e dá outras providências. Diário Oficial da União, Brasília, DF, 15 de jan. 2009. 1 p. Disponível em: <https://www.planalto.gov.br/ccivil_03/_ato20072010/2009/lei/l11904.htm> Acesso em: 17 dez. 2013.

BRUNO, M. C. O. Estudos de Cultural Material e Coleções Museológicas: avanços, retrocessos e desafios. MAST - Museu de Astronomia e Ciências a fins. Cultura Material e Patrimônio de C\&T, [s.d.]. Disponível em: <http://www.mast.br/projetovalorizacao/textos/livro\%20cultura $\% 20$ material\%20e\%20 patrim\%C3\%B4nio\%20de\%20C\&T/3\%20Artigo\%20Cristina\%20Bruno.pdf>. Acesso em: 03 out. 2013.

BUSSIO, M. Concierto em EI Museo de Ciencias Naturales. 2012. Disponivel em: <http://caballitotequiero.com.ar/portal/2012/09/30/concierto-en-el-museo-de-cienciasnaturales/>. Acesso em: 19 dez. 2013

CAMPOS, F. de. A escrita da história: ensino médio. Volume único: Livro do professor. São Paulo: Escala Educacional, 2005.

CÂNDIDO, L. F. Carl Fr. Ph. vonMartius: estudo e registro da flora brasileira. Brasiliana USP. Disponível em: <http://www.brasiliana.usp.br/node/1102>. Acesso em: 08 jan. 2014.

CARVALHO, M. C. M. P. de. Espaços de cultura e formação de professores Imonitores. IN: LEITE, Maria Isabel. OSTETTO, Luciana E. (org.). Museu Educação e Cultura: encontros de crianças e professores com a arte. Campinas, SP: Papirus Editora, 2005. 
CASSEDANNE J. P.; BAPTISTA, A. The Sapucaia pegmatite Minas Gerais, Brazil. Mineralogical Record, September, 1999. Vol.30(5).

CASSEDANNE, J. P.; ALVES, J. N. The Jaguaracu Pegmatite (pegmatite deposits in Minas Gerais, Brazil). The Mineralogical Record, 1994. Vol.25(3).

CIRCUITO TURÍSTICO - CAMINHOS GERAIS. Museu Histórico e Geográfico de Poços de Caldas. Disponivel em: <http://www.caminhosgerais.org/cidades/turismo_e.php?husij=bc1a59ea23432661dd 7f84f4d0b5686a\&nomeCidade=Po\%C3\%A7os\%20de\%20Caldas\&idTurismo=111>. Acesso em: 14 jan. 2014.

COLEÇÃO DE MINERAIS. Artigo eletrônico publicado em: 2009. Disponível em: $<$ http://artigosimportantesdalu.blogspot.com.br/2009/08/colecao-de-minerais. html>. Acesso em 05 dez. 2013.

CORNEJO, C.; BARTORELLI, A. Minerais e Pedras Preciosas do Brasil. São Paulo, Solaris, 2010.

CORREIOS. Eu Amo Filatelia: A Arte de Colecionar Selos. Belo Horizonte. 2012. Disponível em: <http://blog.correios.com.br/filatelia/encontro-de-colecionadores-embelo-horizonte/>. Acesso em: 15 dez. 2013.

CPRM. Barão de Eschwege. Disponível em: <http://www.cprm.gov.br/publique/cgi/cgilua.exe/sys/start.htm?infoid=519\&sid=8>. Acesso em: 11 dez. 2013.

CPRM. Octávio Barbosa - Vida e Obra. Serviço Geológico do Brasil, 2012. Disponível <http://www.cprm.gov.br/publique/cgi/cgilua.exe/sys/start.htm?infoid=151\&sid=8>. Acesso em: 06 jan. 2014.

CPRM. Orville Adelbert Derby. 2010. Disponível em: <http://www.cprm.gov. br/publique/cgi/cgilua.exe/sys/start.htm?infoid=528\&sid=8>. Acesso em: 06 jan. 2014.

DANA, J. D.; DANA E. S. Dana's new mineralogy.The system of mineralogy of James D. Dana and Eduard S. Dana. 8th ed. New York, J. Wiley and Sons, 1997.

DINIZ, D. C. B. Cartas Inéditas de Dom Pedro II a Henri Gorceix. 2010. Disponível em: <http://periodicos.letras.ufmg.br/index.php/caligrama/article/viewFile/155/109>. Acesso em: 17 jan. 2014.

ESCOLA DE MINAS DA UNIVERSIDADE FEDERAL DE OURO PRETO. Disponível em: <http://www.em. ufop.br/em/diretores/gorceix.php>. Acesso em: 27 nov. 2013.

ESCOLA WALDORF SÃO PAULO. Disponível em: $<$ http://www.waldorf.com.br/quem-somos-58/a-pedagogia.html>. Acesso em: 11 jan. 2013.

FERRI, M. G.; MOTOYAMA, S. História das Ciências no Brasil. 3 v. São Paulo, EPU, Edusp, 1979, 1980. 
FGV - Fundação Getúlio Vargas/CPDOC. Eliezer Batista. Disponível em:< http://cpdoc.fgv.br/producao/dossies/Jango/biografias/eliezer_batista>. Acesso em: 11 dez. 2013.

FOUCAULT, M. As palavras e as coisas. São Paulo: Martins Fontes, 1999.

GAENSLY, G. Museu Paulista do Ipiranga (1890). 2004. Disponível em: < http://www.aprenda450anos.com.br/450anos/vila_metropole/2-

3_museu_ipiranga.asp >. Acesso em: 17 dez. 2013.

GEOSOL - Geologia e Sondagens S/A. Disponível em: <http://www.geosol.com.br/empresa/>. Acesso em: 21 jan. 2014.

GIL, Antônio Carlos. Como elaborar projetos de pesquisa. 5. ed. São Paulo: Atlas, 2008.

GOMES, M. F. D. L. Museus Mineralógicos - armazéns de minerais ou parceiros de ensino? Três Museus - Três Perspectivas. In Actas do I Seminário de Investigação em Museologia dos Países de Língua Portuguesa e Espanhola, 2010. Volume 1 , pp. 248-258. Disponível em: <http://ler.letras.up.pt/uploads/ficheiros/8130.pdf> Acesso em: 17 set. 2013.

GONÇALVES, M. L. C. M. R.; AMORIM, A. C. Gabinetes de curiosidades: paradoxos das maravilhas. UNIVERSIDADE FEDERAL DE CAMPINAS. EDUCAperiódicos online de educação Scielo. Educação: teoria e prática, Rio Claro, SP, Brasil - elSSN: 1981-8106. 2012. Disponivel em: $<$ http://educa.fcc.org.br/pdf/eduteo/v22n40/v22n40a14.pdf>. Acesso em $14 \mathrm{dez}$. 2013.

GONSALVES, A. D. Orville A. Derby's Studies on the Paleontology of Brazil. Rio de Janeiro, 1952.

GOODE, W. J.; HATT, P. K. Métodos em pesquisa social. São Paulo: Companhia Editora Nacional, 1952.

GRANATO, M. Panorama sobre o patrimônio da ciência e tecnologia no Brasil: objetos de C\&T. Cultura Material e Patrimônio de C\&T. Rio de Janeiro: MAST. Artigo eletrônico publicado em: 2009. Disponível em: <http://www.mast.br/projetovalorizacao/textos/livro\%20cultura\%20material\%20e\%20 patrim\%C3\%B4nio\%20de\%20C\&T/8\%20PANORAMA\%20SOBRE\%200\%20PATRI M\%C3\%94NIO\%20DA\%20CIENCIA\%20E\%20TECNOLOGIA\%20NO\%20BRASILM arcus.pdf>. Acesso em 20 jan. 2014.

GROUPAMENT D'ESTUDES GEOLOGIQUES E MINIERES. Mineralogie et Historie. 2009. Disponível em: <http://www.gegmfrance.org/nouveau_fichier_15.htm>. Acesso em: $19 \mathrm{dez} .2013$.

GUIMARAENS, D. P. Gestão Cultural, Patrimônio e "Museu Vivo" Indígena. Portal Estácio, 2007. Disponível em: <http://www.estacio.br/restauro/palestras_gestaocultural.asp>. Acesso em: 20 nov. 2013. 
GUIMARÃES. D. Arrojadita, um novo mineral do grupo da wagnerita. Ministério da Agricultura Indústria e Comércio, Serviço Geológico e Mineralógico do Brasil, 1925. $11 \mathrm{p}$.

HENRIQUES, R. P. B. A viagem que revelou a Biodiversidade. Revista Ciência Hoje, vol. 42, n. 252. 2008.

HUSSAK, E. PRIOR, G. T. Derbylite, a new antimono-titanate of iron from Tripuhy, Brazil. Min. Mag. Jour. Mineralogical Society 9(52):176-179. 1897.

IBRAM. Guia dos Museus Brasileiros. Brasília, Instituto Brasileiro de Museus, 2011.

ILUSTRATUS. Museus e Fundações. 2009. Disponível em: <http://blogillustratus.blogspot.com.br/p/museus-e-fundacoes.html>. Acesso em: 19 dez. 2013.

INSUGEO - INSTITUTO SUPERIOR DE CORRELACIÓN GEOLÓGICA. Mineralogía em el siglo XX: La Asociación Mineralógica Internacional (IMA). [s.d.]. Disponível em:<http://insugeo.org.ar/libros/cg_23/21.htm>. Acesso em: 13 jan. 2014.

INTERNATIONAL MINERALOGICAL ASSOCIATION. List of Minerals. Disponivel em: <http://www.ima-mineralogy.org/Minlist.htm>. Acesso em: 02 jan. 2014.

JELINEK, A. R.; PRADO, M.; NETO, A. C. B.; PEREIRA, V. P.; RONCHI, L. H.; SAVI, C. N. Ocorrência de gorceixita e de inclusões sólidas de halita em fluorita da jazida Nova Fátima: implicações na gênese da mineralização do distrito fluorítico de Santa Catarina. Revista Brasileira de Geociências 33 (3): 363-370, 2003.

JULIÃO, L. Cadernos de Diretrizes Museológicas 2: mediação em museus: curadorias, exposições, ação educativa. Belo Horizonte: Secretaria de Estado de Cultura de Minas Gerais, Superintendência de Museus, p.14 - 23, 2008. Museus, identidades e patrimônio cultural. Revista do Museu de Arqueologia e Etnologia. Suplemento, 2008. 145-151 p.

KORBEL, P.; NOVÁK, M. Enciclopédia de Minerais: descrição de mais de 600 minerais de todo mundo. Lisboa: Livros e Livros, 2000.

KRAUS, M.; PEREIRA, P. NOVOS MUNDOS - NEUE WELTEN Portugal e a Época dos Descobrimentos - VIII. Os Gabinetes de Curiosidades e os Quartos das Maravilhas Uma Exposição do Deutsches Historisches Museum Berlin. Em cooperação com o Instituto Camões em Lisboa e a Embaixada de Portugal em Berlin. Disponível em:<http://www.dhm.de/ausstellungen/neuewelten/pt/kunst_und_wunderkammern.html>. Acesso em: 12 ago. 2013.

LÉVI-STRAUSS, C. Raça e História. São Paulo: Martins Fontes, 1973. Imput SCHWARCZ, L. M.; DANTAS, R. O Museu do Imperador: quando colecionar é representar a nação. 2008. Disponível em: <http://dx.doi.org/10.11606/issn.2316901X.v0i46p123-164>. Acesso em: 23 out. 2013. 
LEWIS, G. Como gerir um museu: manual prático - 0 papel dos museus e o código de ética profissional. ICOM / UNESCO, França. 1 p. 2004. Disponível em: <http://unesdoc.unesco.org/images/0018/001847/184713por.pdf>. Acesso em: 11 set. 2013.

LIMA, P. R. A. dos S. Guia de mineralogia Victor Dequech / Paulo Roberto Amorim dos Santos Lima. Belo Horizonte: Rona Editora, 2004.

LINDBERG, M. L. Leucophosphite from the Sapucaia pegmatite, Minas Gerais, Brazil. Am. Mineral., 42, 1956.

LINDBERG, M. L; PECORA, W. T. Avelinoite, a new hydroussodiumferricphosphate mineral from Minas Gerais, Brazil. Science, 120, 1074-1075; Abstract (1955) in Mineralog. Abstracts, 12, 512. 1954.

LINDBERG, M. L; PECORA, W. T. Tavorite and barbosalite, two new phosphate minerals from Minas Gerais, Brazil. Science, v. 119, 1954.

LOPES, J. R. Colecionismo e ciclos de vida: uma análise sobre percepção, duração e transitoriedade dos ciclos vitais. Universidade do Vale do Rio dos Sinos. Horiz. antropol. vol.16 n.34. Porto Alegre, 2010. Disponível em: <http://www.scielo.br/scielo.php?pid=S0104-

71832010000200016\&script=sci_arttext>. Acesso em: 27 dez. 2013.

LOPES, M. M. Museu: uma perspectiva de educação em geologia. Dissertação de mestrado. Campinas, Faculdade de Educação/UNICAMP, 1988.

LOPES, M. M. O Brasil descobre a pesquisa científica - os museus e as ciências naturais no século XIX. São Paulo: Hucitec. 1997.

MACHADO, A. M. A. Cultura, ciência e política: olhares sobre a história da criação dos museus no Brasil. IN: FIGUEIREDO, B. G. e Gonçalves D. V. MUSEUS dos Gabinetes de Curiosidades à Museologia Moderna. Belo Horizonte: Argumentum, 2005.

MANDARINO, J. A.; BACK, M. E. Fleischer Glossary of Mineral Species. Tucson, Arizona USA: The Mineralogical Record Inc. 2004

MENESES, U. T. B. de. $O$ museu na cidade $x$ a cidade no museu: para uma abordagem histórica dos museus de cidade. Revista Brasileira de História, São Paulo, v. 5, n. 8/9, 1984/1985.

MENEZES, L. A. D.: CHAVES, M. L. S. C. Minerais de Coleção: ciência, estética e mercado. GEONOMOS 15(2): 65 - 73, 2007. Universidade Federal de Minas Gerais, $2007 . \quad$ Disponível em: <http://www.igc.ufmg.br/geonomos/PDFs/15_2_65_72_Menezes.pdf> Acesso em ago. 2013.

MINDAT - MINERALOGICAL DATA. Cassedannite. [s. d.]. Disponível em: <www.mindat.org/min-915.html>. Acesso em: 11. Jan. 2014. 
MINDAT - MINERALOGICAL DATA. Disponível em: <www.mindat.org/min915.html>. Acesso em: 06. Jan. 2014.

MINISTÉRIO DA CIÊNCIA, TECNOLOGIA E INOVAÇÃO. Semana Nacional de Ciência e Tecnologia: Djalma Guimarães (1894-1973). 2013. Disponível em< http://semanact.mct.gov.br/web/snct/cientistas-brasileiros>. Acesso em: 13. Jan. 2014.

MMM - MUSEU DAS MINAS E DO METAL. Roteiros. Disponível em: $<$ http://www.mmm.org.br/index.php?p=19\#sthash.6lsTCYbV.dpuf>. Acesso em: 11 dez. 2013.

MUNDO DAS MARCAS. Amsterdam Sauer. Disponível em: $<$ http://mundodasmarcas.blogspot.com.br/2006/07/amsterdam-sauer-o-luxo-dasjias.html>. Acesso em 07 jan. 2014.

MUSEU DA ESCOLA DE MINAS - UFOP. Mineralogia. Disponivel em: <http://www.museu.em.ufop.br/museu/mineralogia.php>. Acesso em: 27 nov. 2013.

MUSEU DAS MINAS E DO METAL - BELO HORIZONTE - MINAS GERAIS. Disponivel em: <http://www.belohorizonte.mg.gov.br/local/atrativosturisticos/culturais-lazer/museu-das-minas-e-do-metal>. Acesso em: 11 dez. 2013.

MUSEU DE CIÊNCIAS DA TERRA ALEXIS DOROFEEF. Disponível em: <http://www.mctad.ufv.br/area/historico>. Acesso em: 12 jan. 2014.

MUSEU DE GEOCIÊNCIAS - IGc/USP. Disponível em: <http://www.igc.usp.br/museu/omuseu.htm>. Acesso em 03 Dez. 2013.

MUSEU DE MINERAIS E ROCHAS "HEINZ EBERT". Prof. Dr. Heinz Ebert. Disponível em: <www.rc.unesp.br/museudpm/ebert.html>. Acesso em: 10 jan. 2014. s.d.

MUSEU DE MINERALOGIA DE PARIS. Disponível em: <http://www.minesParistech.fr/Ecole/ Culture-scientifique /Musee-de-mineralogie/>. Acesso em $04 \mathrm{dez}$. 2013.

MUSEU GEOLÓGICO VALDEMAR LEFRÉVE - MUGEO. Disponível em: <http://www.mugeo.sp.gov.br/> Acesso em 21 jan. 2014.

MUSEU NACIONAL/UFRJ. Disponível em: $<$ http://www.museunacional.ufrj.br/MuseuNacional/Principal/omuseu.htm>. Acesso em: 12 jan 2014.

NEVES, P. C. P. ATENCIO, D. Enciclopédia dos Minerais do Brasil: elementos nativos e halogenetos. Canoas: Ed. ULBRA, 2013.

NEVES, P. C. P. das; BRANCO, P. M.; MATIOLI, P. A. The Pércio de Moraes Branco collection of rare minerals of the UniversidadeLuterana do Brasil (ULBRA). Porto Alegre, Southern Brazilian Journal of Chemistry, 5(5): 51-66. 1997. 
NEVES, P. C. P. das; SCHENATO, F.; BACHI, F. A. Introdução à Mineralogia Prática. Canoas: Ed. ULBRA, 2003.

NUNES, G. A.; RAINHO, M. E.; REZENDE, E. F. de.; GANDINI, A. L.; DELICIO, M. P.; JOTTA, C. A.; HOFFMAN, F. E. As Coleções do Museu de ciência e Técnica da Escola de Minas/UFOP. Cultura Material e Patrimônio de C\&T. Rio de Janeiro: MAST, 2010.

Disponível

em:

<http://www.mast.br/projetovalorizacao/textos/cole\%C3\%A7\%C3\%B5es\%20lusobrasileiras/04\%20AS\%20COLE\%C3\%87\%C3\%95ES\%20DO\%20MUSEU\%20DE\%2 0CI\%C3\%8ANCIA\%20E\%20T\%C3\%89CNICA.pdf>. Acesso em: 20 jan. 2014.

OVERSTREET, L. K. Johann Baptist Von Spix Simiarum et Vespertilionum Brasiliensium Espécies Novae (1823). Smithsonian Institution Libraries. Coleções Especiais 2000.2 Departamento. 2 em: <http://www.sil.si.edu/DigitalCollections/NHRareBooks/Spix/spix-introduction.htm>. Acesso em: 10 jan. 2014.

PEARCE, J. Frederick H. Pough, Writer of Gem Guide, Dies at 99. The New York Times Books, 2006. Disponível em: <http://www.nytimes.com/2006/04/14/books/14pough.html>. Acesso em: 15 jan. 2014.

PEREIRA, M. da S. A Exposição de 1908 ou o Brasil visto por dentro. UFRG Universidade Federal do Rio Grande do Sul. PROPAR, 2012. Disponível em: <http://www.ufrgs.br/propar/publicacoes/ARQtextos/pdfs_revista_16/01_MSP.pdf>. Acesso em: 15 nov. 2013.

PEREIRA, R. M. A. Gabinetes de curiosidades e os primórdios da ilustração científica. (407) II Encontro de História da Arte - IFCH / UNICAMP, 2006. Disponível em:<http://www.unicamp.br/chaa/eha/atas/2006/PEREIRA,\%20Rosa\%20Maria\%20A Ives\%20-\%20IIEHA.pdf>. Acesso em: dez. 2013.

PINTO, T. A idade média era a idade das trevas? Escola Kids. Disponível em: $<$ http://www.escolakids.com/a-idade-media-era-a-idade-das-trevas.htm>. Acesso em out. 2013.

PIRSSON, L. V. Biographical Memoir of James Dwight Dana, 1813-1895. The National Academy ofSciences, Biographical memoirs. Part of vol. IX. Harvard University: USA, $1919 . \quad$ Disponível em: https://archive.org/details/biographicalmem00pirsgoog. Acesso em: 20 dez. 2013;

POMIAN, K. Coleção. In: ROMANO, Ruggiero (Dir.). Enciclopédia Einaudi. Porto: Imprensa Oficial/Casa da Moeda, V. I. Memória-História, 1994.

PORTAL DO INSTITUTO BRASILEIRO DE MUSEUS - Ângelo Oswaldo de Araújo Santos - Presidente do Instituto Brasileiro de Museus. Disponível em: <http://www.museus.gov.br/os-museus/>. Acesso em: 14 out. 2013.

PORTAL DO INSTITUTO BRASILEIRO DE MUSEUS - História dos Museus. Disponivel em: <http://www.museus.gov.br/museu/\#sthash.0A6UAG5e.dpuf>. Acesso em: out. 2013. 
PORTAL DO TURISMO DE OURO PRETO. Museu de Ciência e Técnica da Escola de Minas (Palácio do Governador). Disponível em: <http://www.ouropreto.mg.gov.br/portaldoturismo/index/index.php?pag=9\&\&id=1>. Acesso em: 20 dez. 2013.

POSSAS, H. C. G. Classificar e ordenar: os gabinetes de curiosidades e a história natural. IN: FIGUEIREDO, Betânia G. e Diana Gonçalves Vidal (org.) MUSEUS dos Gabinetes de Curiosidades à Museologia Moderna. Belo Horizonte: Argumentum, 2005.

RAINHAS TRÁGICAS. Imperatriz Teresa Cristina. Disponível em: http://rainhastragicas.com/2013/07/22/d-teresa-cristina-uma-imperatriz-silenciosa/.

Acesso em: 11 jan. 2014.

REZENDE, R. M. Cadastro Geral das Minas Brasileiras. Brasília. DNPM, 1982. Apud LOPES, M. M. Museu: uma perspectiva de educação em geologia. Dissertação de Mestrado. Campinas, Faculdade de Educação/UNICAMP, 1988.

SAKALL, S. E. Parque Zoobotânico do MPEG - Museu Paraense Emílio Goeldi. 2012. Disponível em: <http://www.girafamania.com.br/introducao/zoo_goeldi.htm>. Acesso em: 19 dez. 2013.

SANTOS, A. C. M. dos. Memória-cidadã: história e patrimônio cultural. Anais do Museu Histórico Nacional. Rio de Janeiro, v.29, 1997. Apud Letícia Julião Apontamentos sobre a História do Museu. CADERNO de diretrizes museológicas. Brasília: Ministério da Cultura/Instituto do Patrimônio Histórico e Artístico Nacional/Departamento de Museus e Centros Culturais, Belo Horizonte: Secretaria do Estado da Cultura/Superintendência de Museus, $2^{\mathrm{a}}$ ed., 2006.

SANTOS, M. C. T. M. Museu Escola: uma experiência de integração. Salvador: Dissertação apresentada ao mestrado de educação. Biblioteca USP, 1981.

SANTOS, M. C. T. M. Museu, Escola e Comunidade: uma integração necessária. Salvador: BUREAU GRÁFICA e EDITORA, 1981.

SCANAPIECO, L. Um Museu de Cidade: Imaginário, Debate Museológico e o caso de Juiz de Fora. 2013. Dissertação (Mestrado) - Programa de Pós-Graduação em Museologia e Patrimônio, UNIRIO/MAST, Rio de Janeiro, 2013.

SCHWARCZ, L. M.; DANTAS, R. O Museu do Imperador: quando colecionar é representar a nação. 2008. Disponível em: <http://dx.doi.org/10.11606/issn.2316901X.v0i46p123-164>. Acesso em: out. 2013;

SCIELO. Rui Ribeiro Franco: o início da Geociências. Disponível em: <http://www.scielo.br/scielo.php?pid=S0103-

40141994000300009\&script=sci_arttext>. Acesso em 03 dez. 2013.

SERVIÇO GEOLÓGICO BRASILEIRO. Disponível em: http://www.cprm.gov.br/publique/cgi/cgilua.exe/sys/start.htm?infoid=341\&sid=19. Acesso em: 14 nov 2013. 
SILVA, K. A. da. Trajetórias Intelectuais - A Expedição Thayer. Artigo eletrônico publicado em: 27 set. 2011. Disponível em: <http://trajetoriasintelectuais.blogspot.com.br/2011/09/expedicao-thayer.html>. Acesso em: 06 jan. 2014.

SILVA, M. P. F. da. Coleção, colecionador, museu: entre o visível e o invisível: um estudo acerca da Casa de Cultura Christiano Câmara em Fortaleza, Ceará. Universidade do Rio de Janeiro UNIRIO/MAST. 2010. Disponível em: http://www.unirio.br/cch/ppg-pmus/dissertacoes/Dissertacao_

Michel_Platini_Fernandes.pdf. Acesso em 23 fev. 2013.

SINDCOMERCIO DE CONGONHAS. Disponivel em: <http://www.congonhasdocampo.com.br/ssiobrecongonhas2.htm>. Acesso em: 05 dez. 2013.

SKYSCRAPERCITY. NYC, Panoramas. 2007. Disponível em: <http://www.skyscrapercity.com/showthread.php?t=560712>. Acesso em: 18 dez. 2013.

SOFKA, V. A pesquisa no museu e sobre o museu. MUSEOLOGIA E PATRIMÔNIO - vol.II n. 80, 2009. Disponível em: <http://revistamuseologiaepatrimonio.mast.br/index.php/ppgpmus/article/viewFile/49/ 38>. Acessoem: 28 jan. 2014.

SOUZA, L. C. C. MORAES, N. A. Museu e Museologia: instituição e conhecimento em mudança. Universidade Federal de Santa Catarina - XIV Encontro Nacional de Pesquisa em Ciência da Informação. Disponível em: http://enancib.sites.ufsc.br/index.php/enancib2013/XIVenancib/paper/viewFile/311/39 4. Acesso em: 05 nov. 2013.

SPIX, J. B. von; MARTIUS, C. F. P. von. Reise in Brazilian (1817-1820). London: Longman, Hurst, Rees, Orme, Brown, and Green, 1824.

STRUNZ, H.; NICKEL, E. H. Strunz Mineralogical Table Chemical Structural Mineral Classification System. 9th ed. E.Stuttgart: Schweizerbart, 2001.

THE ARQUENSTONE. Disponível em: http://www.irocks.com/minerals. Acesso em: 01 fev. 2014.

THE PHILADELPHIA MINERALOGICAL SOCIETY. New Minerals Name. The Academy of Natural Science of Philadelphia. 1945.

TORRENS, H. Early Collecting in the Field of Geology. In: IMPEY, o. e MACGREGOR, A. The Origins of Museums. Oxford.Clarendon Press, 1985. Apud LOPES, M. M. Museu: uma perspectiva de educação em geologia. Dissertação de Mestrado. Campinas, Faculdade de Educação/UNICAMP, 1988.

TOSSATO, P. Orville A. Derby "O Pai da Geologia do Brasil". DNPM - Museu de Ciências da Terra; CPRM - Serviço Geológico do Brasil. 2001.

U.S.G.S. - U.S. Geological Survey. William T. Pecora, Pioneer of Earth Science from Space. Geological Survey: science for a changing world, 2012. Disponível em: 
http://www.usgs.gov/blogs/features/usgs_top_story/william-t-pecora-pioneer-of-earthscience-from-space/?from=image. Acesso em: 20 jan. 2014.

UIVERSIDADE FEDERAL DO ESPÍRITO SANTO. Disponível em: <http://www.oceanografia.ufes.br/laborat\%C3\%B3rio-de-geologia-museu-deminerais-e-rochas>. Acesso em 07 jan. 2014.

UNIVERSIDADE ESTADUAL PAULISTA. Introdução à Mineralogia. Disponível em: http://www.rc.unesp.br/igce/petrologia/nardy/n3.pdf. Acesso em: 15 jan. 2014.

UNIVERSIDADE ESTADUAL PAULISTA. Introdução para o banco de dados de minerais.

Disponível

em:

<http://www.rc.unesp.br/museudpm/banco/introducao.html>. Acesso em: $10 \mathrm{dez}$. 2013.

UNIVERSIDADE FEDERAL DO RIO GRANDE DO SUL. Disponível em::http://www.ufrgs.br/propar/publicacoes/ARQtextos/pdfs_revista_16/01_MSP.pdf. Acesso em: 11 nov 2013.

UNIVERSIDADE FEDERAL DO RIO DE JANEIRO - Departamento de Geologia. Museu da Geodiversidade. Disponivel em: $<$ http://www.geologia.ufrj.br/index.php?module=pagemaster\&PAGE_user_op=view_p age\&PAGE_id=50>. Acesso em: $21 \mathrm{dez} .2013$.

UNIVERSITY OF OXFORD. British Collection of Ashmolean Museum. 2012. Disponível em: <http://britisharchaeology.ashmus.ox.ac.uk/collections/collectionindex.html>. Acesso em: 17 dez. 2013.

VARELA, A. G.; LOPES, M. M. e FONSECA, M. R. F. da. As atividades do filósofo natural José Bonifácio de Andrada e Silva em sua fase portuguesa (1780-1819). História, Ciências, Saúde - Manguinhos, vol. 11(3): set.-dez. 2004.

VIBRATIONAL SPECTROCOPY AND PHOTO ATLAS MINERAL. Disponível em: http://www.mineralatlas.com/General\%20introduction/Introduction.htm. Acesso em: 13 fev. 2014.

WEBACADEMIA - CONOCEMOS TODO. Karl Hugo Strunz, Vida, Trabajar, Honores, Selección de publicaciones. Disponível em: <http://centrodeartigos.com/articulos-utiles/article_104782.html>. Acesso em: $10 \mathrm{dez}$. 2013.

WORLD ATLAS OF SANDS. Yet another sand collector. 2009. Disponivel em: <http://www.sand-atlas.com/en/yet-another-sand-collector/>. Acesso em: $15 \mathrm{dez}$. 2013. 